National Research Program of the

U.S. Geological Survey,

Water Resources Division Fiscal Year 1994

United States

Geological

Survey

Open-File Report 95-356 


\section{NATIONAL RESEARCH PROGRAM \\ OF THE \\ U.S. GEOLOGICAL SURVEY, WATER RESOURCES DIVISION, FISCAL YEAR 1994}

Compiled by MARTHA L. NICHOLS

U.S. GEOLOGICAL SURVEY

Open-File Report 95-356

RESTON, VIRGINIA

1995 


\section{U.S. DEPARTMENT OF THE INTERIOR BRUCE BABBITT, Secretary}

\section{U.S. GEOLOGICAL SURVEY \\ Gordon Eaton, Director}

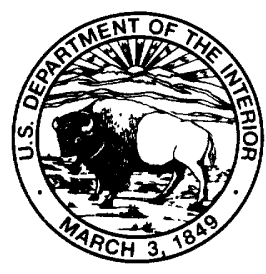

Any use of trade, product, or firm names in this publication is for descriptive

purposes only and does not imply endorsement by the U.S. Government

For additional information write to:

Chief, Office of Hydrologic Research U.S. Geological Survey 436 National Center 12201 Sunrise Valley Drive Reston, Virginia 22092
Copies of this report can be purchased from:

U.S. Geological Survey

Earth Science Information Center

Open-File Reports Section

Federal Center, Box 25046

Denver, Colorado 80225 


\section{CONTENTS}

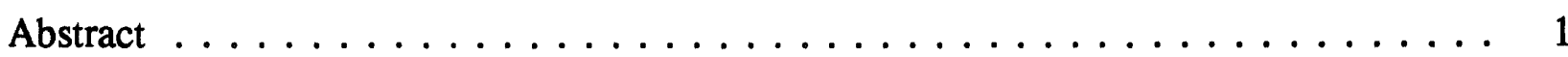

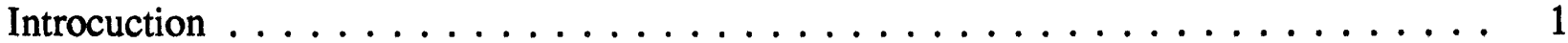

Background ........................... 1

Organization of the National Research Program ................ 2

Technology Transfer .......................... 5

Research Disciplines and Projects .................... 7

Ecology ........................... 7

CR 84-286 Interactions Between Organic Solutes and Trace Metals in

Natural Waters, and Their Ecological Role .......... 8

Diane M. McKnight, Project Chief

CR 85-293 The Role of Chemical Fluxes in the Biogeochemistry of

Inland Surface Waters, Including Lakes, Reservoirs, and

Wetlands . . . . . . . . . . . . . . . . . . . ${ }^{-13}$

James W. LaBaugh, Project Chief

CR 86-295 Microbial Transformation of Dissolved Organic Carbon in

Aquatic Environments . . . . . . . . . . . . . 15

Richard L. Smith, Project Chief

CR 91-320 Characterization of Biotic and Biogeochemical Interactions

at Environmental Interfaces . . . . . . . . . . . . . . 20

Robert G. Striegl, Project Chief

CR 90-323 Interdisciplinary Research Initiative (IRI) at the Shingobee

Headwaters Research Area, Minnesota . . . . . . . . . . . 23

Thomas C. Winter, Project Chief

CR 91-325 Limnological Phenomena in Impounded Rivers . . . . . . . . 26

G. Richard Marzolf, Project Chief

CR 91-327 Interaction of Bacteria with Environmental Contaminants

and Solid Surfaces in the Aquatic Environment . . . . . . . . 29

Ronald W. Harvey, Project Chief

CR 92-337 Effects of Toxic Substances on Aquatic Communities . . . . . . 34

Harry V. Leland, Project Chief 
NR 73-090 Remote Sensing and Ecological Research in Wetlands . . . . . . 36 Virginia P. Carter, Project Chief

NR 87-136 Modeling of Microbially Catalyzed Geochemical Reactions in Aquatic Environments . . . . . . . . . . . . . . . 41

Derek R. Lovley, Project Chief

NR 90-145 Vegetation and Hydrogeomorphic Relations . . . . . . . . . 46 Cliff R. Hupp, Project Chief

WR 68-046 Geochemistry of Riverine and Estuarine Waters . . . . . . . 5 50 David H. Peterson, Project Chief

WR 71-068 Fate of Organic Chemicals in Subsurface Environments . . . . . . 55 Edward M. Godsy, Project Chief

WR 75-125 Availability of Trace Elements in Sediments to Aquatic

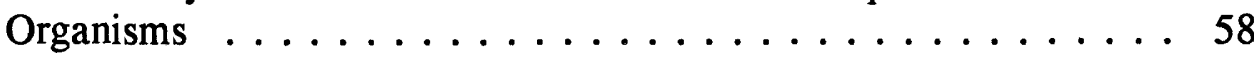
Samuel N. Luoma, Project Chief

WR 76-145 Biotic Response to Climatic Variability and Human Impacts

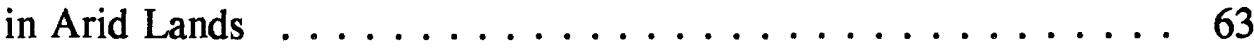
Julio L. Betancourt, Project Chief

WR 79-164 Plankton Dynamics in Tidal Estuaries . . . . . . . . . . . . 71 James E. Cloern, Project Chief

WR 81-174 Microbial Biogeochemistry of Aquatic Environments . . . . . . . 76 Ronald S. Oremland, Project Chief

WR 84-186 Biotic Interface with Fluvial Transport: Processes Associated with Dissolved Solutes in Transport . . . . . . . . . . . 80 Frank J. Triska, Project Chief

WR 86-190 Solute Transport Involving Biological Processes in Surface Waters . . . . . . . . . . . . . . . . . . . . . . . 84 James S. Kuwabara, Project Chief

WR 86-192 Environmental Influences on Estuarine Benthic Community Dynamics . . . . . . . . . . . . . . . . . . . . 87 Frederic H. Nichols, Project Chief 
Geomorphology and Sediment Transport . . . . . . . . . . . . . . 91

CR 75-102 Movement and Storage of Sediment in River Systems . . . . . . . 92 Robert H. Meade, Project Chief

CR 65-105 Effects of Water and Sediment Discharges on Channel Morphology . . . . . . . . . . . . . . . . . . . 94 Garnett P. Williams, Project Chief

CR 74-187 Hydraulics and Mechanics of Bedload-Transport Processes . . . . 96 William W. Emmett, Project Chief

CR 82-273 River Mechanics . . . . . . . . . . . . . . . . . . . . . 99

Edmund D. Andrews, Project Chief

CR 87-309 Sediment-Transported Pollutants in the Mississippi River . . . . 103 Robert H. Meade, Jr., Project Chief

CR 91-324 Applications of Fluid and Sediment Mechanics to Basin and Regional Scale Hydrologic and Geomorphic Problems . . . . . . 108 J. Dungan Smith, Project Chief

WR 89-200 Response of Fluvial Systems to Climatic Variability . . . . . . . 112 Robert H. Webb, Project Chief

WR 79-311 Sediment Impacts from Disturbed and Undisturbed Lands . . . . . 116 Waite R. Osterkamp, Project Chief

Ground-Water Chemistry . . . . . . . . . . . . . . . . . . . . . . . . . . . . . . . 119

CR 82-207 Arid Regions Climate and Chemistry . . . . . . . . . . . 120 Larry V. Benson, Project Chief

CR 82-276 Geochemistry of Clay-Water Reactions . . . . . . . . . . 123 Dennis D. Eberl, Project Chief

CR 83-283 Environmental Dynamics of Persistent Organic Compounds . . . . 126 Cary T. Chiou, Project Chief

CR 89-318 Reaction-Transport Modeling in Ground-Water systems . . . . . 130 David L. Parkhurst, Project Chief 
CR 92-326 Chemical Modeling and Thermodynamic Data Evaluation of Major and Trace Elements in Acid Mine Waters and Ground Waters . . . . . . . . . . . . . . . . . . . 133

Darrell $K$. Nordstrom, Project Chief

CR 79-336 Chemical Models of Natural Systems . . . . . . . . . . . 137 Donald C. Thorstenson, Project Chief

NR 69-020 Mineral-Water Interaction in Saline Environments $\ldots . . . . . .139$ Blair F. Jones, Project Chief

NR 57-034 Spatial Distribution of Chemical Constituents in Ground Water . . . . . . . . . . . . . . . . . . . . . . 143 William Back, Project Chief

NR 74-041 Interface of Paleoclimatology and Aquifer Geochemistry $\ldots \ldots 147$ Isaac J. Winograd, Project Chief

NR 76-056 Kinetics and Thermodynamics of Chemical Evolution in Ground-Water Systems . . . . . . . . . . . . . . . . . . . . 150 L. Niel Plummer, Project Chief

NR 75-064 Physical Chemistry of Stable Isotope Fractionation in Hydrologic Processes . . . . . . . . . . . . . . . . . . . . . 159 Tyler B. Coplen, Project Chief

NR 78-092 Hydrogeochemical Controls on the Migration of Radionuclides from Uranium Mill Tailings . . . . . . . . . . . . . . . . . 166 Edward R. Landa, Project Chief

NR 81-122 Dispersion of Toxic and Radioactive Wastes in Ground-Water Systems . . . . . . . . . . . . . . . . . . . . . . . . . . . . 169 Warren W. Wood, Project Chief

NR 83-129 Comparative Study of Organic Degradation in Selected Hydrogeologic Environments . . . . . . . . . . . . . . . 173 Mary Jo Baedecker, Project Chief

NR 79-132 Relationship Between Chemical Quality of Natural Waters and Human Health and Disease 177

Gerald L. Feder, Project Chief 
NR 82-138 Uranium-Thorium Series Radioisotopes in Ground-Water and Surface-Water Systems . . . . . . . . . . . . . . . . . . . . 179 Thomas F. Kraemer, Project Chief

NR 91-151 Transport and Biogeochemical Fate of Organic Substances in Aquatic Environments . . . . . . . . . . . . . . . . . 181 Robert P. Eganhouse, Project Chief

WR 68-036 Factors Determining Solute Transfer in the Unsaturated Zone . . . . . . . . . . . . . . . . . . . . . . . . . . 184 Ronald V. James, Project Chief

WR 70-065 Partitioning of Solutes between Solid and Aqueous Phases . . . 186 James A. Davis, III, Project Chief

WR 91-080 Stable Isotope Tracers of Biogeochemical and Hydrologic Processes

Carol Kendall, Project Chief

WR 76-139 Geochemistry of Water in Fine Grained Sediments . . . . . . . 199 Yousif K. Kharaka, Project Chief

WR 79-165 Chemical and Isotope Studies of Thermal Waters of the Western United States . . . . . . . . . . . . . . . 203 Robert H. Mariner, Project Chief

WR 84-189 Chemistry of Aquatic Organic Matter . . . . . . . . . . . . 207 Donald F. Goerlitz, Project Chief

WR 88-196 Geochemical Reactions Between Water and Mineral Substrates . . . 210 Arthur F. White, Project Chief

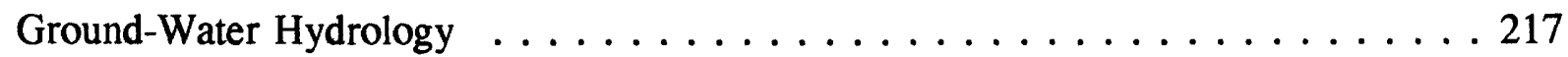

CR 73-085 The Mathematical Simulation of the Transport and Reaction of Chemical Species in Ground Water . . . . . . . . . 218 David B. Grove, Project Chief

CR 74-090 The Role of Lakes in the Hydrologic System, with Emphasis on Their Relation to Ground Water 220 Thomas C. Winter, Project Chief 
CR 64-140 Borehole Geophysics as Applied to Geohydrology . . . . . . . . 224 Frederick L. Paillet, Project Chief

CR 76-191 Mathematical Simulation of Subsurface-Water Flow Using Uncertain and Incomplete Data . . . . . . . . . . . . . 231 Richard L. Cooley, Project Chief

CR 69-200 Field Applications of Unsaturated Zone Flow Theory . . . . . 236 Edwin P. Weeks, Project Chief

CR 85-292 Ground-Water Solute-Transport Simulation . . . . . . . . . . . . . 242 Kenneth L. Kipp, Project Chief

CR 90-319 Application of Stochastic Processes in Hydrogeology . . . . . . . 246 Richard L. Naff, Project Chief

NR 81-035 Hydrologic Behavior of Cretaceous Shales . . . . . . . . . . 249 Christopher E. Neuzil, Project Chief

NR 78-089 Investigations of Single and Multiphase Fluid Flow, Mass and Energy Transport, and Fluid Phase Change in the Subsurface Environment . . . . . . . . . . . . . 251 Clifford I. Voss, Project Chief

NR 81-120 Digital Modeling of Transport in the Saturated Zone . . . . . . . 254 Leonard F. Konikow, Project Chief

NR 84-130 Multivariate Statistical Techniques for Assessing Regional Ground-Water Quality and Quantity . . . . . . . . . . . . 259 Charles E. Brown, Project Chief

NR 84-134 Transport Phenomena in Fractured Rock . . . . . . . . . . . . 261 Allen M. Shapiro, Project Chief

NR 91-152 Quantitative Analysis of Heterogeneous Hydrogeologic Controls on Ground-Water Flow and Transport . . . . . . . . 265 Thomas E. Reilly, Project Chief

NR 91-153 Reaction-Transport Phenomena in Hydrogeologic Settings . . . . . 269 Ward Sanford, Project Chief 
WR 63-024 Application of the Unsaturated Flow Theory to the Phenomena of Infiltration . . . . . . . . . . . . . . . . . . 271 David A. Stonestrom, Project Chief

WR 73-102 Modeling and Monitoring Heat and Fluid Flow in Geothermal Systems . . . . . . . . . . . . . . . . . . . . . 274 Michael L. Sorey, Project Chief

WR 72-108 Technical Coordination and Support of Water Resources Division Geothermal Studies 277 Michael L. Sorey, Project Chief

WR 74-121 Hydrologic Studies of Heat and Mass Transport . . . . . . . . . . 279 Steven E. Ingebritsen, Project Chief

WR 75-127 Analytical Modeling of Flow and Transport in Aquifers and Geothermal Reservoirs . . . . . . . . . . . . . . . . . . 282 Allen F. Moench, Project Chief

WR 75-176 Water Wells as Strain Meters . . . . . . . . . . . . . . . 284 John D. Bredehoeft, Project Chief

WR 82-178 Ground-water Monitoring Network Design . . . . . . . . . . . 288 Brian J. Wagner, Project Chief

WR 82-179 Nonisothermal Multiphase Flow . . . . . . . . . . . . . . . 290 William N. Herkelrath, Project Chief

WR 82-180 Theories of Water Flow and of Solute Transport in the Unsaturated Zone . . . . . . . . . . . . . . . . . . . . 293 Jacob Rubin, Project Chief

WR 83-184 Hydrology of Fractured Rocks . . . . . . . . . . . . . . . 296 Paul A. Hsieh, Project Chief

WR 87-193 Temperature Effects in the Unsaturated Zone . . . . . . . . . 300 James E. Constantz, Project Chief

WR 89-198 Physical Characteristics that Determine Flow in the Unsaturated Zone . . . . . . . . . . . . . . . . . . . . . . . 302 John R. Nimmo, Project Chief 
WR 89-199 The Fate and Transport of Immiscible Contaminants in the

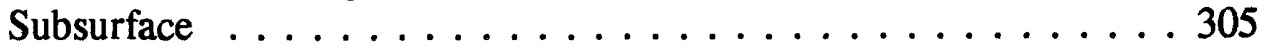

Hedeff I. Essaid, Project Chief

Surface-Water Chemistry . . . . . . . . . . . . . . . . . . . . . . . . . . 309

CR 68-046 Origin, Characterization, and Quantification of Natural

Organic Solutes in Water . . . . . . . . . . . . . 310

Ronald L. Malcolm, Project Chief

CR68-132 Behavior of Natural Polyelectrolytes in Water . . . . . . . . . 314 Robert L. Wershaw, Project Chief

CR75-189 Geochemical Kinetics Studies of Silicate Rock Hydrologic

Systems . . . . . . . . . . . . . . . . . 320

Hans C. Claassen, Project Chief

CR83-282 Research in Analytical Environmental Trace Element

Chemistry and Its Impact on Water Quality . . . . . . . 323

Howard E. Taylor, Project Chief

CR83-284 Aqueous Crystal Growth and Dissolution Kinetics of Earth

Surface Minerals . . . . . . . . . . . . . . . . . 327

Michael M. Reddy, Project Chief

CR84-285 Comprehensive Organic Analysis of Water . . . . . . . . . 331

Jerry A. Leenheer, Project Chief

CR77-301 Transport and Degradation of Organic Substances in

Streams . . . . . . . . . . . . . . . . . . . . . 337

Ronald E. Rathbun, Project Chief

CR88-313 Sediment-Water Chemistry in Large River Systems:

Biogeochemical, Geomorphic, and Human Controls . . . . . . 340

Robert F. Stallard, Project Chief

CR 93-331 Organic Carbon Migration in Aquatic Environments . . . . . . 345

George R. Aiken, Project Chief

NR 76-065 Sedimentary Geochemical Processes Affecting the Exchange

of Nutrients and Transition Metals Between Sediment and

Water in Riverine, Estuarine, and Lacustrine Environments . . . . . 348

Edward Callender, Project Chief 
NR 79-099 Carbon Fluxes in Hydrologic and Geologic Processes . . . . . . . 352 Eric T. Sundquist, Project Chief

NR 81-109 Geochemical Cycling of Trace Elements and Nutrients in Natural Water Systems . . . . . . . . . . . . . . . . 355 Owen P. Bricker, Project Chief

NR 86-135 Distribution and Speciation of Metals in Sedimentary

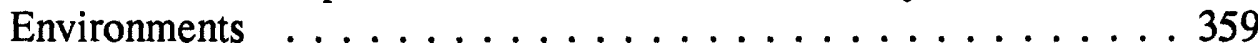
Nancy S. Simon, Project Chief

WR 57-076 Chemistry of Hydrosolic Metals and Related Constituents of Natural Water . . . . . . . . . . . . . . . . 362 John D. Hem, Project Chief

WR 83-204 Origin, Fate, and Transport of Organic Compounds in Surface and Ground Waters and Their Effect on Water Quality ...................... 366 Wilfred E. Pereira, Project Chief

Surface-Water Hydrology . . . . . . . . . . . . . . . . . . . . . . . . . . . 369

CR 77-228 Precipitation-Runoff Modeling of Watershed System . . . . . . . 370 George H. Leavesley, Project Chief

CR 83-279 Statistical Analysis of Errors in Hydrologic Models . . . . . . . 380 Brent M. Troutman, Project Chief

CR 90-321 Paleohydrology and Climate Change . . . . . . . . . . . . . 384 Robert D. Jarrett, Project Chief

CR 94-341 Lake-Atmosphere Interations . . . . . . . . . . . . . 388 S. W. Hostetler, Project Chief

CR 84-343 Mathematical Modeling Principles . . . . . . . . . . . . 391 James P. Bennett, Project Chief

NR 69-019 Numerical Simulation of Hydrodynamic Processes in Rivers, Estuaries, and Coastal Embayments . . . . . . . . . 393 Robert A. Baltzer, Project Chief 
NR 80-104 Simulation Modeling of Hydrodynamic Systems . . . . . . . . . 397 Raymond W. Schaffranek, Project Chief

NR 82-125 Hydrologic Regression and Data-Network Design . . . . . . . . 401 Gary D. Tasker, Project Chief

NR 84-133 Regional Hydrologic Processes . . . . . . . . . . . . . . . 405 Jurate M. Landwehr, Project Chief

NR 88-144 Continental Hydrology and Global Climate . . . . . . . . . . . 408 P.C.D. Milly, Project Chief

NR 90-147 Transport of Dissolved and Suspended Materials in Surface Waters . . . . . . . . . . . . . . . . . . 411 Jonathan Lee, Project Chief

WR 76-140 Hydrodynamics and Mathematical Modeling of Circulation and Transport Phenomena in Tidal Estuaries . . . . . . . . . 414 Ralph T. Cheng, Project Chief

WR 77-156 Research Vessel Polaris Operations in San Francisco Bay and Adjacent Coastal Ocean . . . . . . . . . . . . . . 418 T. John Conomos, Project Chief

WR 83-183 Analysis and Modeling of Conservative and Nonconservative Transport Processes . . . . . . . . . . . . . . . . . . . . . 419 Roy A. Walters, Project Chief

WR 84-187 Coupled Transport and Geochemical Processes Determining the Fate of Chemicals in Surface Waters . . . . . . . . . . 422 Kenneth E. Bencala, Project Chief

WR 83-194 Fluvial Processes and River Mechanics . . . . . . . . . . . . 427 Cheng-lung Chen, Project Chief

APPENDIXES 431

Appendix 1.-Alphabetical Listing by Project Chief $\ldots \ldots \ldots . \ldots \ldots 32$ Appendix 2.-Topical Listing . . . . . . . . . . . . . . . . . . . . 441 


\title{
THE NATIONAL RESEARCH PROGRAM OF THE U.S. GEOLOGICAL SURVEY, WATER RESOURCES DIVISION FISCAL YEAR 1994
}

\author{
Compiled by MARTHA L. NICHOLS
}

\section{ABSTRACT}

This report provides current information about the National Research Program (NRP) of the U.S. Geological Survey's Water Resources Division (WRD) during fiscal year 1994. Organized by NRP's six research disciplines-ecology, geomorphology and sediment transport, ground-water chemistry, ground-water hydrology, surface-water chemistry, and surface-water hydrology-the volume contains a summary of the problem, objective, approach, and progress for each project that was active during fiscal year 1994. It also contains bibliographic information that, because of the long-term nature of the program, covers a 5-year period.

\section{INTRODUCTION}

This report, one in a series of annual reports, provides current information about the National Research Program (NRP) of the U.S. Geological Survey's Water Resources Division (WRD) during fiscal year 1994. Organized by NRP's six research disciplines, the volume contains a summary of the problem, objective, approach, and progress for each project that was active during fiscal year 1994. It also contains bibliographic information that, because of the long-term nature of the program, covers a 5-year period. The bibliographic information does not include abstracts or informal reports. Rather it contains those reports that are readily available in the form of journal articles, U.S. Geological Survey (USGS) publications, book chapters, or books.

\section{BACKGROUND}

The National Research Program has been an integral part of the U.S. Geological Survey's Water Resources Division since the late 1950's. The NRP conducts basic and problem-oriented research in support of the mission of the U.S. Geological Survey. Relevant hydrologic information provided by the USGS is available today to assist the Nation in solving its water problems because of a conscious decision made in years past to invest in research. The NRP is designed to encourage pursuit of research topics aimed at providing 
new knowledge and insights into varied and complex hydrologic processes that are not well understood. The emphasis of these research activities changes through time, reflecting the emergence of promising new areas of inquiry and the demand for new tools and techniques with which to address water-resources issues. Knowledge gained and methodologies developed in this program apply to all of the hydrologic investigations of the USGS, to the water-oriented investigations and operations of other agencies and to the general scientific community. Through the years, many of the Geological Survey's major research and resource assessment initiatives related to existing and emerging national water-resources problems have had their origins in the NRP.

Since its beginning in the late 1950's, the NRP has grown to encompass a broad spectrum of scientific investigations. The sciences of hydrology, mathematics, chemistry, physics, ecology, biology, geology, and engineering are used to gain a fundamental understanding of the processes that affect the availability, movement, and quality of the Nation's water resources. Results of NRP's long-term research investigations often lead to the development of new concepts, techniques, and approaches that are applicable not only to the solution of current water problems but also to future issues that may affect the Nation's water resources. Basic tools of hydrology that have been developed by the NRP include ground-water modeling, geochemical modeling, and regional flood frequency analysis. These and other tools developed by the NRP are in common use today throughout the USGS, in other agencies, and in the private sector.

In consultation with NRP managers and research advisors, NRP projects set long-term research goals. Projects typically conduct research during a period of several years as studies progressively resolve questions of great complexity. In conducting such long-term efforts, most projects employ a combination of detailed field observations, laboratory experiments and analyses, and some kind of conceptual or mathematical modeling of the processes involved. Often, NRP projects cooperate with WRD District projects and other NRP projects to conduct multidisciplinary studies-combining, for example, ground-water flow with ground-water chemistry or surface-water chemistry and ecology.

\section{ORGANIZATION OF THE NATIONAL RESEARCH PROGRAM}

The NRP is located principally in Reston, Virginia; Denver, Colorado; and Menlo Park, California. A Chief, Branch of Regional Research (BRR), at each location is responsible for managing the program and serves as a liaison with the WRD's operational program. The Chief, BRR, reports directly to the Chief, Office of Hydrologic Research, who oversees the entire program. Organized into about 120 projects, the NRP program has a permanent staff of approximately 290 individuals and a nonpermanent staff that is made up primarily of university students and faculty. 
For technical administration, the NRP is subdivided into six disciplines with a Research Adviser and Assistant Research Adviser assigned to each. The Research Advisers serve as a peer resource to the research projects and as a technical consultant to management. The six research disciplines, the scope of their activity, and the emphasis of current study are listed below:

(1) Ecology.-Concerned with biological and microbiological processes that affect the quality of water. To improve understanding of the biological effects of stress, hydrologic events, and climatic trends, the solute composition of and solute transport in surface and subsurface waters are investigated and studies are made of the response of organisms to environmental factors. Current investigations include studies of the influence of microbial processes on the fate of hazardous substances in ground water; the effect of geochemical processes on the transfer of hazardous substances to food chains that could include humans; the effect of hydrologic processes and associated environmental variables on the composition of benthic and pelagic communities; the use of organisms to help quantify and identify hydrologic events, such as floods or stress inputs; and the effect of microbial production and transformations of organic materials in the carbon, nitrogen, and sulfur cycles. Most studies are process-oriented and emphasize the interaction of physical and chemical aspects of hydrology with biological processes. The types of hydrologic regimes included in these ecological investigations range from ground waters to lakes, rivers and estuaries, and from coastal wetlands to forests and deserts.

(2) Geomorphology and sediment transport.-Focuses on the understanding of channel morphology and erosional processes that govern the source, mobility, and deposition of sediment. Currently, research is aimed primarily at providing the capability for deterministic and stochastic modeling, modeling sediment transport in alluvial channels, and assessing the causes of changes in stream-sediment loads with time and the rates at which rivers adjust to changes in the quantity of water and sediment contributed to the channel.

(3) Ground-water chemistry.-Concerned with inorganic, organic, and biochemical reactions affecting natural and contaminated water in relation to mineralogic, geochemical, and hydrologic conditions in the ground-water environment. Laboratory research includes studies of the kinetics and mechanisms of electron-transfer reactions between mineral surfaces and aqueous solutions, the adsorption behavior of inorganic and organic solutes on particulate surfaces, the kinetics of silicate and carbonate mineral dissolution and crystal growth, isotopic fractionation in mineral-water-gas systems, the exchange properties of clays, and the thermodynamics of solubility and coprecipitation phenomena. Field studies involve controls of mineral-water-gas reactions in a wide variety of hydrochemical environments including shallow ground-water systems, regional aquifer systems, deep sedimentary basins and subsurface brines, geothermal systems, freshwater- 
saltwater interfaces, and the unsaturated zone. Studies include investigations of the degradation of organic matter and attenuation of toxic metals in environmentally stressed hydrochemical environments, relations between water quality and human health and disease, and physical and chemical processes affecting dispersion of dissolved solutes. Extensive applications of isotope data are made to identify water sources, crossformational leakage, water age, paleoclimatic conditions, and reactants and products in the ground-water environment. Current modeling research focuses on the speciation of metals and other dissolved solutes in natural and contaminant waters, prediction of the thermodynamic properties of mineral-water reactions in ground-water systems, including brines and other highly saline fluids, prediction of chemical and isotopic evolution in water-rock systems, and age-dating ground water.

(4) Ground-water hydrology.-Focuses on developing understanding and techniques for evaluating and predicting the quantity and quality of water moving through porous and fractured media in order to effectively manage ground-water resources. Research into the role of the unsaturated zone is being conducted to provide information needed to evaluate ground-water conservation and management practices, such as artificial recharge, phreatophyte control, and the reduction of evapotranspiration. Currently, investigations of land subsidence are underway as are studies to determine how fracture zones, permeability distributions, and geothermal conditions affect, or are affected by, subsurface hydrologic processes. Comprehensive studies in borehole geophysics are being conducted to improve the resolution and effectiveness of these subsurface techniques. Efforts also are being made to develop new models and to refine existing two- and three-dimensional models for use in understanding flow and solute transport in porous media in both the saturated and unsaturated zones. Parameter-estimation techniques to enhance and assess model accuracy also are being developed.

(5) Surface-water chemistry. - Involves an assessment of natural and contaminant chemicals in water and sediment, as well as the study of fundamental chemical and biochemical processes that affect the movement of organic and inorganic solutes and gases through primarily surface-water systems. Projects now underway include characterization of natural and manmade organic substances, identification of organic pollutants in natural waters, interaction of trace metals and radionuclides with natural organic substances and sediments, study of biodegradation processes of organic compounds, study of climate and carbon fluxes, hydrochemistry and paleoclimatology in arid regions, investigations of nutrient and metal fluxes in natural-water systems, study of the effect of contaminated precipitation on corrosion of building materials, and study of the effects of acid rain on water quality.

(6) Surface-water hydrology.-Stresses studies to develop understanding and techniques needed to improve the ability to predict the occurrence, distribution, movement, and 
quantity of the Nation's surface-water resources, and to explain quantitatively how these resources may be affected by natural or human-induced changes. Ongoing projects generally can be grouped into studies of: (a) all hydrologic processes that govern the infiltration, evapotranspiration and runoff from basins, especially as they relate to an analysis of the effect of land uses such as surface mining, agriculture, and urbanization; (b) the laws of random processes and how these laws are related to the statistics of extreme events, such as floods, droughts, or other natural hazards; the areal distribution of hydrologic information; and the accuracy and reliability of deterministic models of hydrologic systems; (c) the hydraulics or hydrodynamics of flow in single or multidimensional surface-water systems, and how this flow is related to the safety and welfare of people that encroach on the water body; (d) the sources, transport, and fate of constituents that are related to water quality in surface waters; and (e) the accumulation, movement, and melting of snow or ice, particularly the ways in which the presence of affects climate, water supply, and (or) safety.

\section{TECHNOLOGY TRANSFER}

The dissemination of the new understanding and techniques that are developed by the research projects is considered an important NRP activity. Results from NRP studies are published in appropriate publication outlets to assure wide dissemination of research results. Outlets include refereed scientific journals and USGS Water-Supply Papers and Professional Plapers. Knowledge of new techniques for hydrologic investigations, such as: sampling methods, laboratory methods, or mathematical models, and other research results is transferred to the scientific community and to the public through presentations at professional society meetings and other scientific and public gatherings as well as through publications. Furthermore, to disseminate research knowledge within and throughout the USGS, project personnel conduct appropriate USGS training courses, collaborate with and advise other USGS scientists, and provide technical programmatic advice to USGS management.

This report is intended to help with technology transfer by describing the work in progress, the expertise, and most importantly the publications produced by the NRP. Readers are encouraged to seek copies of these publications from the specific NRP project that prepared them. Addresses and phone numbers of Project Chiefs are provided in the text. For the reader's convenience two appendices are provided. The first is arranged alphabetically by the name of the Project Chief and the second is arranged alphabetically by topic. 

RESEARCH DISCIPLINES AND PROJECTS

\section{ECOLOGY}




\section{ECOLOGY}

TITLE: Interactions Between Organic Solutes and Trace Metals in Natural Waters, and Their Ecological Role (CR 84-286)

PERSONNEL: Diane M. McKnight, Project Chief

Debra A. Litwin, Secretary

Richard A. Harnish, Hydrologist

Michael W. Anthony, Student
James McGutchen, Student (University of Colorado)

Sarah A. Spaulding, Student, (Colorado State University)

ADDRESS: $\quad$ U.S. Geological Survey

3215 Marine Street

Boulder, CO 80303

TELEPHONE: (303) 541-3015

PROBLEM: Aquatic humic substances and other classes of dissolved organic material present in natural waters can control the biogeochemistry of trace metals and other solutes and can influence ecological processes in lakes and streams. The nature and reactivity of the dissolved organic material is in turn influenced by biological, chemical, and physical processes occurring in the aquatic environment. Recent advances in isolating and characterizing different fractions of the dissolved organic carbon (DOC) and in measuring rates of microbial processes can be used to advance the understanding of the dynamic relationship between aquatic biota and dissolved organic material and trace metals in different environments.

OBJECTIVE: (1) Determine the processes involved in the biogeochemistry of dissolved organic material and selected trace metals in several aquatic environments; (2) Describe the temporal and spatial dynamics controlling the concentration and chemical speciation of trace metals and DOC in aquatic environments; (3) quantify carbon and nutrient flux and other ecological processes involving dissolved solutes in aquatic ecosystems over a range of spatial and temporal scales.

APPROACH: (1) Use conventional and newly-developed methods to isolate and characterize aquatic and humic substances and other organic acids from samples collected at several ongoing field sites; (2) conduct potentiometric titrations and other laboratory experiments to determine the dependence of copper and iron complexation by humic substances and other 


\section{ECOLOGY}

organic fractions on $\mathrm{pH}$ and counterion concentration; (3) conduct field studies of biogeochemical interactions between dissolved organic material and trace metals. Field sites include two mountain streams, a shallow ground-water system and several lakes in Colorado; (4) conduct field research at lakes and ponds in the Dry Valleys in Antarctica to determine the carbon and nutrient cycling in ecosystems with only autochthonous production by algal and microbial processes; (5) Evaluate global scale interactions involving dissolved organic material and trace metals.

PROGRESS: A study of the temporal and spatial dynamics of trace metals and natural organics in St. Kevin Gulch, a mountain stream, has shown that even at neutral pH, photoreductive dissolution of hydrous iron oxides is an important process. We characterized dissolved fulvic acids and colloidal organic material from three lakes in Loch Vale, the Water, Energy, and Biogeochemical Budgets (WEBB) site in Rocky Mountain National Park. We found that colloidal organic material was a more important fraction in the subalpine lake than in the alpine lake where algal organic sources predominate. In previous research, we have developed a way to evaluate dissolved organic carbon (DOC) sources by plotting atomic $\mathrm{C} / \mathrm{N}$ ratios versus the ratio of aromatic and aliphatic carbon. We are examining this approach in Loch Vale by segregating samples from the alpine and subalpine parts of the watershed. We are conducting a study of polar desert lakes and streams in Antarctica, through the National Science Foundation (NSF)-Division of Polar Programs supported Long-Term Ecological Research (LTER) project. This past season the antarctic research included measurements of streamflow, mapping of algal distribution, and quantification of geochemical reactions in the substream zone. We have conducted a study of radionuclide transport at the Rocky Flats Plant; results indicate that interaction with organic-rich colloids are important in transport, and that complexation by dissolved fulvic acid controls the chemical speciation of dissolved plutonium.

\section{REPORTS PUBLISHED 1989-1994:}

Aiken, G.R., McKnight, D.M., Thorn, K.A., and Thurman, E.M., 1992, Isolation of hydrophilic organic acids from water using nonionic macroporous resins: Organic Geochemistry, v. 18 , no. 4 , p. $567-573$.

Aiken, G.R., McKnight, D.M., Wershaw, R.L., and Miller, L., 1991, Evidence for the diffusion of aquatic fulvic acids from the sediments of Lake Fryxell, Antarctica, in Baker,
R.A., ed., Organic substances and sediments in water: Chelsea, Mich., Lewis Publishers, p. 75-88.

Baron, Jill, McKnight, Diane and Denning, Scott, 1991, Sources of dissolved and suspended organic material in Loch Vale Watershed, Rocky Mountain National Park, Colorado, U.S.A.: Biogeochemistry, v. 15, p. 89-110. 


\section{ECOLOGY}

Bencala, K.E., Kimball, B.A., and McKnight, D.M., 1991, Use of variation in solute concentration to identify interactions of the substream zone with instream transport, in Mallard, G.E., and Aronson, D.A., eds., U.S. Geological Survey Toxics Substances Hydrology Program-Proceedings of the technical meeting, Monterey, Calif., March 11-15, 1991: Water-Resources Investigations Report 91-4034, p. 377-379.

Bencala, K.E., McKnight, D.M., and Zellweger, G.W., 1990, Characterization of transport in an acidic and metal-rich mountain stream based on a lithium tracer injection and simulations of transient storage: Water Resources Research, v. 26, no. 5, p. 989-1000.

Harnish, R.A., Ranville, J.F., McKnight, D.M., and Spalding, S.A., 1992, Redox-mediated cycling of iron and manganese in Lake Fryxell, Antarctica-Associations with particulate, colloidal, and dissolved forms: U.S. Antarctic Journal, v. XXVI, no. 5, 230-232.

Harnish, R.A., McKnight, D.M., and Ranville, J.F., 1993, Colloidal and solution-phase associations of plutonium and americium in ground water, Rocky Flats Plant, Colorado: U.S. Geological Survey Water-Resources Investigations Report 93-4175, 27 p.

Kimball, B.A., Broshears, R.E., Bencala, K.E., and McKnight, D.M., 1991, Comparison of rates of hydrologic and chemical processes in a stream affected by acid mine drainage, in Mallard, G.E., and Aronson, D.A., eds., U.S. Geological Survey Toxics Substances Hydrology Program-Proceedings of the technical meeting, Monterey, Calif., March 11-15, 1991: U.S. Geological Survey WaterResources Investigations Report 91-4034, p. 407-412.
Kimball, B.A., Broshears, B.A., McKnight, D.M. and Bencala, K.E., 1992, Effect of instream pH modification on aluminum, in Kharaka, Y.K., and Maest, A.S., eds., Proceedings of the 7th International Symposium on WaterRock Interaction, July 9-23, 1992, Park City, Utah: Rotterdam, The Netherlands, A.A. Balkema, p. 393-396.

1994, Effects of an instream pH modification on transport of sulfide-oxidation products, in Alpers, C.N., and Blowes, D.W., eds., Environmental Geochemistry of Sulfide Oxidation: American Chemical Society, chap. 16, p. 224-243.

Kimball, B.A., McKnight, D.M., Wetherbee, G.A., and Harnish, R.A., 1992, Mechanisms of iron photoreduction in a metal-rich, acidic stream (St. Kevin Gulch, Colorado, U.S.A.): Chemical Geology, v. 96, p. 227-239.

Leenheer, J.A., McKnight, D.M., Thurman, E.M., and MacCarthy, P., 1989, Structural components and proposed Structural models for Suwannee River fulvic acid, in Leenheer, J.A., Averett, R.C., McKnight, D.M., and Thorn, K.A., eds., Humic Substances in the Suwannee River, Georgia-Interactions, Properties, and Proposed Structures: U.S. Geological Survey Open-File Report 87-557, p. 331359.

Malcolm, R.L., McKnight, D.M., and Averett, R.C., 1989, The Okefenokee Swamp: Origin of the Suwannee River, in Leenheer, J.A., Averett, R.C., McKnight, D.M., and Thorn, K.A., eds., Humic Substances in the Suwannee River, Georgia-Interactions, Properties, and Proposed Structures: U.S. Geological Survey Open-File Report 87-557, p. 1-21.

McKnight, D.M., 1990, "How do organic acids interact with organisms, solutes, and particu- 


\section{ECOLOGY}

late surfaces?" in Perdue E.M., and Gjessing, E.T., eds., Organic Acids in Aquatic Ecosystems: Dahlem Konferenzen, John Wiley and Sons, p. 223-243.

1991, Feedback mechanisms involving humic substances in aquatic ecosystems, in Schneider, S.H., and Boston, P.J., eds., Scientists on Gaia: Cambridge, Mass., The MIT Press, p. 330-338.

McKnight, D.M., Aiken, G.R., Andrews, E.D., Bowles, E.C., and Miller, L., 1993, Dissolved organic material in dry valley lakes-a comparison of Lake Fryxell, Lake Hoare and Lake Vanda, in Green, W.J., ed., Physical and biogeochemical processes in Antarctic lakes: Antarctic Research Series, v. 59, p. 119-133.

McKnight, D.M., Aiken, G.R. and Smith, R.L., 1991, Aquatic fulvic acids in microbially based ecosystems-results from two desert lakes in Antarctica: Limnology and Oceanography, v. 36 , no. 5, p. 998-1006.

McKnight, D.M., and Andrews, E.D., 1993, Hydrologic and geochemical processes at the stream-lake interface in a permanently icecovered lake in the McMurdo Dry Valleys, Antarctica: Verhandelingen International Verein Limnology, v. 25, p. 957-959.

McKnight, D.M. and Bencala, K.E., 1989, Reactive iron transport in an acidic mountain stream in Summit County, Colorado-a hydrologic perspective: Geochimica et Cosmochimica Acta, v. 55, no. 9, p. 2225-2234 p.

1990, The chemistry of iron, aluminum, and dissolved organic material in three acidic, metal-enriched, mountain streams, as controlled by watershed and in-stream processes: Water Resources Research, v. 26, no. 12, p. 3087-3100.
McKnight, D.M., Bencala, K.E., Zellweger, G.W., Aiken, G.R., Feder, G.L., and Thorn, K.A., 1992, Sorption of dissolved organic carbon by hydrous aluminum and iron oxides occurring at the confluence of Deer Creek with the Snake River, Summit County, Colorado: Environmental Science and Technology, v. 26, no. 7, p. 1388-1396.

McKnight, D.M., Ranville, J.F. and Harnish, R.A., 1991, Particulate and colloidal organic material and associated trace metals in Pueblo Reservoir, Colorado, in Mallard, G.E., and Aronson, D.A., eds., U.S. Geological Survey Toxics Substances Hydrology Program-Proceedings of the technical meeting, Monterey, Calif., March 11-15, 1991: U.S. Geological Survey Water-Resources Investigations Report 91-4034, p. 428-433.

McKnight, D.M., Smith, R.L., Bradbury, J.P., Baron, J.S., and Spaulding, Sarah, 1990, Phytoplankton dynamics in three Rocky Mountain Lakes, Colorado, U.S.A.: Arctic and Alpine Research, v. 22, no. 3, p. 264274.

McKnight, D.M., Smith, R.L., Harnish, R.A., Miller, C.L., and Bencala, K.E., 1993, Seasonal relationships between planktonic microorganisms and dissolved organic material in an alpine stream: Biogeochemistry, v. 21, p. 39 $-59$.

McKnight, D.M., and Wershaw, R.L., 1989, Complexation of copper by fulvic acid from the Suwannee River-effect of counter-ion concentration, in Leenheer, J.A., Averett, R.C., McKnight, D.M., and Thorn, K.A., eds., Humic Substances in the Suwannee River, Georgia-Interactions, Properties, and Proposed Structures: U.S. Geological Survey Open-File Report 87-557, p. 59-79. 


\section{ECOLOGY}

McKnight, D.M., Wershaw, R.L., Bencala, K.E., and Feder, G.L., 1992, Humic substances and trace metals associated with $\mathrm{Fe}$ and $\mathrm{Al}$ oxides deposited in an acidic mountain stream: The Science of the Total Environment, v. 117/118, p. $485-498$.

Ranville, J.F., Harnish, R.A., and McKnight, D.M., 1991, Particulate and colloidal organic material in Pueblo Reservoir, Coloradoinfluence of autochthonous source on chemical composition, in Baker, R.A., ed., Organic Substances and Sediments in Water, Volume 1. Humics and Soils: Chelsea, Mich., Lewis Publishers, p. 47-73.

Ranville, J.F., Smith, K.S., McKnight, D.M., Macalady, D.L., and Rees, T.F., 1991, Effect of organic matter coprecipitation and sorption and sorption with hydrous iron oxides on electrophoretic mobility of particles in acid mine drainage, in Mallard, G.E., and Aronson, D.A., eds., U.S. Geological Survey Toxics Substances Hydrology Program-Proceedings of the technical meeting, Monterey, Calif., March 11-15, 1991: U.S. Geological Survey Water-Resources Investigations Report 914034, p. 422-427.

Spaulding, S.A., 1991, Phytoplankton and zooplankton under ice-cover in a subalpine lake, The Loch, Rocky Mountain National Park, Colorado, 1987-89: U.S. Geological Survey Open-File Report 91-489, 33 p.

Spaulding, S.A., McKnight, D.M., Smith, R.L., and Dufford, R., 1994, Phytoplankton population dynamics in perennially ice-covered Lake Fryxell, Antarctica: Journal of Plankton Research, v. 16(5), p. 527-541.

Tate, C.M., McKnight, D.M., and Spaulding, S.A., 1991, Phosphate uptake by algae in a stream contaminated by acid mine drainage,
St. Kevin Gulch, Leadville, Colorado, in Mallard, G.E., and Aronson, D.A., eds., U.S. Geological Survey Toxics Substances Hydrology Program-Proceedings of the technical meeting, Monterey, Calif., March 11-15, 1991: U.S. Geological Survey WaterResources Investigations Report 91-4034, p. 387-391.

Wissmar, R.C., McKnight, D.M., and Dahm, C.N., 1990, Contribution of organic acids to alkalinity in lakes within the blast zone of Mount St. Helens, Washington: Limnology and Oceanography, v. 35, no. 2, pp. 535-542.

Zellweger, G.W., Bencala, K.E., McKnight, D.M., Hirsch, R.M., and Kimball, B.A., 1988, Practical aspects of tracer experiments in acidic, metal enriched streams, in Mallard, G.A., ed., Proceedings of the technical meeting, Denver, Colorado, February 2-4, 1987: U.S. Geological Survey Open-File Report 87-764, p. $125-130$. 


\section{ECOLOGY}

TITLE: $\quad$ The Role of Chemical Fluxes in the Biogeochemistry of Inland Surface Waters, Including Lakes, Reservoirs, and Wetlands (CR 85-293)

PERSONNEL: James W. LaBaugh, Project Chief

Evelyn R. Warren, Office Auto. Assist.

Lana K. Gerlick, Office Auto. Clerk

ADDRESS: U.S. Geological Survey

P.O. Box 25046, MS 413

Denver Federal Center

Denver, CO 80225

TELEPHONE: (303) 236-4989

PROBLEM: Most studies of the biogeochemistry of inland aquatic ecosystems have been confined to processes within the water body. The effect of ground-water fluxes to the water body on ecosystem biogeochemical processes has been ignored. Detailed studies of all external chemical fluxes and their relationship to the supply and loss of biologically important chemical elements are virtually nonexistent, particularly for aquatic ecosystems lacking channelized surface-water inflow and outflow. Research on these external fluxes and their quantitative significance is critical for decision makers responsible for water quality and biological productivity of lakes, reservoirs and wetlands.

OBJECTIVE: The primary objective of hydrological-biogeochemical interaction research is to understand relative contribution of all hydrologic processes controlling fluxes of biologically important chemical elements between surface waters and their watersheds. The importance of different transport pathways affecting the supply and loss of those elements from surface water will be quantified. Although this research will emphasize experimental field work, conceptual models of hydrologicalbiological interactions will be used to identify important mechanisms to be investigated further in the field.

APPROACH: The supply and loss of biologically important chemical elements in surface waters (lakes, reservoirs, wetlands) will be quantified by field sampling and experimental studies at existing experimental field sites that have been the subject of intensive hydrologic research including onsite measurement of the entire hydrologic cycle. Field data will be used to develop empirical models and calibrate conceptual models of hydrological-biogeochemical interactions.

PROGRESS: Coauthor of one published report (U.S. Geological Survey Water Fact Sheet) and two reports in press (journal-Limnology and Oceanography, and U.S. Geological Survey Public Issues in Earth Science Circular), two reports submitted to journals, a chapter written for U.S. Fish and Wildlife Service Biological Report submitted for Survey approval, and two chapters written for U.S. 


\section{ECOLOGY}

Geological Survey Water Supply Paper (all of the latter five as senior author). Prairie wetlands in the same wetland complex (Cottonwood Lake area, North Dakota) were found to respond in different ways to common changes in climate conditions over a 27 -year period of study puncutated by intermittent wet and dry conditions, including drought and high water levels of historic magnitude. These data indicate the importance of understanding the hydrological processes that result in changes in aquatic ecosystems before those changes are used to interpret changing climate conditions.

\section{REPORTS PUBLISHED 1989-1994:}

LaBaugh, J.W., 1989, Chemical characteristics of water in northern prairie wetlands, in van der Valk, A., ed., Northern Prairie Wetlands: Ames, Iowa, Iowa State University Press, p. 56-90.

1991, Spatial and temporal variation in chemical characteristics of ground water adjacent to selected lakes and wetlands in the north-central United States: Verhandlungen Internationale Vereinigung Limnologie, v. 24, p. $1588-1594$.

LaBaugh, J.W., in press, Prairie pothole wetlands, in Owen, D.E., ed., Wetlands-Public Issues in Earth Science: U.S. Geological Survey Circular 1095, $32 \mathrm{p}$.

LaBaugh, J.W., and Swanson, G.A., 1992, Changes in chemical characteristics of water in selected wetlands in the Cottonwood Lake area, North Dakota, U.S.A., 1967-1989, in Robarts, R.D., and Bothwell, M.L., eds., Aquatic Ecosystems in semi-arid regions: Saskatoon, Saskatchewan, Environment Canada, The National Hydrology Research Institute Symposium Series 7, p. 149-162.

McConnaughey, T.A., LaBaugh, J.W., Reddy, M.M., Schuster, P.F., Rosenberry, D.O., Striegl, R.G., and Carter, V., in press, Carbon budget of a groundwater-fed lakecalcification supports summertime photosynthesis: Limnology and Oceanography, v. 00.
Rosenberry, D.O., LaBaugh, J.W., McConnaughey, T.A., Striegl, R.G., and Winter, T.C., 1994, The interdisciplinary research initiative: Hydrologic research in the Shingobee River headwaters area: U.S. Geological Survey Water Fact Sheet, Open-File Report 93-446, 2 p. 


\section{ECOLOGY}

TITLE: $\quad$ Microbial Transformation of Dissolved Organic Carbon in Aquatic Environments (CR 86-295)

PERSONNEL: Richard L. Smith, Project Chief

Betty L. Callahan, Secretary

Myron H. Brooks, Research Chemist

Craig Walker, Student

ADDRESS: U.S. Geological Survey

3215 Marine Street

Boulder, Colorado 80303

TELEPHONE: (303) 541-3032

PROBLEM: Although it is recognized that micro-organisms play an important role in the transformation of organic compounds in aquatic habitats, very little is known about the exact nature of these transformations in either pristine or contaminated environments. Within the context of in situ environmental conditions, the mechanisms, pathways, rates, and factors controlling carbon cycling by micro-organisms are poorly understood; however, these particular processes can significantly affect the entire range of biogeochemical and geochemical processes occurring within the aquatic environment.

OBJECTIVE: Study the mechanisms, pathways, and rates of transformation of organic compounds (natural and contaminant) mediated by micro-organisms in aquatic habitats and identify some of the factors controlling these transformations. Examine the effect that these transformations have upon other biogeochemical processes.

APPROACH: Select a pristine alpine stream, an amictic Antarctic lake, and a sewage-contaminated aquifer as the habitats of primary focus. Determine microbial processes in both water and sediment samples by use of tracer techniques for laboratory and field studies. Develop sample-handling techniques needed to maintain in situ conditions. Employ experiments with isolated cultures of micro-organisms, when necessary, to help interpret the results obtained with natural samples.

PROGRESS: (1) A field trial was conducted to investigate denitrification (the microbial reduction of nitrate to nitrogen gas) as a bioremediation mechanism to treat nitrate contamination in ground water. Sodium formate was continuously injected for 16 days into a nitrate-contaminated aquifer to stimulate in situ denitrification. The experiment was successful. The injection reduced ground-water nitrate concentrations by 73 percent at a sampling well located 10 meters downgradient from the injection well. However, the response time by the ground-water bacteria was longer than anticipated and nitrite 


\section{ECOLOGY}

concentrations increased. Therefore, more research is needed to learn how to better apply the approach to the ground-water environment.

(2) A natural gradient tracer test was conducted at the USGS ground-water toxics site at Cape Cod, Massachuseets, using ${ }^{15} \mathrm{~N}$ enriched nitrate to measure the in situ, endogenous activity of denitrifying bacteria in a nitrate-contaminated sand and gravel aquifer. Enrichment of ${ }^{15} \mathrm{~N}$ in nitrite, nitrous oxide, and nitrogen gas was detected after 30 days of transport, but the rate of activity was slow as compared to the rate of nitrate transport. A transport model that can be used to determine the rates of the individual steps of the denitrification pathway based on these breakthrough curves is currently being developed. The tracer test-model approach will be applicable to measure other terminal electronaccepting, microbial processes in ground water.

(3) A study was completed testing the ability of a genetically-engineered micro-organism (GEM) to survive in sewage-contaminated ground water. The purpose was to test the utility of using GEMs for ground-water bioremediation and to determine whether they could compete with indigenous populations of micro-organisms for the long term in different geochemical conditions. The organism that we tested survived for more than 15 months in contaminated ground-water, but rapidly declined in uncontaminated areas. We used gene probes specific for the organism, to conclude that there was some potential for gene exchange between the introduced bacterium and the native ground-water populations.

\section{REPORTS PUBLISHED 1989-1994:}

Brooks, M.H., 1991, Development and Evaluation of a Technique for Measuring Denitrification Enzyme Activity in Nitrate-Contaminated Ground Water: Golden, Colo., Colorado School of Mines, M.S. Thesis, $94 \mathrm{p}$.

Brooks, M.H., and Smith, R.L., 1989, Total adenylate and adenylate energy charge measurements from bacterial communities in ground water, in Mallard, G.E., and Ragone, S.E., eds., U.S. Geological Survey Toxic Substances Hydrology Program-Proceedings of the technical meeting, Phoenix, Ariz., September 26-30, 1988: U.S. Geological Survey Water-Resources Investigations Report 88-4220, p. 541-545.

Brooks, M.H., Smith, R.L., and Macalady, D.L., 1992, Inhibition of exisiting denitrification enzyme activity by chloramphenicol: Applied and
Environmental Microbiology, v. 58, p. 17461753.

Ceazan, M.L., Thurman, E.M., and Smith, R.L., 1989, Cation exchange as a retardation mechanism in an ammonium and nitrate-contaminated sand and gravel aquifer: Environmental Science and Technology, v. 23, no. 11, p. 1402-1408.

Harvey, R.W., Garbedian, S.P., Smith, R.L., Barber, L.B., Metge, D.W., and Scholl, M.A., 1991, The role of physical and chemical heterogeneity in the interpretation of small-scale tracer tests involving micro-organisms, in Mallard, G.E., and Aronson, D.A., eds., U.S. Geological Survey Toxic Substances Hydrology Program-Proceedings of the technical meeting, Monterey, Calif., March 11-15, 1991: U.S. Geological Survey Water- 


\section{ECOLOGY}

Resources Investigations Report 91-4034, p. 148-151.

Harvey, R.W., George, L.H., Smith, R.L., and LeBlanc, D.R., 1989, Transport of microspheres and indigenous bacteria through a sandy aquifer-Results of natural and forcedgradient groundwater tracer experiments: Environmental Science and Technology, v. 23, no. 1, p. 51-56.

Howes, B.L., and Smith, R.L., 1990, Sulfur cycling in a permanently ice covered amictic Antarctic lake, Lake Fryxell: Antarctic Journal of the U.S., v. xxv, p. 230-233.

Krumme, M.L., Smith, R.L., and Dwyer, D.F., 1990 , Survival of genetically engineered micro-organisms and their ability to catabolize substituted benzoates in aquifer microcosms, in Fliermans, C.B., and Hazen, T.C., eds., Proceedings of the First International Symposium on Microbiology of the Deep Subsurface: Aiken, S.C., Westinghouse Savannah River Co. Information Services, p. 7-117 to 7-126.

1991, Survival of a model pollutant-degrading micro-organism in a sand and gravel aquifer and in microcosms, in Mallard, G.E., and Aronson, D.A., eds., U.S. Geological Survey Toxic Substances Hydrology Program-Proceedings of the technical meeting, Monterey, Calif., March 11-15, 1991: U.S. Geological Survey Water-Resources Investigations Report 91-4034, p. 144-147.

Krumme, M.L., Smith, R.L., Thiem, S.M., Egestorff, J., Tiedje, J.M., Timmis, K.N., and Dwyer, D., 1994, Small-scale field tests and microcosms for prediciting behavior of genetically modified bacteria in aquifers: Environmental Science and Technology, v. 28, no. 6, p. 11341138.
McKnight, D.M., Aiken, G.R., and Smith, R.L., 1991, Aquatic fulvic acids in microbially-based ecosystems-results from two Antarctic desert lakes: Limnology and Oceanography, v. 36, p. 998-1006.

McKnight, D.M., Smith, R.L., Bradbury, J.P., Baron, J.J., and Spaulding, S., 1990, Phytoplankton dynamics in Rocky Mountain lakes, Colorado, U.S.A.: Arctic and Alpine Research, v. 22, no. 3, p. 264-274.

McKnight, D. M., Smith, R. L., Harnish, R. A., Miller, C.L., and Bencala, K.E., 1993, Seasonal relationships between planktonic microorganisms and dissolved organic material in an alpine stream: Biogeochemistry, v. 21, p. 39-59.

Metge, D.W., Brooks, M.H., Smith, R.L., and Harvey, R.W., 1993, Effect of treated sewage contamination upon bacterial energy charge, adenylates, and DNA content in a sandy aquifer on Cape Cod: Applied and Environmental Microbiology, v. 59, no. 7, p. 2304-2310.

Oremland, R.S., Miller, L.G., Culbertson, C.W., Robinson, S.W., Smith, R.L., Lovley, D.R., Whiticar, M.J., King, G.M., Kiene, R.P., Iversen, N., and Sargent, M., 1993, Aspects of the biogeochemistry of methane in Mono Lake and the Mono Basin of California, in Oremland, R.S., ed., Biogeochemistry of global change, radioactively active trace gases: New York, Chapman and Hall, p. 704-41.

Smith, R.L., Brooks, M.H., and Ceazan, M.L., 1992, The use of natural gradient tracer tests to identify and quantify microbial processes occurring in ground water, in Stanford, J.A., and Simons, J.J., eds., Proceedings of the First International Conference on GroundWater Ecology: American Water Resources Association, p. 59-65. 


\section{ECOLOGY}

Smith, R.L., and Ceazan, M.L., 1991, Isolation and characterization of autotrophic, hydrogenoxidizing, denitrifying bacteria from ground water as potential agents for bioremediation of nitrate contamination, in Mallard, G.E., and Aronson, D.A., eds., U.S. Geological Survey Toxic Substances Hydrology Program-Proceedings of the technical meeting, Monterey, Calif., March 11-15, 1991: U.S. Geological Survey Water-Resources Investigations Report 91-4034, p. 123-127.

Smith, R.L., Ceazan, M.L., and Brooks, M.H., 1994, Autotrophic, hydrogen-oxidizing denitrifying bacteria in ground water, potential agents for bioremediation of nitrate contamination: Applied and Environmental Microbiology, v. 60 , no. 6, p. 1949-1955.

Smith, R.L. and Harvey, R.W., 1990, Development of sampling techniques to measure in situ rates of microbial processes in a contaminated sand and gravel aquifer, in Fliermans, C.B., and Hazen, T.C., eds., Proceedings of the First International Symposium on Microbiology of the Deep Subsurface: Aiken, S.C., Westinghouse Savannah River Co. Information Services, p. 2-19 to 2-32.

Smith, R.L., Harvey, R.W., and LeBlanc, D.R., 1991, Importance of close-interval vertical sampling in delineating chemical and microbiological gradients in groundwater studies: Journal of Contaminant Hydrology, v. 7, p. 285-300.

Smith, R.L., and Howes, B.L., 1990, Bacterial biomass and heterotrophic activity in the water column of an amictic Antarctic lake: Antarctic Journal of the United States, v. xxv, p. 233235.

Smith, R.L., Howes, B.L., and Duff, J.H., 1989, The use of tracer tests to measure the transport and consumption of methane in a contaminated aquifer, in Mallard, G.E., and Ragone, S.E. eds., U.S. Geological Survey Toxic Substances Hydrology Program-Proceedings of the technical meeting, Phoenix, Ariz., Sept. 26-30, 1988: U.S. Geological Survey WaterResources Investigations Report 88-4220, p. 167-175.

1991, Denitrification in nitrate-contaminated ground water-occurrence in steep vertical geochemical gradients: Geochimica et Cosmochimica Acta, v. 55, no. 7, p. 1815-1822.

1991, Effects of denitrification on nitrogen geochemistry in a nitrate-contaminated sand and gravel aquifer, Cape Cod, Massachusetts, in Mallard, G.E., and Aronson, D.A., eds., U.S. Geological Survey Toxic Substances Hydrology Program-Proceedings of the technical meeting, Monterey, Calif., March 11-15, 1991: U.S. Geological Survey WaterResources Investigations Report 91-4034, p. 128-134.

Smith, R.L., Howes, B.L., and Garabedian, S.P., 1991, In situ measurement of methane oxidation in ground water using natural gradient tracer tests: Applied and Environmental Microbiology, v. 57, p. 1997-2004.

Smith, R.L., Miller, L.G., and Howes, B.L., 1993, The geochemistry of methane in Lake Fryxell, an amictic, permanently ice-covered, Antarctic lake: Biogeochemistry, v. 21, p. 95115.

Spaulding, S.A., McKnight, D.M., Smith, R.L., and Dufford, R., 1994, Phytoplankton population dynamics in perennially ice-covered Lake Fryxell, Antarctica: Journal of Plankton Research, v. 16, no. 5, p. 527-541. 


\section{ECOLOGY}

Thiem, S.M., Krumme, M.L., Smith, R.L., and Tiedje, J.M., 1994, Use of molecular techniques to evaluate the survival of a microorganism injected into an aquifer: Applied and Environmental Microbiology, v. 60, no. 4, p. 1059-1067.

Walton-Day, K., Macalady, D.L., Brooks, M.H., and Tate, V.T., 1990, Field methods for determination of ground water redox chemical parameters: Ground-Water Monitoring Review, v. 10, p. 81-89. 


\title{
ECOLOGY
}

TITLE: Characterization of Biotic and Biogeochemical Interactions at Environmental Interfaces (CR 91-320)

PERSONNEL: Robert G. Striegl, Project Chief

Evelyn R. Warren, Secretary

Edward A. McConnaughey, Hydrologist

Kimberly Wickland, Biologist

Lana K. Gerlick, Clerk

\author{
Patrick G. Hern, Student \\ (University of Colorado) \\ Catherine Michmerhuizen, Student \\ (University of Minnesota)
}

\section{TELEPHONE: (303) 236-4993}

PROBLEM: Recent increases in the atmospheric concentrations of carbon dioxide and methane have emphasized the need for a more complete understanding of the processes that control carbon transfer among air, land, and water. Knowledge of the amount, rate and chemical form of carbon transfer across environmental interfaces, such as the land-air and water-air interfaces, is of particular importance. These fluxes are commonly controlled by a combination of physical, biological, and chemical processes at or near the interface. Isolation of the primary mechanisms that determine carbon transfer across the interface allows for development of process-based models that can be used for carbon mass-transfer estimates at the ecosystem or landscape scale. This process-based knowledge is also useful for prediction of the long-term effects of land- or water-use change on carbon mass transfer rates.

OBJECTIVE: Characterize and quantify the carbon transfers that naturally environmental interfaces, and isolate the physical, biological and chemical controls of those fluxes. Where possible, evaluate the effects of environmental change on the observed interactions. Develop process based models that explain field and laboratory observations.

APPROACH: Select field sites that represent a range in abiotic and biotic conditions that control carbon transfer across environmental interfaces, and systematically measure relevant control variables and fluxes. Conduct field and laboratory experiments to test hypothesized interactions. Current investigations are focused on characterization of carbon dioxide and methane transfer across land-air and water-air interfaces. Emphasis is placed on the physical and geochemical properties that control carbon dioxide and methane transport and on factors that control the production and consumption of these gases by microbiota in soil, fresh water, and sediments. 


\section{ECOLOGY}

PROGRESS: Research is underway at the Boreal Ecosystem Atmosphere Study (BOREAS) site in Saskatchewan, Canada. We are studying the influence of forest clear-cut practices on carbon dioxide and methane flux in Jack Pine forest.

A test hole was drilled to the water table in the Amargosa Desert, Nevada, and gas sampling ports were installed throughout the overlying unsaturated zone. Study of the upward migration of carbon dioxide and water vapor from the water table to the atmosphere is ongoing.

Study of methane cycling in the North temperate lakes region indicate that up to 80 percent of $\mathrm{CH}_{4}$ released from lake sediments is oxidized in the water column. The remainder is released to the atmosphere. Spring release of $\mathrm{CH}_{4}$ accumulated in lake water under-ice cover was measured at 20 lakes in Minnesota and Wisconsin during the spring of 1993. The magnitude of these fluxes was related to lake landscape position and hydrogeologic setting. Springtime $\mathrm{CH}_{4}$ flux estimates are being made for the United States portions of the north temperate lakes region. Measurements of atmospheric $\mathrm{CO}_{2}$ exchange with lakes at the Interdisciplinary Research Initiative (IRI) site indicate that some lakes in the same watershed continually de-gas $\mathrm{CO}_{2}$ throughout the summer, while others continually uptake $\mathrm{CO}_{2}$. Chemical and biological control of these processes are being studied.

Numerical modeling of gas movements in and near static chambers placed on the soil surface indicates that the chambers substantially under measure actual flux. The chambers actually disrupt the gradient (and decrease the flux) that they are intended to measure. Field measurements verify the predicted decrease.

\section{REPORTS PUBLISHED 1989-1994:}

McConnaughey, T.A., 1991, Calcification in Chara corallina $-\mathrm{CO}_{2}$ hydroxylation generates protons for bicarbonate assimilation: Limnology and Oceanography, v. 36, p. 619-628.

McConnaughey, T.A., and Falk, R.H., 1991, Calcium proton exchange during algal calcification: Biological Bulletin, v. 180, p. 180-195.

Peters, C.A., Striegl, R.G., Mills, P.L. and Healy, R.W., 1991, Effects of low-level radioactivewaste disposal on water chemistry in the unsaturated zone at a site near Sheffield, Illinois: U.S. Geological Survey Water-Supply Paper 2390, 74 p.
Shen, G.T., Cole, J.E., Lea, D.W., Linn, L.J., McConnaughey, T.A., and Fairbanks, R.G., 1992, Surface ocean variability at Galapagos from 1936-1982-Calibration of geochemical tracers in corals: Paleoceanography, v. 7, no. 5, p. 563-588.

Striegl, R.G., 1990, Radioactive gases at low-level radioactive-waste repository sites, in Bedinger, M.S., and Stevens, P.R., eds., Safe disposal of radionuclides in low-level radioactive-waste repository sites: U.S. Geological Survey Circular 1036, p. 40-44.

1991, Gases in the unsaturated zone, in Ryan, B.J., ed., Results of hydrologic research at a low-level radioactive waste disposal site near 


\section{ECOLOGY}

Sheffield, Illinois: U.S. Geological Survey

Water-Supply Paper 2367. p. 69-80.

1991, Processes controlling the transfer of carbon-14 at radioactive waste disposal sites, in Trask, N.J., and Stevens, P.R., eds., U.S. Geological Survey Research in Radioactive Waste Disposal: U.S. Geological Survey Water-Resources Investigations Report 914084, p. 71-72.

1993, Diffusional limits to the consumption of atmospheric methane by soils: Chemosphere, v. 26 , p. $715-720$.

1993, Consumption of atmospheric methane in unsaturated soils, in Kelmelis, J.A., and Snow, M., eds., Proceedings of the U.S. Geological Survey Global Change Research Forum, March 18-20, 1991: U.S. Geological Survey Circular 1086, p. 111-112.

Striegl, R.G. and Armstrong, D.E., 1990, Carbon dioxide retention and carbon exchange on unsaturated quaternary sediments: Geochimica et Cosmochimica Acta, v. 54, no. 8, p. 2277-2283.

Striegl, R.G. and Healy, R.W., 1990, Transport of 14-carbon dioxide in unsaturated glacial and eolian sediments, in Bassett, R.L. and Melchoir, D.C., eds., Chemical Modeling in Aqueous Systems II: American Chemical Society Symposium Series, no. 416 , chap. 15, p. 202-210.

Striegl, R.G., McConnaughey, T.A., Thorstenson, D.L., Weeks, E.P. and Woodward, J.C., 1992, Consumption of atmospheric methane by desert soils: Nature, v. 357, p. 145-147.

Tate, C.M., and Striegl, R.G., 1993, Methane consumption and carbon dioxide emission in tallgrass prairie-effects of biomass burning and conversion to agriculture: Global Biogeochemical Cycles, v. 7, no. 4, p. 735-748. 


\section{ECOLOGY}

TITLE: Interdisciplinary Research Initiative (IRI) at the Shingobee Headwaters Research Area, Minnesota (CR 90-323)

PERSONNEL: Thomas C. Winter, Project Chief

Dennis Merk, Technician

ADDRESS: $\quad$ U.S. Geological Survey

P.O. Box 25046, MS 413

Denver Federal Center

Denver, CO 80225

TELEPHONE: (303) 236-4987

PROBLEM: Many advances in hydrologic research are limited by the lack of communication between specialists in the large number of disciplines involved in studying the hydrologic system. For example, nearly all specialists need estimates of the fluxes to and from the component of the hydrologic system with which they are dealing. Lack of interaction among specialists studying the interfaces of hydrologic components such as at the ground-water-surface-water interface, or the earthatmosphere interface has stymied progress in understanding the mutual interdependence of physical, chemical and biological processes on the site scale as well as on the landscape scale. Ecosystems that integrate all components of the hydrologic system and all phases of matter, such as lakes, are in greatest need of interdisciplinary research.

OBJECTIVE: The Interdisciplinary Research Initiative (IRI) was designed to focus attention on lakes and their contiguous watersheds. Lakes were selected because they are important aquatic systems that integrate a large number of processes within their watersheds, and they have great importance to society. Initial efforts will focus on the carbon cycle at two contrasting lakes and a few wetlands.

APPROACH: The basic question with respect to comparing carbon cycling processes relates to lakewater residence time: how do lakes that have a short residence time because of large streams entering and leaving them and that are presumably dominated by external fluxes, differ from those that have a long residence time because they have no streams or very small streams entering and leaving them and that are presumably dominated by internal cycling? Field experiments for both terrestrial and aquatic systems will be selected jointly by all interested specialists and sampled for physical, chemical, and biological characteristics so that all involved will be working with a common data base on common problems.

PROGRESS: In addition to continuing to monitor a large array of climate variables, ground-water levels, and stream discharge, specific research at the IRI site concentrated on: (1) biogeochemistry of the hyporheic zone along the Shingobee River, (2) present and paleo-ecological characteristics of the 


\section{ECOLOGY}

Little Shingobee fen, (3) small-scale hydrologic and geochemical processes in the near-shore and hyporheic zones on the inflow and outflow sides of Williams Lake, and (4) gas fluxes from Williams Lake following ice-melt.

The study of small-scale ground-water flow and geochemical processes along the edge of Williams Lake involved collection of hydraulic head gradients and water samples for major ion chemistry and environmental isotopes along two transects on the inseepage side and two transects on the outseepage side of the lake. The data were collected during two field trips, immediately after ice-melt in spring and in midsummer. The head and chemistry data both indicated the commonality of flow reversals related to focused recharge that occurred in early spring due to snowmelt and spring rains.

The paleoecological studies of the fen and of the lake sediments indicated that the major climate changes that occurred since the last ice age are recorded in the sediments at the study site. This record will be useful in relating the present day processes that are being monitored and studied to climate changes over the past 13,000 years.

The studies of the hyporheic zone along the Shingobee River have indicated the importance of understanding the biogeochemical transformations that take place in the several decimeters of sediment directly underlying the river. These studies have been expanded to include the relatively large contribution of water and solutes from springs along sections of the river bank.

A large number of papers reporting results from the IRI studies were presented at scientific meetings, including, the Geological Society of America, Minnesota Lakes Association, American Geophysical Union (fall meeting), American Geophysical Union (Ocean Sciences Meeting), North American Bethological Society, American Chemical Society, American Society of Limnology and Oceanography, Society of Wetland Scientists, and the American Quaternary Association. The fall American Geophysical Union meeting had nearly half of a session devoted to IRI and the Society of Wetland Scientistis meeting had a full session devoted to the Little Shingobee fen.

\section{REPORTS PUBLISHED 1989-1994:}

Carter, V., Gammon, P.T., Rosenberry, D.O., and Turtora, M., 1993, Aquatic macrophytes and selected physical properties of Shingobee and Williams Lakes, Minnesota, 1991-92: U.S. Geological Survey Open-File Report 93-143, $41 \mathrm{p}$.

Cloern, J.E., Alpine, A.E., and Cole, B.E., and Heller, T., 1992, Seasonal changes in the spatial distribution of phytoplankton in small, temperature-zone lakes: Journal of Plankton Research, v. 14, no. 7, p. 1017-1024.

LaBaugh, J.W., 1990, Spatial and temporal variation in chemical characteristics of ground water adjacent to selected lakes and wetlands in the north-central United States: Verhandlungen Internationale Vereinigung Limnologie, v. 23, p. 131-137. 


\section{ECOLOGY}

McConnaughey, T.A., LaBaugh, J.W., Striegl, R.G., Carter, V.P., and Reddy, M.M., in press, $\mathrm{CO}_{2}$ Depletion induces $\mathrm{HCO}_{2}$-based photosynthesis in a ground-water fed lake: Limnology and Oceanography, v. 00.

Parkhurst, R.S., Merk, D.A., Rosenberry, D.O., and Winter, T.C., 1993, Climatic data for Williams Lake, Hubbard County, Minnesota 1989-91: U.S. Geological Survey Open-File Report 93-127, 34 p.

Rosenberry, D.O., LaBaugh, J.W., McConnaughey, T.M., Striegl, R.G., and Winter, T.C., 1993, the interdisciplinary research initiative-hydrologic research in the Shingobee headwaters area, Minnesota: U.S. Geological Survey Open-File Report 93-446, 2 p.

Rosenberry, D.O., Sturrock, A.M., and Winter, J.C., 1993, Evaluation of the energy budget method of determining evaporation at Williams Lake, Minnesota, using alternative instrumentation and study approaches: Water Resources Research, v. 29, no. 8, p. 2473-2483.

Sturrock, A.M., Winter, T.C., and Rosenberry, D.O., 1992, Energy-budget evaporation from Williams Lake-a closed lake in north-central Minnesota: Water Resources Research, v. 28, no. 6, p. $1605-1617$. 


\section{ECOLOGY}

TITLE: $\quad$ Limnological Phenomena in Impounded Rivers (CR 91-325)

PERSONNEL: G. Richard Marzolf, Project Chief

Darlene Puhr, Secretary

ADDRESS: $\quad$ U.S. Geological Survey

P.O. Box 25046, MS 458

Denver Federal Center

Denver, CO 80225

TELEPHONE: (303) 541-3040

PROBLEM: Dams have been built in this century that impound virtually all major rivers in the United States. The purposes vary and include flood control, navigation, hydropower generation, and storage for irrigation and domestic uses. About 2,500 reservoirs of 5,000 acre-feet or more, store about 480 million acre-feet, about $1 / 4$ of the annual runoff. Storage capacity is dominated by large reservoirs such that the 600 largest store more than 90 percent of the total. Lake Powell, behind Glen Canyon dam, stores water (about 27 million acre-feet) in the upper basin of the Colorado River for controlled release according to the Colorado River Compact ( 8.23 million acre-ft per year) and to generate electricity for sale to consumers in the southwestern United States (about 80 percent of the generating capacity of the Colorado River Storage Project). Phenomena that control the quantity (evaporation, losses to ground water, consumptive uses in the basin, regional drought or El Niño effects, and so forth) and (or) quality (salinity (chemistry), productivity, sediment-water column exchange, and so forth) of Lake Powell waters are not understood.

OBJECTIVE: General: To continue review of literature and of historic data sets, to continue field reconnaissance, and to development long-term monitoring and research with the National Park Service and the Bureau of Reclamation, the agencies with management and regulatory responsibility for Lake Powell.

Specific: To initiate investigation of basic processes that mediate water quality in Lake Powell; and, to couple understanding of processes in Lake Powell to management of water quality of the Colorado River in the Grand Canyon National Park.

APPROACH: Several approaches have been explored, including (1) using of LANDSAT imagery, (2) examining sediment and benthic chemistry, (3) examining productivity and water chemistry work in the tailwaters of Glen Canyon Dam, and (4) initiating work on nutrient and trophic gradients in Navajo Canyon. 


\section{ECOLOGY}

PROGRESS: Physical processes and biological responses: The reconnaissance profiling work in Lake Powell with data logging conductivity/temperature/depth (CTD) instrumentation that was started in 1992 is now complete.

Sediment chemistry and benthic phenomena: The sampling phase of this study is complete. In the 1993 "shake-down" phase, 40 sediments cores and 30 benthic invertebrate samples were collected from transects across the Colorado River arm of Lake Powell from near Hite, Utah, to Lower Good Hope Bay in Lake Powell. Preliminary analysis of these cores was performed and used in the design of 1994 sampling. The same transects of the Colorado River arm were revisited and a parallel set of cores and benthic invertebrate samples were collected from sediments in the San Juan arm (from Nokai Wash to Upper Piute Bay). There are about 140 cores in this set. The analysis has been delayed by a shortage of technical help but it should be completed by fall 1994 .

Diel cycles in the Lees Ferry tailwater: Hypolimnetic water from Lake Powell, released through Glen Canyon Dam, is clear and cold $\left(7-12^{\circ} \mathrm{C}\right.$ since the reservoir first filled in 1981). The nitrate concentration is high $(0.30-0.40 \mathrm{mgN} / \mathrm{L})$. Ammonia and soluble phosphorous concentrations are low (less than detection limit of $2.5 \mathrm{fg} \mathrm{N}$ or $\mathrm{P} / \mathrm{L}$ ).

Estimates of the magnitude of primary production have been difficult to achieve in this reach of the river. Cladophora is not evenly distributed on the substrate, so even precise measurement of carbon fixation or photosynthetic oxygen production on a given piece of substrate placed in a chamber for the measurement, yields the statistical problem of assessing the spatial variation and calculating an integral rate of photosynthesis for the reach.

The approach of measuring diurnal changes in ambient oxygen concentrations is compromised by high turbulence, crude bed roughness estimates required to assess it and the resultant diffusive exchange with the atmosphere. All this may "swamp" photosynthetic oxygen addition beyond useful correction. However, oxygen concentrations at the dam are often below saturation and the few measurements that have been made suggest that full aeration is not realized until some distance below the Paria riffle, some $30 \mathrm{~km}$ downstream from the dam.

Similarly diel changes in nitrate concentrations are difficult to observe because the $\mathrm{NO}_{3}-\mathrm{N}$ concentrations are so high. Diel ammonia or phosphorus changes were not seen because concentrations were below detection limits on rare occasions when those observations were made. The search for chemical changes mediated by photosynthetic activity will require careful measurement and analysis at short time intervals through a diel cycle.

The most likely time to observe such change is when Cladophora biomass is high, when daylength is maximal, when discharge is low, and when measurements are made in water near the shore (brighter light, lowest turbulent dilution). 


\section{ECOLOGY}

A minimum flow of $227 \mathrm{~m}^{3} / \mathrm{s}\left(8,000 \mathrm{ft}^{3} / \mathrm{s}\right)$ for aerial photography in Grand Canyon was scheduled for three days at the end of May 1994. Short interval sampling on the second of these days (3 sensors sampling at $\mathbf{4}$ minute intervals and water sampling at $\mathbf{1 5}$ minute intervals from before dawn until after dark) revealed significant changes in temperature, $\mathrm{pH}$, oxygen concentration, specific conductance, nitrate, and total soluble phosphorus. Analyses are incomplete but the approach has been shown to yield interpretable information, so investigation will continue. 


\section{ECOLOGY}

TITLE: Interaction of Bacteria with Environmental Contaminants and Solid Surfaces in the Aquatic Environment (CR 91-327 formerly WR 86-191)

PERSONNEL: Ronald W. Harvey, Project Chief

Betty L. Callahan, Secretary

David W. Metge, Hydrologist

ADDRESS: $\quad$ U.S. Geological Survey

3215 Marine Street

Boulder, Colorado 80303-1066

TELEPHONE: (303) 541-3034

PROBLEM: Although efforts have been made to explain the behavior of heavy metals and refractory organic contaminants in aquatic habitats in the framework of known geophysical and geochemical processes, much remains to be learned about the role of bacteria in such behavior. Of particular interest are bacteria-contaminant interactions in ground water. Because of the persistence of some contaminants in the subsurface environment and because of increasing demands for both highquality ground water and on-land disposal of toxic chemicals and radioisotopes, these interactions should remain important environmental problems for the next few decades. Because significant biotransformation/biodegradation of many environmental contaminants in aquifers and particle-laden surface waters can occur at particle surfaces, explanations for bacteria-contaminant interactions in such environments should take the presence of particles into account.

OBJECTIVE: Provide some of the microbiological information necessary for realistic predictions of contaminant behavior in aquatic environments. Obtain information on specific mechanisms of interactions between environmental contaminants and aquatic bacteria, taking into account adsorption, active uptake, competition, biotransformation reactions, interaction with extracellular polymers, effects of nutrient and physicochemical gradients, and effects of particle surfaces. Investigate the effect of nutrient and physicochemical conditions on subsurface transport of bacteria (because the role of bacterial transport on the fate of environmental contaminants in ground water is unknown).

APPROACH: (1) Study the influence of solid surfaces on microbial activity and mobility in particleladen aquatic environments, particularly freshwater aquifers; (2) study the effect of organic contaminants on the distribution, transport, and activity of the bacterial population and the nature of the microbial community in ground-water habitats; and (3) conduct flow-through column experiments to assess the role of adherent bacteria on the mobility and fate of selected inorganic and organic contaminants in simulated aquifer environments. Conduct flow-through column experiments to investigate factors affecting sorption and movement of bacteria in porous media. 


\section{ECOLOGY}

PROGRESS: Three papers on subsurface microbial transport and one paper on bacterial communities in contaminated groundwater were published. Research was completed on the initial ground waterprotozoa grant funded by the National Science Foundation (NSF) (Principal Investigators: Nancy Kinner (University of New Hampshire (UNH)), Ronald Harvey (U.S. Geological Survey (USGS)), and Colin Curds (the Natural History Museum (NHM), London)]. Four papers involving results from this research were presented at the International Symposium on Subsurface Microbiology (Bath, United Kingdom, September 1993). Research was started on a new (continuation) NSF grant focusing on the role of protozoa in groundwater microbial communities and in the fate of subsurface organic contaminants at the USGS Cape Cod Toxic Substances Hydrology Research Site. The research again involves a collaborative effort between the USGS, UNH, and NHM. Graduate students from the University of Colorado (CU), working in the USGS Boulder research facilities on a joint U.S. Environmental Protection Agency (USEPA) grant to the USGS and CU, successfully radiolabelled selected components of PRD1 phage (bacteria-specific virus) by adding radiolabelled compounds to chemically-defined, minimal media containing its growing host. This allowed important new information to be collected on both the transport behavior and inactivation rate of the virus under different geochemical conditions in flow-through, porous media columns. A series of ground water injection and recovery experiments to examine the effects of surfactants and geochemical conditions upon the transport behavior of virus, virus-sized microspheres, protozoa, and bacteria was initiated at the USGS study site in Cape Cod. Collaborators include UNH, CU, and Oregon State University (OSU). Funding is provided by the USGS, NSF, USEPA, and National Geographic Society. Dave Metge (USGS) demonstrated the strong pH-dependency of bacterial sorption in the presence of selected dissolved organic contaminants in saturated columns of aquifer sediments. The 1993 editor's citation for excellence in reviewing was awarded to Ron Harvey by the editor-in-chief of Water Resources Research. Ron Harvey also co-organized a series of microbiology sessions for the Second International Conference on Ground Water Ecology (Atlanta in March, 1994).

\section{REPORTS PUBLISHED 1989-1994:}

Bitton, G. and Harvey, R.W., 1992, Transport of pathogens through soil, in Mitchell, R., ed., New Concepts in Environmental Microbiology: New York, Wiley Interscience, chap. 7, p. 103-124.

Harvey, R.W., 1989, Considerations for modeling transport of bacteria in contaminated aquifers, in Abriola, L., ed., Groundwater Contamination: Wallingford, Oxfordshire, United Kingdom, IAHS Press, No. 185 , p. 75-82.
1989, Transport of bacteria in a contaminated aquifer, in Mallard, G.E., and Ragone, S.E., eds., U.S. Geological Survey Toxic Substances Hydrology Program-Proceedings of the technical meeting, Phoenix, Ariz., Sept. 2630, 1988: U.S. Geological Survey WaterResources Investigations Report 88-4220, p. 183-188.

1989, Transport of bacteria in a contaminated aquifer, in McCarthy, J.F., and Wobber, F.J., eds., Mobility of colloidal particles in the subsurface, Chemistry and hydrology of colloid- 


\section{ECOLOGY}

aquifer interactions-Proceedings of the technical meeting, Manteo, North Carolina, October 4-6, 1988: U.S. Department of Energy Report No. ER-0425, p. 72-76.

1991, Evaluation of particulate and solute tracers for investigation of bacterial transport behavior in groundwater, in Fliermans, C.B., and Hazen, T.C., eds., Proceedings of the First International Symposium on Microbiology of the Deep Subsurface, January 15-19, 1990, Orlando, Florida: Aiken, S.C., WSRC Information Services, p. 7-159 to p. 7-163.

1991, Parameters involved in modeling movement of bacteria in groundwater, in Hurst, C.J., ed., Modeling the environmental fate of micro-organisms: Washington, D.C., American Society for Microbiology, p. 89-114.

1993, Fate and transport of bacteria injected into aquifers: Biotechnology [Current Opinion], v. 4 , p. $312-317$.

Harvey, R.W., and Barber, L.B., 1992, Associations of free-living bacteria and dissolved organic compounds in a plume of contaminated groundwater: Journal of Contaminant Hydrology, v. 9, p. 91-103.

Harvey, R.W., and Bouwer, E.J., 1992, Limits on quantitative descriptions of biocolloid mobility in contaminated groundwater, in McCarthy, J.F., and Wobber, F.J., eds., Concepts in Manipulating Groundwater Colloids for Environmental Restoration: London, Lewis Publishers, p. 57-64.

Harvey, R.W., and Garabedian, S., 1991, Use of colloid filtration theory in modeling movement of bacteria through a contaminated sandy aquifer: Environmental Science and Technology, v. 25, p. $178-185$.
1992, Comment on Use of Colloid filtration theory in modeling movement of bacteria through a contaminated sandy aquifer: Environmental Science and Technology, v. 26, p. 401-402.

Harvey, R.W., Garabedian, S.P., Smith, R.L., Barber, L.B., Metge, D.W., and Scholl, M.A., 1991, The role of physical and chemical heterogeneity in the interpretation of smallscale tracer tests involving micro-organisms, in Mallard, G.E., and Aronson, D.A., eds., U.S. Geological Survey Toxic Substances Hydrology Program-Proceedings of the technical meeting, Monterey, Calif., March 11-15, 1991: U.S. Geological Survey WaterResources Investigations Report 91-4034, p. 148-151.

Harvey, R.W., George, L.H., Smith, R.L., LeBlanc, D.R., 1989, Transport of microspheres and indigenous bacteria through a sandy aquifer-Results of natural and forcedgradient tracer experiments: Environmental Science and Technology, v. 23, p. 51-56.

Harvey, R.W., Kinner, N., Bunn, A., MacDonald, D., 1993, Transport of protozoa through an organically contaminated sandy aquifer, in Stanford, J., and Simon, J., eds., Proceedings of the First International Conference on Ground Water Ecology, Tampa, Florida, April 26-29: Huntsville, Alabama, American Water Resource Association, p. 111-118.

Harvey R.W., Kinner, N.E., MacDonald, D., Metge, D.W., and Bunn, A., 1993, Role of physical heterogeneity in the interpretation of small-scale laboratory and field observations of bacteria, microbial-sized microsphere and bromide transport through aquifer sediments: Water Resources Research, v. 29, p. 27132721. 


\section{ECOLOGY}

Harvey, R.W., and Widdowson, M., 1992, Microbial distributions, activities, and movement in the terrestrial subsurface: experimental and theoretical studies, in Wagenet, R.J., Baveye, P., and Stewart, B.A., ed., Interacting processes in soil science: Ann Arbor, Michigan, Lewis Publishers, p. 185-225.

Kinner, N.E., Bunn, A.L., Harvey, R.W., Warren, A., and Meeker, L.D., 1991, Preliminary evaluation of the relations among protozoa, bacteria, and chemical properties in sewagecontaminated ground water near Otis Air Base, Massachusetts, in Mallard, G.E., and Aronson, D.A., eds., U.S. Geological Survey Toxic Substances Hydrology ProgramProceedings of the technical meeting, Monterey, Calif., March 11-15, 1991: U.S. Geological Survey Water-Resources Investigations Report 91-4034, p. 141-143.

Kuwabara, J.S., and Harvey, R.W., 1990, Application of a hollow-fiber tangential-flow device for sampling suspended bacteria and particles from natural waters: Journal of Environmental Quality, v. 19, p. 625-629.

Metge, D.W., 1991, DNA determination and bacterial biomass estimation in a contaminated and uncontaminated shallow sandy aquifer: San Francisco, California, San Francisco State University, M.S. thesis, $163 \mathrm{p}$.

Metge, D.W., Brooks, M., Smith, R., and Harvey, R.W., 1993, Effect of treated-sewage contamination upon bacterial energy charge adenine nucleotides, and DNA in a sandy aquifer on Cape Cod: Applied and Environmental Microbiology, v. 59, p. 2304-2310.

Metge, D.W., and Harvey, R.W., 1989, Partitioning, distribution, and recovery of DNA (deoxyribonucleic acid) from water and sediment in a contaminated aquifer in Cape Cod, Massa- chusetts, in Mallard, G.E., and Ragone, S.E., eds., U.S. Geological Survey Toxic Substances Hydrology Program-Proceedings of the technical meeting, Phoenix, Ariz., September 26-30, 1988: U.S. Geological Survey Water-Resources Investigations Report 88-4220, p. 547-554.

1991, Deoxyribonucleic acid distributions and recovery in estimation of biomass in a sand and gravel aquifer on Cape Cod, Massachusetts, in Mallard, G.E., and Aronson, D.A. eds., U.S. Geological Survey Toxic Substances Hydrology Program-Proceedings of the technical meeting, Monterey, Calif., March 11-15, 1991: U.S. Geological Survey Water-Resources Investigation Report 914034, p. 135-140.

Scholl, M.A., and Harvey, R.W., 1991, Laboratory studies of bacterial sorption to aquifer sediments from the Cape Cod toxic-substanceshydrology site, in Mallard, G.E., and Aronson, D.A., eds., U.S. Geological Survey Toxic Substances Hydrology ProgramProceedings of the technical meeting, Monterey, Calif., March 11-15, 1991: U.S. Geological Survey Water-Resources Investigations Report 91-4034, p. 152-154.

1992, Laboratory' investigations on the role of sediment surface and groundwater chemistry in transport of bacteria through a contaminated sandy aquifer: Environmental Science and Technology, v. 26, no. 7, p. 1410-1417.

Smith, R.L., and Harvey, R.W., 1991, Development of sampling techniques to measure in situ rates of microbial processes in a contaminated sand and gravel aquifer, in Fliermans, C.B., and Hazen, T.C., eds., Proceedings of the First International Symposium on Microbiology of the Deep Subsurface, January 15-19, 1990, Orlando, Florida: Aiken, South 


\section{ECOLOGY}

Carolina, WSRC Information Services, $p$.

2-19 to 2-27.

Smith, R.L., Harvey, R.W., and LeBlanc, D.R., 1991, Importance of closely spaced vertical sampling in delineating chemical and microbiological gradients in groundwater studies: Journal of Contaminant Hydrology, v. 7, p. 285300. 


\section{ECOLOGY}

TITLE: $\quad$ Effects of Toxic Substances on Aquatic Communities

(CR 92-337 formerly WR 75-137)

PERSONNEL: Harry V. Leland, Project Chief

Debra A. Litwin, Secretary

ADDRESS: $\quad$ U.S. Geological Survey

3215 Marine Street

Boulder, CO 80303

\section{TELEPHONE (303) 541-3021}

PROBLEM: Water pollution is principally a biological problem in that its primary effect is on aquatic organisms. Yet, most pollution assessment emphasizes the measurement of chemical and physical variables rather than responses of aquatic organisms to these variables. There are several reasons for this contradictory emphasis on physiochemical variables, but perhaps the most compelling is the lack of predictive information on responses of aquatic organisms, singly or in association, to specific environmental factors. There is a need to evaluate the predictability of measurements based on such biological responses with a view towards their greater acceptance in water-quality assessment and towards development of methods for objectively defining relationships among biological and physiochemical variables in aquatic ecosystems.

OBJECTIVE: Determine through detailed studies of organisms, simplified ecosystems, and natural sites, the extent to which waterborne contaminants and (or) disturbance affect the production and structure of aquatic plant assemblages and the growth and reproductive capacity of aquatic animals. Evaluate methods assessing effects of chronic exposure to contaminants and (or) disturbances on individual species and natural aquatic communities.

APPROACH: Evaluate methods for assessing effects of waterborne contaminants released to the environment, including tests of embryogenesis and growth in fishes, survival of critical life stages of aquatic invertebrates, and population growth rate of algae. Determine physiochemical factors affecting responses and bioaccumulation of these contaminants. Evaluate methods and results of laboratory studies by field experiments. Determine the utility of biological test methods for detecting and monitoring environmental concentrations of toxicants. Examine the factors (physiochemical and biological) influencing responses of natural aquatic communities.

PROGRESS: The project chief provided continuing support to national, regional and study-unit National Water Quality Assessment (NAWQA) personnel in the development of the ecological assessment element of the program. Integrated analyses of data on distributions of aquatic communities, water quality and physical characteristics (basin-, segment-, reach- and microhabitat- 


\section{ECOLOGY}

scales) of the Yakima River Basin in Washington and the San Joaquin River Basin in California were completed. "Distributions of Phytobenthos in the Yakima River Basin, Washington, in Relation to Geology, Land Use and Other Environmental Factors" is the first report from pilot ecological investigations in the NAWQA program. It describes an appropriate approach for integrating biogeographic, physical and chemical-quality data for synoptic (spatial distribution) studies in other NAWQA study-units. Reports prepared on the composition and structure of aquatic communities (phytoplankton, periphyton and benthic invertebrates) of the San Joaquin River and its tributaries in relation to water quality, instream/riparian habitat, and land use consider both spatial and temporal trend analyses. Three reports on San Joaquin River investigations are in review or preparation. The San Joaquin River studies provide NAWQA study-unit biologists an appropriate approach to temporaltrend assessment.

\section{REPORTS PUBLISHED 1989-1994:}

Cain, D.J., Fend, S.V., and Carter, J.L., 1989, Temporal and spatial variability of arsenic in benthic insects from Whitewood Creek, South Dakota, in Mallard, G.E., ed., U.S. Geological Survey Toxic Substances Hydrology Program-Proceedings of the Technical Meeting, Phoenix, Ariz.: U.S. Geological Survey Water-Resources Investigations Report 884220, p. $257-268$.

Leland, H.V., in press, Distribution of phytobenthos in the Yakima River basin, Washington, in relation to geology, land use and other environmental factors: Canadian Journal of Fisheries and Aquatic Sciences, v. 00.

Leland, H.V., Fend, S.V., Dudley, T.L., and Carter, J.L., 1989, Effects of copper on species composition of benthic insects in a Sierra Nevada, California stream: Freshwater Biology, v. 21, p. 163-179.

Leland, H.V., and Scudder, B.C., 1990, Trace elements in Corbicula fluminea from the San Joaquin River, California: Science of the Total Environment, v. 97/98, p. 641-672.
Scudder, B.C., Carter, J.L., and Leland, H.V., 1989, Effects of copper on development of the fathead minnow, Pimephales promelas Rafinesque: Aquatic Toxicology, v. 12, p. 107-124. 


\section{ECOLOGY}

TITLE: $\quad$ Remote Sensing and Ecological Research in Wetlands (NR 73-090)

PERSONNEL: Virginia P. Carter, Project Chief

Carol L. Padgett, Secretary

Nancy B. Rybicki, Hydrologist

Christopher Lewis, Hydrologic Aid

ADDRESS: $\quad$ U.S. Geological Survey

430 National Center

12201 Sunrise Valley Drive

Reston, VA 22092

\section{TELEPHONE: (703) 648-5897}

PROBLEM: Wetlands are hydrologically controlled ecosystems essential to estuarine, marine, lacustrine, and riverine productivity. To improve our understanding of these ecosystems we need information on (1) wetland hydrologic variables/budgets and their relation to wetland vegetation and nutrient cycling; (2) wetland dynamics and boundary fluctuations; (3) wetland functions and values; and (4) short- and long-term temporal changes. Wetland plants may serve as sensitive hydrologic indicators of water-quality parameters such as salinity, turbidity, $\mathrm{pH}$, nutrients; presence of various pollutants; or frequency and duration of inundation.

Submersed aquatic wetlands have many functions including (1) providing habitat for invertebrate species; (2) providing food and (or) shelter for juvenile and adult fish, waterfowl, and other wildlife; (3) retarding flow velocities, stabilizing bottom sediments, and slowing erosion; and (4) oxygenating the water, recycling or transforming nutrients and heavy metals. Decline or disappearance of aquatic plant communities or overgrowth of submersed vegetation under nutrient-enriched conditions is of concern to scientists, ecologists, environmentalists, and managers. The factors affecting distribution and abundance of submersed aquatic vegetation and the effect of submersed aquatic vegetation on water quality are poorly understood.

OBJECTIVE: (1) Determine factors responsible for the changing distribution of submersed macrophyte beds in the tidal Potomac River and other lacustrine and riverine environments; (2) study processes controlling the survival, expansion, and decline of macrophyte populations; (3) determine the effect of submersed macrophytes on water velocity, water quality, and carbon flux; (4) characterize wetland transition zones and relate distribution of vegetation to soils, hydrology and elevation; (5) examine seasonal and long-term changes in wetland ecology as related to changes in environmental parameters including hydrology, water quality and land use; and (6) aid in the development of models that utilize biological, hydrologic, and remotely sensed wetland data as part of their primary data base. 


\section{ECOLOGY}

APPROACH: (1) Conduct field and laboratory investigations of the factors affecting survival and growth of submerged aquatic plants, (2) conduct field and laboratory experiments to measure productivity and to determine the effect of submersed macrophytes on water quality and carbon flux, (3) develop models illustrating relationships between plant success and other environmental factors, (4) conduct studies on the hydrology and ecology of selected wetlands in the local area, at the ShingobeeWilliams Lake Watershed in Minnesota, and at the Water, Energy, and Biogeochemical Budgets (WEBB) program site in Wisconsin.

PROGRESS: Continued research at the Allequash watershed in Wisconsin as part of the Water, Energy, and Biogeochemical Budget (WEBB) thrust. The primary emphasis of the research is on the effects of wetlands on carbon cycling and the identification of major carbon pools in the watershed. We are working closely with members of the Wisconsin District office. Several vibracores were taken in the primary wetland; they were sectioned, subsampled, and mailed to Reston, Virginia. We are working closely with Geologic Division personnel to look at the carbon isotope concentration of the peat, submersed and emergent macrophytes, and surface litter in the watershed. Preliminary carbon isotope measurements from peat cores show considerable variability in the peat profile. Peat depths were measured in the primary wetland and several other wetlands in the watershed. Observation wells and piezometers were installed in the primary wetland and water level measurements are being made monthly except during the winter. Water quality is being measured in these wells as well. We have completed maps of the wetlands and lakes in each of the four watersheds entering Trout Lake-Allequash, Mann, Stephenson, and North-and plan to digitize these maps using the Geographic Information System (GIS) facility in Reston, Virginia.

Continued research in the Integrated Research Initiative (IRI) site in Minnesota. We completed the stratigraphic profiling of the Little Shingobee Fen based on previous corings and took two additional piston cores in the deepest part of the fen and over a shallow ridge which divides the fen into two parts at the south end. These will be used for carbon isotope and pollen analysis. Stratigraphic profiles of Little Shingobee Fen show that the fen began to form about 10,000 years ago in two deep interconnected basins; early deposits were lake deposits and marl and later deposits show the presence of emergent vegetation and trees. The deepest peat ( 17 meters) is found in the south end of the fen. We installed additional piezometers in the south end of the fen for water level and water-quality measurements. We also made diurnal measurements of dissolved oxygen and $\mathrm{pH}$ in the center and the littoral zone of Williams and Shingobee Lakes to determine the effect of submersed aquatic macrophytes on water quality in the littoral zone. Problems with the hydrolabs prevented us from making maximum use of these data, and we plan to repeat the experiment when funding permits. Organized and chaired a session on the IRI work at the Society of Wetland Scientists Meeting in Portland, Oregon, in June 1994, and presented a paper on the vegetation and stratigraphy of Little Shingobee Fen. 


\section{ECOLOGY}

Began a study of propagule availability in the tidal Potomac River. Previous work leads us to believe that local increases in turbidity are primarily responsible for failure of certain areas in the river to revegetate, but there is also the possibility that propagule transport into these areas is lacking or that propagules transported to unvegetated sites during the growing season are not viable. We are testing this hypothesis at three unvegetated sites (two previously vegetated, one never vegetated), using two vegetated sites for reference. There are two manuscripts in press giving results of previous research in the tidal Potomac River, "Role of weather and water quality in population dynamics of submersed macrophytes in the tidal Potomac River and Estuary" (Estuaries) and "Invasions and declines of submersed macrophytes in the tidal Potomac River and Estuary, the Currituck Sound-Back Bay system and the Pamlico River Estuary" (Lake and Reservoir Management). Nancy Rybicki organized and chaired a session on "Processes affecting submersed aquatic vegetation dynamics" at the Society of Wetland Scientists Meeting in Portland, Oregon, in June 1994 and presented a paper on our laboratory studies of the comparative growth of Hydrilla verticillata and Vallisneria americana under different conditions of light and temperature.

Final manuscript on the hydrology and ecology of the western transition zone of the Great Dismal Swamp of Virginia and North Carolina was published in Ecological Applications. Virginia Carter presented the plenary address at the International Symposium on Wetlands: Ecological Gradients, Boundaries, and Buffers in Niagara Falls, Canada, in April, 1994. Virginia Carter has also been invited to be a member of the Environmental Task Force Wetlands Working Group, an interagency Committee involved in determining the usefulness of classified data for mapping wetlands. Virginia Carter still serves as technical consultant to the Branch of National Water Summary for the upcoming National Water Summary on Wetlands. Virginia Carter consulted with the Mexican National Water Commission on a recently completed study of the lagoon-wetland system of the Tamesi River in the Mexican state of Tamaulipas, spending a week in Mexico at the expense of the Mexican Government.

\section{REPORTS PUBLISHED 1989-1994:}

Batiuk, Richard, Heasley, Patricia, Orth, Robert, Moore, Kenneth, Stevenson, J.C., Dennison, William, Staver, Lori, Carter, Virginia, Rybicki, N.B., Hickman, R.E., Kollar, Stan, Bieber, Steven, Bergstrom, Peter, 1993, Chesapeake Bay submerged aquatic vegetation habitat requirements and restoration goals-A Technical Synthesis: U.S. Environmental Protection Agency, Chesapeake Bay Program/ Technical Rreport Series 83/92, 162 .

Carter, Virginia, 1990, The Great Dismal Swamp-an illustrated case study, in Lugo,
A.E., Brinson, Mark, and Brown, Sandra, eds., Ecosystems of the World 15: Amsterdam, Elseviers Publishing company, Forested Wetlands, p. 201-211.

1990, Importance of hydrologic data for interpreting wetland maps and assessing wetland loss and mitigation: in Kiraly, S.J. Cross, F.A., and Buffington, J.D., eds., Federal Coastal Wetland Mapping Programs: U.S. Fish and Wildlife Biological Report 90, no. 18 , p. 79-85. 


\section{ECOLOGY}

Carter, Virginia, Gammon, P.T., and Garrett, M.K., 1993, Ecotone dynamics and boundary determination in the Great Dismal Swamp, Virginia and North Carolina: Ecological Applications, v 4, no. 1, p. 189-203.

Carter, Virginia, Gammon, P.T., Rosenberry, D.O., and Turtora, Michael, 1993, Aquatic macrophytes and selected physical properties of Shingobee and Williams Lakes, Minnesota, 1991-1992: U.S. Geological Survey Open-File Report 93-143, 41 p.

Carter, Virginia, and Rybicki, N.B., 1991, Light attenuation in Back Bay, Virginia, in Marshall H.G., and Norman M.D., eds., Back Bay Symposium [Proceedings]: Old Dominion University, Norfolk, Va., Department of Biological Sciences, p. 20-28.

1991, Light attenuation and submersed macrophyte distribution in the tidal Potomac and Estuary: Estuaries, v. 13, no. 4, p. 441-452.

Carter, Virginia, Rybicki, N.B., and Hammerschlag, Richard, 1991, Effects of submersed macrophytes on dissolved oxygen, $\mathrm{pH}$, and temperature under different conditions of wind, tide and bed structure: Journal of Freshwater Ecology, v. 6, no. 2, p. 121-133.

Carter, Virginia, Rybicki, N.B., Jones, R.C., Barko, J.W., Dresler, P.V., Hickman, R.E., and Anderson, R.T., 1989, Data on physical, chemical, and biological data and characteristics of Hydrilla beds, mixed beds, and unvegetated sites in the tidal Potomac River, Maryland and Virginia, 1987: U.S. Geological Survey Open-File Report 88-709, 196 p.

Carter, Virginia, Rybicki, N.B., Landwehr, J.M., and Turtora, Michael, in press, Role of weather and water quality on population dy- namics of submersed macrophytes in the tidal Potomac River: Estuaries, v. 00.

Carter, Virginia, Rybicki, N.B., and Turtora, Michael, 1991, Population dynamics of submersed macrophytes in the tidal Potomac River, in 25th Annual Meeting, Aquatic Plant Control Research Program: U.S. Army Corps of Engineers, Miscellaneous Paper A-91-3, [Proceedings], p. 41-53.

Dennison, W.C., Orth, R.J., Moore, K.A., Stevenson, J.C., Carter, Virginia, Kollar, Stan, Bergstrom, P.W., and Batiuk, R.A., 1993, Assessing water quality with submersed aquatic vegetation: Bioscience, v. 43, no. 2, p. 86-94.

Jenter, H.L., Rybicki, Nancy, Baltzer, R.A., and Carter, Virginia, 1990, Tidal mass exchange between a submerged aquatic vegetation bed and the main channel of the Potomac River: American Society of Civil Engineers Hydraulic Conference, Nashville, Tennessee, 1991, [Proceedings], p. 298-304.

Killgore, K.J., Morgan, R.P., II, and Rybicki, N.B., 1989, Seasonal and temporal distribution and abundance of fishes associated with submersed aquatic plants: North American Journal of Fisheries Management, v. 9, no. 1, p. 101-111.

McConnaughey, T.A., LaBaugh, J.W., Rosenberry, D.O., Strigel, R.G., Reddy, M.M., Schuster, P.F., and Carter, Virginia, in press, Carbon budget for a groundwater-fed lakeCalcification supports summertime photosynthesis: Limnology and Oceanography, v. 00.

Orth, Robert, Moore, Kenneth, Batiuk, Richard, Heasly, Patsy, Dennison, William, Stevenson, J.C., Staver, Lori, Carter, Virginia, Rybicki, Nancy, Kollar, Stan, Hickman, R.E., and 


\section{ECOLOGY}

Bieber, Steven, 1991, Water quality standards based on species' habitat requirements-a case study from the Chesapeake Bay using submerged aquatic vegetation, in Water Quality Standards for the 21st Century, Proceedings: U.S. Environmental Protection Agency, Office of Water WH-553, p. 177-181.

Robbins, E.I., D'Agostino, J.P., Ostwald, J., Fanning, D.S., Carter, Virginia, and Van Hoven, R.L., 1993, Manganese nodules and microbial oxidations of manganese in the Huntley Meadows Wetland, Virginia, U.S.A.: Catena, Supplement 21, p. 170-202.

Rybicki, Nancy, and Schening, M.R., 1990, Data on the distribution and abundance of submersed aquatic vegetation in the tidal Potomac River and transition zone of the Potomac Estuary, Maryland and Virginia, and the District of Columbia, 1988: U.S. Geological Survey Open-File Report 90-123, 19 p. 


\section{ECOLOGY}

TITLE: $\quad$ Modeling of Microbially Catalyzed Geochemical Reactions in Aquatic Environments (NR 87-136)

PERSONNEL: Derek R. Lovley, Project Chief

Carol L. Wakelee, Secretary

Elizabeth J. Phillips, Microbiologist

Peggy Widman, Microbiologist

Debra Lonergan, Microbiologist

Joan C. Woodward, Phys. Sci. Technician

Todd Anderson, Geochemist

ADDRESS: $\quad$ U.S. Geological Survey

430 National Center

12201 Sunrise Valley Drive

Reston, VA 22092

TELEPHONE: (703) 648-5825

PROBLEM: Micro-organisms catalyze most of the natural redox reactions involving carbon, sulfur, nitrogen, and metals. Thus, geochemical models of the distribution and fate of natural and contaminant compounds must include a microbiological component, which requires an understanding of the physiological characteristics of micro-organisms that control the rate and extent of microbially catalyzed reactions.

OBJECTIVE: (1) Quantify the rates of microbial processes that influence the geochemistry of surface water and ground water; (2) determine the physiological characteristics that control the rate and extent of microbial processes; and (3) develop mathematical models of the distribution of microbial processes in surface water and ground water.

APPROACH: Quantify rates and pathways of microbial processes with radiotracer, stable-isotope and inhibitor techniques. Determine microbial physiological characteristics with experimental manipulations of natural, mixed populations and pure cultures. Combine data on physiological characteristics with appropriate geochemical models to generate models for the distribution of microbial processes.

PROGRESS: It was demonstrated for the first time that, under the appropriate conditions, microorganisms can rapidly degrade benzene in the absence of oxygen. This finding is significant because benzene is the contaminant of most concern when ground water is polluted with petroleum. Most petroleum-contaminated aquifers contain extensive anoxic zones in which benzene and other aromatic hydrocarbons persist. Numerous studies had suggested that micro-organisms needed oxygen to degrade benzene. We demonstrated that the addition of Fe(III) ligands to sediments from a contaminated aquifer made the Fe(III) oxides present in the aquifer more available for microbial reduction. The stimulation of microbial Fe(III) reduction greatly increased the rates of aromatic 


\section{ECOLOGY}

hydrocarbon degradation. Even benzene was rapidly degraded in the absence of oxygen after an adaption period. These studies demonstrate that oxygen is not necessarily required for rapid aromatic hydrocarbon degradation and that the poor ability of micro-organisms to access Fe(III) oxides is an important and previously unknown factor limiting the anoxic degradation of aromatic hydrocarbons in aquifers. Furthermore, these results suggest that stimulating microbial Fe(III) reduction may be a novel alternative to oxygen additions for bioremediating petroleum-contaminated aquifers. Field trials on the use of enhanced microbial Fe(III) reduction for the bioremediation aromatic hydrocarbons are underway. A paper describing these findings will be published in Nature in July 1994.

Molecular techniques were developed for studying microbial Fe(III) reduction in sedimentary environments. This provides the opportunity to directly study the microbial ecology of environments where Fe(III) reduction has a significant geochemical effect such as contaminated aquifers, deep pristine aquifers, and aquatic sediments. Results to date indicate that Fe(III)-reducing communities are highly diverse and that there is the potential for numerous interactions between these organisms. Understanding these interactions will help understand the factors controlling the rate and extent of $\mathrm{Fe}(\mathrm{III})$ reduction in sedimentary environments. Furthermore, these molecular techniques have potential broad application to the study of a variety of other microbial processes.

We discovered that sulfate-reducing micro-organisms can enzymatically reduce $\mathrm{Cr}$ (VI) to $\mathrm{Cr}$ (III) and purified the enzyme responsible for this activity. This finding is significant because the reduction of $\mathrm{Cr}(\mathrm{VI})$ to $\mathrm{Cr}$ (III) is a potentially useful mechanism for bioremediaton of chromate-contaminated waters and waste streams. A paper describing this discovery was published in Applied and Environmental Microbiology.

We discovered micro-organisms with the capacity to oxidize $S^{0}$ to sulfate with $\mathrm{Mn}(\mathrm{IV})$ as the electron acceptor at circumneutral $\mathrm{pH}$ as well as an organism which can disproportionate $\mathrm{S}^{0}$ to sulfate and sulfide. These findings help explain important geochemical phenomena in aquatic sediments for which there were no previous pure culture microbiological models. A paper describing this will be published in the July 1994 issue of Applied and Environmental Microbiology.

We found that a number of hydrofluorocarbons are readily consumed by micro-organisms living in aquatic sediments and soils. These findings have iniportant implications since the compounds are being considered as alternatives to freon.

Studies on the use of dissolved hydrogen gas to predict the distribution of microbial processes in ground water were completed and a manuscript describing this method will be published in the July 1994 issue of Environmental Science and Technology. 


\section{ECOLOGY}

A study demonstrating that uranium-reducing micro-organisms can be used as part of a processes for concentrating uranium from uranium-contaminated soils was completed. A manuscript describing this has received favorable reviews and publication is expected in Journal of Industrial Microbiology.

\section{REPORTS PUBLISHED 1989-1994:}

Caccavo, F., Blakemore, R.P, and Lovley, D.R., 1992, A hydrogen-oxidizing, iron-reducing microorganism from the Great Bay Estuary, New Hampshire: Applied Environmental Microbiology, v. 58, p. 3211-3216.

Chapelle, F.H., and Lovley, D.R., 1990, Rates of microbial metabolism in deep coastal plain aquifers: Applied Environmental Microbiology, v. 56, p. 1858-1864.

1992, Competitive exclusion of sulfate reduction by Fe(III)-reducing bacteria-a mechanism for producing discrete zones of high-iron ground water: Ground Water, v. 30, p. 29-36.

Coleman, M.L., Hedrick, D.B., Lovley, D.R., White, D.C., and Pye, K., 1993, Reduction of $\mathrm{Fe}(\mathrm{III})$ in sediments by sulphate-reducing bacteria: Nature, v. 361, p. 436-438.

Gorby, Y., and Lovley, D.R., 1991, Electron transport in the dissimilatory iron-reducer, GS-15: Applied and Environmental Microbiology, v. 57, p. 867-870.

1992, Enzymatic uranium precipitation: Environmental Science Technology, v. 26, p. 205-207.

Landa, E.R., Phillips, E.J.P., and Lovley, D.R., 1992, Release of 226Ra from uranium mill tailings by microbial Fe(III) reduction: Applied Geology, v. 6, p. 647-652.

Lonergan, D.J., and Lovley, D.R., 1991, Microbial oxidation of natural and anthropogenic aromatic compounds coupled to $\mathrm{Fe}(\mathrm{III})$ reduction, in Baker, R.A., ed., Organic Substances and Sediments in Water: Chelsea, Mich., Lewis Publishers, Inc., p. 327-338.

Lovley, D.R., 1990, Magnetite Formation during Dissmilatory Fe(III) Reduction, in Frankel, R.B., and Blakemore, R.P., eds., Iron Biominerals: New York: Plenum Press, p. 151-166.

1991, Dissimilatory Fe(III) and Mn(IV) reduction: Microbiological Reviews, v. 55, p. 259-287.

1992, Microbial oxidation of organic matter coupled to the reduction of $\mathrm{Fe}$ (III) and $\mathrm{Mn}$ (IV) oxides: Catena, v. 21, p. 101-114.

1993, Microbes into Heavy Metal-Trends in Ecology and Evolution, v. 8, p. 213-217.

1993, Dissimilatory reduction of iron and uranium, in Guerrero, R., and Pedros-Alio, C., eds., Trends in Microbial Ecology: Barcelona: Spanish Society for Microbiology, p. 71-74.

Lovley, D.R., Baedecker, M.J., Lonergan, D.J., Cozzarelli, I.M., Phillips, E.J. P., and Siegel, D.I., 1989, Oxidation of aromatic contaminants coupled to microbial iron reduction: Nature, v. 339, p. 297-299.

Lovley, D.R., Chapelle, F.H., and Phillips E.J.P., 1990, Recovery of Fe(III)-reducing bacteria 


\section{ECOLOGY}

from deeply buried sediments of the Atlantic Coastal Plain: Geology, v. 18, p. 954-957.

Lovley, D.R., Chapelle, F.H., and Woodward, J.C., in press, Use of dissolved $\mathrm{H}_{2}$ concentrations to determine the distribution of microbially catalyzed redox reactions in anoxic ground water: Environmental Science Technology, v. 28.

Lovley, D.R., Giovannoni, S.J., White, D.C., Champine, J.E., Phillips, E.J.P., Gorby, Y.A., and Goodwin, S., 1993, Geobacter metallireducens gen. nov. sp. nov., a microorganism capable of coupling the complete oxidation of organic compounds to the reduction of iron and other metals: Archives of Microbiology, v. 159, p. 336-344.

Lovley, D.R., and Lonergan, D.J., 1990, Anaerobic oxidation of toluene, phenol, and p-cresol by the dissimilatory Fe(III)-reducing organism, GS-15: Applied Environmental Microbiology, v. 56, p. 1858-1864.

Lovley, D.R., and Phillips, E.J.P., 1989, Requirement for a microbial consortium to completley oxidize glucose in $\mathrm{Fe}$ (III)-reducing sediments: Applied Environmental Microbiology, v. 55, p. 3234-3236.

1992, Reduction of Uranium by Desulfovibrio desulfuricans: Applied Environmental Microbiology, v. 58, p. 850-856.

1992, Bioremediation of uranium contamination with enzymatic uranium reduction: Environmental Science Technology, v. 26 , p. $2228-2234$.

in press, Novel processes for anaerobic sulfate production from elemental sulfur by sulfatereducing bacteria: Applied Environmental Microbiology, v. 60.
1994, Reduction of chromate by Desulfovibrio vulgaris and its $\mathrm{C}_{3}$ cytochrome: Applied Environmental Microbiology, v. 60, p. 726-728.

Lovley, D.R., Phillips, E.J.P., and Caccavo, F. Jr., 1992, Acetate oxidation by dissimilatory Fe(III) reducers: Applied and Environmental Microbiology, v. 58, p. 3205-3206.

Lovley, D.R., Phillips, E.J.P., Gorby, Y.A., and Landa, E.R., 1991, Microbial reduction of uranium: Nature, v. 350, p. 413-416.

Lovley, D.R., Phillips, E.J.P., and Lonergan, D.J., 1989, Hydrogen and formate oxidation coupled to dissimilatory reduction of iron or manganese by Alteromonas putrefaciens: Applied Environmental Microbiology, v. 55, p. 700-706.

1991, Enzymatic versus nonenzymatic mechanisms for $\mathrm{Fe}$ (III) reduction in aquatic sediments: Environmental Science and Technology, v. 25, p. 1062-1067.

Lovley, D.R., Roden, E.E., Phillips E.J.P., and Woodward, J.C., 1993, Enzymatic iron and uranium reduction by sulfate-reducing bacteria: Marine Geology, v. 113, p. 41-553.

Lovley, D.R., and Stolz, J.F., 1989, Origin of soil magnetite: Nature, v. 340, p. 106.

Lovley, D.R., Widman, P.K., and Woodward, J.C., 1993, Reduction of uranium by cytochrome $\mathrm{C}_{3}$ of Desulfovibrio vulgaris: Applied and Environmental Microbiology, v. 55, p. 3572-3576.

Lovley, D.R., and Woodward, J.C., 1992, Consumption of freons CFC- 11 and CFC-12 by anaerobic sediments and soils: Environmental Science Technology, v. 26, p. 925-929. 


\section{ECOLOGY}

Lovley, D.R., Woodward, J.C., Chapelle, F.H., in press, Stimulation of anoxic aromatic hydrocarbon degradation with Fe (III) Ligands: Nature, v. 368.

Moskowitz, B.M., Frankel, R.B., Bazylinski, D.A., Jannasch, H.W., and Lovley, D.R., 1989, A comparison of magnetite particles produced anaerobically by magnetotactic and dissimilatory iron-reducing bacteria: Geophysical Research Letters, v. 16, p. 665-668.

Oremland, R.S., Miller, L.G., Culbertson, C.W., Robinson, S.W., Smith, R.L., Lovley, D.R., Whiticar, M.J., King, G.M., Kiene, R.P., Iversen, M., and Sargent, M., 1993, Aspects of the biogeochemistry of methane in Mono Lake and the Mono basin of California, U.S.A., in Oremland, R.S., ed., Biogeochemistry of Global Change-Radiative Trace Gases: New York, Chapman and Hall, p. 704-741.

Phillips, E.J.P., Lovley, D.R., and Roden, E.E., 1993, Composition of non-microbially reducible Fe(III) in aquatic sediments: Applied Environmental Microbiology, v. 59, p. 27272729.

Roden, E.E., and Lovley, D.R., 1993, Dissimilatory $\mathrm{Fe}$ (III) reduction by the marine micro-organism, Desulfuromonas acetoxidans: Applied Environmental Microbiology, v. 59,

... p. 734-742.

1993, An evaluation of ${ }^{55} \mathrm{Fe}$ as a tracer for $\mathrm{Fe}$ (III) reduction in aquatic sediments: Geomicrobiology Journal, v. 11, p. 49-56.

Sparks, N.H.C., Mann, S., Bazylinski, D.A., Lovley, D.R., Jannasch, H.W., and Frankel, R.B., 1990, Structure and morphology of magnetite formed by a marine magnetotactic bacterium and dissimilatory iron-reducing bacteria: Earth and Planet Science Letters, v. 98, p. 14-22.

Stolz, J.F., Lovley, D.R., and Haggerty, S.E., 1990, Biogenic magnetite and magnetization of sediments: Journal of Geophysical Research, v. 95 , p. 4335-4361. 


\section{ECOLOGY}

TITLE: Vegetation and Hydrogeomorphic Relations (NR 90-145)

PERSONNEL: Cliff R. Hupp, Project Chief

Carolyn Wakelee, Secretary

Thomas M. Yanosky, Botanist

Michael Schening, Ecologist

ADDRESS: $\quad$ U.S. Geological Survey

430 National Center

12201 Sunrise Valley Drive

Reston, VA 22092

TELEPHONE: (703) 648-5206

PROBLEM: Many hydrogeomorphic processes are poorly understood. Botanical evidence studies can improve flood or debris flow prediction for streams with short or no gaging-station records.

Improvement of our understanding of the relation among fluvial geomorphology, sedimentation, mass wasting, plant chemistry, and plant ecology will provide insight into such problems as assessment of water quality, wetland loss, long-term effects of climatic variation, and the frequency and magnitude of destructive hydrogeomorphic phenomena. Botanical and geomorphic analyses may provide substantial information about variable source areas of runoff production and ground-water recharge.

OBJECTIVE: (1) Continue development of the combined use of botanical evidence and maximum likelihood estimators in flood-frequency prediction; (2) conduct basic research in the analysis and interpretation of the role of vegetation in natural and disturbed fluvial systems, including riparian and wetlands systems; (3) conduct basic research in the hydrogeomorphic-plant ecological aspects of watershed dynamics, including the delineation of variable source areas of runoff production and ground-water recharge, and analyses of nonpoint source pollution and basic plant-landform relations, and (4) conduct basic research into tree-ring chemistry as an indication of ground and surface water quality.

APPROACH: The approach is broadly interdisciplinary, employing techniques from the hydrologic, geomorphic, chemical and ecologic sciences. Dendrogeomorphic (tree-ring landform analyses), hydrologic (stream flow modeling, step-backwater analyses), and statistical (maximum likelihood estimator, time series) techniques are used in the paleohydrologic (floods, debris flows, landsliding) aspects of the project. The above techniques are combined with plant ecological analyses (plot and plotless sampling, species/landform mapping, multivariate biostatistical analyses), geomorphic analyses, and sedimentologic analyses to accomplish objectives 2 and 3 . Objective 4 is accomplished by investigating the relationship between pollutants in water and sediments, and subsequent levels in plant tissues. 


\section{ECOLOGY}

PROGRESS: A study of element concentrations within trees growing at an abandoned woodpreserving plant site in Jackson, Tennessee, found that trees along the ground-water flowpath contained elevated concentrations of some nutrients and trace metals seemingly related to site activities. Trees sampled farthest downgradient from the site did not show evidence that contaminants had reached them. This study was in an area of extreme hydrogeomorphic complexity, and extended and refined the application of dendrochemistry to ground-water assessments.

Intensive investigations of baldcypress within the Cape Fear estuary, North Carolina, found large concentrations of chloride, bromide, and sodium within growth rings of trees subjected to saline flooding. A new technique to estimate the local onset of saltwater encroachment was based on reconstruction of the heartwood/sapwood interface of trees at various times in the past. This technique should be useful in situations in which large concentrations of elements are mobilized across ring boundaries and stored in heartwood tissues. The study of trees within the Cape Fear estuary will allow for the development of tree-growth and mortality models that may be applied in areas where intrusion is expected.

A dendrochemical investigation of trees growing over a shallow aquifer near Baltimore, Maryland, contaminated by a thick layer of floating oil found large concentrations of iron and some trace metals in rings that formed during the suspected onset of contamination. Major nutrients (calcium, potassium, and magnesium) were more highly concentrated in trees growing within than outside the zone of oil contamination. It seems likely that concentrations of nutrients increased after the onset of contamination, resulting in increased uptake by trees and translocation into heartwood rings. For the first time in our studies, it was demonstrated that cadmium was taken up and stored in the rings of some trees.

Studies have continued in wetland and bottomlands of the southeastern United States. Stream channelization in Tennessee has altered sedimentation rates and the subsequent growth of bottomland tree species. Dendrogeomorphic methods continue to be developed and tested in order to estimate sedimentation rates in forested wetlands, thus providing information that otherwise is generally not available.

\section{REPORTS PUBLISHED 1989-1994:}

Bazemore, D.E., and Hupp, C.R., 1991, Floodplain sedimentation rates near bridge crossings: Federal Sediment Conference, 5th, [Proceedings], no. 1: p. 48-54.

Bazemore, D.E., Hupp, C.R., and Diehl, T.H., 1991, Wetland sediment deposition and vegetation patterns near selected highway crossings in west Tennessee: U.S. Geological Survey, Water-Resources Investigations Report 914106, p. 46.

Carey, W.P., Lyverse, M.A., and Hupp, C.R., 1990, Hillslope erosion Kentucky: U.S. Geological Survey, Water-Resources Investigations Report 89-4199, p. 38. 


\section{ECOLOGY}

Hupp, C.R., 1990, Vegetation patterns in relation to basin hydrogeomorphology, in, Thornes, J.B., ed., Vegetation and erosion: Chichester, England, Wiley and Sons Ltd., p. 217-237.

1992, Riparian vegetation recovery patterns following stream channelization-A geomorphic perspective: Ecology, v. 73, p. 1209-1226.

Hupp, C.R., and Bazemore, D.E., 1991, Dendrogeomorphic analysis of wetland sedimentation: Federal Interagency Sediment Conference, 5th, [Proceedings], no. 1, p. 40-47.

1992, Spatial and temporal aspects of sediment deposition in west Tennessee forested wetlands: Journal of Hydrology, v. 141, p. 179196.

Hupp, C.R., and Carey, W.P., 1990, Dendrogeomorphic approach to slope retreat, Maxey Flats, Kentucky: Geology, no. 18 , p. $658-$ 661.

Hupp, C.R., and Morris, E.E., 1990, A dendrogeomorphic approach to measurement of sedimentation in a forested wetland, Black Swamp, Arkansas: Wetlands, no. 10, p. 107124.

Hupp, C.R., and Osterkamp, W.R., in press, Riparian vegetation and fluvial geomorphic processes: Geomorphology, v. 00.

Hupp, C.R., and Simon, A., 1991, Bank accretion and the development of vegetated depositional surfaces along modified alluvial channels: Geomorphology, no. 4, p. 111-124.

Hupp, C.R., Woodside, M.D., and Yanosky, T.M., 1993, Sediment and trace element trapping in a forested wetland, Chickahominy River, Virginia: Wetlands, v. 13, p. 95-104.
Puckett, L.J., Woodside, M.D., Libby, B., and Schening, M.R., 1993, Sinks for trace metals, nutrients, and sediments in wetlands of the Chickahominy River near Richmond, Virginia: Wetlands, v. 13, p. 105-114.

Simon, A., and Hupp, C.R., 1990, The recovery of alluvial systems in response to imposed channel modifications, west Tennessee, in, Thornes, J.B., ed., Vegetation and erosion: Chichester, England, Wiley and Sons Ltd., p. 145-160.

Simon, A., and Hupp, C.R., 1992, Geomorphic and vegetative recovery processes along modified stream channels in West Tennessee: U.S. Geological Survey Open-File Report 91-502, $142 \mathrm{p}$.

Simon, A., Larsen, M.C., and Hupp, C.R., 1990, The role of soil processes in determining mechanisms of slope failure and hillslope development in a humid tropical forest, eastern Puerto Rico: Proceedings of the 21st Geomorphology Symposium, Geomorphology 3, p. 263-286.

Vroblesky, D.A., and Yanosky, T.M., 1990, Use of tree-ring chemistry to document historical ground-water contamination events: Ground Water, v. 28 , p. 677-684.

Vroblesky, D.A., Yanosky, T.M., and Siegel, F.R., 1992, Increased concentrations of potassium in heartwood of trees in response to groundwater contamination: Environmental Geology and Water Science, v. 19, p. 71-74.

Yanosky, T.M., and Carmichael, J.K., 1993, Element concentrations in growth rings of trees near an abandoned wood-preserving plant site at Jackson, Tennessee: U.S. Geological Survey Water-Resources Investigations Report 93$4223,69 \mathrm{p}$. 


\section{ECOLOGY}

Yanosky, T.M., Hupp, C.R., and Hackney, C.T., in press, Chloride concentrations in growth rings of Taxodium distichum in a saltwaterintruded estuary, North Carolina, USA:

Ecological Applications, v. 00.

Yanosky, T.M., and Vroblesky, D.A., 1992, Relation of nickel concentrations in tree ring to groundwater contamination: Water Resources Research, v. 28, p. 2077-2083.

Yanosky, T.M., and Vroblesky, D.A., in press, Element analysis of tree rings in ground-water contamination studies, in Lewis, T.E., ed., Tree Rings as Indicators of Ecosystem Health: CRC Press, Inc., Boca Raton, Florida. 


\section{ECOLOGY}

TITLE: Geochemistry of Riverine and Estuarine Waters (WR 68+046)

PERSONNEL: David H. Peterson, Project Chief

Lucenia Thomas, Secretary

Laurence E. Schemel, Oceanographer

Stephen W. Hager, Oceanographer

Richard E. Smith, Research Oceanographer

Daniel R. Cayan, Meteorologist

Reginald Uncles, Oceanographer

(United Kingdom)

ADDRESS: $\quad$ U.S. Geological Survey

345 Middlefield Road, MS 496

Menlo Park, CA 94025

TELEPHONE: (415) 354-3366

PROBLEM: The physical and chemical variability in rivers and estuaries is large, but forced by weather and climate causes and interactions are not clearly defined. Variations appear to be very important, but we don't yet understand how riverine-estuarine systems operate on very short and moderately long time scales. Furthermore, the effect of anthropogenic activities also may be important. Without such information we cannot understand and predict how these systems respond to variations in climate and human activities including changes in the amount, character, and timing of freshwater, toxic-waste, sediment and plant-nutrient inflows to these environments.

OBJECTIVE: To better understand the variability of the physics (circulation) and chemistry (primarily oxygen, carbon, silicon, nitrogen and phosphorous dynamics) in riverine and estuarine environments. To discriminate between natural variations due to atmospheric/ oceanic forcing and human-caused impacts.

APPROACH: Defining temporal/spatial variability in riverine/estuarine systems is largely observational and will use shipboard and in place instrumentation as well as large meteorological/ hydrological/oceanographical data bases. Methods of analysis include statistical and numerical simulation models of physical, chemical and biological processes influencing these systems over a broad spectrum of space and time scales. Major estuaries, such as San Francisco Bay, will be used as models for understanding and comparing behavior in others. Regional watershed variability will be interpreted vis-a-vis large scale regional-atmospheric, global-atmospheric and oceanic conditions including circulation, temperature, and precipitation. Intermediate linkage to watershed hydrology will be incorporated.

PROGRESS: Decades of observations supported by results from statistical-dynamical and numerical models identify freshwater delta flow (DF) as the master control on mean-monthly salinity in the bay. Further, even on tidal and spring/neap-time scales, DF influences the complex tidal signature of 


\section{ECOLOGY}

salinity stratification/destratification. Delta flow, in turn, is driven by two distinct, but perhaps not independent, factors: atmospheric circulation and human intervention. San Francisco Bay salinity is lowest in late spring in response to peak DF and is highest in late summer when DF is minimum. Superimposed on this annual cycle is considerable interannual variability, which is largely dependent on both the water content of winter snow pack in the Sierra Nevada to the east and the timing of snowmelt runoff in spring. Human influences, such as the long-term decrease in DF due to water diversions/exports, are most apparent in spring and are reflected in a long-term increase in the bay's salinity. This "artificial" decrease in DF (or increase in exported DF) is confounded by atmospheric influences. In dry years, the percent exported is higher than in wet years and, beyond that, a longterm shift in atmospheric circulation has forced a trend toward earlier runoff, slightly decreasing spring DF, and increasing salinity.

The Sacramento River is an important, if not most important, source of San Francisco Bay variability including freshwater flows and associated suspended sediment. Thus, in wet years, the Yolo bypass is a major source of suspended sediment as well as freshwater discharge. Similarly, winter transport of particulate organic carbon to the bay is larger than previously thought. South San Francisco Bay, the bay's cul-de-sac, shows important chemical characteristics that are more obscure in North Bay. The response of South Bay water chemistry includes effects of changes in waste flow quality, evaporation, as well as wet and dry year scenarios.

\section{REPORTS PUBLISHED 1989-1994:}

Aguado, E., Cayan, D., Reece, B., Riddle, L., 1993, Patterns of orographic uplift in the Sierra Nevada and their relationship to upper-level atmospheric circulation, in Redmond, K.T., and Tharp, V.L., eds., Proceedings of the Ninth Annual Pacific Climate (PACLIM) Workshop: Pacific Climate Workshop, Asilomar, Calif., April 21-24, 1992, p. 153-164.

Aguado, E., Cayan, D., Riddle, L., and Roos, M., 1992, Climatic fluctuations and the timing of West Coast streamflow: Journal of Climatology, v. 5, p. 1468-1483.

Carlton, J.T., Thompson, J.K., Schemel, L.E., and Nichols, F.H., 1990, The remarkable invasion of San Francisco Bay (California, U.S.A.) by the Asian clam Potamocorbula amurensis-I.
Introduction and dispersal: Marine Ecology Progress Series, v. 66, p. 81-94.

Cayan, D.R., 1991, "Cool" vs. "Warm" winter precipitation and its effect on streamflow in California, in Betancourt, J., and Tharp, V., eds., Proceedings of the Seventh Annual Pacific Climate (PACLIM) Workshop: Pacific Climate Workshop, Asilomar, Calif., April 10-13, 1990.

Cayan, D.R., 1991, "Cool" vs. "Warm" winter precipitation and its effect on streamflow in western North America: U.S. Department of Commerce, 15th Annual Climate Diagnostics Workshop, National Climatic Data Center, Asheville, N.C., October 29-November 2, 1990. 


\section{ECOLOGY}

Cayan, D.R., Gardner, J.V., Landwehr, J.M., Namias, J., and Peterson, D.H., 1989, Introduction, in Peterson, D.H., ed., Aspects of Climate Variability in the Pacific and the Western Americas: Washington, D.C., American Geophysical Union, Monograph 55, p. 13-16.

Cayan, D.R., McClain, D.R., Nichols, W.D., DiLeo-Stevens, J., 1991, The monthly climate time series data for the Pacific Ocean and western Americas: U.S. Geological Survey Open-File Report No. 91-92, p. 380.

Cayan, D.R., and Peterson, D.H., 1989, The Influence of North Pacific Atmospheric Circulation on Stream Flow in the West, in Peterson, D.H., ed., Aspects of Climate Variability in the Pacific and the Western Americas: Washinton, D.C., American Geophysical Union, Monograph 55, p. 375-397.

Cayan, D.R., and Peterson, D.H., 1990, Influence of winter atmospheric circulation on streamflow and stream chemistry in western North America: American Meteorological Society Annual Meeting, Anaheim, Calif., February 1990 [Proceedings].

Cayan, D.R., and Peterson, D.H., 1993, Spring climate and salinity in the San Francisco Bay estuary: Water Resources Research, v. 29, no. 2, p. 293-303.

Cayan, D.R., and Riddle, L., 1992, Atmospheric circulation and precipitation in the Sierra Nevada: American Water Resources Association, 28th Annual Conference and Symposium, November 1-5, 1992, Reno, Nev., Iproceedings], p. 711-720.

Cayan, D.R., and Riddle, L.G., 1993, A multibasin seasonal streamflow model for the Sierra Nevada, in Redmond, K.T., and Tharp, V.L., eds., Proceedings of the Ninth Annual Pacific Climate (PACLIM) Workshop: Pacific Climate Workshop, Asilomar, Calif., April 21-24, 1992, p. 141-152.

Cayan, D.R., Riddle, L.G., and Aguado, E., 1993, The influence of precipitation and temperature on seasonal streamflow in California: Water Resources Research, v. 29, p. 1127-1140.

Cayan, D.R., Riddle, L.G., Garen, D.C., and Aguado, E., 1992, Winter climate variability and snowpack in the west, in Redmond, K.T., ed., Proceedings of the Eighth Annual Pacific Climate (PACLIM) Workshop: Pacific Climate Workshop, Asilomar, Calif., March 10-13, 1991, p. 125-134.

Cayan, D.R., and Webb, R.H., 1992, El Niño/ Southern Oscillation and streamflow in the western United States, in Diaz, H.F., and Markgraf, V. eds., El Niño-Historical and Paleoclimatic Aspects of the Southern Oscillation: Cambridge, Mass., Cambridge University Press, p. 29-68.

Cifuentes, L.A., Schemel, L.E., and Sharp, J.H., 1990, Qualitative and numerical analyses of the effects of river inflow variations on mixing diagrams in estuaries: Estuarine, Coastal and Shelf Science, v. 30, p. 411-427.

Chen, S.C., Cayan, D.R., Roads, J.O., and Dettinger, M., 1992, A numerical simulation of cool/wet and warm/wet episodes in the Western United States, in Redmond, K.T., ed., Proceedings of the Eighth Annual Pacific Climate (PACLIM) Workshop: Pacific Climate Workshop, Asilomar, Calif., March 10-13, 1991, p. 91-98.

Cole, B.E., Hager, S.W., and Hollibaugh, J.T., 1990, Hydrographic, biological and nutrient properties of Tomales Bay, California, March 


\section{ECOLOGY}

1985 to May 1986: U.S. Geological Survey Open-File Report 90-178, p. 93.

Dettinger, M.D., and Cayan, D.R., 1992, Climatechange scenarios for the Sierra Nevada, California, based on winter atmospheric-circulation patterns: American Water Recources Aassociation, 28th Annual Conference and Symposium, Reno, November 1-5, 1992, p. 681-690.

Ebbesmeyer, C., Cayan, D.R., McClain, D.R., Nichols, F.H., Peterson, D.H., and Redmond, K., 1991, Sensitivity of marine biological to climate change in a North Pacific Swath in Bentancourt, J., and Tharp, V., eds., Proceedings of Seventh Annual Pacific Climate (PACLIM) Workshop, Asilomar, Calif., April 10-30, 1990, p. 115-126.

Ely, L.L., Enzel, Y., Baker, V.R., and Cayan, D.R., 1993, 5,000-year record of extreme paleofloods and associated atmospheric circulation patterns: Science, 262 p.

Enzel, Y., Cayan, D.R., Anderson, R.Y. and Wells, S.G., 1989, Atmospheric circulation during Holocene lake stands in the Mojave Desert-evidence of regional climatic change: Nature, v. 341 , p. 44-48.

Giese, B.S., and Cayan, D.R., 1993, Surface heat flux parameterization and tropical Pacific SST simulations: Journal of Geophysical Research, v. 98 , p. $6979-6989$.
Hager, S.W. and Schemel, L.E., 1992, Sources of Nitrogen and phosphorus to Northern San Francisco Bay: Estuaries, v. 15, no. 1, p. 40-52.

Nichols, F.H., Thompson, J.K., and Schemel, L.E., 1990, The remarkable invasion of San Francisco Bay (California, U.S.A.) by the Asian clam, Potamocorbula amurensis-II. Displacement of a former community: Marine Ecology Progress Series, v. 66, p. 95-101.

Ota, A.Y., Schemel, L.E., and Hager, S.W., 1989, Physical and chemical properties of San Francisco Bay, California, 1980: U.S. Geological Survey Open-File Report 89-421, p. 251.

Peterson, D.H., 1994, Book Review, Oxygen Dynamics in the Chesapeake Bay: Continental Shelf Research, v. 14, p. 321-323.

Peterson, D.H., Cayan, D.R., Festa, J.F., Nichols, F.H., Walters, R.A. Slack, J.R., Hager, S.W., and Schemel, L.E., 1989, Climate variability in an estuary-Effects of riverflow on San Francisco Bay, in Peterson, D.H., ed., Aspects of Climate Variability in the Pacific and Western Americas: Washington, D.C., American Geophysical Union, Monograph 55, p. 419-442.

Peterson, D.H., Noble, M. and Smith, R.E., 1993, Suspended sediments in San Francisco Bay Estuary, California-Recent History and available data sets: U.S. Geological Survey Water Resources Investigations Report 93-4128, 35 p. 


\section{ECOLOGY}

Schemel, L.E., Ota, A.Y., Hager, S.W., and Swithenbank, A.N., 1989, Sources of dissolved and particulate substances to the Sacramento River near Sacramento, California, Summer 1985: U.S. Geological Survey Open-

File Report 45-89, 62 p.

Schemel, L.E., Ota, A.Y., Harmon, J.G., Shay, J.M., and Adorador, R.N., 1989, Benthic Macrofauna and Ancillary Data for San Francisco Bay, California, January to November 1988: U.S. Geological Survey Open-File Report 89-596, 65 p.

Uncles, R.J., and Peterson, D.H., in press, A microcomputer model of long-term salinity in San Francisco Bay: Environmental International, $10 \mathrm{p}$. 


\section{ECOLOGY}

TITLE: $\quad$ Fate of Organic Chemicals in Subsurface Environments (WR 71-068)

PERSONNEL: Edward M. Godsy, Project Chief

Kim N. Bui, Secretary

Ean Warren, Environmental Engineer

Jeff G. Ritchey Student, (San Jose State University)

ADDRESS: $\quad$ U.S. Geological Survey

345 Middlefield Road, MS 458

Menlo Park, CA 94025

TELEPHONE: (415) 329-4504

PROBLEM: Release of various synthetic organic compounds to the environment has caused soil and ground-water pollution in many places. The processes that control the persistence and movement of these compounds are not well understood. A better understanding is necessary to aid in construction of models to predict movement and fate of pollutants in the subsurface and for design of control and abatement techniques.

OBJECTIVE: (1) Determine the transformation pathways of selected organic compounds by means of a combination of field observations and laboratory simulations of environmental conditions; (2) assess the relative importance of physical, chemical, and biochemical processes in the transformation of these compounds under ambient conditions; and (3) study relevant biotransformation processes in the subsurface.

APPROACH: Select one or more field sites where ground water has become contaminated with organic compounds. Collect and analyze water samples to discover the chemical transformations that are occurring in the subsurface environment. Use laboratory-simulation studies to elucidate the controls on these transformations.

PROGRESS: The project consists of field and laboratory studies of creosote and crude oil contaminated ground water at the USGS Hazardous Waste Sites at Pensacola, Florida, and Bemidji, Minnesota, respectively, with the aim of elucidating the various microbial and physical processes, and factors that influence them, affecting separate groups of water soluble creosote and crude-oil derived compounds during down gradient travel in the aquifer. Determination of the kinetics of substrate utilization and transformation pathways of the major aromatic biodegradable components of the water soluble fraction of creosote and crude oil using single compounds as carbon and energy sources under aerobic, sulfate reducing, iron reducing, and denitrifying conditions is presently underway. The kinetics of biodegradation of the creosote derived compounds under methanogenic conditions has been completed. Laboratory columns have been developed and the abiotic factors that affect movement of 


\section{ECOLOGY}

the major components of the creosote-derived compounds during down gradient travel with the ground water have been determined. A solute transport model utilizing the laboratory determined Monod kinetic substrate utilization parameters and sorption characteristics has been developed and refined. This model has successfully modeled the transport of phenol, 2-, 3-, 4-methylphenol, quinoline, and isoquinoline in the aquifer at the Pensacola study site. Work continues for the crude oil-derived compounds found at the Bemidji study site.

\section{REPORTS PUBLISHED 1989-1994:}

Bekins, B.A., Godsy, E.M., and Goerlitz, D.F., 1994, Steady-state methanogenic kinetics of phenolic compounds in ground water-Inferences from modeling: Journal of Contaminant Hydrology, v. 14, p. 279-294.

Bekins, B.A., Godsy. E.M., and Goerlitz, D.F., in press, Steady-state methanogenic degradation of phenols in groundwater at Pensacola, Florida, in Morganwalp, D.W., and Aronson, D.A., eds., U.S. Geological Survey Toxic Substances Hydrology Program-Proceedings of the technical meeting, Colorado Springs, Colo., September 20-24, 1993: U.S. Geological Survey Water-Resources Investigations Report 94-4014.

Godsy, E. M., Goerlitz, D. F., and Grbic-Galic, Dunja, 1989, Transport and degradation of water-soluble creosote-derived compounds, in Allen, D.T., ed., Intermedia Pollutant Transport-Modeling and Field Measurements: New York, Plenum Publishing, p. 112-143.

1990, Anaerobic biodegradation of creosote contaminants in natural and simulated ground water ecosystems: Falls Church, Va., Symposium on Bioremediation of Hazardous Wastes, EPA's Biosystems Technology Development Program, 1990, p. 39-42.

1991, Methanogenic degradation kinetics of phenolic compounds: Falls Church, Va., Symposium on Bioremediation of Hazardous
Wastes, EPA's Biosystems Technology Development Program, 1991, p. 67-69.

1992, Anaerobic biodegradation of creosote contaminants in natural and simulated ground water ecosystems: Ground Water, v. 30, p. 232-242.

1992, Methanogenic degradation of heterocyclic aromatic compounds by aquifer derived microcosms: Chicago, Illinois, Symposium on Bioremediation of Hazardous Wastes, EPA Biosystems Technology Development Program, p. 120-125.

1992, Methanogenic degradation kinetics of phenolic compounds in aquifer-derived microcosms: Biodegradation, v. 2, p. 211-221.

Godsy, E.M., Goerlitz, D.F., and Grbic-Galic, Dunja, 1993, Methanogenic degradation kinetics of nitrogen and sulfur containing heterocyclic aromatic compounds in aquifer-derived microcosms: Symposium on bioremediation of hazardous wastes-research, development, and field evaluations, U.S. Environmental Protection Agency EPA/600/R-93/054, p. 123-128.

Godsy, E.M., Goerlitz, D.F., and Grbic-Galic, Dunja, 1994, Methanogenic biodegradation of creosote derived compounds in an aquifer at Pensacola, Florida, in Dutton, A.R., ed., Proceedings of American Institute of Hydrology, Symposium on Toxic Substances and the 


\section{ECOLOGY}

Hydrologic Sciences: Austin, Texas, April 10-14, 1994, p. 1-18.

Godsy, E.M., Goerlitz, D.F., and Grbic-Galic, Dunja, in press, Pathways of methanogenic biodegradation of creosote-derived aromatic compound, in Morganwalp, D.W., and Aronson, D.A., eds., U.S. Geological Survey Toxic Substances Hydrology Program-Proceedings of the technical meeting, Colorado Springs, Colo., September 20-24, 1993: U.S. Geological Survey Water-Resources Investigations Report 94-4014.

Godsy, E.M., and Grbic-Galic, Dunja, 1989, Biodegradation pathways for benzothiophene in methanogenic microcosms, in Mallard, G. E, and Ragone, S. E., eds., U.S. Geological Survey Toxic Substances Hydrology ProgramProceedings of the technical meeting, Phoenix, Ariz., September 26-30, 1988: U.S. Geological Survey Water-Resources Investigations Report 88-4220, p. 559-564.

Grbic-Galic, Dunja, Henry, S. M., Godsy, E. M., Edwards, Elizabeth, and Mayer, K. P., 1991, Anaerobic degradation of aromatic hydrocarbons and aerobic degradation of trichloroethylene by subsurface microorganisms, in Baker, R.A., ed., Organic substances and sediments in water, Volume III, Biological: Boca Raton, Fla., Lewis Publishers, Inc., p. 239-266.

Van Denburgh, A.S., Goerlitz, D.F., and Godsy, E.M., in press, Depletion of nitrogen-bearing explosives waste in a shallow ground-water plume near Hawthorne, Nevada, in Morganwalp, D.W., and Aronson, D.A., eds., U.S. Geological Survey Toxic Substances Hydrology Program-Proceedings of the technical meeting, Colorado Springs, Colo., September 20-24, 1993: U.S. Geological Survey WaterResources Investigations Report 94-4014.
Warren, Ean, and Godsy, E.M., 1994, Comparison of sulfur and nitrogen heterocyclic compound transport in creosote-contaminated aquifer material: U.S. Environmental Protection Agency, Symposium on Bioremediation of Hazardous Wastes-Research, Developement, and Field Evaluations, EPA/600/R-94/075, p. 153-157.

Warren, Ean, and Godsy, E.M., in press, Modeling breakthrough of nitrogen heterocyclic compounds in laboratory column containing creosote contaminated aquifer material, in Morganwalp, D.W., and Aronson, D.A., eds., U.S. Geological Survey Toxic Substances Hydrology Program-Proceedings of the technical meeting, Colorado Springs, Colo., September 20-24, 1993: U.S. Geological Survey Water-Resources Investigations Report 94-4014. 


\section{ECOLOGY}

TITLE: $\quad$ Availability of Trace Elements in Sediments to Aquatic Organisms (WR 75-125)

PERSONNEL: Samuel N. Luoma, Project Chief J. Stacey, Andrews, Secretary

James L. Carter, Hydrologist

Daniel J. Cain, Biologist

Steven V. Fend, Hydrologist

Alexander Van Geen, Chemist

Susan S. Kennelly, Hydrologist

Cynthia L. Brown, Physical Scientist

Michelle I. Hornberger, Physical Scientist

ADDRESS: $\quad$ U.S. Geological Survey

345 Middlefield Road, MS 465

Menlo Park, CA 94025

\section{TELEPHONE: (415) 329-4481}

PROBLEM: Concentrations of potentially toxic elements in sediments are orders of magnitude higher than concentrations of these elements in water. The ability of the aquatic environment to assimilate many toxic wastes depends upon how available this concentrated sediment-bound pool of elements is to aquatic organisms. Development of realistic pollution regulations, in turn, depends on prediction of assimilation capacities. Assessment of biological-indicator data for mineral exploration and pollution assessment also depend upon the understanding of factors affecting the biological availability of trace elements bound to sediments. It is established that the same biota in different environments may differ widely in their susceptibility or their response to trace elements, and that these differences may be at least partly related to the differences in the availability of metals in sediments; however, little is known about the geochemical and physiological factors that influence the transport of metals from sediments to organisms.

OBJECTIVE: (1) Study the partitioning of trace metals among the components of sediments and identify the processes that control partitioning; (2) study the influence of geochemical partitioning of trace metals in sediments on metal uptake by and effects of metals in organisms that contact sediments directly; (3) study physiological characteristics of aquatic organisms that uptake metal; (4) improve methodology that makes use of biota and sediments as indicators of geochemical conditions; (5) develop indices or models for predicting the bioavailability of metals after their release to the aquatic environment; and (6) develop methods for assessing the presence of biological effects from toxic wastes in aquatic communities in nature.

APPROACH: (1) Collect organisms and sediments from rivers, lakes, or estuaries across spatial or temporal gradients of physicochemical conditions; analyze geochemical partitioning through the use of chemical extractions, mathematical models, and statistics; and statistically assess relation of metal concentrations in organisms to aspects of the specific geochemical gradient under study. (2) Use laboratory studies on metal burdens in animals to assess biological influences such as animal size, 


\section{ECOLOGY}

intraspecific differences in metal tolerance, and physiological controls on metal uptake and metabolism. (3) Geochemically modify sediments or use well-defined model sediments in laboratory studies of metal uptake by organisms to identify physicochemical factors that affect metal availability and to test models derived from field studies.

PROGRESS: CLARK FORK RIVER, MONTANA: Continued study of year-to-year variability in metal concentrations in river. The past year was one of exceptionally high flows (and runoff) and was one of two years with greatest metal concentrations. Four fold changes have occurred in metal concentrations in the Clark Fork since 1986; all appear to be related to natural variability. Superfund activities, in progress since the late 1980's, have had no discernable influence on contamination in the river. Second year of seasonal sediment sampling indicated a distinct seasonal cycle in concentrations in a low flow year that indicated metals are pumped out of sediments (geochemically) during low flows; and sediment appear to be recontaminated by terrigenous inputs during high runoff. Methods were developed to determine contribution of gut content to metal concentrations in small bioindicators. Contribution varies with metal, but is less than 50 percent for most metals, even in undepurated insect larvae.

SAN FRANCISCO BAY: Obtained first good data on metal concentrations on suspended particles in Bay and began study of how concentrations and transect of metals change seasonally. Desorption of most labile metals is obvious at freshwater-seawater interface; others are not desorbed. Obtained first measurements of acid volatile sulfides (AVS) in intertidal sediments. Initial results show method gives repeatable results, but AVS concentrations in surface sediments are highly variable. In studies of sediment cores we have found a distinct discontinuity in contaminant concentrations that occurred in approximately the late 1950's in the North and Central Bays. It appears that contaminants increased dramatically in concentration at approximately the same time as the water projects began the rapid increase in water diversion from the Bay. A simple model was developed by D. Shoellhamer of California District based on these observations. Studies of clam, Potamocorbula amurensis, which show great differences in metal distributions between a year of very high river flow and lower flow years, appear consistent with these observations. Model development has begun that will allow separation of interactions between particle inputs, dissolved metal concentrations and effects of salinity in the clam data. Completed sampling in experiment to determine if sediment resuspension increases dissolved metal concentrations in South Bay, as indicated by seasonal metal concentrations.

METAL BIOAVAILABILITY: Finished paper showing that clams avoid intensive digestion of particles heavily contaminated with metals. By re-routing such particles through a less intensive process they are able to reduce their metal exposure in contaminated environments. This also suggests that metals were in sufficient concentrations (natural) in the environments where these animals evolved (that is, the sediments) to cause selection for a mechanisms to avoid the costs of digestive assimilation of too much metal. 


\section{ECOLOGY}

YAKIMA RIVER BASIN, WASHINGTON: Finished two papers discussing separation of factors controlling benthic community structure in the Yakima basin. Results contrasted and complemented NAWQA approach. NAWQA focused on anthropogenic factors as only thing important in determining communities in Yakima. The present work showed that natural factors such as altitude must be subtracted if anthropogenic effects are to be accurately interpreted.

COORDINATION: Through work with Aquatic Habitat Institute, F. Nichols' USGS Ecosystem Initiative, and as chair of Interagency Ecological Program science advisory committee we contributed to interagency efforts to coordinate research activities in San Francisco Bay.

\section{REPORTS PUBLISHED 1989-1994:}

Axtmann, E.V., and Luoma, S.N., 1991, Large scale distribution of metal contamination in the fine grained sediments of the Clark Fork River, Montana, U.S.A.: Applied Geochemistry, v. 6, p. $75-88$.

Cain, D., 1990, Studies using the clam Macoma balthica to identify bioavailable trace metals in San Francisco Bay, in Gunther A.J., ed., Bioavailability of Toxic Contaminants in the San Francisco Bay-Delta: San Francisco Bay-Delta Aquatic Habitat Institute, Report AHI-90-01, p. 55-69.

Cain, D.J., and Luoma, S.N., 1990, Influence of seasonal growth, age and environmental exposure on $\mathrm{Cu}$ and $\mathrm{Ag}$ in a bivalve indicator, Macoma balthica, in San Francisco Bay: Marine Ecology Progress Series, v. 60, p. 45-55.

1991, Benthic insects as indicators of largescale trace metal contamination in the Clark Fork River, Montana, in Mallard, G.E., and Aronson, D.A., eds., U.S. Geological Survey Toxics Substances Hydrology ProgramProceedings of the technical meeting, Monterey, Calif., March 11-15, 1991: U.S. Geological Survey Water-Resources Investigations Report 91-4034.
Cain D.J., Luoma, S.N., Carter, J.L., and Fend, S.V., 1992, Aquatic insects as bioindicators of trace element contamination in cobble-bottom rivers and streams: Canadian Journal Fisheries and Aquatic Science, v. 49, p. 2141-2154.

Crawford, J.K., and Luoma, S.N., 1992, Guidelines for studies of contaminants in biological tissues for the National Water Quality Assessment Program: U.S. Geological Survey OpenFile Report 92-494, 71 p.

Decho, A.W., and Luoma, S.N., 1991, Timecourses in the retention of food material in the bivalves Potamocorbula amurensis and Macoma balthica-Significance to the absorption of carbon and chromium: Marine Ecology Progress Series, v. 78, p. 303-314.

Decho, A.W., and Luoma, S.N., 1994, Geopolymers (humic and fulvic acids)-Sink or source in the availability of metals to marine animals?: Marine Ecology Progress Series, v. 108 , p. $133-145$.

Hostettler, F.D., Rapp, J.B., Kvenvolden, K.A., and Luoma, S.N., 1989, Organic markers as source discriminants and sediment transport indicators in south San Francisco Bay, California: Geochimica et Cosmochimica Acta, v. 53, p. 1563-1576. 


\section{ECOLOGY}

Johns, C., and Luoma, S.N., 1990, Arsenic in benthic bivalves of San Francisco Bay and the Sacramento/San Joaquin Delta: Science of the Total Environment, v. 97/98, p. 673-684.

Kuwabara, J.S., Chang, C.C.Y., Cloern, J.E., Fries, T.L., Davis, J.A., and Luoma, S.N., 1989, Trace metal associations in the water column of south San Francisco Bay: Estuarine Coastal and Shelf Science, v. 28, p. 307-325.

Luoma, S.N., 1989, Can we determine the biological availability of sediment-bound trace elements?: Hydrobiologia, v. $176 / 177$, p. $379-$ 396.

1990, Teaching environmental science (Review of Environmental ecology: The impacts of pollution and other stresses on ecosystem structure and function): Bioscience, v. 40, p. 612-613.

1990, Processes affecting metal concentrations in estuarine and coastal marine sediments, in Rainbow and Furness, Heavy Metals in Marine Environment: Uniscience, Boca Raton, Fla., CRC Press, p. 52-66.

1991, Environment for the uninformed-Book review of Imperiled Planet: Bioscience, v. 41, $643 \mathrm{p}$.

1990, Processes affecting metal concentrations in estuarine and coastal marine sediments, in Furness, R., and Rainbow, P., eds., Heavy metals in marine environment, chap. 4 , p. 5162: Boca Raton, Fla., CRC Press, p. 51-66.

1991, Environment for the uninformed-Book Review of Imperiled Planet: Bioscience, October, 643 p.
1994, No quick fix-Review of "Restoring the Nation's Marine Environment": California Coast and Ocean, v. 10, 46 p.

Luoma, S.N., Cain, D.J., Brown, C., 1992, Trace metals in clams (Macoma balthica) at the Palo Alto mudflat in South San Francisco BayMay 1991 to May 1992: U.S.Geological Survey Open-File Report 92-456, 51 p.

Luoma, S.N., Cain, D.J., Hornberger, M., 1993, Trace metals in clams (Macoma balthica) at the Palo Alto mudflat in South San Francisco Bay-May 1991 to May 1992: U.S. Geological Survey Open-File Report 93-500, 51 p.

Luoma, S.N., and Carter, J.L., 1991, Effects of trace metals on aquatic benthos, in Newman, M.C., and McIntosh, A.W., Metal Ecotoxicology: Concepts and Applications: Lewis Publishers, Chelsea, Michigan, p. 261-287.

1993, Understanding the toxicity of contaminants in sediments-Beyond the bioassay-based paradigm: Environmental Toxicology and Chemistry, v. 12, p. 793-796.

Luoma, S.N., Carter, J., Brown, C., 1991, Assessing adverse effects of contaminants on benthic species at the San Francisco Toxics Site, in Mallard, G., ed., U.S. Geological Survey Toxics Substances Hydrology Program Proceedings: U.S. Geological Survey WaterResources Investigation Report 91-4034.

Luoma, S.N., Dagovitz, R., and Axtmann, E.V., 1990, Temporally intensive study of trace metals in sediments and bivalves from a large river-estuarine system-Suisun Bay/delta in San Francisco Bay: The Science of the Total Environment, v. 97/98, p. 685-712.

Luoma, S.N., Johns, C., Fisher, N.S., Steinberg, N.A., Oremland, R.S., and Reinfelder, J., 


\section{ECOLOGY}

1992, Determination of selenium bioavailability to a benthic bivalve from particulate and solute pathways: Environmental Science and Technology, v. 26, p. 485-491.

Moore, J.N., and Luoma, S.N., 1990, Hazardous wastes from large-scale metal extraction: Environmental Science and Technology, v. 24, p. 1279-1285.

Moore, J.N., Luoma, S.N., and Peters, D., 1990, Effects of acid mine drainage on the Blackfoot River, Montana: Canadian Journal of Fisheries and Aquatic Sciences, v. 60, p. 45-55.

Van Geen, A., and Luoma, S.N., 1993, Trace metals $\mathrm{Cd}, \mathrm{Cu}, \mathrm{Ni}, \mathrm{Zn}$, and nutrients in coastal waters adjacent to San Francisco Bay, California: Estuaries, v. 16, 559-566.

Van Geen, A., Luoma, S.N., Fuller, C.C., Anima, R., Clifton, H.E., and Trumbore, S., 1992, Evidence from $\mathrm{Cd} / \mathrm{Ca}$ ratios in foraminifera for greater upwelling off California 4,000 years ago: Nature, v. 358 , p. 54-56. 


\section{ECOLOGY}

TITLE: Biotic Response to Climatic Variability and Human Impacts in Arid Lands (WR 76-145)

PERSONNEL: Julio L. Betancourt, Project Chief

Ana M. MacKay, Admin. Ops. Assist.

Douglas Wellington, Comp. Prog. Analysist

Elizabeth A. Pierson, Botanist

Diane K. Aasen-Rylander, Biological Techn.

ADDRESS: $\quad$ U.S. Geological Survey

Desert Laboratory

1675 W. Anklam Road

Tucson, AZ 85745

TELEPHONE: (602) 670-6821

PROBLEM: Biotic responses to climatic change or human manipulation are inherently complex because of wide differences in organism sensitivities and response times, the influence of history and scale, and the various interactions between organisms and with the physical system. In arid and semiarid lands, which cover about 12.5 percent of the Earth's land surface, the effects of climatic variability on vegetation are greatly magnified, particularly because most plants exist near their physiological limits. How arid land vegetation might in turn affect climate is uncertain, though there is some indication that decreasing cover and increasing albedo could promote regional drought. Whether in response to projected Greenhouse climates or intensified land use, vegetation in such critical watersheds as the Rio Grande and Colorado River basins is apt to change in the near future. There is a need to understand the direction and rate of this change and how it might affect water use and availability in the region.

OBJECTIVE: To achieve a dynamic understanding of vegetation change and its relation to water resources; to develop such an understanding in a manner appropriate to the hierarchy of spatial and temporal scales implicit in a study of global change; and to determine whether responses of dryland vegetation to global change are predictable from the past and present behavior of vegetation.

APPROACH: The primary task of the project is to document vegetation and hydrological responses to climate variability on millennial to decadal time scales. The research entails monitoring of vegetation plots, analysis of instrumental records, and development of proxy data for times and places where direct measurements are unavailable. Plant demographic data will be collected to test hypotheses about short-term (decadal) vegetation responses to climatic variability in the 20th century. Paleoclimatological data will be developed for the southwestern region for the past 40,000 years. These data can be used to illustrate the influence of climatic change on arid ecosystems; to anticipate 


\section{ECOLOGY}

how these ecosystems are apt to change in the future; and to test and validate outputs from global circulation models.

PROGRESS: 1. Climate-plant distribution model: Funding from National Biological Survey, Global Change Program FY93-97, and collaboration with Kent State and University of Arizona.

Global change could affect the distribution of vascular plants in the Sonoran Desert. To forecast these changes, we are developing an integrated climate-plant distribution model based on individual species. Our modeling effort draws from (1) a plant distributional data base that includes 100,000 documented occurrences for nearly 3,000 species in the Sonoran Desert; (2) detailed knowledge of the physiology, ecology and demography of dominant species, which can be formalized in a rule-based expert system; and (3) a statistically-based local climate model (LCM) that can predict key variables in bioclimatology at monthly to daily resolution.

The monthly local climate model (MLCM) is a statistical model based on a canonical regression function that estimates monthly maximum temperature and total precipitation., Solution of the canonical regression function requires a set of predictor variables that represent the primary and interactive effects of five boundary conditions: terrain, sea-surface temperatures in January and July, $\mathrm{CO}_{2}$ concentration, solar insolation, and windfield (January and July surface and $500 \mathrm{mb}$ ). Thus, the MLCM uses boundary conditions that can be estimated for past, present, and future climate scenarios. Most of the predictor variables represent changes in boundary conditions along windfield trajectories that extend $1,000 \mathrm{~km}$ upwind and $30 \mathrm{~km}$ downwind from solution points. In this way, MLCM is considered a semi-Lagrangian model.

The MLCM is calibrated with boundary conditions and instrumental records from a large number of stations in the western United States (and in the near future, Mexico). The spatial distribution of these stations is sufficient to allow solutions of the MLCM over a large area of the southwestern United States and Mexico; in this case, the "solution domain" is the Sonoran Desert. Solutions are made at a 10-km spacing over the solution domain. We have been using 1980 to 1984 as the calibration period, but the model can also be calibrated with other periods (and verified against others). Solutions of modern climate are made by setting boundary conditions to those representing 1980-1984. Given these boundary condtions, predictor variables are computed at all grid points in the solution domain and applied to the canonical regression function.

Using the MLCM calibrated with only United States stations, we generated monthly climate estimations for points of saguaro occurrence in our digitized atlas of saguaro distribution. The model can actually solve for points south of the border, though less accurately than if calibrated with both United States and Mexican data. Most saguaro locations did not have precise elevations noted, so elevations were estimated based on averages within the grid cells; these "average" elevations were used to calculate climatic variables for points of saguaro occurrence. 


\section{ECOLOGY}

In general the experimental runs gave reasonable estimates for daily maximum temperature and precipitation over much of the region. Probably the most serious breach of actual climate was in the Vizcaino region of northern Baja California. The model predicted relatively high precipitation on the Vizcaino Plain and adjacent areas during July and August, when, in fact, these places are very dry during the summer. The discrepancy was caused by the model's inability to account for the effects of strong upwelling just offshore, which dominates the climate of the Vizcaino region for most of the

year. These results are of interest in that they suggest that climates favorable for saguaro would occur in the northern part of Baja California in the absence of upwelling. The relationship between upwelling regimes and plant distribution could be tested in the fossil record. However, the history of upwelling during the Holocene is poorly known, as is the vegetation history of the Vizcaino Plain.

In most monthly simulations, points of saguaro occurrence showed sharp frigid, arid, and thermal limits within the two-dimensional regional climate space. As expected, the points clustered in the tropical semiarid part of the regional space. Within the zone occupied by saguaro, the points of known occurrence were concentrated in the warmer arid quadrant during most months. This suggests that in the cooler, wetter parts of its range, saguaros are restricted to edaphic outposts where local aspect and soil effects ameliorate the prevailing climate toward warmer, more arid conditions.

There was a consistent tendency for the arid limits to occur at higher precipitation amounts under cool temperatures than at warm ones. This trend could be a result of a seasonal reversal in maximum temperatures over the latitudinal range of saguaros. In winter, the northern part of the range is cooler and receives more rainfall. In summer, the northern part of the range is hotter and receives less rain than the southern limits. Thus, within any month the warmer parts of the range extend to drier limits, but the actual geographic location of the warm, dry extremes changes from month to month. Saguaros occur over a wider range of elevations in the north than in the south. In the estimated climate space, this translates to a relatively broader precipitation zone occupied toward the cool end of the climatic range during the winter, and a shift of this broader rainfall occupation toward the warm end during the summer, when the northern range heats up relative to the south.

\section{Long-term saguaro demography plots in Sonoran Desert: Saguaro (Carnegiea giganteae)} populations, like those of many long-lived species with episodic establishment and mortality, fluctuate on decadal scales; capturing this variability requires multi-decadal monitoring, and, in the absence of actual tree rings, models of plant growth (height) for estimating age of individual plants. For example, at the Desert Laboratory in Tucson, Ariz., all plants within four 11-ha plots on Tumamoc Hill were surveyed and measured in 1964, 1970, and 1993 to develop and verify a predictive ageheight model and to compare the effect of slope aspect on plant growth, patterns of biomass allocation and demography. Differences between plots discriminate specific climatic events or trends with variable impact across slope. We've applied similar methods to six other long-term saguaro plots in the Sonoran Desert to evaluate the influence of climate on regional demographic patterns. 


\section{ECOLOGY}

3. Influence of climate on New Mexico pinyon-juniper woodlands: Funding from Forest Service (Ecosystem Management Program, Central Rio Grande) and collaboration with University of Arizona and Forest Service.

We are using the 1950's drought as a model system for studying the direct impacts of catastrophic drought across vegetation types and geographic scales. The driest episode in several hundred years, the 1950's drought caused broadscale vegetation dieoffs, reset demographic clocks, impacted rates of carbon and nutrient cycling, and accelerated shrub invasion of grasslands. Recent improvement in range conditions may have more to do with recovery from the 1950 's drought as wet conditions returned to the Southwest than with land use reform in recent decades, as is often assumed. We now have funding from the National Science Foundation (NSF) and the Forest Service to continue these studies to test the hypothesis that, in pinyon-juniper woodlands that cover ca. 20 million ha in the southwest, the regional cadence of births and deaths is driven primarily by episodes of wet and dry conditions. As a target, we are hypothesizing that age structures in pinyon-juniper woodlands can be cross-dated like tree rings. This hypothesis, though common sense, has never been tested at the regional scale; also, this is the first time in the Southwest that tree demographic studies have been attempted at annual resolution (based on cross-dating year of birth or death of both dead and live trees). In cooperation with Tom Swetnam (Laboratory of Tree-Ring Research, University of Arizona) we are setting up 12 one-half hectare plots to define demographic histories on north versus southfacing slopes and limestone versus igneous rock types at three elevations $(1,900,2,100$, and 2,400 m) in the Manzano and Los Pinos Mountains of central New Mexico.

4. The use of plant invasions to understand ecosystem dynamics: South African Euryops multifidus in southern Arizona: Euryops multifidus (COMPOSITAE: sweet resin bush), a shrubby composite native to South Africa, was introduced in Arizona by the Soil Conservation Service in 1935. This shrub readily invades semi-arid grasslands and eventually forms uninterrupted monocultures in which native grasses, shrubs and succulents are excluded. Study of plant responses at the advancing front of the areas occupied by Euryops show that mortality and exclusion of native species are due to aggressive competition, and possibly chemical inhibition. These dramatic changes in vegetation are persistent and can lead to changes in ecosystem properties, including soil erodibility and biodiversity. In southern Arizona, sweet resin bush can occur in vegetation ranging from low-elevation desertscrub (ca. 850-1060 m) to grasslands, chaparral and woodlands at higher elevations (ca. 1,300 m or more). This broad ecological amplitude suggests that, with the exception of cattle and fire, there are few limits to further spread of Euryops.

5. Plant Responses to atmospheric $\mathrm{CO}_{2}$ variations during glacial-interglacial cycles: Knowledge that atmospheric $\mathrm{CO}_{2}$ increased 30 percent during the last deglaciation and again since industrialization has stimulated research linking this greenhouse gas with past, present, and future climate change. This knowledge also has inspired a host of field and laboratory experiments that simulate plant responses at glacial (ca. 180-200 ppmv) to more than twice modern (greater than $700 \mathrm{ppmv}$ ) $\mathrm{CO}_{2}$ levels. 


\section{ECOLOGY}

Beginning in the late 1980 's, the scope was expanded to include measurement of stomatal density and carbon isotopes in leaves from historical plant material, ranging from herbarium specimens collected during the past 200 years to leaf compressions in late Miocene and Pliocene clays of the lower Rhine Embayment in Europe. Applications in the fossil record have been limited by (1) insufficient knowledge about past $\mathrm{CO}_{2}$ variations, except where known from the ice core record for the last 200,000 years; (2) the general paucity of deposits that preserve fossil or subfossil leaf material suitable and abundant enough for both stomatal density and $8^{13} \mathrm{C}$ measurements; (3) the inability to hold climate constant, or the conundrum of separating climatic from direct $\mathrm{CO}_{2}$ effects on leaf morphology, geochemistry, and plant performance in highly-fragmented and poorly-dated fossil records; (4) the general inability to examine individual plant species over the kinds of timescales involved in largescale $\mathrm{CO}_{2}$ variations; and (5) the unavoidable blind interpretation of plant performance from $\delta^{13} \mathrm{C}$ plant in the absence of accurate $8^{13} \mathrm{C}$ air chronologies.

All of these limitations can be surmounted in the analysis of leaves preserved in fossil packrat (Neotoma spp.) middens in the western United States. Packrat middens represent the single richest source of plant macrofossils from the last deglaciation (15-12 ka), when $\mathrm{CO}_{2}$ increased from ca. 180-200 ppmv to ca. 270-280 ppmv. More than 2,000 of these deposits have been sorted, dated, and examined for identification of plant remains, usually to the species level (each midden incorporates a range of from 10 to 40 plant taxa) and are available for the proposed research. Chronologies of stomatal density and $8^{13} \mathrm{C}$ that span the last deglaciation can be developed for a variety of species representing different growth forms, life histories, and photosynthetic pathways (C3, C4, and CAM). In most cases, the effects of climate can be accounted for by developing Holocene chronologies from sites that represent the modern vegetation analog to the glacial assemblages; this takes advantage of the same general approach used for quantifying paleoclimate estimates from paleovegetation.

Additionally, $\delta^{13} \mathrm{C}$ air may be estimated from $8^{13} \mathrm{C}$ values of $\mathrm{C} 4$ plants, allowing estimation of wateruse efficiency and plant performance under different $\mathrm{CO}_{2}$ conditions.

Our pilot study, using limber pine, was recently published in Science (Van de Water and others, 1994). Measurements of stomatal density and carbon isotopes from nearly 1200 limber pine (Pinus flexilis) needles preserved in packrat middens from Idaho, Utah, Nevada, and Arizona show a 17 percent decrease in stomatal density and a 12 percent increase in the water use efficiency of limber pine as $\mathrm{CO}_{2}$ increased 30 percent between 15,000 and 12,000 years ago.

6. Fulbright Scholar-Argentina, 1994: Betancourt was funded for a 3-month stay (July-October 1994) in Argentina to develop the paleoecological potential of middens made by animals other than packrats in the western foothills of the Andes. He will be affiliated with the Centro Regional de Investigaciones Cientificas y Tecnicas in Mendoza.

7. Ancient DNA from plant remains in packrat middens: Ancient DNA was extracted from plant tissue from fossil packrat middens in a collaborative study with the University of Arizona. We are 


\section{ECOLOGY}

also measuring DNA yields for fresh, dried, and fossil plant materials from several species to test if DNA degradation is a function of time, site, or species. Eventually, we hope to test if changes in genotype frequencies occurred as plants expanded and contracted their ranges during the last deglaciation.

\section{REPORTS PUBLISHED 1989-1994}

Betancourt, J.L., 1990, Late Quaternary biogeography of the Colorado Plateau, in Betancourt, J.L.., Van Devender, T.R., and Martin, P.S., eds., Packrat middens-The last 40,000 years of biotic change: Tucson, Ariz., University of Arizona Press, p. 259-292.

1990, Introduction, in Betancourt, J.L., and MacKay, A.M., eds., Proceedings of the Sixth Annual Pacific Climate (PACLIM) Workshop, Asilomar, Calif., March 5-8,1989: California Department of Water Resources, Interagency Ecological Studies Program, Technical Report 23, p. 1-4.

Betancourt, J.L. and MacKay, A.M., eds., 1990, Proceedings of the Sixth Annual Pacific Climate (PACLIM) Workshop, Asilomar, Calif., March 5-8, 1989: California Department of Water Resources, Interagency Ecological Studies Program, Technical Report 23, p. 147.

Betancourt, J.L., Pierson, E.A., Aasen Rylander, K., Fairchild-Parks, J.A., and Dean, J.S., 1993, Influence of history and climate on New Mexico pinon-juniper woodlands, in Aldon, E.F., and Shaw, D.W., eds., Managing Pinon-Juniper ecosystems for sustainability and social needs-Proceedings of the Symposium, Santa Fe, New Mexico, April 26-30: USDA Forest Service, Fort Collins, Colo., Rocky Mountain and Range Experiment Station, General Techical Report RM-236, p. 42-62.
Betancourt, J.L., Schuster, W.S., Mitton, J.B., and Anderson, R.S., 1991, Fossil and genetic history of a pinyon pine (Pinus edulis) isolate: Ecology v. 72, p. 1685-1697.

Betancourt, J.L. and Tharp, V.L., eds., in press, Proceedings of the Eight Annual Pacific Climate (PACLIM) Workshop, Asilomar, Calif., April, 1990: California Department of Water Resources, Interagency Ecological Studies Program, Technical Report 26, 257 p.

Betancourt, J.L., Van Devender, T.R., and Martin, P.S., 1990, Packrat middens-The last 40,000 years of biotic change: Tucson, University of Arizona Press, 467 p.

1990, Introduction, in Betancourt, J.L., Van Devender, T.R., and Martin, P.S., eds., Packrat middens-The last 40,000 years of biotic change: Tucsoll, Ariz., University of Arizona Press, p. 2-11.

1990, Synthesis and prospectus, in Betancourt, J.L., Van Devender, T.R., and Martin, P.S. eds., Packrat middens-The last 40,000 years of biotic change: Tucson, Ariz., University of Arizona Press, p. 435-447.

Bowers, J.E., 1990, Vegetation change at Organ Pipe Cactus National Monument, in Bennett, P.S., Johnson, R.R., and McCarthy, M.M., eds., Assessment of Scientific Information and Activities at Organ Pipe Cactus National Monument Biosphere Reserve: Tucson, Ariz., 


\section{ECOLOGY}

Cooperative National Park Resources Studies

Unit, Special Report No 10, p. 85-132.

1990, William A. Cannon: The Sonoran Desert's first resident ecologist: Madrono, v. 37, p. 6-27.

1990, A debt to the future: Scientific achievements of the Desert Laboratory, Tumamoc Hill, Tucson, Ariz.: Desert Plants, v 10, p. 9-12, 35-47.

Burgess, T.L., Bowers, J.E., and Turner, R.M., 1991, Exotic plants at the Desert Laboratory, Tucson, Ariz.: Madrono, v. 38, p. 96-114.

Long, A., Warnecke, L., Betancourt, J.L., and Thompson, R.S., 1990, Deuterium variations in plant cellulose from packrat middens, in Betancourt, J.L., Van Devender, T.R., and Martin, P.S., eds., Packrat middens-The last 40,000 years of biotic change: Tucson, Ariz., University of Arizona Press, p. 381-396.

Lowenstein, J.M., Rainey, W.N., and Betancourt, J.L., 1991, Immunospecific albumin in fossil packrat, porcupine and hyrax urine: Naturwissenschaften v. 78, p. 26-27.

McLaughlin, Steven P., and Bowers, J.E., 1990, A floristic analysis and checklist for the northern Santa Rita Mountains, Pima County, Ariz.: Southwestern Naturalist, v. 35, p. 61-75.

Spaulding, W.G., Betancourt, J.L., Cole, K.L., and Croft, L.,1990, Packrat middens, their composition and methods of analysis, in Betancourt, J.L., Van Devender, T.R., and Martin, P.S., eds., Packrat middens-The last 40,000 years of biotic change: Tucson, Ariz., University of Arizona Press, p. 59-84.

Swetnam, T.W., and Betancourt, J.L., 1992, Temporal patterns of ENSO-wildfire telecon- nections in the southwestern United States, in Diaz, H.F., and Markgraf, V., El Niño, Historical and paleoclimatic aspects of the Southern Oscillation: Cambridge, England, Cambridge University Press, p. 259-270.

1990, Fire-Southern Oscillation relations in the southwestern United States: Science v. 24, p. 1017-1020.

1990, El Niño-Southern Oscillation (ENSO) phenomena and forest fires in the southwestern United States, in Betancourt, J.L., and MacKay, A.M., eds., Proceedings of the Sixth Annual Pacific Climate (PACLIM) Workshop, Asilomar, Calif., March 5-8, 1989: California Department of Water Resources, Interagency Ecological Study Program, Technical Report 23 , p. 129-135.

Thompson, L., Mosley-Thompson, E., Betancourt, J.L., Love, D. W., Wilson, A., Leonard, G., and Anderson, R.S, 1991, Laminated ice bodies in collapsed lava tubes at El Malpais National Monument, central New Mexico, in Julian, B. and Zidek, J., eds., Field guide to geologic excursions in New Mexico and adjacent areas of Texas and Colorado: New Mexico Bureau of Mines and Mineral Resources Bulletin 137, p. 149.

Turner, R.M., 1990, Long-term vegetation change at a fully protected Sonoran Desert site: Ecology v. 71, p. $464-467$.

Turner, R.M., Bowers, J.E., and Burgess, T.L., 1994, Atlas of Sonoran Desert Plants: University of Arizona Press.

Van Devender, T.R., Burgess, T.L., Felger, R.S. and Turner, R.M., 1990, Holocene vegetation of the Hornaday Mountains of northwestern Sonora, Mexico: Proceedings of the San Diego Society of Natural History, v. 2, p. 1-19. 


\section{ECOLOGY}

Van Devender, T.R., Toolin, L.J., and Burgess, T.L., 1990, The ecology and paleoecology of grasses in selected Sonoran Desert plant communities, in Betancourt, J.L., Van Devender, T.R., and Martin, P.S., eds., Packrat middens-The last 40,000 years of biotic change: Tucson, Ariz., University of Arizona Press, p. 326-349.

Van de Water, P.D., Leavitt, S.L., and Betancourt, J.L. 1994, Trends in stomatal density and $13 \mathrm{C} / 12 \mathrm{C}$ ratios of Pinus flexilis needles during last glacial/interglacial cycle: Science, v. 264, p. 243-245.

Webb, R.H., and Betancourt, J.L., 1990, The spatial distribution of radiocarbon ages from packrat middens, in Betancourt, J.L., Van Devender, T.R., and Martin, P.S., eds., Packrat middens-The last 40,000 years of biotic change: Tucson, Ariz., University of Arizona Press, p. 85-102.

1990, Climatic effects on flood frequency-An example from southern Arizona, in Betancourt, J.L., and MacKay, A.M., eds., Proceedings of the Sixth Annual Pacific Climate (PACLIM) Workshop, Asilomar, Calif., March 5-8, 1989: California Department of Water Resources, Interagency Ecological Studies Program, Technical Report 23, p. 61-66.

1992, Climatic variability and flood frequency of the Santa Cruz River, Pima County, Ariz.: U.S Geological Survey Water-Supply Paper 2379. 


\section{ECOLOGY}

TITLE: Plankton Dynamics in Tidal Estuaries (WR 79-164)

PERSONNEL: James E. Cloern, Project Chief

Carolyn L. McLeod, Secretary

Thomas M. Powell, Hydrologist

Brian E. Cole, Oceanographer

ADDRESS: U.S. Geological Survey

345 Middlefield Road, MS 496

Menlo Park, CA 94025

TELEPHONE: (415) 354-3357

PROBLEM: Phytoplankton photosynthesis is the ultimate engine that drives many biogeochemical and ecological processes in lakes, estuaries, and the ocean. For example, dynamic changes in $\mathrm{pH}$, trace metal speciation, and concentrations of dissolved gases (oxygen, carbon dioxide, methane), inorganic nutrients (nitrate, phosphate, silicate), and organic compounds (amino acids, organosulfur compounds) are closely associated with fluctuations in phytoplankton photosynthesis. Trophic linkages also exist, between the phytoplankton as primary producers and populations of consumer organisms including bacteria, zooplankton, benthic invertebrates, and fish. Our scientific understanding of lakes and estuaries as dynamic ecosystems is therefore dependent upon a mechanistic understanding of both natural and human-induced variability of phytoplankton abundance, community composition, productivity, and connections to geochemical processes and other biological communities. These topics are central to poorly resolved issues such as: the growing worldwide incidence of toxic algal blooms and associated fish mortality; coastal eutrophication and increasing frequency and extent of hypoxia or anoxia; long-term and cyclic changes in fish stocks; the global significance of phytoplankton to the cycling of key elements such as $\mathrm{C}$ and $\mathrm{N}$; and ecosystem-scale responses to both species extinctions and introductions of exotic species.

OBJECTIVE: (1) Study the distribution, abundance, species composition, and productivity of planktonic microalgae, animals, and bacteria in estuaries; (2) define and quantify processes that regulate population dynamics and productivity of planktonic organisms in estuaries; (3) define and quantify processes through which the plankton alter and reflect water quality in estuaries; (4) define and quantify benthic processes that affect plankton dynamics and productivity of estuaries; and (5) define anthropogenic impacts on estuarine ecosystems.

APPROACH: Integrate descriptive and experimental field studies and develop simulation models. Field studies indicate important mechanisms that must be taken into account in models and provide a data base for model calibration and subsequent verification. Conversely, evolving ecological models indicate processes and environmental factors that deserve particular emphasis by field studies. 


\section{ECOLOGY}

Feedback between model development and fieldwork will accelerate understanding of the natural system and should produce ecological models having sufficient realism to predict gross effects of human-induced perturbations.

PROGRESS: Project research activities associated with San Francisco Bay were: (1) to map weekly and monthly changes in the vertical and horizontal distributions of dissolved oxygen, salinity, temperature, turbidity, chlorophyll, and suspended sediments. This measurement program was partially supported with funds from local dischargers. Results of this pilot program will be used to design a permanent regional monitoring program in San Francisco Bay; (2) to characterize phytoplankton-nutrient dynamics in South San Francisco Bay around the spring bloom, a period of intense biogeochemical activity, and adding a 17th year to this observational record; (3) to measure changes in benthic fluxes of oxygen and nutrients associated with the spring phytoplankton bloom (J. Caffrey); (4) to install new instruments and data acquisition system onboard the R/V Polaris (B. Cole); (5) to characterize seasonal changes in the origin and composition of organic matter in sediment and seston (E. Canuel); (7) with researchers from Stanford University, to begin the development of three-dimensional model of phytoplankton dynamics in South San Francisco Bay. This model will account for variations in community composition, nutrient flux, zooplankton and benthic grazing, vertical and horizontal transport, and variations in the light field of the water column (J. Cloern).

In France, we (1) worked with French colleagues at the Centre d'Oceanologie de Marseille to develop a vertical model that describes coupled changes in phytoplankton abundance and nutrients. This model will be used to compare phytoplankton temporal variability in South San Francisco Bay and the Golf de Fos in the Mediterranean Sea (J. Cloern) and (2) collaborated with French researchers to develop a two-dimensional model of circulation and horizontal transport (J. Cloern). These modelling efforts are an attempt to enable us to make meaningful comparisons of different ecosystems.

Papers were published on the following: (1) interannual variability in the seasonal pattern of phytoplankton biomass change in South San Francisco Bay (with A. Jassby, University of California at Davis)-book chapter (J.H. Steele editor, Ecological Time Series, Chapman Hall publisher); (2) nitrogen dynamics in the plankton of San Francisco Bay (collaboration with T. Fisher, University of Maryland and NRP-WR)-Estuarine Coastal and Shelf Science; (3) two papers on the characterization of organic matter in San Francisco Bay and how various sources of organic matter are processed through the ecosystem (with researchers from the University of Tennessee, and NASA Ames Research Center)-Limnology and Oceanography and Proceedings of the American Association for the Advancement of Science; (4) the significance of isohaline positions as predictors of fish population fluctuation and their use as management in setting flow standards in San Francisco Bay and the Sacramento-San Joaquin Delta (with Jassby and others)_Ecological Applications; (5) the environmental conditions necessary to promote the development of blooms by ciliates similar to those of toxic algae-Journal of Plankton Research; (6) two papers on seasonal contrasts in the composition and abundance of seston and primary production in Williams and Shingobee Lakes (a component of 


\section{ECOLOGY}

USGS research at the IRI site in Minnesota)-two chapters in USGS circular to be edited by T.

Winter; (7) the role of organic inputs and bioturbation on benthic fluxes of nutrients in San Francisco Bay (with researchers from the University of Southern California, University Southern Louisiana, and NRP-WR) Proceedings of the American Association for the Advancement of Science; (8) temporal and spatial variations in respiration rates of the plankton community in relation to environmental conditions and community composition-Proceedings of the American Association for the Advancement of Science. A USGS Open-File Data Report was published on hydrographic parameters, phytoplankton composition and abundance, rates of photosynthesis, and water column respiration rates in San Francisco Bay during 1993.

REPORTS PUBLISHED 1989-1994:

Alpine, A.E., and Cloern, J.E., 1992, Trophic interactions and direct physical effects control phytoplankton biomass and production in an estuary: Limnology and Oceanography, v. 37, p. 946-955.

Caffrey, J., Cole, B.E., Cloern, J.E., Rudek, J., Tyler, A.C., and Jassby, A.D., 1994, Studies of the San Francisco Bay, California, estuarine ecosystem-Pilot regional monitoring results, 1993: U.S. Geological Survey Open-File Report, 94-82, $471 \mathrm{p}$.

Caffrey, J.M., Hammond, D.E., Kuwabara, J.S., Miller, L.G., and Twilley, R.R., in press, Benthic processes in San Francisco Bay-The role of organic inputs and bioturbation American Association for the Advancement of Science, 75th Annual Meeting of the Pacific Division [Proceedings].

Canuel, E.A., and Cloern, J.E., in press, Regional differences in the origins of organic matter in the San Francisco Bay ecosystem-Evidence from lipid biomarkers: American Association for the Advancement of Science, 75th Annual Meeting of the Pacific Division [Proceedings].

Canuel E.A., Cloern, J.E., Ringelberg, D., Guckert, J., and Rau, G., in press, Application of molecular and isotopic trancers to understanding sources of organic matter and trophic relationships in the San Francisco Bay estuary: Limnology and Oceanography, v. 0.

Cloern, J.E., 1989, Phytoplankton, in Britton, L.J. and Greeson, P.E., eds., Methods for collection and analysis of aquatic biological and microbiological samples: Techniques of WaterResources Investigations of the U.S. Geological Survey, Chapter A-4, p. 99-115.

Cloern, J.E., 1991, Annual variations in river flow and primary production in the South San Francisco Bay Estuary, in Elliott, M., and Ducrotoy, D., eds., Estuaries and coasts: Spatial and temporal intercomparisons: Denmark, Olsen and Olsen Publishers, p. 91-96.

1991, Tidal stirring and phytoplankton bloom dynamics in an estuary: Journal of Marine Research, v. 49, p. 203-221.

Cloern, J.E., Alpine, A.E, Cole, B.E. and Heller, T., 1992, Seasonal changes in the spatial distribution of phytoplankton in small, temperate-zone lakes: Journal of Plankton Research, v. 14, p. $1017-1024$.

Cloern, J.E., Canuel, E.A., and Wienke, S.M., 1993, Particulate organic matter in the San 


\section{ECOLOGY}

Francisco Bay estuary, California-chemical indicators of its origin and assimilation into the benthic food web: U.S. Geological Survey Open-File Report 93-146, 42 p.

Cloern, J.E., Cole, B.E., and Hager, S.W., in press, Notes on a Mesodinium rubrum red tide in South San Francisco Bay (California, U.S.A.): Journal of Plankton Research, v. 0.

Cloern, J.E. and Jassby, A.D., in press, Yearly fluctuation of the spring phytoplankton bloom in South San Francisco Bay: An example of ecological variability at the land-sea interface, in Steele, J.H, Powell, T.M., and Levin, S., eds., Ecological Time Series: Chapman Hall.

Cloern, J.E., Powell, T.M., and Huzzey, L.M., 1989, Spatial and temporal variability in south San Francisco Bay, II. Temporal changes in salinity, suspended sediments, and phytoplankton biomass and productivity over tidal time scales: Estuarine, Coastal and Shelf Science, v. 28 , p. 599-613.

Cole, B.E., 1989, Carbon-14 light- and dark-bottle method for phytoplankton, in Britton, L.H., and Greeson, P.E., eds., Methods for collection and analysis of aquatic biological and microbiological samples: Techniques of WaterResources Investigations of the U.S. Geological Survey, book 5, chap. A4, p. 483-504.

1989, Temporal and spatial patterns of phytoplankton production in Tomales Bay, California, U.S.A.: Estuarine, Coastal, and Shelf Science, v. 28, p. 103-115.

Cole, B.E., Hager, S.W., and Hollibaugh, J.T., 1990, Hydrographic, biological, and nutrient properties of Tomales Bay, California, March 1985 to May 1986: U.S. Geological Survey Open-File Report 90-178.
Cole, B.E., Thompson, J.K., and Cloern, J.E., 1992, Measurement of filtration rates by infaunal bivalves in a recirculating flume: Marine Biology, v. 113, p. 219-225.

Fisher, T.R., Hager, S.W., and Cloern, J.E., in press, Nitrogen dynamics in the plankton of San Francisco Bay: Estuarine Coastal and Shelf Science, v. 0.

Hollibaugh, J.T., Wong, P.S., Azam, F., Smith, D.C., Steward, G.F., and Cole, B.E., 1992, Measurement of bacterioplankton production in antarctic coastal waters-Comparison of thymidine and L-leucine methods and verification of labeling patterns: Antarctic Journal, v. 27, p. 127-128.

Huzzey, L.M., Cloern, J.E., and Powell, T.M., 1990, Episodic changes in lateral transport and phytoplankton distribution in south San Francisco Bay: Limnology and Oceanography, v. 35 , p. $472-478$.

Jassby, A.D., Cloern, J.E., and Powell, T.M., 1993, Organic carbon sources and sinks in San Francisco Bay-variability induced by river flow: Marine Ecology Progress Series, v. 95/39-54.

Jassby, A.D., Kimmerer, W.J., Monismith, S., Armor, C., Cloern, J.E. Powell, T.M., Schubel, J.R., and Vendlinski, T., in press, Isohaline position as a habitat indicator for estuarine resources-San Francisco Bay-Delta, California, U.S.A.: Ecological Applications, v. 0 .

Koseff, J.R., Holen, J.K., Monismith, S.G., and Cloern, J.E., 1993, Effects of vertical mixing and benthic grazing on phytoplankton populations in shallow, terbid estuaries: Journal of Marine Research, v. 51, p. 843-868. 


\section{ECOLOGY}

Kuwabara, J.S., Chang, C.C.Y., Cloern, J.E., Fries, T.L., Davis, J.A., and Luoma, S.N., 1989, Trace metal associations in the water column of south San Francisco Bay, California: Estuarine, Coastal and Shelf Science, v. 28, p. 307-325.

McBride, G.B., Vant, W.N., Cloern, J.E., and Liley, J.B., 1993, Development of a model of phytoplankton blooms in Manukau Harbour: Hamilton, New Zealand, NIWA Ecosystems Publication No. 3., 51 p.

Powell, T.M, Cloern, J.E., and Huzzey, L.M., 1989, Spatial and temporal variability in south San Francisco Bay, I. Horizontal distributions of salinity, suspended sediments, and phytoplankton biomass and productivity: Estuarine, Coastal and Shelf Science, v. 28, p. 583-597.

Wienke, S.M., Alpine, A.E., Cloern, J.E., and Cole, B.E., 1990, Plankton studies in San Francisco Bay, X. Chlorophyll distributions and hydrographic properties in San Francisco Bay, 1987: U.S. Geological Survey Open-File Report 90-145, 50 p.

Wienke, S.M., Cloern, J.E., and Cole, B.E., 1990, Plankton studies in San Francisco Bay, XI. Chlorophyll distributions and hydrographic properties in San Francisco Bay, 1988-1989: U.S. Geological Survey Open-File Report 90-562, 212 p.

Wienke, S.M., Cole, B.E., Cloern, J.E., and Alpine, A.E., 1991, Plankton studies in San Francisco Bay. XII. Chlorophyll distributions and hydrographic properties in San Francisco Bay, 1990: U.S. Geological Survey Open-File Report 91-476, 85 p.

1992, Plankton studies in San Francisco Bay. XIII. Chlorophyll distributions and hydrographic properties in San Francisco Bay, 1991:
U.S. Geological Survey Open-File Report 92-158, $116 \mathrm{p}$.

Wienke, S.M., Cole, B.E., and Cloern, J.E., 1993, Plankton studies in San Francisco Bay, XIV. Chlorophyll distributions and hydrographic properties in San Francisco Bay, 1992: U.S. Geological Survey Open-File Report 93-423, $175 \mathrm{p}$. 


\section{ECOLOGY}

TITLE: $\quad$ Microbial Biogeochemistry of Aquatic Environments (WR 81-174)

PERSONNEL: Ronald S. Oremland, Project Chief

Charles W. Culbertson, Hydrologist

Laurence G. Miller, Oceanographer

Jodi Switzer Blum, Physical Scientist

Dowdle, P., Student, (Univ. of Calif.-Los Angles)

Frances E. Strohmaier, Phys. Sci. Tech.

Robinson, A., High School Student

ADDRESS: $\quad$ U.S. Geological Survey

345 Middlefield Road, MS 465

Menlo Park, CA 94025

TELEPHONE: (415) 329-4482

PROBLEM: Micro-organisms alter the chemistry and productivity of aquatic environments by performing complex transformations of organic and inorganic molecules. In many cases, microbes can affect the speciation, mobility, bioavailability, and toxicity of toxic elements, such as $\mathrm{Se}, \mathrm{Hg}$, and As. The mechanisms by which these reactions proceed, the in place rates of the transformation, their quantitative significance to element cycling, the responsible micro-organisms and their physiology are poorly understood.

OBJECTIVE: Conceptual models of biogeochemical transformations will be developed by a combination of laboratory and field experimental work. Laboratory work will focus on identification of biochemical pathways, isolation and physiological characterization of relevant microbes. Field work will consist of measuring in place rates of transformations, based on methods developed in the laboratory. Physical exchanges between components, such as flux of biogenic gases to or from the atmosphere from water or soil will be quantified.

APPROACH: Microbial pathways will be studied in the laboratory for materials from various field locations. Biochemical experiments will be performed on isolated cultures of important microorganisms. The findings from these investigations will guide the methodology employed in field work to assess in place rates of these transformations as well as physical exchange (flux) of important materials (for example, reduced gases) between components.

PROGRESS: Atmospheric Gases and Global Change: Methylbromide (MeBr), a fumigant destructive to stratospheric ozone was found to be degraded by aerobic and anaerobic bacteria. In anaerobic environments, $\mathrm{MeBr}$ reacts with sulfide to form methylated sulfur compounds which are attacked by methanogenic bacteria. In aerobic environments, methyl bromide is oxidized to $\mathrm{CO}_{2}$ by methaneoxidizing bacteria. These results suggest that a biospheric sink exists for $\mathrm{MeBr}$. Because $\mathrm{MeBr}$ is a competitive inhibitor of methane oxidation and nitrification, fumigated fields were found to accumulate 


\section{ECOLOGY}

soil methane and nitrous oxide. The nitrous oxide accumulation was due the inhibitory effects of the chloropicrin (tear gas) upon denitirifcation and nitrification. (1 paper in EST, 1994; 1 paper submitted to AEM; 1 paper in preparation.)

Trifluoroacetate (TFA), an atmospheric oxidation product of HFC-143a (tetrafluoroethane) is extremely unreactive chemically and recalcitrant to degradation biologically. Use of "new generation" freon substitutes runs the risk of forming products which will accumulate in nature, possibly causing toxic effects to biota. We discovered that in anoxic sediments, TFA is sequentially defluorinated to the level of acetate. This is the first demonstration of microbiological defluorination of a perfluorinated compound. Acetate was degraded to $\mathrm{CH}_{4}$ and $\mathrm{CO}_{2}$. In aerobic sediments, TFA was found to be cleaved to $\mathrm{CF}_{3} \mathrm{H}$ and $\mathrm{CO}_{2}$. These results suggested that TFA can be decomposed by soil microbes, however some of the products, monofluoroacetate and $\mathrm{CF}_{3} \mathrm{H}$, may cause environmental problems. (1 paper in Nature 1994; 1 paper in prepration.)

Biogeochemistry of Toxic Elements: A selenate-respiring bacterium (SES-3) isolated from an irrigation drainage site was found to grow anaerobically on selenate, nitrate, thiosulfate, iron, and manganese as electron acceptors. Growth on selenate resulted in the formation of toxic selenite, the accumulation of which prevented further reduction. However, nongrowing cell suspensions were readily able to reduce selenate to elemental selenium. Selenate and nitrate were reduced by separate enzymes, but selenite and nitrite may have in part shared a common reductase. These physiological results have significance with respect to understanding the mechanisms of selenium precipitation in drainwater, as well as to the remediation of these systems by biotechnological treatment of wastewaters. In cooperation with $\mathrm{T}$. Bullen, we are attempting to see if a fractionation of stable Se isotopes occurs with bacterial reduction of Se VI and Se IV (1 paper in AEM, 1994; 1 review paper in Se book, 1994; 1 paper in prepration).

The mechanism(s) for bacterial demethylation of methylated forms of mercury and arsenic are currently being investigated.

Cooperative research investigations with California and Nevada Districts:

- Methane fluxes in the Sacramento/San Joaquin R.Delta (Bronwyn Wang)

- Arsenate reduction by bacteria (Roger Fujii)

- Methylation/demethylation of mercury in the Carson River/Lahontan Resevoir system (NAWQA site): Hugh Beavans

\section{REPORTS PUBLISHED 1989-1994:}

Dubrovsky, N.M., Neil, J.M., Fujii, R., Oremland, R.S., and Hollibaugh, J.T., 1990, Influence of redox potential on selenium distribution in ground water, Mendota, Western San Joaquin Valley, California: U.S. Geological Survey Open-File Report 90-138, p. 24.
Jellison, R., Miller, L.G., Melack, J.M., and Dana, G.L., 1993, Meromixis in hypersaline Mono Lake, California. 2. Nitrogen fluxes: Limnology and Oceanography, v. 38, p. 1020-1039. 


\section{ECOLOGY}

Luoma, S.N., Johns, C., Fischer, N.S., Steinberg, N.A., Oremland, R.S., and Reinfelder, J.A., 1992, Determination of selenium bioavailability to a benthic bivalve from particulate and solute pathways: Environmental Science and Technology, v. 26, p. 485-491.

Miller, L.G., Coulatkis, M.D., Oremland, R.S., and Ward, B.B., 1993, Selective inhibition of ammonium oxidation and nitrification-linked $\mathrm{N}_{2} \mathrm{O}$ formation by methyl fluoride and dimethyl ether: Applied Environmental Microbiology, v. 59, p. 2447-2464.

Miller, L.G., Jellison, R., Oremland, R.S., and Culbertson, C.W., 1993, Meromixis in hypersaline Mono Lake, California, 3. Biogeochemical response to stratification and overturn: Limnology and Oceanography, v. 38, p. 1040-1051.

Oremland, R.S., 1989, Present day activities of anaerobic bacteria and their relevance to future exobiological investigations: Advances in Space Research, v. 9, p. 127-136.

1990, Nitrogen fixation dynamics of two diazotrophic communities in Mono Lake, California: Applied and Environmental Microbiology, v. 56, p. 614-622.

Oremland, R.S., and Culbertson, C.W., 1992, Importance of methane-oxidizing bacteria in the methane budget as revealed by the use of a specific inhibitor: London, Nature v. 356, p. 421-423.

1992, Evaluation of methyl fluoride and dimethylether as inhibitors of aerobic methane oxidation: Applied and Environmental Microbiology, v. 58, p. 2983-2992.

Oremland, R.S., Culbertson, C.W., and Winfery, M.R., 1991, Methylmercury decomposition in sediments and bacterial cultures: involvement of methanogens and sulfate reducers in oxidative demethylation: Applied and Environmental Microbiology, v. 57, p. 130-137.

Oremland, R.S., Hollibaugh, J.T., Maest, A., Presser, T., Miller, L., and Culbertson, C., 1989, Selenate reduction to elemental selenium by anaerobic bacteria in sediments and culture: biogeochemical significance of a novel, sulfate-independent respiration: Applied and Environmental Microbiology, v. 55, p. 23332343.

Oremland, R.S., Kiene, R.P., Mathrani, I., Whiticar, M.J., and Boone, D., 1989, Description of an estuarine methylotrophic methanogen which grows on dimethylsulfide: Applied and Environmental Microbiology, $v$. 55, p. 994-1002.

Oremland, R.S., and King, G.M., 1989, Methanogenesis in hypersaline environments, in Cohen Y., and Rosenberg E., ed., Microbial matsphysiological ecology of benthic microbial communities: Washington, D.C., American Society for Microbiology, p. 180-189.

Oremland, R.S., and Miller, L.G., 1993, Biogeochemistry of natural gases in three alkaline, permanently stratified (meromictic) lakes, in Howell, D. ed., The future of energy gases: U.S. Geological Survey Professional Paper 1570 , p. $439-452$.

Oremland, R.S., Miller, L.G., Culbertson, C.W., Robinson, S.W., Smith, R.L., Lovley, D., Whiticar, M.J., and others, 1993, Aspects of the biogeochemistry of methane in Mono Lake and the Mono Basin of California, U.S.A., in Oremland, R.S., ed., Biogeochemistry of global change-Active trace gasses: New York, Chapman and Hall, p. 704-745. 


\section{ECOLOGY}

Oremland, R.S., Miller, L.G., and Strohmaier, F.E., 1994, Degradation of methylbromide in anaerobic sediments: Environmental Science and Technology, v. 28, p. 514-520.

Oremland, R.S., Steinberg, N.A., Maest, A.S., Miller, L.G., and Hollibaugh, J.T., 1990, Measurement of in situ rates of selenate removal by dissimilatory bacterial reduction in sediments: Environmental Science and Technology, v. 24, p. 1157-1164.

Oremland, R.S., Steinberg, N.A., Presser, T.S., and Miller, L.G., 1991, In situ bacterial selenate reduction in the agricultural drainage systems of Western Nevada: Applied and Environmental Microbiology, v. 57, p. 615617.

Oremland, R.S., Switzer Blum, J., Culbertson, C.W., Visscher, P.T, Miller, L.G., Dowdle, P., and Strohmaier, F.E, 1994, Isolation, growth, and metabolism of an obligately anaerobic, selenate-respiring bacterium, strain SES-3: Applied and Environmental Microbiology, p. 3011-3019.

Smith, R.L., Miller, L.G., and Howes, B.L., 1993, The geochemistry of methane in Lake Fryxell, an amictic, permanently ice-covered, Antarctic lake: Biogeochemistry, v. 21, p. 95-115.

Steinberg, N.A., and Oremland, R.S., 1990, Dissimilatory selenate reduction potentials in a diversity of sediment types: Applied and Environmental Microbiology, v. 56, p. 3550-3557.

Steinberg, N.A., Switzer Blum, J., Hochstein, L., and Oremland, R.S., 1992, Nitrate is a preferred electron acceptor for growth of freshwater selenate-respiring bacteria: Applied and Environmental Microbiology, v. 58, p. 426428. 


\section{ECOLOGY}

TITLE: $\quad$ Biotic Interface with Fluvial Transport: Processes Associated with Dissolved Solutes in Transport (WR 84-186)

PERSONNEL: Frank J. Triska, Project Chief Carolyn Harden, Secretary

Alan P. Jackman, Chemical Engineer

Ronald J. Avanzino, Chemist

John H. Duff, Hydrologist

ADDRESS: $\quad$ U.S. Geological Survey

345 Middlefield Road, MS 496

Menlo Park, CA 94025

TELEPHONE: (415) 354-3333

PROBLEM: Biogeochemical processes associated with the microbial community (algae, bacteria, fungi) constitute the interface between solute transport and biotic production in riverine environments. Identifying and estimating the role of biotic processes such as nitrification and denitrification by bacteria, nutrient uptake and production by epilithic algal films and decomposition of particulate and dissolved organic matter, as well as abiotic processes such as absorption, are important for understanding the linkage between terrestrial, riparian, hyporheic and in-channel contributions to the nutrient chemistry of a drainage network. Relative biotic response to solutes in transport between pristine and anthropogenically modified riverine environments is poorly understood, but necessary for long-term management of surface waters.

OBJECTIVE: Identify and determine rates of biotic transformations of transported solutes at chemical-biotic interfaces in fluvial environments, including seepage areas, riparian zones, sediment/surface-water interfaces, intragravel-subsurface flow interfaces (hyporheic zone) and floodplains.

APPROACH: Laboratory experiments using communities collected from small to large streams and in place field experiments are used to estimate biotic transformation of dissolved solutes. Field experiments are conducted at background concentrations and with mixtures of conservative and nonconservative solutes injected into both pristine and man-impacted fluvial environments. Cycling of elements which have high assimilative demand and (or) are subsequently passed to higher trophic levels are emphasized (that is, $\mathrm{C}, \mathrm{N}, \mathrm{P}$ ).

PROGRESS: (1) Research at the Water Resource Division's Integrated Research Initiative (IRI) site continues on the Shingobee River in north-central Minnesota. Comparison of dissolved inorganic nitrogen concentration (DIN) between channel water and groundwater in summer, indicates effective depletion of DIN as ground water moves upward between $20 \mathrm{~cm}$ beneath and the surface of the bed. 


\section{ECOLOGY}

DIN consists almost entirely of ammonium. We hypothesize that DIN depletion involves a nitrification-denitrification coupling in the top $5 \mathrm{~cm}$ of sediments. Uptake by rooted macrophytes may also be a factor at times of high plant production. During winter, surface water DIN concentration is similar to summer groundwater concentration $(0.2-1.0 \mathrm{~m})$ beneath the channel. At these times ground-water DIN passes through the bed unaltered due to inhibition of biotic processes by cold temperature. Thus, during summer temperature and redox-dependent processes control DIN transport, whereas in winter hydrologic mechanisms control DIN transport through the bed.

(2) An interstitial sampler has been devised to sample subchannel nutrient profiles to $1.0 \mathrm{~cm}$ resolution. The sampler can withdraw interstitial water at rates as low as $1 \mathrm{uL} \mathrm{s}^{-1}$, which permits sampling with minimal distortion of dissolved solute profiles in surficial sediments. Water samples as small as $\mathbf{5 0} \mathrm{uL}$ can subsequently be passed through a set of flow-through microelectrodes measuring dissolved oxygen, specific conductance, $\mathrm{pH}$ temperature and ammonium on the same sample.

\section{REPORTS PUBLISHED 1989-1994:}

Avanzino, R.J., and Kennedy, V.C., 1993, Longterm frozen storage of stream water samples for dissolved orthophosphate, nitrate plus nitrite, and ammonia analysis: Water Resources Research, v. 29, no. 10, p. 33573362.

Bencala, K.E., Duff, J.H., Harvey, J.W., Jackman, J.P. and Triska, F.J., 1993, Physical transport influencing biogeochemistry within the stream catchment continuum, in Modeling change in environmental systems: Chickester, U.K., J. Wiley and Sons, 602 p.

Duff, J.H., 1989, Nitrate reduction with epilithic algal communities, San Francisquito Creek, San Mateo County, California: U.S. Geological Survey Open-File Report 89-416, p. 113.

Duff, J.H., and Triska, F.J., 1990, Denitrification in sediments from the hyporheic zone adjacent to a small forested stream: Canadian Journal of Fisheries and Aquatic Sciences v. 47, no. 6, p. 1140-1147.
Kim, B.K., Jackman, A.P., and Triska, F.J., 1990, Modeling transient storage and nitrate uptake kinetics in a flume containing a natural periphyton community: Water Resources Research, v. 26, no. 3, p. 505-515.

1992, Modeling biotic uptake by periphyton and transient hyporheic storage of nitrate in a natural stream: Water Resources Research, v. 28, p. 2743-2752.

Osborne, L.L., Bayley, P.B., Higler, L.W.G., Statzner, B., Triska, F. and Iverson, T.M., 1993, Restoration of lowland streams-An introduction: Freshwater Biology, v. 29, p. 187-194.

Pringle, C.M., and Triska, F.J., 1991, Effects of geothermal groundwater on nutrient dynamics of a lowland Costa Rican stream: Ecology v. 72 , no. 3, p. 951-965.

1991, Variation in phosphate concentrations of small order streams draining volcanic landscapes in Costa Rica-Sources and implications for nutrient cycling, in Tiessen, $\mathrm{H}$., 


\section{ECOLOGY}

Lopez-Hernandez, D., and Salcedo, I.H., eds., Phosphorus cycles in terrestrial and aquatic ecosystems, Regional Workshop 3South and Central America, Organized by the Scientific Committee of Problems of the Environment (SCOPE) and the United Nations Environmental Programme (UNEP): Maracay, Venezuela, 1989, Turner-Warwick Communications, Saskatoon, Canada, [257 p.] p. 70-83.

Pringle, C.M., Rowe, C.L., Triska, F.J., Fernandez, J.F. and West, J., 1993, Landscape linkages between geothermal activity, solute composition, and ecological response in surface waters draining the Atlantic slope of Costa Rica: Limnology and Oceanography, v. 38, p. 753-774.

Pringle, C.M., Triska, F.J., and Browder, G., 1990, Spatial variation in basic chemistry of streams draining a volcanic landscape on Costa Rica's Caribbean slope: Hydrobiologia, v. 206, p. 73-85.

Smith, R.L., Howes, B.L. and Duff, J.H., 1989, Use of tracer tests to measure the transport and consumption of methane in a contaminated aquifer, in Mallard, G.E., and Ragone, S.E. eds., U.S. Geological Survey Toxic Substances Hydrology Program-Proceedings of the techical meeting, Phoenix, Ariz., September 26-30, 1988: U.S. Geological Survey WaterResources Investigations Report 88-4220, p. 167-175.

1991, Denitification in nitrate-contaminated groundwater-Occurrence in steep vertical geochemical gradients: Geochemica et Cosmochimica Acta v. 55, p. 1815-1825.

Smith, R.L.., Howes, B.L. and Duff, J.H., 1991, Effects of denitrifcation on nitrogen geochemistry in a nitrate-contaminated sand and gravel aquifer, Cape Cod, Massachusetts, in Mallard,
G.E., and Aronson, D.A., eds., U.S. Geological Survey Toxics Substances Hydrology Program-Proceedings of the technical meeting, Monterey, Calif., March 11-15, 1991: U.S. Geological Survey Water-Resources Investigations Report 91-4034. p. 128-134.

Stream Solute Workshop, 1990, Concepts and methods for assessing solute dynamics in stream ecosystems: Journal of the North American Benthological Society, v. 9, no. 2, p. 95-119.

Triska, F.J., Duff, J.H., and Avanzino, R.J., 1990, Influence of exchange flow between the channel and hyporheic zone on nitrate production in a small mountain stream: Canadian Journal of Fisheries and Aquatic Sciences, v. 47, no. 11, p. 2099-2111.

1993, The role of water exchange between a stream channel and its hyporheic zone on nitrogen cycling at the terrestrial-aquatic interface: Hydrobiologia, v. 251, p. 167-184.

1993, Patterns of hydrological exchange and nutrient transformation in the hyporheic zone of a gravel bottom stream: Examining terrestrial aquatic linkages: Freshwater Biology, v. 29 , p. 259-274.

Triska, F.J., Kennedy, V.C., Avanzino, R.J., Zellweger, G.W., and Bencala, K.E., 1989, Retention and transport of nutrients in a thirdorder stream-Channel processes: Ecology, v. 70 , no. 6 , p. $1877-1892$.

1990 , In situ retention-transport response to nitrate loading and storm discharge in a thirdorder stream: Journal of the North American Benthological Society, v. 9, no. 3, p. 229239. 


\section{ECOLOGY}

1989, Retention and transport of nutrients in a third-order stream in northwest Californiahyporheic processes: Ecology v. 70, no. 6, p. 1893-1905.

Triska, F.J., Kennedy, V.C., Avanzino, R.J., and Stanley, K.C., in press, Inorganic nitrogen uptake and regenenration in a small stream at summer base flow-Long-term clearcutting and short-term storm related impacts: U.S. Geological Survey Professional Paper 1454.

Triska, F.J., Pringle, C.M., Zellweger, G.W., Duff, J.H., and Avanzino, R.J., 1993, Dissolved inorganic nitrogen composition, transformation, retention, and transport in naturally phosphate-rich and phosphate poor tropical streams: Canadian Journal of Fisheries and Aquatic Sciences, v. 50, p. 665-675. 


\section{ECOLOGY}

TITLE: $\quad$ Solute Transport Involving Biological Processes in Surface Waters (WR 86-190)

PERSONNEL: James S. Kuwabara, Project Chief

Susan P. Bartaluzzi, Secretary

Cecily C. Chang, Hydrologist

Anne Khechfe, Hydrotech

ADDRESS: $\quad$ U.S. Geological Survey,

345 Middlefield Road, MS 465

Menlo Park, CA 94025

TELEPHONE: (415) 329-4485

PROBLEM: Availability of toxic substances and nutrients to biota is dependent on their chemical form or speciation. Toxicological models, for example, have emphasized the effect of solute speciation on biological processes. Conversely, it has been demonstrated that partitioning of contaminants and nutrients can be affected by biological processes. Chemical processes that control chemical speciation in natural waters are solute complexation, precipitation and dissolution, sorption, and redox. Each of these processes affects and is affected by biological activity. Therefore, understanding and quantifying solute interactions with biota can be important in developing accurate water-quality models. Although inorganic and organic complexation have been emphasized in previous toxicological studies in chemically defined media, it is clear that chemical processes suppressed in these experiments can be important in natural water systems. The effects of biological processes on solute uptake and transport need to be quantified and incorporated in transport models.

OBJECTIVE: Study transport of trace inorganic solutes between particulates and primary producers. Examine and quantify processes controlling that transport (for example, adsorption onto and desorption from particles, and uptake and release from plankton and periphyton.) Establish how biological processes may contribute to the overall behavior of trace inorganic contaminants in surfacewater systems.

APPROACH: Conduct field sampling and laboratory analyses to assess the chemical character of particulate and dissolved phases and to identify potentially important biological-transport processes. Determine trace-metal, macronutrient, and organic carbon and trace sulfide concentrations by means of various analytical and preparative techniques. Use chemically defined media, suspensions and algal cultures to describe processes controlling solute uptake and release by cells. Conduct laboratory culture experiments with field samples and isolates from natural planktonic and periphyton communities and generate biological transport models for testing and eventual incorporation into comprehensive water-quality models. 


\section{ECOLOGY}

PROGRESS: Two publications from our project deal with the importance of considering, even in oxic waters of San Francisco Bay, the competition between dissolved sulfide complexation and dissolved organic carbon (DOC) interactions in regulating trace metal speciation (bioavailability). In place and laboratory flux chamber experiments in 1992 and 1993 are consistent with initial sulfide distribution data indicating a consistently positive dissolved sulfide flux from the sediment. Vertical dissolved sulfide distributions in 1993 (post-drought period) were consistent with 1992 data (that is, a primary benthic source) even during and after the major spring phytoplankton bloom of 1993 . In contrast to sulfide fluxes, and like fluxes for DOC, trace metal benthic fluxes showed a shift in direction. This is contrary to trace metal fluxes estimated on the basis of residual modeling terms and provides the first direct determinations for metal benthic fluxes in the estuary.

In contrast to recent marine chemistry reports, minimal ionic strength effects were observed up to 0.7 molar (that is, seawater ionic strength) on the efficiency of oxidation of the major carbon sources to the northern and southern components of the Bay. Results were further supported by experiments using chemically defined fulvic acids, and by participation in the Joint Global Ocean Flux Study (JGOFS) International Intercalibration Program. This work, accomplished in cooperation with the California District, has direct implications on our understanding of carbon budgets and metal bioavailability within complex estuarine environments.

A dedicated issue of the journal Estuaries was published on "Trace contaminants and nutrients in estuaries" (v. 16, no. 3A). The issue examined process interdependence in estuarine studies involving both inorganic and organic solutes. Contributions to the issue involved estuarine research conducted throughout the world including papers resulting from work within the Toxics Substances Hydrology Program in San Francisco Bay.

In addition to collaborative work with the California District, work with the Idaho District was initiated to: (1) determine dissolved trace metal distributions along a longitudinal DOC gradient within the Coeur d'Alene Lake Basin (a mine drainage area), and (2) determine trace element effects on dominant phytoplankton species isolated from sites along that gradient (for example, our initial results indicate a temporally consistent gradient for dissolved zinc between 2 and 600 nanomolar with a 3,600 nanomolar point source, the Coeur d'Alene River, to the lake). Although the phytoplankton community structure along this gradient is expectedly different, there are actually major species common to the sites. There is obvious concern about ecological implications for the lake and its fisheries, because in our previous laboratory studies, nanomolar zinc ion activities have significantly retarded the growth of certain freshwater bioindicators. The area has been proposed as a future NAWQA site.

\section{REPORTS PUBLISHED 1989-1994:}

Chang, C.C.Y., Kuwabara, J.S., and Pasilis, S.P., 1990, Trace-metal concentrations in three streams during spring runoff in the Tahoe Basin, California/ Nevada, in Poppoff, I.G., Goldman, C.R., Loeb, S.L. and Leopold, L.B., eds., Proceedings of the International
Watershed Symposium, Lake Tahoe, June 8-10, 1988: Tahoe Research Conservation District, p. 103-115.

1992, Phosphate and iron limitation of phytoplankton biomass in Lake Tahoe: Canadian 


\section{ECOLOGY}

Journal of Fisheries and Aquatic Sciences, v. 49, p. 1206-1215.

Hunter, Y.R., and Kuwabara, J.S., 1994, Ionic strength and DOC determinations from various freshwater sources to the San Francisco Bay: Bulletin of Environmental Contamination and Toxicology, v. 52, p. 311-318.

Kuwabara, J.S., 1992, Associations between benthic flora and diel changes in dissolved arsenic, phosphorus, and related physicochemical parameters: Journal of the North American Benthological Society, v. 11, p. 218-228.

Kuwabara, J.S. and Baker, J.E., 1993, Trace contaminants and nutrients in estuaries: the importance of process interdependence: Estuaries, $v$. 16 , p. 383-384.

Kuwabara, J.S., Chang, C.C.Y., Cloern, J.E., Fries, T.L., Davis, J.A., and Luoma, S.N., 1989, Trace metal associations in the water column of South San Francisco Bay, California: Estuarine, Coastal, and Shelf Science, v. 26, p. 307-325.

Kuwabara, J.S., Chang, C.C.Y., and Pasilis, S.P., 1989, Periphyton effects on arsenic transport in Whitewood Creek, South Dakota, in Mallard, G.E., and Ragone, S.E., eds., U.S. Geological Survey Toxic Substances Hydrology Program-Proceedings of the technical meeting, Phoenix, Ariz., September 26-30, 1988: U.S. Geological Survey WaterResources Investigations Report 88-4220, p. 247-256.

1990, Effects of benthic flora on arsenic transport: Journal of Environmental Engineering, v. 116 , p. 394-409. in press, Effects of the benthic flora on arsenic transport in Whitewood Creek, South Dakota, in Goddard, K.E., and Mallard, G.E. eds., Toxic substances in surfaces waters and sediments-a study to assess the effects of arsenic-contaminated alluvial sediment in the Cheyenne River, South Dakota: U.S. Geological Survey Water-Supply Paper 2345.

Kuwabara, J.S., and Harvey, R.W., 1990, Application of a hollow-fiber tangential-flow device for sampling suspended bacteria and particles from natural waters: Journal of Environmental Quality, v. 19, p. 625-629.

Kuwabara, J.S., Hunter, YY.R., and Chang, C.C.Y., in press, Distributions and benthic flux of dissolved sulfides in the oxic water column of San Francisco Bay, California, in Morganwalp, D.W., and Aronson, D.A., eds., U.S. Geological Survey Toxic Substances Hydrology Program-Proceedings of the technical meeting, Colorado Springs, Colorado, September 20-24, 1993: U.S. Geological Survey Water Resources Investigations Report 94-4014.

Kuwabara, J.S., and Luther, G.W. III, 1993, Dissolved sulfides in the oxic water column of San Francisco Bay, California: Estuaries, v. 16, p. $567-573$.

Stream Solute Workshop, 1990, Concepts and methods for assessing solute dynamics in stream ecosystems: Journal of the North American Benthological Society, v. 9, p. 95119. 


\section{ECOLOGY}

TITLE: Environmental Influences on Estuarine Benthic Community Dynamics (WR 86-192)

PERSONNEL: Frederic H. Nichols, Project Chief

Lucenia Thomas, Secretary

Janet K. Thompson, Marine Biologist

Francis Parchaso, Biologist

ADDRESS: $\quad$ U.S. Geological Survey

345 Middlefield Road, MS 472

Menlo Park, CA 94025

TELEPHONE: (415) 329-4411

PROBLEM: (1) Benthic invertebrate communities, composed of sessile, relatively long-lived species, provide a record of effects of short- and long-term environmental changes through species composition and abundance changes. Thus they are often used as water-quality indicators. However, their use in water-quality studies requires assumptions that communities remain at steady state except when influenced by human activity. Long-term studies show that natural variation over a variety of time scales often masks human-induced changes. (2) Estuarine benthic communities, often dominated by suspension feeders, have an unknown but potentially large controlling effect on phytoplankton biomass, and thus may be important in limiting eutrophication.

OBJECTIVE: (1) Characterize long-term patterns in estuarine and coastal benthic communities, in order to determine the contribution of natural factors (climatic events, seasonal/interannual patterns of runoff, water chemistry and circulation, sediment texture and stability, and food availability) to community variability, and to assess the contribution of human activity (waste contamination, control of river runoff) to the remaining unexplained variability in community dynamics. (2) Measure, through field and laboratory studies, the processes which determine the rates at which invertebrates remove phytoplankton from the water column.

APPROACH: (1) Quantitatively sample the benthos at regular intervals through time (and obtain access to data that have been collected by others) at fixed locations in various estuaries and nearshore habitats. Statistically analyze data from these samples for short- and long-term patterns of change in community structure and correlate these patterns through time-series analysis with both natural environmental factors and anthropogenic factors associated with the water column and sediment. (2) Determine the link between benthic community processes (feeding, respiration, substrate disturbance and stabilization) and changes in the water column (changes in planktonic biomass, nutrients, and organic matter) through field-manipulation experiments with transplanted animals and through laboratory experiments with individual species and intact infaunal communities in flumes that simulate changing field conditions. 


\section{ECOLOGY}

PROGRESS: To quantify ecological responses to natural environmental perturbations-for example, responses to short- and long-term variations in river flow and to contaminant inputs-we continue to characterize long-term patterns in the structure and functioning of the benthic community at fixed sites in both northern and southern San Francisco Bay.

Now that the long California drought is over, we have been able to answer the question about the effect of Potamocorbula on phytoplankton abundance in the northern bay. The reduction in the phytoplankton was hypothesized to be due to (1) an increase in grazing pressure by the arrival of the new clam or (2) some physical or chemical change related to the reduction in freshwater inflow into the bay during the drought. Our data confirms that Potamocorbula is the likely cause of the disappearance of the annual phytoplankton bloom: Potamocorbula survived the return of normal runoff (particularly during the wet winter of 1992-93), and the predrought, pre-Potamocorbula summer phytoplankton bloom has not returned. An estimate of secondary production for Potamocorbula at six representative sites shows that the clams are capable of consuming all of the phytoplankton produced in these areas and that Potamocorbula is also using some other carbon source as food, probably river-borne freshwater algae or detritus.

We are continuing the study of the growth of Potamocorbula and other filter feeding bivalves in South Bay to determine how the spring phytoplankton bloom is linked to the growth cycle of the benthic organisms. A joint study with Stanford University has shown that the timing and the magnitude of the spring phytoplankton bloom is due to the relative density of the benthic filter feeding organisms in the shallow and deep water. The key factors for bloom development are lateral transport, benthic grazing, and photic depth. The previous 3 years of benthic biomass data show the lack of a phytoplankton bloom in fall, when physical conditions appear to be conducive to bloom development, maybe due to the large biomass of benthic filter feeders during this time of the year.

Both of these studies demonstrate the susceptibility of the estuary to the effects of introduced species. It is worth noting that one of the newest species introductions, the Atlantic green crab Carcinus maenas, may now be consuming large numbers of clams in the shallow water in South Bay; this could, in turn, influence the occurrence of fall phytoplankton bloom; would this lead to hypoxia? The physical conditions are certainly right for this to happen. These questions are being examined.

Finally, our studies of bivalve filtration rates in the flume have demonstrated clearly that these benthic filter feeding clams change their feeding behavior in response to varying water velocities; for example, they elevate their position in the sediments in slower water currents thereby increasing the turbulence and transport of food to each individual. These studies have clearly shown that using filtration rates that are measured in nonflowing water may result in large errors. 


\section{ECOLOGY}

\section{REPORTS PUBLIŠHED 1989-1994:}

Carlton, J.T., Thompson, J.K., Schemel, L.E., and Nichols, F.H., 1990, The remarkable invasion of San Francisco Bay (California, U.S.A) by the Asian clam Potamocorbula amurensis, I. Introduction and dispersal: Marine Ecology Progress Series, v. 66, p. 81-94.

Cole, B.E., Thompson, J.K., and Cloern, J.E., 1992, Measurement of filtration rates by infaunal bivalves in a recirculating flume: Marine Biology, v. 113, p. 219-225.

Ebbesmeyer, C.C., Cayan, D.R., McLain, D.R., Nichols, F.H., Peterson, D.H., Redmond, K.T., 1991, 1976 Step in the Pacific climateforty environmental changes between 19681975 and 1977-1984, in Betancourt, J.L., and Tharp, V.L., eds., Seventh Annual Pacific Climate (PACLIM) Workshop, Asilomar, Calif., April 1990 [Proceedings]: Interagency Ecological Studies Program for the Sacramento-San Joaquin Estuary, Technical Report 26, p. 115-126.

Kuivila, K.M., and Nichols, F.H., 1991, Overview of San Francisco Bay estuary toxic contaminants study, in Mallard, G.E., and Aronson, D.A., eds., U.S. Geological Survey Toxics Substances Hydrology Program-Proceedings of the technical meeting, Monterey, Calif., March 11-15, 1991: U.S. Geological Survey Water-Resources Investigations Report 914034, p. 659-663.

Luoma, S.N., Nichols, F.H., and Brown, C.L., in press, Challenges in detecting effects of contaminants on an estuarine ecosystem affected by many disturbances in Morganwalp, D.W., and Aronson, D.A., eds., U.S. Geological Survey Toxic Substances Hydrology Program-Proceedings of the technical meeting, Colorado Springs, Colo., September 20-24,
1993: U.S. Geological Survey Water-

Resources Investigations Report 94-4014.

Monismith, S.G., Koseff, J.R., Thompson, J.K., O'Riordan, C.A., and Nepf, H.M., 1990, A study of model bivalve siphonal currents: Limnology and Oceanography, v. 35, p. 680-696.

Nichols, F.N., 1989, The San Francisco Bay estuary-an overview: Biennial Oceanic Society State of the Bay Conference, 4th, San Francisco, Calif., April 1989, [Proceedings], p. 1118.

Nichols, F.H., Cacchione, D.A., Drake, D.E., and Thompson, J.K., 1989, Emergence of burrowing urchins from California continental shelf sediments-a response to alongshore current reversals?: Estuarine, Coastal, and Shelf Science, v. 29, p. 171-182.

Nichols, F.H., Thompson, J.K., and Schemel, L.E., 1990, The remarkable invasion of San Francisco Bay (California, U.S.A) by the Asian clam Potamocorbula amurensis, II. Displacement of a former community: Marine Ecology Progress Series, v. 66, p. 95-101.

Parchaso, Francis, 1993, Seasonal reproduction of Potamocorbula amurensis in San Francisco Bay, California: San Francisco, Calif., California State University, Masters Thesis, 84 p.

Peterson, D.H., Cayan, D.R., Festa, J.F., Nichols, F.H., Walters, R.A., Slack, J.V., Hager, S.E., Schemel, L.E., 1989, Climate variability in an estuary-effects of riverflow on San Francisco Bay: American Geophysical Union, Geophysical Monograph, v. 55, p. 419-442. 



\section{GEOMORPHOLOGY AND SEDIMENT TRANSPORT}




\section{GEOMORPHOLOGY AND SEDIMENT TRANSPORT}

TITLE: $\quad$ Movement and Storage of Sediment in River Systems (CR 75-102)

PERSONNEL: Robert H. Meade, Project Chief

Aleta R. Moores, Secretary

ADDRESS: U.S. Geological Survey

P.O. Box 25046, MS 413

Denver Federal Center

Denver, CO 80225

TELEPHONE: (303) 236-5009

PROBLEM: Sediment moves through a river system in response to specific events and changing conditions in the drainage basin. The movement of sediment is usually discontinuous. Episodes of movement are separated by periods of storage that can range from less than 1 year to more than 1,000 years. Understanding the movement and storage of sediment in rivers is important to navigation, flood control, and other aspects of river engineering, as well as to the prediction of the fate of contaminants absorbed on sediment particles.

OBJECTIVE: Assess (1) changes in river-sediment loads over periods of decades or longer and the factors (natural or artificial) that cause the changes; (2) rates at which sediment is stored in river systems and the residence times of sediment particles in storage; and (3) sources, pathways, and sinks of sediment particles in river systems.

APPROACH: (1) Assess long-term changes in sediment loads from data previously collected by U.S. Geological Survey and other agencies; (2) assess sediment storage by repeated (annual) surveys of selected river channels and by comparing old and new maps and aerial photographs of rivers and their flood plains; and (3) assess sources, pathways, and sinks by intensive field studies of selected large and small rivers.

PROGRESS: On Powder River in southeastern Montana: (1) ice jams during Spring 1994 indicated a possibly significant transport mechanism for sediment; (2) steady flow conditions in early May 1994 provided conditions for determining variability of Lagrangian velocity, cross-sectional area, and water-surface slope along a $5-\mathrm{km}$ reach; (3) we began rating 22 study sections between Moorhead and Broadus.

In Venezuela, technical assistance was provided in developing a field program to evaluate mercury pollution and sediment mobilization from gold mining on the Guayana Shield. 


\section{GEOMORPHOLOGY AND SEDIMENT TRANSPORT}

\section{REPORTS PUBLISHED 1989-1994:}

Gomez, Basil, and Marron, D.C., 1991, Neotectonic effects on sinuosity and channel migration, Belle Fourche River, western South Dakota: Earth Surface Processes and Landforms, v. 16, p. 227-235.

Johnsson, M.J., and Meade, R.H., 1990, Chemical weathering of fluvial sediments during alluvial storage-the Macuapanim Island point bar, Solimoes River, Brazil: Journal of Sedimentary Petrology, v. 60 , p. $827-842$.

Marron, D.C., 1989, Physical and chemical characteristics of a metal-contaminated overbank deposit, west-central South Dakota, U.S.A.: Earth Surface Processes and Landforms, v. 14 , p. $419-432$.

1992, Floodplain storage of mine tailings in the Belle Fourche River system-Sediment budget approach: Earth Surface Processes and Landforms, v. 17, p. 675-685.

1989, The transport of mine tailings as suspended sediment in the Belle Fourche River, west-central South Dakota, U.S.A., in Hadley, R.F., ed., Sediment and the environment: International Association of Hydrologic Sciences Publication 184, p. 19-26.

Meade, R.H., in press, Suspended sediments of the modern Amazon and Orinoco Rivers: Quaternary International, v. 21.

Meade, R.H., and Koehnken, Lois, 1991, Distribution of the river dolphin, tonina Inia geoffren$s i s$, in the Orinoco River basin of Venezuela and Colombia: Interciencia, v. 16, p. 300312.

Meade, R.H., Rayol, J.M., Conceicao, S.C. da, and Natividade, J.R.G., 1991, Backwater ef- fects in the Amazon River basin of Brazil: Environmental Geology and Water Sciences, v. 18, p. $105-114$.

Meade, R.H., Weibezahn, F.H., Lewis, W.M., Jr., and Perez-Hernandez, David, 1990, Suspended-sediment budget for the Orinoco River, in Weibezahn, F.H., Alvarez, H., and Lewis, W.M., Jr., eds., The Orinoco River as an ecosystem: Caracas, Impresos Rubel, p. 5579.

Meade, R.H., Yuzyk, T.R., and Day, T.J., 1990, Movement and storage of sediment in rivers of the United States and Canada, in Wolman, M.G., and Riggs, H.C., eds., Surface water hydrology: Geological Society of America, The Geology of North America, v. 0-1, p. 255-280.

Moody, J.A., and Meade, R.H., 1990, Channel changes at cross sections of the Powder River between Moorhead and Broadus, Montana, 1975-88: U.S. Geological Survey Open-File Report 89-407, 252 p.

Pizzuto, J.E., in press, Channel adjustments to changing discharges, Powder River, Montana: Geological Society of America Bulletin, v. 106, no. 11. 


\section{GEOMORPHOLOGY AND SEDIMENT TRANSPORT}

TITLE: $\quad$ Effects of Water and Sediment Discharges on Channel Morphology (CR 65-105)

PERSONNEL: Garnett P. Williams, Project Chief

Aleta R. Moores, Secretary

ADDRESS: $\quad$ U.S. Geological Survey

P.O. Box 25046, MS 413

Denver Federal Center

Denver, CO 80225

TELEPHONE: (303) 236-5001

PROBLEM: Channels on alluvial streams change with time. Bed elevations and channel widths may change, meander bends shift both laterally and downstreamward, the sizes of the bed particles may change, instream bars grow and migrate, and the amount and type of vegetation along the river may increase or decrease. Sometimes the change is minor and insignificant, even over decades, but in other cases catastrophic modifications occur in minutes. The transformations can be natural or man-induced, and they can have significant effects on man and the environment.

OBJECTIVE: Determine and analyze the influence of the major governing variables, particularly water and sediment discharges, on channel morphology, and evaluate how the many relevant variables and results change with time.

APPROACH: (1) Identify the major variables that govern channel morphology; (2) obtain data sets that span as long a time period as possible; (3) isolate the effects of different variables and analyze stream channels as dynamical systems, with an eye toward prediction of channel changes.

PROGRESS: The newly emerging fields of nonlinear dynamics and chaos may be able to provide new tools for, and insights into, heretofore-intractable geomorphic and hydrologic problems. However, most researchers find the concepts underlying those new fields to be too confusing and complex. For example, some of the standard chaos-type analyses include Lyapunov exponents, Kolmogorov-Sinai entropy, correlation dimension, and mutual information. These and related concepts are totally unknown to nearly all geomorphologists (and to most other scientists, too, for that matter). The main reason why most scientists and engineers find those concepts so baffling is that there is no understandable textbook 


\section{GEOMORPHOLOGY AND SEDIMENT TRANSPORT}

explaining them. Therefore, I am preparing such a textbook. As of June 1994 the first draft of the manuscript is about 98 percent complete.

\section{REPORTS PUBLISHED 1989-1994:}

Williams, G.P., 1989, Sediment concentration versus water discharge during single hydrologic events in rivers: Journal of Hydrology, $v$. 111 , no. $1-4$, p. 89-106.

Williams, G.P., and Rosgen, D.L., 1989, Measured total sediment loads (suspended loads and bedloads) for 93 United States streams: U.S. Geological Survey Open-File Report $89-67,128 \mathrm{p}$.

Williams, G.P., and Troutman, B.M., 1990, Comparison of structural and least-squares lines for estimating geologic relations: Mathematical Geology, v. 22, no. 8, p. 1027-1049. 


\section{GEOMORPHOLOGY AND SEDIMENT TRANSPORT}

TITLE: $\quad$ Hydraulics and Mechanics of Bedload-Transport Processes (CR 74-187)

PERSONNEL: William W. Emmett, Project Chief

Aleta R. Moores, Secretary

J.P. Doerner, Student (Denver Univ.)
L.B. Leopold, Vol. (Retired, USGS)

R. Egemeier, Vol. (Student Denver Univ.)

\section{TELEPHONE: (303) 236-5008}

PROBLEM: Of all processes operating in river channels, and especially of those of practical concern to engineers and others interested in river-channel behavior, perhaps the least information is available regarding the hydraulics and mechanics of bedload transport. As scientific knowledge of river behavior advances and is applied to management of the nation's rivers, additional understanding of bedload-transport processes will be necessary.

OBJECTIVE: (1) Define (a) spatial and temporal variations in transport rate and particle size of bedload; and (b) the average magnitudes of transport rate and particle size throughout a range of geographic locations, channel geometries, and river hydraulics. (2) Evaluate the adequacy of sampling equipment and field procedures, provide interpretation of bedloadtransport processes, and assess the applicability of existing or new predictive techniques in river hydrology. (3) Demonstrate the value of sediment data in designing hydrologic networks and in evaluating regional and temporal trends in water-resources information. (4) Assess the usefulness of numerical simulations as hydrologic tools in fluvial geomorphology. (5) Provide interdiscipline perspectives in evaluation of environmental resources (for example, fishery habitat), impact assessments (for example, alluvial mining), and management alternatives (for example, operating policy). (6) Apply the information to operational programs of the USGS and other organizational units to assist in the solution of practical problems.

APPROACH: (1) Use continuous sampling of bedload (for example, conveyor-belt bedload trap on the East Fork River near Pinedale, Wyoming) as a control to evaluate spatial and temporal variability factors in bedload transport and to evaluate general relations between sediment movement and river hydraulics. (2) Field calibrate the sediment-sampling efficiency of the Helley-Smith bedload sampler simultaneously with operation of the bedload trap. (3) Use the calibrated Helley-Smith sampler and the concurrent measurements of streamflow 


\section{GEOMORPHOLOGY AND SEDIMENT TRANSPORT}

hydraulics in the systematic collection of bedload samples from a variety of sand- and gravel-bed streams, and within the laws of general physics, stochastically develop empirical relations of bedload transport and interpret the physical significance of the developed relations. (4) At the conveyor-belt bedload-trap research facility, initiate a tracer study using fluorescent particles (sand to fine gravel) to evaluate: (a) residence time of sediment, (b) average speed of various sizes of particles, (c) depth of bed material involved in transport, (d) dispersion of bed material, (e) short-term channel changes accompanying sediment transport, (f) influence of availability of sediment on transport rate, and (g) other related aspects of sediment transport. (5) Extend the fluorescent-tracer study to larger particles (coarse gravel to cobbles) by implanting microradio transmitters in individual rocks and, by periodic and (or) continuous detection by receivers/data loggers, provide time-sequence data on motion and location of separately identifiable particles. (6) Establish field sites for bedload sampling that document varying characteristics of geographic coverage (factors of hydrology, meteorology, soils, biology, and so forth); maintain one or more bedload stations as long-term observation sites so that time-trend data can be evaluated. (7) Initiate and participate, as needed, in studies comparing sampler types, sampling procedures, and analytical techniques to formulate and modify guidelines on equipment needs and field/laboratory practices; provide emphasis on relevancy to WRD mission and on need for consistency of data collection. (8) In conjunction with biologists, chemists, and other scientists, develop a field-oriented strategy for comprehensive environmental assessments; apply developed strategy to specific sites to demonstrate and document sediment-related variables as important ecological factors.

PROGRESS: (1) Provided instruction, field assistance, and office visits to national National Water Quality Assessment (NAWQA) program and to several NAWQA study units related to geomorphic assessment of physical habitat. (2) Provided data summaries and interpretation related to bedload-sampling procedures and to bedload-transport characteristics of natural rivers. (3) Provided technical assistance and overview to hydrologic and geomorphic components of Snake River adjudication.

\section{REPORTS PUBLISHED 1989-1994:}

Averett, R.C., and Emmett, W.W., 1992, Geomorphic assessment of stream physical habitat: Colorado Water, v. 9, no. 6, p. 11.

1993, The phytoplankton of Fremont Lake, Wyoming: U.S. Geological Survey WaterResources Investigation Report 92-4071, 68 p.
Chacho, E.F., Jr., Burrows, R.L., and Emmett, W.W., 1989, Detection of coarse sediment movement using radio transmitters-Proceedings of the XXIII Congress on Hydraulics and the Environment, August 21-25, 1989, Ottawa, Canada: International Association for Hydraulic Research, p. B-367 to B-373. 


\section{GEOMORPHOLOGY AND SEDIMENT TRANSPORT}

1990, Detection of coarse sediment movement using radio receivers: The Northern Engineer, v. 22 , no. 3 , p. 5-9.

Emmett, W.W., and Averett, R.C., 1989, Fremont Lake, Wyoming-Some aspects of the inflow of water and sediment: U.S. Geological Survey Water-Resources Investigations Report 88-4021, 25 p.

Gomez, Basil and Emmett, W.W., 1990, Data that describe at-a-point temporal variations in the transport rate and particle-size distribution of bedload-East Fork River, Wyoming and Fall River, Colorado: U.S. Geological Survey Open-File Report 90-193, 53 p.

Gomez, Basil, Emmett, W.W., and Hubbell, D.W., 1991, Comments on sampling bedload in small rivers: Federal Inter-Agency Sedimentation Conference, 5th, Las Vegas, Nevada, March 18-21, [Proceedings], p. 2-65 to 2-72.

Long, Yuqian, Emmett, W.W., and Janda, R.J., 1989 , Comparison of some methods for particle-size analyses of suspended-sediment samples-Proceedings of Fourth International Symposium on River Sedimentation, November 1-5, 1989, Beijing, China: China Ocean Press, p. 1503-1508.

Nelson, J.M., Emmett, W.W., and Smith, J.D., 1991, Flow and sediment transport in rough channels: Federal Inter-Agency Sedimentation Conference, Nevada, Fifth Las Vegas, March 18-21, [Proceedings], p. 4-55 to 4-62.

Osterkamp, W.R., and Emmett, W.W., 1992, The Vigil Network-Long-term monitoring to assess landscape changes, in Erosion and Sediment Transport Monitoring Programmes in River Basins, Oslo, Norway, August 1992, Proceedings: International Association of $\mathrm{Hy}$ - drological Sciences, Publication no. 210, p. 397-404.

Osterkamp, W.R., Emmett, W.W., and Leopold, L.B., 1990, The Vigil Network-A reviving of interest: American Geophysical Union, Transactions, EOS (March 20, 1990), v. 71, no. 12, p. 338.

Osterkamp, W.R., Emmett, W.W., and Leopold, L.B., 1991, The Vigil Network-a means of observing landscape change in drainage basins: International Association of Hydrological Sciences Journal, v. 36, no. 4, p. 331-344.

Smalley, M.L., Emmett, W.W., and Wacker, A.M., 1994, Annual replenishment of bed material by sediment transport in the Wind River near Riverton, Wyoming: U.S. Geological Survey Water-Resources Investigation Report 94-4007, 23 p. 


\section{GEOMORPHOLOGY AND SEDIMENT TRANSPORT}

TITLE: $\quad$ River Mechanics (CR 82-273)

PERSONNEL: Edmund D. Andrews, Project Chief

Eva Brown, Secretary

Jonathan M. Nelson, Hydrologist

R.R. McDonald, Hydrologist

ADDRESS: U.S. Geological Survey

P.O. Box 25046, MS 458

Denver Federal Center

Denver, CO 80225

TELEPHONE: (303) 541-3002

PROBLEM: The geometry and pattern of river channels adjust to significant changes in the water discharge, size, and quantity of sediment supplied to the channel. When the quantity of water and sediment over a period of years remains relatively constant, the channel geometry and pattern vary about a mean or quasi-equilibrium condition. Major watershed alterations that change the supply of water, sediment, and size of sediment reaching the channel necessitate an adjustment of the channel geometry and pattern. That is, the channel is transformed from one quasi-equilibrium state to another. Between the two quasi-equilibrium states, there is a period of instability and adjustment. Existing techniques for examining and predicting river channel adjustment have been developed primarily from investigation of quasi-equilibrium rivers. As a result, it is frequently possible to predict with a modest range of uncertainty the future quasi-equilibrium hydraulic characteristics of a river following a change in its watershed. The dynamics and rate of river channel adjustment during the period of instability, however, have rarely been studied, and are rather poorly understood. The length of time required for the complete adjustment is commonly a few decades to a century or more. In many instances, such as surface mines, reservoirs, and urbanization, the adjustment period may, in fact, be longer than the duration of the watershed change. In watersheds where various land-use changes occur every several years, river channels may be continually adjusting to different contributions of water and sediment, and thus, never reach a quasi-equilibrium condition. In these rivers, instability and adjustment are the prevailing condition. The primary focus of this research project is to understand the dynamics and rate of river channel change and develop numerical models to make predictions of river channel characteristics given a particular change in flow regime and sediment supply. The greatest deficiencies in our present knowledge of river channel adjustment are (1) the longitudinal sorting of bed material, especially gravel, (2) the formation and stability of bed forms, (3) 


\section{GEOMORPHOLOGY AND SEDIMENT TRANSPORT}

adjustment of channel width through the erosion and deposition of bank material, and (4) the rates at which the several hydraulic variables adjust.

OBJECTIVE: Develop physically-based numerical models to describe the processes and rate at which a river channel adjusts in response to a change in the water discharge, sediment size and sediment load supplied to the channel. Emphasize the adjustment of those aspects of river channels known to significantly influence the aquatic ecosystem, that is, the bed-material size distribution, occurrence of bars, and channel width. Describe the hydraulic processes controlling these characteristics of river channels as well as the rate at which they function. Formulate mathematical models of the processes as required for longitudinal routing of water and sediment. Develop new analytical tools for describing river-channel adjustment.

APPROACH: The development of physically-based hydrodynamics models involves an iterative process of model formulation, testing model predictions using field and laboratory measurements, and then model refinement. Precise field and laboratory measurements are essential. Ideally, one would study in great detail the transition of a river channel from one quasi-equilibrium state through a period of instability to another quasi-equilibrium state as a result of a known change in the supply of water and sediment. Unfortunately, this approach is impractical for several reasons including the need to maintain a high level of effort over the period of adjustment, which may last for a few decades to a century or more. Instead, one must limit the detailed study of processes to a duration much less than would normally be required for channel adjustment. These studies, however, can lead to a precise description of physical processes. Although historical information is incomplete and less precise, the course and rate of river channel adjustment through time can only be understood by studying historical examples. Thus, reconstructions of the sequence and rate of channel adjustment using historical examples of river channel change are necessary components of this research. Better understanding of river channel adjustment requires a combination of precise field and laboratory studies, the reconstruction of historical examples using available information, and carefully formulated physically-based models.

PROGRESS: The primary obstacle limiting our ability to compute bed-material transport rates precisely at relatively small boundary shear stresses has been considerable uncertainty in the characteristics of the pockets in which bed particles rest. When the fluid forces acting on a bed particle are just sufficient to overcome the gravitational force, a particle will rotate out of the pocket in which it lies and roll or bounce downstream until it settles into a new resting site. The mechanics of particles rolling across a granular bed have been well formulated, and the transport of various sized bed particles can be computed if distribution of bed pocket angles is known. A technique for measuring pocket angles of actual river deposits, for 


\section{GEOMORPHOLOGY AND SEDIMENT TRANSPORT}

example point-bars, middle channel bars, riffles, etc., has been developed. The technique employs a commercially available force transducer. Results obtained so far are promising.

Over the past year, an evaluation of fluvial sediment transport magnitude and frequency in Zion National Park was completed and presented to Park officials and the Utah State Engineer Based on these findings, various instream flow regimes to protect fluvial resources in the Park are being evaluated.

A field technique has been developed to determine the characteristics of the pockets in which gravel-sized particles rest in stream deposits composed of various particle size mixtures, packing and shape.

\section{REPORTS PUBLISHED 1989-1994:}

Andrews, E.D., 1990, Effects of streamflow and sediment on channel stability of the Colorado River-A perspective from Lees Ferry, Arizona, in Wolman, M.G., and Riggs, H.C., eds., The Geology of North America: Surface Water Hydrology, Geological Society of America, v. 0-1, p. 304-310.

1991, Sediment transport in the Colorado River basin, in Marzolf, G.R., ed., Colorado River Ecology and Dam Management: Washington, D.C., National Academy Press, p. 54-74.

in press, Marginal bedload transport in a gravel-bed stream, Sagehen Creek, California: Water Resources Research, v. 00.

Andrews, E.D. and Nelson, J.M., 1989, Topographic response of a bar in the Green River, Utah, to variation in discharge, in Ikeda, Syunsuke, and Parker, Gary, eds., River Meandering: American Geophysical Union, Water Resources Monograph, v. 12, p. 463485.

Andrews, E.D., and Smith, J.D., 1992, A theoretical model for calculating marginal bedload transport rates of gravel, in Hey, R.D., Thorne, C.R., and Billi, P., eds., Gravel-Bed Rivers III: New York, John Wiley and Sons, p. 267-281.

Helsel, D.R., and Andrews, E.D., 1991, Discussion of "Trends in freshwater inflow to San Francisco Bay from the Sacramento-San Joaquin Delta" by Fox, J.P., Mongon, T.R., and Miller, W.J., 1990: Water Resources Bulletin, v. 27, no. 2, p. 317-319.

McKnight, D.M., Aiken, G.R., Andrews, E.D., Bowles, C., and Harnish, R.A., 1993, Dissolved organic material in Dry Valley lakes: A comparison of Lake Fryxell, Lake Hoare, and Lake Vanda, in Green, William, ed., Physical and biogeochemical processes in Antarctic lakes: Washington, D.C., American Geophysical Union, Monograph Series 59, p. 119-133.

McKnight, D.M., and Andrews, E.D., 1993, Hydrologic and geochemical processes at the stream-lake interface in a permanently icecovered lake in the McMurdo Dry Valleys, Antarctica: Verhandelinger Internationle Verein Limnology, p. 957-959. 


\section{GEOMORPHOLOGY AND SEDIMENT TRANSPORT}

McLean, S.R., Nelson, J.M., and Wolfe, S.R., in press, Turbulence structure over two-dimensional bedforms-Implications for sediment transport: Journal of Geophysical Research, $v$ 00 .

Nelson, J.M., 1991, The initial instability and finite-amplitude stability of alternate bars in straight channels: Earth-Science Review, v. 29 , p. 97-115.

Nelson, J.M., Emmett, W.W., and Smith, J.D., 1991, Flow and sediment transport in rough channels: Proceedings Fifth Federal Interagency Sedimentation Conference, March 18-21, 1991 , chap. R, p. 55-62.

Nelson, J.M., McLean, S.R., and Wolfe, S.R., 1993, Mean flow and turbulence fields over two-dimensional bed forms: Water Resources Research, v. 29, no. 12 , p. 3935-3953.

Nelson, J.M., and Smith, J.D., 1989, Flow in meandering channels with natural topography, in Ikeda, Syunsuke, and Parker, Gary, eds., River Meandering: Washington, D.C., American Geophysical Union Monograph 12, p. 69-102.

1989, Evolution and stability of erodible channel beds, in Ikeda, Syunsuke, and Parker, Gary, eds., River Meandering: Washington, D.C., American Geophysical Union Monograph 12 , p. 321-377.

1989, Mechanics of flow over ripples and dunes: Journal of Geophysical Research, v. 94 no. C6, p. 8146-8162.

Shimizu, Y., Smith, J.D., and Nelson, J.M., 1989, Comparison of models for single thread streams, in Wang, S.Y., ed., Proceedings of the International Symposium on Sediment
Transport Modeling: New York, American Society of Civil Engineers, p. 524-529.

Smith, J.D., and Nelson, J.M., 1989, Mechanics of mud flows in curved channels with uneven beds, in Wang, S.Y., ed., Proceedings of the International Symposium on Sediment Transport Modeling: New York, American Society of Civil Engineers, p. 518-523.

Wiberg, P.L., and Nelson, J.M., 1992, Unidirectional flow over asymmetric and symmetric ripples: Journal of Geophysical Research, v. 97, no. C8, p. 12745-12761. 


\section{GEOMORPHOLOGY AND SEDIMENT TRANSPORT}

TITLE: $\quad$ Sediment-Transported Pollutants in the Mississippi River (CR 87-309)

PERSONNEL: Robert H. Meade, Jr., Project Chief

Aleta R. Moores, Secretary

John A. Moody, Hydrologist

ADDRESS: U.S. Geological Survey

P.O. Box 25046, MS 413

Denver Federal Center

Denver, CO 80225

TELEPHONE: (303) 236-5009

PROBLEM: The source and fate of many pollutant substances in the Nation's largest river system are closely tied to suspended sediment. Accurate prediction of the fate of these pollutants will require more than our present understanding of the interactions between sediments and pollutants and the ways in which large rivers store and remobilize suspended sediment.

OBJECTIVE: Define and understand (1) processes by which pollutant substances, organic and inorganic, are adsorbed onto sediment particles; (2) downstream mixing of pollutants below the confluence of large tributaries with the mainstem; and (3) seasonal storage and remobilization of sediment and pollutants in the Mississippi River system.

APPROACH: One to two boat trips per year, beginning at Minneapolis, Minnesota, and ending at New Orleans, Louisiana, will be made to sample 15-20 cross sections of the Mississippi River and its principal tributaries. Cross sections will be sampled with a large-volume suspended-sediment sampler by the equal-width-increment method. Suspended sediment will be concentrated and analyzed for a large number of organic and inorganic constituents, both natural and manmade. New methods for sampling and analyzing pollutants attached to sediment particles will be developed in the field and in the laboratory.

PROGRESS: The report on contaminants in the Mississippi River, containing chapters on heavy metals, nutrients, pesticides, PCBs, sewage and industrial contaminants (organic), and trihalomethanes, has been approved for publication as a USGS Water-Supply Paper.

A dozen or so data reports are in various stages of preparation, review, and revision so as to be referenced in the Water-Supply Paper. 


\section{GEOMORPHOLOGY AND SEDIMENT TRANSPORT}

The surficial bed sediments in the navigation pools of the Upper Mississippi River, which were sampled during 1991-1992, were resampled to assess the effects of the record flood of 1993. Analysis has begun on the surficial bed sediments for adsorbed contaminants (total organic carbon, total volatile solids, PAHs, LAS, sterols, organochlorines, PCB congeners, and trace elements) to evaluate the effects of a large hydrologic event on river quality. This resampling was done in cooperation with the National Biological Survey and the Wisconsin Department of Natural Resources.

\section{REPORTS PUBLISHED 1989-1994:}

Battaglin, W.A., Goolsby, D.A., and Coupe, R.H., 1993, Annual use and transport of agricultural chemicals in the Mississippi River, 1991-92, in Goolsby, D.A., Boyer, L.L., and Mallard, G.E., compilers, Selected papers on agricultural chemicals in water resources of the midcontinental United States: U.S. Geological Survey Open-File Report 93-418, p. 26-40.

Coupe, R.H., Goolsby, D.A., Iverson, J.L., Markovchick, D.J., and Zaugg, S.D., in press, Pesticide, nutrient, water discharge, and physical-property data for the Mississippi River and some of its tributaries, April 1991-September 1992: U.S. Geological Survey Open-File Report 93-657.

Ellis, G.S., 1994, In situ application of a semipermeable membrane device for the monitoring of lipophilic organic contaminants: Colorado School of Mines, Department of Chemistry and Geochemistry, Masters Thesis, 124 p.

Goolsby, D.A., and Battaglin, W.A., 1993, Occurrence, distribution and transport of agricultural chemicals in surface waters of the midwestern United States, in Goolsby, D.A., Boyer, L.L., and Mallard, G.E., compilers, Selected papers on agricultural chemicals in water resources of the midcontinental United States: U.S. Geological Survey Open-File Report 93-418, p. 1-25.
Goolsby, D.A., Battaglin, W.A., and Thurman, E.M., 1993, Occurrence and transport of agricultural chemicals in the Mississippi River, July through August 1993: U.S. Geological Survey Circular 1120-C, 22 p.

Goolsby, D.A., Coupe, 'R.C., and Markovchick, D.J., 1991, Distribution of selected herbicides and nitrate in the Mississippi River and its major tributaries, April through June 1991: U.S. Geological Survey Water-Resources Investigations Report 91-4163, 35 p.

Hayes, H.C., 1993, Metal associations in suspended sediments and bed sediments from the Mississippi River: Golden, Colorado School of Mines, Department of Chemistry and Geochemistry, Master's Thesis, $131 \mathrm{p}$.

Leenheer, J.A., 1991, Organic substance structures that facilitate contaminant transport and transformations in aquatic sediments, in Baker, R.A., ed., Organic substances and sediments in water: Chelsea, Mich., Lewis Publishers, v. 1, p. 3-22.

Leenheer, J.A., Meade, R.H., Taylor, H.E., and Pereira, W.E., 1989, Sampling, fractionation, and dewatering of suspended sediment from the Mississippi River for geochemical and trace-contaminant analysis, in Mallard, G. E, and Ragone, S. E., eds., U.S. Geological Sur- 


\section{GEOMORPHOLOGY AND SEDIMENT TRANSPORT}

vey Toxic Substances Hydrology ProgramProceedings of the technical meeting, Phoenix, Ariz., September 26-30, 1988: U.S. Geological Survey Water-Resources Investigations Report 88-4220, p. 501-512.

Leenheer, J.A., Noyes, T.I., and Brown, P.A., in press, Data on natural organic substances in dissolved, colloidal and suspended-silt phases in the Mississippi River and its major tributaries, 1987-90: U.S. Geological Survey WaterResources Investigations Report 93-4204.

Leenheer, J.A., Wershaw, R.L., Brown, P.A., and Noyes, T.I., 1991, Detection of polyethyleneglycol residues from nonionic surfactants in surface water by $\mathrm{H}$ - and $\mathrm{C}$-nuclear magnetic resonance spectrometry: Environmental Science and Technology, v. 25, p. 161-168.

Leiker, T.J., Rostad, C.E., Barnes, C.R., and Pereira, W.E., 1991, A reconnaissance study of halogenated organic compounds in catfish from the lower Mississippi River and its major tributaries: Chemosphere, v. 23, p. 817-829.

1991, A reconnaissance study of halogenated organic compounds in catfish from the lower Mississippi River and its major tributaries, in Dhamotharan, Dhamo, ed., Resource Development in the Lower Mississippi River, Proceedings: American Water Resources Association Technical Publication Series TPS 91-3, p. 185-194.

Meade, R.H., 1989, Sediment-transported pollutants in the Mississippi River: U.S. Geological Survey Yearbook 1988, p. 20-23.

Meade, R.H., and Stevens, H.H., Jr., 1990, Strategies and equipment for sampling suspended sediment and associated toxic chemicals in large rivers-with emphasis on the Mississippi
River: Science of the Total Environment, v. 97/98, p. 125-135.

Moody, J.A., 1993, Evaluation of the Lagrangian scheme for sampling the Mississippi River during 1987-90: U.S. Geological Survey Water-Resources Investigations Report 934042, $31 \mathrm{p}$.

in press, Propagation and composition of the flood wave on the Upper Mississippi River, 1993: U.S. Geological Survey Circular 1120-F.

Moody, J.A., and Goolsby, D.A., 1993, Spatial variability of triazine herbicides in the kower Mississippi River: Environmental Science and Technology, v. 27, p. 2120-2126.

Moody, J.A., and Meade, R.H., 1992, Hydrologic and sedimentologic data collected during three cruises at low water on the Mississippi River and some of its tributaries, July 1987-June 1988: U.S. Geological Survey Open-File Report 91-485, $143 \mathrm{p}$.

Moody, J.A., and Meade, R.H., 1993, Hydrologic and sedimentologic data collected during four cruises at high water on the Mississippi River and some of its tributaries, March 1989-June 1990: U.S. Geological Survey Open-File Report 92-651, $227 \mathrm{p}$.

in press, Evaluation of the method of collecting suspended sediment from large rivers by discharge-weighted pumping and separating it by continuous-flow centrifugation: Hydrological Processes, v. 8.

Moody, J.A., and Troutman, B.M., 1992, Evaluation of the depth-integration method of measuring water discharge in large rivers: Amsterdam, Netherlands, Journal of Hydrology, v. 135, p. 201-236. 


\section{GEOMORPHOLOGY AND SEDIMENT TRANSPORT}

Pereira, W.E., and Hostettler, F.D., 1993, Nonpoint source contamination of the Mississippi River and its tributaries by herbicides: Environmental Science and Technology, v. 27, p. 1542-1552.

Pereira, W.E., and Rostad, C.E., 1990, Occurrence, distributions, and transport of herbicides and their degradation products in the Lower Mississippi River and its tributaries: Environmental Science and Technology, v. 24, p. $1400-1406$.

Pereira, W.E., Rostad, C.E., and Leiker, T.J., 1989, Preliminary assessment of the fate and transport of synthetic organic agrochemicals in the lower Mississippi River and its tributaries, in Mallard, G. E, and Ragone, S. E., eds., U.S. Geological Survey Toxic Substances Hydrology Program-Proceedings of the technical meeting, Phoenix, Ariz., September 26-30, 1988: U.S. Geological Survey WaterResources Investigations Report 88-4220, p. 453-464.

1990, Determination of trace levels of herbicides and their degradation products in surface and ground waters by gas chromatography-ion trap mass spectrometry: Analitica Chimica Acta, v. 228, p. 69-75.

1990, Distributions of agrochemicals in the Lower Mississippi River and its tributaries: Science of the Total Environment, v. 97/98, p. 41-53.

Pereira, W.E., Rostad, C.E., and Leiker, T.J., 1992, Synthetic organic agrochemicals in the lower Mississippi River and its major tributaries-Distribution, transport and fate: Journal of Contaminant Hydrology, v. 9, p. 175-188.

Rathbun, R.E., and Bishop, L.M., 1993, Trihalomethane and nonpurgeable total organic halide formation potentials for the Mississippi River and some of its tributaries, June-August 1991: U.S. Geological Survey Open-File Report 93-158, $57 \mathrm{p}$.

in press, Trihalomethane and nonpurgeable total organic-halide formation potentials for the Mississippi River and some of its tributaries, September-October 1991: U.S. Geological Survey Open-File Report 94-36.

Rees, T.F., 1990, Comparison of photon correlation spectroscopy with photosedimentation analysis for the determination of aqueous colloid size distributions: Water Resources Research, v. 26, p. 2777-2781.

Rees, T.F., Leenheer, J.A., and Ranville, J.F., 1991, Use of a single-bowl continuous-flow centrifuge for dewatering suspended sediments-effect on sediment physical and chemical characteristics: Hydrological Processes, v. 5, p. 201-214.

Rees, T.F., and Ranville, J.F., 1989, Characterization of colloids in the Mississippi River and its major tributaries, in Mallard, G. E, and Ragone, S. E., eds., U.S. Geological Survey Toxic Substances Hydrology Program-Proceedings of the technical meeting, Phoenix, Ariz., September 26-30, 1988: U.S. Geological Survey Water-Resources Investigations Report 88-4220, p. 513-522.

1990, Collection and analysis of colloidal particles transported in the Mississippi River, U.S.A.: Journal of Contaminant Hydrology, v. 6, p. 241-250.

Rostad, C.E., Bishop, L.M., Ellis, G.S., Leiker, T.J., Monsterleet, S.G., and Pereira, W.E., in press, Organic contaminants on suspended sediment collected during five cruises of the Mississippi River and its principal tributaries, 


\section{GEOMORPHOLOGY AND SEDIMENT TRANSPORT}

May 1988 to June 1990: U.S. Geological Survey Open-File Report 93-360.

Rostad, C.E., Pereira, W.E., and Leiker, T.J., 1989, Determination of herbicides and their degradation products in surface waters by gas chromatography/positive chemical ionization/tandem mass spectrometry: Biomedical and Environmental Mass Spectrometry, v. 18, p. $820-827$.

1994, Distribution and transport of selected anthropogenic organic compounds on Mississippi River suspended sediment (U.S.A.), May/June 1988: Journal of Contaminant Hydrology, v. 16, p. 175-199.

Roth, D.A., 1994, Ultratrace analysis of mercury and its distribution in some natural waters in the United States: Colorado State University, Department of Chemistry, Ph.D. Dissertation, 309 p.

Tabor, C.F., Jr., 1993, The occurrence and fate of linear alkylbenzene sulfonate in the Mississippi River-a molecular indicator of sewage contamination: Boulder, University of Colorado, Department of Geology, M.S. Thesis, 78 p.

Taylor, H.E., Antweiler, R.C., Brinton, T.I., Roth, D.A., and Moody, J.A., 1994, Major ions, nutrients, and trace elements in the Mississippi River near Thebes, Illinois, July through September 1993: U.S. Geological Survey Circular 1120-D, 21 p.

Taylor, H.E., Garbarino, J.R., and Brinton, T.I., 1990 , Occurrence and distribution of trace metals in the lower Mississippi River and its tributaries: Science of the Total Environment, v. $97 / 98$, p. $369-384$.

Writer, J.H., 1992, Sewage contamination in the Upper Mississippi River as measured by the fecal sterol coprostanol: Boulder, Colo., University of Colorado, Department of Civil, Architectural, and Environmental Engineering, M.S. Thesis, $99 \mathrm{p}$. 


\section{GEOMORPHOLOGY AND SEDIMENT TRANSPORT}

TITLE: Applications of Fluid and Sediment Mechanics to Basin and Regional Scale Hydrologic and Geomorphic Problems (CR 91-324)

PERSONNEL: J. Dungan Smith, Project Chief

Eva Brown, Secretary

Eleanor Griffin, Student, (University of Colorado)

Stephen M. Wiele, Hydrologist

David Topping, Student, (University of Washington)

ADDRESS: U.S. Geological Survey

P.O. Box 25046, MS 458

Denver Federal Center

Denver, CO 80225

TELEPHONE: (303) 541-3004

PROBLEM: Stream systems function as integrated units from the zero-order basins at their heads to their terminations at the sea. Interior adjustments to changes in their headwaters or along their lengths occur in a variety of ways, some of which leave sedimentary deposits that provide important information with regard to the sensitivity of the systems to disturbances of various magnitudes and with respect to the nature of past disturbances. The former type of information is crucial to reliable interpretation of paleoflood deposits and the latter knowledge is essential for testing hydrologic predictions derived from climate models. In order to interpret fluvial deposits properly, however, an extremely accurate knowledge of stream system mechanics is required.

OBJECTIVE: The long-term goal of this project is to develop precise, process-based algorithms for flow, sediment transport, stream channel adjustment, erosion, and deposition in characteristic segments of a wide variety of fluvial systems. These algorithms then can be used to assess local environmental problems along particular types of stream segments, or they can be coupled with each other and with analogous algorithms for hill slope processes in order to produce models for erosion, sediment transport, and deposition on a regional scale and, thereby, provide a sound, process-based connection between regional hydrology and the salient characteristics of the sedimentary deposits in a wide variety of stream systems.

APPROACH: Stream systems are far too complex to be understood using empirical data only, but mathematical models that are to be used to provide reliable information from extreme or past events must be predictive in character and they must be devoid of parameters that make calibration of the models necessary. These models must be thoroughly tested using data from comprehensive studies of carefully chosen natural systems. The complex 


\section{GEOMORPHOLOGY AND SEDIMENT TRANSPORT}

morphology of river channels and the intricate topography of hill slopes is generally not well known, and, thus, cannot be treated effectively in a completely deterministic fashion. In contrast, the flow and sediment transport over these surfaces usually can be computed with reasonable accuracy from available fluid mechanical theory if the topography is known. Comprehensive, processes-based flow and sediment transport models for rivers and hill slopes, therefore, must represent the topographic elements in an appropriate stochastic manner while treating the response of the flow to this topography in a proper deterministic fashion. Models that are useful for environmental reconstruction require the judicious combination of modern fluid mechanical theory with a carefully crafted statistical treatment of the surface over which fluid is moving, so that the dominant nonlinear interactions between the topography and the flow are fully characterized and the evolution of the landscape is accurately represented.

PROGRESS: During the past several years the emphasis on this project has centered on the effects of operation of Glen Canyon Dam on the fluvial and riparian environments of the Colorado River through the Marble and Grand Canyons, and specifically on the development of physically based numerical models for flow, sediment transport and the exchange of sand between the bed and margins of the mainstem Colorado River and its two major sand contributing tributaries (the Little Colorado River and the Paria River). Owing to the sensitivity of fluvial and riparian processes in arid regions to variations in discharge and fine sediment transport in the associated rivers, and to the importance of water for irrigation, municipal use and the generation of hydroelectric power in the arid West, there is a critical need for mathematical models that clearly and conclusively show the environmental effects resulting from both engineering works and natural causes. Ultimately, such models can and should be used for environmentally sensitive operation of large dams.

Our present research on the Colorado River System between Lake Powell and Lake Mead falls into the following categories: (1) Input of sand to the Colorado River from the Paria and Little Colorado Rivers and its relationship to the dominant hydrologic processes in these two drainage basins. (2) Development of an accurate, reach averaged flow model for the Colorado River between the Glen Canyon Dam and Lake Mead that is forced by unsteady discharge from the Glen Canyon Dam. (3) Construction of a comprehensive, reach averaged model of sand transport in the Colorado River through the Grand Canyon driven by the unsteady flow emanating from the Glen Canyon Dam. (4) Accurate characterization of the discharge dependant exchange of sand between the bed of the Colorado River and the channel margins. (5) Development of quasi three-dimensional models for flow, sand transport and sand deposition in long reaches below the mouth's of the Paria and Little Colorado Rivers. All of these tasks involve the analysis of large amounts of data previously collected by USGS 


\section{GEOMORPHOLOGY AND SEDIMENT TRANSPORT}

personnel, as well as, the development of fluid mechanically accurate algorithms for computation of key flow and sediment transport parameters.

Discharge on the Paria River is event dominated, so in order to calculate the historical flow and sand transport past the gage at its mouth we have had to digitize the graphic records for the entire pre-dam period (1923 to 1963). This task is nearly complete and Topping and Smith are now in the process of writing a comprehensive report on the sand contribution to the mainstem Colorado River from the Paria. This report will be completed by the end of Fiscal Year 1994. A similar examination of sand transport out of the Little Colorado River will be carried out during the next fiscal year.

A comprehensive discharge model for the Colorado River has been under development for the past several years. First, the topography of the channel was characterized, then a reach averaged stage dependent roughness for the channel was established. Subsequent to these initial efforts a method for determining inputs from ungaged tributaries was developed and is now being used to examine a series of experimental flows, called "Research Flows," that were carried out in 1991. Also, the bed topography used in the original flow model extended only to a level corresponding to a discharge of approximately $30,000 \mathrm{cfs}$ and current research is oriented toward extending that to much higher levels. During the past fiscal year a manuscript on the present flow model has been produced by Wiele and Smith and has been submitted for colleague review. A previous manuscript by Smith and Wiele has been revised after colleague review and will be submitted shortly for Director's approval. In addition, a manuscript on application of our flow model to the set of test flows carried out in 1991 is being written by Griffin, Wiele, and Smith and will be submitted for colleague review by the end of the fiscal year. A manuscript by Wiele and Smith on application of the model to various operational scenarios, showing which flow characteristics are sensitive to dam operation and which are not also is being written and probably will be sent out for colleague review by the end of the present fiscal year. Finally, a manuscript describing a statistical analysis of the limited available topographic information for the river channel above the $30,000 \mathrm{cfs}$ level and an extrapolation of this data that permits extension of the model to levels corresponding to 1983 and pre-dam flood discharges is in preparation by Smith and Furey and should be released for colleague review by the end of Fiscal Year 1994.

During the past year an earlier suspended sand transport model has been expanded to permit estimation of cross channel sand transport, and then has been used to investigate the exchange of sand between the bed of the Colorado River and its banks. Understanding and modeling this exchange process and its variation with stage is fundamental to coupling discharge controlled flow processes in the channel to maintenance of (1) a healthy riparian environment, 


\section{GEOMORPHOLOGY AND SEDIMENT TRANSPORT}

and (2) channel margin habitats needed by endangered species. A manuscript on this topic by Smith is in preparation and will be available for colleague review by the end of the fiscal year. Sand is contributed to the Colorado River by the Paria and Little Colorado Rivers during floods in these drainage basins. Typically it is then deposited below the mouths of these tributaries and remobilized by subsequent high flow events on the mainstem Colorado. Accurate knowledge of how much material is in these sand reservoirs and how fast it is being removed by Dam controlled flows is important with regard to River management; therefore, accurate, quasi three-dimensional models are being constructed for both localities. These models, when used in combination with topographic data from monumented cross sections, permit computation of the patterns and rates of sand deposition during tributary floods, as well as, subsequent redistribution and removal of this material. These models currently are under development.

\section{REPORTS PUBLISHED 1989-1994:}

Andrews, E.D., and Smith, J.D., 1992, A theoretical model for calculating marginal bedload transport rates of gravel, in Hey, R.D., Thorne, C.R., and Billi, P., eds., Gravel-Bed Rivers III: New York, p. 267-281.

Nelson, J.M., and Smith, J.D., 1989, Evolution and stability of erodible channel beds, in Ikeda, S., and Parker, G., eds., River Meandering: American Geophysical Union Water Resources Monograph 12, Washington, D.C., p. 321-377.

1989 , Flow in meandering channels with natural topography, in Ikeda, S., and Parker, G., eds., River Meandering: American Geophysical Union Water Resources Monograph 12, Washington, D.C., p. 69-102.

1989, Mechanics of flow over ripples and dunes: Journal of Geophysical Research, $v$. 94, no. C6, p. 8146-8162.

Shimizu, Y., Smith, J.D., and Nelson, J.M., 1989, Comparison of models for single thread streams, in Wang, S.Y., ed., Proceedings of the International Symposium on Sediment Transport Modeling: New York, American Society of Civil Engineers, p. 524-529.

Smith, J.D., and Nelson, J.M., 1989, Mechanics of mud flows in curved channels with uneven beds, in Wang, S.Y., ed., Proceedings of the International Symposium on Sediment Transport Modeling: New York, American Society of Civil Engineers, p. 518-523. 


\section{GEOMORPHOLOGY AND SEDIMENT TRANSPORT}

TITLE: Response of Fluvial Systems to Climatic Variability (WR 89-200)

PERSONNEL: Robert H. Webb, Project Chief

Janice E. Bowers, Botanist

Douglas D. Wellington, Computer Analyst

Theodore S. Melis, Hydrologist

Marilyn B. Murov, Hydrology Technician

Thomas W. Wise, Physical Scientist

ADDRESS: $\quad$ U.S. Geological Survey

1675 W. Anklam Road

Tucson, AZ 85745

\section{TELEPHONE: (602) 670-6821}

PROBLEM: Understanding the effects of climatic variability is important to development of water resources, mitigation of flood hazards, and interpretation of geomorphic surfaces. Climatic variability, which is characterized by temporal changes in variability of seasonal climate that spans decades or centuries, may be more important to water-resources evaluations than changes in mean climatic conditions. Watershed conditions, particular the status of plant communities, is also affected by climate, and these changes may reinforce or mitigate direct effects of climatic variability. Changes in variability of climate has a large effect on the probability of occurrence of extreme events, such as floods or droughts. Understanding of climatic variability and its effect on the landscape is paramount for valid estimation of flood frequency, sediment-transport rates, and long-term watershed and channel changes.

OBJECTIVE: The objective of this project is to define historic climatic variability in the western United States over the past century; to identify specific time periods of statistically stationary precipitation, discharge, flood frequency, and sediment transport; to assess the net effects of climatic variability on watershed conditions and fluvial systems; and to determine the extent that historic changes reflect Holocene climatic fluctuations.

APPROACH: Historic climatic variability will be assessed through regionalization of temporal climatic signals including temperature and precipitation amounts and intensity. Proxy synthetic records such as tree-ring widths, varved ocean sediments, and nonanthropogenic changes in vegetation will be determined. General circulation of the atmosphere will be examined for long-term changes in precipitation-generating mechanisms that affect the western United States. Generation mechanisms for specific storm types, which 


\section{GEOMORPHOLOGY AND SEDIMENT TRANSPORT}

include tropical cyclones and winter frontal storms, will be examined for frequency changes in time and space. Paleoflood records will be developed for rivers that are sensitive to climatic variability. Regional flood frequency, streamflow, and precipitation models will be used to assess the effects of variability changes. The stability of desert vegetation will be assessed to determine possible interactions among climate, vegetation change, and storm runoff.

PROGRESS: Use of repeat photography to evaluate geomorphic and ecological changes in Grand and Cataract Canyons, which is now complete, has yielded significant results for historic changes in riparian and desert vegetation, alluvial sand deposits, and debris fans. A book reporting the findings is in press. A journal article on demography and longevity of desert vegetation has been submitted. Data on the magnitude and frequency of debris flows in Grand Canyon National Park has been compiled into a report and submitted for approval; a monograph and several journal articles are in preparation. A draft of a circular on downstream effects of dams has passed through peer review. A significant advance was made in paleoflood research using Monte Carlo analyses designed to simulate the information obtained from paleoflood deposits. The floods of 1993 in Arizona indicate that flood frequency in the southwestern United States may be responding to low frequency increases in high pressure during winter over the Pacific Northwest.

\section{REPORTS PUBLISHED 1989-1994:}

Bowers, J. E., 1991, The Mountains Next Door: Tucson, University of Arizona Press, 196 p. 1992, Plant World and its metamorphosis from a popular journal into Ecology: Bulletin of the Torrey Botanical Club, v. 119, p. 333-341.

1993, A Full Life in a Small Place and Other Essays from a Desert Garden: Tucson, University of Arizona Press, $166 \mathrm{p}$.

Bowers, J.E., 1994, Natural conditions for seedling emergence of three woody species in the northern Sonoran Desert: Madrono, v. 41, p. 73-84.
Bowers, J.E., and Dimmitt, M.A., 1994, Flowering phenology of six woody plants in the northern Sonoran Desert: Bulletin of the Torrey Botanical Club, v. 121, p. 215-229.

Bowers, J.E., and McLaughlin, S.P., 1993, Noteworthy collections: Arizona, Madroño, v. 40, p. 132-133.

Burgess, T.L., Bowers, J.E., and Turner, Raymond M., 1991, Exotic plants at the Desert Laboratory, Tucson, Arizona, Madroño, v. 38 , p. $96-114$.

Cayan, D.R., and Webb, R.H., 1992, El Niño/ Southern Oscillation and streamflow in the western United States, in Diaz, H.F., and 


\section{GEOMORPHOLOGY AND SEDIMENT TRANSPORT}

Markgraf, V., eds., El Niño, historical and paleoclimatic aspects of the Southern Oscillation: Cambridge, England, Cambridge University Press, p. 29-68.

Ely, L.L., Webb, R.H., and Enzel, Y., 1992, Accuracy of post-bomb ${ }^{137} \mathrm{Cs}$ and ${ }^{14} \mathrm{C}$ in dating fluvial deposits: Quaternary Research, v. 37, p. 196-204.

Enzel, Yehouda, Ely, L.L., House, P.K., Baker, V.R., and Webb, R.H., 1993, Paleoflood evidence for a natural upper bound to flood magnitudes in the Colorado River basin: Water Resources Research, v. 29, p. 2287-2297.

Graf, J.B., Hereford, Richard, and Webb, R.H., 1991, Relation of sediment load and floodplain formation to climatic variability, Paria River drainage basin, Utah and Arizona: Geological Society of America Bulletin, v. 103, p. 1405-1415.

Gray, J.R., and Webb, R.H., 1991, Radionuclides in the Puerco and lower Little Colorado River basins, New Mexico and Arizona, before 1987, in Gunderson, L.C.S., and Wanty, R.V., eds., Field studies of radon in rocks, soils, and water: U.S. Geological Survey Bulletin 1971, p. 297-311.

Gray, J.R., Webb, R.H., and Hyndman, D.W., 1991, Low-flow sediment transport in the Colorado River, in Fan, S.S., and Kuo, Y.H., eds., Proceedings of the Fifth Federal Interagency Sedimentation Conference: Washington, D.C., Federal Energy Regulatory Commission, v. 1, p. 4-63 to 4-71.

Hereford, Richard, and Webb, R.H., 1992, Historic variation in warm-season rainfall on the Colorado Plateau, U.S.A.: Climatic Change, v. 22 , p. $239-256$.
Hyndman, D.W., Roberts, R.A., and Webb, R.H., 1991, Modeling sediment transport in an ephemeral river, in Fan, S.S., and Kuo, Y.H., editors, Proceedings of the Fifth Federal Interagency Sedimentation Conference: Washington, D.C., Federal Energy Regulatory Commission, v. 2, p. 8-101 to 8-108.

Melis, T.S., and Webb, R.H., 1993, Debris flows in Grand Canyon National Park, Arizona, Magnitude, frequency and effects on the Colorado River, in Shen, H.W., Su, S.T., and Wen, F., eds., Hydraulic Engineering '93: American Society of Civil Engineers, ASCE Conference, San Francisco, Calif. [Proceedings], p. 1290-1295.

Nelson, D.J., Webb, R.H., and Long, Austin, 1990, Stick-nest rat (Leporillus: Muridae) middens from central Australia, in Betancourt, J.L., Van Devender, T.R., and Martin, P.S. eds., Fossil packrat middens-The last 40,000 years of biotic change: Tucson, Ariz., The University of Arizona Press, p. 428-434.

Webb, R.H., and Betancourt, J.L., 1990, The spatial and temporal distribution of radiocarbon ages from packrat middens, in Betancourt, J.L., Van Devender, T.R., and Martin, P.S., eds., Fossil packrat middens-The last 40,000 years of biotic change: Tucson, Ariz., The University of Arizona Press, p. 85-102.

1990, Climatic effects on flood frequency-An example from southern Arizona, in Betancourt, J.L., and MacKay, A.M., eds., Proceedings of the Sixth Annual Pacific Climate (PACLIM) Workshop, March 5-8, 1989: California Department of Water Resources, Interagency Ecological Studies Program Technical Report 23, p. 61-66.

1992, Climatic variability and flood frequency of the Santa Cruz River, Pima County, Arizo- 


\section{GEOMORPHOLOGY AND SEDIMENT TRANSPORT}

na: U.S. Geological Survey Water-Supply

Paper 2379, 40 p.

Webb, R.H., and Bowers, J.E., 1993, Changes in frost frequency and desert vegetation assemblages in Grand Canyon, Arizona, in Redmond, K.T., ed., Proceedings of the Ninth Annual Pacific Climate (PACLIM) Workshop, April 21-24, 1992: California Department of Water Resources, Interagency Ecological Studies Program Technical Report 34, p. 71-82.

1993, Plant demography and burro grazing in Grand Canyon, in Young, D.D., ed., Vegetation management of hot desert rangeland ecosystems: Tucson, Arizonia, University of Arizona, School of Renewable Natural Resources, p. 210-222.

Webb, R.H., Pringle, P.T., and Rink, G.R., 1989, Debris flows in tributaries of the Colorado River in Grand Canyon National Park, Arizona: U.S. Geological Survey Professional Paper $1492,39 \mathrm{p}$.

Webb, R.H., and Rathburn, S.L., 1989, Paleoflood hydrologic research in the southwestern United States: Transportation Research Board Record 1201, p. 9-21.

Webb, R.H., Smith, S.S., and McCord, V.A.S., 1991, Historic channel change of Kanab Creek, southern Utah and northern Arizona: Grand Canyon Natural History Association Monograph, no. 9, 91 p.

Wohl, E.E., Webb, R.H., Baker, V.R., and Pickup, G., 1994, Sedimentary flood records in the bedrock canyons of rivers in the monsoonal region of Australia: Fort Collins, Colo., Water Resources Papers no. 107, 102 p. 


\section{GEOMORPHOLOGY AND SEDIMENT TRANSPORT}

TITLE: $\quad$ Sediment Impacts from Disturbed and Undisturbed Lands (WR 79-311 Formerly CR 79-311)

PERSONNEL: Waite R. Osterkamp, Project Chief

ADDRESS: U.S. Geological Survey

1675 W. Anklam Road

Tucson, AZ 85745

TELEPHONE: (602) 670-6821

PROBLEM: The acquisition and meaningful interpretation of sediment data from areas disturbed by land-use activities or natural processesare two of the most deficient areas of recognizing nonpoint-source pollution in the United States. The comparison of sediment data from disturbed and undisturbed areas provides a means to (1) evaluate the effects that land-use activities cause, (2) investigate the geomorphic processes that regulate the detachment and transport of sediment, and (3) develop strategies for remedial action to reduce excessive sediment discharges. This information is especially necessary to minimize sediment discharges and sorbed chemical loads from surface-mine, industrial, agricultural, and urban areas.

OBJECTIVE: (1) Evaluate the extent and utility of sediment data from a variety of land-use areas; (2) predict the movement of sediment from drainage basins affected by those land uses; and (3) assess existing techniques and develop new ones based on geomorphic principles and the application of statistics, geochemistry, and botany to the limited data available as aids in improving our interpretive capabilities.

APPROACH: Field investigations are being conducted to evaluate available techniques for predicting sediment yields. Of particular interest are the Water Erosion Prediction Project model and the U.S. Department of Agriculture (USDA) rainfall simulation model. Research is to be conducted to develop technology for determining (1) predisturbance sediment-delivery ratios (proportion of gross erosion that appears as sediment yield at some place in the watershed) based on factors such as land use, contributing drainage area, runoff, basin morphology, relief, vegetation, and geochemical tracers, (2) sediment yields during disturbance, which are influenced by sediment-control measures used during land-use activity, and (3) sediment-delivery ratios for the post-disturbance period. In cooperation with other agencies and field offices of the Survey, available sediment and related hydrologic and 


\section{GEOMORPHOLOGY AND SEDIMENT TRANSPORT}

chemical data are being acquired and interpreted to develop techniques and possibly models to aid in the prediction of sediment impacts from land disturbance.

PROGRESS: Manuscripts were completed reporting development and use of a transmissionloss model designed to estimate ground-water recharge in arid/semiarid areas using geomorphic field techniques. The model was used to estimate recharge in the upper Amargosa River Basin, Nevada and California, and in a large are of Oman and the United Arab Emirates. Studies were begun on hillslope processes of disturbed landscapes of southern Arizona. Initial results provide rates of sediment movement due to disturbance, and rates of healing or slope recovery as a result of veneering processes by coarse sediment.

REPORTS PUBLISHED 1988-1994:

Blodgett, J.C., Poeschel, K.R., and Osterkamp, W.R., in press, Characteristics of debris flows of noneruptive northern California: U.S. Geological Survey Professional Paper 1396-A.

Lane, L.J., Nichols, M.H., Hernandez, M.A., Manetsch, C., and Osterkamp, W.R., in press, Variability in discharge, stream power, and particle-size distributions in ephemeral-stream channel systems, in Variability in Sediment Transport, International Association of Hydrological Sciences symposium, Canberra, Australia [Proceedings].

Lane, L.J., and Osterkamp, W.R., 1991, Estimating upland recharge in the Yucca Mountain area: Irrigation and Drainage Division Proceedings, American Society of Civil Engineers, p. 170-176.

Osterkamp, W.R., 1990, Gentry Playa-origin by hydrologic processes in Gustavson, T.C., ed., Tertiary and Quaternary stratigraphy and vertebrate paleontology of parts of northwestern Texas and eastern New Mexico: Bureau of Economic Geology Guidebook 24, The University of Texas at Austin, p. 32-35.
1990, Seepage weathering and sapping of the southern High Plains escarpments, Texas and New Mexico, in Higgins, C.G., and Coates, D.R., eds., Groundwater geomorphology; The role of subsurface water in Earth-surface processes and landforms: Boulder, Colo., Geological Society of America Special Paper 252, p. 300-305.

1992, Book Review, Hydrological research basins and the environment: Hydrological Sciences Journal, International Association of Hydrological Sciences, v. 37, no. 3, p. 331344.

Osterkamp, W.R., Day, T.J., and Parker, R.S., 1992, A sediment monitoring program for North America: International Symposium on Sediment Transport Monitoring Programmes in Rivers, International Association of Hydrologic Sciences, p. 391-396.

1991, The Vigil Network-a means of observing landscape change in drainage basins: International Association of Hydrological Sciences Journal, v. 36, no. 4, p. 331-344.

1992, Book Review, Hydrological research basins and the environment: Hydrological Sci- 


\section{GEOMORPHOLOGY AND SEDIMENT TRANSPORT}

ences Journal, International Association of Hydrological Sciences, v. 37, no. 3, p. 331344.

Osterkamp, W.R., Day, T.J., and Parker, R.S., 1992, A sediment monitoring program for North America: International Symposium on Sediment Transport Monitoring Programmes in Rivers, International Association of Hydrologic Sciences, p. 391-396.

Osterkamp, W.R., and Emmett, W.W., 1992, The Vigil Network-long-term monitoring to assess landscape changes: International Symposium on Sediment Transport Monitoring Programmes in Rivers, International Association of Hydrological Sciences, p. 397-404.

Osterkamp, W.R., Emmett, W.W., and Leopold, L.B., 1990, The Vigil Network, a reviving of interest: EOS, v. 71 , no. 12, p. 338.

Osterkamp, W.R., Emmett, W.W., and Leopold, L.B., 1991, The Vigil Network-a means of observing landscape change in drainage basins: International Association of Hydrological Sciences Journal, v. 36 , no. 4, p. 331-344.

Osterkamp, W.R., and Hupp, C.R., 1992, Memorial to John T. Hack, 1913-1991: Geological Society of America Memorials, p. 59-61.

Osterkamp, W.R., Lane, L.J., and Menges, C.M., in press, Techniques of groundwater recharge estimates in arid/semiarid areas, with examples from Abu Dhabi: Journal of Arid Environments, v. 00 .

Osterkamp, W.R., Lane, L.J., and Savard, C.S., 1994, Recharge estimates using a geomorphic/ distributed-parameter simulation approach, Amargosa River Basin: Water Resources Bulletin, v. 30 , no. 3, p. 1-15.
Osterkamp, W.R., and Parker, R.S., 1991, Sediment monitoring in the United States: Federal Inter-Agency Sedimentation Conference, Fifth, Las Vegas, Nevada, [Proceedings], p. 1-15 to 1-23.

Osterkamp, W.R., and Toy, T.J., 1994, The healing of disturbed hillslopes by gully gravure: Geological Society of America Bulletin, v. 106, no. 10.

Simanton, J.R., Osterkamp, W.R., and Renard, K.G., 1993, Sediment yield in a semiarid basin-sampling equipment impacts, in Sediment Problems-Strategies of Monitoring, Prediction, and Control, in Sediment Problems: International Association of Hydrological Sciences Symposium H4, [Proceedings], p. 3-9.

Toy, T.J., Osterkamp, W.R., and Renard, K.G., 1993, Prediction by regression and intra-range data scatter in surface-process studies: Environmental Geology and Water Sciences, v. 22 , p. $121-128$.

Waythomas, C. F., Jarrett, R. D., and Osterkamp, W. R., 1991, Late Quaternary fluvial activity and climate variability in the Colorado Front Range Foothills and Piedmont: Paleoenvironments, v. 8 p. 122-124. 


\section{GROUND-WATER CHEMISTRY}




\section{GROUND-WATER CHEMISTRY}

TITLE: $\quad$ Arid Regions Climate and Chemistry (CR 82-207)

PERSONNEL: Larry V. Benson, Project Chief

Eva Brown, Secretary

Steven W. Hostetler, Hydrologist

ADDRESS: U.S. Geological Survey

3215 Marine Street

Boulder, CO 80303

TELEPHONE: (303) 541-3005

PROBLEM: Few guidelines have been established for the quantitative characterization of past climates in terms of proxy-climate data obtained from paleolacustrine systems. The connection between insolation forcing of climate and change in the energetics of hydrologic systems has yet to be established. In particular, application of stable isotopes to an understanding of the timing and magnitude of past changes in the Great Basin hydrologic cycle is just beginning.

OBJECTIVE: Determination of (1) the frequency and magnitude of change in the hydrologic cycle of the Great Basin, (2) the type and magnitude of change in the synoptic climate responsible for change in the hydrologic cycle, and (3) the cause of climate change.

APPROACH: (1) Core closed-basin lakes such as Pyramid Lake, Nevada; (2) Analyze organic and inorganic materials (for example, oxygen-18) from cores in order to establish time-series proxy-records of change in lake size; (3) Perform real-time studies of the behavior of oxygen-18 in the hydrologic system in order to establish the relation between oxygen-18, lake size, and climate; (4) Apply oxygen-18/climate model to core data in order to establish quantitative record of climate change for the past $150,000 \mathrm{yr}$; (5) Develop record of lake-size change based on outcrop data; (6) Compare core-based record of lake-size change with outcrop-based record of lake-size change.

PROGRESS: Stable-isotope and total inorganic carbon analyses of three sediment cores from Pyramid Lake have been completed. The data represent the first high-resolution record of change in the hydrologic balance of a Great Basin lake for the period 41,000 to 1,000 yr B.P (years before present). Periods of low lake level (extreme drought) have been documented in the late Holocene. Stable isotope monitoring of the Truckee and Walker River systems was terminated in January of 1994 . The $\mathbf{8}^{13} \mathrm{C}$ data from this program together with $\boldsymbol{8}^{13} \mathrm{C}$ data 


\section{GROUND-WATER CHEMISTRY}

from cored sediment in Pyramid Lake indicate that 25 percent of the dissolved organic carbon in Pyramid Lake was added since 1865 as a result of the deforestation of the Truckee River-Lake Tahoe watershed.

\section{REPORTS PUBLISHED 1989-1994:}

Benson, L.V., 1991, Timing of the last highstand of Lake Lahontan: Journal of Paleolimnology 5, p. 115-126.

1993, Factors affecting ${ }^{14} \mathrm{C}$ ages of lacustrine carbonates-timing and duration of the last highstand lake in the Lahontan basin: Quaternary Research v. 39, p. 163-174.

1994, Stable isotopes of oxygen and hydrogen in the Truckee River-Pyramid Lake surfacewater system, 1. Data analysis and extraction of paleoclimatic information: Limnology and Oceanography, v. 39, p. 344-355.

Benson, L.V., Currey, D.R., Dorn, R.I., Lajoie, K.R., Oviatt, C.G., Robinson, S.W., Smith, G.I., and Stine, S., 1990, Chronology of expansion and contraction of four Great Basin lake systems during the past 35,000 years, in Meyers, P.A., and Benson, L.V., eds., Paleolakes and Paleo-oceans: Palaeogeography, Palaeoclimatology, Palaeoecology, v. 78, p. 241-286.

Benson, L.V., Currey, D., Lao, Y., and Hostetler, S., 1992, Lake-size variations in the Lahontan and Bonneville basins between 13,000 and $9,000{ }^{14} \mathrm{C}$ yr B.P.: Palaeogeography, Palaeoclimatology, Palaeoecology, v. 95, p. 19-32.

Benson, L.V., Meyers, P.A., and Spencer, R.J., 1991, Change in the size of Walker Lake during the past $\mathbf{5 0 0 0}$ years: Palaeogeography, Palaeoclimatology, Palaeoecology, v. 81, p. 189-214.
Benson, L.V., and Paillet, F.L., 1989, The use of total lake-surface area as an indicator of climatic change-Examples from the Lahontan basin: Quaternary Research, v. 32, p. 262275.

Benson, L.V. and White, J.W.C., in press, Behavior of the stable isotopes of oxygen and hydrogen in the Truckee River-Pyramid Lake surface-water system, Part 3. Source of water vapor over Pyramid Lake, Nevada: Limnology and Oceanography, v. 00.

Hostetler, S., and Benson, L.V., 1990, Paleoclimatic implications of the high stand of Lake Lahontan derived from models of evaporation and lake level: Climate Dynamics, v. 4, p. 207-217.

1993, Meteorological and water-temperature data for Pyramid Lake, Nevada 1987-89: U.S. Geological Survey Open-File Repcrt 92-159, 15 p. (includes floppy disk).

1994, Stable isotopes of oxygen and hydrogen in the Truckee River-Pyramid Lake surfacewater system, 2. A predictive model of $\delta^{18} \mathrm{O}$ and $\boldsymbol{\delta}^{2} \mathrm{H}$ in Pyramid Lake: Limnology and Oceanography, v. 29, p. 356-364.

McKinley, P.W., Long, M.P., and Benson, L.V., 1990 , Chemical analyses of water from selected wells and springs in the Yucca Mountain area, Nevada and southeastern California: U.S. Open-File Report 90-355, 47 p. 


\section{GROUND-WATER CHEMISTRY}

Noorishad, J., Carnahan, C.L., and Benson, L.V., 1989, Simulation of the fractionation of ${ }^{13} \mathrm{C}$ during nonequilibrium reactive solute transport in geologic systems-Formulation and example calculation: Water Resources Research, v. 25, p. 754-756.

Smith, G.I., Benson, L.V., and Currey, D.R. 1989, Quaternary Geology of the Great Basin, Inglewood, California to Salt Lake City, Utah, June 27-July 8, 1989: 28th International Geological Congress Field Trip Guidebook T117, $78 \mathrm{p}$. 


\section{GROUND-WATER CHEMISTRY}

TITLE: $\quad$ Geochemistry of Clay-Water Reactions (CR 82-276)

PERSONNEL: Dennis D. Eberl, Project Chief

Debra Litwin, Secretary

Howard M. May, Chemist

ADDRESS: U.S. Geological Survey

P.O. Box 25046, MS 458

Denver, Federal Center

Denver, CO 80225

TELEPHONE: (303) 541-3028

PROBLEM: Clay minerals can influence the chemistry of ground water and other aqueous solutions through precipitation, dissolution, and ion-exchange reactions. An understanding of these reactions is crucial for predicting the behavior of toxic wastes in disposal areas. How do the various clays react with waters of varying composition at different temperatures and pressures? After the fundamentals of these processes are understood, how can they be applied to prediction, maintenance, and (or) improvement of water quality?

OBJECTIVE: (1) Develop a theory for ion exchange that would allow prediction of the exchange properties of a clay on the basis of clay's crystal chemistry; (2) gather basic information on clay-mineral structure and chemistry; and (3) try to understand the precipitation and alteration of clay minerals in natural and synthetic systems.

APPROACH: Test and develop theoretical models through laboratory experiments (for example, measurement of exchange isotherms with well-characterized clay minerals). Study clay-water reactions in natural systems in the field.

PROGRESS: Three papers are now being written based on work accomplished in Boulder this year by Eberl and two visiting foreign scientists, Jan Srodon from Poland and Victor Drits from Moscow. This work includes a theoretical method for describing crystal growth in open and closed systems, including a quantitative method for calculating the effects of Ostwald ripening during mineral recrystallization. A 2MB computer program, called GALOPE (Growth According to the Law of Proportionate Effect) was written to do these calculations, together with several other, peripheral programs. The other papers deal with calculating crystal size distributions from the shapes of $x$-ray diffraction profiles. A 5MB computer program was written, based on fundamental $x$-ray diffraction theory, to do these 


\section{GROUND-WATER CHEMISTRY}

calculations, and is currently being tested. Work on nonpolluting fertilizer has been put on hold due to a lack of manpower.

Eberl was the Brindley lecturer at the annual Clay Minerals Society meeting in San Diego, California, where he also was made president and interviewed Linus Pauling for the CMS newsletter. He also was an invited speaker at the Mineralogical Society meeting in Glasgow in January, and at a geological meeting at Dartmouth College later in the year.

May is completing development of a high-precision dissolution calorimeter for determining or improving as yet unknown or imprecise thermodynamic properties of clays, zeolites and other aquifer minerals, in support of water chemistry modeling efforts. Also, May is improving heat capacity measurements for fine-grained minerals, through a cooperative research effort with the University of Wisconsin faculty and USGS, Geologic Division, Reston, Virginia.

\section{REPORTS PUBLISHED 1989-1994:}

Barbarick, K.A., Eberl, D.D., and Lai, T.M., 1991, Pine Ridge zeolite and Fort Hall mill shale $\mathbf{P}$ effects on sorghum-sudangrass: Technical Bulletin TB91-2, Department of Agronomy, Colo., Colorado State University, 47 p.

Barbarick, K.A., Lai, T.M., and Eberl, D.D., 1990, Exchange fertilizer (phosphate rock plus ammonium-zeolite) effects on sorghum-sudangrass: Soil Science Society of America Journal, v. 54, p. 911-916.

Blum, A.E., and Eberl, D.D., 1992, Determination of clay particle thickness and morphology using scanning force microscopy, in Kharaka, Y.K., and Maest, A.S., eds., Water-rock interaction: Rotterdam, A.A. Balkema, p. 133-136.

Byler, D.M., Gerasinowicz, W.V., Stockette, V.M., and Eberl, D.D., 1991, Infrared spectroscopic examination of the interaction of area with the naturally occurring zeolite clinoptilolite: Microchemical Journal, v. 44, p. 130 139.
Eberl, D.D., 1992, Slow-release nitrogen fertilizer and soil conditioner: U.S. Patent Application US 789,206, 15 April, 1992.

1992, Three zones for burial metamorphism, in Kharaka, Y.K., and Maest, A.S., eds., Proceedings of the 7th International Symposium on Water-Rock Interaction, July 9-23, 1992, Park City, Utah: Rotterdam, The Netherlands, A.A. Balkema, v. 2, p. 11651167.

1993, Three zones for illite formation during burial diagenesis and metamorphism: Clays and Clay Minerals, v. 41, p. 26-37.

1993, Zeo-agriculture: Small Mining International Bulletin, Numbers 5-6, p. 10.

Eberl, D.C., and Blum, A., 1993, Illite crystallite thickness by $\mathrm{x}$-ray diffraction in Reynolds, R.C., Jr., and Walker, J.R., Clay Mineral Society workshop lectures-Computer applications to $\mathrm{x}$-ray powder diffraction analysis of 


\section{GROUND-WATER CHEMISTRY}

clay minerals: Boulder, Colo., The Clay Minerals Society, v. 5, p. 123-154.

Eberl, D.D. Srodon, J., Kralik, M., Taylor, B.E., and Peterman, Z.E., 1990, Ostwald ripening of clays and metamorphic minerals: Science, v. 248 , p. $474-477$.

Eberl, D.D., Velde, B., and McCormick, T., 1992, Synthesis of illite/smectite from smectite at Earth surface temperatures and high $\mathrm{pH}$ : Clay Minerals, v. 28, p. 49-60.

May, H., 1992, The hydrolysis of aluminum-Conflicting models and the interpretation of aluminum geochemistry, in Kharaka, Y.K., and Maest, A.S., eds., Proceedings of the 7th International Symposium on Water-Rock Interaction, July 9-23, 1992, Park City, Utah:

Rotterdam, The Netherlands, A.A. Balkema, v. 1, p. 13-21.

May, H.M., and Nordstrom, D.K., 1991, Assessing the solubilities and reaction kinetics of aluminous minerals in soils, in Ulrich, B., and Sumner, eds., Soil Acidity: Berlin, Springer Verlag, p. 123-148.

Nordstrom, D.K., and May, H.M., 1989, Aqueous equilibrium data for mononuclear aluminum species, in Sposito, G., ed., The environmental chemistry of aluminum: Raton, Florida, CRC Press, chap. 2, p. 27-53.

Nordstrom, D.K., Plummer, L.N., Langmuir, D.L., Busenberg, E., May, H.M., Jones, B.F., and Parkhurst, D.L., 1990, Revised chemical equilibrium data for major watermineral reactions and their limitations, in Melchior, D.C., and Bassett, R.L., eds., Chemical modeling in aqueous systems, II: American Chemical Society Symposium Series, v. 416, chap. 31 , p. 398-413.
Sucha, V., and Eberl, D.D., 1992, Postsedimentarna premena sedimentov permu severneho gemerika a hronika Zapadnych Karpat (Postsedimentary alteration of the Permian sediments in the northern Gemericum and Hronicum Units, West Carpathians): Mineralia Slovaca, v. 24, p. 399-405. 


\section{GROUND-WATER CHEMISTRY}

TITLE: $\quad$ Environmental Dynamics of Persistent Organic Compounds (CR 83-283)

PERSONNEL: Cary T. Chiou, Project Chief

Cathy M. Rubin, Secretary

Daniel E. Kile, Research Chemist

David W. Rutherford, Chemist

ADDRESS: $\quad$ U.S. Geological Survey

P.O. Box 25046, MS 408

Denver, Federal Center

Denver, CO 80225

TELEPHONE: (303) 467-8260

PROBLEM: Many persistent organic compounds are hazardous to human and ecological health. The transport characteristics of these compounds across environmental interfaces are strongly influenced by adsorption and partition interactions with the individual phases. Quantification of process rates and partition constants of organic pollutants in air, water, soil, and biota is an important step in defining the level of organic contaminants in environmental systems and their potential effects on environmental quality.

OBJECTIVE: Delineate and quantify processes affecting the movement and distribution of persistent organic compounds in hydrogeologic systems. (1) Determine the sorptive capacity of soil and sediment for organic compounds that are in air and water; (2) identify the roles of soil and sediment organic matter, mineral components, and moisture in sorption of organic compounds; (3) establish the physical basis of bioconcentration and lipophilicity of organic compounds; and (4) characterize the effect of dissolved organic matter on the solubility and mobility of organic contaminants in natural water.

APPROACH: Make laboratory measurements to determine the sorption of various organic compounds from water, analyzing data in terms of the properties of the compounds and soil constituents. Study sorption from the vapor phase to determine the effect of soil moisture. Make measurements to determine the alteration of the apparent water solubility of solutes by dissolved organic matter from various sources. Measure the partition coefficients of solutes in solvent and lipid-water systems to obtain information related to bioconcentration. Collaborate with field researchers to relate laboratory findings with field data obtained from organic-contamination sites. 


\section{GROUND-WATER CHEMISTRY}

PROGRESS: The solubilities of various polar and nonpolar liquids in soil organic matter (SOM) were determined from their vapor sorption by a high-organic-content peat. The extrapolated liquid solubility from the vapor isotherm increases sharply from 3-6 weight percent for low-polarity liquids (hexane, carbon tetrachloride, and benzene) to 62 weight percent for polar methanol and correlates positively with the liquid's component solubility parameters for polar interaction and hydrogen bonding. The same polarity effect is found to influence the partition coefficients $\left(\mathrm{K}_{\mathrm{om}}\right)$ of polar and nonpolar organic pollutants between SOM and water. As a result, a polar compound gives a higher $K_{o m}$ than a nonpolar one when they have about equal water solubilities.

In another sorption study, we observed that polar organic solutes (for example, phenols and substituted ureas) exhibit greatly enhanced sorption coefficients between soil and water at very low relative concentrations (ratios of solute concentrations in water to solute's water solubility), whereas nonpolar solutes exhibit only a small increase in their sorption coefficients. The behavior for polar solutes suggests that their sorption by soil from water may be predominated by residual adsorption on soil minerals at low relative concentrations, while partition to SOM predominates at high relative concentrations. Further experiments are being carried out to verify this concept. If this should be the case, it would have a tremendous impact on the environmental transport and fate of polar organic contaminants; that is, the transport and fate would be a function of the solute concentration.

The partition coefficients of 1,2-dichlorobenzene and carbon tetrachloride between soil/ sediment organic matter and water $\left(\mathrm{K}_{\mathrm{oc}}\right)$ were determined on a wide variety of samples from United States and China, including those from Mississippi River, Ohio River, Illinois River, Yellow River, and Yantze River. Nonpolar organic pollutants are found to partition (sorb) more effectively to sediment organic matter than to soil organic matter, while their Koc values between soils or between sediments are relatively invariant. The higher partition coefficient with sediment organic matter is ascribed to the lower polarity of sediment organic matter, which results likely from the selective release of polar organic components in soil when the soil is sedimented. This finding provides a basis to identify the origin of suspended solids in river water and to distinguish normal soils (or sediments) from those highly contaminated by man-made hydrocarbons.

We studied the sorption of various polar (for example, water) and nonpolar (for example, $\mathrm{N}_{2}$ ) vapors by kaolinite and by a series of montmorillonite clays of varying cationic types to characterize how clay types and cations affect the surface and interlayer interactions of vapors with clays. The clay surface with -Si-O-Si-structure (as with montmorillonite) appears to be less hydrophilic than the surface with -Si-OH (as with kaolinite). The hydration of ex- 


\section{GROUND-WATER CHEMISTRY}

changeable cations in montmorillonite depends strongly on the cation. This information allows us to better understand the sorptive behavior of clay minerals in dry and water saturated soils. The work is still in progress.

\section{REPORTS PUBLISHED 1989-1994:}

Chin, Y.P., Weber, W.J., Jr., and Chiou, C.T., 1991, A thermodynamic partition model for binding of nonionic organic compounds by organic colloids and implications for their sorption to soils and sediment, in Baker, R.A., ed., Organic substances and sediments in water, v. I: Chelsea, Michigan, Lewis Publishers, p. 251-273.

Chiou, C.T., 1989, Partition and adsorption on soil and mobility of organic pollutants and pesticides, in Gerstl, Z., Chen, Y., Mingelgrin, U., and Yaron, B., eds., Toxic organic chemicals in porous media: Berlin, Springer-Verlag, p. 163-175.

1989, Theoretical considerations of the partition uptake of nonionic organic compounds by soil organic matter, in Sawhney, B.J., and Brown, K., eds., Reactions and movement of organic chemicals in soils: Madison, Wisconsin, Soil Science Society of America, p. 1-29.

1990 , roles of organic matter, minerals and moisture in sorption of nonionic compounds and pesticides by soil, in MacCarthy, P., Clapp, C.E., Malcolm, R.L., and Bloom, P.R., eds., Humic substances in soil and crop sciences-Selected readings: Madison, Wisconsin, American Society of Agronomy and Soil Science Society of America, p. 111-160.

Chiou, C.T. Kile, D.E., and Rutherford, D.W., 1991, The neutral oil in commercial linear alkylbenzenesulfonate and its impact on organic solute solubility in water: Environmental Science and Technology, v. 25, p. 660-665.
Chiou, C.T., Lee, J.F., and Boyd, S.A., 1990, The surface area of soil organic matter: Environmental Science and Technology, v. 24, p. 1164-1166.

1992, Reply to comment on The surface area of soil organic matter: Environmental Science and Technology, v. 25, p. 404-406.

Chiou, C.T., and Manes, M., 1990, Comment on Temperature dependence of the aqueous solubilities of highly chlorinated dibenzo-p-dioxins: Environmental Science and Technology, v. 24, p. 1755-1756.

Chiou, C.T., Rutherford, D.W., and Manes, M., 1993, Sorption of $N_{2}$ and EGME vapors on some soils, clays, and mineral oxides and determination of sample surface areas by use of sorption data: Environmental Science and Technology, v. 27, p. 1587-1594.

Kile, D.E., and Chiou, C.T., 1989, Water solubility enhancements of nonionic organic contaminants by dissolved humic substances, in Suffet, I.H., and MacCarthy, P., eds., Influence of aquatic humic substances on the fate and treatment of pollutants: Washington D.C., Advances in Chemistry Series, American Chemical Society, v. 219, p. 131-157.

1989, Water solubility enhancements of DDT and trichlorobenzene by some surfactants below and above the critical micelle concentration: Environmental Science and Technology, v. 23 , p. $932-838$. 


\section{GROUND-WATER CHEMISTRY}

1991, The effect of surfactants and emulsions on water solubility of organic contaminants, in Mallard, G.E., and Aronson, D.A., eds., U.S. Geological Survey Toxics Substances Hydrology Program-Proceedings of the technical meeting, Monterey, Calif., March 11-15, 1991: U.S. Geological Survey WaterResources Investigations Report 91-4034, p. 562-567.

Kile, D.E., Chiou, C.T., and Brinton, T.I., 1989, Interactions of organic contaminants with fulvic and humic acids from the Suwannee River and other Humic substances in aquatic systems, with inferences to the structures of humic molecules, in Averett, R.C., Leenheer, J.A., McKnight, D.M., and Thorn, K.A., eds., Humic substances in the Suwannee River, Georgia and Florida-Interactions, properties, and proposed structures: U.S. Geological Survey Open-File Report 87-55, p. 37-57.

Kile, D.E., Chiou, C.T., and Helburn, R.S., 1990, Effect of some petroleum sulfonate surfactants on the apparent water solubility of organic compounds: Environmental Science and Technology, v. 23, p. 205-208.

Lee, J.F., Mortland, M.M., Boyd, S.A., and Chiou, C.T., 1989, Shape-selective adsorption of aromatic molecules by tetramethylammonium-smectite: Journal of Chemical Society, Faraday Transactions I, v. 85, p. 2953-2962.

Lee, J.F., Mortland, M.M., Chiou, C.T., Kile, D.E., and Boyd, S.A., 1990, Adsorption of benzene, toluene and xylene by two tetramethylammonium-smecties having different charge densities: Clays and Clay Minerals, v. 38, no. 2, p. 113-120.

Reddy, M.M., Claassen, H.C., Rutherford, D.W., and Chiou, C.T., in press, Welded tuff porosity characterization using mercury intrusion porosimetry, nitrogen adsorption/desorption, ethylene glycol monoethyl ether gas phase sorption and epifluorescence microscopy: Applied Geochemistry, v. 00.

Rutherford, D.W., and Chiou, C.T., 1992, Effect of water saturation in soil organic matter on the partition of organic compounds: Environmental Science and Technology, v. 26, p. 965-970.

Rutherford, D.W., Chiou, C.T., and Kile, D.E., 1992, Influence of soil organic matter composition on the partition of organic compounds: Environmental Science and Technology, v. 26, p. 336-340.

Rutherford, D.W., Chiou, C.T., and Manes, M., 1993, Interactions of polar and nonpolar vapors with soil organic matter, clays, and organo-clays, in Yong, R.N., Hadjinicolaou, J., and Mohamed, A.M.O., eds., Joint CSCEASCE National Conference on Environmental Engineering-Proceedings of the technical meeting: Montreal, Quebec, Canada, v. II, p. 1057-1064.

Smith, J.A., Chiou, C.T., Kammer, J.A., and Kile, D.E., 1990, Effect of soil moisture on the sorption of trichloroethene vapor to vadose-zone soil at Picatinny Arsenal, New Jersey: Environmental Science and Technology, v. 24 , p. $676-683$.

Smith, J.A., Jaffe, P.R., and Chiou, C.T., 1990, Effect of ten quaternary ammonium cations on tetrachloromethane sorption to clay from water: Environmental Science and Technology, v. 24 , p. $1167-1172$.

Smith, J.A. Witkowski, P.J., and Chiou, C.T., 1988, Partition of nonionic organic compounds in aquatic systems: Reviews of Environmental Contamination and Toxiculogy, v. 103, p. 127-151. 


\section{GROUND-WATER CHEMISTRY}

TITLE: $\quad$ Reaction-Transport Modeling in Ground-Water systems (CR 89-318)

PERSONNEL: David L. Parkhurst, Project Chief

ADDRESS: U.S. Geological Survey

P.O. Box 25046, MS 418

Denver, Federal Center

Denver, CO 80225

TELEPHONE: (303) 236-5098

PROBLEM: In order to address urgent problems in contaminant migration and to understand many natural geologic processes, we need to be able to model the movement of substances undergoing chemical reactions in ground-water systems. Predictive models will be used to assess the risks of nuclear- and chemical-waste disposal, to analyze contaminant migration from pollution sources, and to determine the susceptibility of aquifers to contamination. Models also are needed to investigate many rock-water interactions, such as the formation of ore deposits and the evolution of ground-water chemistry.

OBJECTIVE: The long-range goals of the project are (1) to develop reaction-transport models with varying levels of complexity and data requirements, providing guidelines for the appropriate application of these models given field conditions and limited resources; (2) to incorporate the effects of surface-chemistry phenomena into reaction-transport modeling; (3) to develop methods to identify and quantify important chemical and biological reactions affecting transport of inorganic and organic substances; and (4) to compile estimates of reaction rates and reaction-rate laws for chemical and biological reactions.

APPROACH: The fundamental approach of the project is to develop computer models describing the movement of chemical substances in reacting systems that can be applied to field and experimental data. The project will begin by enhancing and streamlining geochemical-reaction models to make them suitable for inclusion in reaction-transport codes while studying the available literature on solute transport and reaction modeling. Two models will then be developed to test the pure differential equation approach and the coupled reaction and transport approach.

PROGRESS: A Water-Supply Paper for the Central Oklahoma National Water Quality Assessment (NAWQA) project has been published as an open-file report. The paper describes one of the first calibrations of a ground-water flow model by means of carbon-14 


\section{GROUND-WATER CHEMISTRY}

dates of ground-water age. The paper presents an analysis of the important geochemical reactions occurring in the aquifer and the rates and directions of ground-water flow.

A previous open-file report, which analyzed spatial trends in water-quality problems for the Central Oklahoma NAWQA project, has been published as a USGS Water-Supply Paper.

Significant progress has been made in developing a replacement for the geochemical reaction-path model, PHREEQE. The new model is currently capable of treating speciation, mineral-equilibration, ion exchange, surface complexation, and gas-phase equilibration. The program was used in the 1994 geochemistry training course. The new model will ultimately be coupled to a transport model, which will have the capability of modeling water-rock interactions in flowing ground-water systems.

An approach to mass-balance modeling (the attempt to determine geochemical reactions that account for changes in water chemistry) that incorporates uncertainty in the analytical data has been developed. This approach was presented at the spring meeting of the American Geophysical Union and is incorporated into the revised version of PHREEQE.

\section{REPORTS PUBLISHED 1989-1994:}

Glynn, Pierre D., and Parkhurst, D.L., 1992, Modeling non-ideal solid-solution aqueous-solution reactions in mass-transfer computer codes, in Kharaka, Y.K., and Maest, A.S., eds., Proceedings of the 7th International Symposium on Water-Rock Interaction, July 9-23, 1992, Park City, Utah: Rotterdam, The Netherlands, A.A. Balkema, p. 175-179.

Nordstrom, D.K., Plummer, L.N., Langmuir, Donald, Busenberg, Eurybiades, May, H.M., Jones, B.F., and Parkhurst, D.L., 1990, Revised chemical equilibrium data for major water-mineral reactions and their limitations, in Bassett, R.L., and Melchior, D., eds., Chemical modeling in aqueous systems II: Washington, D.C., American Chemical Society Symposium Series 416, p. 398-413.

Parkhurst, D.L., 1990, Ion-association models and mean-activity coefficients of various salts, in
Bassett, R.L., and Melchior, D., eds., Chemical modeling in aqueous systems II: Washington D.C., American Chemical Society Symposium Series 416, p. 30-43.

1992, The geochemical evolution of ground waters in the Central Oklahoma aquifer, in Christenson, Scott, and Carpenter, Lyn, eds., Ground-water quality of the central Oklahoma (Garber-Wellington) aquifer conference, Oklahoma City, Okla., February 20, 1992, Proceedings: U.S. Geological Survey Open-File Report 92-116, p. 7-9.

Parkhurst, D.L., Christenson, Scott, and Breit, G.N., in press, Ground-water quality assessment of the central Oklahoma aquifer, Oklahoma-Geochemical and geohydrologic investigations: U.S. Geological Survey Open-File Report 92-642, $113 \mathrm{p}$. 


\section{GROUND-WATER CHEMISTRY}

Parkhurst, D.L., Christenson, S.C., and Schlottmann, J.L., 1989, Ground-water quality assessment of the central Oklahoma aquifer, Oklahoma-Analysis of available water-quality data through 1987: U.S. Geological Survey Open-File Report 88-728, 80 p.

1994, Ground-water quality assessment of the central Oklahoma aquifer, Oklahoma-Analysis of available water-quality data through 1987: U.S. Geological Survey Water-Supply Paper 2357B, 74 p.

Parkhurst, D.L., and Plummer, L.N., 1993, Geochemical models, in William Alley, ed., Regional ground-water quality: New York, Van Nostrand Reinhold, chap. 9, p. 199-225.

Plummer, L.N., and Parkhurst, D.L., 1990, Geochemical calculations in brines-Application of the Pitzer model to PHREEQE, in Bassett, R.L., and Melchior, D., eds., Chemical modeling in aqueous systems II: Washington, D.C., American Chemical Society Symposium Series 416, p. 128-137.

Plummer, L.N., Prestemon, E.C., and Parkhurst, D.L., 1991, An interactive code (NETPATH) for modeling net geochemical reactions along a flow path: U.S. Geological Survey Water-Resources Investigations Report 91-4087, 227 p.

Plummer, L. Niel, Prestemon, Eric C., and Parkhurst, David L., 1992, NETPATH-An interactive code for interpreting NET geochemical reactions from chemical and isotopic data along a flow PATH, in Kharaka, Y.K., and Maest, A.S., eds., Proceedings of the 7th International Symposium on Water-Rock Interaction, July 9-23, 1992, Park City, Utah: Rotterdam, The Netherlands, A.A. Balkema, p. 239-242. 


\section{GROUND-WATER CHEMISTRY}

TITLE: $\quad$ Chemical Modeling and Thermodynamic Data Evaluation of Major and Trace Elements in Acid Mine Waters and Ground Waters (CR 92-326 formerly WR 75-128)

PERSONNEL: Darrell K. Nordstrom, Project Chief Betty L. Callahan, Secretary Heidi Koehler, Office Automation Clerk

Kirkwood M. Cunningham, Research Chemist James W. Ball, Chemist

TELEPHONE: (303) 541-3037

PROBLEM: Aqueous chemical models have become popular tools for the interpretation of natural water chemistry. Unfortunately, these models have deficiencies because of (1) incorrect or inconsistent thermodynamic data, (2) invalid assumptions regarding the equilibrium state, (3) inappropriate or unvalidated corrections for nonideality, (4) inadequate expressions for temperature dependence, (5) unvalidated limitations for ionic strength, composition and temperature, and (6) lack of data on solid solution solubility. The plethora of models and databases has prompted federal agencies, especially hazardous waste and nuclear waste managers, to request geochemical code validation. Acid mine waters are a major source of water pollution and provide one of the best challenges to the application of trace element speciation models.

OBJECTIVE: Develop, test, evaluate and make field applications of chemical models for equilibrium speciation and mass transfer of major and trace constituents in acid mine waters and ground waters.

APPROACH: (1) Compile and evaluate physical and chemical data for individual constituents and for reaction equilibria pertinent to natural waters. (2) Test applicability of current models to interpret natural water chemistry in acid mine waters and ground waters in field situations. (3) Identify limitations of current models in terms of ionic strength, composition, temperature and inhibitions to equilibrium. (4) Develop a chemical model based on mean activity coefficient data and reliable reaction equilibria to evaluate relevant chemical reactions in natural waters over a wide range of ionic strength. (5) Test the equilibrium assumption of current or new models against field data where both water and mineralogical 


\section{GROUND-WATER CHEMISTRY}

analyses can be obtained. (6) Measure mineral solubilities or other reaction equilibria in the lab or in the field where necessary data are lacking from the literature.

PROGRESS: Presentations on the Iron Mountain Mine Superfund Site have been given at two Department of Interior HazMat Meetings, at the Interior Department, and at a U.S. Environmental Protection Agency Technical Training Meeting. In addition, we have been collaborating with Martin Schooren from State Univery of New York, Stony Brook, on sulfur speciation studies in mineral springs and hot springs. A presentation was given at a Geological Society of America Annual Meeting by Martin Schoonen on our preliminary results showing the formation of thiosulfate from the oxidation of $\mathrm{H}_{2} \mathrm{~S}$ in a mineral spring drainage. This work also represents the first use of a new research mobile laboratory vehicle for on-site chemical analysis of natural waters. Preliminary results show that $\mathrm{H}_{2} \mathrm{~S}$ is volatilized and oxidized much faster than lab studies indicate. A presentation and a short paper have also been given on the limitations of science and why it is inappropriate to validate models.

\section{REPORTS PUBLISHED 1989-1994:}

Alpers, C.N., and Nordstrom, D.K., 1990, Stoichiometry of mineral reactions from mass balance computations for acid mine waters, Iron Mountain, California, in Gadsby, J.W., Malick, J.A., and Day, S.J., eds., Acid mine drainage-Designing for closure: Vancouver, B.C., BiTech Publishers Ltd, p. 23-33.

1991, Geochemical evolution of extremely acid mine waters at Iron Mountain, California-Are there any lower limits to $\mathrm{pH}$ ?: Second International Conference on the Abatement of Acidic Drainage, Mine Environment Neutralization Drainage (MEND), Montreal, Canada, v. 2, p. 321-341.

Alpers, C.N., Nordstrom, D.K., and Ball, J.W., 1989 , Solubility of jarosite solid solutions precipitated from acid mine waters, Iron Mountain, California, U.S.A.: Sciences Geologiques Bulletin no. 42, p. 281-298.
Alpers, C.N., Nordstrom, D.K., and Burchard, J.M., 1992, Compilation and interpretation of water quality and discharge data for acid mine waters at Iron Mountain, Shasta County, California, 1940-91: U.S. Geological Survey Water-Resources Report, 91-4160, 173 p.

Alpers, C.N., Nordstrom, D.K., and Thompson, J.M., 1994 Seasonal variations in copper and zinc concentrations from Iron Mountain Mine: American Chemistry Society Symposium Series 550, 324-344.

Alpers, C.N., Rye, R.O., Nordstrom, D.K., White, L.D., and King, B.-S., 1992, Chemical, crystallographic and isotopic properties of alunite and jarosite from acid hypersaline Australian lakes: Chemical Geology, v. 96, p. 203-226.

Ball, J.W., and Nordstrom, D.K., 1989, Final revised analyses of major and trace elements from acid mine waters in the Leviathan Mine 


\section{GROUND-WATER CHEMISTRY}

drainage basin, California and NevadaOctober 1981 to October 1982: U.S. Geological Survey Water-Resources Investigations Report 89-4138, 46 p.

1991, User's manual for WATEQ4F with revised thermodynamic data base and test cases for calculating speciation of major, trace and redox elements in natural water: U.S. Geological Survey Open-File Report 91-183, 185 p.

Cross, J.E., Haworth, A., Lichtner, P.C., Mackenzie, A.B., Moreno, L., Neretnieks, I., Nordstrom, D.K., Read, D., Romero, L., Scott, R.D., Sharland, S.M., and Tweed, C.J., 1991, Testing models of redox front migration and geochemistry at the Osamu Utsumi mine and Morro de Ferro analogue study sites, Pocos de Caldas, Brazil: NAGRA Techechnical Report NTB 90-21, 79 p.

Davis, S.N. and Nordstrom, D.K., eds., $1992 \mathrm{Hy}-$ drogeochemical investigations in boreholes at the Stripa mine: Stripa Project Technical Report $92-19,178 \mathrm{p}$.

Maest, A.S., Pasilis, S.P., Miller, L.G., and Nordstrom, D.K., 1992, Redox geochemistry of arsenic and iron in Mono Lake, California, U.S.A., in Kharaka, Y.K., and Maest, A.S., eds., Proceedings of the 7th International Symposium on Water-Rock Interaction, July 9-23, 1992, Park City, Utah: Rotterdam, The Netherlands, A.A. Balkema, p. 507-511.

May, H.M., and Nordstrom, D.K., 1991, Assessing the solubilities and reaction kinetics of aluminous minerals in soils, in Ulrich, B., and Sumner, M.E., eds., Soil Acidity: Berlin, Germany, Springer-Verlag, p. 125-148.

Nordstrom, D.K., 1991, Chemical modeling of acid mine waters in the western United States, in Mallard, G.E., and Aronson, D.A., eds., U.S.
Geological Survey Toxics Substances Hydrology Program-Proceedings of the technical meeting, Monterey, Calif., March 11-15, 1991: U.S. Geological Survey Water-

Resources Investigations Report 91-4034, p. 534-538.

Nordstrom, D.K., and Alpers, C.N., 1991, Geochemical evaluation of acid mine waters at Iron Mountain, California, 1990: U.S. Geological Survey Administrative Report, 36 p.

Nordstrom, D.K., and Ball, J.W., 1989, Mineral saturation states in natural waters and their sensitivity to thermodynamic and analytical errors: Sciences Geologiques Bulletin, no. 42, p. 269-280.

Nordstrom, D.K., Ball, J.W., Donahoe, R.J., and Whittemore, D., 1989, Groundwater chemistry and water-rock interactions at Stripa: Geochimica et Cosmochimica Acta, v. 53, p. 1727-1740.

Nordstrom, D.K., Burchard, J.M., and Alpers, C.N., 1990, The production and variability of acid mine drainage at Iron Mountain, California, in Gadsby, J.W., Malick, J. A., and Day, S.J., eds., Acid mine drainage-Designing for closure: Vancouver, B.C., BiTech Publishers, Ltd, p. 13-21.

Nordstrom, D.K., Lindblom, S., Donahoe, R.J., and Barton, C.C., 1989, Fluid inclusions in the Stripa Granite and their possible influence on the groundwater chemistry: Geochimica et Cosmochimica Acta, v. 53, 1741-1756.

Nordstrom, D.K., and May, H.M., 1989, Aqueous equilibrium data for mononuclear aluminum species, in Sposito, G., ed., The environmental chemistry of aluminum: Boca Raton, Fla., CRC Press, chap. 2, p. 27-53. 


\section{GROUND-WATER CHEMISTRY}

Nordstrom, D.K., McNutt, R.H., Puigdomenech, I., Smellie, J.A.T., and Wolf, M., 1992, Groundwater chemistry and geochemical modeling of water-rock interactions at the Osamu Utsumi mine and the Morro do Ferro analogue study sites, Pocos de Caldas, Minas Gerais, Brazil: Journal of Geochemical Exploration, v. 45 , p. 249-287.

Nordstrom, D.K., Olsson, T. Carlsson, L., and Fritz, P., 1989, Introduction to the hydrogeochemical investigations within the International Stripa Project: Geochimica et Cosmochimica Acta, v. 53, 1717-1726.

Nordstrom, D.K., Plummer, L.N., Langmuir, D., Busenberg, E., May, H.M., Jones, B.F., and Parkhurst, D.L., 1990, Revised chemical equilibrium data for water-mineral reactions and their limitations, in Bassett, R.L., and Melchior, D.,eds., Chemical modeling in aqueous systems II: American Chemical Society Symposium Series 416 , chap. 31, p. 398413.

Nordstrom, D.K., Puigdomenech, I., and McNutt, R.H., 1990, Geochemical modeling of waterrock interactions at the Osamu Utsumi mine and Morro de Ferro analogue study sites, Pocos de Caldas, Brazil: NAGRA Technical Report, NTB 90-23, 33 p.

Nordstrom, D.K., Smellie, J.A.T., and Wolf, M., 1990, Chemical and isotopic composition of groundwaters and their seasonal variability at the Osamu Utsumi mine and Morro de Ferro analogue study sties, Pocos de Caldas, Brazil: NAGRA Techical Report NTB 90-24, 111 p.

Stipp, S.L., Parks, G.A., Nordstrom, D.K., and Leckie, J.O., 1993, Solubility product constant and thermodynamic properties for synthetic otavite, $\mathrm{CdCO}_{3}(\mathrm{~s})$, and aqueous association constants for the $\mathrm{Cd}$ (II) $-\mathrm{CO}_{2}-\mathrm{H}_{2} \mathrm{O}$ system: Geo- chimica et Cosmochimica Acta, v. 57, p. 2699-2713.

Waber, Niklaus, and Nordstrom, D.K., 1992, Geochemical modeling of granitic ground waters at the Stripa site (Sweden) using a mass balance approach, in Kharaka, Y.K., and Maest, A.S., eds., Proceedings of the 7th International Symposium on Water-Rock Interaction, July 9-23, 1992, Park City, Utah: Rotterdam, The Netherlands, A.A. Balkema, p. 243-246.

Wanty, R.C., and Nordstrom, D.K., 1993, Natural radionuclides, in Alley, W.M., ed., Regional Ground-Water Studies: New York, Van Nostrand Reinhold, p. 423-441.

Webster, J.G., Nordstrom, D.K., and Smith, K.S., 1994, Transport and natural attenuation of $\mathrm{Cu}$, $\mathrm{Zn}$, As, and $\mathrm{Fe}$ in the acid mine drainage of Leviathan and Bryant Creeks: American Chemistry Society Symposium Series 550, 244-260. 


\section{GROUND-WATER CHEMISTRY}

TITLE: $\quad$ Chemical Models of Natural Systems (CR 79-336 formerly NR 79-093)

PERSONNEL: Donald C. Thorstenson, Project Chief

Jeanea Shown, Secretary

Herbert Haas, Hydrologist, Desert Research Institute, Las Vegas, Nevada

ADDRESS: U.S. Geological Survey

P.O. Box 25046, MS 421

Denver Federal Center

Denver, CO 80225

TELEPHONE: (303) 236-6229

PROBLEM: The increasing need for understanding the effects of human activity on the chemistry of natural systems requires a continually increasing degree of sophistication in the models used to describe the processes through which these effects occur. Such models include thermodynamic and (or) kinetic models of aqueous speciation, the chemistry of dissolved gases, gaseous and aqueous diffusion, transport of constituents across interfaces, redox processes, mineral-water interactions, the chemistry of anthropogenic inputs to natural systems, and isotope effects associated with these processes.

OBJECTIVE: (1) Identify the factors influencing the reactions and transport of solutes in natural waters; (2) evaluate reactions and transport processes for volatile constituents in unsaturated zones; (3) identify processes occurring at the interface of the saturated and unsaturated zones (the capillary fringe); and (4) investigate the application of isotope effects as a tool for understanding these processes.

APPROACH: (1) Conduct field studies at sites selected for investigation of particular processes; (2) analyze gaseous and (or) dissolved constituents (and their isotopes) as needed; (3) develop theoretical reaction and (or) transport models for specific processes under investigation; and (4) apply these theoretical models to natural systems.

PROGRESS: Annual gas sampling from open boreholes at Yucca Mountain crest was repeated this spring, near the end of the winter period of thermal-topographic convective gas flow in the mountain. Gases were analyzed for $\mathrm{CO}_{2}$ and $\mathrm{CH}_{4}$ concentrations, and for the ${ }^{13} \mathrm{C}$ and ${ }^{14} \mathrm{C}$ contents of $\mathrm{CO}_{2} . \mathrm{CO}_{2}$ concentrations in gases from shallow depths (0 to 20 meters) at borehole USW-UZ6S, which exhausts steadily all winter, have gradually diminished from 0.121 percent in 1986 to 0.113 percent in 1993 . The ${ }^{14} \mathrm{C}$ activity in the atmosphere at Yucca 


\section{GROUND-WATER CHEMISTRY}

Mountain has decreased from 124 percent modern carbon $(\mathrm{pmc})$ to $117 \mathrm{pmc}$ in the same period. In contrast, the ${ }^{14} \mathrm{C}$ and ${ }^{13} \mathrm{C}$ signatures of the $\mathrm{CO}_{2}$ at USW-UZ6S remain constant at $108 \mathrm{pmc}$ and -17.0 permil, respectively. Although no reaction/transport model that is consistent with these observations has yet been found, progress is being made in modeling and interpretation of some of the processes occurring in the gas flow system. $\mathrm{CO}_{2}$ productivity estimated from seasonal variability of $\mathrm{CO}_{2}$ concentrations at a soil and subsoil-unsaturated zone study site in alluvium at Jackass Flats are consistent with $\mathrm{CO}_{2}$ productivity estimates by other researchers at other sites with similar climate and vegetation. The $\mathrm{CO}_{2}$ productivity at Yucca Mountain crest is assumed to be similar to that at Jackass Flats, based on similar $\mathrm{CO}_{2}$ concentrations in shallow soils at both locations. This level of $\mathrm{CO}_{2}$ productivity over a reasonable geographic area appears capable of producing the quantity of $\mathrm{CO}_{2}$ that annually exhausts from the borehole. It is possible that the decrease in $\mathrm{CO}_{2}$ concentrations in gases exiting USW-UZ6S is due to a slight decrease in productivity over the period of record.

\section{REPORTS PUBLISHED 1989-1994:}

Striegl, R.G., McConnaughey, T.A., Thorstenson, D.C., Weeks, E.P., and Woodward, J.C., 1992, Consumption of Atmospheric methane by desert soils: Nature, v. 357, p. 145-147.

Thorstenson, D.C., 1990, Chemical modeling of regional aquifer systems-Implications for chemical modeling of low-level radioactivewaste repository sites, in Bedinger, M.S., and Stevens, P.R., eds., Safe disposal of radionuclides in low-level radioactive-waste disposal workshop, U.S. Geological Survey, Big Bear Lake, California, July 11-16, 1987 [proceedings]: U.S. Geological Survey Circular 1036, p. 110-113.

1993, The composition and $\mathrm{CO}_{2}$ carbon isotope signature of gases from borehole USW UZ-6, Yucca Mountain, Nevada, in Workshop on flow and transport through unsaturated fractured rock-Related to high-level radioactive waste disposal: Tucson, Arizona, University of Ariz., January 7-10, 1991, U.S. Nuclear Regulatory Commission, NUREG/ CP-0040, p. 184-188.
Thorstenson, D.C., and Pollock, D.W., 1989, Gas transport in unsaturated zones-Multicomponent systems and the adequacy of Fick's Laws: Reviews of Geophysics, v. 27, p. 61-78.

1989, Gas transport in unsaturated zonesmulticomponent systems and the adequacy of Fick's laws: Water Resources Research, v. 25, p. $477-507$.

Thorstenson, D.C., Weeks, E.P., Haas, H., and Woodward, J.C., 1990, Physical and chemical characteristics of topographically affected airflow in an open borehole at Yucca Mountain, Nevada, in Nuclear waste isolation in the unsaturated zone, Focus ' 89 [Proceedings]: La Grange Park, Ill., American Nuclear Society, p. 256-270.

Yang, I.C., Peters, C.A., and Thorstenson, D.C., 1993, Carbon isotopic data from test hole USW UZ-1, Yucca Mountain, Nevada: Fourth Annual International High Level Radioactive Waste Management Conference (HLRWMC), Las Vegas, Nev., April 26-30, [Proceedings], p. 401-405. 


\section{GROUND-WATER CHEMISTRY}

TITLE: $\quad$ Mineral-Water Interaction in Saline Environments (NR 69-020)

PERSONNEL: Blair F. Jones, Project Chief

Margery M. Shapira, Secretary

Daniel M. Webster, Hydrologist

Brenda Libby, Chemist

ADDRESS: U.S. Geological Survey

432 National Center

12201 Sunrise Valley Drive

Reston, VA 22092

TELEPHONE: (703) 648-5854

PROBLEM: Saline hydrologic systems provide a wide range of conditions within which to examine hydrochemically important mineral reactions (alteration or genesis) and to define reactants and products controlling the chemical composition of many natural waters. The effects of complex reactions, in addition to simple solution and hydrolysis, are reflected in relatively gross chemical change and interaction with fine-grained sediment.

OBJECTIVE: Use saline environments to determine mechanisms and relative importance of mineralogic processes that influence the solute composition of natural waters.

APPROACH: Study in the field and make laboratory analyses of saline waters and associated deposits, mostly from surficial sites or shallow cores in selected pilot or problem areas.

Separate and examine solid and solution phases by use of high-speed and gradient centrifugation, microscopy, X-ray diffractometry, and special potentiometric apparatus, as well as detailed constituent analysis of both solids and solutions. Relate composition of these materials to the hydrochemical environment, thermodynamic conditions, and structural elements of associated mineral species.

PROGRESS: Preliminary results have been presented on correlation of major constituent and normative analyses for brines from the Salado and underlying formations at Waste Isolation Pilot Plant (WIPP). Sporadic work continues on refinement of the criteria to separate inclusion from intergranular fluids; in contrast, deeper Delaware Basin brines can be readily distinguished from fluids in the evaporite horizons. Interpretation and advice was also given to Oak Ridge National Laboratories on determination of the nature and origin of subsurface 


\section{GROUND-WATER CHEMISTRY}

brines in that area. An unsuccessful attempt was made to obtain additional support for work related to WIPP.

With Carl Bowser of the University of Wisconsin, spreadsheet mass-balance modeling of hydrochemical evolution in crystalline and clastic rocks has extended to include not only considerations of principal silicate solid solutions, especially feldspar and smectite clay, but also the effects of differential dissolution kinetics. Preliminary results were given at the International Clay Conference in Adelaide (Bowser) and the BIOGEOMON symposium in Prague (Jones). Material developed in these studies was extensively utilized in lectures for the WRD training course on the geochemistry of ground waters at the Denver Center, an interdepartmental seminar on weathering at Johns Hopkins University, and other presentations.

Work continued on pore fluids and mineralogy in support of the Utah District's Bureau of Land Management funded study of hydrology of the Bonneville Salt Flats, and the effects of clay strata in the intermediate aquifer system of central Florida on the hydrochemistry of ground water. The latter involved contribution to mass-transfer modeling in central Florida (Brian Katz), and to consideration of clay-related diffusion and diagenesis in such a system (students at the University of Virginia). These studies have further elucidated the influence of pore fluids and mineralogy in very fine-grained clastic sediment on overall aquifer hydrochemistry, as previously emphasized in our own project efforts.

Further work has been done on the paleohydrologic implications of fine sediment mineralogy in lacustrine sediments of the Double Lakes, Texas; Bonneville and Siever basins, Utah; Fish Lake Valley, Nevada; and certain Mojave basins, California, in conjunction with interdivisional paleoclimate studies.

The project continued review of minor element sampling and analysis protocols, consulted on saline water problems, and provided information and instruction on brines, silicates, and related aqueous reaction modeling not only at the Denver Center, but also for a short course with D.K. Nordstrom on behalf of the Spanish nuclear waste agency, ENRESA. The latter permitted additional advising of thesis work at the Complutense University on the Madrid Basin, and continued collaboration with Spanish colleagues from other institutions on mineral-water interaction in intermontane basins. 


\section{GROUND-WATER CHEMISTRY}

\section{REPORTS PUBLISHED 1989-1994:}

Banfield, J.F., Jones, B.F., and Veblen, D.R., 1991, An AEM-TEM study of weathering and diagenesis, Abert Lake, Oregon-I. Weathering reactions in the volcanics: Geochimica et Cosmochimica Acta, v. 55, p. 2781-2793.

Banfield, J.F., Jones, B.F., and Veblen, D.R., 1991, An AEM-TEM study of weathering and diagenesis, Abert Lake, Oregon-II. Diagenetic modification of the sedimentary assemblage: Geochimica et Cosmochimica Acta, v. 55 , p. 2795-2810.

Banfield, J.F., Veblen, D.R., and Jones, B.F., 1990, Transmission electron microscopy of subsolidus oxidation and weathering of olivine: Contributions to Mineralogy and Petrology, v. 106, p. 110-123.

Bodine, M.W., Jr., and Jones, B.F., 1990, Normative analysis of ground waters from the Rustler formation associated with the Waste Isolation Pilot Plant (WIPP), southeastern New Mexico, in Spencer, R.J., and Chou, I.M., Fluid-Mineral Interactions-A Tribute to H.P. Eugster: The Geochemical Society Special Publication no. 2 , p. $213-269$.

Clark, A.E., Herman, J.S., and Jones, B.F., 1992, The chemical influence of clay minerals on groundwater composition in a lithologically heterogenous carbonate aquifer, in Kharaka, Y.K., and Maest, A.S., eds., Proceedings of the 7th International Symposium on WaterRock Interaction, July 9-23, 1992, Park City, Utah: Rotterdam, The Netherlands, A.A. Balkema, p. 779-782.

Deike, R.G., Webster, D.M., and Callender, E., in press, Sedimentary changes and authigenic mineralogy determined from Site 307 Cores, Academician Ridge, Lake Baikal, Siberia, in
Kuzmin, M., and William, D., eds., Journal of Geology and Geophysics (Geologica i Geofizika), Special Issue on Baikal Drilling Project, Novosibirsk, Russia.

Domagalski, J., Eugster, H.P., and Jones, B.F., 1990, Trace metal geochemistry of Walker, Mono, and Great Salt Lakes, in Spencer, R.J., and Chou, I.M., Fluid-Mineral Interactions-A Tribute to H.P. Eugster: The Geochemical Society, Special Publication no. 2, p. 315353.

Jones, B.F., Hanor, J.S., and Evans, W.R., 1993, Sources of dissolved salts in the central Murray Basin, Australia: Chemical Geology, p. 135-154.

Jones, B.F., and Llamas, M.R., 1989, Normative analysis of ground waters from the Madrid Basin, Spain: International Symposium on Water-Rock Interaction, Sixth, Malvern, United Kingdom, p. 341-347.

Manzano, M., Custodio, E., and Jones, B.F., 1990 , Progress in the understanding of groundwater flow through the aquitard of the Llobregat delta (Barcelona, Spain): Livro de Homenagem a Carlos Romariz, Seccao de Geologia Economica e Aplicada, Lisboa, Portugal, p. 115-126.

Nordstrom, D.K., Plummer, L.N., Langmuir, D., Busenberg, E., May, H.M., Jones, B.F., and Parkhurst, D.L., 1990, Revised chemical equilibrium data for major water-mineral reactions and their limitations-Chemical Modeling of Aqueous Systems I: American Chemical Society Symposium Series 416, chap. 31, p. 398413. 


\section{GROUND-WATER CHEMISTRY}

Tilling, R.I., and Jones, B.F., 1991, Composition of waters from the research drill hole at summit of Kilauea Volcano and of selected thermal and non-thermal groundwaters, Hawaii: U.S. Geological Survey Open-File Report 91-133A, 27 p.

Webster, D.M., and Jones, B.F., in press, Paleoenvironmental implications of lacustrine clay minerals from Double Lakes area, Southern High Plains, Texas: Journal of Sedimentary Petrology, v. 00.

Wood, W.W., and Jones, B.F., 1990, Origin of solutes in saline lakes and springs on the southern High Plains of Texas and New Mexico, in Gustavson, T.C., ed., Geologic Framework and Regional Hydrology-Upper Cenozoic Blackwater Draw and Ogallala Formations, Great Plains: Bureau of Economic Geology, University of Texas, p. 193-208. 


\section{GROUND-WATER CHEMISTRY}

TITLE: $\quad$ Spatial Distribution of Chemical Constituents in Ground Water (NR 57-034)

PERSONNEL: William Back, Project Chief

Janet Herman, Associate Professor, University of Virginia

Carol Wicks, Assistant Professor, University of Missouri

ADDRESS: $\quad$ U.S. Geological Survey

431 National Center

12201 Sunrise Valley Drive

Reston, VA 22092

TELEPHONE: (703) 648-5856

PROBLEM: Reactions and processes that control the chemical character of ground water need to be identified to predict physical and chemical changes that occur in natural and stressed environments. This project focuses on effects of these reactions in (1) regional limestone aquifers, (2) contaminated environments, and (3) coastal aquifers.

OBJECTIVE: Study hydrogeologic phenomena reactions that relate to (1) geologic processes; (2) generation, migration, and attenuation of contaminants; and (3) processes of isotopic fractionation. Demonstrate (1) contributions that can be made to ground-water science by study of historical aspects, and (2) the role of hydrogeology for sustainable development of this environment and water resources.

APPROACH: Design field studies for the collection and interpretation of chemical and isotopic data within the hydrogeologic framework. Select areas that are feasible to demonstrate the occurrence, extent, rate, and consequences of chemical reactions. (1) Study changes in porosity and permeability by karstification of coastal aquifers; (2) investigate the degradation and migration of organic compounds and isotopic fractionation at contamination sites and in sulfide-rich ground water; and (3) undertake comparative studies of regional systems in order to evaluate the environmental impact on the hydrogeologic processes and geochemical reactions.

PROGRESS: Much of my work for the past year has been in the area of public policy, water management and the history and philosophy of science. A review of the significant accomplishments for the field of hydrogeology for 1993 and speculation on its future was published in Geotimes. The concept of hydrologic time and its importance in data collection programs, particularly those involved with chemical and physical heterogeneity and 


\section{GROUND-WATER CHEMISTRY}

sustainability of aquifers, has been developed and articulated. A paper on this subject has been accepted for publication by the International Association of Hydrogeologists. Another paper accepted for publication (Ground Water) coauthored with Ed Landa, discusses water use in America and its relation to the history of chemistry.

REPORTS PUBLISHED 1989-1994:

Back, William, 1989, Review of Paleokarst, James, N.P., and Choquette P.W., eds., Episodes, v. 12 , no. 2 , p. 140 .

1989, Early Concepts of the Role of Microorganisms in Hydrogeology: Ground Water, guest editorial, v. 27 , no. 5, p. 618-619.

1990, Hydrologic ancient history and archaeology of the southwestern shore of Turkey, Supplement to Field Guide Book: International Symposium and Field Seminar on Hydrogeologic Processes in Karst Terranes, Antalya, Turkey, $35 \mathrm{p}$.

1991, Ground Water: Encyclopedia on Earth Systems Science: Academic Press, v. 2, p. 429-439.

1991, Presentation of the O.E. Meinzer Award to John D. Hem, Citation, Geological Society of America Bulletin, p. 586-587.

1991, Review of Opportunities in the Hydrologic Sciences: EOS, Transactions, American Geophysical Union, v. 72, no. 5, p. 491.

1992, Coastal karst formed by ground-water discharge, Yucatan, Mexico, in Back, William, Herman, Janet S., and Paloc, H., eds., Hydrogeology of Selected Karst Regions of the World, International Association of Hydrogeologists, v. 13, p. 461-466.
1992, Introduction to Hydrogeology of Selected Karst Regions of the World, International Association of Hydrogeologists v. 13, p. 1-9.

1992, Opportunities in hydrogeology: National Symposium on New Directions in Clean Water Policy and UCOWR 1992 Annual Meeting, July 28-31, 1992, p. 50-54.

Back, William, 1994, Hydrogeology: Geotimes, February, v. 39, no. 2, p. 23.

Back, William, 1994, Whose oxymoron is being gored? (In defense of "Watershed"): Hydata, v. 13 , no. 2 , p. $22-23$.

Back, William, and Arenas, A.D., 1989, Karst terrains: Resources and Problems: Nature and Resources, Special Issue, UNESCO, Paris, p. 19-26 (in English, French, and Spanish).

1990, Rationale for karst investigations, in Fuxing, Wang, Xinhong, Lin, and Zaihua, Liu, eds., Geology, Climate, Hydrology and Karst Formation: IGCP 299 Newsletter, Institute of Karst Geology, Guilin, China, p. 21-32.

Back, William, and Baedecker, M.J., 1989, Chemical hydrogeology in natural and contaminated environments: Journal of Hydrology, v. 106, p. 1-28.

Back, William, Baedecker, M.J., and Wood, W.W., 1993, Scales in Chemical Hydrogeology-A Historical Perspective, in Alley, William M., ed., Regional Ground-Water 


\section{GROUND-WATER CHEMISTRY}

Quality: New York, Van Nostrand Reinhold, chap. 5, p. 111-129.

Back, William, and Gunay, Gultekin, 1992, Tectonic influences on ground-water flow systems in karst of the southwestern Taurus Mountains, Turkey, in Back, William, Herman, Janet S., and Paloc, H., eds., Hydrogeology of Selected Karst Regions of the World, International Association of Hydrogeologists v. 13, p. 263272.

Back, William, and Herman, J.S., 1990, Significance of chemical boundaries to ground-water management of coastal aquifers, in Krishna, J. Hari, Quinones-Aponte, Vicente, GomezGomez, Fernando, and Morris, Gregory, eds., Proceedings of the International Symposium on Tropical Hydrogeology and the Fourth Caribbean Islands Water Resources Congress: American Water Resources Association, San Juan, Puerto Rico, p. 31-38.

Back, William, and Herman, Janet S., 1991, Geochemical consequences of saltwater intrusion into carbonate aquifers: International Association of Hydrogeologists, XXIII International Congress, Aquifer Overexploitation, General Papers, Extended Abstracts and Posters, April 1991, Canary Islands, Spain, v. 1, p. 35-38.

Back, William, Herman, Janet S., and Paloc, H., eds., 1992, Hydrogeology of Selected Karst Regions of the World: International Association of Hydrogeologists, v. 13, 439 p.

Back, William and Landa, E.R., 1992, Ingesting the consequences of water-rock interactionHistorical notes on bottled water and spas, in Kharaka, Y.K., and Maest, A.S., eds., Proceedings of the 7th International Symposium on Water-Rock Interaction, July 9-23, 1992, Park City, Utah: Rotterdam, The Netherlands, A.A. Balkema, p. 767-770.
Back, William, Landa, E.R., and Meeks, L., in press, Bottled Water, spas, and early years of water chemistry: Ground Water Journal, v. 00 .

Gultekin, G., Johnson, A.I., and Back, W., eds., 1993, Hydrogeological processes in karst terranes: Wallingford, U.K., IAHS Publication no. $207,412 \mathrm{p}$.

Herman, Janet S., 1989, Review of Geomorphology and Hydrology of Karst Terrains, by William B. White: Water Resources Bulletin, v. 25, p. 221-222.

1989, Review of Processes in Karst Systems Physics, Chemistry, and Geology, by Wolfgang Dreybodt: Hydrological Sciences Journal, v. 34 , p. $729-730$.

1989, A geochemical model of calcite precipitation and $\mathrm{CO}_{2}$ outgassing in karst streams, in Miles, D.L., ed., Proceedings of the Sixth International Meeting on Water-Rock Interaction, Malvern, United Kingdom: Rotterdam, The Netherlands, A.A. Balkema, p. 301-304.

1989, Review of Karst Hydrology-Concepts from the Mammoth Cave Area, in White, Elizabeth L., and White, William B., eds.: Water Resources Bulletin, v. 25, p. 10981099.

Herman, Janet S., and Hubbard, David A., Jr., 1990, A Comparative study of travertine-marldepositing streams in Virginia, in Herman, Janet S., and Hubbard, David A., Jr., eds., Travertine-Marl: Stream Deposits in Virginia: Virginia Division of Mineral Resources Publication 101, p. 43-64.

Herman, Janet S., and Hubbard, Jr., David A., eds., 1990, Travertine-Marl-Stream Deposits 


\section{GROUND-WATER CHEMISTRY}

in Virginia: Virginia Division of Mineral Resources Publication 101, $184 \mathrm{p}$.

Herman, Janet S., and Hubbard, Jr., David A., 1992, The role of ground water in the deposition of travertine-marl, in Back, William, Herman, Janet S., and Paloc, H., eds., Hydrogeology of Selected Karst Regions of the World: International Association of Hydrogeologists, v. 13, p. 421-434.

Hoffer, Kimberly J., and Herman, Janet S., 1990, $\mathrm{A} \mathrm{CO}_{2}$ outgassing model for Falling Springs Run, Augusta County, Virginia, in Herman, Janet S., and Hubbard, David A., Jr., eds., Travertine-Marl-Stream Deposits in Virginia: Virginia Division of Mineral Resources Publication 101, p. 6-15.

Hoffer-French, Kimberly J., and Herman, Janet S., 1989, Evaluation of hydrological and biological influences on $\mathrm{CO}_{2}$ fluxes from a karst stream: Journal of Hydrology, v. 108, p. 189212.

Hubbard, David A., Jr., and Herman, Janet S., 1990, Overview of travertine-marl volume, in Herman, Janet S., and Hubbard, David A., Jr., eds., Travertine-Marl: Stream Deposits in Virginia: Virginia Division of Mineral Resources Publication 101, p. 1-4.

Hubbard, D.A., Jr., Herman, J.S., and Bell, P.E., 1990, Speleogenesis in a travertine scarp: observations of sulfide oxidation in the subsurface, in Herman, Janet S., and Hubbard, David A., Jr., eds., Travertine-Marl-Stream Deposits in Virginia: Virginia Division of Mineral Resources Publication 101, p. 177184.

Llamas, M.R., and Back W., 1989, Tendencias en hidrogeoquimica, in Homenaje, Tomo, a Martin, Jorge Porras, eds., Hidrogeologia Y Recursos Hidraulico: Asociacion Espanola de Hidrologia Subterranea, Madrid, Spain, v. 14, p. 315-323.
Llamas, Ramon, Back, W., and Margat, J., 1992, Groundwater use-Equilibrium between social benefits and potential environmental costs: Applied Hydrogeology, v. 1, no. 2, p. 1-14.

Lora, M.M., and Herman, J.S., 1990, Geochemical evolution and calcite precipitation rates in Falling Spring Creek, Virginia, in Herman, Janet S., and Hubbard, David A., Jr., eds., Travertine-Marl: Stream Deposits in Virginia: Virginia Division of Mineral Resources Publication 101, p. 177-184.

Norris, Robert M., 1990, Erosion of seacliffs by groundwater, with a case study by Back, W., in Higgins, C.G., and Coates, D.R., eds., Groundwater geomorphology; The role of subsurface water in Earth-surface processes and landforms: Boulder, Colo., Geological Survey of America Special Paper 252.

Price, Rene M., and Herman, Janet S., 1991, Geochemical investigation of saltwater intrusion into a coastal carbonate aquifer: Mallorca, Spain, Geological Society of America Bulletin, v. 103 , no. 10 , p. 1270-1279.

Sacks, L.A., Herman, J.S., Konikow, L.F., and Vela, A.L., in press, Seasonal dynamics of groundwater-lake interactions at Donana National Park, Spain: Journal of Hydrology, v. 136 , no. 2 , p. $123-154$.

Wicks, Carol, and Grove, Chris, 1993, Acidic mine drainage in carbonate terrains-Geochemical processes and rates of calcite dissolution: Journal of Hydrology, v. 146, p. 13-27.

Yuan, Daoxian, and Back, William, 1991, International Geologic Correlation Program Project 299: Geology, climate, hydrology and karst formation: Episodes, March. 


\title{
GROUND-WATER CHEMISTRY
}

TITLE: Interface of Paleoclimatology and Aquifer Geochemistry (NR 74-041)

\author{
PERSONNEL: Isaac J. Winograd, Project Chief \\ Laura A. Bricker, Clerial Assistant \\ Alan C. Riggs, Hydrologist \\ Peter T. Kolesar, Professor, Utah State University
}

ADDRESS: U.S. Geological Survey

432 National Center

12201 Sunrise Valley Drive

Reston, VA 22092

TELEPHONE: (703) 648-5849

PROBLEM: Reconstructions of continental paleoclimates of the Pleistocene Epoch have relied almost exclusively on packrat midden, lacustrine, and speleothem records; such records are typically discontinuous and (or) are difficult to date. The isotopic (deuterium, oxygen-18, carbon-13) records of calcitic veins marking the sites of fossil ground water discharge, have not been utilized. Preliminary work indicates that such veins contain continuous dateable records of Pleistocene paleoclimate and paleohydrology. The paleohydrologic interpretations should also be pertinent to selection of sites for the disposal and long term isolation of toxic wastes.

OBJECTIVE: (1) Infer paleoclimate and paleohydrology of selected regions based on variations in isotopic content of calcitic veins of ground water origin; (2) attempt correlation of inferred local variations in continental paleoclimate with global variations deduced from marine and polar ice core studies; (3) differentiate between, and determine relative magnitude of, summer and winter recharge to major uplands.

APPROACH: Sample: (1) water from regional aquifers for which quantitative hydrogeologic and geochemical studies are available; (2) rain, snow, snowmelt, and springs in major upland recharge areas; (3) calcite veins at modern and fossil springs. The water and calcite deposits will be analyzed for $\mathrm{D},{ }^{18} \mathrm{O},{ }^{13} \mathrm{C}$, and will be dated using the TIMS U-Series methods. Initial work will be in the southern Great Basin where a major fossil spring discharge area (with a modern analogue, the Ash Meadows region) has been exhumed by uplift and erosion. 


\section{GROUND-WATER CHEMISTRY}

PROGRESS: The year was marked by four highlights:

1. Publication of a 500,000-year stable carbon isotope time series from Devils Hole vein calcite. This record will be of major interest to both geochemists and paleoclimatologists. I shows that we have major gaps in our knowledge of the carbon chemistry of fractured aquifers, and also that Devils Hole may have recorded global changes in the carbon-13 of atmospheric $\mathrm{CO}_{2}$ during the Pleistocene.

2. Publication of 100,000 year water-table hydrograph for the southern Great Basin. 'iis record, arguably the longest water-table record in existence, is highly relevant to the use of thick unsaturated zones of the Great Basin for toxic waste disposal.

3. Continued commentary in major journals on our Ou, iober 1992 Devils Hole oxyg n 18 paper (Science, 258, 255, 1992). To date, there have been eight published discussions of this paper, four in the journal Nature.

4. We have located a Devils Hole-type deposit in Turcty which we intend to t.X. in ine in detail late in Fiscal Year 1994 and extending into Fiscal Year 1995.

\section{REPORTS PUBLISHED 1989-1994:}

Coplen, T.B., Winograd, I.J., Landwehr, J.M., and Riggs, A.C., 1994, 500,000-year stable carbon isotopic record from Devils Hole, Nevada: Science, v. 263, p. 361-365.

Edwards, R.L., Gallup, C.D., Ludwig, K.R., Simmons, K.R., Winograd, I.J., Szabo, B.J., and Riggs, A.C., 1993, Dating of the Devils Hole calcite vein: Science, v. 259, p. 16261627.

Landwehr, J.M., Winograd, I.J., and Coplen, T.B., 1994, No verification for Milankovitch: Nature, v. 368, p. 594.

Ludwig, Kenneth R., Simmons, Kathleen R., Szabo, Barney J., Winograd, Isaac J., Landwehr, Jurate M., Riggs, Alan C., and Hoffman, Ray J., 1992, Mass-spectrometric ${ }^{230} \mathrm{Th}$ -
${ }^{234} \mathrm{U}-{ }^{238} \mathrm{U}$ dating of the Devils Hole calcite vein: Science, v. 258, 284-287.

Shackleton, N.J., Ludwig, K.P , Simmons, K.R., Winograd, I.J., Szabc. B.J., Landwehr, J.M., and Riggs, A.C., 1993, Last interglacial in Devils Hole: Nature. v. 362, p. 596.

Szabo, B.J., Kolesar, grad, I.J., and I.udwis, K.R., 1994, Paleoclimatic inferences from a 120,000-year calcite record of water rtable fluctuations in Browns Ronm of Devils Hole, Nevada: Quaternary Research, v. 41, p. 59-69.

Winograd, I.J. 1990, The Yucca Mountain Project-Anoiner perspective: Environmental Science and Technology, v. 24, no. 9, p. 1291-1253. 


\section{GROUND-WATER CHEMISTRY}

1991, Yucca Mountain as a nuclear waste

repository-Neither myth nor millennium: U.S. Geological Survey, Open-file Report 91-170, 25 p.

Winograd, I.J., Coplen, B.J., Landwehr, J.M., Riggs, A.C., Ludwig, K.R., Szabo, B.J., Kolesar, P.T., and Revesz, K.M., 1992, Continuous 500,000-year climate record from vein calcite in Devils Hole, Nevada: Science, $v$. 258, p. 255-260. 


\section{GROUND-WATER CHEMISTRY}

TITLE: $\quad$ Kinetics and Thermodynamics of Chemical Evolution in Ground-Water Systems (NR 76-056)

PERSONNEL: L. Niel Plummer, Project Chief

Bonnie H. Hower, Secretary

Eurybiades Busenberg, Hydrologist

Pierre D. Glynn, Hydrologist

Eric C. Prestemon, Hydrologist

Julian E. Wayland, Hydrologist

ADDRESS: U.S. Geological Survey

432 National Center

12201 Sunrise Valley Drive

Reston, VA 22092

\section{TELEPHONE: (703) 648-5841}

PROBLEM: The responsible use of our Nation's ground-water resources requires an ability to predict changes in water quality as a result of human impacts. Prediction of chemical quality in the ground-water environment depends on a detailed understanding of both chemical and hydrologic processes. To determine the spatial and temporal variability of ground-water quality, it is necessary to identify reactions occurring in the system, to define their kinetic and thermodynamic properties, and to determine how the configuration of the hydrologic regime influences ground-water quality.

OBJECTIVE: (1) Identify chemical reactions in ground-water systems using observed chemical and isotopic composition of dissolved solutes and minerals; (2) develop geochemical models to aid in interpretation of chemical and isotopic data from ground-water systems; (3) develop tools for age-dating groundwaters; (4) determine rates of chemical reactions in ground-water systems from field hydrochemical data and modeled water ages; (5) conduct laboratory experiments to obtain thermodynamic data for mineral-water systems for use in geochemical models; (6) obtain laboratory kinetic data on rates of mineral dissolution and precipitation for comparison with field rates and (7) study the fundamental mechanisms of mineral dissolution and precipitation as they apply to pure phases and to solid-solution minerals.

APPROACH: Flow paths in ground-water systems are sampled extensively for chemical and isotopic composition. Geochemical mass balance calculations are used to interpret reaction 


\section{GROUND-WATER CHEMISTRY}

possibilities, test reaction sensitivity to stable isotope data for aquifer minerals and dissolved solutes, and to obtain adjusted carbon-14 water ages. Rates of reactions are calculated from modeled mass transfers and water ages. Tools developed for age-dating of groundwaters include interpretation of chlorofluorocarbon (CFC) content in recharge areas and unconfined aquifers. Mathematical models are developed to (1) calculate speciation and thermodydnamic properties of a wide range of water compositions from dilute to highly saline formation waters, (2) model water-rock evolution, (3) test sensitivity of chemical evolution to advection and hyrodynamic dispersion in ground-water environments, and (4) model dissolution and precipitation reactions for water-rock systems containing solid-solution minerals. In the laboratory, synthetic solid-solution minerals are prepared using constant composition, constant growth-rate techniques. The stoichiometric solubilities of solid-solution minerals are measured to estimate the thermodynamic mixing properties of the minerals. Laboratory kinetic studies are conducted to investigate (1) fundamental mechanisms of dissolution and crystal growth of rock-forming minerals in relatively pure water-rock systems and (2) the effects of added inorganic and organic solutes on mineral-water reaction kinetics in hydrochemical environments.

PROGRESS: A series of papers was published demonstrating the usefulness and applications of chlorofluorocarbons (CFC) as tracers and age-dating tools of young ground water (0-50 year time scale). The most extensive paper (Dunkle and others, 1993, Water-Resources Research, v. 29, p. 3837-3860) investigates CFC dating on the Delmarva Peninsula of Delaware, Maryland and Virginia (NAWQA study unit). This study shows that CFC ages can agree within several years when determined independently from CFC-11 and CFC-12. The CFC ages also agreed with ground water ages determined independently from ${ }^{3} \mathrm{H} /{ }^{3} \mathrm{He}$ and ${ }^{85} \mathrm{Kr}$ dating on Delmarva (Ekwurzel and others, 1994, Water-Resources Research, v. 30, p. 1693-1708). The CFC ages were used to reconstruct the tritium input to Delmarva, and indicate the tracers are little affected by hydrodynamic dispersion along the studied flow paths. Further studies identified some limitations to CFC dating of older ground water that can easily be contaminated with trace amounts of CFCs introduced from the sampling equipment. Several studies were conducted on Delmarva and southern New Jersey that showed very similar ages between CFC dating and dating by the ${ }^{3} \mathrm{H} /{ }^{3} \mathrm{He}$ method. These studies were combined with simulation of ground-water flow and showed that the effect of hydrodynamic dispersion on $\mathrm{CFC}$ and ${ }^{3} \mathrm{H} /{ }^{3} \mathrm{He}$ dating was very small. In another paper a numerical model of ground-water flow was refined and improved by including ground-water age dating (Reilly and others, 1994, Water-Resources Research, v. 30, p. 421-433).

Ground-water travel times from numerical simulation strongly support the age dating with CFCs. 


\section{GROUND-WATER CHEMISTRY}

Numerous other studies were conducted, but are not yet published. Detailed sampling for CFC-11, CFC-12 and CFC-113 along a 20 meter profile in a largely anaerobic silty sand containing approximately 0.03 percent organic matter at Sturgeon Falls, Ontario, Canada, was compared to tritium data to show degradation of CFC-11. The CFC-113 was retarded relative to $\mathrm{CFC}-12$, presumably due to sorption. The CFC-12 age matched the hydraulic age, determined from the position of the bomb-tritium peak, within 20 percent (up to 30 years). Another manuscript was completed interpreting our earlier data from the Idaho National Engineering Laboratory. This study demonstrates that the unsaturated zone CFC profile at INEL is determined by diffusive processes, and shows that recharge to the Snake River Plain aquifer at Idaho National Engineering Laboratory (INEL) probably by-passes contact with the unsaturated zone air, because ground-water ages based on CFC-11 and CFC-12 are nearly identical. The CFCs were used to date recharge to the Upper Floridan aquifer from Lake Barco, a seepage lake in north-central Florida, and demonstrated degradation of CFC-11. A manuscript was completed showing strong correlation between ground-water ages based on numerical simulation-flow path analysis (particle tracking) with ages determined from CFC-11, CFC-12, CFC-113 and ${ }^{3} \mathrm{H} /{ }^{3} \mathrm{He}$ in a shallow sand aquifer in southern New Jersey. CFC ages were determined for separate fracture zones at the USGS Toxic Substances research site at Mirror Lake, New Hampshire, showing, in some cases, relatively young water beneath older water. Large excesses of dissolved nitrogen were also found in ground water at Mirror Lake. Two extensive data reports were completed-one summarizing all CFC data from the Delmarva (NAWQA) study and another summarizing all chemical, isotopic and CFC data from the Valdosta, Georgia, study area.

The CFC, chemical, and isotopic data from the Floridan aquifer at Valdosta, Georgia, collected between 1988 and 1993 were studied. They show that ground water at Valdosta is a mixture of relatively old regional Floridan aquifer water with relatively young portions of Withlacoochee River water recharged through sinkholes in the river north of Valdosta. A model was constructed to predict historical tritium concentrations in the Withlacoochee River and was compared to recent monthly tritium data from the river. These calculations indicate that tritium input to the Floridan aquifer near Valdosta probably did not exceed 40 Tritium units, which compares well with the measured tritium +helium- 3 in the ground water. Ages of the young fraction of ground water at Valdosta, determined from tritium/helium-3 and CFC-12 (the later after correction for dilution) agree well. Apparently most of the young fraction of ground water sampled at Valdosta is in the range of 10 to 30 years. The CFC-11 has been removed from anaerobic ground water at Valdosta, due most likely to microbial degradation, but indicates reasonable ages in aerobic waters. Laboratory microcosm experiments show degradation of CFC-11 but not degradation of CFC-12 in sealed, anaerobic cells. The CFC-113 appears to have been removed by sorption processes at Valdosta. 


\section{GROUND-WATER CHEMISTRY}

Tritium/helium-3 and CFC dating of the Floridan aquifer at Albany, Georgia (sampled July, 1993), where recharge occurs by normal infiltration processes, show nearly complete agreement.

Age-dating with CFC-113 was further refined by reconstruction and extension of the air CFC-113 concentrations to approximately the mid-1960s. The air values were determined from CFC-113 concentrations measured in previously dated ground water from Delmarva and other parts of the United States. We are presently conducting interlaboratory calibration tests with several other laboratories to establish a scale on which previously measured CFC-113 concentrations can be compared. A gas chromatographic analytical system was constructed to determine trace amounts of sulfur hexafluoride $\left(\mathrm{SF}_{6}\right)$. A vacuum-extraction system was constructed for field sampling of $\mathrm{SF}_{6}$, and is currently being tested. A new purge and trap gas chromatographic system for analyzing dissolved concentrations of nitrogen, oxygen, argon, carbon dioxide, and methane in ground water, was designed and constructed, and is currently being tested. We began design and purchase of equipment for a planned expansion of a Divisional CFC analytical facility, to be located in Reston, Virginia. Numerous CFC samples, collected from various sites in Ohio, Montana, Colorado, Minnesota, South Dakota, Tennessee, Massachusetts, California, Arizona, New Jersey, Georgia, Nevada, Canada, Hungary, and Denmark were analyzed in the Reston, Virginia, CFC laboratory and interpreted. A Theme Session on "Advances in age-dating young groundwater" was organized for the Geological Society of America Annual Meeting (Boston), October 1993.

Ground-water and unsaturated-zone investigations continue at the Pinal Creek Toxics site. The CFC stable isotope and dissolved gas concentrations in the ground waters were sampled in June 93, so as to determine the age of the waters, their origin, recharge altitude, recharge temperature and infiltration conditions. A major flood occured at the site in the spring of 1993. A primary purpose of the June 1993 trip was to compare CFC ages, dissolved gas concentrations, and isotopic compositions in ground waters after this flooding event to measurements obtained previously in November 1991. Preliminary results indicate some agreement between the CFC-11 ages determined in November 1991 and those determined for last June, especially for the deeper parts of the aquifer. Surprisingly, however, CFC, dissolved-gas and isotopic measurements indicate that in some wells water from the 1993 recharge event can be sampled at depths of up to 20 meters below the 1991 water table. The CFC-113 ages occasionally agree with the CFC- 11 ages. CFC- 12 ages, however, are often unreasonably high as was also found previously. The $\mathrm{CO}_{2},{ }^{13} \mathrm{CO}_{2}$ and $\mathrm{O}_{2}$ gas sampling in the unsaturated zone was also conducted in June 1993 to quantify fluxes and determine the source of the $\mathrm{CO}_{2}$, furthering results previously obtained in 1991. These ground-water and 


\section{GROUND-WATER CHEMISTRY}

unsaturated-zone investigations will hopefully lead to improved ground water flow and reactive transport models for the site.

The geochemical characterization of ground waters near the Aspo Hard-Rock-Laboratory is nearly finished, and has resulted in some fairly restrictive constraints on the hydrogeology and structural geology of the site. Five types of water have been identified, based primarily on the $\mathrm{D}, \mathrm{O}^{18}$ and $\mathrm{Cl}$ contents: (1) recent shallow $\mathrm{NaHCO}_{3}$ rich waters, (2) old shallow glacial melt waters, (3) deep $\mathrm{CaCl}_{2}$ rich waters presumably old, (4) waters with a Baltic or seawater "imprint" generally shallower than 500 meters depth, and (5) "intermediate" waters near 500 meters, generally with $5,000 \mathrm{mg} / \mathrm{L} \mathrm{Cl}$ which seem to be mixtures of the other types. Based on this classification and on a jump near 500 meters in the trend of $\mathrm{Br} / \mathrm{Cl}$ ratios with depth, the existence of a major subhorizontal hydraulic conduit is postulated near 500 meter depth, which is precisely where the Swedes want to put their analog high-level radioactive waste repository. A draft of the geochemical chracterization report is being completed for the Swedish Government.

An interpretation of unsaturated-zone gas and isotope measurements at the Bemidji Toxics site was conducted together with Kinga Revesz. Based on mass balance calculations, derived from the gas and isotope measurements, we estimated that the oil lens floating on the water table would take at least a 130 years to disappear due to ongoing oxidation and degradation processes.

Work continued on the refinement of the NETPATH geochemical mass balance code. The code was modified to use a generalized aqueous model, simulate fractionation processes with nitrogen isotopes and treat more mixing problems. The software was completed and new documentration is currently in review. A manuscript was written applying NETPATH to C-14 dating of highly methanogenic ground water from the Alliston aquifer in Ontario, Canada. The code was used to determine C-14 ages of ground water in the Floridan aquifer of Georgia demonstrating the presence of waters recharged during the last glacial maximum. Dissolved nitrogen and argon were determined on paleowaters from the Floridan aquifer in southeast Georgia and showed an average cooling in the recharge temperature of 5.3 degrees Celsius during the last glacial maximum. Even though it was clearly colder during the last glacial maximum in southeast Georgia, the stable isotopes show dramatic and significant enrichment. This is opposite to that observed in paleowaters in Europe and in other parts of the United States. It was suggested that the paleowaters in Georgia record recharge from late summer hurricanes and other tropical storms during the last glacial period (Plummer, 1993, Science, v. 262, p. 2016-2020). 


\section{GROUND-WATER CHEMISTRY}

\section{REPORTS PUBLISHED 1989-1994:}

Busby, J.F., Plummer, L.N., Lee, R.W., and Hanshaw, B.B., 1991, Geochemical evolution of water in the Madison aquifer in parts of Montana, South Dakota, and Wyoming: U.S. Geological Survey Professional Paper 1273-F, 89 p.

Busenberg, E., and Plummer, L.N., 1989, Thermodynamics of magnesian calcite solid-solutions at $25^{\circ} \mathrm{C}$ and $1 \mathrm{~atm}$ total pressure: Geochimica et Cosmochimica Acta, v. 53, p. 1189-1208.

1991, Chlorofluorocarbons $\left(\mathrm{CCl}_{3} \mathrm{~F}\right.$ and $\mathrm{CCl}_{2} \mathrm{~F}_{2}$ )-Use as an age-dating tool and hydrologic tracer in shallow ground-water systems, in Mallard, G.E., and Aronson, D.A., eds., U.S. Geological Survey Toxics Substances Hydrology Program-Proceedings of the technical meeting, Monterey, Calif., March 11-15, 1991: U.S. Geological Survey WaterResources Investigations Report 91-4034, p. 542-547.

1992, Use of chlorofluorocarbons $\left(\mathrm{CCl}_{3} \mathrm{~F}\right.$ and $\mathrm{CCl}_{2} \mathrm{~F}_{2}$ ) as hydrologic tracers and age-dating tools, Example-The alluvium and terrace system of central Oklahoma: Water Resources Research, v. 28 , no. 9, p. 2257-2284.

in press, Concentrations of chlorofluorocarbons and other gases in ground waters at Mirror Lake, New Hampshire, in Mallard, G.E., and Aronson, D.A., eds., U.S. Geological Survey Toxic Substances Hydrology Program-Proceedings of the technical meeting, Colorado Springs, Colo., September 20-24, 1993: U.S. Geological Survey Water-Resources Investigations Report 91-4014.

Busenberg, E., Weeks, E.P., Plummer, L.N., and Bartholemay, R.C., 1993, Age dating ground water by use of chlorofluorocarbons $\left(\mathrm{CCl}_{3} \mathrm{~F}\right.$ and $\mathrm{CCl}_{2} \mathrm{~F}_{2}$ ), and distribution of chlorofluorocarbons in the unsaturated zone, Snake River Plain aquifer, Idaho National Engineering Laboratory, Idaho: U.S. Geological Survey Water-Resources Investigations 93-4054, 47 p.

Dunkle, S.A., Plummer, L.N., Busenberg, E., Phillips, P.J., Denver, J.M., Hamilton, P.A., Michel, R.L., and Coplen, T.B., 1993, Chlorofluorocarbons $\left(\mathrm{CCl}_{3} \mathrm{~F}\right.$ and $\left.\mathrm{CCl}_{2} \mathrm{~F}_{2}\right)$ as dating tools and hydrologic tracers in shallow ground water of the Delmarva Peninsula, Atlantic Coastal Plain, United States: Water Resources Research, v. 29, no. 12, p. 3837-3860.

1993, Chlorofluorocarbons $\left(\mathrm{CCl}_{3} \mathrm{~F}\right.$ and $\left.\mathrm{CCl}_{2} \mathrm{~F}_{2}\right)$ as dating tools and hydrologic tracers in shallow ground water of the Delmarva Peninsula, Atlantic Coastal Plain, U.S.A: Water Resources Research, v. 29, no. 12, p. 3837-3860.

Ekwurzel, B., Schlosser, P., Smethie, Jr., W.M., Plummer, L.N., Busenberg, E., Michel, R.L., Weppernig, R., and Stute, M., 1994, Dating of shallow groundwater: Comparison of the transient tracers $3 \mathrm{H} / 3 \mathrm{He}$, chlorofluorocarbons and ${ }^{85} \mathrm{Kr}$ : Water Resources Research, v. 30, no. 6 , p. $1693-1708$.

Glynn, P.D., 1990, Modeling solid-solution reactions in low-temperature aqueous systems, in Melchoir, D.C., and Bassett, R.L., eds., Chemical modeling of aqueous systems II: American Chemical Society, American Chemical Society Symposium Series 416, Washington, D.C., p. 74-86.

1991, Effect of impurities in gypsum on contaminant transport at Pinal Creek, Arizona, in Mallard, G.E., and Aronson, D.A., eds., U.S. Geological Survey Toxics Substances Hydrology Program-Proceedings of the technical 


\section{GROUND-WATER CHEMISTRY}

meeting, Monterey, Calif., March 11-15, 1991: U.S. Geological Survey Water-

Resources Investigations Report 91-4034, p. 466-474.

1991, MBSSAS-A code for the computation of Margules parameters and equilibrium relations in binary solid-solution aqueous-solution systems: Computers and Geosciences, v. 17, no. 7 , p. $907-966$.

Glynn, P.D., and Busenberg, E., 1994, Dissolved gas and chlorofluorocarbon content of ground waters in the Pinal Creek Basin, Arizona, in Morganwalp, D.W., and Aronson, D.A., eds., U.S. Geological Survey Toxic Substances Hydrology Program-Proceedings of the technical meeting, Colorado Springs, Colo., September 20-24, 1993: U.S. Geological Survey WaterResources Investigations Report 94-4014.

in press, Unsaturated zone diffusion of carbon and oxygen in the Pinal Creek Basin, Arizona, in Mallard, G.E., and Aronson, D.A., eds., U.S. Geological Survey Toxic Substances Hydrology Program-Proceedings of the technical meeting, Colorado Springs, Colo., September 20-24, 1993: U.S. Geological Survey WaterResources Investigations Report 94-4014.

Glynn, P.D., Engesgaard, Peter, and Kipp, K.L., 1991, Use and limitations of two computer codes for simulating geochemical mass transport at the pinal creek toxic-waste site, in Mallard, G.E., and Aronson, D.A., eds., U.S. Geological Survey Toxics Substances Hydrology Program-Proceedings of the technical meeting, Monterey, Calif., March 11-15, 1991: U.S. Geological Survey WaterResources Investigations Report 91-4034, p. 454-460.

Glynn, P.D., and Parkhurst, D.L., 1992, Modeling non-ideal solid-solution aqueous-solution re- actions in mass transfer computer codes, in Kharaka, Y.K., and Maest, A.S., eds., Proceedings of the 7th International Symposium on Water-Rock Interaction, July 9-23, 1992, Park City, Utah: Rotterdam, The Netherlands, A.A. Balkema, p. 175-179.

Glynn, P.D., and Reardon, E.J., 1990, Solid-solution aqueous-solution equilibria: Thermodynamic theory and representation: American Journal of Science, v. 290, p. 164-201.

1992, Reply to a Comment by Knigsberger, E., and Gamsjger, H., on Solid-solution aqueous-solution equilibria-Thermodynamic theory and representation: American Journal Science, v. 292 , p. $215-225$.

Glynn, P.D., Reardon, E.J., Plummer, L.N., and Busenberg, E., 1990, Reaction paths and equilibrium end-points in solid-solution aqueoussolution systems: Geochimica et Cosmochimica Acta, v. 54, p. 267-282.

1992, Reply to Dr. Stoessell's comment on Reaction paths and equilibrium end-points in solid-solution aqueous-solution systems: Geochimica Cosmochimica Acta, v. 56, p. 25592572.

McCartan, L., Plummer, L.N., Hosterman, J.W., Busenberg, E., Dwornik, E.J., Duerr, A.D., Miller, R.L., and Kiesler, J.L., in press, Celestine $\left(\mathrm{SrSO}_{4}\right)$ in Hardee and De Soto Counties, Florida, in Gohn, G.S., ed., Proceedings of the 1988 U.S. Geological Survey Workshop on the Geology and Geohydrology of the Atlantic Coastal Plain: U.S. Geological Survey Circular 1059, p. 129-137.

Nordstrom, D.K., Plummer, L.N., Langmuir, D., Busenberg, E., May, H.M., Jones, B.F., and Parkhurst, D.L., 1990, Revised chemical equilibrium data for major water-mineral reactions 


\section{GROUND-WATER CHEMISTRY}

and their limitations, in Melchoir, D.C., and Bassett, R.L., eds., Chemical modeling of aqueous systems II: American Chemical Society, American Chemical Society Symposium Series 416, Washington, D.C., p. 398-413.

Parkhurst, D.L., and Plummer, L.N., 1993, Geochemical Models, in Alley, W.M., ed., Regional Ground-water Quality: Van Nostrand Reinhold, chap. 9, p. 199-225.

Plummer, L.N., 1992, Geochemical ModelingPast, Present, Future, in Kharaka, Y.K., and Maest, A.S., eds., Proceedings of the 7th International Symposium on Water-Rock Interaction, July 9-23, 1992, Park City, Utah: Rotterdam, The Netherlands, A.A. Balkema, p. 23-33.

Plummer, L.N., 1993, Stable isotope enrichment in paleowaters of the southeast Atlantic Coastal Plain, U.S.A.: Science, v. 262, p. 2016-2020.

Plummer, L.N., Busby, J.F., Lee, R.W., and Hanshaw, B.B., 1990, Geochemical modeling of the Madison aquifer in parts of Montana, Wyoming, and South Dakota: Water Resources Research, v. 26, no. 9, p. 1981-2014.

Plummer, L.N., and Busenberg, E., 1993, CFC'sTools for Age-Dating and Tracing Shallow Ground Water: U.S. Geological Survey Yearbook Fiscal Year 1992, p. 45-47.

Plummer, L.N., and Busenberg, E., in press, Chlorofluorocarbons (CFC's) as tracers and agedating tools for young ground water-Selected field examples, in Joint U.S. Geological Survey, U.S. Nuclear Regulatory Commission Workshop on "Research Related to Low-Level Radioactive Waste Disposal," May 4-6, 1993, Reston, Va., [Proceedings].
Plummer, L.N., Busenberg, E., Glynn, P.D., and Blum, A.E., 1992, Dissolution of aragonitestrontianite solid solutions in non-stoichiometric $\mathrm{Sr}\left(\mathrm{HCO}_{3}\right)_{2}-\mathrm{Ca}\left(\mathrm{HCO}_{3}\right)_{2}-\mathrm{CO}_{2}-\mathrm{H}_{2} \mathrm{O}$ solutions: Geochimica Cosmochimica Acta, v. 56, no. 7 , p. 3045-3072.

Plummer, L.N., Dunkle, S.A., and Busenberg, E., 1993, Data on chlorofluorocarbons (CC13F and $\mathrm{CC} 12 \mathrm{~F} 2$ ) as dating tools and hydrologic tracers in shallow ground water of the Delmarva Peninsula: U.S. Geological Survey, Open-File Report 93-484, 56 p.

Plummer, L.N., Michel, R.L., Thurman, E.M., and Glynn P.D., 1993, Environmental Tracers for age-dating young ground water, in Alley, W.M., ed., Regional Ground-water Quality: Van Nostrand Reinhold, chap. 11, p. 255-294.

Plummer, L.N. and Parkhurst, D.L., 1990, Application of the Pitzer Equations to the PHREEQE geochemical model, in Melchoir, D.C., and Bassett, R.L., eds., Chemical modeling of aqueous systems II: American Chemical Society, American Chemical Society Symposium Series 416, Washington, D.C., p. 128-137.

Plummer, L.N., Prestemon, E.C., and Parkhurst, D.L., 1991, An interactive code (NETPATH) for modeling NET geochemical reactions along a flow PATH: U.S. Geological Survey WaterResources Investigations Report 91-4078, 227 p.

1992, NETPATH-An interactive code for interpreting NET geochemical reactions from chemical and isotopic data along a flow PATH, in Kharaka, Y.K., and Maest, A.S., eds., Proceedings of the 7th International Symposium on Water-Rock Interaction, July 9-23, 1992, Park City, Utah: Rotterdam, The Netherlands, A.A. Balkema, p. 239-242. 


\section{GROUND-WATER CHEMISTRY}

Reilly, T.E., Plummer, L.N., Phillips, P.J., and Busenberg, E., 1994, Estimation and corroboration of shallow ground-water flow paths and travel times by environmental tracer and hydraulic analyses-A case study near Locust Grove, Maryland: Water Resources Research, v. 30 , no. 2 , p. $421-433$.

Shapiro, A.M., Wood, W.W., Busenberg, E., Drenkard, S., Plummer, L.N., Torgersen, T., and Schlosser, P., in press, Conceptual model for estimating regional fluid velocity in the bedrock of the Mirror Lake area, Grafton County, New Hampshire, in Mallard, G.E., and Aronson, D.A., eds., U.S. Geological Survey Toxic Substances Hydrology Program-Proceedings of the technical meeting, Colorado Springs, Colo., September 20-24, 1993: U.S. Geological Survey Water-

Resources Investigations Report 91-4014.

Vacher, H.L., Bengtsson, T.O., and Plummer, L.N., 1990, Hydrology of meteoric diagenesis-Residence time of meteoric ground water in island fresh-water lenses with application to aragonite-calcite stabilization rate in Bermuda: Geological Society of America, v. 102, p. 223-232. 


\section{GROUND-WATER CHEMISTRY}

TITLE: Physical Chemistry of Stable Isotope Fractionation in Hydrologic Processes (NR 75-064)

PERSONNEL: Tyler B. Coplen, Project Chief Paula McMahon, Secretary Johnkarl Böhlke, Hydrologist Jeanne Jaseschke, Physical Scientist Janet Hannon, Phy. Sci. Technician Robert L. Michel, Research Chemist Kinga M. Revesz, Chemist Jessica A. Hopple, Chemist Joe D. Wildman, Electronics Technician Janet Prosser, Phy. Sci. Technician Rebecca Carmody, Phy. Sci. Aid Mark A. Farnsworth, computer clerk K. Christiana Grim, PST, Student, William and Mary, Williamsburg, Va.

Casey Peele, Student, Elizabeth City State University, N.C.

Marisa Morgan, PST, Student, Virginia Tech, Blacksburg, Va.

Dyane Kim, PST (ECO), Student, Univer. of Virginia, Charlottesville, Va.

Janette Prosser, PST, South Lakes High School

Volunteers:

Professor H. Steffen Peiser (retired)

Michael E. O'Connell, Graduate Student

Wendy Coplen, Herndon High School

David Rosenthal, So. Lakes High School

Jeffrey Boyce, Elmira College, Elmira, N.Y.

ADDRESS: U.S. Geological Survey

431 National Center

12201 Sunrise Valley Drive

Reston, VA 22092

TELEPHONE: (703) 648-5873

PROBLEM: Several light stable isotopes $(\mathrm{H}, \mathrm{C}, \mathrm{N}, \mathrm{O}, \mathrm{Si}$, and $\mathrm{S}$ ) show variations in their isotope abundances and offer great promise for study of evaporation, ground-water mixing, biotransformations, lake or reservoir circulation and stratification, and associated hydrochemical phenomena. These isotope fractionations are related to: (1) purely physical processes; (2) heterogeneous chemical equilibria; and (3) reaction kinetics. Many of these processes are not sufficiently understood or quantified to make the most effective use of stable isotope techniques in hydrologic research.

OBJECTIVE: Develop theoretical and instrumental mass spectrometric techniques through experimental investigation, and test in suitable field locations, such as internontane ground-water reservoirs, closed-lake basins, and suitable surface reservoir, lake, ground water, or estuarine systems, to aid in more complete utilization of light stable-isotope phenomena in hydrologic studies. 


\section{GROUND-WATER CHEMISTRY}

APPROACH: Water and mineral samples from experimental studies, from evaporating surface water bodies, and from ground-water basins, will be analyzed for light stable isotope abundances. These experimental results and field data will then be related to other measurement factors such as relative humidity, temperature, density, and water chemistry, in an attempt to develop an understanding and a theoretical predictive model of the processes involved.

PROGRESS: Continuing studies involving the nitrogen isotope laboratory, whose chief is J.K. Böhlke, fall mainly into two major categories: (1) exploring methods and field applications of nitrogen isotope analyses in hydrogeology, and (2) using a variety of isotopic, chemical, and chronologic data to assess the history and fate of nitrate contamination in selected ground water-surface water systems. In support of these studies, we have produced relevant data for a variety of soil and organic solids, dissolved ammonium, nitrate, nitrite, and nitrogen gas in waters, and nitrogen in mixed gases.

Major effort has been given to several collaborative field projects investigating the fate of nonpoint source nitrate contamination along ground water flow paths in diverse hydrogeologic settings, and involving the use of a wide variety of geochemical and isotopic analytical tools. A manuscript was completed describing flow-path studies in eastern Maryland (with J.M. Denver), and the major parts of field collection and laboratory analysis were completed for similar studies in Minnesota and Colorado (with R. Wanty, P. McMahon, and others). Those studies are aimed in part at defining hydrogeologic controls of nitrate-reducing reactions and developing criteria for distinguishing the effects of those reactions from the effects of varying nitrate recharge rates on the distribution of nitrate in aquifers. Manuscripts describing parts of an ongoing investigation of natural and anthropogenic nitrate occurrences in the Mojave Desert in southern California have been approved for publication (with G. Ericksen, R. Schroeder, and others).

Under the direction of J.K. Böhlke, isotopic analyses were done in support of an in situ tracer test on the rate of denitrification in ground water at the Cape Cod Toxics Program site (with R.L. Smith, T. Yoshinari, and M. Brooks). K. Revesz developed a laboratory method to extract and separate nitrous oxide and nitrogen gas from ground waters from this tracer test. The $\mathrm{N}-15$ spike added to the aquifer as nitrate was detected in decreasing amounts as nitrate, nitrite, nitrous oxide, and nitrogen gas after 2 to 4 weeks in the aquifer. Isotopic mass balances will be used to calculate the rates at which the individual reaction steps occurred in the denitrification process. 


\section{GROUND-WATER CHEMISTRY}

Isotopic analyses were done as part of an investigation of the relations between stream chemistry and ground-water discharge during a major storm event in the Maryland coastal plain (with K. Prestegaard and students at the University of Maryland). The results indicate the relative contributions of various kinds of macropore flow and overland flow to stream flow in different parts of a small but heterogeneous watershed.

A year-long study was initiated on the use of radioactive and stable isotopes to determine the mass balances and residence times of sulfate in two small undeveloped watersheds in northern Virginia (with R. Michel, A. O'Brien, and others). Preliminary results indicate substantial but different residence times for the two adjacent stream drainages.

An international intercomparison test of seven nitrogen isotope reference materials was completed and the results were presented to the IAEA; a manuscript summarizing the results is in review.

In a study at the crude oil spill at Bemidji, Minnesota, Kinga Revesz analyzed carbon, hydrogen, and oxygen stable isotope abundances of methane and coexisting carbon dioxide and water from the ground water and from the unsaturated zone soil gas above the crude-oil lens. These data showed that major methane production was occurring in the saturated zone through an acetate fermentation pathway and major methane consumption was occurring in the unsaturated zone 3 meters below the surface. Two papers resulted: "Methane production and consumption monitored by stable hydrogen and carbon isotope ratio at Bemidji, Minnesota" by K. Revesz, T. Coplen and M.J. Baedecker, to be published in a USGS Toxic Substances Hydrology Program Proceedings, and "Methane Production and Consumption Monitored by Stable Hydrogen and Carbon Isotope Ratios at a Toxic Waste Site, Bemidji, Minnesota" by K. Revesz, T. Coplen. M.J. Baedecker, P.D. Glynn, to be submitted to Applied Hydrology.

First results from the U.S.-Hungarian Science and Technology program, whose U.S. principal investigator is $\mathrm{K}$. Revesz, show that most of the ground water within $20 \mathrm{~km}$ of the Danube is river water and it contains a preserved record of river contamination (with CFC's) spanning a period of 40 to 50 years. The specific objectives of this program are: (1) to test the combined use of CFC's, tritium, and light stable isotope abundances to estimate flow rates, mixing ratios, and leakage of ground water recharged from the Danute into the adjoining gravel aquifer, (2) to investigate possible denitrification of Danube River water as it enters the gravel aquifer, and (3) to forecast the effects of potential changes in the stage of the Danube on the flow and chemistry of ground water in the gravel aquifer. These studies 


\section{GROUND-WATER CHEMISTRY}

indicate that this aquifer is a "ground water archive" of past contamination, relating ground-water recharge and contaminant histories. Two abstracts have been published.

A cooperative study between $\mathrm{B}$. Katz and $\mathrm{K}$. Revesz is aimed at investigating the interaction between ground-water and lake-water leakage at Lake Barco in northern Florida. One paper and one abstract have been written thus far.

In a technology transfer program, a multisample automated gaseous hydrogen-water equilibration technique developed in this project for the analysis of Division water samples has proven ideal for the analysis of urine from individuals with diabetes by the National Institutes of Health. Other isotopic methods have given poor reproducibility, perhaps due to albumin in urine from diabetic individuals.

Leading to publication in the journal Science, Devils Hole carbon-13 studies (with I. Winograd, A. Riggs, and J. Landwehr) show C-13 minima in calcite that precipitated between 560 and 60 thousand years ago. This may reflect periods of enhanced vegetation in the southern Great Basin and(or) periods with low global carbon-13 content.

R. Carmody has studied and tested techniques for collection of dissolved sulfide and sulfate and analysis of their sulfur isotopic composition. Field procedures outlined in two nearlycompleted reports produce sufficiently large, unfractionated samples suitable for isotopic analysis. Improved data that have resulted from adherence to these methods have made important contributions to the understanding of hydrologic systems in eastern Maryland and in the Mill Run watershed, Virginia.

During the past year, the U.S. Geological Survey Tritium Laboratory, under the supervision of R. Michel, has continued to study the application of tritium and sulfur-35 to hydrologic systems. Approximately 1000 tritium samples and 100 sulfur-35 samples were analyzed during the past year. Tritium analyses were provided for the Branch of Analytical Services, other projects within the NRP, and precipitation and surface water samples collected from the long-term monitoring sites that the Laboratory has operated since the 1960's. These sites provide the basis for interpreting data collected in other programs. Sulfur-35 samples were collected in cooperative programs with district and(or) WEBB sites in Vermont, New York, Virginia, Colorado and Utah. Several papers on the results of these analyses were published or accepted during the past year. 


\section{GROUND-WATER CHEMISTRY}

\section{REPORTS PUBLISHED 1989-1994:}

Böhlke, J.K., Gwinn, C.J., and Coplen, T.B., 1993, New reference materials for nitrogenisotope-ratio measurements: Geostandards Newsletter, v. 17, p. 159-164.

Böhlke, J.K., and Irwin, J.J., 1992, Laser microprobe analyses of noble gas isotopes and halogens in fluid inclusions-Analyses of microstandards and synthetic inclusions in quartz: Geochimica et Cosmochimica Acta, v. 56, p. 187-201.

1992, Brine history indicated by argon, krypton, chlorine, bromine, and iodine analyses of fluid inclusions from the $\mathrm{Pb}$-fluorite deposits at Hansonburg, New Mexico: Earth and Planetary Science Letters, v. 110, p. 51-66.

1992, Laser microprobe analyses of $\mathrm{Cl}, \mathrm{Br}, \mathrm{I}$, and $\mathrm{K}$ in fluid inclusions-Implications for sources of salinity in some ancient hydrothermal fluids: Geochimica et Cosmochimica Acta, v. 56, p. 203-225.

Böhlke, J.K., and Shanks, W.C., III, in press, O, $\mathrm{H}$, and $\mathrm{S}$ isotope study of hydrothermal vents at Escanaba Trough, northeast PacificObserved and calculated effects of sedimentseawater interaction: U.S. Geological Survey Bulletin 2202.

Cecil, L.D., Pittman, J.R., Beasley, T.M., Michel, R.L., Kubik, P.W., Sharma, P., Fehn, U., and Gove, H.E., 1992, Water infiltration in the unsaturated zone at the Idaho National Engineering Laboratory estimated from chlorine-36 and tritium profiles, and neutron logging, in Kharaka, Y.K., and Maest, A.S., eds., Proceedings of the 7th International Symposium on Water-Rock Interaction, July 9-23, 1992, Park City, Utah: Rotterdam, The Netherlands, A.A. Balkema, p. 709-714.
Coplen, T.B., 1993, Uses of environmental isotopes, in Alley, W.M., ed., Regional groundwater quality: New York, Van Nostrand Reinhold, p. 227-254.

1994, Reporting of stable hydrogen, carbon, and oxygen isotopic abundances: Pure and Applied Chemistry, v. 66, p. 273-276.

in press, Reporting of stable carbon, hydrogen, and oxygen isotopic abundances, in Stichler, W., ed., Counsultants' meeting on stable isotope standards and intercalibration: Vienna, International Atomic Energy Agency.

Coplen, T.B., Greenwood, N.N., and Peiser, H.S., 1994, Table of standard atomic weights abridged to five significant figures: Inorganica Chemica Acta, v. 217, p. 217-218.

Coplen, T.B., and Harper, I.T., in press, An improved technique for the $2 \mathrm{H} / 1 \mathrm{H}$ analysis of urines from diabetic volunteers: Biological Mass Spectrometry, v. 00.

Coplen, T.B., Krouse, H.R., and Böhlke, J.K., 1992, Reporting of nitrogen-isotope abundances: Pure and Applied Chemistry, v. 64, p. 907-908.

Coplen, T.B., Wildman, J.D., and Chen, J., 1991, Improvements in the gaseous hydrogen-Water equilibration technique for hydrogen isotoperatio analysis: Analytical Chemistry, v. 63, p. 910-912.

Davis, G.H., and Coplen, T.B., 1989, Late Cenozoic paleohydrogeology of the Western San Joaquin Valley, California, as related to structural movements in the Central Coast Ranges: Geological Society of America Special Paper 234, $40 \mathrm{p}$. 


\section{GROUND-WATER CHEMISTRY}

Dunkle, S.A., Plummer, L.N., Busenberg, E., Phillips, P.J., Denver, J.M., Hamilton, P.A., Michel, R.L., and Coplen, T.B., 1993, Chlorofluorocarbons $\left(\mathrm{CCl}_{3} \mathrm{~F}\right.$ and $\left.\mathrm{CCl}_{2} \mathrm{~F}_{2}\right)$ as dating tools and hydrologic tracers in shallow ground water of the Delmarva Peninsula, Atlantic Coastal Plain, U.S.A.: Water Resources Research, v. 12, p. 3837-3860.

Ekwurzel, Brenda, Schlosser, Peter, Smethie, Jr., W.M., Plummer, L.N., Busenberg, Eurybiades, Michel, R.L., Weppernig, Ralf, and Stute, Martin, 1994, Dating of shallow groundwater: Comparison of the transient tracers $3 \mathrm{H} / 3 \mathrm{He}$, chlorofluorocarbons, and ${ }^{85} \mathrm{Kr}$ : Water Resources Research, v. 30, no. 6, p. $1693-1708$.

Evans, W.C., White, L.D., Tuttle, M.L., Kling, G.W., Tanyileke, G., and Michel, R.L., in press, Six years of change at Lake Nyos, Cameroon, yield clues to the past and cautions for the future: Geochemistry, v. 00 .

Irwin, J.J., and Böhlke, J.K., 1991, Microanalysis of trace elements and noble gas isotopes in minerals and fluid inclusions, in Howitt, D.G., ed., Microbeam Analysis-1991: Microbeam Analysis Conference, 26th, San Francisco Press, p. 35-40.

Izbicki, J., Michel, R.L., and Martin, P., 1992, $\mathrm{H}-3$ and $\mathrm{C}-14$ as tracers of ground-water recharge, in Proceedings of the American Society of Civil Engineers 1992 National Conference: p. 122-127.

Kendall, C., and Grim, E., 1990, Combustion tube method for measurement of nitrogen isotope ratios using calcium oxide for total removal of carbon dioxide and water: Analytical Chemistry, v. 62., p. 526-529.
Keir, R.S., and Michael, R.L., 1993, Interface dissolution control of the ${ }^{14} \mathrm{C}$ profile in marine sediment: Geochemica et Cosmochemica Acta, v. 57 , p. $3563-3574$.

Keir, R.S., and Michael, R.L., and Weiss, R.F., 1992 , Ocean mixing versus gas exchange in Antarctic shelf waters near $150^{\circ}$ E: Deep-Sea Research, v. 39, p. 97-119.

Landwehr, J.M., Winograd, I.J., and Coplen, T.B., 1994, No verification for Milankovitch: Nature, v. 368, p. 594.

Landwehr, J.M., Winograd, I.J., Coplen, T.B Riggs, A.C., Ludwig, K.R., and Szabo, B.J., 1993 , Stochastic analysis of delta ${ }^{18} \mathrm{O}$ and delta ${ }^{13} \mathrm{C}$ time series found in a continuous 500 , vi:(0)year climatic record from Great Basin vein calcite, in Proceedings of the U.S. Geologiv: Survey Global Change Forum: U.S. Geological Survey Circular 1086, 86 p.

Michel, R.L., 1989, Tritium deposition over the continental United States, 1953-1983, in Delleur, J.W., ed., Atmospheric Deposition Symposium-Proceedings of the Third Scientific Assembly of the International Association of Hydrological Sciences: Baltimore, Md., p. 109-115.

1989, Tritium Deposition in the Continental United States: U.S. Geological Survey WaterResources Investigation Report 89-4072, 46 p.

1992, Residence times in river basins as determined by analyses of long-term tritium records: Journal of Hydrology, v. 130, p. 367378.

Michel, R.L., Busenberg, E., Plummer, L.N., Izbicki, J.A., Martin, P., and Densmore, J.N., in press, Use of tritium and chlorofluorocarbons to evaluate the rate of seawater 


\section{GROUND-WATER CHEMISTRY}

intrusion in a coastal aquifer system, in Proceedings of the 13th Salt Water Intrusion Conference, Cagliari, Italy, June, 1994.

Michel, R.L., Hamlin, S.N., and Phillips, S.P., 1994, Recharge rates and changes in groundwater quality in a shallow unconfined aquifer in Western San Francisco, in Hasfurther, V., and Marston, R.A., eds., Proceedings of the AWRA Symposium on Effects of HumanInduced Changes on Hydrologic Systems: $p$. 841-850.

Michel, R.L., and Schroeder, R.A., 1990, Stable Isotope Results, Wilkes Land Oceanographic Expedition, Antarctic Journal of the United States, v. 25, p. 107-109.

1994, Use of long-term tritium records from the Colorado River to determine timescales for hydrologic processes associated with irrigation in the Imperial Valley, California: Applied Geochemistry, v. 9, p. 387-401.

Naftz, D.L., Michel, R.L., and Miller, K.A., 1993, Isotopic indicators of climate in ice cores, Wind River Range, Wyoming, in Swart, P.K., Lohman, K.C., McKenzie, J., and Savin, S., eds., Climate Change in Continental Isotopic Records, Geophysical Monograph 78, p. 55-66.

Plummer, L.N., Michel, R.L., Thurman, E.M., and Glynn, P.D., 1993, Environmental tracers for age-dating young ground water, in Alley, W.M., ed., Regional ground-water quality: New York Van Nostrand Reinhold, p. 255294.

Revesz, K., and Coplen, T.B., 1990, Gas chromatographic separation of carbon dioxide and nitrous oxide for stable isotopic analysis of carbon dioxide: Analytical Chemistry, v. 62, p. 972-973.

1991, Caution on the use of Viton or FETFE O-rings in carbon dioxide sample containers for delta ${ }^{18} \mathrm{O}$ analysis: Chemical Geology (Isotope Geoscience Section), v. 86, p. 259261.

Revesz, K., and Woods, P., 1990, A method to extract soil water for stable isotope analysis: Journal of Hydrology, v. 115, p. 397-406.

Schroeder, R.A., Martin, P., and Böhlke, J.K., in press, Chemical, isotopic, and microbiological evidence for denitrification during transport of domestic wastewater through a thick aerobic unsaturated zone in the Mojave Desert: U. S. Geological Survey, Toxic Substances Hydrology Program.

Sturchio, N.C., Böhlke, J.K., and Markun, F.J., 1993, Radium isotope geochemistry of thermal waters, Yellowstone National Park, Wyoming: Geochimica et Cosmochimica Acta, v. 57, p. 1203-1214.

Wanty, R.B., Tuttle, M.L., Landon, M.K., Delin, G.N., and Böhlke, J.K., in press, Geochemistry of nitrogen in a farmed watershed near Princeton, central Minnesota, in Morganwalp, D.W., and Aronson, D.A., eds., U.S. Geological Survey Toxic Substances Hydrology Program-Proceedings of the technical meeting, Colorado Springs, Colo., September 20-24, 1993: U.S. Geological Survey Water-

Resources Investigations Report 94-4014.

Winograd, I.J., and Coplen, T.B., 1989, Comment on Johnson, R.G., and Wright, H.E., Jr., Great Basin calcite vein and the Pleistocene time scale: Science, v. 246, p. 262-263.

Winograd, I.J., Coplen, T.B., Landwehr, J.M., Riggs, A.C., Ludwig, K.R., Szabo, B.J., Kolesar, P.T., and Revesz, K.M., 1992, Continuous 500,000-year global climatic record from vein calcite in Devils Hole, Nevada: Science, v. 258, p. 255-260. 


\section{GROUND-WATER CHEMISTRY}

TITLE: Hydrogeochemical Controls on the Migration of Radionuclides from Uranium Mill Tailings (NR 78-092)

PERSONNEL: Edward R. Landa, Project Chief

C.L. Wakelee, Secretary

T.B. Councell, Hydrologist

ADDRESS: $\quad$ U.S. Geological Survey

430 National Center

12201 Sunrise Valley Drive

Reston, VA 22092

TELEPHONE: (703) 648-5898

PROBLEM: Uranium mill tailings and related forms of low-level radioactive waste contain elevated contents of naturally occurring radionuclides that have been brought to the surface, processed for the recovery of uranium and other components, and then disposed of in near-surface impoundments. The long-term fate of the tailings and their constituents will be determined by surficial earth processes.

OBJECTIVE: Study the chemical form in which radionuclides and selected stable elements are retained in surficial earth materials, particularly uranium mill tailings, and identify processes operating in natural aqueous and terrestrial systems that may influence the transport of these constituents from these earth materials.

APPROACH: Determine the partitioning of nuclides and elements of interest in tailings, ores, soils, rocks, and waters through the use of leaching and sorption studies, particle sizing, radon emanation measurements, and nuclear emulsion microscopy.

PROGRESS: Nuclear emulsion microscopy has demonstrated the presence of small, intensely $\boldsymbol{\alpha}$-active particles in laboratory-produced tailings derived from the sulfuric acid milling of uranium ores. The alpha activity is associated with the isotope pair ${ }^{210} \mathrm{~Pb} /{ }^{210} \mathrm{Po}$, and the host mineral appears to be $\mathrm{PbSO}_{4}$ occurring as inclusions in gypsum laths.' These particles represent potential inhalation hazards at uranium mill tailings disposal areas.

A process for concentrating uranium from contaminated soils in which the uranium is first extracted with bicarbonate and then the extracted uranium is precipitated with U(VI)-reducing microorganisms was evaluated for a variety of uranium-contaminated soils. Bicarbonate (100 


\section{GROUND-WATER CHEMISTRY}

$\mathrm{mM}$ ) extracted 20 to 94 percent of the uranium that was extracted with nitric acid. The U(VI)-reducing microorganisms, Desulfovibrio desulfuricans reduced the U(VI) to U(IV) in the bicarbonate extracts. In some instances unidentified dissolved extracted components, presumably organics, gave the extract yellow color and inhibited U(VI) reduction and/or the precipitation of U(IV). Removal of the dissolved yellow material with the addition of hydrogen peroxide alleviated this inhibition. These results demonstrate that bicarbonate extraction of uranium from soil followed by microbial U(VI) reduction might be an effective mechanism for concentrating uranium from some contaminated soils.

\section{REPORTS PUBLISHED 1989-1994:}

Back, W., and Landa, E.R., 1992, Ingesting the consequences of water-rock interaction-Historical notes on bottled water and spas: in Kharaka, Y.K., and Maest, A.S., eds., Proceedings of the 7th International Symposium on Water-Rock Interaction, July 9-23, 1992, Park City, Utah: Rotterdam, The Netherlands, A.A. Balkema, p. 767-770.

Landa, E.R., 1991, Radon emanation from uranium mill tailings, in Field Studies of Radon in Rocks, Soils and Water: U.S. Geological Survey Bulletin 1971, p. 145-154.

1991, Uranium mill tailings-Radium geochemistry, in U.S. Geological Survey research in radioactive waste disposal, Fiscal years 19861990: Water-Resources Investigations Report 91-4084, p. 88-90.

1991 , Leaching of ${ }^{226} \mathrm{Ra}$ from components of uranium mill tailings: Hydrometallurgy, v. 26, p. 361-368.

1992, The International Chernobyl Project: World Meteorological Organization Bulletin, v. 41 , no. 1 , p. 63-66.

1993, A brief history of the American radium industry and its ties to the scientific communi- ty of the early twentieth century: Environment International, v. 19, p. 503-508.

Landa, E.R., in press, Geochemical and biogeochemical aspects of uranium mill tailings disposal-recent studies: Society of Economic Geologists Special Publication, v. 00.

Landa, E.R., and Bush, C.A., 1990, Geochemical hosts of solubilized radionuclides in uranium mill tailings: Hydrometallurgy, v. 24, p. 361372.

Landa, E.R., and Councell, T.B., 1992, Leaching of uranium from glass and ceramic foodware and decorative items: Health Physics, v. 63, p. 343-348.

Landa, E.R., and DiSantis, D.J., 1993, A brief history of radioactive glassware, Radiographics, Medical Journal, Radiological Society of North America, v. 13, p. 697-699.

Landa, E.R., Perkin, R.G., and Grantz, A., 1993, Sampling for possible radionuclide contamination of Russian origin in the Canada Basin region, in Grantz, A., ed., Cruise report and preliminary results, U.S. Geological Survey Cruise P1-93-AR, Northwind Ridge and Canada Basin, Arctic Ocean abroad USCGC POLAR STAR, August 16-September 15, 


\section{GROUND-WATER CHEMISTRY}

1993: U.S. Geological Survey Open-File Report 93-389, p. 15-17.

Landa, E.R., Phillips, E.J.P., and Lovley, D.R., 1991, Release of ${ }^{226} \mathrm{Ra}$ from uranium mill tailings by microbial Fe(III) reduction: Applied Geochemistry, v. 6, p. 647-652.

Landa, E.R., Stieff, L.R., Germani, M.S., Tanner, A.B., and Evans, J.R., in press, Intense alphaactive crystallites in uranium mill wastes:

Nuclear Geophysics, v. 00.

Lovley, D.R., Phillips, E.J.P., Gorby, Y.A., and Landa, E.R., 1991, Microbial reduction of uranium: Nature, v. 350, p. 413-41.

1991, Microbial reduction of uranium, in Mallard, G.E., and Aronson, D.A., eds., U.S. Geological Survey Toxics Substances Hydrology Program-Proceedings of the technical meeting, Monterey, Calif., March 11-15, 1991: U.S. Geological Survey Water-

Resources Investigations Report 91-4034, p. 548-551.

Phillips, E.J.P., Landa, E.R., and Lovley, D.R., 1993, Extraction of uranium from soils and earth materials and its precipitation by microbial reduction-Proceedings of Soil Decon '93/Technology Targeting Radionuclides and Heavy Metals: Oak Ridge National Laboratory Report ORNL-6769, Section 36, 6 p. 


\section{GROUND-WATER CHEMISTRY}

TITLE: Dispersion of Toxic and Radioactive Wastes in Ground-Water Systems (NR 81-122)

PERSONNEL: Warren W. Wood, Project Chief

Melissa Schomody, Secretary

Terry B. Councell, Hydrologist

C.C. Reeves, Geologist

ADDRESS: U.S. Geological Survey

431 National Center

12201 Sunrise Valley Drive

Reston, VA 22092

TELEPHONE: (703) 648-5875

PROBLEM: Movement of toxic and radioactive substances in aquifer systems occurs in all gaseous, liquid, and solid phases and is controlled by hydrologic and chemical forces. Solute movement can be greatly affected not only by physical dispersion but also by other factors such as exchange, sorption, chemical kinetics, and ionic distributions. Movement of gases and particulate material in the unsaturated zone is controlled by many additional factors. Knowledge of how these physical and geochemical factors affect prediction of movement of toxic and radioactive wastes is only generally known for ideal systems.

OBJECTIVE: Develop field methods and techniques that will yield values for physical and geochemical factors of regional significance in a ground-water system.

APPROACH: Undertake studies in which appropriately developed field methods and techniques are applied to stressed systems. Define the importance of the various factors and find a means for measuring the magnitude of each.

PROGRESS: Quantifying diffusion in granite and schist documents its importance in solute transport and solute dating in fractured crystalline rocks.

Research with Alan Shapiro and Paul Hsieh on diffusion in granites and schists at the fractured rock toxic waste research site at Mirror Lake, New Hampshire, clearly documented the significant role of diffusion in these rocks and illustrates the care one must take in using dating techniques in rocks of this type. Initial findings are in press of the proceeding of the Toxic waste program (1993), an abstract was given at the Geological Society of America 


\section{GROUND-WATER CHEMISTRY}

(GSA) national meeting in Boston, Massachusetts, 1993; and a detailed publication for submission to Water Resources Research is in preparation.

Ground water solute chemistry of a low permeability system in West Texas constrains paleoclimate models in the midcontinent area for the last 35,000 years.

A paper has been submitted to Geology on the paleohydrology of our research saline lake basin in West Texas. This paper documents the changes in solute chemistry in a low permeability shale and by inference the climatic changes that occurred in the mid-continent region over the last 30,000 years.

How wet is wet? Paleohydrology of the Arabian subcontinent.

Water is a major factor in the Middle East peace process and work with Jeff Imes (Missouri District) on the paleo-rainfall in the Arabian Subcontinent is important in this evaluation. We have radiocarbon dated and mapped the topography of a 28,000 year old paleo-capillary zone. Ground-water modeling suggests that $1.4 \mathrm{~mm} / \mathrm{yr}$ of recharge would be required to support this surface. Given the relationship between rainfall and recharge in arid areas we are able to estimate that rainfall during this period was approximately $200 \mathrm{~mm} / \mathrm{yr}$ or 5 times the present rainfall. This is the first time that paleo-rainfall has been quantified in this environment as it is usually referred to as "wet or pluvial." A paper has been accepted by Journal of Hydrology describing this work.

The use of isotopes and solutes to evaluate recharge in the unsaturated zone of arid and semi arid areas. Work with Ward Sanford generated a paper on the use of isotopes to evaluate recharge in semiarid areas which has been accepted by Ground Water for publication. Warren Wood was a featured speaker at the Playa Lake Symposium in Lubbock, Texas, in May 1994. This paper was published in June.

Use of ${ }^{14} \mathrm{C}$ dating to constrain ground water flow modes. A paper has been accepted by IAEA on work that we have done using radiocarbon dating of water to constrain the estimates of velocity of ground water in the Pearl Harbor aquifer in Hawaii. The aquifer is a carbonate free basalt and poorly constrained by knowledge of the physical properties and appears a suitable candidate to use ${ }^{14} \mathrm{C}$ dating. However, the effects of blind pore diffusion are difficult to evaluate and the analysis in not straight forward. 


\section{GROUND-WATER CHEMISTRY}

\section{Chromium in Ground Water of Abu Dhabi}

Over 20 percent of my time this past year was spent on the USGS/Abu Dhabi cooperative program. A potential natural hazard in which concentration of hexavalent $\mathrm{Cr}$ (500 to 1000 $\mathrm{ug} / \mathrm{L}$ ) in ground water was used as public supply was identified. The findings were transmitted by the U.S. Ambassador to the Abu Dhabi government officials who immediately shut down the wells. Water is now being trucked $200 \mathrm{~km}$ to supply 11,000 people until a desalinization system can be constructed at a cost of $\$ 0.5$ billion.

\section{REPORTS PUBLISHED 1989-1994:}

Back, William, Baedecker, M.J., and Wood, W.W., 1993, Scales in chemical hydrogeology-A historical perspective, in Alley, W.M., ed., Regional Ground-Water Quality: New York, Van Nostrand Reinhold, 634 p.

Goode, D. J., Hsieh, P. A., Shaprio, A. A., Wood, W. W., and Kraemer, T. F., 1993, Concentration history during pumping from a leaky aquifer with stratified initial concentration, Proceedings of the National Conference on Hydraulic Engineering: American Society of Civil Engineers, p. 29-35.

Le Blanc, D.R., Garabedian, S.P., Hess, K.M., Gelhar, L.W., Quadri, R.D., Stollenwerk, K.G., and Wood, W.W., 1991, Large-scale natural-gradient tracer test in sand and gravel, Cape Cod, Massachusetts-1. Experimental design and observed tracer movement: Water Resources Research, v. 27, no. 5, p. 895-910.

Rosenshein, J.S., Moore, J.E., and Wood, W.W., 1991, Hydrogeology: Geotimes, v. 36, no. 2 , p. 51-52.

Sanford, W.E., and Wood, W.W., 1991, Brine evolution and mineral deposition in hydrologically open evaporite basins: American Journal of Science, v. 291, p. 687-710.
Sanford, W.E., Wood, W.W., and Councell, T.B., 1992, Calcium chloride-dominated brines-An ion-exchange model, in Kharaka, Y.K., and Maest, A.S., eds., Proceedings of the 7th International Symposium on Water-Rock Interaction, July 9-23, 1992, Park City, Utah:

Rotterdam, The Netherlands, A.A. Balkema, p. 669-672.

Shapiro, A.M, Wood, W.W, Busenberg, E., Drenkard, S., Plummer, L.N. Torgersen, T., and Schlosser, P., in press, A conceptual model for estimating regional fluid velocity in the bedrock of the Mirror Lake area, Grafton County, New Hampshire, in Morganwalp, D.W., and Aronson, D.A., eds., U.S. Geological Survey Toxic Substances Hydrology Program-Proceedings of the technical meeting, Colorado Springs, Colo., September 20-24, 1993: U.S. Geological Survey WaterResources Investigations Report 94-4014.

Wood, W.W., 1989, Birdsall Lecture Report: Groundwater, v. 27, no. 5, p. 729-730.

1990, Case study: Solution and piping development of playa-lake basins on the Llano Estacado of Texas and New Mexico, in Charles, Higgins, ed., Groundwater Geomorphology, Piping and pseudokarst in drylands: 


\section{GROUND-WATER CHEMISTRY}

Geological Society of America Special Paper 252, chap. 4, p. 101-110.

Wood, W.W., in press, Diffusion in solute transport-Three scales of importance, Proceedings of the U.S. Geological Survey/U.S. Nuclear Regulatory Workshop, May 4-6, 1993 Reston, Va.

Wood, W.W., and Jones, B.F., 1990, Origin of solutes in saline lakes and springs on the Southern High Plains of Texas and New Mexico, in Gustavson, Thomas C. ed., Geologic Framework and Regional Hydrology: Upper Cenozoic Blackwater Draw and Ogallala Formations, Great Plains: Texas Bureau of Economic Geology, p. 193-208.

Wood, W.W., Kraemer, T.F., and Hearn P.P. Jr., 1990, Intergranular diffusion-An important mechanism influencing solute transport in clastic aquifers?: Science, v. 247, p. 15691572.

Wood, W.W., and Sanford, W.E., 1990, Groundwater control of evaporite deposition: Economic Geology, v. 85, p. 1226-1235.

Wood W.W., and Sanford, W.E., 1991, The origin of Evaporite deposits-A model based on a hydrologically open system, in Good, E.E., Slack, J.F., and Kotra, R.K., eds., Research on minerals resources-1991: U.S. Geological Survey Circular 1062, p. 79-80.

Wood, W.W., Sanford, W.E., and Reeves, C.C., 1992, Large lake basins of the southern High Plains-Ground-water control of their origin?: Geology, v. 20, p. 535-538.

Wood, W.W., Shapiro, A.M., and Councell, T.M., in press, Observational, experimental and inferred evidence from solute diffusion in fractured granite aquifers, Examples from the
Mirror Lake watershed, Grafton County, New Hampshire, in Morganwalp, D.W., and Aronson, D.A., eds., U.S. Geological Survey Toxic Substances Hydrology Program-Proceedings of the technical meeting, Colorado Springs, Colo., September 20-24, 1993: U.S. Geological Survey Water-Resources Investigations Report 94-4014. 


\section{GROUND-WATER CHEMISTRY}

TITLE: Comparative Study of Organic Degradation in Selected Hydrogeologic Environments (NR 83-129)

PERSONNEL: Mary Jo Baedecker, Project Chief

Isabelle M. Cozzarelli, Hydrologist

My-Chau Tran, Chemist

ADDRESS: $\quad$ U.S. Geological Survey

431 National Center

12201 Sunrise Valley Drive

Reston, VA 22092

TELEPHONE: (703) 648-5858

PROBLEM: Degradation of organic material produces organic compounds that both alter the quality of water and affect the inorganic reactions. The hydrogeologic controls on organic-inorganic reactions, their rates, and progress are not well understood. This project focuses on the occurrence and fate of organic compounds in (1) contaminated aquifers, (2) soils, and (3) lake sediments.

OBJECTIVE: Increase our understanding of reactions involving organic matter and evaluate the significance of these reactions in geochemical studies. Specific objectives are (1) to identify organic and inorganic compounds that are present as a result of the degradation of organic material; (2) to study the interaction of organic compounds with soil and aquifer materials; and (3) to develop geochemical models in organic-rich environments.

APPROACH: Several organic-rich environments with chemical and hydrologic background data will be selected from which samples can be obtained and analyzed for organic and inorganic constituents. In these areas, where degradative processes are primarily anaerobic, the extent and effects of chemical reactions and processes will be investigated. Of interest is the type of organic material present, the interaction of organic compounds with sediment, the migration of organic compounds, the fractionation of isotopes and generation of gases, and the fate of inorganic constituents in association with organic material.

PROGRESS: Field investigations and laboratory experiments were conducted to understand processes in shallow sand and gravel aquifers contaminated with petroleum products. Work continued on identifying the nature of the organic compounds dissolved in ground water and the controlling biogeochemical reactions that occur in contaminant plumes downgradient from 


\section{GROUND-WATER CHEMISTRY}

hydrocarbon sources. At the Bemidji, Minnesota, site the transport of monoaromatic hydrocarbons and the distributions of products that result from degradation reactions were examined on a small scale and the findings verify the chemical heterogeneity of the contaminant plume. The conditions that affect the extent of plume migration were evaluated and it was determined that natural biodegradation is the major control on contaminant attenuation.

At the Galloway Township, New Jersey, site an investigation of low-molecular-weight organic acids in ground water was undertaken to understand the distribution and fate of the acids under various geochemical and hydrologic conditions. Aliphatic, aromatic, and alicyclic organic acids were associated with hydrocarbon degradation in oxygen-depleted zones of the aquifer. The biogeochemical fate of specific organic acids observed in ground water was controlled by the availability of electron acceptors. Temporal and spatial shifts in the biogeochemical reactions occurred in response to changes in hydrogeochemical conditions in the aquifer.

\section{REPORTS PUBLISHED 1989-1994:}

Back, William, and Baedecker, M.J., 1989, Chemical hydrogeology in natural and contaminated environments: Journal of Hydrology, v. 106, p. 1-28.

Back, William, Baedecker, M.J., and Wood, W., 1993, Scales in chemical hydrogeology: An historical perspective, in Alley, W., ed., Regional Ground Water Quality: New York, Van Nostrand Reinhold, p. 111-129.

Baedecker, M.J., and Cozzarelli, I.M., 1991, Geochemical modeling of organic degradation reactions in an aquifer contaminated with crude oil, in Mallard, G.E., and Aronson, D.A., eds., U.S. Geological Survey Toxics Substances Hydrology Program-Proceedings of the technical meeting, Monterey, Calif., March 11-15, 1991: U.S. Geological Survey Water-Resources Investigations Report 914034, p. 627-632.
1992, The determination and fate of unstable constituents in contaminated ground water, in Lesage, S., and Jackson R., ed., Groundwater Quality and Analysis at Hazardous Waste Sites: New York, Marcel Dekker, Inc., p. 425-461.

1994, Biogeochemical processes and migration of aqueous constituents in ground water contaminated with crude oil, in Dutton, A.R., ed., Toxic Substances and the Hydrologic Sciences: American Institute of Hydrology, April 10-13, 1994, Austin, Texas, [Proceedings] p. 63.

Baedecker, M.J., Cozzarelli, I.M., Bennett, P.C., Eganhouse, R.P., and Hult, M.F., in press, Evolution of the contaminant plume in an aquifer contaminated with crude oil, Bemidji, Minnesota, in Morganwalp, D.W., and Aronson, D.A., eds., U.S. Geological Survey Toxic Substances Hydrology Program-Proceedings of the technical meeting, Colorado Springs, Colo., September 20-24, 1993: U.S. Geologi- 


\section{GROUND-WATER CHEMISTRY}

cal Survey Water-Resources Investigations Report 94-4014.

Baedecker, M.J., Cozzarelli, I.M., Eganhouse, R.P., Siegel, D.I., and Bennett, P.C., 1993, Crude oil in a shallow sand and gravel aquifer 3-Biogeochemical reactions and mass balance modeling in anoxic groundwater: Applied Geochemistry, v. 8, p. 569-586.

Baedecker, M.J., Cozzarelli, I.M., Evans, J.R., and Hearn, P.P., 1992, Authigenic mineral formation in aquifers rich in organic material in Kharaka, Y.K., and Maest, A.S., eds., Proceedings of the 7th International Symposium on Water-Rock Interaction, July 9-23, 1992, Park City, Utah: Rotterdam, The Netherlands, A.A. Balkema, p. 257-261.

Baedecker, M.J., Cozzarelli, I.M., and Phinney, C.S., 1991, Distribution of organic and inorganic constituents in ground water at Galloway Township, New Jersey, in Mallard, G.E., and Aronson, D.A., eds., U.S. Geological Survey Toxics Substances Hydrology Program-Proceedings of the technical meeting, Monterey, Calif., March 11-15, 1991: U.S. Geological Survey Water-Resources Investigations Report 91-4034, p. 287-293.

Bennett, P.C., Siegel, D.I., Baedecker, M.J., and Hult, M.F., 1993, Crude oil in a shallow sand and gravel aquifer-I. Hydrgeology and inorganic geochemistry: Applied Geochemistry, v. 8, p. 529-549.

Cozzarelli, I.M., and Baedecker, M.J., 1992, Oxidation of hydrocarbons coupled to reduction of inorganic species in groundwater, in Kharaka, Y.K., and Maest, A.S., eds., Proceedings of the 7th International Symposium on WaterRock Interaction, July 9-23, 1992, Park City, Utah: Rotterdam, The Netherlands, A.A. Balkema, p. 261-275. in press, Biogeochemical fate of organic acid metabolites produced during the microbial degradation of hydrocarbons in groundwater, in Morganwalp, D.W., and Aronson, D.A., eds., U.S. Geological Survey Toxic Substances Hydrology Program-Proceedings of the technical meeting, Colorado Springs, Colo., September 20-24, 1993: U.S. Geological Survey Water-Resources Investigations Report 94-4014.

Cozzarelli, I.M., Baedecker, M.J., Aiken, G., and Phinney, C.S., in press, Small-scale chemical heterogeneity's in a crude-oil-contaminated aquifer, Bemidji, Minnesota, in Morganwalp, D.W., and Aronson, D.A., eds., U.S. Geological Survey Toxic Substances Hydrology Program-Proceedings of the technical meeting, Colorado Springs, Colo., September 20-24, 1993: U.S. Geological Survey WaterResources Investigations Report 94-4014.

Cozzarelli, I.M., Baedecker, M.J., Eganhouse, R.P., and Goerlitz, D.F., 1994, The geochemical evolution of low-molecular-weight organic acids derived from the degradation of petroleum contaminants in ground water: Geochimica et Cosmochimica Acta, v. 58, p. 863-877.

Cozzarelli, I.M., Baedecker, M.J., and Hopple, J.A., 1991, Geochemical gradients in shallow ground water caused by the microbial degradation of hydrocarbons at Galloway Township, New Jersey, in Mallard, G.E., and Aronson, D.A., eds., U.S. Geological Survey Toxics Substances Hydrology Program-Proceedings of the technical meeting, Monterey, Calif., March 11-15, 1991: U.S. Geological Survey Water-Resources Investigations Report 914034, p. 256-262.

Cozzarelli, I.M., Baedecker, M.J., Fischer, J., and Phinney, C.S., in press, Ground-water contamination by petroleum hydrocarbons: Natural 


\section{GROUND-WATER CHEMISTRY}

biodegradation in a dynamic hydrologic and geochemical system, American Chemical Society, Washington, D.C., August 21-26, 1994 [Proceedings].

Cozzarelli, I.M., Eganhouse, R.P., and Baedecker, M.J., 1989, The fate and effects of crude oil in a shallow aquifer, II. Evidence of anaerobic degradation of monoaromatic hydrocarbon, in Mallard, G. E, and Ragone, S. E., eds., U.S. Geological Survey Toxic Substances Hydrology Program-Proceedings of the technical meeting, Phoenix, Ariz., September 26-30, 1988: U.S. Geological Survey WaterResources Investigations Report 88-4220, p. 21-33.

1990, Transformation of monoaromatic hydrocarbons to organic acids in anoxic groundwater environments: Environmental Geology and Water Sciences, v. 16, p. 135-141.

Eganhouse, R.P., Baedecker, M.J., Cozzarelli, I.M., Aiken, G.R., Thorn, K.A., and Dorsey, T.F., 1993, Crude oil in a shallow sand and gravel aquifer-II. Organic geochemistry: Applied Geochemistry, v. 8, p. 551-567.

Lovley, D.R., Baedecker, M.J., Lonergan, D.J., Cozzarelli, I.M., Phillips, E.J.P., and Siegel, D.I., 1989, Oxidation of aromatic contaminants coupled to microbial iron reduction: Nature, v. 339, p. 297-299.

Mallard, G.E., and Baedecker, M.J., 1993, Hydrocarbon transport and degradation in groundwater: U.S. Geological Survey Investigations, Proceedings of the Air Combat Command Environmental Quality T93 Symposium, Denver, Colo., March 1-5, 1993, p. 102-108.

Phinney, C.S., 1993, Enhancement of molecular ion detection by variation of mass analyzer thermal energy for $\mathrm{C}^{10}-\mathrm{C}^{28}$ alkanes by ion-trap mass spectrometry: ASMS Conference on Mass Spectrometry and Allied Topics, 41st, San Francisco, California, May 30-June 4, 1993 [Proceedings], p. 632A-632B.

Phinney, C.S., and Cozzarelli, I.M., 1992, A comparison of analytical techniques for measurement of volatile hydrocarbons in ground water, in ASMS Conference on Mass Spectrometry and Allied Topics, 40th, Washington, D.C., May 31-June 5, 1992 [Proceedings], p. 659660 .

Sigleo, A.C. and Shultz, D.J., 1993, Amino acid composition of suspended particles, sediment trap material, and benthic sediment in the Potomac estuary: Estuaries, v. 16, p. 405415. 


\section{GROUND-WATER CHEMISTRY}

TITLE: $\quad$ Relationship Between Chemical Quality of Natural Waters and Human Health and Disease (NR 79-132)

PERSONNEL: Gerald L. Feder, Project Chief

Bonnie H. Hower, Secretary

ADDRESS: $\quad$ U.S. Geological Survey

432 National Center

12201 Sunrise Valley Drive

Reston, VA 22092

TELEPHONE: (703) 648-5830

PROBLEM: In recent years, there has been increasing interest and study concerned with the possible relations between the chemical quality of natural waters and human health and disease. Medical researchers recognize areal patterns of health and disease in the United States and suspect that these patterns may be controlled by environmental and nonenvironmental factors. After excluding nonenvironmental factors, local and regional differences in water quality appear to have an effect on health and disease. Such differences influence the total dietary intake of necessary major and trace elements and the concentration of certain potentially toxic chemical constituents.

OBJECTIVE: Discover and quantify relations between the chemical quality of natural waters and human health and disease.

APPROACH: Identify chemical constituents in natural waters that are most likely to affect health and disease and those medical conditions most likely to be affected by water quality. Determine the temporal and spatial associations between specific chemical characteristics of water and specific states of health and disease. Exclude known high-risk factors related to geographic areas (for example, urban environment, mining activity) to increase the likelihood of detecting risk factors associated with natural water quality. Initially, use existing data from sources such as the U.S. Geological Survey and the Bureau of Vital Statistics for the medical and hydrologic aspects of the study. Collect new data in the field if data are lacking. Supplement data collection through cooperative programs with District and aquifer-study water-quality specialists. Obtain information on chemical composition of soils, rocks, and plants through cooperation with the Branch of Regional Geochemistry, Geologic Division. Cooperate with Dr. Howard C. Hopps, Curators Professor of Pathology, University of Missouri Medical School, throughout this study. 


\section{GROUND-WATER CHEMISTRY}

PROGRESS: Collected water samples from field sites in Hungary. Preliminary data indicate that drinking water with very high nitrate levels (above $150 \mathrm{mg} / \mathrm{l}$ ) may be related to stomach cancer, while drinking waters below $50 \mathrm{mb} / 1$ show no relation. Analyzed data on high and low ischemic heart disease areas in the United States. Drinking water supplies in the high ischemic death rate area (Southeast Coastal Plain) appear to have much lower magnesium concentrations than drinking water in the low ischemic heart disease area (Great Plains). Medical researchers believe magnesium may play an important role in ischemic heart disease.

\section{REPORTS PUBLISHED 1989-1994:}

Feder, G.L., Finkleman, R.B., Radovanovic, Zoran, 1991, Relationship between weathered coal deposits and the etiology on Balkan endemic nephropathy: Kidney International, v. 40, supp. 34 (1991), p. S-9 through S-11.

Finkleman, R.B., Feder, G.L., Orem, W.H., Radovanovic, Zoran, 1991, Relation between low-rank coal deposits and Balkan endemic nephropathy: AGID News, no. 65, February 1991, p. 23.

Goldberg, M.C., Feder, G.L., and Radovanovic, $Z$., in press, Geohydrologic implications in the contraction of Balkan endemic nephropathy as evidenced by fluorescence excitation-emission matrix spectroscopy: Journal of Contaminant Hydrology, v. 00.

McKnight, D.M., Bencala, K.E., Zellweger, G.W., Aiken, G.R., Feder, G.L., Thorn, K.A., 1992, Sorption of dissolved organic carbon by hydrous aluminum and iron oxides occuring at confluences of Deer Creek with the Snake River, Summit County, Colorado: Environmental Science and Technology, v. 26, no. 7, p. 1388-1396.

McKnight, D.M., Wershaw, R.L., Bencala, K.E., Zellweger, G.W., Feder, G.L., 1992, Humic substances and trace metals associated with $\mathrm{Fe}$ and $\mathrm{Al}$ oxides deposited in an acidic mountain stream: The Science of the Total Environment, v. $117 / 118$, p. $485-498$.

McNeal, J.M., Feder, G.L., Wilber, W.G., Deverel, S.J., 1990, Environmental concerns related to selenium in the western United States, in Doe, B.R., ed., Proceedings of a U.S. Geological Survey Workshop on Environmental Geochemistry: U.S. Geological Survey Circular 1033, p. 177-178. 


\section{GROUND-WATER CHEMISTRY}

TITLE: $\quad$ Uranium-Thorium Series Radioisotopes in Ground-Water and Surface-Water Systems (NR 82-138)

PERSONNEL: Thomas F. Kraemer, Project Chief

M. Schomody, Secretary

Joseph Albiston, Physical Science Technician

Daniel Chian, Hydrologic Technician, Student, (University of Virginia)

J. Fine, Summer Volunteer

ADDRESS: $\quad$ U.S. Geological Survey

431 National Center

12201 Sunrise Valley Drive

Reston, VA 22092

TELEPHONE: (703) 648-5868

PROBLEM: Naturally occurring uranium and thorium series radioisotopes possess great potential as natural tracers for examining movement and mixing of water bodies. At present, however, not enough is known of their geochemical behavior to use them even semiquantitatively for this purpose. In addition, new analytical techniques are being developed which will allow determination of isotopes of chlorine, krypton, iodine and other elements. These isotopes will also be of use in the hydrologic sciences as tracers, if sufficient understanding of their geochemical behavior can be achieved.

OBJECTIVE: Understand the geochemical behavior of uranium and thorium series radioisotopes sufficiently to permit their use as naturally occurring tracers to solve hydrological problems.

APPROACH: Studies of uranium and thorium series radioisotopes will be carried out in a variety of well known surface and subsurface conditions and their behavior related to specific physical and chemical conditions and processes. Laboratory studies will be carried out as needed under carefully controlled conditions to examine specific aspects of behavior. When behavior of these radioisotopes is well known, these principles can be applied to hydrologic problems of less well-defined systems to determine if methods developed can contribute answers which are reasonable with respect to results from other hydrologic approaches. As confidence is gained through these processes, methods will be applied to poorly constrained hydrologic problems not amenable to solution by standard hydrologic techniques. 


\section{GROUND-WATER CHEMISTRY}

PROGRESS: Completed manuscript on the determination of water retention times in the eleven Finger Lakes of central New York State using tritium. This manuscript has been accepted by the Journal of Hydrology for publication.

Mathematical modeling of radium cycling in the Finger Lakes has begun. When this model, which will incorporate all sources, sinks and pathways for radium in lacustrine systems, is completed it will be used to compare with chemical and isotopic results to gain insight into what processes are actually operating.

Participated in making plans for radiochemical study of rivers in Russia for the next 2 years. Study will investigate the movement of radioactive contamination through major drainage basins.

REPORTS PUBLISHED 1989-1994:

Goode, D.J., Hsieh, P.A., Shapiro, A.M., Wood, W.W., and Kraemer, T.F., 1993, Concentration history during pumping from a leaky aquifer with stratified initial concentration, in Shen, H.W., ed., Hydraulic Engineering, National Conference, San Francisco, July 25-30, 1993, Proceedings: New York, American Society of Civil Engineers, P. 29-35.

Kraemer, T.F., 1990, Geological factors governing radon concentration in natural gas, in Smith, J., ed., Proceedings of Gas Quality Measurement Symposium: Institute of Gas Technology, Chicago, Illinois, July, 1990, 41 p.

1991, Uranium, radium and radon in deeply buried sediments of the U.S. Gulf Coast, in Wanty R., and Gundersen, L., eds., Field Study of Radon in Rocks, Soils, and Water: U.S. Geological Survey Bulletin 1971, p. 125-130.

Kraemer, T.F., and Curwick, P.B., 1991, Radium isotopes in the Lower Mississippi River: Journal of Geophysical Research (Oceans), v. 96, no. C2, p. $2797-2806$.
Miller, R.L., Kraemer, T.F., and McPherson, B.J., 1990, Radium and radon in Charlotte Harbor estuary, Florida: Estuarine, Coastal and Shelf Science, v. 31, p. 439-457.

Wood, W.W., Kraemer, T.F., and Hearn, P.P., Jr., 1990, Intragranular diffusion-An important mechanism influencing solute transport in clastic aquifers?: Science, v. 247 , no. 4950 , p. 1569-1572. 


\section{GROUND-WATER CHEMISTRY}

TITLE: Transport and Biogeochemical Fate of Organic Substances in Aquatic Environments (NR 91-151)

PERSONNEL: Robert P. Eganhouse, Project Chief

Bonnie Hower, Secretary

Wendy R. Gomez, Chemist

ADDRESS: $\quad$ U.S. Geological Survey

432 National Center

12201 Sunrise Valley Drive

Reston, VA 22092

TELEPHONE: (703) 648-5879

PROBLEM: Organic substances are transported in both particulate and dissolved phases in aquatic environments. However, our understanding of the processes affecting phase exchange and removal are incomplete. In order to predict the short- and long-term fate of toxic organic substances in a variety of aquatic environments, it is necessary to determine the physical properties of these compounds and establish kinetic data on their removal rates using a combination of field studies and laboratory experiments.

OBJECTIVE: To investigate the composition and concentration of organic matter associated with dissolved and particulate phases in surface and subsurface waters and compare these data with distributions based on laboratory partitioning experiments and physical partitioning (for example, fugacity) models. Develope data on the rates at which organic matter is transformed (and remineralized) and the products that result in aquatic environments. This information will be used to establish the relative importance of different removal processes under a variety of environmental conditions. Ultimately these results will be incorporated into particle and solute transport models.

APPROACH: Studies will be carried out at one or more field sites that present favorable opportunities for examining the transport and fate of organic contaminants in different aquatic environments. Particulate and dissolved phases will be analyzed for the presence and concentration of a variety of natural and anthropogenic organic substances and their variation over time. Experiments will be performed in the laboratory to determine the equilibrium phase partitioning, desorption rates and biodegradation potential (and rates) of selected organic compounds. These equilibrium and kinetic data will be compared with the results of field studies and models that predict physical partitioning. 


\section{GROUND-WATER CHEMISTRY}

PROGRESS: During the report period I published one article (as lead author) in Applied Geochemistry and was coauthor on three others that appeared in Applied Geochemistry, Geochimica et Cosmochimica Acta and Geotimes on the fate of crude oil in a sand and gravel aquifer. A chapter on the chemical oceanography and geochemistry of the southern California Bight was published. During the latter half of 1993 I hosted a visiting Commonwealth Scientific and Industrial Research Organization (CSIRO) scientist, Mark Rayner, who carried out analyses in my laboratory on environmental samples brought from Australia. I also collaborated with other investigators within the National Research Program and Oklahoma District to prepare a successful proposal for a new site in the Toxic Substances Hydrology Program at the Norman, Oklahoma, municipal landfill. I participated as an expert in two International Atomic Energy Agency (IAEA) workshops on the development of improved monitoring methods for the Mediterranean Sea.

\section{REPORTS PUBLISHED 1989-1994:}

Baedecker, M.J., Cozzarelli, J.M., Eganhouse, R.P., Siegel, D.I., and Bennett, P.C., 1993, Crude oil in a shallow sand and gravel aquifer-III. Biogeochemical reactions and mass balance modeling in anoxic ground water: Applied Geochemistry, v. 8, p. 569-586.

Cozzarelli, I.M., Baedecker, M.J., Eganhouse, R.P., and Goerlitz, D.F., 1994, The geochemical evolution of low-molecular-weight organic acids derived from the degradation of petroleum contaminants in groundwater: Geochimica et Cosmochimica Acta, v. 58, no. 2., p. 863-877.

Cozzarelli, I.M., Eganhouse, R.P., and Baedecker, M.J., 1990, Transformation of monoaromatic hydrocarbons to organic acids in anoxic ground-water environments: Environmental Geology and Water Science, v. 16, p. 135141.

Eganhouse, R.P., Baedecker, M.J., Cozzarelli, J.M., Aiken, G.R., Thorn, K.A., and Dorsey, T.F., 1993, Crude oil in a shallow sand and gravel aquifer-II. Organic geochemistry: Applied Geochemistry, v. 8, p. 551-567.

Eganhouse, R.P., Dorsey, T.F., Phinney, C.S.. and Westcott, A.M., 1993, Determination of $\mathrm{C}_{6}-\mathrm{C}_{10}$ aromatic hydrocarbons in water by purge-and-trap capillary gas chromatography: Journal of Chromatography, v. 628, p. 81-92.

Eganhouse, R.P., and Gossett, R.W., 1991 ، Sources and magnitude of bias associated wi 1 : determination of polychlorinated biphenyls $\quad \mathrm{B}$ in environmental samples: Analytical Cheriatst:, v. 63 , p. $2130-2137$.

1991, Historical deposition and bogeosh ni al fate of polycyclic aromatic hydrocarbers ii: sediments near a major submarin: wastew $1: r$ outfall in Southern California, in lialer, $l$, 1 , ed., Organic substances and sedirnents in water: Boca Raton, Florida, Lewis Publisl $\because \cdots$ v. 2, p. 191-220.

Eganhouse, R.P., Gould, B.R., Olaguer, D.M. Phinney, C.S., and Sherblom, P.M., 1989, Congener-specific determination of chloro- 


\section{CR:I ND-WATER CHEMISTRY}

biphenyls in biological tissues usm clor-based secondary calibration standard: International Journal of Environmental Analytical Chemistry, v. 35, p. 175- 198.

Eganhouse, R.P., and Venkatesan, M.I., 1993. Chemical Oceanography and Geochemistry, in Frazier, Rebecca, ed., Ecology of the Sowitern California Bight: Los Angeles, University of California Press, Minerals Management Service, chap. 3, 71-189.

Mallard, G.E., Baedecker, M.J., Essaid, H.I. and Eganhouse, R.P., 1993, Hydrocarton uansport and degradation in ground water: Geotimes, December 1993, p. 18-19.

Olmez, I., Sholkovitz, E.R., Hermann, D., and Eganhouse, R.P., 1991, Rare earth elements in sediments off southern California-- 4 , new anthropogenic indictor: Envirominemal Scienke and Technology, v. 25, p. 310-316.

Sherblom, P.M., and Eganhouse, R.P., 1991, Bioaccumulation of molecular markers for municipal wastes by Mytilus edulis, in Fikkt:r, R.A.., ed., Organic substances and sediments in water: Boca Raton, Florida, Lewis Publishers, v. 3 , p. $139-158$.

Sherblom, P.M.. Ischwend, P.M... Eganhouse. R.P., 1992. :que sus sclubility, v tyor pressure and 1-or:anol-water partition coefficients for $\mathrm{C}_{9-14}$ lin: $\mathrm{r}$ alkylbenzenes: Jo srial of Chemical anl Engin ring Data. $\vee 37, p$. 394-399. 


\section{GROUND-WATER CHEMISTRY}

TITLE: $\quad$ Factors Determining Solute Transfer in the Unsaturated Zone (WR 68-036)

PERSONNEL: Ronald V. James, Project Chief

Andrew R. Brackenbury, Phys. Sci. Techn., Student, Palo Alto High School

ADDRESS: U.S. Geological Survey

345 Middlefield Road, MS 472

Menlo Park, CA 94025

TELEPHONE: (415) 329-4521

PROBLEM: Quality of ground and surface waters often is influenced significantly by chemical and solute-dispersion processes of the unsaturated zone. Frequently, these influences are impossible to predict because the effects of certain relevant, unsaturated-zone factors (for example, changes in water content or in the nature of solid surfaces) are understood imperfectly and because the current transport-modeling methods may not be well adapted to the situations encountered in practice. As a result, it may be impossible to assess properly the availability and quality of a given water resource or to predict the effects of certain human activities or management practices upon such water quality.

OBJECTIVE: Develop and test theories and mathematical models of reacting-solute transport to enhance the usefulness of such theories and models for assessing the effects of solute transport in the unsaturated zone on water resources and environment quality. Include in the study chemical reactions involving radioactive nuclides as well as reactions of certain solutes found in industrial and agricultural effluents. Develop mathematical models aimed at managing subsurface water quality.

APPROACH: Develop new mathematical models to predict transport of reacting solutes through porous media or at media boundaries, with consideration of the special conditions encountered in the unsaturated zone. Use theory, numerical methods, and controlled experiments. Use the interaction between theory and experiment to enhance the understanding of processes involved. Stress unidirectional transport. Study water-saturated systems with slow, steady water flows and a single, primarily equilibrium-controlled chemical reaction; study steady but unsaturated flows, paying special attention to the influence of water content on chemical and dispersion parameters; and study fast, perhaps transient, flows and chemical-kinetics influences and interactions among several reactions. Develop ground-water pollutant management models that combine numerical-simulation models and management techniques such as linear programming. Initially focus on pollutant-source management in 


\section{GROUND-WATER CHEMISTRY}

transient one-dimensional systems with linear chemistry. Subsequently, investigate pollutant-source management in two dimensions with nonlinear, one-component chemical systems. Use existing simulation models and management models to enhance joint management and simulation capabilities.

PROGRESS: The study of the effects of solute concentration and solution composition on the transport of nonreactive solutes in water-saturated sandy soil was continued. Tritium and chloride tracers were used to measure dispersion, anion exclusion and permeability as a function of the relative concentrations of sodium and calcium and the ionic strength of the soil water. Evidence was found for tritium diffusion into nonflowing pore space in media with significantly low permeability. Soil permeability was found to be unstable under similar conditions. The effects of biological processes on the partitioning of polychlorinated biphenyls (PCBs) between sediment and water in the Lower Fox River (LFR), Wis., was investigated. This effort is part of an ongoing study of the processes that affect transfer of PCBs from LFR sediments to the overlying water and subsequent transport to Green Bay and Lake Michigan. Partitioning of carbon-14 labeled 2,2',5,5'-tetrachlorobiphenyl (TCB52) between LFR sediments and water was observed. The sediment samples used in this study were taken from a site in Little Lake Butte Des Mortes and at a site upstream from the De Pere Dam. The sediment samples were collected and stored under anaerobic conditions. During the experiment, flow rate and oxygen concentration were varied independently. The partitioning of TCB52 was not affected by changes in flow rate indicating that the system was in chemical equilibrium. Changes in oxygen concentration resulted in conflicting observations. In one of two sets of experiments, aerobic conditions were found to increase partitioning of TCB52 to the water phase over that observed for anaerobic conditions. This result agreed with findings reported earlier. No significant dependence of TCB52 partitioning on oxygen concentration was observed in the other set of experiments which had a nearly identical design.

\section{REPORTS PUBLISHED 1989-1994:}

Elder, J.F., James, R.V., and Steuer, J.J., in press, Mobility of 2,2',5,5'-tetrachlorobiphenyl in model systems containing bottom sediments and water from an industrialized river basin in northeastern Wisconsin: Environmental Science and Technology, v. 00.1 


\section{GROUND-WATER CHEMISTRY}

TITLE: $\quad$ Partitioning of Solutes between Solid and Aqueous Phases (WR 70-065)

PERSONNEL: James A. Davis, III, Project Chief

Stacey J. Andrews, Secretary

Christopher C. Fuller, Hydrologist

Douglas B. Kent, Hydrologist

Matthias Kohler, Chemist

Patrick Brienen, Hydrologist

Jennifer A. Coston, Physical Scientist

Brigid A. Rea, Chemist

Jennifer Joye, Contract employee

John Morton, Hydrologist, Student,

Linda D. Anderson, Hydrologist

University of Michigan

ADDRESS: U.S. Geological Survey

345 Middlefield Road, MS 465

Menlo Park, CA 94025

TELEPHONE: (415) 329-4484

PROBLEM: When solutes are introduced into a ground-water system or into surface waters, physicochemical reactions can occur between the dissolved solutes and native solid materials. Detailed knowledge of the chemical reactions that occur at solid surfaces is required to assess the effects of such inputs on water quality. In addition, the geochemical cycling of some trace elements may be controlled by the distribution between solid and aqueous phases. A fundamental understanding of the surface-chemistry reactions is needed to incorporate a mathematical description of these processes into chemical-equilibrium and solute-transport models.

OBJECTIVE: (1) Study the adsorption behavior of inorganic and organic solutes on particulate materials that are important in natural systems, including aluminosilicate minerals, model colloids (such as hydrous oxides of aluminum, silicon, iron, or manganese), and solids of biogenic origin; (2) derive stability constants for the partitioning of solutes between a particular solid surface and the aqueous phase and understand the mechanisms of surface bonding from a theoretical perspective, including electrical double-layer theory; and (3) generate a surface-stability-constant data base that is compatible with existing computer models of chemical equilibrium and that could be used in the field evaluation of solute-transport models.

APPROACH: (1) Conduct experiments in the laboratory, of physical-chemical techniques to characterize surfaces and to measure adsorption behavior as the type of solute, type of surface, and water composition are varied; (2) use controlled laboratory solutions in both 


\section{GROUND-WATER CHEMISTRY}

kinetic and equilibrium studies to evaluate the importance of surface reactions for a given solute in a given geochemical environment; (3) develop quantitative phenomenological models to describe observed laboratory results and predict the behavior of solutes under other experimental conditions with the aid of a computer; and (4) conduct field studies periodically to assess the applicability of the models to natural aqueous systems.

PROGRESS: The most chemically complex, large-scale tracer test ever conducted was begun at the Toxic Substances Hydrology research site at Cape Cod, Massachusetts, in April 1993. Chemical tracers injected in the natural-gradient test included bromide (a conservative tracer), chromium(VI), and four heavy metal-EDTA complexes. The test was conducted across a steep gradient in $\mathrm{pH}$ and redox conditions. $\mathrm{Cr}(\mathrm{VI})$ transport was strongly influenced by adsorption and reduction processes, while the heavy metal-EDTA complexes were influenced by adsorption and iron oxide dissolution processes. The rates and extent of these processes were significantly influenced by the chemical gradients at the site. Monthly spatial samplings (3,000 water samples for each sampling) were conducted from April 1993 until December 1993, followed by additional samplings in March and July 1994. The results show that the mobility of heavy metals in aquifers is influenced greatly by chemical processes in comparison to hydrologic processes.

An extraction strategy was evaluated for removing reduced chromium from suboxic Cape Cod sediments. The overall goal is to be able to quantify the amount and location of chromium(VI) removed from ground water by aquifer sediments during field injection experiments at the Cape Cod site. This includes being able to distinguish background chromium concentrations from the injected chromium that is reduced on the sediments. Towards this end, substantial progress has been made on developing a chromium separation technique that will allow the determination of stable chromium isotopic signatures of background minerals and the injected chromium tracer.

A column study of uranium(VI) transport through a column packed with fine-grained quartz particles was started, where the transport of uranium(VI) was influenced by $\mathrm{pH}$ and complexation with fluoride. It was demonstrated that the $\mathrm{Kd}$ for a given set of conditions could be predicted in advance if the system was modeled with an aqueous speciation model that included surface complexation for a description of adsorption equilibria. Breakthrough curves for uranium(VI) suggest that local chemical equilbrium during transport was a good assumption for this system. Work was continued in developing a predictive method for determining the spatial variability of heavy metal sorption by aquifer material at the Cape Cod Toxics Substances Hydrology research site, by studying the variability in the amount of surface coatings of iron and aluminum oxides and the surface area. The results show that 


\section{GROUND-WATER CHEMISTRY}

adsorption of lead and zinc varied by a factor of four, and the variability was only poorly correlated with hydraulic conductivity.

Field work in collaboration with Jud Harvey (Arizona District) has been conducted to quantify the role of sorption processes on mineral surfaces in the streambed and hyporheic zone at the Pinal Creek Toxic Substance Hydrology research site. The work focused on downstream and cross-channel variability of emerging ground water in the near-stream zone. A decrease in metal concentrations was observed in the shallow zone on the flanks of the stream channel due to reductive-dissolution of iron oxides and subsequent precipitation of iron and other metals near the oxic interface of this zone. Laboratory sorption studies were begun to characterize the sorption properties of streambed materials, including a study of the reversibility of sorbed metals (nickel, cobalt), sorption of metals by bed material, and uptake of metals during Mn oxidation. Findings to date suggest that the nickel is reversibly sorbed, while cobalt is largely irreversibly bound. Elevated manganese, nickel, and cobalt concentrations on the abundant magnetite grains, relative to their concentrations on other mineral grains, suggest that enhanced oxidation of manganese occurs at the surface of magnetite grains.

\section{REPORTS PUBLISHED 1989-1994:}

Anderson, L.D., Kent, D.B., and Davis, J.A., 1991, Adsorption and reduction of $\mathrm{Cr}(\mathrm{VI})$ under oxic conditions-Studies of $\mathrm{Cr}(\mathrm{VI})$ reactions with sand from a shallow aquifer at Cape Cod, Massachusetts, in Mallard, G.E., and Aronson, D.A., eds., U.S. Geological Survey Toxics Substances Hydrology Program-Proceedings of the technical meeting, Monterey, Calif., March 11-15, 1991: U.S. Geological Survey Water-Resources Investigations Report 91-4034, p. 63-71.

Anderson, L.C.D., Kent, D.A. and Davis, J. A., 1992, Reduction of $\mathrm{Cr}(\mathrm{VI})$ under mildly reducing conditions in a sand and gravel aquifer, in Kharaka, Y.K., and Maest, A.S., eds., Proceedings of the 7th International Symposium on Water-Rock Interaction, July 9-23, 1992, Park City, Utah: Rotterdam, The Netherlands, A.A. Balkema, p. 495-498.
Anderson, L.D., Kent, D.B., and Davis, J.A., 1994, Batch experiments characterizing the reduction of $\mathrm{Cr}(\mathrm{VI})$ using suboxic material from a mildly reducing sand and graver aquifer: Environmental Science and Technology, v. 28 , p. $178-185$.

Coston, J.A., Fuller, C.C., and Davis, J.A., 1992, The search for a geochemical indicator of lead and zinc sorption in a sand and gravel aquifer, Falmouth, Massachusetts, U.S.A., in Kharaka, Y.K., and Maest, A.S., eds., Proceedings of the 7th International Symposium on WaterRock Interaction, July 9-23, 1992, Park City, Utah: Rotterdam, The Netherlands, A.A. Balkema, p. 41-44.

Davis, J.A., Fuller, C.C., Coston, J.A., Hess, K.M., and Dixon, E., 1993, Spatial heterogeneity of geochemical and hydrologic parameters affecting metal transport in ground 


\section{GROUND-WATER CHEMISTRY}

water: Enviromental Research Brief, EPA/600/ S-93/066, U.S. Environmental Protection Agency, Ada, Oklahoma, 22 p.

Davis, J.A., Fuller, C.C., Rea, B.A., and Claypool-Frey, R.G., 1989, Sorption and coprecipitation of arsenate by ferrihydrite, in Miles, D.L., ed., Proceedings of the Sixth International Meeting on Water-Rock Interaction: Rotterdam, The Netherlands, A.A. Balkema, p. 187-189.

Davis, J.A., and Hem, J.D., 1989, The surface chemistry of aluminum oxides and hydroxides, in Sposito, G., ed., The environmental chemistry of aluminum: Boca Raton, Fla., CRC Press, Inc., chap. 7, p. 185-219.

Davis, J.A., and Kent, D.B., 1990, Surface complexation modeling in aqueous geochemistry, in Hochella, M.F., and White, A.F., eds., Mineral-water interface geochemistry: Washington, D.C., Mineralogical Society of America, Reviews in Mineralogy, v. 23, p. 177260.

Davis, J.A., Kent, D.B., Coston, J.A., and Hess, K.A., in press Heavy-metal transport in a sand and gravel aquifer with variable chemical conditions, cape Cod, Massachusetts, in Morganwalp, D.W., and Aronson, D.A., eds., U.S. Geological Survey Toxic Substances Hydrology Program-Proceedings of the technical meeting, Colorado Springs, Colo., September 20-24, 1993: U.S. Geological Survey WaterResources Investigations Report 94-4014.

Davis, J.A., Kent, D.B., and Rea, B.A., 1989, Field and laboratory studies of coupled flow and chemical reactions in the ground-water environment, in Mallard, G. E, and Ragone, S. E., eds., U.S. Geological Survey Toxic Substances Hydrology Program-Proceedings of the technical meeting, Phoenix, Ariz., Sep- tember 26-30, 1988: U.S. Geological Survey Water-Resources Investigations Report 884220, p. 189-198.

Davis, J.A., Kent, D.B., Rea, B.A., Garabedian, and Anderson, L.C.D., 1991, Effect of the geochemical environment on heavy metal transport in groundwater, in Mallard, G.E., and Aronson, D.A., eds., U.S. Geological Survey Toxics Substances Hydrology Program-Proceedings of the technical meeting, Monterey, Calif., March 11-15, 1991: U.S. Geological Survey WaterResources Investigations Report 91-4034, p. 53-62.

Davis, J.A., Waite, T.D., Kent, D.B., and Anderson, L.C.D., 1991, Reduction of $\mathrm{Cr}(\mathrm{VI})$ under mildly reducing conditions in a shallow, sand and gravel aquifer, in Mallard, G.E., and Aronson, D.A., eds., U.S. Geological Survey Toxics Substances Hydrology Program-Proceedings of the technical meeting, Monterey, Calif., March 11-15, 1991: U.S. Geological Survey Water-Resources Investigations Report 91-4034, p. 72-77.

Fuller, C.C., in press, Experimental studies of trace-metal partitioning in perennial reaches of Pinal Creek, Arizona, in Morganwalp, D.W., and Aronson, D.A., eds., U.S. Geological Survey Toxic Substances Hydrology Program-Proceedings of the technical meeting, Colorado Springs, Colo., September 20-24, 1993: U.S. Geological Survey WaterResources Investigations Report 94-4014.

Fuller, C.C., Coston, J.A., Davis, J.A., and Dixon, E.A., in press, Geochemical indicators of metal adsorption in a sand and gravel aquifer, Cape Cod, Massachusetts, in Morganwalp, D.W., and Aronson, D.A., eds., U.S. Geological Survey Toxic Substances Hydrology Program-Proceedings of the technical 


\section{GROUND-WATER CHEMISTRY}

meeting, Colorado Springs, Colo., September 20-24, 1993: U.S. Geological Survey WaterResources Investigations Report 94-4014.

Fuller, C.C., Coston, J.A., Hess, K.M., and Davis, J.A., 1991, Spatial heterogeneity of geochemical and hydrologic properties of subsurface materials in a sand and gravel aquifer, Cape Cod, Massachusetts, in Mallard, G.E., and Aronson, D.A., eds., U.S. Geological Survey Toxics Substances Hydrology Program-Proceedings of the technical meeting, Monterey, Calif., March 11-15, 1991: U.S. Geological Survey Water-Resources Investigations Report 91-4034, p. 84-87.

Fuller, C.C., and Davis, J.A., 1989, Influence of coupling of sorption and photosynthetic processes on trace element cycles in natural waters: Nature, v. 340, p. 52-54.

Fuller, C.C., and Davis, J.A., in press, Evaluation of the processes controlling dissolved arsenic in Whitewood Creek, South Dakota: U.S.Geological Survey Water-Supply Paper 2385, Chap. E, 55 p.

Fuller, C.C., Davis, J.A., Cain, D.J., Lamothe, P.J., Fries, T.L., Fernandez, G., Vargas, J.A., and Murillo, M.M., 1990, Distribution and transport of sediment-bound metal contaminants in the Rio Grande de Tarcoles, Costa Rica (Central America): Water Research, v. 24 , p. $805-812$.

Fuller, C.C., Davis, J.A., and Waychunas, G.A. 1993, Surface chemistry of ferrihydrite, 2. Kinetics of arsenate adsorption and coprecipitation: Geochimica Cosmochimica Acta, v. 57, p. 2271-2282.

Fuller, C.C., Davis, J.A., Zellwegger, G.W., and Goddard, K.E., 1989, Coupled chemical, biological and physical processes in Whitewood
Creek, South Dakota-Evaluation of the controls of dissolved arsenic, in Mallard, G. E, and Ragone, S. E., eds., U.S. Geological Survey Toxic Substances Hydrology ProgramProceedings of the technical meeting, Phoenix, Ariz., September 26-30, 1988: U.S. Geological Survey Water-Resources Investigations Report 88-4220, p. 235-246.

Harvey, J.W., and Fuller, C.C., in press, Association of metal contaminants with colloidal and suspended material in shallow groundwater and surface water at Pinal Creek, Arizona, in Morganwalp, D.W., and Aronson, D.A., eds., U.S. Geological Survey Toxic Substances Hydrology Program-Proceedings of the technical meeting, Colorado Springs, Colo., September 20-24, 1993: U.S. Geological Survey WaterResources Investigations Report 94-4014.

Harvey, J.W., Fuller, C.C., and Wagner, B.J., 1994, Interactions between shallow groundwater and surface water that affect metal transport in Pinal Creek, Arizona, in Morganwalp, D.W., and Aronson, D.A., eds., U.S. Geological Survey Toxic Substances Hydrology Program-Proceedings of the technical meeting, Colorado Springs, Colo., September 20-24, 1993: U.S. Geological Survey WaterResources Investigations Report 94-4014.

Hess, K.M., Davis, J.A., Fuller, C.C., and Coston, J.A., in press, Spatial variability of metal-ion adsorption and hydraulic conductivity in a san and gravel aquifer, Cape cod, Massachusetts, in Morganwalp, D.W., and Aronson, D.A., eds., U.S. Geological Survey Toxic Substances Hydrology Program-Proceedings of the technical meeting, Colorado Springs, Colo., September 20-24, 1993: U.S. Geological Survey Water-Resources Investigations Report 94-4014. 


\section{GROUND-WATER CHEMISTRY}

Kent, D.B., Davis, J.A., Maest, A.S., and Rea, B.A., 1989, Field and laboratory studies of transport of reactive solutes in groundwater, in Miles, D.L., ed., Proceedings of the Sixth International Meeting on Water-Rock Interaction, Malvern, United Kingdom: Rotterdam, The Netherlands, A.A. Balkema, p. 381-383.

1991, Transport of $\mathrm{Zn}$ in ground water in the presence of a strong complexing agent-Competing roles of sorption, complexation, and mineral dissolution, in Mallard, G.E., and Aronson, D.A., eds., U.S. Geological Survey Toxics Substances Hydrology Program-Proceedings of the technical meeting, Monterey, Calif., March 11-15, 1991: U.S. Geological Survey Water-Resources Investigations Report 91-4034, p. 78-83.

1992, Ligand-enhanced transport of strongly adsorbing metal ions in the ground-water environment, in Kharaka, Y.K., and Maest, A.S., eds., Proceedings of the 7th International Symposium on Water-Rock Interaction, July 9-23, 1992, Park City, Utah: Rotterdam, The Netherlands, A.A. Balkema, p. 805-808.

Kent, D.B., Davis, J.A., Anderson, L.C.D., Rea, B.A., and Waite, T.D., 1994, Transport of chromium and selenium in the suboxic zone of a shallow aquifer-Influence of redox and adsorption reactions: Water Resources Research, v. 30, p. 1099-1114.

Kuwabara, J.S., Chang, C.C.Y., Cloern, J.E., Fries, T.L., Davis, J.A., and Luoma, S.N., 1989, Trace metal associations in the water column of south San Francisco Bay, California: Estuarine, Coastal and Shelf Science, v. 28 , p. $307-325$.

Mehr, S.R., Eatough, D.J., Hanson, L.D., Lewis, E.A., and Davis, J.A., 1989, Calorimetry of heterogeneous systems- $\mathrm{H}$ binding to TiO in
NaCl: Thermochimica Acta, v. 154, p. 129143.

Payne, T.E., Sekine, K., Davis, J. A., and Waite, T. D., 1992, Modeling of radionuclide sorption processes in the weathered zone of Koongarra ore body: Third Annual Report, Alligator Rivers Analogue Project, Australian Nuclear Science and Technology Organization, $p$. $57-86$.

Rea, B.A., Davis, J.A., and Waychunas, G.A., 1994, Studies of the reactivity of the ferrihydrite surface by iron isotopic exchange and Mossbauer spectroscopy: Clay and Clay Minerals, v. 42, p. 23-34.

Rea, B.A., Kent, D.B., Anderson, L.C.D., Davis, J.A., and LeBlanc, D.R., in press, The transport of inorganic contaminants from a sewage plume in the Cape Cod aquifer, Massachusetts, in Morganwalp, D.W., and Aronson, D.A., eds., U.S. Geological Survey Toxic Substances Hydrology Program-Proceedings of the technical meeting, Colorado Springs, Colo., September 20-24, 1993: U.S. Geological Survey Water-Resources Investigations Report 94-4014.

Rea, B.A., Kent, D.B., LeBlanc, D.R., and Davis, J.A., 1991, Mobility of $\mathrm{Zn}$ in a sewage-contaminated aquifer, Cape Cod, Massachusetts, in Mallard, G.E., and Aronson, D.A., eds., U.S. Geological Survey Toxics Substances Hydrology Program-Proceedings of the technical meeting, Monterey, Calif., March 1115, 1991: U.S. Geological Survey WaterResources Investigations Report 91-4034, p. 88-95.

VanGeen, A., Luoma, S.N., Fuller, C.C., Anima R., Clifton, H.E., Trumbore, S., 1992, Evidence from $\mathrm{Cd} / \mathrm{Ca}$ ratios in foraminifera for 


\section{GROUND-WATER CHEMISTRY}

greater upwelling off California 4,000 years ago: Nature, v. 358 , p. 54-56.

Waite, T.D., Davis, J.A., Payne, T.E., Waychunas, G.A., and Xu, N., 1994, Uranium(VI) adsorption to ferrihydrite: Application of a surface complexation model: Geochimica et Cosmochimica Acta, v. 00.

Waychunas, G.A., Rea, B.A., Fuller, C.C., and Davis, J.A., 1993, Surface chemistry of ferrihydrite, I. EXAFS studies of the geometry of coprecipitated and adsorbed arsenate: Geochimica Cosmochimica Acta, v. 57, p. 22512269. 


\section{GROUND-WATER CHEMISTRY}

TITLE: $\quad$ Stable Isotope Tracers of Biogeochemical and Hydrologic Processes (WR 91-080)

PERSONNEL: Carol Kendall, Project Chief Gloria M. Castagne, Secretary

John C. Radyk, Hydrological Technician

Steven R. Silva, Hydrologist

Robert L. Michel, Chemist

Cecily C. Chang, Hydrologist

Lloyd D. White, Chemist

Mark Huebner, Hydrologist

ADDRESS: U.S. Geological Survey

345 Middlefield Road, MS 434

Menlo Park, CA 94025

TELEPHONE: (415) 329-4576

PROBLEM: Stable and radioactive isotopes of elements such as oxygen, hydrogen, carbon, nitrogen, and sulfur have proved to be extremely useful tracers of hydrologic pathways, biogeochemical processes, and residence times of waters and solutes. However, use of these isotopes as tracers is presently hampered by our limited understanding of the physical processes and chemical reactions influencing isotopic compositions. The unsaturated zone, particularly the soil zone and the top of the water table, is probably the portion of the hydrologic system most responsible for alteration of the isotopic compositions of potential isotope tracers; this environmental component is also one of the least studied.

OBJECTIVE: The overall goal is to increase our understanding of reactions involving stable isotopes and to evaluate the significance of these reactions in geochemical and hydrologic modeling. This will be accomplished by field and laboratory investigations of processes and reactions which may fractionate isotopes and affect their utilization as tracers of processes, flowpaths, and sources of water and solutes.

APPROACH: Define the processes which could affect the use of isotopes as tracers; identify suitable field areas for collaborative research; develop field sampling techniques and laboratory analytical methods which do not fractionate the isotopic compositions; investigate the extent and effects of isotope exchange between gases, water, bound-water, dissolved species, and matrix materials through field studies, and laboratory and field experiments; develop conceptual models for infiltration, streamflow generation, unsaturated and saturated zone flow, and biogeochemical reactions; test biogeochemical-process and hydrologic-flow models 


\section{GROUND-WATER CHEMISTRY}

with isotope tracers; establish guidelines for application of stable isotope techniques to problems of national importance.

PROGRESS: Nitrate-oxygen Technique: We have developed a simple, safe, cheap, and precise method to analyze nitrate samples for $8^{18} \mathrm{O}$; it eliminates the need to combust samples with mercuric cyanide which has thus far been hindering the use of $\delta^{18} \mathrm{O}$ in tracing nitrate sources. We think that $8^{18} \mathrm{O}$ will be more useful than the $\boldsymbol{8}^{15} \mathrm{~N}$ of nitrate in tracing $\mathrm{N}$ sources and expect a high interest in using the method. The new method piggy-backs on our recently developed method for concentrating nitrate on exchange columns in the field. We think this dual isotope method will be of great help to the NAWQA programs interested in sources of nitrate.

Snowmelt Nitrate Studies: We hypothesize that our recently developed capability to analyze both the $8^{18} \mathrm{O}$ and $8^{15} \mathrm{~N}$ of nitrate might allow the determination of the source of the high nitrate in snowmelt observed in a number of catchments. Use of nitrogen isotopes alone cannot distinguish between soil and atmospheric sources; however, the oxygen isotopic compositions are expected to be distinctive. Since this is a topic of interest to the Colorado WEBB and the New York District researchers, we are conducting collaborative pilot studies at the Loch Vale, Colorado, and Catskills Mountains, New York, catchments to test this hypothesis. We are also working at the Sleepers River Watershed in Vermont in collaboration with students and faculty at State University of New York-Syracuse.

North American Water Isotope Database (NAWID): In collaboration with T. Coplen's project, we are assembling a database of all oxygen and hydrogen isotope analyses generated by either of WRD's two stable isotope laboratories for samples collected from North America. We are making good progress towards a goal of assembling locality, date, and sample-type data for samples submitted to either lab prior to 1992. NOAA's Paleoclimatology Program has agreed to provide funds to this project for two students for 2 years to compile non-USGS isotope data into our database. We plan to eventually release this database on CD roms, updated periodically. This database will be of great use to WRD, university, private industry scientists by reducing unnecessary duplication of efforts. The database will also be very valuable for climate modelers because the isotopic compositions of meteoric water are directly related to present and past climate patterns.

Water, Energy and Biogeochemical Balance (WEBB) Collaborations: We are actively working with District and National Research Project (NRP) researchers at the Vermont, Georgia, Wisconsin, and Colorado WEBB (climate program) sites on using oxygen, hydrogen, nitrogen, carbon, and sulfur isotopes as tracers of water sources, alkalinity sources, 


\section{GROUND-WATER CHEMISTRY}

subsurface flowpaths, and water residence time. We analyze about 1,000 samples/year in various collaborative studies.

Changing Flowpaths with Catchment Scale: In collaboration with J. Shanley (Vermont WEBB), we have found that there are greater contributions from shallow flowpaths and new water at increasing catchment scale, both during snowmelt and storm events. This finding agrees with recently calibrated TOPMODELs of the area. We are currently using the $\boldsymbol{\delta}^{18} \mathrm{O}$ and $\boldsymbol{\delta}^{15} \mathrm{~N}$ of nitrate in these nested catchments to determine the changing role of shallow flowpaths in delivering nitrate to streamflow.

Snow Hydrology Studies: In collaboration with J. McDonnell (SUNY), we have determined that there is considerable heterogeneity in the $\boldsymbol{\delta}^{18} \mathrm{O}$ values of the snowpack and snowmelt developing under various cover types in the Adirondack Mountains, New York. This finding makes it clear that water and snow samplers must be sited carefully for conducting snowmelt hydrograph studies.

Laboratory Automation: We have partially completed a new hydrogen-water equilibration system. This automated system will allow the preparation and analysis of 48 water samples/day for hydrogen isotopic composition for about 2 manhours (an 8-fold improvement).

Textbook on Isotope Hydrology: There is a lack of a suitable textbook for the Isotope Hydrology training course we teach yearly at the National Training Center; too much of the literature focuses on deep ground-water issues which are unrelated to public water supplies. To solve this problem, J.J. McDonnell (SUNY Syracuse) and C. Kendall are coediting an Elsevier book entitled "Isotope Tracers in Catchment Hydrology." Most of the chapters have been written and we hope it will be published in late 1994.

Interdivisional Isotope Cooperation: We made significant progress towards building an interdivision-al isotope program in Menlo Park: (1) When the Geologic Division (GD) shut down its stable isotope lab in Menlo Park, we rolled their remaining programs and technicians into our space and program; (2) Part of Michel's tritium equipment will be housed in the GD C-14 lab; (3) We will be building an interdivisional vacuum line to prepare water and solid samples for C-14 analysis by AMS; (4) We are trying to seek funds for an interdivisional He-3/He-4 mass spectrometer for age-dating young waters and rocks; (5) We are putting together plans for an interdivisional workshop on isotopes and the environment. 


\section{GROUND-WATER CHEMISTRY}

\section{REPORTS PUBLISHED 1989-1994:}

Adams, M.C., Mink, L.L., Moore, J.N., White, L.D., and Anchissi, A.C., 1990, Geochemistry and hydrology of the Zunil geothermal system, Guatemala: Geothermal Resources Council Transactions, August 1990, v. 14, pt. II, p. 837-844.

Adams, M.C., Moore, J.N., White, L.D., Mink, L.L., Leiva, O., Ramirez, S., and Anchissi, A.C., 1992, Fluid recharge of the Zunil, Guatemala Geothermal System: Geothermal Resources Council Transactions, v. 16. p. 113.

Blevins, D.W., Wilkison, D.H., Silva, S.R., and Kelly, B.P., in press, Use of $15 \mathrm{~N}$ to trace movement of nitrogen fertilizer at a field plot, in Morganwalp, D.W., and Aronson, D.A., eds., U.S. Geological Survey Toxic Substances Hydrology Program-Proceedings of the technical meeting, Colorado Springs, Colo., September 20-24, 1993: U.S. Geological Survey Water-Resources Investigations Report 94-4014.

Calvo, J.P., Jones, B.F., Bustillo, M., Fort, R., Alonzo-Zarza, A.M., and Kendall, C., in press, Sedimentology and geochemistry of carbonate from lacustrine sequences in the Madrid basin, central Spain: Chemical Geology, $50 \mathrm{p}$.

Evans, W.C., Kling, G.W., Tuttle, M.L., Tanyileke, G., and White, L.D., 1993, Gas buildup in Lake Nyos, Cameroon-The recharge process and its consequences: Applied Geochemistry, v. 8, p. 207-221.

Gat, J.R., Bowser, C.J., and Kendall, C., 1994, The contribution of evaporation from the North American Great Lakes to the continental atmospheric water balance-detection by means of the stable isotope signature of evaporated waters: Geophysical Research Letters, v. 21 , p. $557-560$.

Hearn, P.P., Jr., Steinkampf, W.C., Horton, D.G., Solomon, G.C., White L.D., and Evans, J.R., 1989, Oxygen-isotope composition of ground water and secondary minerals in Columbia Plateau basalts; implications for the paleohydrology of the Pasco Basin: Geology (Boulder), v. 17 , no. 7 , p. 606-610.

Hearn, P.P., Steinkampf, W.C., White, L.D., and Evans, J.R., 1990, Geochemistry of RockWater Reaction in Basalt Aquifers of the Columbia River Plateau, in Doe, Bruce R., ed., U.S. Geological Survey workshop on Environmental Geochemistry, Proceedings: U.S. Geological Survey Circular 1033, p. 63-68.

Hein, J.R., Gray, S.C., Richmond, B.M., and White, L.D., 1992, Dolomitization of Quaternary reef limestone, Aitutaki, Cook Islands: Sedimentology, v. 39, 645-661.

Huntington, T.G., Hooper, R.P., Peters, N.E., Bullen, T.D., and Kendall, C., 1993, Water energy, and biogeochemical budgets investigation at Panola Mountain Research Watershed, Stockbridge, Georgia-A research plan: U.S. Geological Survey Open-File Report 93-55.

Kendall, C., 1993, Impact of Isotopic Heterogeneity in Shallow Systems on Stormflow Generation: College Park, Md., University of Maryland, $\mathrm{Ph} . \mathrm{D}$. dissertation, $310 \mathrm{p}$.

Kendall, C., and Cappellato, R., in press, Temporal, spatial, and species-related variations in the Delta 180 and Delta D of throughfall: Water Resources Research, v. 00, 50 p. 


\section{GROUND-WATER CHEMISTRY}

Kendall, C., and Gu, W., 1992, Development of isotopically heterogeneous infiltration waters in an artificial catchment in Chuzhou, China, in Proceedings of Isotope Techniques in Water Resources Development Symposium, Vienna, March 1991, p. 61-73.

in press, A look inside black-box models of stormflow generation-isotopic, chemical, and hydrologic modeling at an artificial catchment: Water Resources Research, v. 00, 40 p.

Kendall, C., Mast, A.M., and Rice, K.C., 1992, Tracing watershed weathering reactions with Delta C-13, in Kharaka, Y.K., and Maest, A.S., eds., Proceedings of the 7th International Symposium on Water-Rock Interaction, July 9-23, 1992, Park City, Utah: Rotterdam, The Netherlands, A.A. Balkema, p. 569-572.

Kendall, C., and McDonnell, J.J., 1993, Effect of intrastorm heterogeneities of rainfall, soil water and ground water on runoff modeling, in Peters, N.E., and others, eds., Tracers in Hydrology Symposium, Yokohama, Japan, July 11-23, 1993, Proceedings: International Association of Hydrology, Scientific Publication no. 215 , p. $41-48$.

Kendall, C., and Mills, A.L., in press, Tracing sources of carbonate alkalinity in small streams using stable carbon isotopes: Journal of Hydrology, v. 00, 41 p.

Kharaka, Y.K., Evans, W.C., Ambats, Gil, and White, L.D., 1989, California origin of water and solutes in granitic rocks at Cajon Pass, California, U.S.A., in Miles, D.L., ed., Proceedings of the Sixth International Meeting on Water-Rock Interaction, Malvern, United Kingdom: Rotterdam, The Netherlands, A.A. Balkema, p. 385-388.
Kharaka, Y.K., Mariner, R.H., Ambats, Gil, Evans, W.C., White, L.D., Bullen, T.D., and Kennedy, B.M., 1990, Origins of water and solutes in and north of the Norris-Mammoth Corridor, Yellowstone National Park: Geothermal Resources Council Transactions, August 1990, v. 14, pt. 1, p. 705-714.

King, C.Y., Basler, D., Presser, T.S., Evans, W.C., and White, L.D., 1994, In search of earthquake-related hydrologic and chemical changes along Hayward Fault: Applied Geochemistry, v. 9, p. 83-91.

Kling, G.W., Tuttle, M.L., and Evans, W.C., 1989, The evolution of thermal structure and water chemistry in Lake Nyos: Journal of Volcanology and Geothermal Research, v. 39, p. 151-165.

Kling, G.W., Tuttle, M.L., and Evans, W.C., 1989, Safety of Cameroonian lakes: Nature (scientific correspondence), v. 337, p. 215.

Krabbenhoft, D.P., Bowser, C.J., Gat, J.R., and Kendall, C., 1991, Stable isotopic approaches to the hydrology of ground-water/lake systems, in Division of Environmental Chemistry, American Chemical Society, Atlanta, Georgia, April 1991, Proceedings: American Chemical Society, v. 31, p. 247-250.

Krabbenhoft, D.P., Bowser, C.J., Kendall, C., and Gat, J.R., 1994, Use of oxygen-18 and deuterium to assess the hydrology of groundwater/lake systems, in Baker, L., ed., Environmental chemistry of lakes and reservoirs: American Chemical Society, Monograph 237, p. 67-90.

Krohn, M.D., Kendall, C., Evans, J.R., and Fries, T.L., 1993, Relations of ammonium minerals at several hydrothermal systems in the western 


\section{GROUND-WATER CHEMISTRY}

U.S.: Journal of Volcanology and Geothermal Research, v. 56, p. 401-414.

Mariner, R.H., Kharaka, Y.K., Ambats, G., and White, L.D., 1992, Chemical composition and stable isotopes of thermal waters, NorrisMammoth corridor, Yellowstone National Park, U.S.A., in Kharaka, Y.K., and Maest, A.S., eds., Proceedings of the 7th International Symposium on Water-Rock Interaction, July 9-23, 1992, Park City, Utah: Rotterdam, The Netherlands, A.A. Balkema, p. 963.

Mariner, R.H., Presser, T.S., Evans, W.C., and Pringle, M.K.W., 1989, Discharge rates of thermal fluids in the Cascade Range of Oregon and Washington and their relationship to the geologic environment, in Muffler, L.J.P., Weaver, C.S., and Blackwell, D.D., eds., Geological, Geophysical, and Tectonic Setting of the Cascade Range: U.S. Geological Survey Open-File Report 89-178 (data), p. 663-674.

Mariner, R.H., Young, H.W., Parliman, D.J., and Evans, W.C., 1989, Geochemistry of thermal water from selected wells, Boise, Idaho: Geothermal Resources Council Transactions, v. 13, p. 173-178.

McCarthy, K.A., McFarland, W.D., Wilkinson, J.M., and White, L.D., 1992, The dynamic relationship between ground water and the Columbia River-using deuterium and oxygen-18 as tracers: Journal of Hydrology, $v$. 135 , p. $1-12$.

McDonnell, J.J., and Kendall, C., 1992, Isotope Tracers and Hydrology: EOS, Transactions of the American Geophysical Union, v. 73, p. 260-261.

Nokleberg, W.J., Aleinikoff, J.N., Lange, I.M., Silva, S.R., Miyaoka, R.T., Schwab, C.E., Zehner, R.E., 1992, Preliminary geologic map of the Mount Hayes Quadrangle, Eastern Alaska Range, Alaska: U.S. Geological Survey Open-File Report 90-594, 39 p., 1 sheet, scale $1: 250,000$.
Shanley, J.B., Sunquist, E.T., and Kendall, C., 1994, Water, energy, and biogeochemical budget research at Sleepers River Research Watershed, Vermont: U.S. Open-File Report 94:xxx, $43 \mathrm{p}$.

Thompson, J.M., Mariner, R.H., White, L.D., Presser, T.S., and Evans, W.C., 1992, Thermal waters along the Konocti Bay fault zone, Lake County, California-a re-evaluation: Journal of Volcanology and Geothermal Research, v. 53, p. 167-183.

Thompson, J.M., Nathenson, M., and White, L.D., 1990, Chemical and isotopic compositions of waters from Crater Lake, Oregon, and nearby vicinity, in Drake, Ellen T., Larson, Gary L., Dymond, Jack and Collier, Robert, eds., Crater Lake an ecosystem study, p. 91102.

Thompson, J.M., and White, L.D, 1991, Chemical analyses of water from the GTA-1 well, Parkfield, California, and other nearby spring and well waters: U.S. Geological Survey OpenFile Report 91-0003.

Thordsen, J.J., Kharaka, Y.K., Mariner, R.H., and White, L.D., 1992, Controls on the distribution of stable isotopes of meteoric water and snow in the greater Yellowstone National Park region, U.S.A., in Kharaka, Y.K., and Maest, A.S., eds., Proceedings of the 7th International Symposium on Water-Rock Interaction, July 9-23, 1992, Park City, Utah: Rotterdam, The Netherlands, A.A. Balkema, p. 591.

Vallier, T.L., Jenner, G.A., Frey, F.A., Gill, J.B., Davis, A.S., Volpe, A.M., Hawkins, J.W., Morris, J.D., Cawood, P.A., Morton, J.L., Scholl, D.W., Rautenschlein, M., White, W.M., Williams, R.W., Stevenson, A.J., and White, L.D., 1991, Subalkaline andesite from Valu Fa Ridge, a back-arc spreading center in southern Lau Basin-Petrogenesis, comparative chemistry, and tectonic implications: Chemical Geology, v. 91, p. 227-256. 


\section{GROUND-WATER CHEMISTRY}

TITLE: $\quad$ Geochemistry of Water in Fine Grained Sediments (WR 76-139)

PERSONNEL: Yousif K. Kharaka, Project Chief

Jacqueline Hamilton, Secretary

Gil Ambats, Chemist

James J. Thordsen, Geologist

ADDRESS: $\quad$ U.S. Geological Survey

345 Middlefield Road, MS 427

Menlo Park, CA 94025

TELEPHONE: (415) 329-4535

PROBLEM: The energy potential of geothermal waters from geopressured systems is enormous. Geochemical data are necessary for delineating favorable exploration areas, estimating the recoverable geothermal resources from a given reservoir, and identifying potential pollution, waste disposal, and corrosion problems.

OBJECTIVE: To study the chemistry and controls on the chemistry of water in geothermal and other subsurface systems. Provide basic data needed to estimate the geothermal energy and other resources and to identify potential pollution, waste disposal, and corrosion problems associated with extraction of energy and other resources from these systems.

APPROACH: Collect water, gas, and rock samples from prospective geopressured and other subsurface systems for chemical, mineralogic, and isotopic analyses. Carry out membrane and water/rock interaction laboratory studies. Data analyses will be performed by available and planned computer programs.

PROGRESS: 1. Organic-inorganic interactions. Determinination of the stability constants of acetate and other reactive organic species with $\mathrm{Al}$ and other metals and cations. Results of laboratory experiments indicate that acetate forms moderately strong complexes with $\mathrm{Al}$ at $\mathrm{pH}$ values of about 3-6. Carried out literature search of thermochemical data on inorganic aqueous species of $\mathrm{Al}$ and several $\mathrm{Al}$ minerals. The new results which differ by several Kcal from old data were incorporated in SOLMINEQ.

2. Dicarboxylic acid anions in oil field waters. Some investigators have reported high (up to $2,640 \mathrm{mg} / \mathrm{L}$ ) concentrations of oxalate, malonate and other dicarboxylic acid anions in oil field waters. Because these anions form strong complexes with metals and cations and our 


\section{GROUND-WATER CHEMISTRY}

analyses of waters from California and other sedimentary basins showed much lower values, we sampled several wells from Paloma and North Coles Levee fields that reportedly had the high dicarboxylic acid anions. Our results, published in Chemical Geology, confirm the types and modest concentration values reported by us from other fields.

3. Geochemistry of fluids along the San Andreas fault. There is a major effort by scientists from the USGS (mainly Office of Earthquakes, Volcanos, and Engineering), national laboratories and universities to investigate the geotectonics of this major plate boundary. As part of this effort, we (including Mariner and Bullen from WRD, and Mack Kennedy from Lawrence Berkely Laboratory) are investigating the geochemistry of water and gases and the role of fluids on fault dynamics. Our project has compiled data on the springs and wells along this fault. We have identified about 30 springs and wells close to this fault that are high in termperature, salinity and/or gas content. Field sampling of water, gases and rocks from these sites will be completed during Fiscal Year 1994.

REPORTS PUBLISHED 1989-1994:

Bullen, T.D., and Kharaka, Y.K., 1992, Isotope composition of $\mathrm{Sr}, \mathrm{Nd}$, and $\mathrm{Li}$ in thermal waters from the Norris-Mammoth corridor, Yellowstone National Park and surrounding region, in Kharaka, Y.K., and Maest, A.S., eds., Proceedings of the 7th International Symposium on Water-Rock Interaction, July 9-23, 1992, Park City, Utah: Rotterdam, The Netherlands, A.A. Balkema, v. 2, p. 897-901.

Curiale, J.A., Lundegard, P.D., and Kharaka, Y.K., in press, Hydrous pyrolysis of crude oil in gold-plated reactors: Organic Geochemistry, v. 18, p. $625-641$.

DeBraal, J.D., and Kharaka, Y.K., 1989, SOLINPUT: A computer code to create and modity input files for the geochemical program SOLMINEQ.88: U.S. Geological Survey Open-File Report 89-616, 140 pp.

Giordano, T.H., and Kharaka, Y.K., 1994, Organic ligand distribution and speciation in sedimentary basin brines, diagenetic fluids and related ore solutions, in Parnel, J., and Ruffell, A., eds., Origin, migration and evolution of fluids in sedimentary basins: Geological Society (of London) Publishing House.

Kharaka, Y.K., Ambats, Gil, and Thordsen, J.J., 1993, Distribution and significance of dicarboxylic acid anions in oil field waters: Chemical Geology, v. 107, p. 499-501.

Kharaka, Y.K., and Barnes, H.L., 1990, Introduction: Memorial volume to honor Ivan Barnes (1931-1989): Applied Geochemistry, v. 5, p. 537-539. Also Guest Editor of the volume with $\mathrm{H}$. Barnes.

Kharaka, Y.K., Evans, W.C., Ambats, G., and Thordsen, J.J., in press, Major potential precipitation problems from the deep injection of ground water brine from Paradox Valley, Colorado, in Morganwalp, D.W., and Aronson, D.A., eds., U.S. Geological Survey Toxic Substances Hydrology Program-Proceedings of the technical meeting, Colorado 


\section{GROUND-WATER CHEMISTRY}

Springs, Colo., September 20-24, 1993: U.S. Geological Survey Water-Resources Investigations Report 94-4014.

Kharaka, Y.K., Evans, W.C., Ambats, G., and White, L.D., 1989, Origin of water and solutes in granitic rocks at Cajon Pass, California, U.S.A, in Miles, D.L., ed., Proceedings of the Sixth International Meeting on WaterRock Interaction, Malvern, United Kingdom: Rotterdam, The Netherlands, A.A. Balkema, p. 385-3881.

Kharaka, Y.K., Lundegard, P.D., Ambats, G., Evans, W.C., and Bischoff, J.L., 1993, Generation of aliphatic acid anions and carbon dioxide by hydrous pyrolysis of crude oils: Applied Geochemistry, v. 8, p. 317-324.

Kharaka, Y.K., and Mariner, R.H., 1989, Chemical geothermometers and their application to formation waters from sedimentary basins, in Naesser, N.D., and McCulloh, T.H., eds., Thermal History of Sedimentary Basins: Methods and Case Histories, Springer-Verlag, No. 6, p. 99-1117.

Kharaka, Y.K., Mariner R.H., Ambats, G., Evans, W.C., White, L.D., Bullen, T.D., and Kennedy, B.M., 1990, Origin of water and solutes in and north of the Norris-Mammoth Corridor, Yellowstone National Park: Transactions of the Geothermal Resources Council, v. 4, p. $705-714$.

Kharaka, Y.K., Mariner, R.H., Bullen, T.D., Kennedy, B.M., and Sturchio, N.C., 1991, Geochemical investigations of hydraulic connections between the Corwin Springs Known Geothermal Resources Area and adjacent parts of Yellowstone National Park, in Sorey, M.L., ed., Effect of potential geothermal development in the Corwin Springs Known Geothermal Resources Area, Montana, on the thermal features of Yellowstone National Park: U.S. Geological Survey Water-Resources Investigation Report 91-4052, p. F1-F38.

Kharaka, Y.K., Mariner, R.H., and Evans, W.C., 1992, Composition of gases from the NorrisMammoth corridor, Yellowstone National Park-Evidence for a magmatic source near Mammoth Hot Springsin Kharaka, Y.K., and Maest, A.S., eds., Proceedings of the 7th International Symposium on Water-Rock Interaction, July 9-23, 1992, Park City, Utah: Rotterdam, The Netherlands, A.A. Balkema, v. 2 , p. $1303-1307$.

Kharaka, Y.K., and Thordsen, J.J., 1992, Origin and geochemistry of water in sedimentary basins, in Chauduri, S., and Clauer, C., eds., Isotopic signatures and sedimentary records: Springer-Verlag, p. 411-466.

Lundegard, P.D., and Kharaka, Y. K., 1990, Geochemistry of organic acids in subsurface waters-field data, experimental data and models, in Melchior D.C., and Bassett, R.L., eds., Chemical modeling of aqueous systems II: ACS Symposium Series 416, p. 87-103.

in press, Distribution and occurance of organic acids in subsurface waters, in Pittman, E.D., and Lewan, M.D., eds., The role of organic acids in geological processes: Springer-Verlag.

Lundegard, P.D., Kharaka, Y.K., and Rosenbauer, R.J., 1992, Petroleum as a potential diagenetic agent-Expermental evidence, in Kharaka, Y.K., and Maest, A.S., eds., Proceedings of the 7th International Symposium on WaterRock Interaction, July 9-23, 1992, Park City, Utah: Rotterdam, The Netherlands, A.A. Balkema, v. 1, p. 329-335.

Mariner, R.H., Kharaka, Y.K., Ambats, G., and White, L.D. 1992, Chemical composition and 


\section{GROUND-WATER CHEMISTRY}

stable isotopes of thermal waters, NorrisMammoth corridor, Yellowstone National Park, U.S.A., in Kharaka, Y.K., and Maest, A.S., eds., Proceedings of the 7th International Symposium on Water-Rock Interaction, July 9-23, 1992, Park City, Utah: Rotterdam, The Netherlands, A.A. Balkema, v. 2, p. 963-966.

Perkins, E.H., Kharaka, Y.K., Gunter, W.D., and DeBraal, J.D., 1990, Geochemical modeling of water-rock interactions using SOLMINEQ.88, in Melchior D.C., and Bassett, R.L., eds., Chemical Modeling of Aqueous Systems II: ACS Symposium Series 416, p. 87-103.

Rosenbauer, R.J., Bischoff, J.L., and Kharaka, Y.K., 1992, Geochemical effects of deep-well injection of the Paradox Valley brines into Paleozoic carbonate rocks, Colorado, U.S.A: Applied Geochemistry, v. 7, p. 1-14.

Sorey, M.L., Colvart, E.M., Nimick, D.A., Shields, R.R., Thordsen, J.J., and Ambats, G., 1991, Hydrologic investigations in the Corwin Springs Known Geothermal Resources Area and adjacent part of Yellowstone National Park, in Sorey, M.L., ed., Effect of potential geothermal development in the Corwin Springs Known Geothermal Resources Area, Montana, on the thermal features of Yellowstone National Park: U.S. Geological Survey Water-Resources Investigation Report 914052, F1-F38.

Sorey, M.L., Kharaka, Y.K., Stanley, W.D., and Sturchio, N.C., 1994, Geothermal Systems in the Mammoth corridor at Yellowstone National Park: Transactions of Geothermal Resources Council, v. 9, p. xxx-xxx.

Stille, P., Chaudhuri, S., Kharaka, Y.K., and Cluaer, N., 1992, Neodymium, strontium, oxygen, and hydrogen isotope compositions of waters in present and past oceans-A review, in Chauduri, S., and Clauer, N., eds., Isotopic signature and sedimentary records: SpringerVerlag, p. 389-410.

Thordsen, J.J., Kharaka, Y.K., Mariner, R.H., and White, L.D., 1992, Controls on the distribution of stable isotopes of meteoric water and snow in the greater Yellowstone National Park region, U.S.A., in Kharaka, Y.K., and Maest, A.S., eds., Proceedings of the 7th International Symposium on Water-Rock Interaction, July 9-23, 1992, Park City, Utah: Rotterdam, The Netherlands, A.A. Balkema, v. 1, p. 591-595. 


\section{GROUND-WATER CHEMISTRY}

TITLE: $\quad$ Chemical and Isotope Studies of Thermal Waters of the Western United States (WR 79-165)

PERSONNEL: Robert H. Mariner, Project Chief

Maria M. Watts, Secretary

William Carothers, Hydrologist

William C. Evans, Chemist

ADDRESS: $\quad$ U.S. Geological Survey

345 Middlefield Road, MS 434

Menlo Park, CA 94025

TELEPHONE: (415) 329-4507

PROBLEM: Reconnaissance and chemical and isotope sampling of thermal springs in the western United States generally has not provided information of sufficient detail to permit the geothermal potential of most individual areas to be determined with any certainty. This is especially true in the Cascade Mountain Range, where the chemical geothermometers indicate much lower temperatures of water-rock equilibrium than the sulfate-isotope geothermometer and the geologic setting seem to indicate. This discrepancy could be due to simple mixing of thermal water and freshwater or rapid equilibration of water with surrounding country rock as the fluids rise to the surface; alternatively, the sulfate-isotopic composition could be an artifact reflecting the original source.

OBJECTIVE: Investigate the origin of the dissolved constituents, water, and gases discharging in hot springs and determine their relation to fumaroles and cold mineral springs. Determine the recharge areas for the thermal springs and the amount of mixing of thermal and nonthermal waters.

APPROACH: Do chemical isotopic analyses on samples of water and gas discharging from thermal, cold, and mineral springs. Use the chemical and isotopic data to determine the extent of mixing and ascertain the probable recharge areas for the individual thermal systems. Investigate the factors that control the chemical and isotopic composition of the fluids.

PROGRESS: Chemical and isotopic data for the geothermal system at Steamboat Springs, Nevada, are related in such a way that an integrated picture of the chemical and physical processes which convert the high-temperature fluids to moderate- and low-temperature fluids can be constructed. Enthalpy-chloride, chemical constituent ratios, and chemical geothermo- 


\section{GROUND-WATER CHEMISTRY}

metry show how boiling, dilution, and water-rock reactions modify the original high-temperature fluid as it cools. A precipitation inhibitor injected into fluids in the geothermal plant feedwater, alters the composition of the fluid enough that we can detect it's presence in the adjacent moderate temperature zone. Addition of 12 new geothermal well in the moderate temperature part of the system is inducing changes in water composition associated with carbonate mineral precipitation. Anomalously hot low-chloride waters generated at the contact between the high and moderate temperature parts of the field provide a useful sensor to physical changes in either zone.

High discharge cold springs of slightly anomalous temperature in the Cascade Range carry very large amounts of heat to the land-surface. The headwater springs of the Falls River in northern California discharge about $300 \mathrm{MW}$ thermal more than expected for a spring at that altitude.

\section{REPORTS PUBLISHED 1989-1994:}

Evans, W.C., Kling, G.W., Tuttle, M.L., Tanyileke, G., and White, L.D., 1993, Gas buildup in Lake Nyos, Cameroon-The recharge process and its consequences: Applied Geochemistry, v. 8, p. 207-221.

Evans, W.C., White, L.D., Tuttle, M.L., Kling, G.W., Tanyileke, G., and Michel, R.L., in press, Six years of change at Lake Nyos, Cameroon, yield clues to the past and cautions for the future: Geochemical Journal, v. 28, no. 4.

Goff, F., Evans, W.C., Gardner, J.N., Adams, A., Janik, C.J., Kennedy, B.M., Trijillo, P.E., and Counce,D., in press, Interpretations of in-situ fluid samples from hole VC-2B, Valles Caldera, New Mexico: Geothermal Science and Technology, v. 00.

Goff, Fraser, Gardner, J.N., Solbau, R.D., Adams, Andrew, Evans, W.C., Lippert, D.R., Jacobsen, Ron, Bayhurst, Greg, Trujillo, P.E., Jr., Counce, Dale, and Dixon, Paul, 1990, The "art" of in situ fluid sampling and the remark- able compositional variations in the wellbore fluid of VC-2B, Valles Caldera, New Mexico: Geothermal Resources Council Transactions, v. 14, p. $403-410$.

Guffanti, Marianne, Muffler, L.J.P., Mariner, R.H., Sherrod, D.R., Smith, J.G., Blackwell, D.D., and Weaver, C.S., 1990, Geothermal segmentation of the Cascade Range in the U.S.A: Geothermal Resources Council Transactions, v. 14, p. 1431-1435.

Ingebritsen, S.I., Mariner, R.H., and Sherrod, D.R., 1994, Hydrothermal systems of the Cascade Range, north-central Oregon: U.S. Geological Survey Professional Paper 1044L., $86 \mathrm{p}$.

Ingebritsen, S.E., Sherrod, D.R., and Mariner, R.H., 1989, Heat flow and hydrothermal circulation in the Cascade Range, north-central Oregon: Science, v. 243, p. 1458-1462.

1992, Rates and patterns of goundwater flow in the Cascade Range volcanic arc, and the 


\section{GROUND-WATER CHEMISTRY}

influence on subsurface temperature: Journal of Geophysical Research, v. 97, no. B4, p. 4599-4627.

Kharaka, Y.K., Lundgeard, P.D., Ambats, G., Evans, W.C., and Bischoff, T.L., 1993, Generation of aliphatic acid anions and carbon dioxide by hydrous pyrolysis of crude oils: Applied Geochemistry, v. 8, p. 317-324.

Kharaka, Y.K., and Mariner, R.H., 1989, Chemical geothermometers and their application to formation waters from sedimentary basins, in Naeser N.D., and McCulloh, T.H., eds., Thermal History of Sedimentary Basins: Methods Case Histories, Springer-Verlag, chap. 6, p. 99-117.

Kharaka, Y.K., Mariner, R.H., Ambats, Gil, Evans, W.C., White, L.D., Bullen, T.D., and Kennedy, B.M., 1990, Origins of water and solutes in and north of the Norris-Mammoth Corridor, Yellowstone National Park: Geothermal Resources Council Transactions, v. 14, p. 705-714.

Kharaka, Y.K., Mariner, R.H., Bullen, T.D., Kennedy, B.M., and Sturchio, N.C., 1991, Geochemical investigations of hydrothermal connections between Corwin Springs Known Geothermal Resource Area and adjacent parts of Yellowstone National Park: U.S. Geological Survey Water-Resources Investigations Report No. 91-4052, F1-F38.

Kharaka, Y.K., Mariner, R.H., Evans, W.C., and Kennedy, B.M., 1992, Compositions of gases from the Norris-Mammoth corridor, Yellowstone National Park, U.S.A,-Evidence for a magmatic source beneath Mammoth Hot Springs, in Kharaka, Y.K., and Maest, A.S., eds., Proceedings of the 7th International Symposium on Water-Rock Interaction, July 9-23, 1992, Park City, Utah: Rotterdam, The
Netherlands, A.A. Balkema, v. 2, p. 13031307.

King, C.Y., Basler, D., Presser, T.S., Evans, W.C., White, L.D., and Minissale, A., 1994, In search of earthquake-related hydrologic and chemical changes along the Hayward Fault: Applied Geochemistry, v. 9, p. 83-91.

Kling, G.W., Evans, W.C., Tuttle, M.L., and Tanylicke, G., 1994, Degassing of Lake Nyos: Nature, v. 368, p. 405-406.

Kling, G.W., Tuttle, M.L., and Evans, W.C., 1989, Safety of Cameroonian lakes: Nature, v. 337, p. 215.

1989, The evolution of thermal structure and water chemistry in Lake Nyos: Journal of Volcanology and Geothermal Research, v. 39, p. 151-165.

Mariner, R.H., Kharaka, Y.K., Ambats, Gil, and White, L.D., 1992, Chemical composition and stable isotopes of thermal waters, NorrisMammoth corridor, Yellowstone National Park, U.S.A., in Kharaka, Y.K., and Maest, A.S., eds., Proceedings of the 7th International Symposium on Water-Rock Interaction, July 9-23, 1992, Park City, Utah: Rotterdam, The Netherlands, A.A. Balkema, v. 2, p. 963-966.

Mariner, R.H., and Presser, T.S., in press, Conditions of stilbite and chabazite formation in the hot springs of the Idaho batholith: Zeolite '93 Proceedings of the 4th International Conference on the Occurrence, Properties, and Utilization of Natural Zeolites.

Mariner, R.H., Presser, T.S., and Evans, W.C., 1993, Geothermometry and water-rock interaction in selected thermal systems in the Cascade Range and Modoc Plateau, western United States: Geothermics, v. 22, p. 1-15. 


\section{GROUND-WATER CHEMISTRY}

Mariner, R.H., Presser, T.S., Evans, W.C., and Pringle, M.K.W., 1989, Discharge rates of thermal fluids in the Cascade Range of Oregon and Washington and their relationship to the geologic environment: U.S. Geological Survey Open File Report 89-178, p. 663-694.

1990, Discharge rates of fluid and heat by thermal springs of the Cascade Range, Washington, Oregon, and northern California: Journal of Geophysical Research, v. 95, no. B12, p. $19,517-19,531$.

Mariner, R.H., Young, H.W., and Evans, W.C., in press, Chemical, isotopic, and gas compositions of the hot springs of the Owyhee Uplands, Malheur County, Oregon: Geothermal Resources Council Transactions, v. 18.

Mariner, R.H., Young, H.W., Evans, W.C., and Parliman, D.J., 1991, Chemical, Isotopic, and dissolved gas compositions of the hydrothermal system in Twin Falls and Jerome Counties, Idaho: Geothermal Resources Council Transactions, v. 15., p. 257-263.

Mariner, R.H., Young, H.W., Parliman, D.J., and Evans, W.C., 1989, Geochemistry of thermal waters from selected wells, Boise, Idaho: Geothermal Resources Council Transactions, $v$. 13, p. 173-178.

Mozley, P.S., and Carothers, W.W., 1992, Elemental and isotopic composition of siderite in the Kuparuk Formation, Alaska-Effect of microbial activity and water/sediment interation on early pore-water chemistry: Journal of Sedimentary Petrology, v. 62, p. 681-692.

Nathenson, M., Mariner, R.H., and Thompson, J.M., in press, Convective heat discharge of Wood River group of springs in the vicinity of Crater Lake, Oregon: Geothermal Resources Council Transactions, v. 18.
Oscarson, R.L., Presser, T.S., and Carothers, W.W., 1992, Ca-Mg carbonate deposits, Warnik Canyon, Colusa County, California: U.S. Geological Survey Open-File Report 92-707, $32 \mathrm{p}$.

Sorey, M.L., Kennedy, B.M., Evans, W.C., Farrar, C.D., and Suemnicht, G.A., 1993, Helium isotope and gas discharge variations associated with crustal unrest in Long Valley, California, 1989-1992: Journal Research, v. 98, B9, p. $15,871-15,889$.

Thompson, J.M., Mariner, R.H., White, L.D., Presser, T.S., and Evans, W.C., 1992, Thermal waters along the Konocti Bay fault zone, Lake County, California-A re-evaluation: Journal of Volcanology and Geothermal Research, v. 53, p. 167-183.

Thordsen, J.J., Kharaka, Y.K., Mariner, R.H., and White, L.D., 1992, Controls on the distribution of stable isotopes of meteoric water and snow in the greater Yellowstone National Park region, in Kharaka, Y.K., and Maest, A.S., eds., Proceedings of the 7th International Symposium on Water-Rock Interaction, July 9-23, 1992, Park City, Utah: Rotterdam, The Netherlands, A.A. Balkema, v. 1, p. 591-595.

Tuttle, M.L., Briggs, P.H., Evans, W.C., Kling, G.W., and Lockwood, J.P., 1992, Infuence of mafic minerals on water chemistry and watercolumn stability of Lake Nyos, Cameroon, in Kharaka, Y.K., and Maest, A.S., eds., Proceedings of the 7th International Symposium on Water-Rock Interaction, July 9-23, 1992, Park City, Utah: Rotterdam, The Netherlands, A.A. Balkema, v. 1, p. 449-452. 


\section{GROUND-WATER CHEMISTRY}

TITLE: $\quad$ Chemistry of Aquatic Organic Matter (WR 84-189)

PERSONNEL: Donald F. Goerlitz, Project Chief

ADDRESS: U.S. Geological Survey

345 Middlefield Road, MS 421

Menlo Park, CA 94025

TELEPHONE: (415) 329-4561

PROBLEM: The intrusion of industrial, agricultural, and domestically produced organic chemicals and wastes into the aquatic environment is well known and is considered to be one of the most important environmental problems. The widespread distribution of these anthropogenic substances, in addition to naturally occurring organics, and their detrimental impact on the Nation's water resources points to the need to understand how these substances act and react in the environment. Knowledge of transport, persistence, transformation, solubility, sorption, and reaction kinetics is needed to determine the fate of the substances in the hydrosphere.

OBJECTIVE: (1) Identify organic substances associated with a given field problem, in aqueous and nonaqueous phases, sorbed, and in an unsaturated atmosphere; (2) chemically determine any biotic or abiotic degradation or transformations occurring in the field; (3) measure sorption and reaction equilibria and rates within the aqueous system and at the water-mineral interface from field observations and laboratory simulations; and (4) determine the behavior of organic solutes and vapors in the unsaturated zone.

APPROACH: (1) Use high-performance liquid chromatography, capillary gas chromatography, and computerized gas chromatography/mass spectrometry to make qualitative and quantitative organic analyses; (2) do sorption studies by means of column technology previously developed in this laboratory; and (3) conduct work at two field sites on organic wood preservatives, which are ground-water contaminants, and initiate work at two other field sites where the ground water is contaminated by crude and refined petroleum products.

PROGRESS: Research on the transport and fate of solutes and alteration products of wood preserving chemicals in contaminated ground water continued. Detailed organic analysis, namely gas chromatography-mass spectrometry (GC/MS), of nearly continuous cores and pore water from the surface to depths of about 20 feet has provided a record of the organic contaminants and alteration products resulting from chemical and microbiological reactions 


\section{GROUND-WATER CHEMISTRY}

occurring at Pensacola, Florida. The findings confirm the presence of enhanced microbiological activity in the zone of aerobic-anaerobic transition. Individual microcosms (digestors) prepared using aquifer material and single creosote derived chemicals obtained from the Pensacola site are being compared to results of organic analyses of the contaminated aquifer, in order to improve the understanding of metabolic pathways and the processes involved. The analysis of water samples from an abandoned wood-preserving plant at Jackson, Tennessee, and interpretation of the data were completed. Samples collected by Direct Push Technology (coring) were compared to samples obtained using conventional drilling techniques.

\section{REPORTS PUBLISHED 1989-1994:}

Bekins, B.A., Godsy, E.M., and Goerlitz, D.F., 1993, Modeling steady-state methanogenic degradation of phenols in groundwater: Journal of Contaminant Hydrology v. 14, p. 279-294.

in press, Steady-state methanogenic degradation of phenols in groundwater at Pensacola, Flori$\mathrm{da}$, in Morganwalp, D.W., and Aronson, D.A., eds., U.S. Geological Survey Toxic Substances Hydrology Program-Proceedings of the technical meeting, Colorado Springs, Colo., September 20-24, 1993: U.S. Geological Survey Water-Resources Investigations Report 94-4014.

Cozzarelli, I.M., Baedecker, M.J., Eganhouse, R.P., and Goerlitz, D.F., 1994, The geochemical evolution of low-molecular-weight organic acids derived from the degradation of petroleum contaminants in groundwater: Geochimica et Cosmochimica Acta, v. 58 no. 2, p. 863-877.

Godsy, E.M., Goerlitz, D.F., and Grbic'-Galic', D., 1989, Transport and degradation of watersoluble creosote-derived compounds, in Allen, D.T., ed., Intermedia pollutant transportModeling and Field Measurements: New York, Plenum Publishing, p. 112-143.
1990, Methanogenic degradation kinetics of phenolic compounds: EPA's Biosystems Technology Development Program, Falls Church, Virginia, p. 39-42.

1991 Methanogenic degradation kinetics of phenolic compounds, in Bioremediation of Hazardous Wastes-A symposium: U.S. Environmental Protections Agency Biosystems Technology Development Program, April 16-18, 1991, Falls Church, Va., p. 67-69.

1992, Methanogenic biodegradation of creosote contaminants in simulated ground-water ecosystems: Ground Water, v. 30, p. 232242.

1992, Methanogenic degradation kinetics of phenolic compounds in aquifer-derived microcosms: Biodegradation v. 2, p. 211-221.

1992, Methanogenic degradation kinetics of phenolic compounds in aquifer-derived microcosms: Symposium on Bioremediation of Hazardous Wastes: U.S. Environmental Protection Agency Biosystems Technology Development Program, 1992, Chicago, Illinois, p. 120-125.

1993, Methanogenic degradation kinetics of nitrogen and sulfur containing heterocyclic 


\section{GROUND-WATER CHEMISTRY}

aromatic compounds in aquifer-derived microcosms-Symposium on bioremediation of hazardous wastes-research, development, and field evaluations: U.S. Environmental Protection Agency EPA/600/R-93/054, p. 123-128.

1994, Methanogenic biodegradation of creosote derived compounds in an aquifer at Pensacola, Florida, in Dutton, A.R., ed., Toxic Substances and the Hydrologic Sciences: American Institute of Hydrology, April 10-13, 1994, Austin, Texas, [Proceedings] p. 1-18.

in press, Pathways of methanogenic biodegradation of creosote-derived aromatic compounds, in Morganwalp, D.W., and Aronson, D.A., eds., U.S. Geological Survey Toxic Substances Hydrology Program-Proceedings of the technical meeting, Colorado Springs, Colo., September 20-24, 1993: U.S. Geological Survey Water-Resources Investigations Report 94-4014.

Goerlitz, D.F., 1992, A review of studies of contaminated ground water conducted by the U.S. Geological Survey organics project, Menlo Park, Calif., 1961-1990, in Lesage, S., and Jackson, R., eds., Ground water quality and analysis at hazardous waste sites: New York, Marcel Dekker, p. 295-355.

Goerlitz, D.F., and Franks, B.J., 1989, Use of on-site high performance liquid chromatography to evaluate the magnitude, extent and transport of organic contaminants in aquifers: Ground-Water Monitoring Review, v. 9, No.2, p. 122-130.

Turney, G.L., and Goerlitz, D.F., 1989, Groundwater contamination at an inactive coal and oil gasification plant site, Gas Works Park, Seattle, Washington: U.S. Geological Survey Water-Resources Investigations Report 884224, $31 \mathrm{p}$.
1990, Organic contamination of ground water at Gas Works Park, Seattle, Washington: Ground Water Monitoring Review, v. 10, no. 3, p. 187-198.

Van Denburgh, A.S., Goerlitz, D.F., and Godsy, E.M., in press, Depletion of nitrogen-bearing explosives waste in a shallow ground-water plume near Hawthorne, Nevada, in Morganwalp, D.W., and Aronson, D.A., eds., U.S. Geological Survey Toxic Substances Hydrology Program-Proceedings of the technical meeting, Colorado Springs, Colo., September 20-24, 1993: U.S. Geological Survey WaterResources Investigations Report 94-4014. 


\section{GROUND-WATER CHEMISTRY}

TITLE: Geochemical Reactions Between Water and Mineral Substrates (WR 88-196)

PERSONNEL: Arthur F. White, Project Chief

Gloria M. Castagne, Secretary

Thomas D. Bullen, Hydrologist

Alex E. Blum, Hydrologist

Marjorie Schulz, Hydrologist

Tina Takaga, Student, (Univ. of Calif., Berkeley)

Theresa S. Presser, Chemist

Maria Peterson, Student (Stanford University)

ADDRESS: $\quad$ U.S. Geological Survey

345 Middlefield Road, MS 420

Menlo Park, CA 94025

TELEPHONE: (415) 329-4519

PROBLEM: Water quality and pollution contamination depend strongly on geochemical processes involving reactions with mineral surfaces and substrates. Such processes include weathering reactions that contribute dissolved chemicals, sorption that removes aqueous species, and electron transfer mechanisms that establish redox conditions. Although extensive research has been conducted on the aqueous chemistry, minimal information exists on the corresponding solid phases and their effects on chemical transport.

OBJECTIVE: Investigate the composition and structure of common mineral surfaces and determine the extent of heterogeneity between specific surfaces and the bulk mineral phase. Determine the mechanism and rates of chemical and electron transfer between mineral substrates and surface- and ground-water systems. Determine the nature and extent of temporal changes in surface compositions during natural weathering and contaminant introduction and assess the effects on sorption and retardation. Assess environmental hazards due to the weathering of toxic materials contained in natural minerals and rocks and plan mitigation and cleanup under geologic constraints. Assess the effects of hydrologic parameters on rates of chemical weathering in soil profiles and watersheds and predict impacts of climate change.

APPROACH: Methods used will define concurrent changes in mineral substrates and water during geochemical reactions in natural and contaminated aqueous systems. Characterization of surface chemistry will utilize recent advances in ultra-high vacuum systems including $\mathrm{x}$-ray photoelectron spectroscopy, auger electron spectroscopy, and secondary ion mass spectroscopy. Use also will be made of high-sensitivity solid state electrochemistry. Investigations will include both controlled laboratory studies and natural systems. Detailed field projects 


\section{GROUND-WATER CHEMISTRY}

will be conducted to quantify the significance of mineral substrates in controlling major element chemistry, $\mathrm{pH}$, and Eh, and as sources of trace toxic components such as chromium, copper, selenium and arsenic. Results will permit development of coupled models describing reaction kinetics and mass transport between aqueous and solid phases.

PROGRESS: Work continued assessing the effects of time and climate on chemical weathering rates in soils and the relationship to global $\mathrm{CO}_{2}$ cycles and past climate change. Work entailed both detailed field studies and a world-wide synthesis of existing watershed data. For the Merced chronosequence in California, 5 years of chemical data have been collected for soil waters extracted from suction water samplers in addition to unsaturated hydrologic data including gravimetric water content and matric potentials. A gas chromatography system for analyzing soil gas data was brought on line and a years worth of data collected from samplers at Merced.

Results have indicated significant changes based on yearly precipitation differences reflecting significantly above and below average rain fall over the last several years. Characterization of variations in solid phase chemistry and mineralogy with time have been completed and the results are being written up. Included are detailed analyses of changes of mineral surface areas with time; information that has never been obtained before for such a natural system and data that are critical for calculation of chemical weathering rates. Comparison of rates based on total weathering and current rates of weathering appear comparable, suggesting relatively constant geochemical conditions during the last 3-million years. The data indicate weathering rates are approximately 10,000 times slower than predicted by previous experimental studies.

Two year's worth of chemical and hydrologic data has been collected at the Panola Mountain watershed, Georgia, and Luquillo, Puerto Rico, Water, Energy and Biogeochemical Balance (WEBB) sites. A $\mathrm{LiBr}$ tracer test was conducted at Panola. Results indicate significant vertical variations in the soil zone in addition to lateral hillslope transport. The chemistry is controlled in part by development of aquitards within the granitic saprolite. Seasonal evapotranspiration occurs above this zone and relatively steady state hydrologic and chemical conditions occur below. Principle weathering mechanisms involve alteration of feldspars to kaolinite and the formation of hydrobiotite. The sampling nest in the riparian zone permits a detail picture of hydrochemical interaction between the groundwater and unsaturated zone.

A major effort was undertaken this year to synthesize existing data on reported chemical fluxes from a world-wide distribution of watersheds into a model which describes chemical weathering rates as function of climatic variables, principally precipitation and temperature. 


\section{GROUND-WATER CHEMISTRY}

The model describes the reinforcing effects of climatic parameters on weathering and $\mathrm{CO}_{2}$ uptake, particularly in wet and warm climates. These results have been written up in two publications which are currently in review.

Development of lithogenic isotope capabilities continued. A negative ion source was added to the solid source mass spectrometer which resulted in the capability to analyze for environmentally important elements including $\mathrm{Se}, \mathrm{B}$ and $\mathrm{Cl}$. A new ion counting and negative ion detection on the Finnigan solid-source mass spectrometer was installed, allowing for substantially increased analytical capabilities. Use of the ion counter established analytical protocol for mass spectrometry of uranium, thorium and iron isotopes. Systematic and analytical methods for these elements are currently actively under investigation. U/Th isotopes are important in terms of age dating geological material and for use as hydrologic tracers.

Several hundred $\mathrm{Sr}$ isotope analyses for five WEBB projects were run in addition to a number of $\mathrm{Pb}$ isotope analyses for Panola WEBB and Sleepers River Experimental Watershed (Vermont) WEBB sites. Also studies on $\mathrm{Sr}, \mathrm{Li}$ and $\mathrm{B}$ isotope systematics in fluids and solid phases from two regional carbonate aquifer systems (Ohio and Indiana RASA, Upper Floridan) were performed in an attempt to track fluid migration on a regional scale.

Cooperative studies were undertaken with the Utah District in defining the source of contamination of the Jordan River from extensive milling tailings.

Studies continued defining sources of selenium in the Central Valley of California. Panoche and Silver Creeks have been instrumented with sediment-water collectors. Major element chemistry and isotopic analyses on waters have been completed in order to distinguish between the two hypotheses of an initial flush of selenium or a later outflow of older groundwater. Sediments were analyzed for Se along with amount of sediment per volume of water carried by the streams.

The atomic force microscope (AFM) has been used to develop new techniques for characterization of clay particles Applications of these techniques to illite/smectites have resulted in one publication and another in press that have aroused considerable interest. The AFM system is also being used to characterize surface areas and extent of internal porosity in soil and aquifer materials. 


\section{GROUND-WATER CHEMISTRY}

\section{REPORTS PUBLISHED 1989-1994:}

Benson, S., White, A.F., Halfman, S., and Flexser, S., 1991, Groundwater contamination at the Kesterson Reservoir, California; Part I. Hydrologic setting and conservative solute transport: Water Resources Research, v. 27, pp. 1071-1084.

Blum, A.E., 1994, Feldspars in Weathering, in Parsons I., ed., Feldspara and Theor Reactions: NATO Advanced Study Series, Netherlands, Kluwer Academic Publishers, p. 595629.

Blum, A.E., and Eberl, D.D., 1992, Determination of clay particle thicknesses and morphology using Scanning Force Microscopy, in Kharaka, Y.K., and Maest, A.S., eds., Proceedings of the 7th International Symposium on WaterRock Interaction, July 9-23, 1992, Park City, Utah: Rotterdam, The Netherlands, A.A. Balkema, p. 133-136.

Blum, A.E. and Lasaga, A.C., 1991, The role of surface speciation in the dissolution of albite: Geochimica et Cosmochimica Acta, v. 55, p. 2193-2201.

Blum, A.E., Yund, R.A., and Lasaga, A. C., 1990, The effect of dislocation density on the dissolution rate of quartz: Geochimica et Cosmochimica Acta, v. 54, 283-297.

Bullen, T.D. and Kharaka, Y.K., 1992, Isotopic composition of $\mathrm{Sr}, \mathrm{Nd}$ and $\mathrm{Li}$ in thermal waters from the Norris-Mammoth corridor, Yellowstone National Park and surrounding region, in Kharaka, Y.K., and Maest, A.S., eds., Proceedings of the 7th International Symposium on Water-Rock Interaction, July 9-23, 1992, Park City, Utah: Rotterdam, The Netherlands, A.A. Balkema, p. 895-890.
Davisson, M.L., Presser, T.S., and Criss, R.E., 1993, Geochemistry of technonically expelled fluids from the northern coast ranges: Rumsey Hills, California, Lawerence Livermore National Laboratory Report UCRL-JC-112841, $24 \mathrm{p}$.

Eberl, D.D. and Blum, A. E., 1993, Illite crystallite thickness by X-ray diffraction, in Reynolds, R.C., and Walker, J.R., eds., Computer to X-ray diffraction of clay minerals: Clay Mineral Society, p. 123-154.

Hochella, M.F. and White, A.F., 1990, Mineralwater interface geochemistry, an overview, in Hochella, M.F., and White, A.F., eds, Mineral-Water Interface Geochemistry: Reviews in Mineralogy, no. 23, p. 1-15.

Huntington, T.G., Hooper, R.P., Peters, N.E., Bullen, T.D. and Kendall, C., 1993, Water, energy and biogeochemical budgets investigation at Panola Mountain research watershed, Stockbridge, Georgia-A research plan: U.S. Geological Survey Open-File Report 93-55.

Johnson, P.A., Blum, A.E., Hochella, M.F., Parks, G.A., and Sposito, G., 1992, Direct observation of muscovite basal-plane dissolution and secondary phase formation-An XPS, LEED, and SFM study, in Kharaka, Y.K., and Maest, A.S., eds., Proceedings of the 7th International Symposium on Water-Rock Interaction, July 9-23, 1992, Park City, Utah: Rotterdam, The Netherlands, A.A. Balkema, p. 159-162.

Kharaka, Y.K., Mariner, R.H., Bullen, T.D., Kennedy, B.M. and Sturchio, N.C., 1991, in Sorey, M.L., ed., Effects of potential geothermal development in the Corwin Springs known Geothermal Area, Montana, on the 


\section{GROUND-WATER CHEMISTRY}

thermal features of Yellowstone National Park: U.S. Geological Survey Water-Resources Investigations Report 91-4052, p. F1-F38.

Nagy, K.L., Blum, A.E., and Lasaga, A.C., 1991, Dissolution and precipitation kinetics of kaolinite at $80^{\circ} \mathrm{C}$ and $\mathrm{pH} 3$-the effect of deviaition from equilibrium: American Journal Science, v. 291, p. 649-686.

Oscarson, R.L., Presser, T.S., and Carothers, W.W., 1992, Ca-Mg Carbonate deposits, Warnick Canyon, Colusa County, California: U.S. Geological Survey Open-File Report 92-707.

Plummer, L.N., Busenberg, E., Glynn, P.D. and Blum, A.E., 1992, The dissolution of aragonite-strontianite solid solutions in non-stoichiometric $\mathrm{Sr}\left(\mathrm{HCO}_{3}\right) 2-\mathrm{Ca}\left(\mathrm{HCO}_{3}\right) 2-\mathrm{CO}_{2}-\mathrm{H}_{2} \mathrm{O}$ solutions-A test of stoichiometric saturation: Geochimica et Cosmochimica Acta, v. 56, p. 3045-3072.

Presser, T.S., 1993 The geologic origin and pathways of mobility of selenium from the California Coast Ranges to the west-central San Joaquin Valley, in Frankenger W.T., and Benson, S., eds., Selenium in the Environment: New York, Marcel Dekker, p. 139-156.

Presser, T.S., Swain, W.C. Tidball, R.R., and Severson, R.C., 1990, Geologic sources, mobilization, and transport of selenium from the California Coast Ranges to the Western San Joaquin Valley-A Reconnaissance Study: U.S. Geological Survey Water-Resources Investigation Report 90-4070, 24 p.

White, A.F., 1990, Heterogenous electrochemical reactions associated with oxidation of ferrous oxide surfaces, in Hochella, M.F., and White, A.F., eds., Mineral water interface geochemis- try: Reviews in Mineralogy, v. 23, p. 467555.

White, A.F., Benson, S. M., Yee, A. W., Wollenberg, H. A. and Flexser, S., 1991, Groundwater contamination at the Kesterson Reservoir, Calif.; Part II. Geochemical parameters influencing selenium mobility: Water Resources Research, no. 27, p. 1085-1098.

White, A. F., Blum, A.E., Bullen, T.D., Peterson, M.L., and Harden, J.W., 1992, A three million year weathering record for a soil chronosequence developed in granitic alluvium, Merced, California, U.S.A, in Kharaka, Y.K., and Maest, A.S., eds., Proceedings of the 7th International Symposium on Water-Rock Interaction, July 9-23, 1992, Park City, Utah: Rotterdam, The Netherlands, A.A. Balkema, p. $607-610$.

White, A.F., Chuma, N.J., and Goff, F., 1992, Mass transfer constraints on the chemical evolution of an active hydrothermal system, Valles caldera, New Mexico: Journal of Volcanology and Geothermal Research, v. 49, p. 233-253.

White, A.F., and Dubrovsky, N.M., 1994, Chemical Oxidation-Reduction Controls on Selenium Mobility in Groundwater Systems, in Fankenberger, W.T., and Benson, S.M., eds. Selenium in the Environment: New York, Marcel Dekker, p. 185-223.

White, A.F. and Hochella, M.F., 1989, Electron transfer mechanisms associated with surface dissolution and oxidation of magnetite and ilmenite, in Miles, D.L., ed., Proceedings of the Sixth International Meeting on Water-Rock Interaction, Malvern, United Kingdom: Rotterdam, The Netherlands, A.A. Balkema, p. 765-768. 


\section{GROUND-WATER CHEMISTRY}

1992, Surface chemistry associated with the cooling and subaerial weathering of recent basalt flows: Geochimica et Cosmochimica Acta, v. 56, p. 3711-3721.

White, A.F., and Peterson, M.L., 1990, Role of reactive-surface area characterization in geochemical kinetic models, in Melchoi, D.C., and Bass, R.L., eds., Chemical modeling of aqueous systems: American Chemical Society Symposium Series 416, p. 461-475.

1990, Sources and fractionation processes influencing the isotopic distribution of $\mathrm{H}, \mathrm{O}$, and $\mathrm{C}$ in the Long Valley hydrothermal system, California, U.S.A.: Applied Geochemistry, v. 5, p. 571-585.

1990, The role of reactive surface areas in chemical weathering: Chemical Geology v. 84, p. 334-336.

White, A.F., Peterson, M.L., and Hochella, M.F., 1994, Electrochemistry and dissolution of magnetite and ilmenite: Geochimica et Cosmochimica Acta, v. 58, 1859-1875.

White, A.F., Peterson, M.L., and Janik, C., 1991, Chemical equilibrium and mass balance relationships associated with the Long Valley hydrothermal system, California, U.S.A.: Journal of Volcanology and Geothermal Research,v. 48, p. 283-302.

White, A.F., Peterson, M.L., and Solbau, R.D., 1990, Measurement and interpretation of low levels of dissolved oxygen in ground water: Ground Water 28, p. 584-590. 



\section{GROUND-WATER HYDROLOGY}




\section{GROUND-WATER HYDROLOGY}

TITLE: The Mathematical Simulation of the Transport and Reaction of Chemical Species in Ground Water (CR 73-085 formerly NR 73-139)

PERSONNEL: David B. Grove, Project Chief

Evelyn R. Warren, Secretary

Lana K. Gerlick, Clerk

ADDRESS: U.S. Geological Survey

P.O. Box 25046, MS 413

Denver Federal Center

Denver, CO 80225

TELEPHONE: (303) 236-4980

PROBLEM: Mathematical techniques that describe the transport and reactions of dissolved chemical species during their flow through saturated porous media are necessary to the prediction of water-quality changes in ground water. Such predictions are necessary to allow a decision-making capability prior to possible injection of wastes, as well as to provide remedial action in the case of accidental contamination of aquifers.

OBJECTIVE: Demonstrate the applicability of numerical-modeling techniques to the prediction of water-quality changes during transport of solutes through saturated ground-water systems and analyze the effects of these changes on the ground-water environment. Predict the effects of chemical and physical stresses on the quality of ground water.

APPROACH: Solve the mass-transport equation through numerical means by use of finite-difference and finite-element methods and thus produce a water-quality model that will predict the effects of chemical disturbances on the ground-water system. Evaluate the effects of the disturbances on the aquifer. Take a systems-oriented approach, concentrating on the use of field data and laboratory experiments to verify the model. Work closely with District, other Federal, and State research projects involved in similar studies.

PROGRESS: Considerable time was spent reviewing possible research sites for a proposed USGS bioremediation study with the Air Force Combat Command. The status of the possible contract is on hold. Finite difference numerical simulations of radial diffusion during transport through porous media compared well with Crank's analytical solutions. Diffusion and reaction in porous spheres are one mechanism being explored to better explain contaminant attenuation during flow through aquifers. 


\section{GROUND-WATER HYDROLOGY}

\section{REPORTS PUBLISHED 1989-1994:}

Rathbun, R.E., Shultz, D.J., Stephens, D.W., and Tai, D.Y., 1989, Transport and fate of acetone in an outdoor model stream, Stennis Space Center, Bay St. Louis, Mississippi: U.S. Geological Survey Water-Resources Investigations Report 89-4141.

Shultz, D.J., 1989, Nitrogen dynamics in the Tidal Freshwater Potomac River, Maryland and Virginia, Water Years 1979-81: U.S. Geological Survey Water-Supply Paper 2234-J, 44 p. 


\section{GROUND-WATER HYDROLOGY}

TITLE: $\quad$ The Role of Lakes in the Hydrologic System, with Emphasis on Their Relation to Ground Water (CR 74-090)

PERSONNEL: Thomas C. Winter, Project Chief

Evelyn R. Warren, Office Auto. Assist. Donald O. Rosenberry, Hydrologist

Lana K. Gerlick, Off. Auto. Clerk Renee S. Parkhurst, Hydrologist

ADDRESS: $\quad$ U.S. Geological Survey

P.O. Box 25046, MS 413

Denver Federal Center

Denver, CO 80225

TELEPHONE: (303) 236-4987

PROBLEM: Many hydrological and geochemical processes associated with lakes and wetlands are poorly understood. Characteristics of wind and vapor profiles over lakes, which are basic controls on evaporation, have been studied in detail for only a few large reservoirs in the western United States. Many commonly used methods of estimating surface runoff to lakes and wetlands are inaccurate. Hydrogeologic controls on seepage to and from all surface-water bodies have not been studied adequately, either from theoretical or field perspectives. Research on these components of lake and wetland hydrology is especially critical to individuals responsible for management, protection, and restoration of these resources.

OBJECTIVE: Gain understanding of the basic principles controlling the interaction of lakes and wetlands with ground water, including associated chemical fluxes. Emphasize integration of theoretical and experimental field work. Emphasize the study of ground water, but include state-of-the-art studies of the atmospheric and surface-water components of lake and wetland hydrology as needed for the evaluation of the ground-water component. Evaluate error in hydrologic methodology for the various aspects of water balances of lakes and wetlands.

APPROACH: Construct theoretical and field-related mathematical models of steady-state and transient, variably-saturated ground-water conditions as related to lakes and wetlands.

Choose field experimental sites in selected parts of the United States for calibration and modification of models, instruments, and methods. Measure all components of the hydrologic system, as related to the experimental lakes and wetlands, by various methods in support of the ground-water studies. Use multiple-level sensors on the lake for evaporation research. Integrate chemical flux and biological studies with the hydrologic work at selected sites. 


\section{GROUND-WATER HYDROLOGY}

PROGRESS: Working in collaboration with colleagues from the Institute of Ecosystem Studies, we evaluated uncertainty in calculation of chemical flux rates with respect to Mirror Lake, New Hampshire. These studies indicated that it is critical to measure streamflow accurately especially at high flow in the spring because relatively small errors in outflow discharge result in significant errors in the net loss of solutes from the lake. Furthermore, chemical sampling needs to be done such that water samples are collected on an event basis, during both the rising and falling limbs of the outflow hydrograph.

Another study at Mirror Lake completed this year involved determining ground-water recharge and baseflow from streamflow hydrographs. Two methods of determining recharge were compared, one is based on the assumption that recharge is instantaneous and the other is based on the assumption that recharge is constant over a period of several months. Both methods assume that recharge is distributed uniformly over the watershed. The results indicated that recharge determined by both methods agreed to within about 10 percent. In addition, recharge in the Mirror Lake area was twice as great during wet years as it was during dry years. Three methods of determining baseflow were also compared. Two methods were graphical and one was mathematical, using digital filtering. The graphical methods compared well, but the digital filtering method significantly underestimated baseflow.

As a result of analyzing test drilling data collected over a number of years in the Cottonwood Lake area, North Dakota, a buried sand deposit was delineated that was a great benefit in understanding the interaction of wetlands and ground water. The high permeability of the sand causes it to function as a shunt in the ground-water flow field. As a result, some wetlands overlying the upgradient end of the sand deposit are perennial recharge wetlands, and a complex water-table configuration is present between them. Conversely, wetlands on the downgradient end of the buried sand deposit receive the discharge from the sand, resulting in a relatively stable water supply for the wetland and a chemical water type unlike any other wetlands in the area. These results indicate the necessity of defining the three-dimensional geologic framework of a ground-water flow field as a basis for understanding the hydrologic function of surface water as well as for the chemical and biological characteristics of surface-water bodies.

At the request of the American Geophysical Union, a paper was prepared that summarizes some of the recent advances in understanding the interaction of ground water and surface water. The paper is based on an extensive search of bibliographic data bases, and concentrates on papers prepared during the past ten years. The paper discusses ground water and surface water interaction with respect to different landscapes: such as, mountainous, 


\section{GROUND-WATER HYDROLOGY}

riverine, coastal, glacial, and karst. The paper will be published as part of the U.S. National Report to the International Union of Geodesy and Geophysics.

\section{REPORTS PUBLISHED 1989-1994:}

Bukaveckas, P.A., Likens, G.E., Buso, D.C., and Winter, T.C., 1993, Hydrologic controls of chemical flux rates in the Mirror lake watershed: Verhandlungen Internationale Vereinigung Limnologie, v. 25, p. 419-422.

Carter, V., Gammon, P.T., Rosenberry, D.O., and Turtora, M. 1993, Aquatic macrophytes and selected physical properties of Shingobee and Williams Lakes, Minnesota, 1991-92: U.S. Geological Survey Open-File Report 93-143, $41 \mathrm{p}$.

Harte, P.T., and Winter, T.C., in press, Factors affecting recharge to crystalline rock in the Mirror Lake area, Grafton County, New Hampshire, in Morganwalp, D.W., and Aronson, D.A., eds., U.S. Geological Survey Toxic Substances Hydrology Program-Proceedings of the technical meeting, Colorado Springs, Colo., September 20-24, 1993: U.S. Geological Survey Water-Resources Investigations Report 94-4014.

Hsieh, P.A., Perkins, R.L., and Rosenberry, D.O., in press, Field instrumentation for multi-level monitoring of hydraulic head in fractured bedrock at the Mirror Lake site, Grafton county, New Hampshire, in Morganwalp, D.W., and Aronson, D.A., eds., U.S. Geological Survey Toxic Substances Hydrology Program-Proceedings of the technical meeting, Colorado Springs, Colo., September 20-24, 1993: U.S. Geological Survey Water-Resources Investigations Report 94-4014.

Hsieh, P.A., Shapiro, A.M., Barton, C.C., Haeni, F.P., Honson, C.D., Martin, C.W., Paillet,
F.L., Winter, T.C., and Wright, D.L., 1993, Methods of characterizing fluid movement and chemical transport in fractured rock, in Chaney, J.T., and Hepburn, J.C., eds., Field trip guidebook for northeastern United States: Boston, Massachusetts, Geological Society of American, Annual Meeting, October 25-28, v. 2, p. R1-R30.

McConnaughey, T.A., LaBaugh, J.W., Reddy, M.M., Schuster, P.F., Rosenberry, D.O., Striegl, R.G., and Carter, V., in press, Carbon budget for a groundwater-fed lakecalcification supports summertime photosynthesis: Limnology and Oceanography, v. 00.

Parkhurst, R.S., Merk, D.A., Rosenberry, D.O., and Winter, T.C., 1992, Climatic data for Williams Lake, Hubbard County, Minnesota, 1987-88: U.S. Geological Survey Open-File Report 92-475, 39 p.

Parkhurst, R.S., Merk, D.A., Rosenberry, D.O., and Winter, T.C., 1993, Climatic data for Shingobee Lake and Williams Lake, Hubbard County, Minn., 1989-91: U.S. Geological Survey Open-File Report 93-127, 34 p.

Rosenberry, D.O., 1990, Effect of sensor error on interpretation of long-term water-level data: Ground Water, v. 28, no. 6, p. 927-936.

Rosenberry, D.O., LaBaugh, J.W., McConnaughey, T.A., Striegl, R.G., and Winter, T.C., 1993, The Interdisciplinary Research Initiative: Hydrologic research in the Shingobee River headwaters area, Minnesota [Water Fact 


\section{GROUND-WATER HYDROLOGY}

Sheet]: U.S. Geological Survey Open-File Report 93-446, 2 p.

Rosenberry, D.O., Sturrock, A.M., and Winter, T.C., 1993, Evaluation of the energy budget method of determining evaporation at Williams Lake, Minnesota, using alternative instrumentation and study approaches: Water Resources Research, v. 29 , no. 8 , p. 2473-2483.

Rosenberry, D.O., and Winter, T.C., 1993, The significance of fracture flow to the water balance of a lake situated in fractured crystalline rock terrane, in Banks, Sheila, and Banks, David, eds., Hydrologeology of Hard Rocks: Memoirs of the XXIV Congress of the Internation Association of Hydrogeologists, Oslo, Norway, p. 967-977.

Stannard, D.I. and Rosenberry, D.O., 1991, A comparison of short-term measurements of lake evaporation using eddy correlation and energy budget methods: Journal of Hydrology, v. 122 , p. $15-22$.

Sturrock, A.M., Winter, T.C., and Rosenberry, D.O., 1992, Energy-budget evaporation from Williams Lake, a closed lake in north-central Minnesota: Water Resources Research, v. 28, no. 6, p. 1605-1617.

Winter, T.C., 1989, Hydrologic studies of wetlands in the northern prairie: in van der Valk, Arnold, ed., Northern prairie Wetlands: Ames, Iowa, Iowa State University Press, p. 16-54.

1990, Hydrologic function of wetlands: U.S. Geological Survey Yearbook Fiscal Year 1989, p. 29-31.

1992, A physiographic and climatic framework for hydrologic studies of wetlands, in Robards, R.D., and Bothwell, M.L., eds., Aquatic eco- systems in semi-arid regions, implications for resource management: The National Hydrology Research Institute Symposium Series no. 7, Saskatoon, Saskatchewan, Canada, Environment Canada, p. 127-148.

Winter, T.C., Eaton, J.S., and Likens, G.E., 1989, Evaluation of streamflow from the two largest watersheds of Mirror Lake, New Hampshire: Water Resources Bulletin, v. 25, no. 5, p. 991-1008.

Winter, T.C. and Llamas, M.R., 1993, Introduction to the 28th International Geological Congress Symposium on the Hydrogeology of wetlands: Journal of Hydrology, v. 141, p. 1-3.

Winter, T.C., and Woo, Ming-Ko, 1990, Hydrology of lakes and wetlands, in Wolman, M.G., and Riggs, H.C., eds., Surface Water Hydrology: Boulder, Colo., Geological Society of America, The Geology of North America, v. 0-1, p. 159-187.

Woo, M-K and Winter, T.C., 1993, The role of permafrost and seasonal frost in the hydrology of northern wetlands in North America: Journal of Hydrology, v. 141, p. 5-31. 


\section{GROUND-WATER HYDROLOGY}

TITLE: Borehole Geophysics as Applied to Geohydrology (CR 64-140)

PERSONNEL: Frederick L. Paillet, Project Chief

Richard E. Hodges, Electrical Technician

John E. Hutchens, Electrical Technician

Roger Morin, Geophysicist

Ticie A. Taylor, Computer Programmer

Joyce A. Dey, Computer Assistant

Patricia A. Stamile, Accounting Technician

ADDRESS: U.S. Geological Survey

P.O. Box 25046, MS 403

Denver Federal Center

Denver, CO 80225

TELEPHONE: (303) 236-5913

PROBLEM: A large amount of geophysical data is recorded for water wells and test holes, but interpretation is subject to significant uncertainties. The data are used in ground-water models to evaluate potential waste-disposal sites and the effects of ground-water contamination and to guide development of aquifers, including geothermal reservoirs. The development of quantitative log-interpretation techniques to derive more accurate data and to evaluate the statistical uncertainty in the data will reduce costs in ground-water investigations.

OBJECTIVE: (1) Evaluate presently available logging equipment and log-interpretation techniques, and develop improved instrumentation and analytical techniques for specific ground-water problems, such as site selection and monitoring for disposal of radioactive, municipal, and industrial wastes; (2) improve log-derived data, such as porosity values; (3) attempt to relate the log character of fractures to their hydraulic conductivities and to refine computer techniques for plotting hydraulic-conductivity profiles from logs; (4) develop the capability of making quantitative interpretation of borehole gamma spectra; and (5) do a statistical analysis of the magnitude and sources of errors in log-derived data.

APPROACH: Log selected drill holes, recording data in both analog and digital form, and comparing logs with results of core analyses, hydraulic-test data, and geophysical measurements made in calibration pits and blocks. Develop computer models to predict the behavior of gamma photons, electrical signals of various frequencies, and acoustic wave energy in borehole environments. Compare field-log data, theoretical predictions and hydraulic tests, core analyses, and test-pit values. Modify equipment and develop log corrections on the basis of these comparisons and calculate the statistical accuracy of log data. 


\section{GROUND-WATER HYDROLOGY}

PROGRESS: Experimental procedures have been designed to use transient flow data to infer hydraulic properties of interconnections between permeable beds or fractures in the rock mass adjacent to the borehole, and this procedure is being integrated into a systematic approach to characterize the hydrology of rocks adjacent to boreholes in order to significantly improve the effectiveness and efficiency of sampling and hydraulic testing. These techniques are described by F.L. Paillet in articles published in the Journal of Applied Geophysics, Journal of Ground Water, and Journal of Hydrology in late 1993 and early 1994. The generalized applications of high-resolution flowmeter logging were reviewed in a paper presented at a national environmental symposium in April 1994. Three other papers were published by R.H. Morin in scientific journals and proceedings volumes describing the application of these techniques to site characterization and in situ permeability profiling. T.A. Taylor is making major contributions to two technical reports describing the application of gamma spectral log measurements and other logs to the identification of elevated levels of radium-226 and uranium-238 daughters in community water systems. F.L. Paillet prepared a generalized framework for log analysis and interpretation in ground water studies to be used for training manuals; a preliminary discussion of this framework was prepared for publication in the proceedings volume for a technical meeting in October 1993. Geophysical logs were used to characterize the geomechanical and hydraulic effects of water stimulation as part of a ground water study in Minnesota; results of the study were published as a Water Resources Investigation Report in May 1994.

\section{REPORTS PUBLISHED 1989-1994:}

Barrash, W., Morin, R.H., Wood, S.H., and Bennecke, W., 1994, Hydrostratigraphic interpretation of the upper portion of the Snake River Plain aquifer near the Idaho Chemical Processing Plant at the INEL: Annual Engineering Geology and Geotechnical Engineering Symposium, 32nd, Boise, Idaho, March 1994, [Proceedings], $11 \mathrm{p}$.

Crowder, R., Paillet, F.L., and Hess, A.E., 1994, High resolution flow-meter logging-a unique combination of borehole geophysics and hydraulics; Part I-Flowmeter techniques and equipment development: Symposium on the Application of Geophysics to Engineering and Environmental Problems, Boston, Mass., March 1994, [Proceedings], p. 361-380.
Forster, C.B., Morin, R.H., and Sorey, M.L., 1994, Hydrologic testing and hydrothermal modeling at the Long Valley Exploratory Well: International Symposium on the Observation of the Continental Crust Through Drilling, 7th, Santa Fe, New Mexico, April 1994, [Proceedings], $5 \mathrm{p}$.

Gable, R., Morin, R.H., and Becker, K., 1989, Geothermal state of hole 504B-ODP Leg 111 overview-Proceedings of the Ocean Drilling Program: Scientific Results, v. 111, p. 87-96.

Hess, A.E., 1990, A thermal flowmeter for the measurement of slow velocities in boreholes: U.S. Geological Survey Open-File Report 87-121, 70 p. 


\section{GROUND-WATER HYDROLOGY}

1990, Characterizing fracture hydrology using a sensitive borehole flowmeter with a wirelinepowered packer: International Conference on Fluid Flow in Fractured Rock, Atlanta, Ga., May, 1988, [Proceedings], p. 328-345.

Hess, A.E., and Paillet, F.L., 1990, Applications of the thermal-pulse flowmeter in the hydraulic characterization of fractured rocks: ASTM STP 1101, p. 99-112.

1990, Characterizing flow paths and permeability distribution in fractured-rock aquifers using a sensitive, thermal borehole flowmeter, in Molz, F.J., and others, eds., Proceedings of the conference on new field techniques for quantifying the physical and chemical properties of heterogeneous aquifers: Dublin, Ohio, National Water Well Association, 1989, p. 445-461.

1990 , Measurement of vertical flow in borehole UE-3e 4 using geophysical logs, Nevada Test Site, Nye County, Nevada: U.S. Geological Survey Water-Resources Investigations Report 90-4185, 17 p.

Hodges, R.E., and Teasdale, W.E., 1991, Considerations related to drilling methods in planning and performing borehole-geophysical logging for ground-water studies: U.S. Geological Survey Water-Resources Investigations Report 91-4090, $17 \mathrm{p}$.

Lapcevic, P.A., Novakowski, K.C., and Paillet, F.L., 1993, Analysis of flow in an observation well intersecting a single fracture: Journal of Hydrology, v. 151, p. 227-239.

Molz, F.J., Morin, R.H., Hess, A.E., Melville, J.G., and Guven, O., 1989, The impeller meter for measuring aquifer permeability variations-Evaluation and comparison with other tests: Water Resources Research, v. 25, no. 7, p. $1677-1683$.

Moos, D., and Morin, R.H., 1991, Observations of wellbore failure in the Toa Baja well-Implications for the state of stress in the north coast tertiary basin, Puerto Rico: Geophysical Research Letters, v. 18, no. 3, p. 505-508.

Morin, R.H., 1990, Determining the vertical distribution of hydraulic conductivity in situ by concurrent injection and geophysical logging: International Conference on Fluid Flow in Fractured Rock, Atlanta, Ga., May, 1988, [Proceedings], p. 346-354.

1990, Information on stress conditions in the oceanic crust from oval fractures in a deep borehole: Geophysical Research letters, v. 17, no. 9, p. 1311-1314.

1991, Preliminary determination of hydraulic conductivity in a sand and gravel aquifer, Cape Cod, Massachusetts form analysis of nuclear logs, in Mallard, G.E., and Aronson, D.A., eds., U.S. Geological Survey Toxics Substances Hydrology Program-Proceedings of the technical meeting, Monterey, Calif., March 11-15, 1991: U.S. Geological Survey Water-Resources Investigations Report 914034, p. 23-28.

Morin, R.H., and others, 1989, Analysis and interpretation of the borehole televiewer log-Information on the state of stress and lithostratigraphy at hole 504B-Proceedings of the Ocean Drilling Program: Scientific Results, v. 111 , p. 109-118.

1990, State of lithospheric stress and bore-hole stability at Deep Sea Drilling Project Site 504B, Eastern Equatorial Pacific: Journal of Geophysical Research, v. 95, no. B6, p. 9293-9303. 


\section{GROUND-WATER HYDROLOGY}

Morin, R.H., Barrash, W., Paillet, F.L., and Taylor, T.A., 1993, Geophysical logging studies in the Snake River Plain aquifer at the Idaho National Engineering Laboratory-Wells 44, 45, and 46: U.S. Geological Survey Water-Resources Investigations Report 92-4184, 44 p.

Morin, R.H., Hess, A.E., and Becker, K., 1992, In situ measurements of fluid flow in DSDP holes 395A and 534A-Results from the Dianaut program: Geophysical Research Letters, v. 19 , no. 5 , p. 509-512.

Morin, R.H., Moos, D., and Hess, A.E., 1992, Analysis of the borehole televiewer log from DSDP hole 395A-Results from the Dianaut Program: Geophysical Research Letters, v. 19, no. 5, p. 501-504.

Morin, R.H., Olsen, H.W., Nelson, K.R. and Gill, J.D., 1989, Graphical method for determining the coefficient of consolidation, $\mathrm{cv}$, from a flow-pump permeability test: Geotechnical Testing Journal, December, p. 302-307.

Morin, R.H., Sorey, M.L., and Jacobson, R.D., 1993, Results of the flowmeter-injection test in the Long Valley Exploratory Well (Phase II), Long Valley, California: U.S. Geological Survey Water-Resources Investigations Report 93-4127, $10 \mathrm{p}$.

Morin, R.H. and Urish, D.W., 1994, Hydrostratigraphic characterization of a coastal aquifer by geophysical log analysis, Cape Cod National Seashore, Massachusetts: Minerals and Geotechnical Logging Society International Symposium, 5th, Tulsa, Oklahoma, October 1993, [Proceedings], paper M, $23 \mathrm{p}$.

Paillet, F.L., 1989, A generalized approach to geophysical well-log analysis and interpretation in hydrogeology, in Molz, F.J., and others, eds., Conference of new field techniques for quanti- fying the physical and chemical properties of the heterogeneous aquifers, Dublin, Ohio, Proceedings: National Water Well Association, 1989, p. 99-120.

1989, Analysis of geophysical well logs and flowmeter measurements in boreholes penetrating subhorizontal fracture zones, Lac DuBonnet Batholith, Manitoba, Canada: U.S. Geological Survey Water-Resources Investigations Report 89-4211, 30 p.

1989, Genetic diversity in post-blight populations of American Chestnut-Past, present, and future: Journal of the American Chestnut Foundation, v. 3 , no. 1, p. 16-30.

1990, Characterization of fracture flow systems using geophysical log estimates of in situ permeability and other hydraulic data: International Conference on Fluid Flow in Fractured Rock, Atlanta, Ga., May, 1988, [Proceedings], p. 312-327.

1991, The 1st core hole at Mirror Lake, New Hampshire-Comparing geophysical logs to core and cross-hole flow logging, in Mallard, G.E., and Aronson, D.A., eds., U.S. Geological Survey Toxics Substances Hydrology Program-Proceedings of the technical meeting, Monterey, Calif., March 11-15, 1991: U.S. Geological Survey Water-Resources Investigations Report 91-4034, p. 162-171.

Paillet, F.L., 1991, Graphical overlay applications in geotechnical log analysis: International MGLS/ KEGS Symposium on Borehole Geophysics for Minerals, Geotechnical and Groundwater Applications, 4th, Toronto, Canada, [Proceedings], p. 249-265.

1991, Qualitative and quantitative analysis of fracture permeability using acoustic full-wave- 


\section{GROUND-WATER HYDROLOGY}

form logs: The Log Analyst, v. 32, no. 3, p. 256-270.

1991, Use of geophysical well-logs in evaluating crystalline rocks for siting of radioactive waste repositories: The Log Analyst, v. 33, no. 2 , p. 85-107.

1992, Using cross-borehole flow measurements to define hydraulic connections, in MorelSeytoux, H.J., ed., Annual Hydrology Days, 12th, [proceedings]: American Geophysical Union, p. 198-211.

1993, Using borehole geophysics and crossborehole flow testing to define hydraulic connections between fracture zones in bedrock fracture: Journal of Applied Physics, v. 30, no. 3, p. 261-279.

1993, Growth form and life histories of American chestnut and Alleghany and Ozark Chinquapin at various North American sites: Bulletin of the Torrey Botanical Club, v. 120, no. 3, p. 257-268.

1993, Integrating geophysical well logs, surface geophysics, and hydraulic test and geologic data in ground-water studies-Theory and case histories: Symposium on the Application of Geophysics to Engineering and Environmental Problems, San Diego, Calif., [Proceedings], p. 479-495.

in press, Application of borehole geophysics in the characterization of flow in fractured rocks: Trends in Geophysical Research, review volume, p.127-153.

in press, Applications of borehole geophysics in characterizing the hydrogeology of fractured igneous and metamorphic, in Banks, Sheila and Banks, Dave, eds. I.A.H. Memoires: International Association of hydrogeologists
XXIVth Congress on the hydrology of hard rocks, July, Oslo, Norway, [Proceedings], p. 737-750.

in press, Use of well logs to prepare the way for packer strings and tracer tests-Lessons from the Mirror Lake study, in Morganwalp, D.W., and Aronson, D.A., eds., U.S. Geological Survey Toxic Substances Hydrology Program-Proceedings of the technical meeting, Colorado Springs, Colo., September 20-24, 1993: U.S. Geological Survey Water-

Resources Investigations Report 94-4014.

in press, Hydraulic stimulation of fractured aquifers-a human-induced modification to enhance water production and remediation: American Water Resources Association Symposium, Jackson Hole, Wyoming, June 1994, [Proceedings].

Paillet, F.L., and Cheng, C.H., 1991, Acoustic waves in boreholes-The theory and application of acoustic full-waveform logs: Boca Raton, Fla., CRC Press, 264 p.

Paillet, F.L., Cheng, C.H., and Pennington, W.D., 1992, Acoustic waveform logging-advances in theory and application: The Log Analyst, v. 33 , no. 3, p. 239-258.

Paillet, F.L., Cheng, C.H., and Tang, X.M., 1989, Theoretical models relating acoustic tube-wave attenuation to fracture permeabilityReconciling model results with field data: Society of Professional Well Log Analysts Logging Symposium, 30th, Denver, Colo., Paper FF, p. FF1FF24.

Paillet, F.L., and Crowder, R., 1993, A generalized approach to geophysical $\log$ analysis for ground-water studies: International Symposium on Geophysics for Minerals, Geotechnical, Groundwater, and Environmental Applications, 


\section{GROUND-WATER HYDROLOGY}

5th, Tulsa, Oklahoma, October 1993, [Proceedings], 24 p.

Paillet, F.L., Crowder R., and Hess, A.E., 1994, High-resolution flow-meter logging-a unique combination of borehole geophysics and hydraulics; Part II-Borehole applications with the heat-pulse flowmeter: Symposium on the Application of Geophysics to Engineering and Environmental Problems, Boston, Mass., March 1994, [Proceedings], p. 381-404.

Paillet, F.L., and Duncanson, R., 1994, Comparison of drilling reports and detailed geophysical analysis of ground-water production in bedrock wells: Ground Water Journal, v. 32, no. 2, p. 200-206.

Paillet, F.L., and Goldberg, D., 1991, Acoustic televiewer log images of natural fractures and bedding planes in the Toa Baja borehole, Puerto Rico: Geophysical Research Letters, v. 18 , no. 3, p. 501-504.

Paillet, F.L., Green, A., and Gurierri, J., 1992, Identification of hydraulically conductive fractures intersecting boreholes in fractured gneiss near Ashford, Connecticut: U.S. Geological Survey Water-Resources Investigations Report 92-4074, 28 p.

Paillet, F.L., Hess, A.E., and Morin, R.H., 1990, Estimation of the relative permeability distribution in fractured granitic rocks by means of vertical flow measurements in the Siblingen borehole, Switzerland, in Mallard, G.E., and Aronson, D.A., eds., U.S. Geological Survey Toxics Substances Hydrology Program-Proceedings of the technical meeting, Monterey, Calif., March 11-15, 1991: U.S. Geological Survey Water-Resources Investigations Report 91-4034, 26 p.
Paillet, F.L., and Kapucu, K., 1989, Characterization of fracture permeability and fracture flow modeling at Mirror Lake, New Hampshire: U.S. Geological Survey Water-Resources Investigations Report 89-4058, 49 p.

Paillet, F.L., Kay, R.T., Yeskis, D., and Pedler, W.H., 1993, Integrating well logs into a multiple-scale investigation of a fractured sedimentary aquifer: The Log Analyst, v. 34, no. 1, p. 13-23.

Paillet, F.L., Novakowski, K., and Lapcevic, P., 1992, Analysis of transient flows in boreholes during pumping in fractured formations, in Society of Professional Well Log Analysts Annual Logging Symposium Transactions, 33rd, Oklahoma City, Oklahoma, 1992, p. S1-21.

Paillet, F.L., and Olson, J.D., in press, Analysis of the results of hydraulic-fracture stimulation of two crystalline bedrock boreholes, Grand Portage, Minnesota: U.S. Geological Survey Water-Resources Investigations Report 94 4044.

Paillet, F.L., and others, eds., 1990, Borehole imaging: Society of Professional Well Log Analysts Reprint Volume, 472 p.

Paillet, F.L., and Ruhl, J., in press, Using borehole geophysics to evaluate the effects of hydraulic stimulation of fractured bedrock aquifers: Society of Professional Well Log Analysts Annual Logging Symposium, 35th, Tulsa, Oklahoma, 1994, Transactions.

Paillet, F.L., and Rutter, P.A., 1989, Replacement of native oak hickory tree species by the introduced American Chestnut in southwestern Wisconsin: Canadian Journal of Botany, v. 67, no. 12 , p. $3457-3469$. 


\section{GROUND-WATER HYDROLOGY}

Paillet, F.L., Waltz, J., and Boyle, R.E., 1989, Geophysical log investigation of formation changes produced by hydraulic fracture stimulation in a crystalline-bedrock aquifer: Symposium on Borehole Geophysics for Minerals Geōtechnical, and Groundwater Applications, 3rd, Las Vegas, Nevada, 1989, Proceedings, p. EE571-594.

Paillet, F.L., and Williams, J.H., in press, Proceedings of the U.S. Geological Survey Workshop on the applications of borehole geophysics to ground-water investigations: U.S. Geological Survey Water-Resources Investigations Report 94-4103.

Paillet, F.L., Winkler, M.G., and Sanford, P.R., 1991, Relationship between pollen frequency in moss polsters and forest composition in a naturalized stand of American Chestnut: Implications for paleoenvironmental interpretation: Bulletin of Torrey Botanical Club, v. 118, no. 4 , p. 432-443.

Paillet, F.L., Zaghloul, E.S., and Daftar, T.E., 1990, Application of geophysical well log analysis to characterization of aquifers in the Sinai Region, Republic of Egypt: U.S. Geological Survey Water-Resources Investigations Report 90-4194, 54 p.

Taylor, T.A., 1989, Correlation in abnormal gamma readings with fluid movement through fractures in a formation by use of gammaspectral logs: Symposium on Borehole Geophysics for Minerals Geotechnical, and Groundwater Applications, 3rd, Las Vegas, Nevada, 1989, Proceedings, p. AA471-499.

Vernon, J.H., Paillet, F.L., Pedler, W.H., and Griswold, W.J., 1993, Application of borehole geophysics in defining the wellhead protection area for a fractured crystalline bedrock aquifer: The Log Analyst, v. 34, no. 1, p. 41-57. 


\section{GROUND-WATER HYDROLOGY}

TITLE: $\quad$ Mathematical Simulation of Subsurface-Water Flow Using Uncertain and Incomplete Data (CR 76-191)

PERSONNEL: Richard L. Cooley, Project Chief

Evelyn R. Warren, Office Auto. Assist.

Lana K. Gerlick, Office. Auto. Clerk

Mary C. Hill, Hydrologist (Colorado School of Mines, Adjunct Professor)

ADDRESS: $\quad$ U.S. Geological Survey

P.O. Box 25046, MS 413

Denver Federal Center

Denver, CO 80225

TELEPHONE: (303) 236-4995

PROBLEM: Satisfactory formulations and solutions of equations approximately describing (1) movement of fluids and components contained in fluids through consolidated and unconsolidated rocks and (2) interactions of the fluids and rocks accompanying fluid movement are needed for proper understanding and management of ground-water resources. Such formulations and solutions of equations are not generally available for application to general field situations where the flow system is complex and hydrologic data are inexact.

OBJECTIVE: (1) Reformulate, as necessary, the equations describing the flow of fluids through porous or fractured rock to include stochastic processes, emphasizing equations that are suitable for field use; (2) derive techniques to solve for dependent variables and estimate parameters in the equations; (3) assess the degree of reliability and significance of the model formed by the basic equations and the parameters estimated for it in terms of the input data; and (4) assess the degree of reliability and predictive capability of the model.

APPROACH: Develop fundamental equations from methods of mathematical physics, stochastic processes, statistics, and basic physical concepts from geology, geochemistry, geophysics, and so forth. Develop solutions to the equations analytically or numerically, depending on the problem. Analyze error propagation, stability, and convergence by means of techniques of linear and nonlinear algebra if feasible and appropriate. Use techniques of nonlinear regression to estimate parameters so that the reliability and significance of estimated parameters and the predictive capability of the model can be assessed. 


\section{GROUND-WATER HYDROLOGY}

PROGRESS: 1 . Work on including travel-time data as observations in regression were pursued in cooperation with Evan Anderman, a Ph.D. student at the Colorado School of Mines. Preliminary results are as follows. (a) One-dimensional travel times were used to represent seepage into a lake and to evaluate the value of seepage measurements in calibrating a model of ground-water flow beneath the lake. Comparison of results using the seepage measurements to published data on the transport of a tracer beneath the lake indicated that using seepage data did not produce a ground-water flow model that accurately reproduced tracer transport beneath the lake. The study was presented at the Spring American Geophysical Union (AGU) Meeting. (b) MODFLOWP was expanded to include travel times for two-dimensional particle movement. The method was applied to calibration of a ground-water model involving a seepage plume from Otis Air Force Base, Cape Cod, Massachusetts. Estimated parameter values and simulated results were compared with a previously developed model of the area, and the study is to be published in a conference proceedings (See Anderman, Hill, and Poeter, in press).

2. Support continued for the computer program MODFLOWP, which solves three-dimensional, ground-water flow, parameter estimation problems using nonlinear regression (published 1992). Support included consultation on applications within the USGS in New York, Ohio, and Kentucky, and outside of the USGS in New Mexico; teaching MODFLOWP to personnel of the South Florida Water Management District; and making modifications and corrections to the code as needed.

3. Documentation for five post-processing programs for MODFLOWP was published. These programs support testing of weighted residuals from MODFLOWP for randomness and normality and calculation of linear confidence and prediction intervals.

4. Development of Monte Carlo methods for uncertainty analysis using MODFLOWP was initiated.

5. A controlled experiment in nonlinear regression using a synthetic test case developed by Dave Pollock was completed and a journal article was prepared and submitted for colleague review.

6. A study of parameterization methods for spatially distributed quantities such as hydraulic conductivity progressed through collaboration with Donna Rizzo of the University of Vermont. Neural network maps of hydraulic conductivity and areal extent of a confining unit were produced for Pollock's synthetic test case. 


\section{GROUND-WATER HYDROLOGY}

7. A new method of measuring travel time and path of ground-water flow to a stream was developed and is being evaluated using a numerical model of ground-water flow adjacent to the Shingobee River, Minnesota.

8. A segment of research was completed on Scheffe-type and simultaneous confidence and prediction intervals for output and other functions of parameters of ground-water models. Two papers were completed, but the methodology proved to be somewhat more complicated than desirable for reasonably short journal articles. An approximate methodology was developed to handle the principal source of complexity, the unknown variance of model errors. The result, which involves integrating out the unknown variance, is a much simplified, but apparently accurate method. The two papers are being revised to incorporate the new methodology.

9. A much more rigorous theory was developed than before as a basis for the simultaneous confidence and prediction intervals discussed above. This will be included in the revision of the second paper.

10. A review of current Monte Carlo methodology for radioactive risk assessment was undertaken for possible application to uncertainty analysis of ground-water models. Some of these methods may be useful as alternative procedures in case there are instances when the current methodology fails.

11. Codes were written and documentation was initiated for normal distribution-based versions of the confidence and prediction interval methodology. These should be useful for standard, nonlinear least-squares regression models, such as MODFLOWP.

12. The recently published finite element model MODFE was revised to solve highly nonlinear problems involving large numbers of unsaturated areas (so-called "dry" nodes). This work required development of a new procedure to damp changes in transmissivity during the iterative solution procedure. The method was developed for a model of the Rocky Mountain Arsenal, and must be tested further when the final version of the finite element mesh is completed.

\section{REPORTS PUBLISHED 1989-1994:}

Anderman, E.R., Hill, M.C., and Poeter, E.P., in press, Two-dimensional advective transport in nonlinear regression: Sensitivities and uncertainty of plume-front observations, in Proceedings of the 1994 Ground Water Modeling Conference, August 1994.
Battaglin, W.A., and Hill, M.C., 1989, Simulated effects of future withdrawals on water levels in the northeastern coastal plain aquifers of New Jersey: U.S. Geological Survey WaterResources Investigations Report 88-4199, 58 p. 


\section{GROUND-WATER HYDROLOGY}

Bennett, G.D., Reilly, T.E., and Hill, M.C., 1990, Technical training notes in ground-water hydrology-Radial flow to a well: U.S. Geological Survey Water-Resources Investigations Report 89-4134, 83 p.

Cooley, R.L., 1992, A modular finite-element model (MODFE) for areal and axisymmetric ground-water flow problems-Part 2. derivation of finite-element equations and comparisons with analytical solutions: Techniques of Water-Resources Investigations of the U.S. Geological Survey, book 6, chap. A4, 108 p.

1993, Exact Scheffe-type confidence intervals for output from groundwater flow models, 1. Use of hydrogeologic information: Water Resources Research, v. 29, no. 1, p. 17-33.

1993, Exact Scheffe-type confidence intervals for output from groundwater flow models, 2. Combined use of hydrogeologic information and calibration data: Water Resources Research, v. 29, no. 1, p. 35-50.

1993, Regression modeling of ground-water flow, supplement 1 -Modifications to the computer code for nonlinear regression solution of steady-state ground-water flow problems: U.S. Geological Survey Techniques of WaterResources Investigations, book 3, chap. B4, supplement $1,8 \mathrm{p}$.

Cooley, R.L., and Hill, M.C., 1992, A comparison of three Newton-like nonlinear least-squares methods for estimating parameters of groundwater flow models, in Russell, T.F., Ewing, R.E., Brebbia, C.A., Gray, W.G., and Pinder, G.F., eds., Computational methods in water resources; IX Numerical methods in water resources, International Conference on Computational Methods in Water Resources, 9th, Denver, Colo., Proceedings: New York, Elsevier, v. 1, p. 379-386.
Cooley, R.L., and Naff, R.L., 1990, Regression modeling of ground-water flow: Techniques of Water-Resources Investigations of the U.S. Geological Survey, book 3, chap. B4, 232 p.

Hill, M.C., 1989, An analysis of accuracy of approximate, simultaneous, nonlinear confidence intervals on hydraulic heads in analytical and numerical test cases: Water Resources Research, v. 25, no. 2, p. 177-190.

1990, Relative efficiency of four parameterestimation methods in steady-state and transient ground-water flow models, in Gambolati, G., Rinaldo, A., Brebbia, C.A., Gray, W.G., and Pinder, G.F., eds., Computational methods in subsurface hydrology: International Conference on Computational Methods in Water Resources, 8th, Venice, Italy, 1990, [Proceedings], New York, Springer-Verlag, p. 103-108.

1990, Preconditioned Conjugate-Gradient 2 (PCG2), a computer program for solving ground-water flow equations: U.S. Geological Survey Water-Resources Investigations Report 90-4048, 43 p.

1990 , Solving groundwater flow problems by conjugate-gradient methods and the strongly implicit procedure: Water Resources Research, v. 26, no. 9, p. 1961-1969.

1992, A computer program (MODFLOWP) for estimating parameters of a transient, threedimensional ground-water flow model using nonlinear regression: U.S. Geological Survey Open-File Report 91-484, 358 p.

Hill, M.C., 1994, Five computer programs for testing weighted residuals and calculating linear confidence and prediction intervals on results from the ground-water parameter-estimation computer program MODFLOWP: U.S. 


\section{GROUND-WATER HYDROLOGY}

Geological Survey Open-File Report 93-481, 81 p.

Hill, M.C., Lennon, G.P., Hebson, C.S., Brown, G.A., and Rheaume, S.J., 1992, Geohydrology of, and simulation of ground-water flow in, the valley-fill deposits in the Ramapo River Valley, New Jersey: U.S. Geological Survey Water-Resources Investigations Report 904151, 92 p.

Schuster, P.F., and Hill, M.C., in press, Hydrogeology and saltwater intrusion in the shallow aquifer system of southern Cape May County, New Jersey: U.S. Geological Survey Water-

Resources Investigations Report 91-4043. 


\section{GROUND-WATER HYDROLOGY}

TITLE: $\quad$ Field Applications of Unsaturated Zone Flow Theory (CR 69-200)

PERSONNEL: Edwin P. Weeks, Project Chief

Evelyn R. Warren, Office Auto. Assist.

Lana K. Gerlick, Office Auto. Clerk

Richard W. Healy, Hydrologist

David I. Stannard, Hydrologist

Dean E. Anderson, Hydrologist

James A. Tindall, Hydrologist

Shawn L. Arbuckle, Student, (Univ. of Colo.)

ADDRESS: U.S. Geological Survey

P.O. Box 25046, MS 413

Denver Federal Center

Denver, CO 80225

TELEPHONE: (303) 236-4981

PROBLEM: Various processes within the unsaturated zone affect ground-water availability and potability, as well as concentrations of water vapor and trace gases in the atmosphere. The rate at which precipitation or applied irrigation water infiltrates, its redistribution following infiltration, and the partitioning of the redistributed soil moisture between ground-water recharge and evapotranspiration affect the rate at which the ground-water reservoir is replenished and the degree to which ground water might be contaminated by chemical applications, spills, or disposal. Consequently, knowledge of and methods to quantitatively measure and predict these processes are needed to determine the impact of such societal practices as irrigation development for agriculture, the use of agricultural chemicals, and the disposal of radioactive and/or hazardous waste in the unsaturated zone on both the availability and potability of ground water. Processes governing transport in the unsaturated zone gas phase are also important in determining the potential for ground-water contamination by volatile compounds, the rate at which water is returned from soil moisture to the atmosphere as vapor, and the fate of other "greenhouse gases," such as carbon dioxide, methane, and chlorofluorocarbons (CFCs). An understanding and quantification of these processes is needed both to assess the hazards of ground-water pollution and to better predict the impact of global change on future climate.

OBJECTIVE: The goals of this project are to develop an improved understanding of the processes governing the movement of liquids and gases in the unsaturated zone, and to develop methods to quantitatively assess and model the phenomena. Processes and phenomena under investigation include those involving the movement of water and chemicals through the unsaturated zone, with particular emphasis on processes that might result in rapid 


\section{GROUND-WATER HYDROLOGY}

transport of dissolved chemicals to the water table and (or) volatile compounds to the atmosphere. An understanding of the role of various gas-phase transport processes, on soil moisture, on the distribution of volatile compounds within the unsaturated zone, and on atmospheric-unsaturated zone exchange is also sought. Processes involving plant-soilatmosphere interactions, including evapotranspiration, plant $\mathrm{CO}_{2}$ uptake, and root respiration of $\mathrm{CO}_{2}$, are being studied to develop measurement and modeling techniques for those phenomena.

APPROACH: Field and laboratory investigations of the movement of water and gas and liquid tracers through both highly structured and unstructured soils are underway. Models are being developed to provide predictive capabilities for assessing the impact of agricultural and waste disposal practices on the potential for ground-water contamination. Gas phase movement is being studied through measurement of flow in open boreholes and models are being developed to simulate the observed phenomena and to assess the importance of various gas-phase transport mechanisms under natural conditions. Evapotranspiration and plant-soilatmosphere interactions are being investigated by the development of various techniques for measuring the interchange of water vapor and other gases between the atmosphere and the plant-soil continuum. These methods include the use of chambers (flux boxes), profile or gradient methods, and eddy correlation techniques. Various modeling techniques are under development to extend such measurement in space and time.

PROGRESS: Evapotranspiration studies, mainly including the research of Dave Stannard and Dean Anderson, continues. Our major field effort currently is with BOREAS, a large NASA-led study to determine whether a combination of surface-based and remote-sensing studies can identify carbon fluxes to northern boreal forests. Our contributions include making continuous measurements of energy, water, and $\mathrm{CO}_{2}$ fluxes at a site with young jack pine cover in Saskatchewan throughout the 1994 growing season, a massive logistical and investigational effort. In addition, publications have been completed on interagency field studies at Walnut Gulch, Arizona, (Monsoon90 experiment) and a study at Washita, Oklahoma. Field work has continued at Williams Lake, Minnesota, to determine $\mathrm{CO}_{2}$ fluxes across the lake-atmosphere interface during various seasons, and report preparation is in progress.

Studies of unsaturated flow and transport of agricultural chemicals, through the efforts of Jim Tindall and Rick Healy, continue at Missouri and Minnesota sites. These studies involve flow and transport through highly structured clay and sand soils, respectively. Also, an agreement has been reached between USGS and the Peoples Republic of China to collaboratively study the effects of agricultural practices on ground water quality. Laboratory studies of nitrate 


\section{GROUND-WATER HYDROLOGY}

transport and transformations through intact cores of sand and claypan soils has been completed and results are being analyzed. Sites on the Denver Federal Center have been instrumented for measurement of soil moisture content and energy status and sampling for chemical transport.

Improved methods to measure trace gas exchanges between soil and atmosphere are under development, based on numerical studies that indicate that standard flux chamber measurements substantially underestimate such exchanges. This work is being conducted by Rick Healy in collaboration with Rob Striegl (project CR-320).

Simultaneous measurements of chlorofluorocarbons in soil gas and in ground water in the Snake River Plain aquifer were analyzed to determine that recharge water does not equilibrate with soil gas, presumably because recharge is intermittent,concentrated and focussed. Hence, potential contaminants may be quickly transported to the ground-water reservoir.

Development (Rick Healy) of the two-dimensional Modified Method of Characteristics code for the simulation of unsaturated zone transport continues. In addition, code VS2DT has been modified to include energy transport through variably saturated media, and is being used by Nevada District personnel.

Studies of gas-phase circulation through fractured rocks at Yucca Mountain continue. More reliable measurements of summertime flow in well UZ6s have been completed, as have tracer tests involving movement of gases from well UZ6s to outcrops along the flanks of Yucca Mountain that indicate gas-phase transport through rocks near Yucca Mountain Crest on the time scale of hours.

REPORTS PUBLISHED 1989-1994:

Anderson, D.E., Miller, D.R., Wang, Y.S., Yendol, W.G., and Mierzejewski, K., 1992, Deposition of aerially applied BT in an oak forest and its prediction with the FSCBG model: Journal of Applied Meteorology, v. 31, p. 1457-1466.

Blanford, J.H., and Stannard, D.I., 1991, Spatial variability of energy fluxes at Walnut Gulch: American Meteorological Society Special Session on Hydrometeorology, Salt Lake City, 1991 [Proceedings], p. 158-160.
Busenberg, E., Weeks, E.P., Plummer, L.N., and Bartholomay, R.C., 1993, Age dating ground water by use of chlorofluorocarbons $\left(\mathrm{CCl}_{3} \mathrm{~F}\right.$ and $\mathrm{CCl}_{2} \mathrm{~F}_{2}$ ) and distribution of chlorofluorocarbons in the unsaturated zone, Snake River Plain aquifer, Idaho National Engineering Laboratory, Idaho: U.S. Geological Survey Water-Resources Investigations Report 934054, 47 p.

deVries, M.P., and Healy, R.W., 1991, Microclimate, evapotranspiration, and tritium release 


\section{GROUND-WATER HYDROLOGY}

by plants, in Ryan, B.J., ed., Results of hydrologic research at a low-level radioactivewaste disposal site near Sheffield, Illinois: U.S. Geological Survey Water-Supply Paper 2367, p. 16-22

Healy, R.W. 1989, Seepage through a hazardouswaste trench cover: Journal of Hydrology, v. 108 , p. 213-234.

1990, Results of some geohydrologic studies at the low-level radioactive-waste repository site near Sheffield, Illinois, in Bedinger, M.S., and Stevens, P.R., eds., Safe disposal of radionuclides in low-level radioactive-water repository sites: U.S. Geological Survey Circular 1036, p. 13-16.

1990, Simulation of solute transport in variably saturated porous media with supplemental information on modifications to the U.S. Geological Survey's Computer Program VS2D: U.S. Geological Survey Water-Resources Investigations Report 90-4025, $125 \mathrm{p}$.

Healy, R.W., 1991, Water movement through a trench cover, in Ryan, B.J., ed., Results of hydrologic research at a low-level radioactivewaste disposal site near Sheffield, Illinois: U.S. Geological Survey Water-Supply Paper 2367, p. 27-33.

Healy, R.W., Gray, J.R., deVries, M.P., and Mills, P.C., 1989, Water balance at a lowlevel radioactive-waste disposal site: Water Resources Bulletin, v. 25, no. 3, p. 1-10.

Healy, R.W., and Mills, P.C., 1992, Variability of an unsaturated sand unit underlying a radioactive-waste trench: Soil Science Society of America Journal, v. 55, no. 4, p. 899-907.

Healy, R.W., Reimer, G.M., Been, J.M., and Szarzi, S.L., 1991, A new method for determining soil macroporosity, in Mallard, G.E., and Aronson, D.A., eds., U.S. Geological Survey Toxic Substances Hydrology Program-Proceedings of the technical meeting,
Monterey, California, March 11-15, 1991: U.S. Geological Survey Water-Resources Investigation Report 91-4034, p. 539-541.

Healy, R.W., and Russell, T.F., 1989, Efficient implementation of the modified method of characteristics in finite-difference models of solute transport, in Proceedings of Conference on Solving Ground Water Problems with Models: Indianapolis, Indiana, National Water Well Association, p. 483-491.

1992, Solution of the advection-dispersion equation by a finite-volume Eulerian-Lagrangian local adjoint method, in Russell, T.F., Ewing, R.E., Brebbia, C.A., and Pinder, G.F., eds., Computational Methods in Water Resources-Numerical methods in water resources: Boston, Computational Mechanics Publications, and London, Elsevier, chap. 9, v. 1, p. 33-39.

1993, A finite-volume Eulerian-Lagrangian localized adjoint method for solution of the advection-dispersion equation: Water Resources Research, v. 29, no. 7.

Healy, R.W., Ryan, B.J., and Garklavs, George, 1991, Water and tritium movement in the saturated zone, in Ryan, B.J., ed., Results of hydrologic research at a low-level radioactivewaste disposal site near Sheffield, Illinois: U.S. Geological Survey Water-Supply Paper 2367, p. 52-56.

Ishii, A.L., Healy, R.W., and Striegl, R.G., 1989, A numerical solution for the diffusion equation in hydrogeologic systems: U.S. Geological Survey Water-Resources Investigations Report 89-4027, 86 p.

Kipp, K.L., and Healy, R.W., 1990, Characterizing and monitoring low-level radioactive-waste repository sites, in Bedinger, M.S., and Stevens, P.R., eds., Safe disposal of radionuclides in low-level radioactive-waste repository sites: U.S. Geological Survey Circular 1036, p. 6-8. 


\section{GROUND-WATER HYDROLOGY}

Kustas, W.P., Goodrich, D.C., Moran, M.S., Amer, S.A., Bach, L.B., Blanford, J.H., Chebouni, A., Claassen, H. Clements, W.D., Doraiswamy, P.C., Dubois, P., Clarke, T.R., Daughtry, C.S.T., Gellman, D.I., Grant, T.A., Hipps, L.E., Huete, A.R., Humes, K.S., Jackson, T.J., Keefer, T.O., Nichols, W.D., Parry, R., Perry E.M., Pinker, R.T., Pinter, P.J. Jr., Qi, J., Riggs, A.C., Schmugge, T.J., Shutko, A.M., Stannard, D.I., Swiatek, E., van Leeuwen, J.D., van Zyl, J., Vidal, A., Washburne, J., and Weltz, M.A., 1991, An interdisciplinary field study of the energy and water fluxes in the atmosphere-biosphere system over semiarid rangelands-Description and some preliminary results: Bulletin of the American Meteorological Society, v. 72 , no. 11 , p. $1683-1705$.

Kustas, W.P., Moran, M.S., Pinter, P.J., Hipps, L.E., Swiatek, E., Stannard, D.I., and Blanford, J.H., 1991, Issues in mapping evapotranspiration over large areas with remote sensing data from Monsoon '90: American meteorological Society Special Session on Hydrometeorology, Salt Lake City, 1991, [Proceedings], p. 151-154.

Kwicklis, E.M., Flint, A.L., and Healy, R.W., 1994, Simulation of flow in the unsaturated zone beneath Pagany Wash, Yucca Mountain, in High Level Radioactive Waste Management, Proceedings of the Fifth Annual International Conference, Las Vegas, May 22-26: Lagrange Park, Ill., American Nuclear Society, p. 2341-2351.

Kwicklis, E.M., Flint, A.L., and Healy, R.W., 1994, Estimation of unsaturated zone liquid water flow at boreholes UZ\#4, UZ\#5, UZ\#7, and UZ\#13, Yucca Mountain, Nevada, from saturation and water potential profiles, in Proceedings of Focus 93, Site Chacaterization Validation, Sept. 26-29, Las Vegas: La Grange Park, Ill., American Nuclear Society, p. 39-57.
Kwicklis, E.M., and Healy, R.W., 1993, Numerical investigations of steady liquid water flow in a variably saturted fracture network: Water Resources Research, v. 29 , no. 12 , p. 4091 4102 .

Lodge, D.M., Krabbenhoft, D.P., and Striegl, R.G., 1989, A positive relationship between groundwater velocity and submersed macrophyte biomass in Sparkling Lake, Wisconsin: Limnology and Oceanography, v. 34 , no. 1 , p. 235-239.

Mills, P.C., and Healy, R.W., 1993, Water and tritium movement through the unsaturated zone at a low-level radioactive-waste disposal near Sheffield, Illinois, 1981-1985: U.S. Geological Survey Water-Supply Paper 2386, 72 p.

Moran, M.S., Kustas, W.P., Vidal, A., Stannard, D.I., and Blanford, J.H., 1991, Use of ground-based remotely sensed data for surface energy balance calculations during Monsoon '90: International Geoscience and Remote Sensing Symposium, Espoo, Finland, 1991, [Proceedings], p. 33-37.

Peters, C.A., Striegl, R.G., Mills, P.C., and Healy, R.W., 1992, Effects of low-level radioactive waste disposal on water chemistry in the unsaturated zone at a site near Sheffield, Illinois, 1982-1984: U.S. Geological Survey Water-Supply Paper 2390, 74 p.

Stannard, D.I., 1990, Tensiometers-Theory, construction, and use: American Society for Testing and Materials Special Technical Publication 1053, p. 34-51.

1990, Energy-budget eddy-correlation technique in Czarnecki, J.B., Geohydrology and evapotranspiration at Franklin Lake Playa, Inyo County, California: U.S. Geological Survey Open-File Report 90-356, p. 32-45.

1992, Tensiometers-Theory, construction, and use: Geotechnical Testing Journal, v. 15, no. 1, p. 48-58. 


\section{GROUND-WATER HYDROLOGY}

1992, Bowen-ratio measurements at sites C and $\mathrm{F}$ in Wilson, D.H., Reginato, R.J., and Hollett, K.J., eds., Evapotranspiration measurements of native vegetation, Owens Valley, California, June, 1986: U.S. Geological Survey Water-Resources Investigations Report 91-4159, chap. B, p. 19-24.

1993, Comparison of Penman-Monteith, Shuttleworth-Wallace, and modified PriestleyTaylor evapotranspiration models for wildland vegetation in semiarid rangeland: Water Resources Research, v. 29, no. 5, p. 1379-1392.

in press, Energy-budget eddy-correlation technique, in Czarnecki, J.B., Geohydrology and evapotranspiration at Franklin Lake Playa, Inyo County, California: U.S. Geological Survey Water-Supply Paper 2377.

Stannard, D.I., and Rosenberry, D.O., 1991, A comparison of short-term measurements of lake evaporation using eddy-correlation and energy-budget methods: Journal of Hydrology, v. 122 , p. $15-22$.

Steffeck, D.W., and Striegl, R.G., 1989, An inventory and evaluation of biological investigations that relate to stream-water quality in the upper Illinois River basin of Illinois, Indiana, and Wisconsin: U.S. Geological Water-Resources Investigations Report 89-4041, $54 \mathrm{p}$.

Striegl, R.G., 1989, Gases in the unsaturated zone, in Ryan, B.J., ed., Results of hydrologic research at low-level radioactive waste site near Sheffield, Illinois: U.S. Geological Survey Open-File Report 88-318, p. 69-80 (pending publication as a Water-Supply Paper).

Striegl, R.G., and Healy, R.W., 1990, Transport of 14-carbon dioxide in unsaturated glacial and eolian sediments, in Bassett, R.L. and Melchoir, D.C., eds., Chemical Modeling in Aqueous Systems II: American Chemical Society Symposium Series, No. 416 , chap. 15 , p. 202-210.
Striegl, R.G., and Ishii, A.L., 1989, Diffusion and consumption of methane in an unsaturated zone in north-central Illinois, U.S.A.: Journal of Hydrology, v. 111 p. 133-143.

Thorstenson, D.C., Weeks, E.P., Haas, H., and Woodward, J.C., 1990, Physical and chemical characteristics of topographically-affected airflow in an open borehole at Yucca Mountain, Nevada: American Nuclear Society Focus 89 Conference [Proceedings], p. 256-270.

Wang, Y.S., Miller, D.R., Anderson, D.E., Cionco, R., and Lin, J.D., 1992, Spatial length scale analysis of turbulent temperature and velocity fluctuations within and above an orchard canopy: Boundary Layer Meteorology, v. 59, p. $125-139$.

Weeks, E.P., 1990, Thoughts on geohydrologic characterization for prospective low-level radioactive-waste repository sites, in Bedinger, M.S., and Stevens, P.R., eds., Safe disposal of radionuclides in low-level radioactive-waste repository sites: U.S. Geological Survey Circular 1036, p. 104-106.

in press, Does the wind blow through Yucca Mountain?-Proceedings of the Fifth Workshop on Flow and Transport in Unsaturated Fractured Rock: Nuclear Regulatory Commission, NUREG, $20 \mathrm{p}$. 


\section{GROUND-WATER HYDROLOGY}

TITLE: $\quad$ Ground-Water Solute-Transport Simulation (CR 85-292)

PERSONNEL: Kenneth L. Kipp, Project Chief

Evelyn R. Warren, Office Auto. Assist.

Lana K. Gerlick, Off. Auto. Clerk

Kenneth G. Stollenwerk, Hydrologist

ADDRESS: U.S. Geological Survey

Thomas F. Russell, Professor (University of Colorado, Denver)

James S. Otto, Professor (University of

Colorado, Denver)

P.O. Box 25046, MS 413

Denver Federal Center

Denver, CO 80225

TELEPHONE: (303) 236-4991

PROBLEM: Ground-water solute-transport simulation modeling is an important tool that aids in the analysis of ground-water contamination problems, both actual and potential. Accidental spills, leakage, and waste disposal operations can lead to ground-water contamination. The ability to analyze and predict the movement of solutes in ground-water systems is necessary to assess the effects of a contamination situation or properly design a waste-disposal operation. Laboratory experiments are essential to understanding geochemical reactions in the field and for obtaining the necessary reaction coefficients and rate constants used in transport models. Simulation modeling also is used to compare alternative strategies for aquifer reclamation. In some cases, the transported component of interest is thermal energy. Heat transport simulation is useful in the analysis of geothermal systems, waste heat storage systems, and some deep aquifer systems.

OBJECTIVE: Develop and apply new analytical, quasi-analytical, and numerical techniques to the field of saturated ground-water solute-transport simulation modeling. Develop mathematical representations of solute-porous medium interactions and chemical reactions and develop and apply efficient algorithms for numerical calculation. Apply analytical and numerical simulation modeling to laboratory and field-scale situations, both actual and experimental. Evaluate accuracy of laboratory experiments for predicting geochemical behavior of solutes in the field.

APPROACH: Formulate transport equations for systems being studied, develop or adapt various methods for solving the equations, develop and test various algorithms for numerical computation or simulation calculations, develop methods to identify and model chemical reactions, and apply the methods to laboratory or field-scale experimental situations and 


\section{GROUND-WATER HYDROLOGY}

actual field situations. Work closely with District, other Federal, and State research projects involved in similar studies.

PROGRESS: Work for the Utah District doing the numerical modeling for the Bonneville Salt Flats Study continued through this year. Flow modeling was done with subregional and regional models. The main goal of the regional model is to provide a quantitative flow and salt balance on the study region over a typical year of production and nonproduction seasons. Calibration started when well elevation data were received from Bureau of Land Management in February. The model is sensitive to evaporation rate, and reported values from the weather stations cause excessive lowering of the water table. The solute transport modeling was begun for boundary conditions representing typical brine production and nonproduction seasons. Software was written to compare measured with calculated water levels and fluid densities at the end of the simulation periods. An evaporation algorithm was installed into the flow and transport model. Extensive consultation on and further development of the HST3D simulator were done with the San Diego Office of the California District working on the Ventura Regional Aquifer System Analyses (RASA) Project. A special project was funded from the Office of Ground Water to do four verification test problems, vectorize the HST3D code, and complete the application to the Ventura RASA. The first and third items are nearly complete but the second item has been discontinued due to time constraints. A paper on the implementation of a new zig-zag renumbering scheme for three-dimensional regions that has low sensitivity of iterations to the renumbering direction was written and will be presented at the Computational Methods in Water Resources meeting in July in Germany.

A journal article describing the geochemistry of a plume of acidic ground water at the Pinal Creek site, Arizona, is in press at Applied Geochemistry. A chapter on the same subject was written for a USGS Water Supply Paper and is awaiting Director's approval. Work was completed on the initial phase of a study designed to evaluate transport of phosphate in an aquifer. The work was partially funded by the Air National Guard. Laboratory column experiments indicate that a large reservoir of phosphate should be present in the aquifer upgradient from a large lake. This phosphate has the potential to cause eutrophication of the lake. An abstract concerning phosphate contamination has been accepted for the third International Symposium on Environmental Geochemistry, in Krakow, Poland. A talk on phosphate contamination was given at the 1993 Program on Toxic Waste meeting in Colorado Springs, and a paper is being published in the meeting proceedings. A Water Supply Paper on phosphate contamination was coauthored and is in the approval process. A proposal for future work on this problem has been submitted to the Air National Guard. A paper describing simulation of molybdate transport in laboratory columns has been submitted for publication. Transport of molybdate was affected by several chemical reactions. These 


\section{GROUND-WATER HYDROLOGY}

reactions were included in a one-dimensional solute transport code which was used to simulate breakthrough curves for molybdate. Work was initiated on a two-dimensional solute transport code with chemical reactions, to be used to simulate molybdate transport in a large-scale natural gradient tracer experiment. Consulting continued with the Idaho District concerning the problem of contamination of the Snake River Plain Aquifer beneath the Idaho National Engineering Laboratory.

\section{REPORTS PUBLISHED 1989-1994:}

Engesgaard, Peter, and Kipp, K.L., 1992, A geochemical transport model for redox-controlled movement of mineral fronts in ground-water flow systems-Denitrification by oxidation of pyrite: Water Resources Research, v. 28, no. 10 , p. $2829-2843$.

Glynn, P.D., Engesgaard, Peter, and Kipp, K.L., 1991, Two geochemical mass transport codes: Their use and limitations at the Pinal Creek Toxic Waste sites, in Mallard, G.E., and Aronson, D.A., eds., U.S. Geological Survey Toxics Substances Hydrology Program-Proceedings of the technical meeting, Monterey, Calif., March 11-15, 1991: U.S. Geological Survey Water-Resources Investigations Report 91-4034, p. 454-460.

Healy, R.W., and Russell, T.F., 1989, Efficient implementation of the modified method of characteristics in finite-difference models of solute transport, in Proceedings of Conference on Solving Ground Water Problems with Models, Indianapolis, Indiana: National Water Well Association, p. 483-491.

Healy, R.W., and Russell, T.F., 1992, Solution of the advection-dispersion equation by a finitevolume Eulerian-Lagrangian localized adjoint method, in Russell, T.F., Ewing, R.E., Brebbia, C.A., and Pinder, G.F., eds., Computational methods in water resources-IX. Numerical methods in water resources: Bos- ton, Computational Mechanics Publications, and London, Elsevier, v. 1, p. 33-39.

1993, A finite-volume Eulerian-Lagrangian localized adjoint method for solution of the advection-dispersion equation: Water Resources Research, v. 29, no. 7, p. 2399-2413.

Kipp, K.L., and Healy, R.W., 1990, Characterizing and monitoring low-level radioactive-waste repository sites, in Bedinger, M.S., and Stevens, P.R., eds., Safe disposal of radionuclides in low-level radioactive-waste repository sites: U.S. Geological Survey Circular 1036, p. 6-8.

Kipp, K.L., Russell, T.F., and Otto, J.S., 1992, D4Z-A new renumbering for iterative solution of ground-water flow and solute-transport equations, in IX. Computational Methods in Water Resources, in Russell, T.F., Ewing, R.E., Brebbia, C.A., Gray, W.G., and Pinder, G.F., eds., Numerical Methods in Water Resources: Southampton, Computational Mechanics Publications, and London, Elsevier Applied Science, v.' 1, p. 495-502.

LeBlanc, D.R., Garabedian, S.P., Hess, K.M., Gelhar, L.W., Quadri, R.D., Stollenwerk, K.G., and Wood, W.W., 1991, Large-scale natural-gradient tracer test in sand and gravel, Cape Cod, Massachusetts, (1) Experimental design and observed tracer movement: Water Resources Research, v. 27, no. 5, p. 895-910. 


\section{GROUND-WATER HYDROLOGY}

Schumacher, J.G., and Stollenwerk, K.G., 1991, Geochemical controls on the migration of molybdenum, uranium, and other constituents at the Weldon Spring Chemical Plant Site, in Proceedings of the Geosciences Workshop, O'Fallon, Missouri, February 21, 1991: U.S. Dept. of Energy DOE/OR/21548-197, p. 87-140.

Stollenwerk, K.G., 1989, Solubility of aluminum and iron in ground water near Globe, Arizona, in Mallard, G. E, and Ragone, S. E., eds., U.S. Geological Survey Toxic Substances Hydrology Program-Proceedings of the technical meeting, Phoenix, Ariz., September 26-30, 1988: U.S. Geological Survey WaterResources Investigations Report 88-4220, p. 581-591.

1991, Simulation of copper, cobalt, and nickel sorption in an alluvial aquifer near Globe, Arizona, in Mallard, G.E. and Arsonson, D.A., eds., U.S. Geological Survey Toxic Substances Hydrology Program-Proceedings of the technical meeting, Monterey, California, March 11-15, 1991: U.S. Geological Survey Water-Resources Investigations Report 914034, p. 502-506.

1991, Simulation of molybdate sorption with the diffuse layer surface-complexation model, in Mallard, G.E. and Arsonson, D.A., eds., U.S. Geological Survey Toxic Substances Hydrology Program-Proceedings of the technical meeting, Monterey, California, March 11-15, 1991: U.S. Geological Survey WaterResources Investigations Report 91-4034, p. 47-52.

Stollenwerk, K.G., and Kipp, K.L., 1989, Simulation of the rate-controlled transport of molybdate in column experiments, in Mallard, G. E, and Ragone, S. E., eds., U.S. Geological Survey Toxic Substances Hydrology Program-
Proceedings of the technical meeting, Phoenix, Ariz., September 26-30, 1988: U.S. Geological Survey Water-Resources Investigations Report 88-4220, p. 151-161.

1990, Simulation of molybdate transport with different rate-controlled mechanisms, in Melchior, D.C., and Bassett, R.L., eds., Chemical modeling of aqueous systems II: Washington, D.C., American Chemical Society Symposium Series No. 416, American Chemical Society, chap. 19, p. 243-257. 


\section{GROUND-WATER HYDROLOGY}

TITLE: $\quad$ Application of Stochastic Processes in Hydrogeology (CR 90-319)

PERSONNEL: Richard L. Naff, Project Chief

Evelyn R. Warren, Office Auto. Assist.

Lana K. Gerlick, Office Auto. clerk

ADDRESS: U.S. Geological Survey

P.O. Box 25046, MS 413

Denver Federal Center

Denver, CO 80225

TELEPHONE: (303) 236-4986

PROBLEM: Many aspects of ground-water flow and transport resist standard, deterministic modeling techniques' there exist elements which either are overly complex or which are simply unpredictabl: . These elements may have either a spatial character, such as heterogeneity in po o media, or a temporal character, such as recharge events to an aquifer. Provided that an ateciuate representation can be found, these aspects of flow and transport frequently are better modeled by taking the complex or unpredictable element to be a stochastic process. Given an adequate representation, then the following questions may be addressed: (1) What is the implication of these elements for flow and transport in porous media? (2) Given observations of the physical process (hydraulic heads, concentrations, discharges), can the stochastic element be characterized (variances, length scales)? (3) Can an adequate monitoring program be designed when the physical process incorporates complex or unpredictable elements?

OBJECTIVE: The principal objective of this research is a better understanding of flow and transport phenomena when the underlying physical process contains one or more stochastic elements. A subsidiary objective is the development of a network model to evaluate sampling schemes when the physical process contains a stochastic element. An inverse procedure whereby the statistical properties of the stochastic element can be determined from the outputs of the physical process will be a necessity if these models are to be utilized. Where practicable, investigation will include development of usable computer codes.

APPROACH: Use probability theory to investigate those elements of flow and transport in porous media which are overly complex or unpredictable. The primary tools used to date to investigate problems with complex spatial elements can be loosely lumped under perturbation techniques and Monte Carlo simulation. Problems with stochastic inputs are usually best 


\section{GROUND-WATER HYDROLOGY}

handled with transfer-function techniques. Both of these techniques usually require that a model of the system be conceptualized such that inputs and outputs are linked; in most cases, this linkage is in the form of a stochastic partial differential equation (SPDE's). Other techniques for solving SPDE's will be investigated: these include the use of Banach spaces from functional analysis and the use of adjoined sensitivities in numerical schemes.

PROGRESS: Completed publication of a second-order correct formulation for the estimation of subsurface spatial moments, entitled "An Eulerian scheme for the second-order approximation of subsurface transport moments." This analysis allows one to consider the effect of a larger variation in the hydraulic conductivity field on subsurface transport than heretofore possible; also, correct estimates of the third and fourth central moment are possible with this technique. In conjunction with colleagues at the University of Waterloo, a numerical simulation of transport in heterogeneous porous media has been published; this publication, entitled "Nonreactive and reactive transport in three-dimensional heterogeneous porous media: Mean displacement, plume spreading and uncertainty," is a multirealization simulation and analysis of reactive and nonreactive transport in random hydraulic conductivity and distribution fields.

Work continues on analyzing the effect of small-scale transients on spatial moments of a tracer cloud; this work is a joint effort with Ed Sudicky at the University of Waterloo. Th? analytical procedure is based on the method of moments as applied to the standard transport equation in which the velocity is considered to be a function of time but not space. The analysis has been applied to the data base from the Cape Cod natural gradient tracer test with not unreasonable results; we expect to apply the analysis to another data base before proceeding with a formal publication.

In conjunction with colleagues at the University of Waterloo, a Monte-Carlo computer program to simulate transport in heterogeneous porous media is being developed (this research has been the project's major focus in the last year). Using a Monte-Carlo procedure, we hope to be able to quantify and tabulate effective macrodispersivities for a number of scenarios; this tabulation would be a source of information for all transport modelers. At this stage of the project, we have finished development of a computer code to carry out these Monte Carlo simulations which runs reasonably well on a Cray 3 super computer made available through the National Center for Atmospheric Research. The use of a super computer has been made-necessary, in part, by the detailed discretization necessary to obtain reasonable concentration-field results (for a typical problem, on the order of 1,000,000 nodes are used) and also by the time requirements necessary to run the code. To use this super computer more efficiently and effectively, it will be necessary to expend more effort 


\section{GROUND-WATER HYDROLOGY}

making the code multitask capable so that it can take full advantage of this machine's strength: fast multiple processors. Multitasking the code should tremendously decrease execution time, enabling us to obtain our research objective.

\section{REPORTS PUBLISHED 1989-1994:}

Burr, D.T., Sudicky, E.A., and R.L. Naff, 1994, Nonreactive and reactive transport in threedimensional heterogeneous porous mediaMean displacement, plume spreading, and uncertainty: Water Resources Research, $v$. 30 , no. 3 , p. 791-815.

Cooley, R.L., and Naff, R.L., 1990, Regression modeling of ground-water flow: U.S. Geological Survey Techniques of Water-Resources Investigations, book 3, chap. B4, $232 \mathrm{p}$.

Gomez, B., Naff, R.L., and Hubbell, D.W., 1989, Temporal variations in bedload transport rates associated with the migration of bedforms: Earth Surface Processes and Landforms, v. 14 , p. $135-156$.

Naff, R.L., 1990, On the nature of the dispersive flux in heterogeneous porous media: Water Resources Research, v. 26, no. 5, p. 10131026.

1991, Radial flow in heterogeneous porous media: an analysis of specific discharge: Water Resources Research, v. 27, no. 3, p. 307-316.

1991, Temporal and spatial moments for solute transport in heterogeneous porous media-the imperfectly stratified aquifer: Proceedings of Conference and Workshop on Transport and Mass Exchange Processes in Sand and Gravel Aquifers, Field and Modelling Studies, October 1-4, 1990, Ottawa, Canada.

1992, Arrival times and temporal moments of breakthrough curves for an imperfectly strati- fied aquifer: Water Resources Research, v. 28, no. 1, p. 53-68.

Naff, R.L., 1994, An Eulerian scheme for the second-order approximation of subsurface transport moments: Water Resources Research, v. 30, no. 5, p. 1439-1455.

Naff, R.L., Yeh, T.-C. Jim, and Kemblowski, M.W., 1989, Reply to comment by Gideon Dagan: Water Resources Research, v. 25, no. 12, p. 2523-2525. 


\section{GROUND-WATER HYDROLOGY}

TITLE: $\quad$ Hydrologic Behavior of Cretaceous Shales (NR 81-035)

PERSONNEL: Christopher E. Neuzil, Project Chief

ADDRESS: $\quad$ U.S. Geological Survey

431 National Center

12201 Sunrise Valley Drive

Reston, VA 22092

TELEPHONE: (703) 648-5880

PROBLEM: The nature of ground-water flow in low permeability settings is understood poorly because of (1) historic inattention to nonaquifer/nonreservoir rock units, and (2) inherent difficulties, related to time and size scales, of observing the phenomena of interest. Nonetheless, low-permeability units are of great importance because they mediate aquifer/reservoir behavior, have important roles in the evolution of hydrologic systems and geologic processes over geologic time, and can confine toxic materials for long periods. Cretaceous shales in the midcontinent offer the opportunity of studying, at relatively accessible depths, thick and extensive bodies of low-permeability media.

OBJECTIVE: Develop, through theoretical studies coupled with study of the flow systems in midcontinental Cretaceous shales, a better understanding of the significant flow processes in low-permeability environments. Use this information to extract information about flow history from current conditions and to predict future flow behavior.

APPROACH: Develop or improve techniques for measuring hydraulic, mechanical/hydraulic, and osmotic properties; define existing flow systems, and develop rational theoretical tools for describing flow behavior.

PROGRESS: The study of the Pierre Shale hydrology in central South Dakota (Water Resources Research July 1993), which detected strong underpressuring as a result of erosional unburdening, continues to elicit interest from NAGRA, the Swiss Radioactive Waste Cooperative. The site of the proposed Swiss low-level repository seems to have a similar flow regime, and there is controversy over whether the cause is similar to the Pierre mechanisms. I continue to confer with NAGRA scientists, and anticipate visiting their site.

I published a discussion of clay and shale permeability (Water Resources Research February 1994) that compiled careful measurements at both lab and local to regional scales. It showed 


\section{GROUND-WATER HYDROLOGY}

that (1) there is often no scale effect (increasing permeability with scale) in these materials, and (2) permeabilities of these media are smaller than commonly thought or assumed (10E-23 to $10 \mathrm{E}-17$ meters squared at porosities between 0.1 and 0.4 ). These results have elicited considerable interest in the environmental field and have important implications for analyses of regional flow in sedimentary geologic systems.

My analysis of abnormal pressures as hydrodynamic phenomena has been accepted by the American Journal Of Science pending minor revision. Abnormal pressures have been viewed as (1) relict, static phenomena, or (2) dynamic phenomena. My analysis accomplishes two things. First, it presents a synthesized and comprehensive framework for applying the hydrodynamic model to abnormal pressures. Second, it shows that, if one adopts the hydrodynamic model, it is possible to (1) explain the great variety observed in abnormal pressure occurrences, (2) delineate the similarities in such regimes, and (3) extract information about system permeabilities, and geological processes and their rates. This could prove to be a rich source of information about flow and geological processes on a crustal scale.

I have partially completed an analysis of the hydraulic behavior of the Pierre Shale on a regional scale. The Pierre Stretches more than $2,000 \mathrm{~km}$ north to south and attains (in the Denver Basin) a thickness of $2.5 \mathrm{~km}$. (The Pierre is 300 meters thick at my South Dakota study site in the 1993 study above.) Studies by Bredehoeft, Neuzil and Milly (1983) and Belitz and Bredehoeft (1988), in addition to my site study, provide a unique opportunity to analyze the regional to local hydraulic behavior of this very extensive, thick shale unit. The preliminary results suggest that (1) the shale is dominated by fracture permeability in the upper kilometer of thickness, and is not affected by fractures below that, and (2) the fractures are sparse, leaving kilometer size blocks of "intact" shale between.

\section{REPORTS PUBLISHED 1989-1994:}

Neuzil, C. E., 1993, Low fluid pressure within the Pierre Shale-A transient response to erosion: Water Resources Research, no. 29(7), 20072020.

Neuzil, C.E., 1994, How permeable are clays and shales?: U.S. Geological Survey Water Resources Research, v. 30, no. 2, p. 145-150.
Silliman, S.E., and Neuzil, C.E., 1990, Borehole determination of formation thermal conductivity using a thermal pulse from injected fluid: Journal of Geophysical Research, v. 95, no. B6, p. 8697-8704. 


\section{GROUND-WATER HYDROLOGY}

TITLE: Investigations of Single and Multiphase Fluid Flow, Mass and Energy Transport, and Fluid Phase Change in the Subsurface Environment (NR 78-089)

PERSONNEL: Clifford I. Voss, Project Chief

Paul Taney, Computer Graphics Specialist

Allen Provost, NRC Postdoc

ADDRESS: U.S. Geological Survey

431 National Center

12201 Sunrise Valley Drive

Reston, VA 22092

TELEPHONE: (703) 648-5885

PROBLEM: The subsurface environment is subject to both natural and man-imposed stresses, the interaction of which determines both its preservation and its employment as a multifaceted natural resource for water supply, energy production, and subsurface storage of energy and materials. Study of subsurface problems requires synthesis of a theoretical framework of physics of single and multiphase fluid flow, mass and energy transport and fluid phase change as applied to the subsurface environment, and descriptions of subsurface behavior based on measurements in complex heterogeneous environments. Improved understanding is required to solve present subsurface problems.

OBJECTIVE: Elucidate fundamental theory describing flow and transport phenomena in complex heterogeneous geologic environments. Develop quantitative methods for analysis of systems in the subsurface environment involving single and multiphase fluid flow, mass and energy transport and fluid phase change. Apply these methods to field problems in order to illuminate hydrological relationships which are important in both the preservation and optimal employment of the subsurface.

APPROACH: Measure subsurface flow and transport in the field to develop conceptual descriptions of the system. Study system behavior using mathematical models based on either hypothetical or field problem conditions. Develop practical simulation models and analytical methods for quantitative analysis of subsurface problems as well as new measuring techniques as by-products of the investigations. 


\section{GROUND-WATER HYDROLOGY}

PROGRESS: Variable-density flow and solute transport simulation analysis of the transition zone in the major coastal aquifer in Oahu, Hawaii, has resulted in identification of major processes controlling regional transition zone dynamics. Field measurements in Oahu, Hawaii, to determine scale effects in hydraulic and transport behavior of structured heterogeneous aquifers are complete and isotopic and chemical analysis is underway. Integrated hydrologic, geologic, and geochemical analysis of regional ground-water flow in crystalline basement rocks using data collected in Sweden is underway in cooperation with agencies in Sweden.

Multiscale field reconnaissance and simulation analysis of hydraulics and chemical transport is underway in a heterogeneous but regionally structured aquifer fabric, resulting so far in water quality predictions in areas subject to seawater intrusion. The USGS-SUTRA subsurface transport code has been revised and distributed. Simulation analysis of regional ground-water flow in the crystalline basement shows the great impact of regional gradients and conductive structures on local conditions.

\section{REPORTS PUBLISHED 1989-1994:}

Ahlbom, K., Andersson, J-E., Nordqvist, R., Ljunggren, C., Tiren, S., and Voss, C. I., 1991, Gidea study site-Scope of activities and main results: Stockholm, Sweden, Swedish Nuclear Fuel and Waste Management Co. (SKB), SKB Technical Report 91-51, 100 p.

Ahlbom, K., Andersson, J-E., Nordqvist, R., Ljunggren C., Tiren, S., and Voss, C. I., 1991, Fjallveden study site-Scope of activities and main results: Stockholm, Sweden, Swedish Nuclear Fuel and Waste Mangement Co. (SKB), SKBI Technical Report 91-52, 104 p.

Ahlbom, K., Andersson, J-E., Nordqvist, R., Ljunggren, C., Tiren, S., and Voss, C. I., 1992, Sterno study site-Scope of activities and main results: Stockholm, Sweden, Swedish Nuclear Fuel and Waste Mangement Co. (SKB), SKB Technical Report 92-02, 62 p.

Knopman, D.S., and Voss, C.I., 1989, Multiobjective sampling design for parameter estimation and model discrimination in groundwater solute transport: Water Resources Research, v. 25-10, p. 2245-2258.

Knopman, D.S., Voss, C.I., and Garabedian, S.P., 1991, Sampling design for groundwater solute transport: Tests of methods and analysis of Cape Cod tracer test: Water Resources Research, v. 27, p. 925-949.

Multhaup, R. A., Voss, C. I., and Souza, W. R., 1989 , Subsurface mapping of basalts based on petrographic characterization of cuttings from borehole drilling on Oahu, Hawaii: U.S. Geological Survey Water-Resources Investigations Report 89-4181, 40 p.

Nyberg, G., and Voss, C. I., 1991, Problems in modelling ground-water systems in limited scale: Stockholm, Sweden, Swedish Nuclear Fuel and Waste Management Co. (SKB), SKB Arbetsrapport 91-10, 12 p. 


\section{GROUND-WATER HYDROLOGY}

Souza, W.R., and Voss, C.I., 1989, Assessment of potable ground water in a freshwater lens using variable-density flow and solute transport simulation, in Solving Ground Water Problems with Models: National Water Well Association, p. 1023-1043.

-

Underwood, M. R., Peterson, F. L., and Voss, C. I., 1992, Groundwater Lens Dynamics of Atoll Islands: Water Resources Research, v. 28, no. 11 , p. 2889-2902.

Voss, C. I., and Andersson, J., 1991, Some aspects of regional flow of variable-density groundwater in crystalline basement rock of Sweden: Stockholm, Sweden, Swedish Nuclear Power Inspectorate (SKI), SKI Technical Report 91:9, $63 \mathrm{p}$.

Voss, C.I., and Anderson, J., 1993, Regional groundwater flow in the Baltic Shield during Holocene coastal regression: Ground Water, v. 31-6, p. 989-1006.

Voss, C.I., and Knopman, D.S., 1989, Strong classical one-dimensional descriptions of field solute transport exist! Modeling the Cape Cod tracer test, in Solving ground water problems with models: National Water Well Association, p. 209-232.

Voss, C.I., and Souza, W.R., 1991, Modeling a regional aquifer containing a narrow transition between freshwater and saltwater using solute transport simulation-Theory and methods, in De Breuck, W., ed., Selected Papers from SWIM: International Association of Hydrogeologists, Verlag Heize Heise, v. II, p. 189206.

Voss, C.I., and Souza, W.R., in press, Dynamics of a regional freshwater-saltwater transition zone in an anisotropic coastal aquifer system: Journal of Hydrology, v. 00. 


\section{GROUND-WATER HYDROLOGY}

TITLE: Digital Modeling of Transport in the Saturated Zone (NR 81-120)

PERSONNEL: Leonard F. Konikow, Project Chief

Cathy Cather, Secretary

George Z. Hornberger, Phys. Sci.

Steven C. Lessoff, student, Johns Hopkins University

ADDRESS: U.S. Geological Survey

431 National Center

12201 Sunrise Valley Drive

Reston, VA 22092

TELEPHONE: (703) 648-5878

PROBLEM: Management of ground-water resources requires that the extent and rate of movement of contaminants in the saturated and unsaturated zones be understood.

Contaminants have been and will continue to be both accidentally and deliberately introduced into ground-water systems. Some of these contaminants are very hazardous. Because of the immediacy of such contamination problems, understanding of the physical and chemical processes affecting their migration needs to be increased rapidly, and mathematical models derived from this understanding need to be tested and documented.

OBJECTIVE: Investigate the parameters in basic mathematical transport models developed for ground-water systems to increase understanding of the factors influencing these parameters and of the interrelation between parameters. Derive appropriate two- and three-dimensional mathematical models to describe contaminant movement in complex field situations.

APPROACH: Develop numerical models, emphasizing those ground-water systems and contaminants for which transport-models seem most critical. Evaluate the accuracy and efficiency of new and existing modeling techniques through comparisons with analytical solutions, other numerical methods, and observed data from practical field problems.

PROGRESS: An improved version of the methods-of-characteristics (MOC) model (Version 3.1) has been developed and documented (Water Resources Investigations report has been submitted for Director's Approval). The primary new features include input and output options more compatible with interactive use from a terminal, enhanced formats for 80 -character wide printing and viewing, on-screen status messages during execution, and 


\section{GROUND-WATER HYDROLOGY}

additional input and output options to allow generation of separate output files for easy graphical post-processing of model results (files are written in formats directly readable by many graphical software packages). Work continues on the development and documentation of a three-dimensional version of the method-of-characteristics solute-transport module for the McDonald-Harbaugh modular flow model.

The preprocessor for the MOC model (PREMOC) has been updated for consistency and compatibility with MOC (3.1). PREMOC was formerly only operable on IBM-compatible PCs using DOS. A major effort has been completed to develop a version of PREMOC that will run on the Survey's Data General workstations. This version has been tested and used in the WRD Training Class on solute-transport modeling (G0801) that was given in February 1994.

Participation of Konikow as a member of the National Research Council's WIPP (Waste Isolation Pilot Plant) Committee continues. The Committee usually meets four times a year, and provides technical oversight for scientific and engineering activities at the U.S. Department of Energy (DOE) facility in New Mexico, which is planned for disposal of transuranic wastes in deep salt beds. As part of this effort, the project undertook a detailed analysis of a single-well test proposed by Sandia National Labs to identify and measure matrix diffusion in the Culebra Dolomite. Our analysis indicates that there is a high probability that the effects of heterogeneity and drift will make the results of a single-well test ambiguous (that is, it will not definitively measure matrix diffusion). Our preliminary results were presented orally at the Spring 1994 American Geophysical Union (AGU) meeting. A draft report was completed and sent to Sandia for their review and use, and they came to Reston in December to meet with us to review the results. Sandia has significantly modified their proposed test because of our results. A final manuscript is in preparation for publication in a peer-reviewed journal.

A Macintosh version of an interactive aquifer test analysis package has been developed in collaboration with Mark Person (University of Minnesota) and Fred Day-Lewis (University of New Hampshire). A draft report documenting the software package has been prepared and is undergoing colleague review. The Office of Ground Water intends to hire Day-Lewis for the summer to adapt it to the Data General system.

Efforts at documenting and assessing the reliability and validity of ground-water models continues. A manuscript on value of postaudits in ground-water modeling applications has been completed and approved. It was presented orally at the 1994 Pacific Northwest Oceania Conference on Assessment of Models for Groundwater Resource Analysis and Management 


\section{GROUND-WATER HYDROLOGY}

in March 1994, and will be published in the conference proceedings. This work demonstrated that the actual predictive accuracy of well-calibrated models is only low to moderate. Regulatory agencies are starting to change their philosophy related to model use and model validation. An analysis of model verification approaches has demonstrated the weakness of the current common philosophy. The analysis focused on one of the base cases of the international HYDROCOIN project, which involved a problem of variable-density ground-water flow and solute transport and was designed to represent a radioactive waste repository in a salt dome. A reanalysis using the USGS MOCDENSE computer model demonstrated some reasons why the basic problem was poorly formulated. One conclusion was that consistency among the results of various models during benchmarking is not the same as, and does not demonstrate, model accuracy or reliability. This analysis also demonstrated some advantages of the method-of-characteristics approach over widely used finite-difference and finite-element methods. A draft manuscript describing these results is almost finished.

I submitted an invited manuscript to the WRD Bulletin entitled, Thoughts on Authorship and Acknowledgments in Reports by WRD Personnel.

REPORTS PUBLISHED 1989-1994:

Brantley, S.L., Rowe, G.L., Konikow, L.F., and Sanford, W.E., 1992, Natural toxic waters of Poas Volcano, Costa Rica: Journal of Research and Exploration, v. 8, no. 3, p. 328334.

Bredehoeft, J. D., and Konikow, L. F., 1993, Ground-water models-Validate or invalidate: Ground Water, v. 31, no. 2, p. 178-179.

Environmental Protection Agency, Modeling Project Subcommittee, Science Advisory Board, 1993, Report-Review of the assessment framework for ground-water model applications: Environmental Protection Agency, Washington, D.C., 12 p. [L.F. Konikow was a member of the committee that prepared this report].

Goode, D.J., 1990, Mixed waste leachates in ground water at low-level waste sites, in Safe disposal of radionuclides in low-level radio- active-waste repository sites: U.S. Geol. Survey Circular 1036, p. 49-57.

1990, Particle velocity interpolation in blockcentered finite difference groundwater flow models: Water Resources Research, v. 26, no. 5, p. 925-940.

1990, Governing equations and model approximation errors associated with the effects of fluid-storage transients on solute transport in aquifers: U.S. Geological Survey Water-Resources Investigations Report 90-4156, 20 p.

Goode, D.J., and Konikow, L.F., 1989, Modification of a method-of-characteristics solute-transport model to incorporate decay and equilibrium-controlled sorption or ion exchange: U.S. Geological Survey Water-Resources Investigations Report 89-4030, 65 p. 


\section{GROUND-WATER HYDROLOGY}

1990, Apparent dispersion in transient groundwater flow: Water Resources Research, v. 26, no. 10 , p. $2339-2351$.

1990, Re-evaluation of large-scale dispersivities for a waste chloride plume-Effects of transient flow, in Kovar, K., ed., Model CARE 90-Calibration and reliability in groundwater modeling: IAHS Publication no. 195, p. 417-426.

1991, Testing a method-of-characteristics model of three-dimensional solute transport in ground water, in Lennon, G.P., ed., Symposium on Ground Water-Proceedings of the International Symposium: Nashville, Tenn., American Society of Civil Engineers, p. 2127.

Granato, G. E., Konikow, L. F., and Srinivasan, P., 1993, PREMOC (version 4.0), A preprocessor for the two-dimensional method of characteristics (MOC) solute-transport model: Golden, Colo., International Ground Water Modeling Center, $22 \mathrm{p}$.

Konikow, L.F., 1991, Flow and transport problems in ground-water systems, in Proceedings of the International Conference on Nitrogen, Phosphorus, and Organic Matter: Danish Ministry of the Environment, p. 57-66.

1992, Discussion of the "modeling process and model validation, " by Chin-Fu Tsang: Ground Water, v. 30 , no. 4 , p. 622-623.

Konikow, L.F., in press, The value of postaudits in ground-water model applications, in El-Kadi, A., ed., Assessment of Models for Groundwater Resources Analysis and Management, Proceedings of the 1994 Pacific Northwest/ Oceania Conference.
Konikow, L.F., and Bredehoeft, J.D., 1992, Ground-water models cannot be validated: Advances in Water Resources, v. 15, no. 3, p. 75-83.

Konikow, L. F., and Rodriguez Arevalo, J., 1993, Advection and diffusion in a variable-salinity confining layer: Water Resources Research, v. 29 , no. 8 , p. $2747-2761$.

Konikow, L.F., and Swain, L.A., 1990, Assessment of predictive accuracy of a model of artificial recharge effects in the upper Coachella Valley, California, in Simpson, E.S., and Sharp, J.M., Jr., eds., Selected Papers on Hydrogeology: International Assoc. of Hydrogeologists, IGC Meeting, Washington, D.C., 1989, [Proceedings], v. 1, p. 433-449.

National Research Council, Committee on Ground Water Modeling Assessment, 1990, Ground Water Models-Scientific and regulatory applications: Washington, D.C., National Academy Press, 303 p.

Sacks, L.A., Herman, J.S., Konikow, L.F., and Vela, A.L., in press, Seasonal dynamics of groundwater-lake interactions at Donana National Park, Spain: Journal of Hydrology, $v$. 136 , no. 2 , p. $123-154$.

Sanford, W.E., and Konikow, L.F., 1989, Porosity development in coastal carbonate aquifers: Geology, v. 17, no. 3, p. 249-252.

1989, Reply to Comment by W.L. Wilson on Porosity development in coastal carbonate aquifers: Geology, v. 17, no. 10, p. 962-963.

- ___ 1989, Simulation of calcite dissolution and porosity changes in saltwater mixing zones in coastal aquifers: Water Resources Research, v. 25 , no. 4 , p. $655-667$. 


\section{GROUND-WATER HYDROLOGY}

Sanford, W.E., Konikow, L.F., Rowe, G.L., and Brantley, S.L., in press, Ground-water transport of crater-lake brine at Poas Volcano, Costa Rica: Journal of Volcanology and Geothermal Research, v. 00.

Sanford, W.E., and Wood, W.W., 1991, Brine evolution and mineral deposition in hydrologically open evaporite basins: American Journal of Science, v. 291, p. 687-710.

Wood, W.W., and Sanford, W.E., 1990, A model for ground-water control of continental evaporite deposition: Economic Geology, v. 85, no. 6, p. 1226-1235.

1990, A model for ground-water control of continental evaporite deposition: Economic Geology, v. 85, no. 6, p. 1226-1235. 


\section{GROUND-WATER HYDROLOGY}

TITLE: $\quad$ Multivariate Statistical Techniques for Assessing Regional Ground-Water Quality and Quantity (NR 84-130)

PERSONNEL: Charles E. Brown, Project Chief

ADDRESS: $\quad$ U.S. Geological Survey

431 National Center

12201 Sunrise Valley Drive

Reston, VA 22092

TELEPHONE: (703) 648-5886

PROBLEM: Regional assessment of the chemical character of ground water requires that unbiased estimates of the chemical species in ground water be obtained. With recent regulations regarding ground-water contamination and disposal of toxic wastes, it is necessary that the methods for assessment of man-induced versus natural chemical character are not biased by experimental design, and that estimates of chemical species present in ground water are not influenced to a large degree by temporal variation and sample collection strategies. It is a requirement as well that populations which are compared are homogeneous in terms of statistical parameters. Implementing statistical design techniques early in the water-quality assessments can lead to maximizing information while minimizing the number of samples needed.

OBJECTIVE: The ultimate objective is to apply and extend statistical design theory to better understand and define ground-water quality parameters. It is the objective also to understand the relations between chemical variables in ground-water systems and to decompose the chemical variability within the system according to contributing sources. The understanding of chemical variability within the ground-water system will provide a basis for application of methodology to other areas with similar hydrogeology.

APPROACH: In order to accomplish this objective, a comprehensive investigation will be undertaken that involves collecting a considerable amount of field data in order to test improved sampling strategies. Multivariate, bivariate, and univariate statistical theory will be applied to all ground-water data collected to improve future sampling designs for ground-water studies. Stochastic and geostatistical analysis will provide better estimates of chemical parameters, which are input to geochemical and transport models. 


\section{GROUND-WATER HYDROLOGY}

PROGRESS: A detailed analysis of aquifers has been documented wherein multivariate statistical techniques were uniquely applied.

\section{REPORTS PUBLISHED 1989-1994:}

Brown, C.E., 1993, Use of principal-Component, correlation, and stepwise multiple-regression analyses to investigate selected physical and hydraulic properties of carbonate-rock aquifers: Journal of Hydrology, v. 147, p. 169195.

Brown, C.E., Mose, D.G., Mushrush, G.W., Chrosniak, C.E., 1991, Use of Statistical Techniques to Assess the Radon Potential of Rocks in Parts of Virginia and Maryland: National Symposium-Naturally occurring radionuclides in agricultural products: University of Florida, Gainesville, Fla., 10 p.

1992, Statistical Analysis of the Radon-222 Potential of Rocks in Virginia: Journal of Environmental Geology and Water Sciences, v. 19 , no. 3 , p. 193-203.

Mose, D.G., Mushrush, G.W., Chrosniak, C.E., Brown, C.E., 1989, Carcinogenic Properties of Radon Enriched Piedmont Ground Water in Virginia and Maryland: Conference on Ground Water in the Piedmont of the Eastern United States, Charlotte, N.C., [Proceedings], p. 536-546. 


\section{GROUND-WATER HYDROLOGY}

TITLE: $\quad$ Transport Phenomena in Fractured Rock (NR 84-134)

PERSONNEL: Allen M. Shapiro, Project Chief

Cathy D. Cather, Secretary

Troy Dorman, Hydrologist, Student (Intermittent)

ADDRESS: U.S. Geological Survey

431 National Center

12201 Sunrise Valley Drive

Reston, VA 22092

TELEPHONE: (703) 648-5884

PROBLEM: There has been an increasing awareness that, in many circumstances, the theories associated with the description of hydrogeologic phenomena in granular porous media are unacceptable in the description of these same phenomena in fractured rock and geologic formations having similar characteristics. Because of the wide extent of fractured formations and their various uses, including proposed repositories for radioactive waste, a need exists to describe and better understand the physics of fluid movement, deformation, contaminant migration, and energy transport under the broad range of physical situations where fractured formations exist.

OBJECTIVE: Develop mathematical models of transport phenomena in fractured rock. Use alternative conceptualizations of the medium in the development of these models because the description of fractured rock is highly dependent on scale of observation. Investigate the relevant parameters, evaluate physical situations where each conceptualization is applicable, and study the adaptability of field measurements to these conceptualizations.

APPROACH: Consider fractured rock and similar formations as a series of discrete fractures and also in various continuum conceptualizations. Develop mathematical models of transport phenomena. Use hypothetical physical situations and later, if possible, field data and field investigations to examine the applicability of these model conceptualizations and the adaptability of field measurements to these conceptualizations.

PROGRESS: This project coordinates a multidisciplinary research effort to develop field techniques and interpretive methods of characterizing and predicting fluid movement and chemical transport in fractured rock over dimensions that range from meters to kilometers. The multidisciplinary research effort is being conducted in cooperation with six national 


\section{GROUND-WATER HYDROLOGY}

research program projects, the New Hampshire and Connecticut District Offices of the Water Resource Division, the Geologic Division, and several outside research institutes. The field investigations are being conducted in the crystalline rock of the Mirror Lake drainage basin in the Hubbard Brook Experimental Forest in central New Hampshire. These investigations couple geologic and fracture mapping, surface- and borehole-geophysics, ground-water geochemistry, hydraulic and tracer testing, and ground-water and solute-transport modeling. In addition to the overall coordination of this multidisciplinary research effort, this project is responsible for interpreting hydraulic and tracer tests to identify the variability of hydraulic properties of the crystalline rock and to identify transport properties of permeable fractures over dimensions of tens of meters. In addition, this project is interpreting geochemical and isotopic analyses of ground water to investigate fluid movement and chemical transport in fractured crystalline rock over dimensions of kilometers.

This project has been involved in a cooperative study with the South Dakota District Office of the Water Resources Division to investigate the water resources of the Madison Aquifer near Rapid City, South Dakota. The project is designing and interpreting tracer tests conducted in the Madison Aquifer to identify transport properties of fractured carbonate formations.

REPORTS PUBLISHED 1989-1994:

Cvetkovic, V.D., Dagan, G., and Shapiro, A.M., 1991, An exact solution of solute transport by one-dimensional random velocity fields: Stochastic Hydrology and Hydraulics, v. 5, p. 45-54.

Cvetkovic, V.D., and Shapiro, A.M., 1989, Solute advection in stratified formations: Water Resources Research, v. 25, p. 1283-1289.

1990, Mass arrival of sorptive solute in heterogeneous porous media: Water Resources Research, v. 26 , p. 2057-2067.

Cvetkovic, V., Shapiro, A. M., and Dagan, G., 1992, A solute flux approach to transport in heterogeneous formations, 2 . Uncertainty analysis: Water Resources Research, v. 28, p. 1377-1388.
Dagan, G., Cvetkovic, V., and Shapiro, A. M., 1992, A solute flux approach to transport in heterogeneous formations, 1 . The general framework: Water Resources Research, v. 28, p. 1369-1376.

Drenkard, S., Torgersen, T., Weppernig, R., Farley, K., Schlosser, P., Michel, R.L., Sharpiro, A.M., and Wood, W.W., in press, Helium isotope analysis and tritium-helium age dating in the Mirror Lake basin, Grafton County, New Hampshire, in Morganwalp, D.W., and Aronson, D.A., eds., U.S. Geological Survey Toxic Substances Hydrology Program-Proceedings of the Technical Meeting, Colorado Springs, Colo., September 2024, 1993: U.S. Geological Survey Water Resources Investigations Report.

Goode, D.J., Hsieh, P.A., Shapiro, A.M., Wood, W.W., and Kraemer, T.F., 1993, Concentra- 


\section{GROUND-WATER HYDROLOGY}

tion history during pumping from a leaky aquifer with stratified initial concentration, in Shen, H.W., ed., Hydraulic Engineering, Proceedings 1993, National Conference, July 25-30, 1993, San Francisco: New York, American Society of Civil Engineers.

Goode, D.J., and Shapiro, A.M., 1991, Comment on Desbarats, A.J., Macrodispersion in sandshale sequences: Water Resources Research, v. 27, p. 135-139.

1992, Comment on Moreno L., and others, Flow and tracer transport in a single fractureA stochastic model and its relation to some field observations: Water Resources Research, v. 27, p. 129-131.

Hsieh, P.A., and Shapiro, A.M., in press, Hydraulic characteristics of fractured bedrock underlying the FSE well field at the Mirror Lake site, Grafton County, New Hampshire, in Morganwalp, D.W., and Aronson, D.A., eds., U.S. Geological Survey Toxic Substances Hydrology Program-Proceedings of the Technical Meeting, Colorado Springs, Colo., Sept. 20-24, 1993: U.S. Geological Survey WaterResources Investigations Report.

Hsieh, P.A., Shapiro, A.M., Barton, C.C., Haeni, F.P., Johnson, C.D., Martin, C.W., Paillet, F.L., Winter, T.C., and Wright, D.L., 1993, Methods of characterizing fluid movement and chemical transport in fractured rock, in Chaney, J.T., and Hepburn, J.C., eds., Field Trip Guidebook for Northeastern United States: Boulder, Colo., Geological Society of America, p. R1-R30.

Shapiro, A.M., 1989, Interpretation of oscillatory water levels in observation wells during aquifer tests in fractured rock: Water Resources Research, v. 25, p. 2129-2137.
1993, The influence of heterogeneity in estimates of regional hydraulic properties in fractured crystalline rock, in Banks, S., and Banks, D., eds.,. Memoires of the 24th Congress: International Association of Hydrogeologists, Hydrogeology of Hard Rocks, Oslo, Norway, June 28-July 2, 1993, p. 125-136.

Shapiro, A.M., and Cvetkovic, V.D., 1990, A comparison of two- and three-dimensional stochastic models of regional solute movement: Transport in Porous Media, v. 5, p. 1-25.

Shapiro, A.M., and Hsieh, P.A., 1991, Research in fractured-rock hydrogeology-Characterizing fluid movement and chemical transport in fractured rock at the Mirror Lake drainage basin, New Hampshire, in Mallard, G.E., and Aronson, D.A., eds., U.S. Geological Survey Toxics Substances Hydrology Program-Proceedings of the technical meeting, Monterey, Calif., March 11-15, 1991: U.S. Geological Survey Water-Resources Investigations Report 91-4034, p. 155-161.

Shapiro, A.M., and Hsieh, P.A., in press, A new method of performing controlled injection of traced fluid in fractured crystalline rock, in Morganwalp, D.W., and Aronson, D.A., eds., U.S. Geological Survey Toxic Substances in Hydrology Program-Proceedings of the Technical Meeting, Colorado Springs, Colo., September 20-24, 1993: U.S. Geological Survey Water-Resources Investigations Report.

Shapiro, A.M., and Hsieh, P.A., in press, Overview of research on use of hydrologic geophysical and geochemical methods to characterize flow and chemical transport in fractured rock at the Mirror Lake site, New Hampshire, in Morganwalp, D.W., and Aronson, D.A., eds., U.S. Geological Survey Toxic Substances Hydrology Program-Proceedings of the Technical Meeting, Colorado Springs, Colo., 


\section{GROUND-WATER HYDROLOGY}

September 20-24, 1993: U.S. Geological

Survey Water-Resources Investigations Report.

Shapiro, A.M., and Nicholas, J.R., 1989, Assessing the validity of the channel model of fracture aperture under field conditions: Water Resources Research, v. 25, p. 817-828.

Shapiro, A.M., Wood, W.W., Busenberg, E., Drenkard, S., Plummer, L.N., Torgersen, T., and Scholosser, P. in press, A conceptural model for estimating regional ground-water velocity in bedrock of the Mirror lake area, Grafton County, New Hampshire, in Morganwalp, D.W., and Aronson, D.A., eds., U.S. Geological Survey Toxic Substances Hydrology Program-Proceedings of the Technical Meeting, Colorado Springs, Colo., September 20-24, 1993: U.S. Geological Survey WaterResources Investigations Report.

Wood, W.W., Shapiro, A.M., Hsieh, P.A., and Councell, T., in press, Observational, experimental and inferred evidence for solute diffusion in fractured granite aquifers: Examples from the Mirror Lake watershed, Grafton County, New Hampshire, in Morganwalp, D.W., and Aronson, D.A., eds., U.S. Geological Survey Toxic Substances Hydrology Program-Proceedings of the technical meeting, Colorado Springs, Colo., September 20-24, 1993: U.S. Geological Survey Water-

Resources Investigations Report 94-4014. 


\section{GROUND-WATER HYDROLOGY}

TITLE: Quantitative Analysis of Heterogeneous Hydrogeologic Controls on Ground-Water Flow and Transport (NR 91-152)

PERSONNEL: Thomas E. Reilly, Project Chief

Cathy Cather, Secretary

ADDRESS: $\quad$ U.S. Geological Survey

431 National Center

12201 Sunrise Valley Drive

Reston, VA 22092

TELEPHONE: (703) 648-5006

PROBLEM: Heterogeneous geologic material affects ground-water flow and transport on all scales. On the local scale, changes in hydraulic and geochemical properties can occur over distances on the order of centimeters. On the intermediate scale, the heterogeneity of intra-aquifer depositional layers in unconsolidated material and fractures in consolidated material influence the pathways of ground-water movement. On a regional scale, the heterogeneities due to extensive aquifers and confining units affect the flow system in a system-wide manner that influences both the boundaries of the system and the generalized pathways of fluid movement in the system.

An assessment of the importance of heterogeneity at all scales is required to better understand and define flow and transport in ground-water systems. In addition, the relationship of field measurements obtained in heterogeneous materials to the actual occurrence and movement of the water and chemical constituents in the system must be defined.

OBJECTIVE: The objective of this project is to quantify the effect of specific heterogeneous geologic controls on ground-water systems. Meeting the objective will entail the development of methods for incorporating the effects of heterogeneous hydrogeologic controls into simulations of ground-water systems. Ideally, the characterization and quantification of the heterogeneous earth material will incorporate basic geologic information on the deposition and history of the materials under study, as well as hydraulic and chemical information.

APPROACH: The general approach is to investigate and quantify the effect of heterogeneous geologic controls on flow and transport in a ground-water system and develop methods of incorporating them in ground-water simulations routinely. The geologic depositional 


\section{GROUND-WATER HYDROLOGY}

environment will play an important role in defining and describing the heterogeneities to be investigated.

The general approach to investigate these hydrogeologic controls will be as follows: (a) selection of the geologic control for investigation, (b) development of hypotheses to be tested, (c) selection of one or more field sites, (d) intensive analysis of "generic" hypothetical systems (based on the hydraulic and geologic information from the field sites) to corroborate or refute the hypotheses and give insight into the appropriate field measurements to be obtained to address the hypotheses, (e) specialized data collection, (f) quantitative analysis using simulation of the field sites, and $(\mathrm{g})$ use of the feedback between the results of the field investigations and the hypothetical "generic" analysis to corroborate or refute the hypotheses and give insight into mechanisms that might have been overlooked.

Information on the geologic depositional history will be used in the characterization of the media under investigation at the field sites. This qualitative characterization then will be evaluated and a quantitative characterization will be developed using stochastic and (or) deterministic methodologies, as appropriate, for both the "hypothetical" simulations and the analysis of the field sites themselves. The "generic" simulations should provide much information in the determination of important processes and the indication of which field measurements will be most appropriate to collect for the specific problem under investigation.

After the generic or "hypothetical" investigations, field data will be collected, as appropriate to define the system and geologic controls. The field data required will consist of head data, borehole geophysical logs, geologist logs, surface geophysical information, water quality information, and other ancillary data. These data will be used to characterize in a statistical sense the geologic terrain under investigation. Then methods of analysis, usually simulation techniques (deterministic and (or) stochastic), will be developed to quantify the effect of the geologic control characterized for the geologic terrain under investigation.

PROGRESS: Heterogeneity as a control of ground-water flow and transport is under investigation at both a local well scale and an intermediate system scale. In the vicinity of a well, an understanding of the effect of the heterogeneous nature of the aquifer permeability and chemical distributions in the aquifer on water samples obtained from wells is being pursued. Work was completed, and a report published, on the evaluation of water samples obtained from a unique multiscreened sampling device developed by Jack Gibs of the New Jersey District at the Toxic Hydrology Research Site at Galloway, New Jersey. Time series information on the chemical concentrations shows that trends in the quality of water sampled from wells can exist during sampling. Numerical simulation of layered systems indicates that 


\section{GROUND-WATER HYDROLOGY}

these trends can be the result of the mixing of waters along the screened interval, and the measured trends can provide information on the distribution of the chemical species. Work at the Cape Cod Toxic Hydrology Research Site on the effect of heterogeneity on sample collection has continued using multipoint samplers installed next to a screened well. A follow-up to well purging experiments conducted in 1992 and 1993 is underway and the results are being analyzed in collaboration with Denis LeBlanc of the Massachusetts District.

At the intermediate scale, an analysis of the effect of hydraulic conductivity heterogeneities on flow paths to wells was completed and a Water-Supply Paper was published. Work is continuing in the analysis of the effect of transient stresses on contributing areas to wells. Preliminary results indicate that cyclic variation in hydraulic stresses at diurnal, seasonal, or long-term climatic frequencies do not greatly affect the location of sources of water to wells. This suggests that it is often sufficient to analyze "well-head" protection areas under steady-state assumptions as is the current practice.

Other accomplishments this year include: The publication of a method for the corroboration of numerical flow models through the use of environmental tracers developed at the National Water Quality Assessment (NAWQA) pilot study area on the Delmarva peninsula, and publication of a computer program for the simulation of cylindrical flow to a well.

\section{REPORTS PUBLISHED: 1989-1994}

Appel, C.A., and Reilly, T.E., in press, Summary of computer programs produced by the U.S. Geological Survey for simulation of groundwater flow and quality-1993: U.S. Geological Survey Circular 1104, 88 p.

Bennett, G.D., Reilly, T.E., and Hill, M.C., 1990, Technical training note in ground-water hydrology: Radial flow to a well: U.S. Geological Survey Water-Resources Investigations Report 89-4134, 83 p.

Buxton, H.T., Reilly, T.E., Pollock, D.W., and Smolensky, D.A., 1991, Particle tracking analysis of recharge areas on Long Island, New York: Ground Water, v. 29, no. 1, p. 63-71.
Franke, O.L., Bennett, G.D., Reilly, T.E., Laney, R.L., Buxton, H.T., and Sun, R.J., 1991, Concepts and modeling in ground-water hydrology-A self-paced training course: U.S. Geological Survey Open-File Report 90-707 $416 \mathrm{p}$.,

Franke, O.L., Reilly, T.E., Buxton, H.T., and Simmons, D.L., 1993, Study guide for a beginning course in ground-water hydrology-Instructor's guide: U.S. Geological Survey Open-File Report 92-637, pt. 2, 128 p.

Franke, O.L., Reilly, T.E., Haefner, R.J., and Simmons, D.L., 1990, A study guide for a beginning course in ground-water hydrologyCourse participants: U.S. Geological Survey Open-File Report 90-183, pt. 1, 184 p. 


\section{GROUND-WATER HYDROLOGY}

Nemickas, Bronius, Mallard, G.E., and Reilly, T.E., 1989, Availability and historical development of ground-water resources on Long Island, New York-An introduction: U.S. Geological Survey Water-Resources Investigations Report 88-4113, 43 p.

Prince, K.R., Reilly, T.E., and Franke, O.L., 1989, Analysis of the shallow ground-water flow system near Connetquot Brook, Long Island, New York: Journal of Hydrology, v. 107, p. $223-250$

Reilly, T.E., 1990, Simulation of dispersion in layered coastal aquifer systems: Journal of Hydrology, v. 114, p. 211-228.

1990, Ground-water flow equation-A simplified development, in Franke, O.L., Reilly, T.E., Haefner, R.J., and Simmons, D.L., eds., A study guide for a beginning course in ground-water hydrology-Course participants: U.S. Geological Survey Open-File Report 90-183, pt. 1, p. 57-64 .

1993, Analysis of ground-water systems in freshwater-saltwater environments, in Alley, William ed., Regional ground-water quality: New York, Van Nostrand Reinhold, p. 443469.

Reilly, T.E., Franke, O.L., and Bennett, G.D., 1989, Bias in ground-water samples caused by wellbore flow: Journal of Hydraulic Engineering, American Society of Civil Engineers, v. 115 , no. 2 , p. $270-276$.

Reilly, T.E., and Gibs, J., 1993, Effects of physical and chemical heterogeneity on waterquality samples obtained from wells: Ground Water, v. 31 , no. 5 , p. $805-813$.

Reilly, T.E., and Harbaugh, A.W., 1993, Source code for the computer program and sample data set for the simulation of cylindrical flow to a well using the U.S. Geological Survey Modular Finite-Difference Ground-Water Flow Model: U.S. Geological Survey Open-File Report 92-659, 7 p.

1993, Simulation of cylindrical flow to a well using the U.S. Geological Survey Modular Finite-Difference Ground-Water Flow Model: Ground Water, v. 31, no. 3, p. 489-494.

Reilly, T.E., and LeBlanc, D.R., in press, An experiment to quantify temporal variability of water samples obtained from screened wells, in Morganwalp, D.W., and Aronson, D.A., eds., U.S. Geological Survey Toxic Substances Hydrology Program-Proceedings of the technical meeting, Colorado Springs, Colo., September 20-24, 1993: U.S. Geological Survey Water-Resources Investigations Report 94-4014.

Reilly, T.E., Plummer, L.N., Phillips, P.J., and Busenberg, E., 1994, The use of simulation and multiple environmental tracers to quantify ground-water flow in a shallow aquifer: Water Resources Research, v. 30, no. 2, p. 421-433.

Reilly, Thomas E., and Pollock, David W., 1993, Factors affecting areas contributing recharge to wells in shallow aquifers: U.S. Geological Survey Water-Supply Paper 2412, 21 p.

Scorca, Michael P., Reilly, Thomas E., and Franke, $O$. Lehn, in press, Hydrogeology and selected water-quality data on Jones Beach Island, Long Island, New York: U.S. Geological Survey Water-Resources Investigations Report 92-4171. 


\section{GROUND-WATER HYDROLOGY}

TITLE: Reaction-Transport Phenomena in Hydrogeologic Settings (NR 91-153)

PERSONNEL: Ward Sanford, Project Chief

ADDRESS: $\quad$ U.S. Geological Survey

431 National Center

12201 Sunrise Valley Drive

Reston, VA 22092

TELEPHONE: (703) 648-5882

PROBLEM: Ground-water transport and geochemical reactions play a significant role in many geological processes. Such processes include diagenesis, ore deposition, petroleum migration, hydrothermal activity, and evaporite formation. These processes are important in that they produce economic mineral deposits and alter the characteristics of aquifers and reservoirs from which we obtain water supplies and mineral resources. Many of these processes have been studied in terms of the geochemical reactions or the ground-water transport involved. However, in many circumstances the reactions and transport are inseparable. Because of the complexity of coupling equations of transport and chemical reactions, very few studies have been made thus far in which geochemical reactions and ground-water transport are coupled and analyzed simultaneously.

OBJECTIVE: To understand the interaction of ground-water transport and geochemical reactions in hydrogeologic settings, including: interactions between geochemical reactions and solute transport, interactions between geochemical reactions and heat transport, and the effects of heat and solute transport on variable-density flow and transport in natural systems. Additional objectives will be to understand the implications these interactions have for the geologic processes being studied, and to develop more efficient methods for studying processes that involve both ground-water transport and geochemical reactions.

APPROACH: The study of ground-water transport and geochemical reactions in hydrogeologic settings will be done both through field investigations and through the development and use of numerical models. Studies will begin with specific geologic processes in mind; field investigations may then be conducted and numerical models will be developed to address the particular process of interest. Field investigations may aid in constraining the numerical models, and conversely, preliminary modeling results may suggest particular strategies for sampling in the field. It is expected that considerable interaction and collaboration will occur with geochemists on a majority of the studies undertaken. 


\section{GROUND-WATER HYDROLOGY}

PROGRESS: Dissolved chloride profiles were obtained from cores taken from the Kiamichi shale adjacent to Double Lake, in west Texas. The profiles provide constraints on the paleohydrology of Double Lake during the last 5,000 years. A paper has been written describing this data and is being submitted to Geology. Numerical analyses are also being performed to describe the chemistry of the shale porewater. The significance of advection, molecular diffusion, ion exchange, and carbonate reactions are being investigated.

A version of the SUTRA ground-water computer model was modified to handle heat and reactive solute transport. A sensitivity analysis was then performed by my collaborator at the University of Bristol, England, on heat and solute transport in carbonate platforms. These simulations illustrate conditions that create significant Kohout convection and subsequent diagenesis (for example, dolomitization).

A preconditioned conjugant gradient solver has been successfully installed into the USGS Mocdense model. Work is also progressing on the development of MOCDENSE3D, a three-dimensional ground-water model for multiple-constituent solute transport in ground water having variable density.

A new training class on Ground Water and Geologic Processes was developed and taught in the Western Region by myself and three other Survey researchers. A contract has now been secured with Cambridge University Press with the same four researchers to write a book on this same subject.

\section{REPORTS PUBLISHED 1989-1994:}

Brantley, S.L., Rowe, G.L., Konikow, L..F., and Sanford, W.E., 1992, Natural toxic waters of Poas Volcano, Costa Rica: Journal of Research and Exploration, v. 8, no. 3, p. 328337.

Sanford, W.E., Konikow, L.F., Rowe, G.L., and Brantley, S.L., in press, Ground-water transport of crater-lake brine at Poas Volcano, Costa Rica: Journal of Volcanology and Geothermal Research, V. 00.

Sanford, W. E., Wood, W.W., and Councell, T.B., 1992, Calcium-dominated brines: an ion exchange model in Kharaka, Y.K., and Maest, A.S., eds., Proceedings of the 7th International Symposium on Water-Rock Interaction, July 9-23, 1992, Park City, Utah:
Rotterdam, The Netherlands, A.A. Balkema, 669-672 p.

Wood, W.W., Sanford, W.E., and Reeves, C.C., 1992, Large lake basins of the Southern High Plains: Ground-water control of their origin?: Geology, v. 20, no. 6, p. 535-538.

Wood, W.W., and Sanford, W.E., in press, An example of chemical and isotopic methods for quantifying ground-water recharge in a regional semi-arid environment: Ground Water.

Wood, W.W., and Sanford, W.E., in press, Recharge to the Ogallala, 60 years after C.V. Theis's Analysis, in Urban, Lloyd, ed., Playa Basin Symposium, Texas Technical University, [Proceedings]. 


\section{GROUND-WATER HYDROLOGY}

TITLE: $\quad$ Application of the Unsaturated Flow Theory to the Phenomena of Infiltration and Drainage (WR 63-024)

PERSONNEL: David A. Stonestrom, Project Chief

Kim N. Bui, Secretary

Katherine C. Akstin, Hydrologist

ADDRESS: $\quad$ U.S. Geological Survey

345 Middlefield Road, MS 421

Menlo Park, CA 94025

TELEPHONE: (415) 329-4528

PROBLEM: Surface-runoff and various ground-water processes often are significantly influenced by water movement in the unsaturated zone. For many situations of hydrologic interest, inadequate knowledge prevents these influences from being properly taken into account in water-resource analyses.

OBJECTIVE: Test present theories of water flow through unsaturated porous materials, with particular attention on theories of infiltration and drainage. Use these theories to develop experimental techniques that will facilitate studies of ground-water recharge, runoff generation, and other hydrologic processes involving the unsaturated zone. Study unsaturated zones in various settings, particularly settings with deep unsaturated profiles, to evaluate water-flow rates and explain these rates in terms of soil, geologic, plant, and atmospheric conditions. Use the results of such studies for the assessment of water movement and attendant solute movement towards ground and surface-water supplies.

APPROACH: Test the validity and accuracy of predictive theories of water flow through unsaturated porous media by laboratory and field-scale studies. Devise improved laboratory and field methods to measure such flows and to evaluate the flow-determining characteristics of soils and sediments. Use these methods, in conjunction with unsaturated-flow theory, for field studies of flow rates of water in unsaturated-zone settings relevant to hydrologic problems.

PROGRESS: Experimental tests confirmed that transmission-zone matric-pressure histories become grossly nonmonotonic and difficult to predict in the case of step-wise increasing rainfall rates, thus rendering standard Richards-equation based predictions of runoff initiation ineffective. An analysis of previous results showing smaller (but statistically significant) 


\section{GROUND-WATER HYDROLOGY}

matric-pressure anomalies during constant-rate infiltration was extended by taking into consideration the effects of air displacement. This analysis showed that air movement can usually be neglected with only small errors in the case of steady infiltration into dry, unbounded profiles, but that air flow may be important in the case of variable rainfall rates. An extended report describing failures of experimental results to conform to the predictions of established infiltration theory was published in Water Resources Research. In collaboration with E.E. Miller (University of Wisconsin) and C. Topp (Environment Canada), experiments were designed to test for scale invariance of the anomalous behavior when ethanol-water mixtures are substituted for water as the wetting fluid. Results of these experiments will test a hypothesis that changing contact angles of moving fluid-solid interfaces modify the course of infiltration from that predicted by theory.

Continued long-term, comparative study of water movement in deep, unsaturated soils and sediments under natural rainfall conditions. Continued ongoing field experiments (near Merced, California) of a new tracer method to investigate factors that control the partitioning of infiltrated precipitation into part that is re-emitted (evapotranspired) and part that eventually moves through the zone of seasonal moisture fluctuations, becoming recharge. Data from two chronosequence sites (one a 10-ka old entisol and the other a 250-ka old alfisol) through one annual (wet-season/dry-season) cycle have established that the magnitude of within-site variability, while considerable, is sufficiently smaller than between-site variations that pedogenic stage can be identified as a controlling factor on deep percolation. The data also indicate the complex dynamics of seasonal moisture movement in undisturbed conditions.

Retrospective tests of the (Parlange-Glass-Selker) theory that predicts wetting fronts are unstable, spontaneously breaking up into fingers, were performed by determining parameters required by the theory and computing expected finger diameters for previously performed infiltration experiments on 5-cm columns of Oakley sand. Fingering was not observed in any of these experiments. The predicted finger diameter (about four $\mathrm{cm}$ ) while smaller than the scale of observation, was sufficiently close to warrant further tests at a larger scale of observation. Apparatus that will allow packing of homogeneous columns up to $15 \mathrm{~cm}$ in diameter was completed. This will allow much needed critical testing of stability theory.

\section{REPORTS PUBLISHED 1989-1994:}

Nimmo, J.R., Akstin, K.C., and Mello, Karen A., 1992, Improved apparatus for measuring hydraulic conductivity at low water content: Soil Science Society of America Journal, v. 56, p. 1758-1761.
Nimmo, J.R., Stonestrom, D.A., and Akstin, K.C., 1994 , The feasibility of recharge rate determinations using the steady-state centrifuge method: Soil Science Society of America Journal, v. 58, n. 1, p. 94-56. 


\section{GROUND-WATER HYDROLOGY}

Stonestrom, D.A., 1990, Soapfilm flowmeter device for measuring gas flow rates: U.S. Patent no. $4,914,955$.

Stonestrom, D.A., 1994, An overview of unsaturated-flow theory as applied to the phenomena of infiltration and drainage, in Proceedings of the U.S. Geological Survey, U.S. Nuclear Regulatory Commission Joint Technical Workshop on Research Related to Low-Level Radioactive Waste Disposal, Reston, Virginia, 1993: U.S. Geological Survey Water-

Resources Investigations Report.

Stonestrom, D.A., and Rubin, J., 1989, Watercontent dependence of trapped air in two soils: Water Resources Research, v. 25, no. 9, p. 1947-1958.

Stonestrom, D.A., and Rubin, J., 1989, Water-content dependence of trapped air in two soils: Water Resources Research, v. 25, no. 9, p. 1947-1958.

Stonestrom, D.A., and Rubin, J., 1989, Air permeability and trapped-air content in two soils: Water Resources Research, v. 25, no. 9, p. 1959-1969. 


\section{GROUND-WATER HYDROLOGY}

TITLE: $\quad$ Modeling and Monitoring Heat and Fluid Flow in Geothermal Systems (WR 73-102)

PERSONNEL: Michael L. Sorey, Project Chief

Susan P. Bartaluzzi, Secretary

Elizabeth M. Colvard, Hydrologist

ADDRESS: U.S. Geological Survey

345 Middlefield Road, MS 439

Menlo Park, CA 94025

TELEPHONE: (415) 329-4420

PROBLEM: Analysis of heat and fluid flow in geothermal systems is needed to adequately describe the natural state of such systems and their response to fluid production for energy development. The analysis may involve analytical or numerical solution techniques, but requires delineation of realistic conceptual models for specific geothermal systems. This, in turn, requires the collection and synthesis of geologic, geophysical, geochemical, and hydrologic data. Periodic monitoring of changes in geothermal systems, including surficial thermal manifestations, can aid in understanding the natural conditions of flow and effects caused by crustal unrest and geothermal development.

OBJECTIVE: Elucidate the processes involved in geothermal systems and their response to stresses imposed by geothermal development, earthquakes, and magmatic intrusions. Develop realistic conceptual models of specific systems. Evaluate the level of natural variability in thermal fluid discharge in hot springs and fumaroles at specific geothermal areas.

APPROACH: Collect and synthesize geologic, geophysical, geochemical, and hydrologic data, including data obtainable from drill holes, for specific geothermal systems at Long Valley caldera (California), Lassen Park (California), and elsewhere. Use this information to develop realistic conceptual models of present and past flow within these systems. Apply numerical and analytical modeling techniques to quantify fluid and heat flow within these systems. Develop hydrologic monitoring programs at Long Valley, Lassen Park, and elsewhere to delineate the natural level of variability within these systems and to detect changes induced by crustal processes and geothermal development.

PROGRESS: Field oriented research was conducted at Long Valley caldera (California), Lassen Volcanic National Park (California), and Grass Valley (Nevada). Progress at Long 


\section{GROUND-WATER HYDROLOGY}

Valley included publication of a journal article on changes in helium isotopes in fumaroles caused by magmatic inflation, and preparation of a manusript describing subsidence induced by geothermal development. Progress at Lassen included prepration of a Water Resources Investigations report describing measurements of heat and mass flow from thermal areas over the 1986-1993 period. A paper was completed for the Geothermal Resources Council Annual Meeting on the geothermal system in Grass Valley and a professional paper on this topic (coauthored by Frank Olmsted, Alan Welch, and Don Schaefer) has been extensively revised. A second Geothermal Resources Council paper on the geothermal system at Mammoth Hot Springs in Yellowstone Park was completed, and a Water Resources Investigations report was published on the effects of a proposed 500-MW geothermal project on ground-water resources on the Island of Hawaii. An article for Geological Society of America (GSA) Today Forum was prepared that explains the findings of the USGS study of geothermal systems in the northern part of Yellowstone Park and the adjacent Corwin Springs known geothermal research are and defends the conclusion that limited geothermal development in the known geothermal research area would not affect the Park's hot springs.

REPORTS PUBLISHED 1989-1994:

Farrar, C.D., Sorey, M.L., Rojstaczer, S.A., and Steinemann, A.C., 1989: U.S. Geological Survey Water-Resources Investigations Report 89-4033, $70 \mathrm{p}$.

Hill, D.P., Ellsworth, W.L., Johnston, M.J.S., Langbein, J.O., Oppenheimer D.H., Pitt, M.A., Reasonberg, P.A., and Sorey, M.L., 1990, The 1989 earthquake swarm beneath Mammoth Mountain, California-An initial look at the 4 May through 30 September activity: Bulletin of the Seismological Society of America, v. 80, no. 2, p. 325-339.

Lopez, D.L., Smith, L., and Sorey, M.L., in press, Modeling fluid flow and heat transfer at Basin and Range faults: Preliminary results for Leach Hot Springs, Nevada: Transactions of the Geothermal Resources Council.

Sorey, M.L., editor, 1991, Effects of potential geothermal development in the Corwin Springs Known Geothermal Resources Area, Montana, on the thermal features of Yellowstone National Park: U.S. Geological Survey WaterResources Investigations Report 91-4052, 205 p.

Sorey, M.L., and Colvard, E.M., 1992, Factors affecting the decline in hot-spring activity in the Steamboat Springs area of critical environmental concern, Washoe County, Nevada: U.S. Geological Survey Administrative Report for the Bureau of Land Management, $109 \mathrm{p}$.

1994, Potential effects of the Hawaii Geothermal Project on ground-water resources on the Island of Hawaii: U.S. Geological Survey Water-Resources Investigations Report 94 $4028,35 \mathrm{p}$.

Sorey, M.L., Colvard, E.M., and Sturchio, N.C., 1990, Geothermal systems within the Mammoth corridor in Yellowstone National Park and the adjacent Corwin Springs KGRA: 


\section{GROUND-WATER HYDROLOGY}

Transactions of the Geothermal Resources Council, v. 14, p. 729-733.

Sorey, M.L., and Farrar, C.D., 1992, A conceptual model of the hydrothermal system in Long Valley caldera, California, U.S.A., in Kharaka, Y.K., and Maest, A.S., eds., Proceedings of the 7th International Symposium on Water-Rock Interaction, July 9-23, 1992, Park City, Utah: Rotterdam, The Netherlands, A.A. Balkema, p. 1357-1362.

Sorey, M.L., Farrar, C.D., and Marshall G.A., 1993, Hydrologic and topographic changes in Long Valley caldera, California, induced by geothermal development 1985-1992-Proceedings of the 15th New Zealand Geothermal Workshop: p. 149-154.

Sorey, M.L., Kennedy, B.M., Evans. W.C., Farrar, C.D., and Suenmnicht, G.A., 1993, Helium isotope and gas discharge variations associated with crustal unrest in Long Valley caldera, California, 1989-1992: Journal of Geophysical Research, v. 98, no. B9, 15,87115,889 .

Sorey, M.L., Kharaka, Y.K., Stanley, W.D., and Sturchio, N.C., in press, Geothermal systems in the Mammoth corridor at Yellowstone National Park, U.S.A.: Transactions of the Geothermal Resources Council.

Sorey, M.L., and Olmsted, F.H., in press, The hydrothermal system associated with Leach Hot Springs in southern Grass Valley, Nevada: Transactions of the Geothermal Resources Council.

Sorey, M.L., Suemnicht, G.A., Sturchio, N.C., and Nordquist, G.A., 1991, New evidence on the hydrothermal system in Long Valley caldera, California, from wells, fluid sampling, electrical geophysics, and age determinations of hot-spring deposits: Journal of Volcanology and Geothermal Research, v. 48, p. 229-263.

Sturchio, N.C., Murrell, M.T., Pierce, K.L., and Sorey, M.L., 1992, Yellowstone travertines$\mathrm{U}$-series ages and isotope ratios $(\mathrm{C}, \mathrm{O}, \mathrm{Sr}$, U), in Kharaka, Y.K., and Maest, A.S., eds., Proceedings of the 7th International Symposium on Water-Rock Interaction, July 9-23, 1992, Park City, Utah: Rotterdam, The Netherlands, A.A.' Balkema, p. 1427-1430.

Sturchio, N.C., Pierce, K.L., Murrell, M.T., and Sorey, M.L., 1994, Uranium-series ages of travertines and timing of the last glaciation in the northern Yellowstone area, WyomingMontana: Quaternary Research, v. 41, p. 265277. 


\section{GROUND-WATER HYDROLOGY}

TITLE: $\quad$ Technical Coordination and Support of Water Resources Division Geothermal Studies (WR 72-108)

PERSONNEL: Michael L. Sorey, Project Chief

Susan P. Bartaluzzi, Secretary

ADDRESS: U.S. Geological Survey

345 Middlefield Road, MS 439

Menlo Park, CA 94025

TELEPHONE: (415) 329-4420

PROBLEM: Geothermal studies in the Water Resources Division are part of a multidivisional nationwide research program of the Geological Survey. These studies require planning, technical supervision, logistical support, and coordination between the divisions. Additional coordination is required between the Geothermal Research Program of the USGS and geothermal program activities in other agencies such as the Department of Energy.

OBJECTIVE: Provide required technical, logistical, and funding support for Water Resources Division projects funded under the Geothermal Research Program.

APPROACH: The Water Resources Division (WRD) geothermal coordinator works with the Geologic Division's geothermal coordinator and the WRD Assistant Chief for Research and External Coordination to establish funding levels and program goals. Water Resources Division coordinator represents the geothermal research program in developing and carrying out various interagency projects such as Environmental Impact Analyses. The coordinator also participates in interdivisional program reviews and in the preparation of reports describing the geothermal research program. Technical supervision and assistance is provided where needed.

PROGRESS: Geothermal coordination activities included budget negotiations with Water Resources Division (WRD) and Geologic Division administrators for seven WRD projects receiving geothermal funding, participation in an annual review of the interdivisional geothermal program, and coauthoring of a PIES (Public Information in the Earth Sciences) Circular describing the USGS geothermal program. My two coauthors are in the Geologic Division. The circular will be available for distribution by October 1994. As geothermal coordinator I also acted as an advisor to county, state, and federal regulatory agencies on 


\section{GROUND-WATER HYDROLOGY}

effects of geothermal developments on hot springs in Long Valley caldera, California, and Steamboat Springs, Nevada.

REPORTS PUBLISHED 1989-1994:

Duffield, W.A., Sass, J.H., and Sorey, M.L., 1994, Mining the earth's heat, information about geothermal energy and the U.S. Geological Survey's program of geothermal investigations: U.S. Geological Survey Circular 1125. 


\section{GROUND-WATER HYDROLOGY}

TITLE: $\quad$ Hydrologic Studies of Heat and Mass Transport (WR 74-121)

PERSONNEL: Steven E. Ingebritsen, Project Chief

Susan P. Bartaluzzi, Secretary

Martha A. Scholl, Hydrologist

ADDRESS: $\quad$ U.S. Geological Survey

345 Middlefield Road, MS 439

Menlo Park, CA 94025

TELEPHONE: (415) 329-4422

PROBLEM: The presence and circulation of fluids profoundly affect volcanic processes and landforms. Eruption styles and cycles are influenced by volatiles dissolved in magma and by pressure-temperature-fluid saturation conditions in the surrounding rock. The presence of magma in turn influences ground-water pressures, temperatures, and chemistry. Advective heat and mass transport affect and locally dominate the thermal and chemical regimes of volcanos. Linkages between fluid flow and mechanical deformation are suggested by observations that subaerial volcanoes deform in response to changes in water-table elevation and that microseismicity can be related to boiling.

OBJECTIVE: The general objective is to characterize selected volcanogenic hydrothermal systems by ascertaining probable recharge and discharge areas; determining modes and quantities of recharge and discharge; interpreting geologic, geochemical, and geophysical data in terms of the size, shape, and hydraulic characteristics of hydrothermal systems; and using analytical and numerical modeling techniques to develop quantitative conceptual models. Research questions include: (1) What are the modes of heat and mass transfer from magma to the shallow subsurface? (2) What are the pressure, temperature, and fluid-saturation conditions between magma and the land surface? (3) What controls the permeability of volcanoes? How does it vary in space and time? What role do temporal variations in permeability play in the evolution of volcanogenic hydrothermal systems? (4) How well-coupled are various fluid flow, transport, and mechanical deformation processes? Do relatively simple models that simulate a subset of these processes provide useful insight into transport processes? (5) How can we evaluate hydrothermal systems in composite cones dominated near the surface by cold-water recharge?

APPROACH: (1) Collect available hydrogeologic and geophysical data from the literature and from the files of public and private agencies. (2) Where data are deficient, supplement 


\section{GROUND-WATER HYDROLOGY}

by field inventory, measurement, and sampling. (3) Develop quantitative conceptual models. Current numerical models cannot rigorously simulate the coupled problem of heat and fluid flow, solute transport, and deformation, and may need to be improved.

PROGRESS: Wrote documentation for HYDROTHERM, the first multiphase hightemperature (to $1,200^{\circ} \mathrm{C}$ ) geothermal simulator (Water Resources Investigations Report 94-4045, in collaboration with Dan Hayba, (Geologic Division)). We have already had many requests for this code and expect it to be quite widely used. Published papers on geysering (in Science, in collaboration with Stuart Rojstaczer, (Duke University)), kinetic isograds near the Skaergaard intrusion, Greenland (in American Journal of Science, in collaboration with Craig Manning (University of California-Los Angeles) and Dennis Bird (Stanford University), new heat-flow data from the Western Cascades, Oregon (in Geothermics), and the hydrogeology of Kilauea volcano, Hawaii (also in Geothermics). Gave talks on the now completed Cascade Range study which is summarized in our new Professional Paper 1044-L. Began work on fluid flow and heat transport near the critical point of $\mathrm{H}_{2} \mathrm{O}$. Organized a Western Region training course on "Groundwater in Geologic Processes." After this rather successful "dry run," we plan to offer the course at the National Training Center in January 1995 and have also accepted Cambridge University Press' invitation to write a textbook on this topic. Nearly completed the fieldwork phase of a 3-year isotope-hydrology study of Kilauea volcano, Hawaii, helped Hawaii District plan a similar study, and made several successful dye-dilution discharge measurements at the Valley of 10,000 Smokes, Alaska.

\section{REPORTS PUBLISHED 1989-1994:}

Bredehoeft, J.D., and Ingebritsen, S.E., 1990, Degassing of carbon dioxide as a possible source of high pore pressures in the crust, in Bredehoeft, J.D., and Norton, D.L., eds., The role of fluids in crustal processes: Washington, D.C., National Academy Press, p. 158-164.

Forster, C.B., and Ingebritsen, S.E., 1991, How fluids affect volcanoes [meeting report]: EOS Transactions, American Geophysical Union, v. 72, p. 395-396.

Hayba, D.O., and Ingebritsen, S.E., 1994, The computer model HYDROTHERM, a threedimensional finite-difference model to simulate ground-water flow and heat transport in the temperature range of 0 to $1,200^{\circ} \mathrm{C}$ : U.S. Geological Survey Water Resources Investigations Report 94-4045, 85 p.

Hayba, D.O., and Ingebritsen, S.E., in press, Flow near the critical point-Examination of some pressure-enthalpy paths: 19th Workshop on Geothermal Reservoir Engineering, Stanford University.

Ingebritsen, S.E., Christenson, B.W., Forster, C.B., Heiken, G.H., and Manning, C.E., 1993, Fluid-volcano interactions (meeting report): Geological Society of America Today, v. 3, p. 123; Bulletin of Volcanology, v. 


\section{GROUND-WATER HYDROLOGY}

55, p. 542-543; WOVO News, v. 1 , no. 3 , p. 8-9.

Ingebritsen, S.E., Mariner, R.H., and Sherrod, D.R., 1991, Hydrothermal systems of the Cascade Range, north-central Oregon: U.S. Geological Survey Open-File Report 91-69, 217 p. [superceeded by U.S. Geological Survey Professional Paper 1044-L].

Ingebritsen, S.E., Mariner, R.H., and Sherrod, D.R., 1994, Hydrothermal systems of the Cascade Range, north-central Oregon: U.S. Geological Survey Professional Paper 1044-L, 86 p., 2 pls.

Ingebritsen, S.E., and Paulson, K.M., 1990, Numerical simulation of hydrothermal circulation in the Cascade Range, north-central Oregon: Geothermal Resources Council Transactions, v. 14, p. $691-698$.

Ingebritsen, S.E., and Rojstaczer, S.A., 1993, Controls on geyser periodicity: Science, $v$. 262, p. 889-892.

Ingebritsen, S.E., and Scholl, M.A., in press, The hydrogeology of Kilauea volcano: Geothermics, v. 22 , p. $255-270$.

Ingebritsen, S.E., and Scholl, M.A., 1993, Annotated bibliography-Hydrogeology of Kilauea Volcano: U.S. Geological Survey Open-File Report 93-551-D, 30 p.

Ingebritsen, S.E., Scholl, M.A., and Sherrod, D.R., 1993, Heat flow from four new research drill holes in the Western Cascades, Oregon, U.S.A.: Geothermics, v. 22, p. 151-163.

Ingebritsen, S.E., Sherrod, D.R., and Mariner, R.H., 1989, Heat flow and hydrothermal circulation in the Cascade Range, north-central Oregon, in Muffler, L.J.P., Weaver, C.S., and Blackwell, D.D., eds., Proceedings of workshop XLIV-Geological, geophysical, and tectonic setting of the Cascade Range: U.S.
Geological Survey Open-File Report 89-178, p. 122-141.

1989, Heat flow and hydrothermal circulation in the Cascade Range, north-central Oregon: Science, v. 243, p. 1,458-1,462.

1989, Heat flow and hydrothermal circulation in the Cascade Range, north-central Oregon, in Muffler, L.J.P., Weaver, C.S., and Blackwell, D.D., eds., Proceedings of workshop XLIVgeological, geophysical, and tectonic setting of the Cascade Range: U.S. Geological Survey Open-File Report 89-178, p. 122-141.

1992, Rates and patterns of groundwater flow in the Cascade Range volcanic arc, and the effect on subsurface temperatures: Journal of Geophysical Research, v. 97, p. 4,599-4,627.

Manning, C.E., Ingebritsen, S.E., and Bird, D.K., 1993, Missing mineral zones in contact metamorphosed basalts: American Journal of Science, v. 293, p. 894-938.

Paulson, K.M., and Ingebritsen, S.E., 1991, Sodium and chloride data from selected streams in the Lassen area, north-central California, and their relation to thermal-fluid discharge from the Lassen hydrothermal system: U.S. Geological Survey Water-Resources Investigations Report 90-4201, 29 p.

Scholl, M.A., Ingebritsen, S.E., and Essaid, H.I., 1993, Comment on Consequences of phase separation on the distribution of hydrothermal fluids at ASHES vent field, Axial Volcano, Juan de Fuca Ridge, by Christopher G. Fox: Journal of Geophysical Research, v. 98, p. $1,813-1,815$.

Scholl, M.A., Janik, C.J., Ingebritsen, S.E., Kauahikaua, J.P., and Trusdell, F.A., 1993, Preliminary results from an isotope hydrology study of the Kilauea volcano area, Hawaii: Geothermal Resources Council Transactions, v. 17, p. $187-193$. 


\section{GROUND-WATER HYDROLOGY}

TITLE: $\quad$ Analytical Modeling of Flow and Transport in Aquifers and Geothermal Reservoirs (WR 75-127)

PERSONNEL: Allen F. Moench, Project Chief

Vera M. Ayers, Secretary

ADDRESS: U.S. Geological Survey

345 Middlefield Road, MS 496

Menlo Park, CA 94025

TELEPHONE: (415) 329-3322

PROBLEM: Efficient management of ground-water aquifers and geothermal reservoirs requires accurate estimates of the hydraulic properties of water-bearing formations. These are needed to predict water-level changes, aquifer storage capacity, and the rate of movement of chemical species or thermal energy. Analytical models, properly applied, can often be used to estimate the hydraulic and transport properties of complex aquifer systems.

OBJECTIVE: Obtain analytical solutions to specific problems of flow and transport in water-bearing formations that can be used for evaluating the hydraulic and transport properties of aquifers and geothermal reservoirs.

APPROACH: Controlling equations for flow and transport in porous and fractured-rock aquifers are modified, linearized and solved with appropriate boundary conditions. For complex systems, the approach often involves the use of integral transforms and special methods of numerical inversion. Field data are used for case studies.

PROGRESS: (1) A detailed analysis of a pumping test conducted in a sand and gravel aquifer on Cape Cod, Massachusetts, was carried out using a computer program (WTAQ1) developed for generating type curves for flow to a partially penetrating well in a water-table aquifer. (A paper describing the technique used by the computer code was published in the November-December 1993 issue of Ground Water.) Results of the pumping test analysis were presented at the USGS Toxics Technical Meeting, Colorado Springs, Colorado, September 1993 and will be published in the proceedings of the meeting.

(2) In an effort to help resolve an ongoing debate in the literature about the use of type-curve analysis to evaluate the specific yield of water-table aquifers I conducted analyses of several pumping tests published in the literature. The results were presented in two USGS informal 


\section{GROUND-WATER HYDROLOGY}

seminars (Menlo Park and Reston) and at the American Geophysical Union (AGU) Fall Meeting, San Francisco, December 1993. A paper was written on the subject and has been accepted for publication in Ground Water.

(3) An analytical solution was developed that accounts for the delayed release of water (from the zone above the water table) that occurs in the course of pumping tests in unconfined aquifers. The solution provides for an improved match between measured drawdown and theoretical type curves. A paper was written on the subject and has been accepted for publication in Ground Water.

(4) An analysis has been made of a published, multitracer field test conducted in northern France in a densely-fractured chalk aquifer from which water was pumped at a constant rate. The analysis involved a modification of my model for convergent-radial dispersion to account for tracer diffusion into the rock matrix. The analysis provides strong support for the concept of fracture skin in double-porosity aquifers that I had introduced in 1984. A paper on the theory and practice is in preparation.

\section{REPORTS PUBLISHED 1989-1994:}

Moench, A.F., 1989, Convergent radial dispersion-A Laplace transform solution for aquifer tracer testing: Water Resources Research, $v$. 25 , no. 3 , p. $439-447$.

1991, Convergent radial dispersion-A note on evaluation of the Laplace transform solution: Water Resources Research, v. 27, no. 12, p 3,261-3,264.

1993, Computation of type curves for flow to partially penetrating wells in water-table aquifers: Ground Water, v. 31, no. 6, p. 966-971.

Moench, A.F., LeBlanc, D.R., and S.P. Garabedian, in press, Preliminary type-curve analysis of an aquifer test in an unconfined sand and gravel aquifer, Cape Cod, Massachusetts, in Morganwalp, D.W., and Aronson, D.A., eds., U.S. Geological Survey Toxic Substances Hydrology Program-Proceedings of the technical meeting, Colorado Springs, Colo., September
20-24, 1993: U.S. Geological Survey Water-

Resources Investigations Report 94-4014. 


\title{
GROUND-WATER HYDROLOGY
}

TITLE: Water Wells as Strain Meters (WR 75-176)

PERSONNEL: John D. Bredehoeft, Project Chief Nona Myers, Secretary

Francis S. Riley, Hydrologist

Rufus Getzen, Hydrologist

Barbara Bekins, Postdoctoral Associate

Brian McPherson, Student, (University of Utah)

\begin{abstract}
ADDRESS: U.S. Geological Survey
345 Middlefield Road, MS 439

Menlo Park, CA 94025
\end{abstract}

TELEPHONE: (415) 329-4431

PROBLEM: Water wells commonly show earth-tide fluctuations. Often, the magnitude of the tidal fluctuation in a well is 1 to 2 centimeters. This fluctuation is produced by a tidal dilatation, the sum of the normal strains, of approximately $1 \times 10^{-8}$. This indicates that the water well is as sensitive to strains of the crust as is a strain seismometer. The problem with the water well is that other factors such as changes in barometric pressure, ground-water recharge, and pumping also can cause the water level to fluctuate. Use of a well for crustal-strain measurements requires separation of the strain response (the signal) from the other effects (noise). Such separation requires careful experiments in areas where we know the crustal strain.

OBJECTIVE: Use water wells as indicators of crustal strain.

APPROACH: Enhance the network of wells for the express purpose of sensing crustal strains along the San Andreas fault near Parkfield, California, with additional wells and improved instrumentation. Address other hydrologic issues involving deep crustal fluids and microbiological reactions.

PROGRESS: The project is subdivided into three distinct efforts:

1. Fluids deep in the crust: The thrust of this effort is to investigate fluids in the deep sedimentary basin where data are available. We are investigating two basins--The Uinta Basin in Utah, and the Illinois basin.

UINTA BASIN: The Uinta Basin has high pore pressure in the Altamont oil-field that is situated in the deepest part of the basin. This past year we submitted a revised manuscript 


\section{GROUND-WATER HYDROLOGY}

to the American Association of Petroleum Geologists bulletin that explains the Altamont pressure as a result of oil generation from oil shale, deep within the basin.

Our initial analysis is based on assuming a single phase-water.

ILLINOIS BASIN: The Illinois basin is interesting because it contains brines that are five times the concentration of sea water, with approximately the same ratio of ions as sea water. These brines appear to be concentrated sea water, probably emplaced early in the Basin's history. Many of the current hypotheses concerning the accumulation of oil in the basin, as well as the creation of Mississippi Valley type lead and zinc deposits, involve the movement of fluids through the Illinois basin. This movement is incompatible with deep brines--at least in our view.

2. Tectonic strain monitoring:

PARKFIELD: Francis Riley is spending much of his time keeping our Parkfield water-well network operating. We continue to record interesting tectonic signals that are associated with creep on the San Andreas fault.

3. The role of microbiology in controlling organic contaminant reactions: The evidence is clear that many, if not most, organic contaminants are degraded chemically by reactions that are microbiologically controlled. These reactions need to be included in our basic transport models. Modeling these reactions using a transport framework provides insights into the processes involved. Barbara Bekins continues this research. Barbara and Mike Godsey investigated a plume of creosote contamination at Pensacola, Florida.

REPORTS PUBLISHED 1989-1994:

Avon, L., and Bredehoeft, J.D., 1989, an analysis of trichloroethylene movement in ground water at Castle Air Force Base, California: Journal of Hydrology, 110, p. 23-50.

Bekins, B.A., Godsy, E.M., and Goerlitz, D.F., in press, Steady-state methogenic degradation of phenols in groundwater: Journal of Contaminant Hydrology, v. 14.

Belitz, K., and Bredehoeft, J.D., 1990, Role of confining layers in controlling large-scale re- gional ground water flow, in Neuman S.P. and Neretnieks I., eds., Hydrology of Low Permeability Environments: International Association of Hydrogeologists, Hanover, Germany, Verlag Heinz Heise Publisher, v. 2, p. 7-18.

Bredehoeft, J.D., 1990, Microcomputer codes for simulating transient ground water flow in two and three space dimensions: U.S. Geological Survey Open-File Report 90-559, 106 p. 


\section{GROUND-WATER HYDROLOGY}

1991, Microcomputer codes for simulating transient ground-water flow in two and three space dimensions (JDB2D/3D): International Ground Water Modeling Center-Groundwater modeling software, Colorado School of Mines, Golden, Colo., IGWMC-FOS 50, 110 p.

1992, Response of the ground-water system at Yucca Mountain to an earthquake (Appendix D), in Raleigh, C.B., and Thompson, G.A., chairs, Ground water at Yucca Mountain-How high can it rise?: NRC Panel on Coupled Hydrologic/Tectonic/Hydrothermal Systems at Yucca Mountain, Washington, D.C., National Academy Press, p. 212-222.

1993, Hazardous waste remediation-A 21st century issue: Forum for Applied Research and Public Policy, University of Tennessee, Energy, Environment and Resource Center Publication, Spring 1993, p. 135-139.

1993, Hazardous waste remediation-a XXIst century problem: Mineral Resources of Russia, Moscow, Russia, no. 5, p. 22-26 [pt. 1] and no. 6 , p. 22-28 [pt. 2].

1993, Hazardous waste remediation-a 21st century problem: Ground Water Monitoring and Remediation, v. 14 , p. 95-100.

Bredehoeft, J.D., Belitz, K., and Sharp-Hansen, S., 1992, The hydrodynamics of the Big Horn Basin-A study in the role of faults: American Association of Petroleum Geologists Bulletin, v. 76, p. $530-546$.

Bredehoeft, J.D., and Ingebritsen, S.E., 1990, Degassing of carbon dioxide as a possible source of high pore pressure in the crust, in The Role of Fluids in Crustal Processes, NRC Study in Geophysics: NAS Press, p. 158-164.
Bredehoeft, J.D., and Norton, D.L., eds., 1990, The role of fluids in crustal processes: National Research Council Study in Geophysics, National Academy Press, Washington, D.C., $170 \mathrm{p}$.

1990, Mass and energy transport in a deforming earth's crust, in The Role of Fluids in Crustal Processes, NRC Study in Geophysics: NAS Press, p. 27-41.

Bredehoeft, J.D., Reichard, E.G., and Gorelick, S.M., in press, If it works, don't fix it-benefits from regional ground water management, in A. El-Kadi ed., Proceedings 1994 Pacific Oceania Conference on Assessment of Models for Groundwater Resources Analysis and Management: Lewis Publishing Co.

Bredehoeft, J.D., Wesley, J.B., and Fouch, T.D., 1994, Simulations of the origin of fluid pressure, fracture generation, and the movement of fluids in the Uinta Basin, Utah: American Association of Petroleum Geologists Bulletin, v. 00 .

Crowley, K.D., McPherson, B.J., and Cameron, M., in press, Experimental studies of annealing of etchable Uranium-fission damage in Durango apatite: Geochemica et Cosmo Chemica Acta, v. 00.

Konikow, L.F., and Bredehoeft, J.D., 1992, Groundwater models cannot be validated, in Celia, M.A., Gray, W.G., and Hassanizadeh, S.M., eds., Validation of Geo-hydrologic Models: Advances in Water Resources, special issue, Elsevier, v. 15, pt. 1, p. 63-83.

McPherson, B.J., and Chapman, D., in press, Thermal analysis of the southern Powder River basin Wyoming: Geophysics, v. 00. 


\section{GROUND-WATER HYDROLOGY}

Riley, F.S., 1989, The Parkfield earthquake prediction experiment: Sensors, December 1989, p. 13-16.

Roeloffs, E., Shulz-Burford, S., Riley, F.S., and Records, A.W., 1989, Hydrologic effects on water level changes associated with episodic creep near Parkfield, California: Journal of Geophysical Research, v. 94, p. 12,38712,402 .

Vartanyan, G.S., Bredehoeft, J.D., and Roeloffs, E., 1991, Hydrogeologic methods of investigating tectonic stresses: Moscow, Russia, Soviet Geology, v. 9/1991, p. 3-2.

1993, Hydrogeological prediction of earthquakes: Nature, Moscow, Russia, no. 11, p. 57-64. 


\title{
GROUND-WATER HYDROLOGY
}

TITLE: $\quad$ Ground-water Monitoring Network Design (WR 82-178)

\author{
PERSONNEL: Brian J. Wagner, Project Chief \\ Maria M. Watts, Secretary \\ ADDRESS: U.S. Geological Survey \\ 345 Middlefield Road, MS 421 \\ Menlo Park, CA 94025
}

TELEPHONE: (415) 329-4567

PROBLEM: There are a variety of ground-water resource and contamination problems that involve determining the state of ground water and detecting or predicting changes in the ground-water environment. Most approaches to ground-water monitoring network design avoid a rigorous formulation of the monitoring objectives and fail to consider the important processes controlling the movement of ground water and migration of ground-water contaminants. It is unlikely that such approaches to network design will be able to effectively and efficiently monitor the subsurface environment in the face of limited resources.

OBJECTIVE: This research aims to develop statistically sound and simulation-based methods for ground-water monitoring network design. The goal is to develop techniques that unify stochastic ground-water flow and contaminant transport simulation with optimization for studying ground-water monitoring options, and to explore the capabilities and limitations of various network design methods.

APPROACH: Techniques for monitoring network design will be developed using three basic classes of tools-statistically based methods for parameter estimation, stochastic aquifer simulation techniques, and optimization methods. The general approach will be to combine the parameter estimation and stochastic simulation components with techniques from mathematics and statistics to develop statistically sound and simulation-based optimal monitoring network design models amenable to a wide range of monitoring objectives.

PROGRESS: Developed a groundwater monitoring network design model that couples stochastic ground-water simulation with a genetic optimization algorithm.

Codeveloped new Water Resources Division training course on ground-water optimization (offered July 11-15, 1994). 


\section{GROUND-WATER HYDROLOGY}

Developed a simulation and statistics based methodology for analyzing data worth and designing stream tracer experiments.

Developed a simulation-optimization ground-water management model to identify pumping strategies for controlling the shallow, saline water table in the western San Joaquin Valley, California.

\section{REPORTS PUBLISHED 1989-1994:}

Barlow, P.M., Wagner, B.J., Belitz, K., and Fio, J.L., 1993, Effects of management alternatives on the shallow, saline groundwater in the western San Joaquin Valley, California: Water Fact Sheet, U.S. Geological Survey Open-File Report 93-665.

Harvey, J.W., Fuller, C.C., and Wagner, B.J., in press, Interactions between shallow ground water and surface water that affect metal contaminant transport in Pinal Creek Basin, Arizona, in Morganwalp, D.W., and Aronson, D.A., eds., U.S. Geological Survey Toxic Substances Hydrology Program-Proceedings of the technical meeting, Colorado Springs, Colo., September 20-24, 1993: U.S. Geological Survey Water-Resources Investigations Report 94-4014.

Wagner, B.J., 1992, Simultaneous parameter estimation and contaminant source characterization for coupled ground-water flow and contaminant transport modelling: Journal of Hydrology, v. 135, p. 275-303.

Wagner, B.J., and Harvey, J.W., in press, Solute transport parameter estimation for an injection experiment at Pinal Creek, Arizona, in Morganwalp, D.W., and Aronson, D.A., eds., U.S. Geological Survey Toxic Substances Hydrology Program-Proceedings of the technical meeting, Colorado Springs, Colo., September
20-24, 1993: U.S. Geological Survey WaterResources Investigations Report 94-4014. 


\section{GROUND-WATER HYDROLOGY}

TITLE: $\quad$ Nonisothermal Multiphase Flow (WR 82-179)

PERSONNEL: William N. Herkelrath, Project Chief

Vera M. Ayers, Secretary

Clyde F. O'Neal, Hydrologist

Fred Murphy, Hydrologist

ADDRESS: $\quad$ U.S. Geological Survey

345 Middlefield Road, MS 496

Menlo Park, CA 94025

TELEPHONE: (415) 329-3314

PROBLEM: Understanding multiphase fluid flow in the subsurface is of increasing importance. Large volumes of organic liquids that are not miscible with water (such as gasoline) are being introduced into ground-water systems from leaking storage tanks. Such fluids have become a major source of ground-water contamination. Understanding how immiscible fluids move in the ground, and how they interact with the sediment, the soil gas, and the ground water, is vital to protecting the nation's water supply. Information on 3-phase flow is available in the petroleum engineering literature, but much of this work is not applicable because capillary pressure effects, which are important in small-scale, near-surface ground-water systems, have generally been ignored.

OBJECTIVE: The objective of the project is to determine the adequacy of the present limited description of the mechanisms of multiphase and immiscible flow in porous media, and to develop more general and realistic fluid-flow models that will be useful in analyzing real field situations. Carry out a program of experimentation designed to test theories of multiphase flow in porous media. Develop methodologies required to measure relevant parameters both at the laboratory scale and the field scale. Develop quantitative descriptions of the flow phenomena in terms of differential equations, and seek solutions by analytical and numerical means.

APPROACH: The basic approach is to use results of computer-modeling studies and field observations to identify important problems for study. Hypotheses are developed from the existing mathematical models of multiphase flow, and experiments are designed to test the hypotheses. Tests are then run in the laboratory where all the important variables can be controlled or measured. If the tests are inconsistent with theory, new theoretical descriptions are developed. Measurements of liquid saturations and fluid pressures involve methods 


\section{GROUND-WATER HYDROLOGY}

developed by soil physicists and petroleum engineers. Limited field experiments are performed in order to test the applicability of methodology developed in theoretical and laboratory studies.

PROGRESS: W.N. Herkelrath, in collaboration with H.I. Essaid, carried out laboratory and field investigations of multiphase, immiscible flow of fluids in sediments. As part of an effort to gain insight into the processes controlling the movement of immiscible contaminants (such as crude oil or jet fuel) in the field, we continued development of techniques for determining the spatial distribution of water, air, and immiscible liquid saturation within a polluted ground-water system. Our approach has been to obtain sediment cores from the field with fluids intact, and then analyze the core in the laboratory to determine fluid saturations. We developed a new cryogenic sampler designed to obtain undisturbed sediment cores. In this sampler, the bottom end of the core is frozen downhole by piping liquid carbon dioxide into an expansion chamber built into the outer wall of the drive shoe of a piston corer. Once the end of the core is frozen, the core is retrieved without loss of sediment or redistribution of liquids. The method was tested with great success at the Bemidji, Minnesota, oil-spill site. We used the core barrel in order to obtain a 3-dimensional grid of oil, air and water saturation measurements within the oil-spill zone. The freezing sampler was also used by Water Resources Division biologists and geochemists working at the Bemidji site in order to obtain detailed distributions of chemical and biological variables within the contaminated ground-water zone. Our fluid-saturation data were used to test a cross-sectional, multiphase numerical flow model. Results suggest that the amount of oil trapped in the unsaturated zone at the Bemidji site is much higher than predicted by standard models. A modified relative permeability relation that improves model predictions was developed. We also investigated fundamental aspects of multiphase immiscible flow in porous media in laboratory experiments. We discovered heretofore unreported coupling between liquid and vapor flow in porous media containing water, air, and organic liquid.

\section{REPORTS PUBLISHED 1989-1994:}

Dillard, L.A., Essaid, H.I., and Herkelrath, W.N., in press, Multiphase flow modeling at the Bemidji, Minnesota, crude-oil spill site using geostatistical simulation of soil hydraulic properties, in Morganwalp, D.W., and Aronson, D.A., eds., U.S. Geological Survey Toxic Substances Hydrology Program-Proceedings of the technical meeting, Colorado Springs, Colo., September 20-24, 1993: U.S. Geologi- cal Survey Water-Resources Investigations Report 94-4014.

Essaid, H.I., Herkelrath, W.N., and Dillard, L.A., 1994, Field and modeling studies of multiphase fluid flow at the Bemidji, Minnesota, crude-oil spill site, in Dutton, A.R., ed., Toxic Substances and the Hydrologic Sciences: 


\section{GROUND-WATER HYDROLOGY}

American Institute of Hydrology, April 10-13, 1994, Austin, Texas, [Proceedings], p. 52-68.

Essaid, H.E., Herkelrath, W.N., and Hess, K.M., 1991, Air, oil, and water distributions at a crude-oil spill site, Bemidji, Minnesota, in Mallard, G.E., and Aronson, D.A., eds., U.S. Geological Survey Toxics Substances Hydrology Program-Proceedings of the technical meeting, Monterey, Calif., March 11-15, 1991: U.S. Geological Survey WaterResources Investigations Report 91-4034, p. 614-620.

Essaid, H.E., Herkelrath, W.N., and Hess, K.M., 1993, Simulation of fluid distributions observed at a crude oil spill site incorporating hysteresis, oil entrapment, and spatial variability of hydraulic properties: Water Resources Research, v. 29, no. 6, p. 1753-1770.

Herkelrath, W.N., Essaid, H.I., and Dillard, L.A., 1994, Multiphase fluid distributions in a shallow water-table aquifer contaminated by crude oil, in Dracos, T.H., and Stauffer, F., eds., Transport and Reactive Processes in Aquifers, Proceedings of the IAHR/AIRH Symposium, Zurich, Switz., April 11-15, 1994: Rotterdam, Netherlands, A.A. Balkema, p. 537-542.

Herkelrath, W.N., Essaid, H.I., and Hess, K.M., 1991, Field and modeling studies of immiscible fluid flow above a contaminated watertable aquifer: International Hydrology and Water Resources Symposium, Perth, Australia, 1991, v. 2, p. 424-428.

Herkelrath, W.N., Hamburg, S.P., and Murphy, Fred, 1991, Automatic, real-time monitoring of soil moisture in a remote field area with time-domain reflectometry: Water Resources Research, v. 27, no. 5, p. 857-864.
Hess, K.M., Herkelrath, W.N., and Essaid, H.E., 1992, Determination of subsurface fluid contents at a crude-oil spill site: Journal of Contaminant Hydrology, v. 10, p. 75-96.

Murphy, F., and Herkelrath, W.N., in press, A sample-freezing drive shoe for a wireline piston core sampler, in Morganwalp, D.W., and Aronson, D.A., eds., U.S. Geological Survey Toxic Substances Hydrology Program-Proceedings of the technical meeting, Colorado Springs, Colo., September 20-24, 1993: U.S. Geological Survey Water-Resources Investigations Report 94-4014. 


\section{GROUND-WATER HYDROLOGY}

TITLE: $\quad$ Theories of Water Flow and of Solute Transport in the Unsaturated Zone (WR 82-180)

PERSONNEL: Jacob Rubin, Project Chief

Kim N. Bui, Secretary

Gary P. Curtis, Environmental Engineer

ADDRESS: $\quad$ U.S. Geological Survey

345 Middlefield Road, MS 421

Menlo Park, CA 94025

TELEPHONE: (415) 329-4523

PROBLEM: The unsaturated zone has a significant influence on the quantity and quality of water resources. Current theoretical methods of evaluating and predicting this influence for a particular set of field conditions cannot adequately account for the complexity of the processes involved and for interactions among them. It is necessary to improve the current theoretical approaches to water-flow and solute-transport problems of unsaturated-zone hydrology to achieve such an accounting.

OBJECTIVE: Determine which conditions are or are not essential to realistically refining the commonly used mathematical models for unsaturated flow. Combine water-flow and water-mixing models with models for chemical reactions and biological processes by use of submodels that are rigorous and appropriate to analyses of solute transport in the unsaturated zone. Explore situations of hydrologic interest and those that may be valuable in connection with model validation or parameter determination for both water-flow and solute-transport processes. Test experimentally the theoretical conclusions reached in cooperation with other projects.

APPROACH: Consider model refinements for unsaturated flow that would account for effects of parameter hysteresis, air trapping, pore-geometry transformations and medium heterogeneity. Determine the conditions under which such refinements are essential. Develop computer-aided theoretical analyses of the interactions between unsaturated-zone waters and ground or surface waters. Attempt to integrate, for solute transport, the hydrodynamic-dispersion approach to transport with the chemist's or ecologist's approaches to chemical equilibria, chemical kinetics, and population ecology. Modify the above standard approaches to treat realistically the special conditions characterizing natural unsaturated zones, such as the presence of two fluid phases, changes in water content, wide range of soil-water 


\section{( \\ GROUND-WATER HYDROLOGY}

fluxes, and chemical heterogeneity of the porous medium. Use or adapt existing mathematical methods, especially numerical methods, and develop new mathematical methods if necessary.

PROGRESS: Studied structural features of reaction systems which play a decisive role in determining equilibrium feasibility. Analyzed feasibility in batch and transport systems of ionic reactions with at most binary compounds. Proved that in such systems, the absence of ion-sharing based cycles of reacting solids is a necessary and a sufficient condition for solvability of problems which involve chemical equilibria. An analogous study for systems with at most ternary compounds is in progress.

Completed implemention and testing of a solute transport model based on the Feed-Forward method. Transport studied is one-dimensional, local equilibrium-controlled, multicomponent. The model can accommodate a broad variety of reaction-types. Before testing, model's applicability was further extended, for example, by enabling it to treat: (1) multiple dissolution and precipitation boundaries; (2) surface reactions with more than one kind of surface-reaction sites; (3) extremely high values of some of the equilibrium-constants. The model testing was successful. It yielded, for example, (1) for a simple transport system (interacting reactions, no moving boundary), a very good agreement with the analytical solution; (2) for a more complex case (seven reactions, one moving boundary) a good agreement with results obtained with different operational equations and a different numerical method; (3) one of the complex cases effectively modeled (16 reactions with moving boundaries) was based on a published field study of ground-water chemistry evolution. The largest system studied consisted of 32 interacting reactions.

Collaboration with another project (fluoride/uranium transport interaction) made it possible for the new model to help significantly in interpreting experimental results.

\section{REPORTS PUBLISHED 1989-1994:}

Bahr, J.M., 1990, Kinetically influenced terms for solute transport affected by heterogeneous and homogeneous classical reactions: Water Resources Research, v. 26, no. 1, p. 21-34.

Ball, W. P., Curtis, G. P., and Roberts, P. V., in press, Physical and Chemical Processes affecting the subsurface fate and transport of synthetic organic chemicals, in Ward, C.H., ed.,
Ground Water Quality: New York, J. Wiley and Sons.

Curtis, G.P., and Reinhard, M.R., in press, Reductive Dehalogenation of Hexachloroethane, Carbon Tetrachloride and Bromoform by Anthrahydroquinone Disulfonate and Humic Acid: Environmental Science and Technology, v. 00. 


\section{GROUND-WATER HYDROLOGY}

Friedly, J.C., 1991, Extent of reaction in open systems with multiple heterogeneous reaction: American Institute of Chemical Engineering, v. 37, p. 687-693.

Friedly, J.C., and Rubin, J., 1992, Solute transport with multiple, equilibrium or kinetically controlled, chemical reactions: Water Resources Research, v. 28, no. 7, p. 1935-1953.

Rubin, J., 1990, Solute transport with multisegment, equilibrium-controlled reactions: a feedforward simulation method: Water Resources Research, v. 26, no. 9, p. 2029-2055.

1992, Solute transport with multisegment, equilibrium-controlled, classical reactions: problem solvability and Feed-Forward Method's applicability for complex segments of at most binary participants: Water Resources Research, v. 28, no. 6, p. 1681-1702.

Stonestrom, D.A., and Rubin, J., 1989, Water-content dependence of trapped air in two soils: Water Resources Research, v. 25, no. 9, p. 1947-1958.

1989, Air permeability and trapped-air content in two soils: Water Resources Research, v. 25, no. 9, p. 1959-1969. 


\section{GROUND-WATER HYDROLOGY}

TITLE: $\quad$ Hydrology of Fractured Rocks (WR 83-184)

PERSONNEL: Paul A. Hsieh, Project Chief

Nona Myers, Secretary

Claire Tiedeman, Hydrologist

ADDRESS: U.S. Geological Survey

345 Middlefield Road, MS 496

Menlo Park, CA 94025

TELEPHONE: (415) 354-3324

PROBLEM: Fractures often serve as major conduits for movement of water and dissolved chemicals through hard rocks in the underground. Understanding fluid flow and mass transport in fractured rocks is essential for assessing the ground-water resources of hard-rock aquifers, investigating the suitability of underground sites for hazardous waste disposal, and predicting the movement of hazardous chemicals if contamination occurs. Existing theory of fluid flow through porous media is of limited usefulness when applied to fractured rocks. The low permeability and highly heterogeneous nature of fractured rocks require extension of current theory and field methods. It is particularly important that theoretical developments be applicable on a scale commensurate with field measurements.

OBJECTIVE: (1) Develop theoretical model of fluid flow and solute transport in fractured rocks with particular emphasis on characterizing the effects of heterogeneities on different scales. (2) Develop field methods (hydraulic and tracer tests) to characterize the flow and transport properties of fractured rocks. (3) Combine the use of geological, geophysical, and geochemical methods with hydraulic and tracer tests to develop an integrated approach to modeling flow and transport in fractured rocks.

APPROACH: (1) Compare different approaches (equivalent porous media, discrete fracture, stochastic continuum) to modeling flow and transport in fractured rocks by analytical methods and computer simulation. (2) Construct mathematical model of hydraulic and tracer tests in heterogeneous fractured rocks, and apply parameter-estimation techniques to analyze test results with emphasis on detecting heterogeneous features such as a highly-permeable fracture zone. (3) Establish a field site for testing theoretical and method developments, for cooperative work with other research projects with expertise in geological, geophysical and geochemical studies, and to synthesize knowledge obtained from different studies through modeling flow and transport at the field site. 


\section{GROUND-WATER HYDROLOGY}

PROGRESS: (1) Analysis of field data collected at the Mirror Lake site, New Hampshire, during 1991-1993 has lead to two conclusions. First, it is demonstrated that a combination of geophysical logging and hydraulic testing at the "FSE" well field can yield a coherent understanding of fluid flow paths in the bedrock. Based on this understanding, a computer model of the well field was constructed, and the model was used to successfully analyze cross-hole hydraulic tests at the well field. This finding was reported at the American Geophysical Union (AGU) spring meeting in Baltimore, Md., in May 1994.

A second conclusion was obtained by comparing hydraulic conductivities of bedrock determined by three different techniques at three different scales: single-well hydraulic tests on a scale of several meters, cross-hole hydraulic tests on 100-meter scale, and calibration of a ground-water flow model of the Mirror Lake area on a scale of several kilometers. Results show that at the meter scale, hydraulic conductivities vary over many orders of magnitude, and it is not apparent whether the higher or lower conductivity fractures control flow on a larger scale. However, larger scale measurements suggest that the highly conductive fractures do not extend over large distances, and it is the less conductive fracture network that controls fluid flow on the kilometer scale at the Mirror Lake site. This finding was reported at an AGU Chapman Conference in June 1994.

(2) A manuscript has been completed that describes a new method for analyzing steady-state pumping test data to determine the location of a highly permeable fracture zone in an aquifer. This manuscript has been accepted for publication in Water Resources Research.

REPORTS PUBLISHED 1989-1994:

Barton, C.C., and Hsieh, P.A., 1989, Physical and hydrologic-flow properties of fractures-Field trip guidebook T385, 28th International Geologic Congress: American Geophysical Union, Washington, D.C., 36 p.

Christian, S.B., 1992, Well test analysis in a twozone aquifer using the boundary integral method: Stanford University, Stanford, Calif., Masters thesis.

Goode, D.J., 1992, Modeling transport in transient ground-water flow-An unacknowledged approximation: Ground Water, v. 30, no.2, p. 257-261.
Goode, D.J., and Appel, C.A., 1993, Finite-difference interblock transmissivity for unconfined aquifers and for aquifers having smoothly varying transmissivity: U.S. Geological Survey Water-Resources Investigations Report 92 $4124,79 \mathrm{p}$.

Goode, D.J., Hsieh, P.A., Shapiro, A.M., Wood, W.W., and Kraemer, T.F., 1993, Concentration history during pumping from a leaky aquifer with stratified initial concentration, in Shen, H.W., ed., Hydraulic Engineering: American Society of Civil Engineers, National Hydraulics Division Conference, San Francis- 


\section{GROUND-WATER HYDROLOGY}

co, Calif., July 25-30, 1993 [Proceedings], v. 1, p. 29-35.

Hsieh, P.A., 1993, Some experience gained from using packers and transducers in ground-water investigations of crystalline-rock aquifers, in Latkovich, V.J., ed., Proceedings of a pressure transducer-packer workshop, June 25-28, 1991: U.S. Geological Survey Open-File Report 93-71, p. 5-7.

Hsieh, P.A., and Freckleton, J.R., 1993, Documentation of a computer program to simulate horizontal-flow barriers using the Modular Three-Dimensional Finite-Difference GroundWater Flow Model: U.S. Geological Survey Open-File Report 92-477, 59 p.

Hsieh, P.A., Perkins, R.L., and Rosenberry, D.O., in press, Field instrumentation for multilevel monitoring of hydraulic head in fractured bedrock at the Mirror Lake site, Grafton County, New Hampshire, in Morganwalp, D.W., and Aronson, D.A., eds., U.S. Geological Survey Toxic Substances Hydrology Program-Proceedings of the technical meeting, Colorado Springs, Colo., September 20-24, 1993: U.S. Geological Survey Water-Resources Investigations Report 94-4014.

Hsieh, P.A., and Shapiro, A.M, in press, Hydraulic characteristics of fractured bedrock underlying the FSE well field at the Mirror Lake site, Grafton County, New Hampshire, in Morganwalp, D.W., and Aronson, D.A., eds., U.S. Geological Survey Toxic Substances Hydrology Program-Proceedings of the technical meeting, Colorado Springs, Colo., September 20-24, 1993: U.S. Geological Survey WaterResources Investigations Report 94-4014.

Hsieh, P.A., Shapiro, A.M., Barton, C.C., Haeni, F.P., Johnson, C.D., Martin, C.W., Paillet, F.L., Winter, T.C., and Wright, D.L., 1993,
Methods of characterizing fluid movement and chemical transport in fractured rock, in Cheney, J.T., and Hepburn, J.C., eds., Field trip guidebook for the northeastern United States: Boston, Geological Society of America, v. 2, p. R1-R30.

Kaehler, C.A., and Hsieh, P.A., 1994, Hydraulic properties of a fractured-rock aquifer, Lee Valley, San Diego County, California: U.S. Geological Survey Water-Supply Paper 2394, $64 \mathrm{p}$.

Ritzi, R.W., Jr., Sorooshian, S., and Hsieh, P.A., 1991, The estimation of fluid flow properties from the response of water levels in wells to the combined atmospheric and earth tide forces: Water Resources Research, v. 27, no. 5, p. 883-893.

Shapiro, A.M., and Hsieh, P.A., 1991, Research in fractured-rock hydrogeology-Characterizing fluid movement and chemical transport in fractured rock at the Mirror Lake drainage basin, New Hampshire, in Mallard, G.E., and Aronson, D.A., eds., U.S. Geological Survey Toxic Substances Hydrology Program-Proceedings of the technical meeting, Monterey, Calif., March 11-15, 1991: U.S. Geological Survey Water-Resources Investigations Report 91-4034, p. 155-161.

in press, Overview of research on use of hydrologic, geophysical and geochemical methods to characterize flow and chemical transport in fractured rock at the Mirror Lake site, New Hampshire, in Morganwalp, D.W., and Aronson, D.A., eds., U.S. Geological Survey Toxic Substances Hydrology Program-Proceedings of the Technical Meeting, Colorado Springs, Colo., Sept. 20-24, 1993: U.S. Geological Survey Water-Resources Investigations Report 94-4014. 


\section{GROUND-WATER HYDROLOGY}

in press, A new method of performing controlled injection of traced fluid in fractured crystalline rock, in Morganwalp, D.W., and Aronson, D.A., eds., U.S. Geological Survey Toxic Substances Hydrology Program-Proceedings of the technical meeting, Colorado Springs, Colo., September 20-24, 1993: U.S. Geological Survey Water-Resources Investigations Report 94-4014.

Wood, W.,W., Shapiro, A.M., and Hsieh, P.A., in press, Observational, experimental and inferred evidence for solute diffusion in fractured granite aquifers-Examples from the Mirror Lake watershed, Grafton County, New Hampshire, in Morganwalp, D.W., and Aronson, D.A., eds., U.S. Geological Survey Toxic Substances Hydrology Program-Proceedings of the technical meeting, Colorado Springs, Colo., September 20-24, 1993: U.S. Geological Survey Water-Resources Investigations Report 94-4014.

Wright, D.L., Olhoeft, G.R., Hsieh, P.A., Majer, E.L., Paillet, F.L., and Lane, J.W., Jr., in press, Electromagnetic and seismic tomography compared to borehole acoustic televiewer and flowmeter logs for subsurface fracture mapping at the Mirror Lake site, New Hampshire, in Morganwalp, D.W., and Aronson, D.A., eds., U.S. Geological Survey Toxic Substances Hydrology Program-Proceedings of the technical meeting, Colorado Springs, Colo., September 20-24, 1993: U.S. Geological Survey Water-Resources Investigations Report 94-4014. 


\section{GROUND-WATER HYDROLOGY}

TITLE: $\quad$ Temperature Effects in the Unsaturated Zone (WR 87-193)

PERSONNEL: James E. Constantz, Project Chief

Vera M. Ayres, Secretary

Timothy R. Green, Civil Engineer

ADDRESS: U.S. Geological Survey

345 Middlefield Road, MS 496

Menlo Park, CA 94025

TELEPHONE: (415) 329-3325

PROBLEM: Transport in the unsaturated zone is strongly dependent upon temperature. However, there is a lack of quantitative information concerning the influence of temperature upon water retention characteristics, unsaturated hydraulic conductivity values, and water fluxes in natural porous materials. When compared to experimental results, existing theories underestimate the magnitude of temperature-induced changes in many pore-water and interfacial properties. Consequently, models incorporating the effects of temperature upon water retention and transport in the unsaturated zone are inadequate.

OBJECTIVE: (1) Measure the influence of temperature upon water retention characteristics, unsaturated hydraulic conductivity, and coefficients derived from these primary parameters, such as water diffusivities and capacities; (2) ascertain whether the behavior of water in close proximity to mineral surfaces is altered sufficiently to result in modified temperature coefficients for gas solubilities, adsorption, viscosity, interfacial surface tensions and contact angles, and other properties important to transport in porous materials; and (3) examine the influence of temperature on primary hydrologic processes in the unsaturated zone, such as infiltration, moisture redistribution, evaporation, and drainage.

APPROACH: Perform laboratory experiments on field cores and repacked samples to measure the temperature dependence of water-retention characteristics and unsaturated hydraulic conductivities in natural porous materials. Examine relations between matric potential, volumetric water content, and temperature in these materials by use of experimental equipment and procedures that have been modified for high temperature. Perform field experiments to determine the influence of temperature on water retention and transport.

PROGRESS: Three research efforts were completed over the last year. The first examined the effect of the rate of approach to hydraulic equilibrium on the static water content of rigid, 


\section{GROUND-WATER HYDROLOGY}

porous materials. This research was performed on laboratory columns of various sands, soils, and consolidated porous materials. Analysis of results indicated that the rate of drainage effected pore-water retention in such a manner, that the more rapid the drainage rate the less pore water was retained at hydraulic equilibrium. Results suggest that this rate-dependent behavior during water retention may contribute to an enhanced temperature dependence of water retention, due to higher rates of drainage at higher temperatures. The second examined the effect of stratigraphic layering on water retention in laboratory columns. Analysis of results indicates that a volume averaging of the water retention characteristics of individual layers successfully predicts the water retention characteristics of a multilayered column. The third examined the effects of daily stream temperature variations on stream-flow loss and ground-water recharge. Two week field experiments were run at Tijeras Arroyo, New Mexico, and St. Kevin Gulch, Colorado, to accurately measure stream and soil temperatures, stream discharge, and ground-water recharge rates. Analysis of results demonstrated that daily variations in stream temperature resulted in variations in recharge of 25 percent between sunrise and early afternoon at both sites. Using measurements of evapotranspiration (ET), we were able to demonstrated that ET was responsible for less than 5 percent of the daily variation in stream-flow loss at these sites.

\section{REPORTS PUBLISHED 1989-1994:}

Constantz, J., 1991, Comparison of isothermal and isobaric water retention paths in nonswelling porous materials: Water Resources Research, v. 27, p. $3165-3170$.

1993, Confirmation of rate-dependent behavior in water retention during drainage in nonswelling porous materials: Water Resources Research, v. 29, 1331-1334.

in press, Determination of water retention in stratified porous materials: Transportion in Porous Media, v. 15(1).

Constantz, J., and Murphy, F., 1990, Monitoring moisture storage in trees using time-domain reflectometry: Journal of Hydrology, v. 119, p.31-42.
1991, The temperature dependence of ponded infiltration under isothermal conditions: Journal of Hydrology, v. 122, p. 119-128.

Constantz, J., Thomas, C.L., Zellweger, G., in press, Influence of daily stream-temperature variations streamflow and groundwater recharge: Water Resources Research, v. 30(10).

Green, T.R., Green, R.E., and Miller, M.E., 1993, Impacts of heterogeneity on simulated water flow in Hawaiian basaltic saprolite: relations to recharge, in Dagan G., and Russo, D., eds., Water Flow and Solute Transport in Soils: Advanced Agricultural Science, v. 20, p. 233-246. 


\section{GROUND-WATER HYDROLOGY}

TITLE: Physical Characteristics that Determine Flow in the Unsaturated Zone (WR 89-198)

PERSONNEL: John R. Nimmo, Project Chief

Kim Bui, Secretary

Stephanie M. Shakofsky, student (San Jose State University)

ADDRESS: $\quad$ U.S. Geological Survey

345 Middlefield Road, MS 421

Menlo Park, CA 94025

TELEPHONE: (415) 329-4537

PROBLEM: Flow in the unsaturated zone profoundly influences the degradation of water quality as well as the loss and replenishment of available water resources. Unsaturated-zone physical characteristics, such as hydraulic conductivity and water retention, are essential to the determination of water and solute fluxes into ground water and to the understanding of surface-subsurface interactions. The theory describing these unsaturated-zone influences has not been adequately tested and may, in fact, be invalid for certain important cases. Limitations of present laboratory and field techniques are a major hindrance to large-scale hydrological application of unsaturated-flow theory because critical physical characteristics cannot be measured with the required speed and accuracy.

OBJECTIVE: (1) Test the validity of existing theories related to unsaturated-zone fluxes and correct or extend them, where necessary, to develop fast, accurate, practical methods for measuring unsaturated-zone fluxes and the physical characteristics that determine them; (2) apply and promote routine use of these experimental and theoretical methods in hydrological studies where the unsaturated zone plays an important role; (3) assess the importance of complicating influences (temperature gradients, dispersion, hysteresis, and so forth.) on water and solute fluxes.

APPROACH: By inventing new devices, applying newly discovered principles, and adapting technology from related and unrelated fields, develop techniques for measuring unsaturated-zone fluxes and the porous-media characteristics essential to their understanding. Integrate field, theoretical, and laboratory methods into a practical system for solving a variety of specific hydrological problems. Apply this system both to water-resource issues and to fundamental problems of unsaturated flow. Use newly developed experimental 


\section{GROUND-WATER HYDROLOGY}

methods, alone or in combination with others, to test theory. Where necessary or desirable, derive new theory from basic physical principles.

PROGRESS: (1) Established an operating field monitoring station at a hazardous waste site at the Idaho National Engineering Laboratory (INEL). Took resposibility for a previously used station and restored instrumentation for measuring soil and atmospheric conditions. Developed remote-communication system to operate the station from Menlo Park. Installed instrumentation for measurements during infiltration tests.

(2) Produced unsaturated hydraulic conductivity measurements to complement our moisture-retention measurements on soil core samples from the vicinity of the waste site at the INEL. The results suggest a distinct alteration of pore-size distributions and confirm that the most pronounced difference in hydraulic properties between undisturbed soil and a simulated landfill is a greater degree of layering in the undisturbed soil. This suggests that unless preferential flow under wet conditions dominates the flow regime, the main effect of creating the landfill is to destroy some of the flow-impeding properties of the layered natural medium.

(3) Using two high-quality core samples from a site in southeastern Washington, measured unsaturated hydraulic conductivity with the steady state centrifuge method (SSCM) to accurately obtain aquifer recharge rates. Preliminary results show consistency with previous measurements.

(4) With extensions of theory and direct experimental comparisons, established the equivalence of our original SSCM and a variation of it developed outside USGS. We also demonstrated certain limitations of the outside version.

(5) Prepared and presented a summary, in the form of 40 lectures, of current problems and research in unsaturated-zone contaminant hydrology.

\section{REPORTS PUBLISHED 1989-1994:}

Nimmo, Jr., 1990, Experimental testing of transient unsaturated flow theory at low water content in a centrifugal field: Water Resources Research, v. 26 , p. $1951-1960$.

1991, Comment on the treatment of residual water content in "A consistent set of paramet- ric models for the two-phase flow of immiscible fluids in the subsurface, " by L. Luckner and others: Water Resources Research, v. 27, p. 661-662. 


\section{GROUND-WATER HYDROLOGY}

1992, A semiempirical model of soil water hysteresis: Soil Science Society of America Journal, v. 56, p. 1723-1730.

Nimmo, J.R., Akstin, K.C., and Mello, K.A., 1992, Improved apparatus for measuring hydraulic conductivity at low water content: Soil Science Society of America Journal, v. 56, p. 1758-1761.

Nimmo, J.R., and Mello, K.A., 1991, Centrifugal techniques for measuring saturated hydraulic conductivity: Water Resources Research, v. 27 , p. $1263-1269$.

Nimmo, J.R., Stonestrom, D.A., and Akstin, K.C., 1994, The feasibility of recharge rate measurements using the steady state centrifuge method: Soil Science Society of America Journal, v. 58 , p. 49-56.

Rossi, Cinzia, and Nimmo, J.R., 1994, Modeling of soil water retention from saturation to oven dryness: Water Resources Research, v. 30, p. 701-708.

Shakofsky, S.M., 1993, Changes in the hydraulic properties of a soil caused by construction of a waste trench at a radioactive waste disposal site: San Jose State University, San Jose Calif., Masters Thesis, $53 \mathrm{p}$.

Shakofsky, S.M., and Nimmo, J.R., in press, Unsaturated zone properties at a waste disposal site at the Idaho National Engineering Laboratory, in Morganwalp, D.W., and Aronson, D.A., eds., U.S. Geological Survey Toxic Substances Hydrology Program-Proceedings of the technical meeting, Colorado Springs, Colo., September 20-24, 1993: U.S. Geological Survey Water-Resources Investigations Report 94-4014. 


\section{GROUND-WATER HYDROLOGY}

TITLE: $\quad$ The Fate and Transport of Immiscible Contaminants in the Subsurface (WR 89-199)

PERSONNEL: Hedeff I. Essaid, Project Chief

Maria M. Watts, Secretary

Leslie Dillard, Hydrologist, student (Stanford University)

ADDRESS: U.S. Geological Survey

345 Middlefield Road, MS 421

Menlo Park, CA 94025

TELEPHONE: (415) 354-3383

PROBLEM: Many highly toxic contaminants commonly found in the subsurface occur as slightly soluble and highly volatile fluids that are immiscible with water. Despite their low solubility, these compounds pose a widespread potential threat to ground-water resources. Such fluids include synthetic organic compounds such as trichloroethylene (TCE) and related chlorinated hydrocarbons, polychlorinated biphenyls, coal tar and creosote wastes, and natural and refined hydrocarbons. Because of the limited knowledge concerning the multiphase nature of transport of such contaminants in the subsurface, the development of methodologies for predicting and controlling the movement and removal of such plumes is still in its infancy.

OBJECTIVE: Understand the migration and fate of immiscible contaminants in the subsurface, including the physics of multiphase flow (that is, the governing equations, the relative permeability and saturation functions, and the effects of hysteresis and porous media heterogeneity); the nature of interphase transfer processes and chemical reactions affecting transport rates and (or) physical-media properties; and the nature of biological processes in the subsurface leading to biodegradation of organic contaminants.

APPROACH: Undertake the study of multiphase contaminant problems through the development of efficient numerical models applicable at laboratory and field scale, in conjunction with experimental and field investigations. Develop methods for incorporating porous-media heterogeneity, mass transfer, and biological processes into numerical simulators. Use these models, ultimately, to simulate and predict the migration of slightly soluble, highly volatile immiscible contaminants in the field. 


\section{GROUND-WATER HYDROLOGY}

PROGRESS: The research efforts of this project are directed towards understanding the combined physical, chemical, and biological processes affecting the migration and fate of slightly soluble, organic contaminants in the subsurface. We have been studying the Bemidji, Minn., crude-oil spill, using the site as a field-scale experiment. In collaboration with researchers from the Nonisothermal Multiphase Flow project, we have collected detailed data characterizing the three-dimensional spatial distribution of air, oil, water, porosity, and particle-size at the Bemidji, Minnesota, crude-oil spill site. The data sets that we have collected from Bemidji have offered us a unique opportunity to test numerical models of multiphase flow and to deduce the field-scale processes influencing the movement of a lighter-than-water, immiscible fluid phase. We have completed the analysis of two-dimensional field data collected from two different oil pools using a cross-sectional multiphase flow model that incorporates hysteresis, oil entrapment, and spatial variability of sediment hydraulic properties. Simulation results for the south oil pool indicated that capillary pressure-saturation hysteresis, oil entrapment, and spatial variability of hydraulic properties had to be included in order to reproduce the general features of the observed oil distribution. At the north pool, we found that the presence of silt lenses within the outwash was the dominant factor influencing the oil distribution, and incorporation of hysteresis into the model was not crucial.

Now that we have a relatively good understanding of the physical aspects of multiphase flow at the field scale, we are beginning to examine other processes determining the distribution of soluble components in the ground water. In collaboration with researchers from the Organic Degradation project, we have begun a study that uses numerical modeling to help analyze the processes affecting the biodegradation of the hydrocarbon components dissolved in the water phase at Bemidji. In addition, we are beginning to examine the effect of heterogeneity on interphase mass transfer processes at the field scale. Our goal is to eventually combine the findings of these individual studies, in order to develop a comprehensive understanding of multiphase flow and transport in the subsurface.

REPORTS PUBLISHED 1989-1994:

Dillard, L.A., Essaid, H.I., and Herkelrath, W.N., in press, Multiphase flow modelling at the Bemidji, Minnesota, crude-oil spill site using geostatistical simulation of soil hydraulic properties, in Morganwalp, D.W., and Aronson, D.A., eds., U.S. Geological Survey Toxic Substances Hydrology Program-Proceedings of the technical meeting, Colorado Springs,
Colo., September 20-24, 1993: U.S. Geological Survey Water-Resources Investigations Report 94-4014.

Essaid, H. I., 1990, The computer model SHARP, a quasi-three-dimensional finite-difference model to simulate freshwater and saltwater flow in layered coastal aquifer systems: U.S. 


\section{GROUND-WATER HYDROLOGY}

Geological Survey Water-Resources Investigation Report 90-4130, 182 p.

1990, A multilayered sharp interface model of coupled freshwater and saltwater flow in coastal systems-Model development and application: Water Resources Research, v. 26, no. 7. p. 1431-1454.

1992, Simulation of freshwater and saltwater flow in the coastal aquifer system of the Purisima Formation in the Soquel-Aptos Basin, California: U.S. Geological Survey WaterResources Investigation Report 91-4148, 35 p.

1992, Long term issues in ground water management: Seawater intrusion, in Changing practices in ground water management-The pros and cons of regulations, in 18th Biennial Conference on Ground Water, Sacramento, Calif., Sept. 16-17, 1991, Proceedings: University of California, Water Resources Center, Report No. 77, p. 75-91.

in press, Simulation of flow and transport processes at the Bemidji, Minnesota, crude-oil spill site: EPA-USGS sponsored Symposium on Intrinsic Bioremediation of Ground Water, Denver, Colo., Aug. 30-Sept. 1, 1994 [Proceedings].

Essaid, H.I., Baedecker, M.J., and Cozzarelli, I.M., in press, Use of simulation to study field-scale solute transport and biodegradation at the Bemidji, Minnesota, crude-oil spill site, in Morganwalp, D.W., and Aronson, D.A., eds., U.S. Geological Survey Toxic Substances Hydrology Program-Proceedings of the technical meeting, Colorado Springs, Colo., September 20-24, 1993: U.S. Geological Survey Water-Resources Investigations Report 94-4014.
Essaid, H. I., Herkelrath, W. N., and Hess, K. M., 1991, Air, Oil, and Water Distributions at a Crude-Oil Spill Site, Bemidji, Minnesota, in Mallard, G.E., and Aronson, D.A., eds., U.S. Geological Survey Toxics Substances Hydrology Program-Proceedings of the technical meeting, Monterey, Calif., March 11-15, 1991: U.S. Geological Survey WaterResources Investigations Report 91-4034, p. 614-620.

Essaid, H.I., Herkelrath, W.N., and Dillard, L.A., 1994, Field and modeling studies of multiphase fluid flow at the Bemidji, Minnesota, crude-oil spill site, in Dutton, A.R., ed., Toxic Substances and the Hydrologic Sciences: American Institute of Hydrology, April 10-13, 1994, Austin, Texas, [Proceedings] p. 52-68.

Essaid, H.I., Herkelrath, W.N., and Hess, H.I., 1993, Simulation of fluid distributions observed at a crude-oil spill site incorporating hysteresis, oil entrapment, and spatial variability of hydraulic properties: Water Resources Research, v. 29, no. 6, p. 1753-1770.

Essaid, H.I., and Hess, K.M., 1993, Monte Carlo simulations of multiphase flow incorporating spatial variability of hydraulic properties: Ground Water, v. 31, no. 1, p. 123-134.

Herkelrath, W.N., Essaid, H.I., and Dillard, L.A., 1994, Multiphase fluid distributions in a shallow water-table aquifer contaminated by crude oil, in Dracos, T.H., and Stauffer, F., eds., Transport and Reactive Processes in Aquifers: Rotterdam, The Netherlands, A.A. Balkema, IAHR/AIRH Symposium, Zurich, Switzerland, April 11-15, 1994, [Proceedings], p. 537-542.

Herkelrath, W.N., Essaid, H.I., and Hess, K.M., 1991, Field and modeling studies of immiscible fluid flow above a contaminted water-table aquifer-Proceedings of the International Hy- 


\section{GROUND-WATER HYDROLOGY}

drology and Water Resources Symposium 1991: Challenges for Sustainable Development, Perth, Australia, 2-4 Oct. 1991, p. 424-428.

Hess, K. M., Herkelrath, W. N., and Essaid, H. I., 1992, Determination of subsurface fluid contents at a crude-oil spill site: Journal of Contaminant Hydrology, v. 10, p. 75-96.

Mallard, G.E., Baedecker, M.J., Essaid, H.I., and Eganhouse, R.P., 1993, Hydrocarbon transport and degradation in ground water: Geotimes, v. 38 , no. 12 , p. $18-20$.

Scholl, M.A., Ingebritsen, S.E., and Essaid, H.I., 1993, Comment on "Consequences of phase separation on the distribution of hydrothermal fluids at ASHES vent field, Axial Volcano, Juan de Fuca Ridge," by Fox, Christopher G.: Journal of Geophysical Research, v. 98, no. B2, p. 1813-1815. 


\section{SURFACE-WATER CHEMISTRY}




\section{SURFACE-WATER CHEMISTRY}

TITLE: $\quad$ Origin, Characterization, and Quantification of Natural Organic Solutes in Water (CR 68-046)

PERSONNEL: Ronald L. Malcolm, Project Chief

Cathy M. Rubin, Secretary

Kay R. Kennedy, Chemist

ADDRESS: U.S. Geological Survey

P.O. Box 25046, MS 408

Denver Federal Center

Denver, CO 80225

TELEPHONE: (303) 467-8270

PROBLEM: More than 90 percent of the organic solutes in water are of natural origin. These substances are known to complex trace metals, to transport pesticides, to be precursors of carcinogenic compounds upon chlorination, and to be a food source for aquatic organisms; yet, little is known about the chemistry or source of these organic materials.

OBJECTIVE: (1) Identify and quantify organic solutes that affect water-quality processes; (2) measure the amount of different organic solutes in various hydrologic environments; (3) determine the origin, structure, and reactivity of aquatic humic substances; (4) predict the processes that affect the fate and movement of organic solutes in surface and subsurface environments; and (5) determine the effects of natural organic solutes on water purification processes (reverse osmosis, chlorination, activated charcoal, and ozonation).

APPROACH: Conduct intensive sampling of several rivers, lakes, and interstitial waters in the United States and other countries to determine climatic, geologic, and season variations in natural organic substances. Groundwaters from different types of geologic formations will be sampled to determine possible organic variations with aquifer type. Organic substances from brackish and ocean water will be sampled for type and composition, variations from freshwaters, and for possible effects upon $\mathrm{CO}_{2}$ and climatic fluctuations. Cooperate with other researchers and District programs with emphasis on organic contaminant movement in ground water. From the characterization of natural organic matter, correlate and predict the amount and variety of chlorinated compounds in water. 


\section{SURFACE-WATER CHEMISTRY}

PROGRESS: Five reports were published and four others were written.

Acid rain produced significant changes in the distribution of organic solutes in Lake

Skjervatjern. After four years of acidification, the hydrophobic/hydrophilic ratio decreased from $64 / 36$ to $48 / 52$.

The organic composition of the surface microlayer in Lake Skjervatjern was 80 percent hydrophobic constituents as compared to 50 percent in the bulk lake water. The composition of the surface microlayer was predominantly hydrophobic neutral compounds.

The recovery of XAD-4 acids from XAD-4 resin has been increased from 50 percent to 90 percent by elution with acetonitrile.

\section{REPORTS PUBLISHED 1989-1994:}

Chen, Y. Inbar, Y., Hadar, Y., and Malcolm, R.L., 1989, Chemical properties and solidstate CPMAS 13C-NMR of composted organic matter: The Science of the Total Environment, v. 81/82, p. 201-208.

Hayes, M.H.B., MacCarthy, P., Malcolm, R.L., and Swift, R.S., 1989, Humic substances-The emergence of structural forms, in Hayes, M.H.B. MacCarthy, P., Malcolm, R.L., and Swift, R.S., eds., Humic substances II-In search of structure: Chichester, England, John Wiley, p. 687-733.

1989, eds., Humic substances II-In search of structure: Chichester, England, John Wiley, $733 \mathrm{p}$.

Hayes, M.H.B., MacCarthy, P., Malcolm, R.L., and Swift, R.S., 1989, The search for structure-Setting the scene, in Hayes, M.H.B. MacCarthy, P., Malcolm, R.L., and Swift, R.S., eds., Humic substances II-In search of structure: Chichester, England, John Wiley, p. 3-31.
Hayes, M.H.B., Malcolm, R.L., and Clapp, E.C., in press, Aspects of the composition, structures, and reactivities of the organic colloids of soils and waters: Advances in Soil Science, v. 00 .

MacCarthy, P., Bloom, P.R., Malcolm, R.L., and Clapp, C.E., 1990, Humic substances in soil and crop sciences-An overview, in MacCarthy, P., Clapp, C.E., Malcolm, R.L., and Bloom, P.R., eds., Humic substances in soils and agronomy: Madison, Wisconsin, Soil Science Society of America and American Society of Agronomy, p. 211-271.

MacCarthy, P., Clapp, C.E., Malcolm, R.L., and Bloom, P.R., eds., 1990, Humic Substances in Soils and Agronomy: Madison, Wisconsin, Soil Science Society of America and American Society of Agronomy, $281 \mathrm{p}$.

MacCarthy, P., Hayes, M.H.B., Malcolm, R.L., and Swift, R.S., 1990 Humic Substances IIIComplexation of Inorganic Ions, Organic Solutes, and Clay Minerals: Chichester, England, John Wiley, 680 p. 


\section{SURFACE-WATER CHEMISTRY}

MacCarthy, P., and Malcolm, R.L., 1989, On the nature of commercial humic acids, in Suffet, I.H., and MacCarthy, P., eds., Aquatic humic substances-influence on fate and treatment of pollutants: Advances in Chemistry Series 219, p. 55-63.

MacCarthy, P., Malcolm, R.L., Clapp, C.E., and Bloom, P.R., 1990, An introduction to soil humic substances, in MacCarthy, P., Clapp, C.E., Malcolm, R.L., and Bloom, P.R., eds., Humic substances in soils and agronomy: Madison, Wisconsin, Soil Science Society of America and American Society of Agronomy, p. 1-12.

Malcolm, R.L., 1989, Applications of solid-state 13C-NMR spectroscopy to geochemical studies of humic substances, in Hayes, M.H.B., MacCarthy, P., Malcolm, R.L., and Swift, R.S., eds., Humic substances II-In search of structure: Chichester, England, John Wiley, chap. 12, p. 339-372.

1989, The relative importance of $\mathrm{pH}$, charge, and water solubility on the movement of organic solutes in soils and ground water, in Gerstl, Z., Chen, Y., Mingelgrin, U., and Yaron, B., eds., Toxic organic chemicals in porous media: Berlin, Germany, SpringerVerlag, p. 288-301.

1990, Evaluation of humic substances from Spodosols, in Kimble, J.M., and Yeck, R.D., eds., Proceedings of the Fifth International Soil Correlation Meeting (ISCOM), Characterization, Classification, and Utilization of Spodosols in Maine, Massachusetts, New Hampshire, New York, Vermont, and New Brunswick, October 1-4, 1988, Part A (papers), (Lincoln, Nebraska): United States Department of Agriculture-Soil Conservation Service, $\mathrm{p}$. 200-210.
1990, Factors to be considered in the isolation and characterization of aquatic humic substances, in Meeting on Humic Substances in the Environment, Proceedings: Linkoping, Sweden, Linkoping University, p. 390-417.

1990, The uniqueness of humic substances in each of soil, stream, and marine environments: Analytica Chimica Acta, v. 232, p. 19-30.

1990, Variations among humic substances isolated from soils, stream waters, and ground waters, in MacCarthy, P., Clapp, C.E., Malcolm, R.L., and Bloom, P.R., eds., Humic substances in soils and agronomy: Madison, Wisconsin, Soil Science Society of America and American Society of Agronomy, p. 13-35.

1992, 13C-NMR Spectra and Contact Time Experiment for Skjervatjern Fulvic and Humic Acids: Environment International, v. 18, p. 609-620.

Malcolm, R.L., in press, The concentration of dissolved organic carbon in soils, streams, and groundwaters: Institute Biology and Environmental Science, $v, 00$.

Malcolm, R.L., Aiken, G.R., Bowles, E.C., and Malcolm, J.D., 1989, Isolation of fulvic and humic acids from the Suwannee River, in Averett, R.C., Leenheer, J.A., McKnight, D.M., and Thorn, K.A., eds., Humic substances in the Suwannee River, GeorgiaInteractions, properties, and proposed structures: U.S. Geological Survey Open-File Report $87-557$, p. 23-36.

Malcolm, R.L., Croue, J.P., Benedicte, M., in press, Isolation of $\mathrm{XAD}-4$ acids from natural waters and their importance as precursors to TOX and THM upon chlorination, in Conference on Naturally Produced Organohalogens, 


\section{SURFACE-WATER CHEMISTRY}

Delft, the Netherlands, September 14-17, 1993, Proceedings.

Malcolm, R.L., and Hayes, M.H.B., 1994, Organic solute changes with acidification in Lake Skjervatjern as shown by $1 \mathrm{H}-\mathrm{NMR}$ spectroscopy: Environment International, v. 20, no. 3, p. 299-305.

Malcolm, R.L., Kennedy, K., Ping, C.L., and Michaelson, G.J., in press, Fractionation, characterization, and comparison of bulk soil organic substances and water-soluble soil interstitial organic constituents in selected cryosols of Alaska: Advances in Soil Science, v. 00.

Malcolm, R.L., and MacCarthy, P., 1991, The individuality of humic substances in diverse environments, in Wilson, W.S., ed., Advances in Soil Organic Matter Research-The Impact on Agriculture and the Environment: Cambridge, England, the Royal Society of Chemistry, p. 23-34.

1992, Quantitative Evaluation of XAD-8 and XAD-4 resins used in tandem for removing organic solutes from water: Environment International, v. 18, p. 597-607.

Malcolm, R.L., McKnight, D.M., and Averett, R.C., 1989, History and description of the Okefenokee Swamp-Origin of the Suwannee River, in Averett, R.C., Leenheer, J.A., McKnight, D.M., and Thorn, K.A., eds., Humic substances in the Suwannee River, Georgia-Interactions, properties, and proposed structures: U.S. Geological Survey Open-File Report, 87-557, p. 1-22.

Miano, T.M., Senesi, N., and Malcolm, R.L., 1991, Chemical and spectroscopic properties of river and marine fulvic acids and their metal complexes: Humics-uutiset (Finish Humus News), v. 3, no. 3, p. 145-150.
Ping, C.L., Michaelson, G.J., and Malcolm, R.L., in press, Fractionation and carbon balance of soil organic matter in selected cryic soils in Alaska: Advances in Soil Science, v. 00.

Reckhow, D.A., Singer, P.C., and Malcolm, R.L., 1990, Chlorination of humic substances-By product formation and chemical interpretations: Environmental Science and Technology, v. 24, p. $1655-1664$.

Reddy, M.M., Leenheer, J.A., and Malcolm, R.L., 1989, Elemental analysis and heat of combustion of fulvic acid from the Suwannee River, in Averett, R.C., Leenheer, J.A., McKnight, D.M., and Thorn, K.A., eds., Humic substances in the Suwannee River, GeorgiaInteractions, properties and proposed structures: U.S. Geological Survey Open-File Report $87-557$, p. $147-162$.

Thurman, E.M., and Malcolm, R.L., 1989, Nitrogen and amino acids in fulvic and humic acids from the Suwannee River, in Averett, R.C., Leenheer, J.A., McKnight, D.M., and Thorn, K.A., eds., Humic substances in the Suwannee River, Georgia-Interactions, properties, and proposed Structures: U.S. Geological Survey Open-File Report 87-557, p. 99-118. 


\section{SURFACE-WATER CHEMISTRY}

TITLE: Behavior of Natural Polyelectrolytes in Water (CR 68-132)

PERSONNEL: Robert L. Wershaw, Project Chief Nora L. Bender, Secretary

Kevin A. Thorn, Research Chemist

W.S. Goldenberg, Technician

S.J. Younger, Technician.

ADDRESS: U.S. Geological Survey

P.O. Box 25046, MS 408

Denver Federal Center

Denver, CO 80225

TELEPHONE: (303) 467-8280

PROBLEM: Natural organic polyelectrolytes are highly active materials that are present in practically all natural water systems. They interact with organic and inorganic pollutants and nutrients, influencing - and in many instances, controlling - the toxicity, rate of movement, persistence, and rate of degradation of the pollutants and nutrients in aquatic environments. Detailed knowledge of the chemistry of natural organic polyelectrolytes is therefore of primary importance in understanding the chemical changes that affect all of the components of natural water systems. Organic polyelectrolytes are partially eliminated from drinking water by coagulation and chlorination; however, the products of chlorination are not known. Natural and synthetic organic compounds are present in all natural waters. Some of these compounds are toxic or mutagenic and it is therefore important that they be identified and quantified in surface and ground water and in precipitation.

OBJECTIVE: (1) Isolation of the various organic polyelectrolytes present in natural water systems from different environments; (2) determination of the physical and chemical properties of the most abundant organic polyelectrolytes; (3) elucidation of the mechanisms of interaction of pollutants with natural organic polyelectrolytes; (4) determination of the types of chemical compounds that result from the chlorination of natural polyelectrolytes; (5) development of nuclear magnetic resonance (NMR) spectroscopic methods for the characterization of humic substances; (6) determination and characterization of selected organic pollutants in ground water; (7) elucidation of the mechanisms of humification in natural systems; (8) identification of diagnostic NMR bands of different functional groups found in natural organic polyelectrolytes; (9) characterization of the nitrogen containing species in natural organic polyelectrolytes; (10) identification of the carbohydrates in humic substances. 


\section{SURFACE-WATER CHEMISTRY}

APPROACH: (1) Isolate chemically unique polyelectrolyte fractions using column chromatography, electrophoresis, and other techniques; (2) determine the physical and chemical properties of the fractions using small angle X-ray scattering, ultracentrifugation, and atomic, molecular, and magnetic resonance spectroscopy; (3) use carefully characterized organic polyelectrolyte fractions in experiments designed to elucidate the sorption and solubilization reactions of pollutants and nutrients with natural organic polyelectrolytes; (4) characterize the effect of fulvic and humic acids on the activity of $\mathrm{Na}$ ions in solution by ${ }^{23} \mathrm{Na}$ NMR spectroscopy; (5) isolate selected organic pollutants from ground waters; (6) measure the ${ }^{15} \mathrm{~N}$ NMR spectra of humic substances reacted with selected ${ }^{15} \mathrm{~N}$ labelled reagents; (7) measure the ${ }^{14} \mathrm{~N}$ and ${ }^{15} \mathrm{~N}$ NMR spectra of humic isolates; (8) isolate and identify carbohydrates from soil and compost extracts; (9) characterize by ${ }^{13} \mathrm{C}$ NMR spectroscopy humic substances isolated from water treatment plants and composts.

PROGRESS: Two studies on the mechanism of adsorption of compost leachate dissolved organic carbon (DOC) have been completed. In the first study measurements of the infrared linear dichroism of carboxylate groups of organic acids from compost leachate adsorbed to an alumina surface and the enthalpy of adsorption of this reaction were made. The linear dichroism measurements indicated that the carboxylate groups are not free to rotate. This limited rotation probably results from bidentate binding of the carboxylate groups. The molar enthalpy of adsorption of the acids is approximately $-100 \mathrm{KJ} / \mathrm{mole}$. This high value for enthalpy of adsorption may best be explained by assuming that two or more carboxylate groups on a single DOC molecule coordinate to the surficial aluminum ions. A report on this work has been prepared and submitted to a journal for publication.

In the second study the adsorption of compost leachate DOC on alumina is used as a model for elucidation of the mechanism of formation of natural organic (humic) coatings on hydrous metal oxide surfaces in soils and sediments. Compost leachate DOC is composed mainly of organic acids molecules; these organic acids are very similar to aquatic humic substances. Carbon-13 NMR data indicate that amphophilic molecules of compost leachate DOC are adsorbed on metal oxide surfaces through a combination of polar and hydrophobic interaction mechanisms. This combination of polar and hydrophobic mechanism leads to the formation of bilayer coatings of the leachate amphophilic molecules on the oxide surfaces.

A new study on the adsorption of DOC from surface waters on alumina has been initiated. Two water samples from the Platte River have been collected by Colorado District personnel. These samples were filtered and equilibrated with alumina. The alumina was then separated from the water samples, freeze dried, and the solid-state ${ }^{13} \mathrm{C}$ NMR spectra of the sorbed DOC on the alumina were measured. Preliminary results indicate that it is possible to characterize 


\section{SURFACE-WATER CHEMISTRY}

the DOC in a natural water sample by studying the DOC that adsorbs on a hydrous oxide mineral surface.

Direct spectroscopic evidence for the covalent binding of ammonia and nitrite with organic matter in whole soils has been obtained using solid-state ${ }^{15} \mathrm{~N}$ NMR. Previous work demonstrated covalent binding of ammonia and nitrite with organic matter isolated from soils. Evidence has been obtained that aniline undergoes covalent binding with humic acid sorbed to alumina in the same manner as with dissolved humic acid, but to a lesser degree.

Preliminary studies characterizing the organic geochemistry at the Pico Rivera, California, have been completed. Carbon-13 NMR analyses have elucidated the fate and transport of surfactants through the system.

REPORTS PUBLISHED 1989-1994:

Aiken, G.R., Brown, Pat, Noyes, Ted, and Pinckney, D.J., 1989, Molecular size and weight measurements on Suwannee River fulvic acid, in Averett, R.C., Leenheer, J.A., McKnight, D.M., and Thorn, K.A., eds., Humic substances in the Suwannee River, GeorgiaInteractions, properties, and proposed structures: U.S. Geological Survey Open-File Report 87-557, p. 167-178.

Aiken, G.R., Capel, P.D., Furlong, E.T., Hult, M.F., and Thorn, K.A., 1991, Mechanisms controlling the transport of organic chemical in subsurface environments, in Mallard, G.E., and Aronson, D.A., eds., U.S. Geological Survey Toxics Substances Hydrology Program-Proceedings of the technical meeting, Monterey, Calif., March 11-15, 1991: U.S. Geological Survey Water-Resources Investigations Report 91-4034, p. 633-637.

Aiken, G.R., and Gillam, A., 1989, Determination of molecular weights of humic substances by colligative property measurements, in Hayes, M.H.B., MacCarthy, Patrick, Malcolm, R.L., and Swift, R.S., eds., Humic substances II-In search of structure: Chichester, England, John Wiley and Sons, p. 515-544.

Aiken, G.R., McKnight, D.M., and Harnish, R.A., 1989, Chemical characteristics of aquatic fulvic acid isolated from Lake Fryxell, Antarctica: Antarctic Journal, 1988 Review Issue, v. XXIII, p. 190-192.

Aiken, G.R., McKnight, D.M., Thorn, K.A., and Thurman, E.M., 1992, Isolation of hydrophilic acids from water using macroporous resins: Organic Geochemistry, v. 18, p. 567-573.

Aiken, G.R., McKnight, D.M., Wershaw, R.L., and Miller, Laurence, 1991, Evidence for the diffusion of aquatic fulvic acid from the sediments of Lake Fryxell, Antarctica, in Baker, R.A., ed., Organic substances and sediments in water: Chelsea, Michigan, Lewis Publishers, p. 75-88.

Aiken, G.R., and Thorn, K.A., 1989, Variability in the chemistry of nonvolatile organic acids downgradient of the oil body at Bemidjii, Minnesota, in Mallard, G. E, and Ragone, S. 


\section{SURFACE-WATER CHEMISTRY}

E., eds., U.S. Geological Survey Toxic Substances Hydrology Program-Proceedings of the technical meeting, Phoenix, Ariz., Sept. 26-30, 1988: U.S. Geological Survey WaterResources Investigations Report 88-4220, p. 35-40.

Averett, R.C., Leenheer, J.A., McKnight, D.M., and Thorn, K.A., eds., 1989, Humic substances in the Suwannee River, GeorgiaInteractions, properties, and proposed structures: U.S. Geological Survey Open-File Report 87-557, 377 p.

Eganhouse, R.P., Baedecker, M.J., Cozzarelli, I.M., Aiken, G.R., Thorn, K.A., and Dorsey, T.F., in press, Crude oil in a shallow sand and gravel aquifer, 2. Organic geochemistry: Applied Geochemistry, v. 00.

Field, J.A., Barber, L.B., Leenheer, J.A., Rostad, C.E., and Thorn, K.A., 1991, Persistence of linear alkylbenzenesulfonates and their metabolites in sewage contaminated groundwater, in Mallard, G.E., and Aronson, D.A., eds., U.S. Geological Survey Toxics Substances Hydrology Program-Proceedings of the technical meeting, Monterey, Calif., March 1115, 1991: U.S. Geological Survey WaterResources Investigations Report 91-4034, p. 116-122.

Field, J.A., Leenheer, J.A., Thorn, K.A., Barber, L.B., Rostad, C.E., Macalady, D.L., and Daniel, S.R., 1991, Comprehensive approach for identifying anionic surfactant-derived chemicals in sewage effluent and groundwater: Journal of Contaminant Hydrology, v. 9, p. 55-78.

Folan, D.W., 1990, Quantitation of the hydroxyl group functionality in humic substances using solution-state C-13 and Si-29 nuclear magnetic resonance spectroscopy: Golden, Colo. School of Mines, Ph.D. dissertation, 239 p.

Goldberg, M.C., Cunningham, K.M., Aiken, G.R., and Weiner, E.R., 1991, Photolytic decomposition of terpenes in environmental waters: Journal of Contaminant Hydrology, $v$. 9, p. 79-89.

Heasley, V.L., Burns, M.D., Kemalyan, N.A., McKee, T.C., Schroeter, Hinako, Teegarden, B.R., Whitney, S.E., and Wershaw, R.L., 1989, Aqueous chlorination of resorcinol: Environmental Toxicology and Chemistry, v. 8, p. 1159-1163.

Leenheer, J.A., Wershaw, R.L., Brown, P.A., and Noyes, T.I., 1991, Detection of poly(ethylene) glycol residues from nonionic surfactants in surface water by ${ }^{1} \mathrm{H}$ and ${ }^{13} \mathrm{C}$ nuclear magnetic resonance spectrometry: Environmental Science and Technology, v. 25, p. 161-168.

Malcolm, R.L., Aiken, G.R., Bowles, E.C., and Malcolm, J.D., 1989, Isolation of fulvic and humic acids from the Suwannee River, in Averett, R.C., Leenheer, J.A., McKnight, D.M., and Thorn, K.A., eds., Humic substances in the Suwannee River, GeorgiaInteractions, properties, and proposed structures: U.S. Geological Survey Open-File Report $87-557$, p. $27-35$.

McKnight, D M., Aiken, G.R., and Smith, R.L., 1991, Aquatic fulvic acids in microbially based ecosystems: Results from two Antarctic desert lakes: Limnology and Oceanography, v. 36, p. 998-1006.

McKnight, D.M., Bencala, K.E., Aiken, G.R., Zellweger, G.W., Feder, G.L., and Thorn, K.A., 1992, Sorption of dissolved organic material by precipitated hydrous aluminum and iron oxides at the confluence of Deer Creek 


\section{SURFACE-WATER CHEMISTRY}

with the Snake River, Summit County, Colorado: Environmental Science and Technology, v. 26, p. 1388-1396.

McKnight, D.M., Wershaw, R.L., Bencala, K.E., Zellweger, G.W., Feder, G.L., 1992, Humic substances and trace metals associated with $\mathrm{Fe}$ and $\mathrm{Al}$ oxides deposited in an acidic mountain stream: The Science of the Total Environment, v. $117 / 118$, p. $485-498$.

Nefcy, A.M., 1990, Chemical characterization of humic acid extracted from a Philippines agricultural soil: Denver, University of Colorado, Masters thesis, $103 \mathrm{p}$.

Steelink, Cornelius, Wershaw, R.L., Thorn, K.A., and Wilson, M.A., 1989, Application of liquid-state NMR spectroscopy to humic substances, in Hayes, M.H.B., MacCarthy, Patrick, Malcolm, R. L., and Swift, R. S., eds., Humic substances II-In search of structure: Chichester, England, John Wiley and Sons, p. 281-308.

Thorn, K.A., 1989, Nuclear magnetic resonance spectrometry investigations of fulvic and humic acids from the Suwannee River, in Averett, R.C., Leenheer, J.A., McKnight, D.M., and Thorn, K.A., eds., Humic substances in the Suwannee River, Georgia-Interactions, properties, and proposed structures: U.S. Geological Survey Open-File Report 87-557, p. 255-309.

Thorn, K.A., and Aiken, G.R., 1989, Characterization of nonvolatile organic acids resulting from the biodegradation of crude oil by nuclear magnetic resonance spectrometry, in Mallard, G. E, and Ragone, S. E., eds., U.S. Geological Survey Toxic Substances Hydrology Program-Proceedings of the technical meeting, Phoenix, Ariz., September 26-30, 1988: U.S. Geological Survey Water-
Resources Investigations Report 88-4220, p. 41-51.

1991, Sources in crude oil of nonvolatile organic acids downgradient from an oil body at Bemidji, Minnesota, in Mallard, G.E., and Aronson, D.A., eds., U.S. Geological Survey Toxic Substances Hydrology Program-Proceedings of the technical meeting, Monterey, Calif., March 11-15, 1991: U.S. Geological Survey Water-Resources Investigations Report 91-4034, p. 654-658.

Thorn, K.A., Arterburn, J.B., and Mikita, M.A., $1992,{ }^{15} \mathrm{~N}$ and ${ }^{13} \mathrm{C}$ NMR investigation of hydroxylamine derivatized humic substances: Environmental Science and Technology, v. 26, p. 107-116.

Thorn, K.A., Folan, D.W., Arterburn, J.B., Mikita, M.A., and MacCarthy, Patrick, 1989, Application of INEPT nitrogen-15 and silicon29 nuclear magnetic resonance spectrometry to derivatized fulvic acids: The Science of the Total Environment, v. 81/82, p. 209-218.

Thorn, K.A., Folan, D.W., and MacCarthy, Patrick, 1991, Characterization of the International Humic Substances Society standard and reference fulvic and humic acids by solution state carbon-13 and hydrogen-1 nuclear magnetic resonance spectrometry: U.S. Geological Survey Water-Resources Investigations Report 89-4196, 93 p.

Thorn, K.A., and Mikita, M.A., 1992, Ammonia fixation by humic substances: a nitrogen-15 and carbon-13 NMR study: The Science of the Total Environment, v. 113, p. 67-88.

Wershaw, R.L., 1989, Sizes and shapes of humic substances by; scattering techniques, in Hayes, M.H.B., MacCarthy, Patrick, Malcolm, R.L., and Swift, R.S., eds., Humic substances II-In 


\section{SURFACE-WATER CHEMISTRY}

search of structure: Chichester, England, John Wiley and Sons, p. 545-559.

1989, Application of a membrane model to the sorptive interactions of humic substances: Environmental Health Perspectives, v. 83, p. 191-203.

1991, The importance of humic substancemineral particle complexes in the modeling of contaminant transport in sediment-water systems, in Baker, R.A., ed., Organic substances and sediments in water: Chelsea, Michigan, Lewis Publishers, p. 23-34.

1992, Membrane-micelle model for humus in soils and sediments and its relation to humification: U.S. Geological Survey Open-File Report 91-513, 64 p.

1993, Model for humus in soils and sediments: Environmental Science and Technology, v. 27, p. 814-816.

Wershaw, R.L., Aiken, G.R., and Imbrigiotta, T.E., 1991, Characterization of high molecular weight, colored compounds in ground water at Picatinny Arsenal, New Jersey, in Mallard, G.E., and Aronson, D.A., eds., U.S. Geological Survey Toxics Substances Hydrology Program-Proceedings of the technical meeting, Monterey, Calif., March 11-15, 1991: U.S. Geological Survey Water-Resources Investigations Report 91-4034, p. 726-730.

Wershaw, R.L., Aiken, G.R., and Imbrigiotta, T.E., in press, Displacement of soil pore water by trichloroethylene: Journal of Environmental Quality, v. 23, no. 4.

Wershaw, R.L., Pinckney, D.J., Llaguno, E.C., and VicenteBeckett, V., 1990, NMR characterization of humic acid fractions from differ- ent Philippine soils and sediments: Analytica Chimica Acta, v. 232, p. 31-42.

Wershaw, R.L., Thorn, K.A., and Pinckney, D.J., 1988, Characterization of humic acid fractions by C13 Nuclear Magnetic Resonance Spectroscopy: Environmental Technology Letters, v. 9, p. 53-62. 


\section{SURFACE-WATER CHEMISTRY}

TITLE: Geochemical Kinetics Studies of Silicate Rock Hydrologic Systems (CR 75-189)

PERSONNEL: Hans C. Claassen, Project Chief

Sandra J. Piksa, Secretary

Douglas R. Halm, Hydrologist

ADDRESS: U.S. Geological Survey

P.O. Box 25046, MS 412

Denver Federal Center

Denver, CO 80225

TELEPHONE: (303) 236-5197

PROBLEM: Adequate description of mass transport in hydrologic systems requires knowledge of the rates of the reactions among the gaseous, solid, and liquid phases present. This knowledge of reaction rates is necessary because many chemical reactions occur simultaneously in natural systems, and only a few of these appear to reach equilibrium, even after long contact times. Therefore, a complete description of the chemical processes and their rates will allow realistic modeling of mass transport in natural and perturbed hydrologic systems.

OBJECTIVE: Determine the relative importance of the factors controlling water quality and devise experiments to quantify the process by studying two model systems representing single lithologies-extrusive volcanic and shale. Determine the kinetics and mechanism(s) of these processes and the effects of natural variation on the controlling factors. Suggest reaction models by combining solution chemistry and the results of surface alteration studies.

APPROACH: Monitor water quality from selected sources in the model study areas on a monthly basis. Monitor measurements of precipitation amounts and quality, soil temperature and moisture profiles, gravitational porewater quality and amount, and soilpore carbon dioxide on either a continuous or periodic basis. On the basis of these measurements, (1) describe the relations between variations input (recharge) and output (discharge) water quality; (2) design controlled laboratory experiments; and (3) use the results of these laboratory experiments to provide data for elucidation of kinetic mechanisms. Determine changes that occur in the solid phase by use of instrumental (nondestructive) and chemical analytical techniques. 


\section{SURFACE-WATER CHEMISTRY}

PROGRESS: Considerable progress in data interpretation was made last year: four papers were approved for publication, three of which are to be published in refereed journals.

Performance characteristics of a wet deposition collector used in the interagency acid precipitation National Trends Network (NTN) were measured with the intent of estimating how much wet deposition is being missed by such a collector operating in semiarid climates. It was determined that a conservative estimate of under reported deposition is about 20-30 percent, but could be much more depending on rain and snowfall rate patterns during storms. A manuscript describing the above results has received Directors' approval.

A method to estimate average evapotranspiration (ET) in a watershed, that requires only minimal data, was confirmed at Deep Creek (southwest Colorado) and tested in diverse watersheds throughout the Rocky Mountain region. The method requires only an estimate of precipitation quantity $(\mathrm{P})$ and chloride concentration input to the watershed, and a chloride analysis of baseflow. Of the watersheds tested, more than two thirds agreed within 10 percent of the ET estimate obtained by subtracting annual discharge from $P$. The other watersheds showed poor agreement either because they had (1) inappropriate lithology, (2) inaccurate estimates of $\mathrm{P}$ or chloride concentration in precipitation, (3) baseflow conditions were not met at the time of sampling. A manuscript describing the above results is in colleague review.

\section{REPORTS PUBLISHED 1989-1994:}

Claassen, Hans C., and Halm, Douglas R., 1992, Design and validation of an onsite atmospheric water vapor sampling system to obtain samples for hydrogen and oxygen isotope analysis: U.S. Geological Survey Open-File Report 92-74, 8 p.

Claassen, Hans C., and Riggs, Alan C., 1993, An estimate of the roughness length and displacement height of Sonoran desert vegetation: U.S. Geological Survey Water-Resources Investigation Report 92-4065, 16 p.
Claassen, Hans C., and Halm, Douglas R., 1994, Performance characteristics of a bulk precipitation collector with respect to measurement of water isotopes oxygen-18 and deuterium: U.S. Geological Survey Water-Resources Investigations Report 94-4008, 3 p.

in press, A possible deficiency in estimates of wet deposition obtained from data generated by the NADP/NTN netwrrk: Atmospheric Environment, v. 00.

Claassen, H.C., and Downey, J.S., in press, A model for deuterium and oxygen-18 isotope 


\section{SURFACE-WATER CHEMISTRY}

changes during evergreen interception of snow fall: Water Resources Research, v. 00.

Kustas, W.P., Goodrich, D.C., Moran, M.S., Amer, S.A., Bach, L.B., Blanford, J.H., Chehbouni, A., Claassen, H., Clements, W.E., Doraiswamy, P.C., Dubois, P., Clarke, T.R., Daughtry, C.S.T., Gellman, D.I., Grant, T.A., Hipps, L.E., Huete, A.R., Humes, K.S., Jackson, T.J., Keefer, T.O., Nichols, W.D., Parry, R., Perry, E.M., Pinker, R.T., Pinter, Jr., P.J., Qi, J., Riggs, A.C., Schmugge, T.J., Shutko, A.M., Stannard, D.I., Swiatek, E., Van Leeuwen, J.D., Van Zyl, J., Vidal, A., Washburne, J., and Weltz, M.A., 1991, An interdisciplinary field study of the energy and water fluxes in the atmosphere biosphere system over semiarid rangelands-Description and some preliminary results: Bulletin of the American Meteorological Society, v. 72, no. 11, p. 1683-1705. 


\section{SURFACE-WATER CHEMISTRY}

TITLE: $\quad$ Research in Analytical Environmental Trace Element Chemistry and Its Impact on Water Quality (CR 83-282)

PERSONNEL: Howard E. Taylor, Project Chief

Darlene Puhr, Secretary

Dale B. Peart, Hydrologist

Ronald C. Antweiler, Hydrologist

Terry I. Brinton, Chemist
David A. Roth, Student, (Colorado State Univ.)

S. Roy Koirtyohann, Chemist

Rodney K. Skogerboe, Chemist

\section{ADDRESS: U.S. Geological Survey \\ 3215 Marine Street \\ Boulder, CO 80303}

TELEPHONE: (303) 541-3007

PROBLEM: The determination of inorganic constituents and their impact on water quality requires an in-depth knowledge of interactive water chemistry relationships. The ability to measure trace and ultratrace concentration levels of inorganic constituents as well as their chemical form and speciation plays a significant role in understanding their chemical, toxicological, transport and overall environmental impact on surface- and ground-water hydrology. The development of state-of-the-art analytical chemistry technology for the solution of specific hydrologically related problems requires extensive laboratory and field research and development effort.

OBJECTIVE: (1) Investigate and develop new concepts and approaches to the identification and measurement of inorganic constituents in water and water related materials. (2) Formulate techniques for the utilization of new field and laboratory technology for the assessment of water quality. (3) Participate in multidisciplinary research programs providing expertise in the field of inorganic water chemistry.

APPROACH: (1) Study the occurrence and distribution of inorganic constituents (trace metals, nutrients, molecular ionic species, inorganic-organic complexes, and so forth) in hydrologic systems. (2) Study water chemical interactive relationships and assess their impact on water quality. (3) Develop field and laboratory technology for sampling and measurement of trace and ultratrace concentrations of toxic and other inorganic constituents in water and water-related materials. (4) Define relative importance of various impacts on water quality in specific hydrologic environments (such as acid rain, geochemical industrial pollution, water 


\section{SURFACE-WATER CHEMISTRY}

treatment, agrichemical, and so forth). (5) Evaluate transport phenomena of inorganic constituents in hydrologic systems.

PROGRESS: (1) Development of technology was continued for the direct measurement of ultra-trace (nanogram/liter) concentrations of constituents in hydrologic systems by state-ofthe-art analytical laboratory instrumentation, including but not limited to inductively-coupled plasma mass spectrometry (ICPMS). Techniques and methodology were pioneered for the measurement of stable isotope ratios of selected heavy metals at trace (microgram/liter) concentration levels in natural waters for use as tracers. Instrumentation modifications were investigated to improve measurement precision, stability and sensitivity. (2) Research continues to develop the technique of sedimentation field flow fractionation coupled with ICPMS (SdFFF-ICP-MS) to study the geochemistry of trace elements associated with colloidal and submicrometer diameter particulate material from natural surface water systems. (3) Research was performed, including field studies, to measure the occurrence, distribution and fate of trace metals, major water chemistry and nutrients in the Mississippi River system. This includes the investigation of interaction of trace metals with other water chemical constituents, with emphasis on the distribution between various size fractions of suspended material, silts, colloids, and bed sediments). Studies were performed to representatively collect and separate statistically valid and uncontaminated samples. Field studies were also carried out to determine interactions of contaminants with each other and suspended sediment at primary mixing zones below confluences of tributaries. This research included studies of bed sediment materials and pore water samples. Sequential extraction techniques were developed for the study of the partitioning of trace elements between the various chemical fractions of bed sediment materials. (4) Research studies were continued to develop an understanding of the geochemistry of mercury and its fate in large river systems including the Mississippi, Colorado and Rio Grande Rivers. (5) Research continued to measure the relationship between water chemistry constituents and the occurrence and distribution of benthic invertebrates populations in rivers and streams. Field work continues in the Gibbon and Firehole Rivers in Yellowstone National Park. (6) Studies continued to evaluate the chemical composition of ice layers in glaciers from the Wind River Mountain range in Wyoming. These studies will assist in evaluating climatic changes and atmospheric deposition. (7) Research was continued to study the water quality of the Colorado River system and the impacts from Glen Canyon dam operation on the ecology and water quality of the river systems. This included the analysis of samples and interpretation of data collected from two large scale synoptic sampling experiments in November 1990 and June 1991. Results of this research will assist in developing an understanding of the occurrence, distribution and chemistry of water quality constituents related to controlled and variable hydrologic discharge. (8) Studies were undertaken to establish the chemical water quality of 


\section{SURFACE-WATER CHEMISTRY}

tributaries to the Colorado River in the Grand Canyon to develop an understanding of the ecological impacts of land use in the water sheds of the tributaries. (9) Studies were initiated to evaluate the occurrence, distribution and interaction of trace elements in the delta's of the Colorado River and San Juan River arms of Lake Powell. (10) Multi year research studies were initiated to assess the chemical and biological water quality of the surface waters in Yellowstone National Park using state-of-the-art field and laboratory techniques. (11) Studies were initiated in collaboration with NAWQA to understand the distribution and fate of trace metals in the Rio Grande in Southern Colorado and Northern New Mexico that may be present from mining activities. (12) Collaborative research studies involving trace element geochemistry and water quality continued on Lake Kinneret (sea of Galilee) in cooperation with the Geological Survey of Israel. (13) Studies were performed, in conjunction with the Colorado District, to study the distribution of trace elements in snowpack in the Rocky Mountains.

\section{REPORTS PUBLISHED 1989-1994:}

Antweiler, R.C., Patton, C.J., and Taylor, H.E., 1993, Automated colorimetric methods for determination of nitrate plus nitrite, ammonium, and orthophosphate ions in natural water samples: U.S. Geological Survey Open-File Report 93-638, 40 p.

Brenner, I.B., Nishri, A., Taylor, H.E., and Garbarino, J.R., 1993, Trace metal distribution in Lake Kinneret waters-Investigation of the mode of occurrence of metals in lake systems: Israel Oceanographics and Limnological Research Report No. TR-GSI/13/93, p. 35.

Brenner, I.B., and Taylor, H.E., 1992, A critical review of inductively coupled plasma-mass spectrometry for geoanalysis, geochemistry and hydrology, Part 1, Analytical performance: Critical Reviews in Analytical Chemistry, v. 11, p. $452-463$.

Garbarino, J.R., and Taylor, H.E., 1994, Inductively Coupled Plasma-Mass Spectrometric Method for the Determination of Dissolved Trace Elements in Natural Water: U.S. Geological Survey Open-File Report No. 94-358, 88 p.
Garbarino, J.R., Taylor, H.E., and Batie, W., 1989, Simultaneous determination of major and trace elements by inductively-coupled plasma mass spectrometry/optical emission spectrometry: Analytical Chemistry, v. 61, p. 793-796.

Hayes, H.C., 1993, Metal Associations in Suspended Sediments and Bed Sediments from the Mississippi River: Golden, Colorado, Colorado School of Mines, Masters Thesis, $130 \mathrm{p}$.

Leenheer, J.A., Meade, R.H., Taylor, H.E., and Pereira, W.E., 1989, Sampling, fractionation and dewatering of suspended sediment from the Mississippi River for geochemical and trace-contaminant analysis, in Mallard, G. E, and Ragone, S. E., eds., U.S. Geological Survey Toxic Substances Hydrology Program-Proceedings of the technical meeting, Phoenix, Ariz., September 26-30, 1988: U.S. Geological Survey Water-Resources Investigations Report 88-4220, p. 501-511.

Murphy, D.M., Garbarino, J.R., Taylor, H.E., Hart, B.T., and Beckett, R., 1993, Determination of Size and Element Composition Distributions of Complex Colloids by Sedimentation 


\section{SURFACE-WATER CHEMISTRY}

Field-Flow Fractionation-Inductively Coupled Plasma Mass Spectrometry: Journal of Chromatography, v. 642, p. 459-467.

Naftz, D.L., Taylor, H.E., Ranville, J.R., and Rice, J.A., 1989, Glacier-ice geochemistry, Knife Point Glacier, Wind River Range, Wyoming-Reconnaissance-Phase Results: EOS transactions, American Geophysical Union v. 70 , no. 43, p. 1084-1085.

Roth, D.A., 1994, Ultra Trace Analysis of Mercury and its Distribution in Some Natural Waters of the United States: Fort Collins, Colorado, Colorado State University, Ph.D. dissertation, 309 p.

Taylor, H.E., 1989, Water Resources, in Date, A.R., and Gray, A.L., eds., Applications of Inductively-Coupled Plasma Mass Spectrometry: London, Blackie, $71 \mathrm{p}$.

Taylor, H.E., Antweiler, R.C., Brinton, T.I., Roth, D.A., and Moody, J.A., 1994, Major Ions, Nutrients and Trace Elements in the Mississippi River Near Thebes, Illinois, July Through September 1993 in Floods in the Upper Mississippi River Basin, 1993: U.S. Geological Survey Circular 1120-D, 21 p.

Taylor, H.E., and Averett, R.C., 1991, Description of water quality synoptic experiments in the Colorado River, in Mallard, G.E., and Aronson, D.A., eds., U.S. Geological Survey Toxics Substances Hydrology Program-Proceedings of the technical meeting, Monterey, Calif., March 11-15, 1991: U.S. Geological Survey Water-Resources Investigations Report 91-4034, p. 576-578.

1993, Measuring Colorado River water quality in the Grand Canyon National Park: Park Service, Winter Issue, p. 12-14.

Taylor, H.E., and Garbarino, J.R., 1989, The Occurrence and Distribution of Selected Trace Metals in the IHHS Standard Humic and Fu- lvic Acids: U.S. Geological Survey Open-File Report No. 87-557, 14 p.

1991, The Measurement of Trace Metals in Water Resource Monitoring Samples by Inductively-coupled Plasma Mass Spectrometry: Spectrochimica Acta Reviews, v. 14, p. 3343.

1992, Analytical applications of inductively coupled plasma-mass spectrometry, in Montaser, A., and Golightly, D.W., eds., Inductively coupled plasmas in atomic spectrometry: VCH Verlogsgesellschaft, $\mathrm{mbH}$, 2nd Edition, p. 651 .

Taylor, H.E., Garbarino, J.R. and Brinton, T.I., 1990, The occurrence and distribution of trace metals in the Mississippi River and its tributaries: The science of the total environment, $v$. 97/98, p. 369-384.

Taylor, H.E., Garbarino, J.R., Murphy, D.M., and Beckett, R., 1992, Inductively coupled plasmamass spectrometry as an element specific detector for field-flow fractionation: Analytical Chemistry, v. 64, p. 2036-2041.

Taylor, H.E., Garbarino, J.R., and Koirtyohann, S.R., 1991, Flame ionization mass spectrometry, isotope ratio determinations for potassium: Applied Spectroscopy, v. 45, p. 886-889.

Taylor, H.E., Shiller, A.M., Garbarino, J.R., and Brinton, T.I., 1993, Dissolved trace metal data from intercomparison experiments in the Mississippi River and its tributaries between the U.S. Geological Survey's National Research Program and the National Stream Quality Accounting Network and the University of Southern Mississippi: U.S. Geological Survey Open-File Report 93-628, 39 p. 


\section{SURFACE-WATER CHEMISTRY}

TITLE: Aqueous Crystal Growth and Dissolution Kinetics of Earth Surface Minerals (CR 83-284)

PERSONNEL: Michael M. Reddy, Project Chief

Debra A. Litwin, Secretary

S. Leith, Chemist

Paul F. Schuster, Hydrologist

R. Fedors, Hydrologist
Charmaine D. Gunther, Computer Assistant

S. Charlton, Hydrologic Technician

T. Henrikson, Hydrologic Technican

H. Brainerd, Hydrologic Technican

ADDRESS: U.S. Geological Survey

P.O. Box 25046, MS 458

Denver Federal Center

Denver, CO 80225

TELEPHONE: (303) 541-3012

PROBLEM: Accelerated decay of carbonate stone monumental works and building materials is apparent in several areas of the United States. This accelerated weathering has been attributed to air pollution and (or) acid deposition; however, little fundamental understanding of processes involved or quantitative relations between important variables are available.

OBJECTIVE: Determine carbonate stone dissolution processes and rates in natural and polluted environments. Attempt to separate the effects of wet deposition from the effects of dry deposition and normal weathering processes.

APPROACH: Onsite measurements of acid rain dissolution and damage to carbonate stone will be used, with supplemental well-controlled laboratory studies and reaction modeling. Onsite studies involve collection of rainfall leachate solutions from an inert reference surface and from limestone and marble surfaces at five acid rain impacted locations: Chester, N.J.; Newcomb, N.Y.; Research Triangle Park, N.C.; Steubenville, Ohio; and Washington, D.C. Air quality, meteorology, rainfall and rain-runoff quality and changes in the chemical composition of limestone and marble will be used to develop a quantitative description of carbonate stone dissolution and damage due to acid rain and air pollution. Laboratory studies and reaction modeling will be used to identify processes involved in acid rain damage and dissolution.

PROGRESS: A manuscript (Materials Performance, 1994) demonstrating acid precipitation and dry deposition of sulfur dioxide $\left(\mathrm{SO}_{2}\right)$ accelerated damage to marble in the central 


\section{SURFACE-WATER CHEMISTRY}

Adirondack Mountains of New York State has been published. Results from these experiments demonstrate the deposition of $\mathrm{SO}_{2}$ gas to the stone surface during dry periods, and a two-fold increase in marble dissolution during coincident episodes of low rain rate and decreased rain fall $\mathrm{pH}$.

A recent paper (Applied Geochemistry, 1994) reported specific surface area of a crushed welded tuff before and after aqueous dissolution. Higher than expected tuff surface areas appear to be due to porous matrix. Tuff reacted with solutions having high acid concentrations exhibited a marked increase in specific surface area compared to unreacted tuff.

\section{REPORTS PUBLISHED 1989-1994:}

Baedecker, P.A., and Reddy, M.M., 1993, The erosion of carbonate stone by acid rainLaboratory and field investigations and a review of the chemistry of carbonate stone weathering: Journal of Chemical Education, v. 70 , no. 2 , p. 104-114.

Baedecker, P.A., Reddy, M.M., Reimann, K.J., Sciammarella, C.A., and Sherwood, S.A., 1992, Effects of acidic deposition on the erosion of carbonate stone-Experimental results from the U.S. National Acid Precipitation Assessment Program (NAPAP): Atmospheric Environment, v. 26B, no. 2, p. 147-158.

Baedecker, P.A., Reddy, M.M., Sciammarella, C.A., and Reimann, K.J., 1990, 3.3.3.3 Field experiments-physical measurements of recession-Results and discussion in acidic deposition: State of Science and Technology, Report 19, Effects of Acidic Deposition on Materials, National Acid Precipitation Assessment Program, Washington, D.C., p. 19-125 to 19131.

Ephraim, J.H., Reddy, M.M., and Marinsky, J.A., 1991, Ion binding by humic substances: Considerations based on the solution chemistry and heterogeneity of humic substances, in Lecture
Notes in Earth Sciences, No. 33, Humic Substances in the Aquatic and Terrestrial Environment: International Symposium, Linkoping, Sweden, August 21-23, 1989, [Proceedings], p. 263-275.

Johnsson, P. A., and Reddy, M.M., 1990, A monitor for continuous measurement of temperature, $\mathrm{pH}$, and conductance of wet precipitation, Preliminary results from the Adirondack Mountains, New York: Atmospheric Environment, v. 24A, No. 1, p. 233-236.

Leenheer, J.A., Wershaw, R.L., and Reddy, M.M., 1992, Strong-acid, carboxyl-group structures in fulvic acid from the Suwannee River, Georgia: American Chemical Society Meeting, Division of Environmental Chemistry, Denver, Colo., March 29-April 3, 1993, p. 25-27.

Marinsky, J.A., and Reddy, M.M., 1991, Employment of Gibbs-Donnan-based concepts for interpretation of the properties of linear polyelectrolyte solutions: Journal of Physical Chemistry, v. 95 , no. 24 , p. 10208-10214.

1991, Vapor-pressure osmometric study of the molecular weight and aggregation tendency of 


\section{SURFACE-WATER CHEMISTRY}

a reference-soil fulvic acid: Analytica Chimica Acta, v. 232, p. 123-130.

1989, Effects on carbonate-dissolution-runoff experiments in materials and cultural resource effects, Task Group VII, Research Program, Washington, D.C., in Proceedings of Materials and Cultural Resources Effects Program Review: National Acid Precipitation Assessment Program, the Interagency Task Force on Acid Precipitation, Charleston, S.C., January 22-27, 1989, p. 221-228.

1989, Preserving and protecting monuments and historical sites: Environmental Science and Technology, v. 23, no. 3, pp. 264-265.

1991, Acid rain and air pollution effects on carbonate-stone-Dissolution-runoff experiments in the conservation of monuments, in Zezza, Fulvia, ed., the Mediterranean Basin: Proceedings of the 1st International Symposium, Bari, Italy, p. 359-364.

1991, Field experiments, run-off measurements, experimental methods, in Acidic deposition: State of science and technology, report 19, Effects of acidic deposition on materials, National Acid Precipitation Assessment Program, Washington, D.C., p. 19-108 to $19-110$.

1991, Soil analysis-Modern instrumental techniques, second edition, book review: Journal of the American Chemical Society, v. 113, no. 26, p. 9910 .

Reddy, Michael M., 1989, Ancient works, monuments and historical sites: EOS, February 21, p. 114.

1994, Materials science and technology, a comprehensive treatment, volume $2 \mathrm{~A}$, Characterization of Materials Part I-Book review:
Journal of the American Chemistry Society, v. 116 , no. 4, p. 1601 .

Reddy, M.M., and Baedecker, P.A., 1991, Field experiments-run-off measurements-Results and discussion, in Acidic Deposition: State of Science and Technology, Report 19, Effects of Acidic Deposition on Materials, National Acid Precipitation Assessment Program, Washington, D.C., p. 19-110 to 19-121.

Reddy, M.M., and Caine, Nel, 1989, A small alpine basin budget-Front Range Colorado, in Poppoff, I.G., Goldman, C.R., Loeb, S.L. and Leopold, L.B., eds., International Mountain Watershed Symposium-Subalpine Processes and Water Quality, Tahoe Resource Conservation District, South Lake Tahoe, Calif., p. 370-385.

Reddy, M.M., Leenheer, J.A. and Malcolm, R.L., in press, Elemental analysis and heat of combustion of a Suwannee River fulvic acid, in Humic Substances in the Suwannee River, Florida and Georgia-Interactions, Properties and Proposed Structure: U.S. Geological Survey Water Supply Paper.

Reddy, M.M., and Leith, S.D., 1993, Dry deposition of sulfur to limestone and marble-Preliminary evaluation of a process based model: Division of Environmental Chemistry, American Chemical Society National Meeting, Denver, Colo., March 29-April 23, 1993, p. 4346.

Reddy, M.M., and Mossotti, V.G., 1990, Stone wetness and water transport in limestone in acidic deposition: State of Science and Technology, Report 19, Effects of Acidic Deposition on Materials, National Acid Precipitation Assessment Program, Washington, D.C., p. 19-145 to 19-146. 


\section{SURFACE-WATER CHEMISTRY}

Reddy, M.M., Schuster, P.F., and Harte, J.J., 1989 , Summary of data from onsite and laboratory analysis of precipitation runoff from carbonate-stone surfaces, National Acid Precipitation Assessment Program, June 1984 to November 1987: U.S. Geological Survey Open-File Report 89-246, 19 p.

Schuster, P.F., Reddy, M.M., and Sherwood, S.I., 1992, A quantitative field study of the role of acid rain and sulfur dioxide in marble dissolution: Proceedings of the 2nd International Symposium for the Conservation of Monuments in the Mediterranean Basin, Geneva, Switzerland, November 19-21, 1991, p. 257266.

Schuster, P.F., Reddy, M.M., and Sherwood, S.I., 1994, Effects of acid rain and sulfur dioxide on marble dissolution: Materials Performance, v. 33 , no. 1 , p. $76-80$.

Tipping, E., Reddy, M.M., and Hurley, M.A., 1990, Modeling electrostatic and heterogeneity effects on proton dissociation from humic substances: Environmental Science and Technology, v. 24 , no. 11 , p. $1700-1705$. 


\section{SURFACE-WATER CHEMISTRY}

TITLE: $\quad$ Comprehensive Organic Analysis of Water (CR 84-285)

PERSONNEL: Jerry A. Leenheer, Project Chief

Cathy M. Rubin, Secretary

Gregory K. Brown, Chemist

Larry B. Barber, Geologist

Charles F. Tabor, Student, Unvi. of Colorado

Ted I. Noyes, Chemist

ADDRESS: U.S. Geological Survey

P.O. Box 25046, MS 408

Denver Federal Center

Denver, CO 80225

TELEPHONE: (303) 467-8290

PROBLEM: A disproportionate amount of research in water chemistry has been directed towards defining trace levels of organic contaminants in water, whereas the structures and characteristics of natural organic substances, in the dissolved, suspended, and bed sediment phases, are very poorly understood. A better knowledge of the nature of natural organic substances in water is essential to the advancement of many diverse sciences, such as organic geochemistry, aquatic biology, soil science, hydrology involving contaminant transport, and even atmospheric chemistry involving carbon cycle research. The Water Resources Division is conducting significant research on the nature of humic substances in water, which comprise less than one-half of the total organic carbon in water; a comprehensive study of the entire suite of compound classes comprising natural organic substances has been lacking.

OBJECTIVE: Conduct comprehensive organic analyses of various surface-water samples where comprehensive analyses is defined as "state-of-the-art" organic analyses on as many classes (humic substances, lipids, proteins, carbohydrates, etc.) as possible within the time and resource limitations of the project. Develop chromatographic, selective extraction, and derivatization methods for organic substance characterization by infrared, nuclear magnetic resonance, and mass spectrometric methods. Define the chemical, biologic, and hydrologic processes that both produce and diagenetically alter natural organic substances in water. Conduct interdisciplinary studies with colleagues to determine significance and mechanisms of contaminant binding with natural organic substances.

APPROACH: Characterize phytoplanktonic inputs to natural organic substances in fresh water (Island Lake, Nebraska) and saline water (Big Soda Lake, Nevada); study terrestrial vegetative contributions in the Suwannee River in southern Georgia, a subtropical 


\section{SURFACE-WATER CHEMISTRY}

environment, and in the Sagavanirtok River of Alaska, an arctic environment. Determine spatial and seasonal differences of organic substances in the dissolved, suspended, and bed sediment phases in the Mississippi River, an integrating environment, to determine the nature and importance of these various organic phases with regards to contaminant interactions and transformations. Apply techniques used to characterize natural organic substances to study organic contaminant transport processes in ground water at Cape Cod, Massachusetts, and in the Mississippi River. If unknown organic contaminants are discovered during the above studies, characterize and quantify the contaminants.

PROGRESS: The major activity for the year was to begin a study of organic matter and organic contaminant transformations in secondary-treated sewage in a constructed wetland near Hemet, California, and in ground water after basin-infiltration at the Pico Rivera site in Los Angeles, California. The dissolved organic carbon (DOC) fractionation procedure, used to assess organic matter transport and transformations in sewage waste waters, was automated by adapting a Millilab Robotics System to the procedures and resin adsorbents used in DOC fractionation. The initial sampling of the constructed wetland site found that more organic matter was exported than input from the wetland, and there was minimal biodegradation of biodegradable detergents because of the anaerobic conditions in the wetlands. An experiment conducted during the initial flooding and infiltration phase at the Pico Rivera site also found limited removal of organic contaminants by biodegradation; organic polyethoxylate surfactants were removed during infiltration by sorption on aquifer sands and gravels. Dissolved organic carbon fractionation assays of sewage at both sites found the neutral fraction percentages in sewage to be much greater than found in natural DOC, and only small changes were found in the DOC fractionation patterns during transport.

At the Cape Cod Toxic Waste Site, a biodegradable surfactant (LAS) was injected with a number of conservative tracers into the anaerobic portion of the sewage plume. Analyses of samples taken during the migration of LAS in ground water showed that LAS was slightly retained by sorption processes, but that there was no detectable biodegradation as assessed by changes in homologue and isomer composition. This experiment substantiates the conclusions about limited biodegradation of surfactants in sewage waste-waters in anaerobic environments being studied at the California sites.

Bed sediments in the 26 navigation pools of the Upper Mississippi River were resampled and analyzed for coprostanol, LAS surfactants, and polynuclear aromatic hydrocarbons. This study was conducted to determine the effect of the 1993 flood on bed sediment contaminants previously analyzed in the 1991-1992 study. 


\section{SURFACE-WATER CHEMISTRY}

An ongoing research study of organic functional groups that contribute to the metal-binding properties of fulvic acid from the Suwannee River, Georgia, found that carboxyl, phenol, ether, and ketone functional groups in close proximity to each other likely formed complex chelate structures in which all of these functional groups simultaneously participate within a fulvic-acid molecule in binding metals. Chromatographic fractionations of this fulvic acid found that these metal-binding characteristics are a major property of fulvic acid rather than a small component of the mass with large-metal binding constants.

\section{REPORTS PUBLISHED 1989-1994:}

Aiken, G., and Leenheer, J.A., 1993, Isolation and chemical characterization of dissolved and colloidal organic matter: Chemistry and Ecology, v. 8 , p. 135-151.

Barber, L.B., II, 1990, Geochemical heterogeneity in a glacial outwash aquifer: Effect of particle size and mineralogy on sorption of nonionic organic solutes: Boulder, Colo., University of Colorado, Ph.D. Thesis, 237 p.

1991, Effects of particle size and mineralogy on sorption of nonionic organic solutes to glacial outwash sediments, Cape Cod, Massachusetts, in Mallard, G.E., and Aronson, D.A., eds., U.S. Geological Survey Toxic Substances Hydrology Program-Proceedings of the technical meeting, Monterey, Calif., March 11-15, 1991: U.S. Geological Survey, Water-Resources Investigations Report 914034, p. 111-115.

Barber, L.B., II, 1994, Sorption of chlorobenzenes to Cape Cod aquifer sediments: Journal of Environmental Science and Technology, v. 28, p. $890-897$.

Barber, L.B., and Leenheer, J.A., 1991, Use of azaarene tracers to evaluate fracture flow from an in situ oil shale retort, Rock Springs, Wyoming, in Mallard, G.E., and Aronson, D.A., eds., U.S. Geological Survey Toxics Sub- stances Hydrology Program-Proceedings of the technical meeting, Monterey, Calif., March 11-15, 1991: U.S. Geological Survey Water-Resources Investigations Report 914034, p. 175-182.

Barber, L.B., II, Leenheer, J.A., Pereira, W.E., and Noriega, M.A., in press, Effects of organic contaminants in municipal and industrial wastewaters on the quality of water and streambed sediments in the Mississippi River, in Morganwalp, D.W., and Aronson, D.A., eds., U.S. Geological Survey Toxic Substances Hydrology Program-Proceedings of the technical meeting, Colorado Springs, Colo., September 20-24, 1993: U.S. Geological Survey Water-Resources Investigations Report 94-4014.

Barber, L.B., II., Thurman, E.M. Field, J.A., LeBlanc, D.R., Smith, R.L., and Harvey, R.W., 1991, Biogeochemical fate of organic compounds in sewage-contaminated groundwater, Cape Cod, Massachusetts, in Mallard, G.E., and Aronson, D.A., eds., U.S. Geological Survey Toxic Substances Hydrology program-Proceedings of the technical meeting, Monterey, Calif., March 11-15, 1991: U.S. Geological Survey Water-Resources Investigations Report 91-4034, p. 102-105. 


\section{SURFACE-WATER CHEMISTRY}

Barber, L.B., II, Thurman, E.M., and Runnells, D.D., 1992, Geochemical heterogeneity in a sand and gravel aquifer-Effects of sediment mineralogy and particle size on the sorption of chlorobenzenes: Journal of Contaminant $\mathrm{Hy}-$ drology, v. 9, p. 35-54.

Barber, L.B., II, Thurman, E.M., Takahashi, Y., and Noriega, M., 1991, Purgeable organic chloride-A surrogate measurement for screening and monitoring volatile chlorinated hydrocarbons in ground water, in Mallard, G.E., and Aronson, D.A., eds., U.S. Geological Survey Toxic Substances Hydrology Program-Proceedings of the technical meeting, Monterey, Caif., March 11-15, 1991: U.S. Geological Survey Water-Resources Investigations Report 91-4034, p. 106-110.

Brown, P.A., and Leenheer, J.A., 1989, Significance of density determination in molecular structures comprising fulvic acid from the Suwannee River, in Averett, R.C., Leenheer, J.A., McKnight, D.M., and Thorn, K.A., eds., Humic Substances in the Suwannee River, Georgia-Interactions, Properties, and Proposed Structures: U.S. Geological Survey Open-File Report 87-557, p. 311-330.

Buszka, P.M., Barber, L.B., II, Schroeder, M.P., and Becker, L.D., in press, Determination of organic compounds downstream from a treated-wastewater discharge, March 1987, near Dallas, Texas: U.S. Geological Survey Water-Resource Investigations Report 934104.

Field, J.A., 1990, Fate and transformations of surfactants in sewage-contaminated groundwater, Golden, Colo., Colorado School of Mines, Ph.D. Thesis, 207 p.

Field, J.A., Barber, L.B., II, Leenheer, J.A., Rostad, C.E., and Thorn, K.A., 1991, Persis- tence of linear alkylbenzenesulfonates and their metobolites in sewage-contaminated ground water, in Mallard, G.E., and Aronson, D.A., eds., U.S. Geological Survey Toxic Substances Hydrology Program-Proceedings of the technical meeting, Monterey, Calif., March 11-15, 1991: U.S. Geological Survey Water-Resources Investigations Report 914034, p. $116-122$.

Field, J.A., Barber, L.B., II, Thurman, E.M., Moore, B.L., Lawrence, D.L., and Peake, D.A., 1992, Fate of alkylbenzenesulfonates and dialkytetralinsulfonates in sewage-contaminated groundwater: Environmental Science and Technology, v. 26, p. 1140-1147.

Field, J.A., Leenheer, J.A., Thorn, K.A., Barber, L.B., II, Rostad, C.E., Macalady, L.L., and Daniel, S.R., 1992, Comprehensive approach for identifying anionic surfactant-derived chemicals in sewage effluent and ground water: Journal of Contaminant Hydrology, v. 9, p. 55-78.

Harvey, R.W. and Barber, L.B., II, 1992, Associations of free-living bacteria and dissolved organic compounds in a plume of contaminated groundwater: Journal of Contaminant Hydrology, v. 9, p. 91-103.

Harvey, R.W., Smith, R.L., Barber, L.B., II, Metge, D.W., Scholl, M.A., and Garabedian, S.P., 1991, The role of physical and chemical heterogeneity in the interpretation of smallscale tracer tests involving micro-organisms, in Mallard, G.E., and Aronson,D.A., eds., U.S. Geological Survey Toxic Substances Hydrology Program-Proceedings of the technical meeting, Monterey, Calif., March 1115, 1991: U.S. Geological Survey WaterResources Investigations Report 91-4034, p. 148-151. 


\section{SURFACE-WATER CHEMISTRY}

Johnson, K.L., and Leenheer, J.A., 1991, Geochemical controls on resuspension and redeposition of contaminated bed sediments by freshwater inputs into the lower Calcasieu River, in Mallard, G.E., and Aronson, D.A., eds., U.S. Geological Survey Toxics Substances Hydrology Program-Proceedings of the technical meeting, Monterey, Calif., March 11-15, 1991: U.S. Geological Survey WaterResources Investigations Report 91-4034, p. 591-596.

Leenheer, J.A., 1989, Implications of mixture characteristics on humic substance chemistry, in Suffet, I.H., and MacCarthy, P., eds., Aquatic Humic Substances-Influence on Fate and Treatment of Pollutants: Advances in Chemistry Series 219, Washington, D.C., American Chemical Society, chapter 3, p. 41-54.

1989, Methods for determination of structural models of fulvic acid by convergent independent analyses, in Averett, R.C., Leenheer, J.A., McKnight, D.M., and Thorn, K.A., eds., Humic Substances in the Suwannee River, Georgia-Interactions, Properties, and Proposed Structures: U.S. Geological Survey Open-File Report 87-557, p. 135-146.

1991, Organic substance structures that facilitate contaminant transport and transformations in aquatic sediments, in Baker, R.A., ed., Organic Substances and Sediments in Water, Humics and Soils: Chelsea, Michigan, Lewis Publishers, Chapter 1, v. 1, p. 3-22.

1992, Book Review of Allard, B., Boren, H., and Grimvall, A., eds., Humic Substances in the Aquatic and Terrestrial Environment: Journal of Environmental Quality, v. 21, no. 2, p. 291.

in press, Chemistry of dissolved organic matter in rivers, lakes, and reservoirs, in Baker,
L.A., ed., Environmental chemistry of lakes and reservoirs: Washington, D.C., American Chemical Society, Advances in Chemistry Series no. 237.

1994, Chemistry of dissolved organic matter in rivers, lakes, and reservoirs, in Baker, L.A., ed., Environmental Chemistry of Lakes and Reservoirs: Washington, D.C., American Chemical Society, Advances in Chemistry Series 237, p. 195-222.

Leenheer, J.A., McKnight, D.M., Thurman, E.M., and MacCarthy, P., 1989, Structural components and proposed structural models of fulvic acid from the Suwannee River, in Averett, R.C., Leenheer, J.A., McKnight, D.M., and Thorn, K.A., eds., Humic Substances in the Suwannee River, Georgia-Interactions, Properties, and Proposed Structures: U.S. Geological Survey Open-File Report 87-557, p. 331360.

Leenheer, J.A., Meade, R.H., Taylor, H.E., and Pereira, W.E., 1989, Sampling, fractionation, and de-watering of suspended sediment from the Mississippi River for geochemical and trace-contaminant analysis, in Mallard, G. E, and Ragone, S. E., eds., U.S. Geological Survey Toxic Substances Hydrology ProgramProceedings of the technical meeting, Phoenix, Ariz., September 26-30, 1988: U.S. Geological Survey Water-Resources Investigations Report 88-4220, p. 501-512.

Leenneer, J.A., and Noyes, T.I., 1989, Derivatization of humic substances for structural studies, in Hayes, M.H.B., MacCarthy, P. Malcolm, R.L., and Swift, R.S., eds., Humic Substances II-In Search of Structure: Chichester, England, John Wiley and Sons, p. 257-280. 


\section{SURFACE-WATER CHEMISTRY}

Leenheer, J.A., Wershaw, R.L., Brown, P.A., and Noyes, T.I., 1991, Detection of polyethyleneglycol residues from nonionic surfactants in surface water by ${ }^{1} \mathrm{H}$ - and ${ }^{13} \mathrm{C}$-nuclear magnetic resonance spectrometry: Environmental Science and Technology, v. 25, p. 161-168.

Metge, D.W., Harvey, R.W., Aiken, G.R., and Barber, L.B., II, in press, Use of static column experiments to identify factors affecting bacterial attachment in contaminated aquifer sediments, in Morganwalp, D.W., and Aronson, D.A., eds., U.S. Geological Survey Toxic Substances Hydrology Program-Proceedings of the technical meeting, Colorado Springs, Colo., September 20-24, 1993: U.S. Geological Survey WaterResources Investigations Report 94-4014.

Noyes, T.I., and Leenheer, J.A., 1989, Proton nuclear magnetic resonance studies of fulvic acid from the Suwannee River, in Averett, R.C., Leenheer, J.A., McKnight, D.M., and Thorn, K.A., eds., Humic Substances in the Suwannee River, Georgia-Interactions, Properties, and Proposed Structures: U.S. Geological Survey Open-File Report 87-557, p. 231250.

Reddy, M.M., Leenheer, J.A., and Malcolm, R.L., 1989, Elemental analysis and heat of combustion of fulvic acid from the Suwannee River, in Averett, R.C., Leenheer, J.A., McKnight, D.M., and Thorn, K.A., eds., Humic Substances in the Suwannee River, GeorgiaInteractions, Properties, and Proposed Structures: U.S. Geological Survey Open-File Report 87-557, p. 147-162.

Rees, T.F., Leenheer, J.A., and Ranville, J.F., 1991, Use of a single-bowl continuous-flow centrifuge for de-watering suspended sediments-Effect on sediment physical and chemi- cal characteristics: Hydrological Processes, v. 5, p. 201-214.

Spitzy, A., and Leenheer, J.A., 1991, Dissolved organic carbon in rivers, in Degens, E.T., Kempe, S., and Richey, J.F., eds., Biogeochemistry of Major World Rivers: New York, John Wiley and Sons, chapter 9, p. 213-232.

Tabor, C.F., 1993, The occurrence and fate of linear alkylbenzene sulfonate in the Mississippi River: A molecular indicator of sewage contamination: Boulder, Colo., University of Colorado, M.S. Thesis, $78 \mathrm{p}$.

Tabor, C.F., Jr., and Barber, L.B., II, in press, Linear alkylbenzene sulfonate in the Mississippi River, in Morganwalp, D.W., and Aronson, D.A., eds., U.S. Geological Survey Toxic Substances Hydrology Program-Proceedings of the technical meeting, Colorado Springs, Colo., September 20-24, 1993: U.S. Geological Survey Water-Resources Investigations Report 94-4014.

Writer, J.H., 1992, Sewage contamination in the Upper Mississippi River as measured by the fecal sterol coprostanol: Boulder, Colo., University of Colorado, M.S. Thesis, $99 \mathrm{p}$.

Zepp, R.G., Braun, A.M., Hoigne, Jurg, and Leenheer, J.A., 1989, Photoproduction of hydrated electrons from natural organic solutes in aquatic environments: Environmental Science and Technology, v. 21 , no. 5, p. 485-489. 


\section{SURFACE-WATER CHEMISTRY}

TITLE: $\quad$ Transport and Degradation of Organic Substances in Streams (CR 77-301)

PERSONNEL: Ronald E. Rathbun, Project Chief

Nora L. Bender, Secretary

Colleen E. Rostad, Research Chemist

P.W. Mahan, Student, Colorado School of Mines

ADDRESS: $\quad$ U.S. Geological Survey

P.O. Box 25046, MS 408

Denver Federal Center

Denver, CO 80225

TELEPHONE: (303) 467-8250

PROBLEM: Organic substances in streams affect the quality and uses of the water. To determine the effect of organic substances on water quality, the physical, chemical, and biological processes involved in the transport and degradation of these substances must be understood. Procedures for measuring or estimating the rate coefficients describing these processes must be developed. Models incorporating these coefficients then must be developed for predicting the fate of organic substances in streams and their effects on water quality.

OBJECTIVE: (1) Study the fundamentals of volatilization, dispersion, and sorption on sediments of organic substances in water; (2) develop submodels of these processes, including methods for measuring or estimating the process rate coefficients; and (3) integrate these submodels into overall transport and fate models for organic substances in streams.

APPROACH: (1) Conduct controlled laboratory studies to determine the volatilization and sediment sorption of specific organic compounds, both as single components and as mixtures; (2) conduct controlled field studies to test, adapt, and (or) develop transport and fate models for organic substances in streams; and (3) apply the models to field problems.

PROGRESS: Samples of suspended sediment collected at Thebes, Illinois, in July during the 1993 Mississippi River flood indicated transport rates of total polychlorinated biphenyls (PCBs), hexachlorobenzene, dachtal, and pentachloroanisole that were about 7, 12, 5, and 9 times larger than the highest previously observed transport rates for these compounds in June of 1990 and May of 1988. Samples from August and September indicated rates decreasing with time and much smaller rates, although the September rates were still 2.0, 2.3, 1.2, and 1.5 times larger than the highest previously observed transport rates. Conversely, the July 


\section{SURFACE-WATER CHEMISTRY}

transport rate for the herbicide trifluralin was only about half the highest previously observed transport rate in June of 1990 when the Missouri River was at flood stage.

Regression analysis of trihalomethane and nonpurgeable total organic-halide formation potential data for the Mississippi River indicated that $\mathrm{pH}$ and dissolved organic-carbon concentration were the most significant variables in the prediction of the formation potentials. The free-chlorine concentration had some effect, the bromide concentration had virtually no effect, and it was not considered in the final analysis. The trihalomethane formation potentials for the summer, fall, and spring sampling trips were predicted with root-meansquare errors of $8.35,8.72$, and 7.32 percent, the nonpurgeable total organic-halide formation potentials with errors of $12.9,11.4$, and 10.7 percent.

Eight experiments on the effect of the size of the dissolved organic carbon on the trihalomethane and nonpurgeable total organic-halide formation potentials were completed. The dissolved organic carbon in samples from four sites for the fall and spring sampling trips was broken into size classes using ultrafiltration. Preliminary analysis of the data indicates that the smaller sizes of the dissolved organic carbon had the highest formation potentials.

A study of the distribution, transport, and persistence of total organic halide compounds in a California wetlands being recharged with reclaimed water was initiated, and one set of total organic halide and trihalomethane samples was collected and analyzed.

A study of the application of the semipermeable membrane device for modeling the uptake by fish of agricultural and industrial organic contaminants in the upper Mississippi River was completed. Concentrations of the contaminant compounds in the membrane devices were in relatively good agreement with concentrations of these compounds in ultrafilter permeates of the same water. However, concentrations in caged fish were not proportional to the water concentrations, apparently because of the relatively high metabolism and depuration rates of these compounds in the fish.

\section{REPORTS PUBLISHED 1989-1994:}

Bishop, L.M., Rostad, C.E., Pereira, W.E., and Leiker, T.J., in press, Data for selected organic contaminants in the Mississippi and Ohio Rivers near their confluence, June 1989 and May-June 1990: U.S. Geological Survey Open-File Report 93-371.
Kilpartick, F.A., Rathbun, R.E., Yotsukura, N., Parker, G.W., and DeLong, L.L., 1989, Determination of stream reaeration coefficients by use of tracers: U.S. Geological Survey Techniques of Water-Resources Investigations, book 3, chap. A18, 52 p. 


\section{SURFACE-WATER CHEMISTRY}

Rathbun, R.E., 1989, Discussion of Effect of temperature on oxygen transfer-Laboratory studies: American Society of Civil Engineers Journal of Environmental Engineering, v. 115, no. 2, p. 482-484.

1990 , Prediction of stream volatilization coefficients: American Society of Civil Engineers Journal of Environmental Engineering, v. 116, no. 3 , p. 615-631.

1992, Discussion of Aeration at Ohio River basin navigation dams: American Society of Civil Engineers Journal of Environmental Engineering, v. 118, no. 3, p. 446-447.

1992, Discussion of Gas-transfer measurements using headspace analysis of propane: American Society of Civil Engineers Journal of Environmental Engineering, v. 118, no. 3, p. 454-456.

Rathbun, R.E., in press, Trihalomethane and nonpurgeable total organic-halide formation potentials for the Mississippi River and some of its tributaries, March-April 1992: U.S. Geological Survey Open-File Report 94-336.

Rathbun, R.E., and Bishop, L.M., 1993, Trihalomethane and nonpurgeable total organic halide formation potentials for the Mississippi River and some of its tributaries, June-August 1991: U.S. Geological Survey Open-File Report 93-158, $57 \mathrm{p}$.

Rathbun, R.E., and Bishop, L.M., in press, Trihalomethane and nonpurgeable total organichalide formation potentials for the Mississippi River and some of it tributaries, SeptemberOctober 1991: U.S. Geological Survey OpenFile Report 94-36.

Rathbun, R.E., Shultz, D.J., Stephens, D.W., and Tai, D.Y., 1989, Transport and fate of acetone in an outdoor model stream, Stennis Space Center near Bay St. Louis, Mississippi: U.S. Geological Survey Water-Resources Investigations Report 89-4141, 101 p.
Rathbun, R.E., Stephens, D.W., Shultz, D.J., and Tai, D.Y., 1989, Fate of acetone in an outdoor model stream in southern Mississippi, U.S.A.: Journal of Hydrology, v. 104, p. 181-209.

Rathbun, R.E., Stephens, D.W., and Tai, D.Y., 1991, Fate of acetone in an outdoor model stream with a nitrate supplement, southern Mississippi, U.S.A.: Journal of Hydrology, v. 123, p. 225-242.

1993, Bacterial degradation of acetone in an outdoor model: Stream Environmental Pollution, v. 79, p. 153-162.

Rathbun, R.E., White, K.D., and Evaldi, R.D., 1992, Trihalomethane formation potential of Kentucky River water: U.S. Geological Survey Water-Resources Investigations Report 92 4057, $16 \mathrm{p}$.

Rostad, C.E., Bishop, L.M., Ellis, G.S., Leiker,T.J., Monsterleet, S.G., and Pereira, W.E., in press, Organic contaminants on suspended sediment collected during five cruises of the Mississippi River and it principal tributaries, May 1988 to June 1990: U.S. Geological Survey Open-File Report 93-360.

Rostad, C.E., and Pereira, W.E., 1991, Distribution of selected anthropogenic organic compounds on suspended sediments in the Mississippi River, in Mallard, G.E., and Aronson, D.A., eds., U.S. Geological Survey Toxic Substances Hydrology Program-Proceedings of the technical meeting, Monterey, Calif., March 11-15, 1991: U.S. Geological Survey Water-Resources Investigations Report 914034, p. 347-348. 


\section{SURFACE-WATER CHEMISTRY}

TITLE: $\quad$ Sediment-Water Chemistry in Large River Systems: Biogeochemical, Geomorphic, and Human Controls (CR 88-313)

PERSONNEL: Robert F. Stallard, Project Chief

Elizabeth L. Callahan, Secretary

Ellen Axtmann, Hydrologist

Deborah A. Martin, Hydrologist

Eli D. Esser, Student (University of Colorado)

John E. Ewing, Student (University of Colorado)

ADDRESS: $\quad$ U.S. Geological Survey

P.O. Box 25046, MS 413

Denver Federal Center

Denver, CO 80225

TELEPHONE: (303) 541-3022

PROBLEM: Rivers are a major pathway to the ocean for erosion products and human wastes. The mechanisms that control the composition of river-borne materials are only imperfectly understood because erosion and the subsequent transport of material by rivers are mediated by a wide variety of closely linked chemical, biological, and physical processes. Moreover, in developed river systems such as those in the United States, these processes are subject to pervasive human-related perturbations. There is a need to develop, through field and theoretical studies, a comprehensive and integrated description of these processes for large river systems in a form that is useful to researchers in many disciplines.

OBJECTIVE: Describe how the biogeochemical and physical aspects of erosion and transport processes are reflected in the composition of river-borne materials for particular large river systems and develop general theoretical models that can be applied to rivers in general; evaluate the extent to which human activity has affected the river systems. Study how various chemical phases, natural or human-introduced, organic or inorganic, are partitioned between solid and dissolved loads in rivers and estuaries as the result of weathering, particlesurface reactions, biological uptake or release, atmospheric exchange, and storage during transit. Evaluate the dispersal pathways of river-borne substances through river systems and estuaries into and across the coastal marine environment.

APPROACH: Assemble, primarily from maps and data bases, current and historic chemical, geomorphic, biological, and demographic data for an entire river system. Identify phenomena that are especially important in controlling the composition of phases containing the major elements $(\mathrm{H}, \mathrm{C}, \mathrm{O}, \mathrm{Na}, \mathrm{Mg}, \mathrm{Al}, \mathrm{Si}, \mathrm{S}, \mathrm{Cl}, \mathrm{K}, \mathrm{Ca}, \mathrm{Ti}, \mathrm{Fe})$ and certain minor 


\section{SURFACE-WATER CHEMISTRY}

indicator elements $(\mathrm{N}, \mathrm{F}, \mathrm{P}, \mathrm{Mn}, \mathrm{Sr}, \mathrm{Zr}$ ) to provide the conceptual framework for solving specific research objectives. Undertake field surveys, design sampling and analytical procedures, and create computer tools to manipulate and model data as part of these investigations. Formulate small scale field and laboratory studies to aid data interpretation as deemed necessary.

PROGRESS: During Fiscal Year 1994, project efforts encompassed four related areas: research related to the Water, Energy, and Biogeochemical Budgets (WEBB) Project in eastern Puerto Rico and related work in Panama; (2) similar watershed research in the basin of South Cascade Glacier in Washington; (3) characterization of terrestrial sedimentation and its relationship to the carbon cycle; and (4) development and testing of methodologies for extrapolating from regional geomorphic and biogeochemical studies to the global scale. During Fiscal Year 1994, two important basic research papers were published. One, in the Journal of Geophysical Research with Michael Keller describes the process of methane emission from Gatun Lake, a tropical lake in Panama. The model shows that methane emission is largely through bubbling. Maximum bubbling appears to be triggered by afternoon winds. Total bubble emission is inversely related to water depth. The other is an Open-file Report that describes the philosophy and approach to the Water, Energy, and Biogeochemical Budgets (WEBB) research in Puerto Rico.

Research in Puerto Rico and Panama is part of the USGS Global Change Program. Sites are in northeastern Puerto Rico, at the Luquillo Experimental Forest, and in central Panama, at the Barro Colorado Nature Monument. The Smithsonian Tropical Research Institute shares funding for the work in Panama. These studies are designed to compare geologically matched natural and developed environments. The studies of weathering and erosion use long-term chemical sampling and physical monitoring to characterize the processes that control the distribution and transport of major, important-minor, and nutrient elements through soils, downslope, and out of the watershed. Exchange of methane and carbon dioxide with the atmosphere is being studied. Phenomena of interest to global-change research include the fixation, storage, and export of carbon and nutrients as related to biogeochemical and geomorphic processes within the watersheds. During Fiscal Year 1994, periodic and event sampling of rivers and periodic sampling of precipitation, soil water, surficial runoff and gases continued. During Fiscal Year 1994, fieldwork focussed mostly on gases. This includes field campaigns that have studied gas emissions from farm ponds and from the Loiza Reservoir. Carbon dioxide, oxygen, and methane have been studied in soils. In addition Be-10 was used to estimate erosion rates and characterize erosion in a manner that is not dependent on long-term watershed budgets. 


\section{SURFACE-WATER CHEMISTRY}

Work in the South Cascade Glacier basin is designed to study weathering and erosion in a wet glacial basin and examine glacial hydrology. Runoff rates and bedrock are similar to sites in Puerto Rico, but chemical weathering here is minimally influenced by biology. Several major hypotheses are being tested to gain understanding of the impact of chemical weathering on atmospheric carbon dioxide for glacial and tectonic (millions of years) time scales. The style of chemical and physical weathering in terrains eroded by warm-based glaciers is not consistent with the model of the weathering of nonglaciated landscapes. Notably, the dissolved load is enriched in potassium and calcium. The breakdown of micas is strongly enhanced; this breakdown may contribute to the $\mathrm{Ge} / \mathrm{Si}$ and $\mathrm{Sr}-87 / \mathrm{Sr}-86$ enrichments in the world ocean described for Pleistocene glaciations.

During Fiscal Year 1994, considerable effort has been devoted to studies of biogeochemical cycles at a global scale. One study focuses on the relation of rates of chemical erosion to runoff and lithology. This work will be published in the Annual Reviews of Earth and Planetary Sciences. The other study examines terrestrial sedimentation and the carbon cycle. Two hypotheses are being examined: 1 . significant amounts of carbon are buried during the deposition of sediments in terrestrial environments; 2 . human modification of hydrologic systems enhances long-term storage of sediments and carbon. During Fiscal Year 1994, the National Inventory of Dams data base, a CD-ROM prepared by the Federal Emergency Management Agency and the Army Corps of Engineers, has been configured into a data base that can be used to study sedimentation behind dams. Additional data bases have been prepared to summarize large lakes and reservoirs, globally. Project members undertook fieldwork in Venezuela and the upper Mississippi to examine sedimentation in river basins being perturbed by human activities.

Puerto Rico and Panama are being used as prototype regions to develop methodologies for extrapolating from small-scale studies to regional and global scales. In Puerto Rico, detailed geographic Information System (GIS) coverage is available and it is being assembled from the area in central Panama that we are examining.

Axtmann continues collaborative work with Water Resources Division, National Research Program and the Montana District, looking at the effects of upstream remediation on metal concentrations in benthic insects and sediments of the Clark Fork River, Montana. Papers are being prepared on these studies. 


\section{SURFACE-WATER CHEMISTRY}

\section{REPORTS PUBLISHED 1989-1994:}

Axtmann, E. V., and Luoma, S. N., 1991, Largescale distribution of metal contamination in fine-grained sediments of the Clark Fork River, Montana: Applied Geochemistry, v. 6, p. 75-88.

Callender, Edward, Kimball, B. A., and Axtmann, E. V., 1991, Transition-metal geochemistry of the upper Arkansas River, Colorado, in Mallard, G.E., and Aronson, D.A., eds., U.S. Geological Survey Toxics Substances Hydrology Program-Proceedings of the technical meeting, Monterey, Calif., March 11-15, 1991: U.S. Geological Survey WaterResources Investigations Report 91-4034.

Harden, J. W., Sundquist, E. T., Stallard, R. F., and Mark, R. K., 1992, Dynamics of soil carbon during deglaciation of the Laurentide Ice Sheet: Science, v. 258, p. 1921-1924.

Jewell, P.W., and Stallard, R.F., 1990, Geochemistry and paleooceanographic setting of central Nevada bedded barites: Journal of Geology, v. 99, p. 151-170.

Jewell, P.W., Stallard, R.F., and Mellor, G.L., 1993, Numerical studies of bottom shear stress and sediment distribution on the Amazon continental shelf: Journal of Sedimentary Petrology, v. 63, p. 734-745.

Johnsson, M.J. and Stallard, R.F., 1989, Physiographic controls on the composition of sediments derived from volcanic and sedimentary terrains on Barro Colorado Island, Panama: Journal of Sedimentary Petrology, v. 59, p. 768-781.

1990, Physiographic controls on the composition of sediments derived from volcanic and sedimentary terrains on Barro Colorado Island,
Panama-Reply: Journal of Sedimentary Petrology, v. 60, p. 799-801.

Johnsson, M.J., Stallard, R.F., and Lundberg, Neil, 1990, Petrology of fluvial sands from the Amazonian foreland basin, Peru and Bolivia. Discussion: Geological Society of America Bulletin, v. 102, p. 1727-1729.

1991, Controls on the composition and texture of fluvial sands from a tropical weathering environment: Sands of the Orinoco River drainage basin, Venezuela and Colombia: Geological Society of America Bulletin, v. 103 , p. 1622-1647.

Keller, Michael, and Stallard, R. F., 1994, Methane emission by bubbling from Gatun Lake, Panama: Journal of Geophysical Research, v. 99, p. 8307-8319.

Keller, Michael, Mitre, M.E., and Stallard, R.F., 1990, Consumption of atmospheric methane in soils of central Panama-Effects of agricultural development: Global Biogeochemical Cycles, v. 4 p. 21-27.

Larsen, M.C., Collar, P.D., and Stallard, R. F., 1993, Research plan for the investigation of water, energy, and biogeochemical budgets in the Luquillo Mountains, Puerto Rico: U.S. Geological Survey Open-File Report 92-150, p. 20.

Maest, A.S., Crerar, D.A., Stallard, R.F., and Ryan, J.N., 1990, Metal and nutrient behavior in the Raritan estuary, New Jersey, U.S.A.the effect of multiple freshwater and industrial waste inputs: Chemical Geology, v. 81, p. 133-149. 


\section{SURFACE-WATER CHEMISTRY}

Murnane, R.J., Leslie,, Bret, Hammond, D.E., and Stallard, R.F., 1989, Germanium geochemistry in the Southern California Borderlands: Geochemica et Cosmocimica Acta, v. 53, p. 28632882.

Murane, R.J., and Stallard, R.F., 1990, Germanium and silicon in rivers of the Orinoco drainage basin, Venezuela and Colombia: Nature, v. 344 , p. $749-752$.

Stallard, R.F., 1992, Tectonic processes, continental freeboard, and the rate-controlling step for continental denudation, in Global Biogeochemical Cycles, in Butcher, S.S., Charlson, R.J., Orians, G.H., and Wolfe, G.V., eds., Global biogeochemical cycles: New York, Academic Press, p. 93-121.

Stallard, R.F., Koehnken, Lois, and Johnsson, M.J., 1990, Weathering processes and the composition of inorganic material transported through the Orinoco River system, Venezuela and Colombia, in Weibezahn, F.H., Alvarez, Haymara, Lewis, W.M., Jr., eds., El Rio Orinoco como Ecosistema/The Orinoco River as an Ecosystem: Impresos Rubel, C.A., Caracas, Venezuela, p. 81-119.

1991, Weathering processes and the composition of inorganic material transported through the Orinoco River system, Venezuela and Colombia: Geoderma, v. 51, p. 133-165.

Yan, L., Stallard, R.F., Crerar, D.A., and Key, R.M., 1992, Experimental evidence on the behavior of metal-bearing colloids in low-salinity estuarine water: Chemical Geology, v. 100, p. $163-174$.

Yan, Lusheng, Stallard, R.F., Key, R.M., and Crerar, D.A., 1990, The chemical behavior of trace metals and 226Rn during estuarine mixing in the Mullica River estuary, New Jersey,
U.S.A., a comparison between field observations and equilibrium calculation: Chemical Geology, v. 85, p. 369-381.

Yan, Lusheng, Stallard, R.F., Key, R.M., And Crerar, D.A., 1991, Trace metals and dissolved organic carbon in estuaries and offshore waters of New Jersey, U.S.A.: Geochimica et Cosmochimica Acta, v. 55, p. 3647-3656. 


\section{SURFACE-WATER CHEMISTRY}

TITLE: $\quad$ Organic Carbon Migration in Aquatic Environments (CR 93-331)

PERSONNEL: George R. Aiken, Project Chief

Eva Brown, Secretary

Jason Tregellas, Physical Science Aid

ADDRESS: U.S. Geological Survey

3215 Marine Street

Boulder, CO 80303

TELEPHONE: (303)541-3036

PROBLEM: Organic matter in aqueous systems often controls geochemical processes by acting as proton donors/acceptors and $\mathrm{pH}$ buffers, by affecting the transport and degradation of pollutants, and by participating in mineral dissolution/precipitation reactions. To more clearly understand the dynamics of carbon cycling and chemical transport, better definition of geochemical processes as they apply to dissolved organic carbon is required. In particular, understanding the chemical mechanisms controlling the fate and transport of both naturally occurring and anthropogenic compounds in ground water and sediments is needed.

OBJECTIVE: To determine the role of chemical processes associated with bulk dissolved organic carbon (DOC) on the transport of both naturally occurring and anthropogenic compounds. These processes include sorption, partitioning, cosolute enhanced transport and colloidal interaction. To demonstrate that nonvolatile organic acids resulting from the degradation of organic matter are interactive components of aquatic environments. To demonstrate that DOC interactions within a given environment control hydrophobic constituent transport in aqueous systems.

APPROACH: Within the conceptual framework of a chromatographic model, a combined field/laboratory approach will be used to study the factors controlling the movement of organic compounds in groundwater and sediment. Samples from a given site will be collected along flow transects to determine the fundamental chemical properties of both dissolved and sorbed organic matter. Established techniques for the isolation and characterization of organic matter will be used. Laboratory studies will be conducted to examine the attenuation of advective transport of organic compounds by sorption, to investigate a number of potentially important interactions involving DOC and other inorganic and organic constituents in water. 


\section{SURFACE-WATER CHEMISTRY}

PROGRESS: Last year, research continued on the nature of nonvolatile organic acids present in the dissolved organic carbon (DOC) plume downgradient of the oil spill at Bemidji, Minnesota. A novel technique for obtaining cores of subsurface material along with the porewater fluids was employed, allowing the investigation of the vertical distribution of both dissolved and sorbed constituents, the relation of the dissolved constituents to the solid phase, and the effects of small-scale heterogeneity on the chemistry of the plume. In addition, a study of the potential for colloidal phase transport of organic matter was initiated.

Research also continued on the factors controlling the DOC in Williams and Shingobee Lakes (Minnesota). Results to date indicate that the nature of the DOC between the two lakes is different, reflecting the differences in hydrology and sources of DOC between the lakes. The organic matter obtained from the ground water entering Williams Lake, and from the Shingobee River during the spring flush, major inputs of organic matter to each lake, were analyzed. Results of these analyses indicate that these samples differ with respect to aromatic carbon content and molecular weight. Study of the flux of organic matter through the sediments of Williams Lake and in the hyporheic zone in the Shingobee River continued.

Research was begun on two new projects. A study of the factors controlling the transport and fate of organic matter in the Sacramento-San Joaquin Delta has begun in conjunction with the San Francisco Bay-Estuary Toxic Contaminants study group. This study has relevance to the Sacramento River and San Joaquin River National Water Quality Assessment (NAWQA) study units and the San Francisco Bay ecosystem study projects. A study of the role of organic matter in the transport of copper in the Blackstone River, Massachusetts was begun in conjunction with the Massachusetts district. Samples from several locations were processed and analyzed to characterize dissolved humic substances and determine EDTA concentrations.

The results of a study of the dynamics of carbon cycling in Lake Fryxell (Antarctica) suggesting that diffusion of organic matter from the bottom waters and sediments of the lake into the overlying waters is the major source of DOC in the water column of the lake are in the publication stage.

\section{REPORTS PUBLISHED 1989-1994:}

Aiken, G.R., 1992, Chloride interference in the analysis of dissolved organic carbon by the wet oxidation method: Environmental Science and Technology, v. 26, p. 2435-2439.
Aiken, G.R., in press, Studies of the Molecular size of Dissolved Organic Carbon Fractions Downgradient of the Oil Body at Bemidji, Minnesota, in Morganwalp, D.W., and Aronson, D.A., eds., U.S. Geological Survey Toxic Substances 


\section{SURFACE-WATER CHEMISTRY}

Hydrology Program-Proceedings of the Technical Meeting, Colorado Springs, Colorado, September 20-24, 1993: U.S. Geological Survey Water-Resources. Investigations Report.

Aiken, G.R. and Leenheer, J.A., 1993, Isolation and characterization of dissolved and colloidal organic matter, Chemistry and Ecology, v. 8, p. 135-151.

Chin, Y., Aiken, G. and O'Loughlin, E., in press, On the molecular weight, polydispersity and spectroscopic properties of aquatic humic substances: Environmental Science and Technology, v. 00 .

Cozzarelli, I.M., Baedecker, M.J., Aiken, G. and Phinney, C., in press, Small-scale chemical heterogeneities in a crude oil contaminated aquifer, Bemidji, Minnesota, in Morganwalp, D.W. and Aronson, D.A., eds., U.S. Geological Survey Toxic Substances Hydrology ProgramProceedings of the Technical Meeting, Colorado Springs, Colorado, September 20-24, 1993: U.S. Geological Survey Water-Resources Investigations Report.

Eganhouse, R.P., Baedecker, M.J., Cozzarelli, I.M., Aiken, G.R., Thorn, K.A., and Dorsey, T.F., 1993, Crude oil in a shallow sand and gravel aquifer, II. Organic Geochemistry: Applied Geochemistry, v. 8, p. 551-567.

Goldberg, M.C., Cunningham, K.M., Aiken, G.R. and Weiner, E.R., 1992, The aqueous photolysis of a-pinene in solution with humic acid: Journal of Contaminant Hydrology, v. 9, p. 79-89.

McKnight, D.M., Aiken, G.R., Andrews, E.D., Bowles, E.C., and Harnish, R.A., 1993, Dissolved organic material in Dry Valley Lakes-A comparison of Lake Fryxell, Lake Hoare, and Lake Vanda, in Green, W.J. ed., Physical and biogeochemical processes in Antarctic lakes: Washington, D.C., American Geophysical Union, Monograph Series 59, p. 119-133.

McKnight, D.M., Andrews, E.D., Spaulding, S.A., and Aiken, G.R., in press Aquatic fulvic acids in algal-rich antarctic ponds and comparison with samples from other environments: Limnology and Oceanography, v. 00.

Metge, D.W., Harvey, R.W., Aiken, G.R., and Barber, L.B., in press, Use of Static Column Experiments to Identify Factors Affecting Bacterial Attachment in Contaminated Aquifer Sediments from Cape Cod, Massachusetts, in Morganwalp, D.W, G.E., and Aronson, D.A., eds., U.S. Geological Survey Toxic Substances Hydrology Program-Proceedings of the Technical Meeting, Colorado Springs, Colorado, September 20-24, 1993, U.S. Geological Survey Water-Resources Investigations Report. 


\section{SURFACE-WATER CHEMISTRY}

TITLE: $\quad$ Sedimentary Geochemical Processes Affecting the Exchange of Nutrients and Transition Metals Between Sediment and Water in Riverine, Estuarine, and Lacustrine Environments (NR 76-065)

PERSONNEL: Edward Callender, Project Chief

Carol Padgett, Secretary

Ruth Deike, Geologist

Brenda Libby, Chemist

ADDRESS: $\quad$ U.S. Geological Survey

430 National Center

12201 Sunrise Valley Drive

Reston, VA 22092

TELEPHONE: (703) 648-5826

PROBLEM: Benthic-sediment exchange processes are potentially a very significant sourcesink of nutrients and metals within an aquatic system. Too often, the quantitative effects of these processes are only estimated when biogeochemical cycling and ecological responses are being considered. Understanding geochemical processes that control nutrient and transition metal chemistry of natural waters is requisite for predicting the effects that human-induced events will have upon natural geochemical cycles and for determining the use of natural waters as a resource (for example, estuarine waters as food resources).

OBJECTIVE: (1) Study the important geochemical processes affecting the nutrient and metal composition of, and exchange between, sediment and water in several different aquatic environments; (2) aid in developing methods for determining nutrient and metal fluxes between sediment and water; and (3) assess the influence of human activities on natural geochemical cycles.

APPROACH: Sample and analyze surface water, ground water, and sediment-pore water for nutrient and transition-metal content of aqueous phases and associated solid phases. Measure nutrient and metal exchange in natural and laboratory-controlled environments to determine the effects of changing environmental conditions (temperature, salinity, nature of inorganic and organic substrates, bioturbation). Analyze samples by use of colorimetry, ion chromatography, and flame and flameless atomic absorption spectrophotometry. Model results in terms of solution-mineral equilibria, ion exchange, and advective-diffusive transport through porous sedimentary media. 


\section{SURFACE-WATER CHEMISTRY}

PROGRESS: Two papers have been published and two presentations at national meetings have been made concerning geochemistry of Lake Baikal sediments. Callender presented a paper at the American Geophysical Union Ocean Sciences Meeting on biogeochemical phosphorus mass balance in Lake Baikal, Russia, and Lake Superior, North America. Lake Baikal is the world's most voluminous lake and Superior has a very large surface area. Both lakes drain vast areas of igneous and metamorphic rocks. Considering total phosphorus inputs, between 85 and 90 percent accumulates in bottom sediment. The areal loading of total phosphorus to Lake Baikal is twice that of Lake Superior. In Lake Baikal, nearly 95 percent of the biogenic uptake of phosphorus is remineralized and converted to dissolved forms; in Lake Superior, 75 percent is remineralized. Sedimentation of phosphorus appears to be more important in Lake Superior than Lake Baikal. Benthic recycling of sedimented phosphorus is an important process in both lakes; approximately one-half is exchanged with bottom water.

Deike presented a paper at the same meeting detailing sedimentological, mineralogical, and geochemical associations of phosphate-bearing laminae preserved in sediments of Lake Baikal. Hard, red-brown laminae are preserved in iron-rich crusts within sediments ranging in age from recent to Pleistocene. The laminae and crusts are composed of postdepositional digenetic phases, and their accumulation requires a well-established redox boundary that is stabilized at the same depth for long periods of time. From many locations and sediment depths throughout the lake, the laminae exhibit remarkably similar elemental compositions and physical properties even though $\mathbf{x}$-ray diffraction indicates that they are amorphous. Extensive microprobe analyses show that $\mathrm{P}, \mathrm{Ca}$, and $\mathrm{Fe}$ are always present and in similar proportions. These elements are not found as a group in the enclosing sediments. In the laminae, $\mathrm{Ca}$ and $\mathrm{P}$ covary and are inverse to $\mathrm{Fe}$. This compositional association may be caused by either adsorption of a Ca-P aqueous complex onto pre-existing ferric oxyhydroxide or the loss of $\mathrm{Fe}$ from a Ca-P-Fe phase.

A paper describing the geochemical situation for these relics of oxidized ferromanganese crusts in bottom sediments of Lake Baikal was published by Liba Granina, Eugene Karabanov (both of the Limnological Institute, Irkutsk, Russia), and Edward Callender in the seventh volume of the International Project on Paleolimnology and Late Cenozoic Climate (IPPCCE) newsletter. This paper describes the stratigraphic and sedimentologic occurrence of these relict oxidized interbeds and hypothesizes that they formed as a result of decreased sedimentation during the Little "Ice Age Epoch" some 300-700 years ago.

Deike, Webster, and Callender published a paper in Russian Geology and Geophysics (v. 34, no. 10/11, 1993) describing sedimentary changes and authigenic mineralogy of a sediment 


\section{SURFACE-WATER CHEMISTRY}

core from Academician Ridge, Lake Baikal. The sediment is composed of more than 50 percent clay minerals and the ultrafine clay fraction is dominated by well-crystallized dioctahedral aluminous smectite. In oxidized layers, the smectite is associated with excess ferric $\mathrm{Fe}$, amorphous $\mathrm{SiO}_{2}$, and $\mathrm{Mn}$. Sedimentologic analysis of this core has provided detailed characteristics of the last glacial-interglacial (Pleistocene-Holocene) sequence in northern Lake Baikal. Glacial sediments are barren of diatom remains and coarser in grain size; interglacial sediments are fine-grained and contain abundant diatom tests. Work continues on the National Water Quality-Assessment (NAWQA) sediment coring project to predict water-quality trends in reservoir sediments that trap contaminant inputs to drainage basins. A manuscript describing this approach in Lake Livingston, Texas (Trinity River Basin), has been written by Peter Van Metre and Edward Callender. Chemical analyses were performed on bottom sediment cores from three sites with the objective to evaluate trends in water quality of the Trinity River using the chemical record preserved in the bottom sediments. Trends of decreasing (toward the sediment surface) concentrations of nitrogen, sodium, barium, lead, and DDT were identified. Decreasing sodium and barium reflect regulation in the discharge of oil-field brines since the early 1970's. Decreasing lead concentrations reflect decreasing trends in atmospheric lead due to the phasing out of leaded gasoline. Decreasing concentrations of DDT and its metabolites are caused by the national ban on the production and use of DDT imposed in 1972. Nitrogen trends in the cores are similar to temporal trends in phosphorus loads in the Trinity River upstream from the reservoir. Sedimentary nitrogen is an indicator of productivity in the reservoir; the similarity between nitrogen trends and phosphorus loads suggests that productivity is limited by phosphorus which is partially removed by sewage treatment in the Dallas-Fort Worth area.

\section{REPORTS PUBLISHED 1989-1994:}

Callender, E., Ficklin, W.H., Kimball, B.A., and Edelmann, P.P., 1989, Heavy metal geochemistry of sediments in the Pueblo Reservoir, Colorado, in Mallard, G. E, and Ragone, S. E., eds., U.S. Geological Survey Toxic Substances Hydrology Program-Proceedings of the technical meeting, Phoenix, Ariz., September 26-30, 1988: U.S. Geological Survey Water-Resources Investigations Report 88-4220, p. 81-91.

Callender, E., and Granina, L., 1992, Transition metal geochemistry of sedimentary pore fluids associated with hydrothermal activity in Lake
Baikal, Russia, in Kharaka, Y.K., and Maest, A.S., eds., Proceedings of the 7th International Symposium on Water-Rock Interaction, July 9-23, 1992, Park City, Utah: Rotterdam, The Netherlands, A.A. Balkema, p. 621-626.

Callender, E., Kimball, B.A., and Axtmann, E.V., 1991, Transition-metal geochemistry of the Upper Arkansas River, Colorado, in Mallard, G.E., and Aronson, D.A., eds., U.S. Geological Survey Toxics Substances Hydrology Program-Proceedings of the technical meeting, Monterey, Calif., March 11-15, 1991: U.S. 


\section{SURFACE-WATER CHEMISTRY}

Geological Survey Water-Resources Investigations Report 91-4034, p. 392-397.

Callender, Edward and Robbins, J.A., 1993, Transport and accumulation of radionuclides and stable elements in a Missouri River reservoir: Water Resources Resarch, v. 29, no. 6, p. 1787-1804.

Callender, E., and Smith, R.A., 1989, Deposition of organic carbon in upper Missouri River reservoirs, in Degens, E.T., Kempe S., and Eisma, D., eds., Transport of carbon and minerals in rivers, lakes, estuaries and coastal seas: Mitteilungen aus dem Geologisch-Paläontologischen Instut, der Universitat Hamburg, SCOPE/UNEP Sonderband, Heft, v. 70, pt. 6, p. 1-15.

Deike, Ruth G. 1990a, Dolomite dissolution rates and possible Holocene dedolomitization of water-bearing units in the Edwards Aquifer, south-central Texas: Journal of Hydrology, $v$. 112 , p. 335-373.

Deike, Ruth G., 1990b, Dolomite dissolution rates and possible Holocene dedolomitization of water-bearing units in the Edwards Aquifer, south-central Texas-A Summary, in Simpson E., and Sharp, J., eds., Selected papers on hydrogeology from the 28th International Geological Congress: International Association Hydrologists, Hydrogeology Selected Papers, v. 1, p. 97-107.

Deike, R.G., Webster, D., and Callender, Edward, 1994, Sedimentary changes and authigenic mineralogy determined from site 307 cores, Academician Ridge, Lake Baikal, Siberia: Russian Geology and Geophysics, v. 34, no. 10/11, p. 136-147.

Ficklin, W.H., and Callender, E., 1989, Arsenic geochemistry of rapidly accumulating sedi- ments, Lake Oahe, South Dakota, in Mallard, G. E, and Ragone, S. E., eds., U.S. Geological Survey Toxic Substances Hydrology Program-Proceedings of the technical meeting, Phoenix, Ariz., Sept. 26-30, 1988: U.S. Geological Survey Water-Resources Investigations Report 88-4220, p. 217-222.

Granina, L., Karabanov, E., and Callender, E., 1994, Relics of oxidized ferromanganese formations in the bottom sediments of Lake Baikal: International Project on Paleolimnology and Late Cenozoic Climate Newsletter, no. 7, p. 32-39.

Shanks, W.C., and Callender, E., 1992, Thermal springs in Lake Baikal: Geology, v. 20, p. 495-497. 


\section{SURFACE-WATER CHEMISTRY}

TITLE: $\quad$ Carbon Fluxes in Hydrologic and Geologic Processes (NR 79-099)

PERSONNEL: Eric T. Sundquist, Project Chief

Gregory C. Winston, Chemist

ADDRESS: $\quad$ U.S. Geological Survey

432 National Center

12201 Sunrise Valley Drive

Reston, VA 22092

TELEPHONE: (508) 457-2397

PROBLEM: Carbon fluxes are an important aspect of many hydrologic and geologic processes. For example, on a global scale, rising atmospheric $\mathrm{CO}_{2}$ concentrations and the increasing use of fossil fuels have led to concern for the future effects of atmospheric $\mathrm{CO}_{2}$ on global climate. Anticipating the effects of atmospheric $\mathrm{CO}_{2}$ requires an understanding of the role of natural hydrologic and geologic processes in the global carbon budget. On a more local scale, ground-water and surface-water contamination problems are often associated with locally significant changes in the transport and sedimentation of carbon. This project evaluates carbon fluxes by studying the hydrologic and geologic processes responsible for them. These studies emphasize the need to understand both human impacts and the evidence for natural changes in local to global carbon fluxes before man's influence.

OBJECTIVE: Evaluate local to global carbon fluxes associated with hydrologic and geologic processes. Determine the geochemical mass balance for carbon in selected hydrologic/ geologic systems. Determine the processes most important in controlling carbon fluxes. Investigate the possibility of past variations in the world's (natural) $\mathrm{CO}_{2}$ balance, and apply this information to the prediction of future global $\mathrm{CO}_{2}$ fluxes. Understand the role of fluxes of carbon compounds in selected local ground water and (or) surface water contamination problems.

APPROACH: Estimates of carbon fluxes and quantities are derived from direct measurements, published literature, and computer models of hydrologic and geologic processes. Analytical methods utilized by this project include infrared gas analysis, gas chromatography, high performance liquid chromatography, and coulometric and potentiometric titration techniques. Stable isotope and ${ }^{14} \mathrm{C}$ measurements are acquired where appropriate. Available data are used to constrain computer models based on chemical thermodynamic and kinetic relationships and the conservation of mass and charge. 


\section{SURFACE-WATER CHEMISTRY}

PROGRESS: Project activities have included both field measurements and modeling. An infrared photosynthesis analyzer has been adapted to measure $\mathrm{CO}_{2}$ concentrations in small soil gas samples and $\mathrm{CO}_{2}$ fluxes through soil and snow surfaces. Soil $\mathrm{CO}_{2}$ field monitoring programs have been continued at the Sleepers River Experimental Watershed in Vermont and at the Harvard Forest Long Term Ecological Research site in Massachusetts. A field monitoring program was established in northern Manitoba, Canada, as part of the Boreal Ecosystem-Atmosphere Study (BOREAS). The initial focus of these studies is to understand the processes that control $\mathrm{CO}_{2}$ fluxes over diurnal to seasonal time scales.

Modeling studies have focused on aspects of the carbon cycle that are related to the geochemical effects of $\mathrm{CO}_{2}$ and to long-term geochemical predictions. To analyze the soil and sediment records of carbon-cycle change, and to assist in long-term $\mathrm{CO}_{2}$ predictions, modeling techniques have been developed to accommodate pedogenesis, carbonate dissolution, and other sediment interactions. These models suggest that, contrary to widely held assumptions, the global carbon cycle was not at a steady state prior to modern human influences. The models also imply that, if humans burn all of the world's fossil fuel reserves, atmospheric and oceanic $\mathrm{CO}_{2}$ concentrations may remain perturbed for thousands to tens of thousands of years.

This project has also contributed substantially to bureau and division climate and global change program development.

\section{REPORTS PUBLISHED 1989-1994:}

Harden, J.W., Sundquist, E.T., Stallard, R.F., and Mark, R.K. 1992, Dynamics of soil carbon during deglaciation of the Laurentide Ice Sheet: Science, v. 258, p. 1921-1924.

Sarmiento, J.S., and Sundquist, E.T., 1992, Revised budget for the oceanic uptake of anthropogenic carbon dioxide: Nature, v. 356, p. 589-593.

Shackleton, N.J., van Andel, T.H., Boyle, E.A., Jansen, E., Labeyrie, L., Leinen, M., McKenzie, J., Mayer, L., and Sundquist, E.T., 1990, Contributions from the oceanic record to the study of global change on three time scales-Report of Working Group 1,
Interlaken Workshop for Past Global Changes: Palaeogeography, Palaeoclimatology, Palaeoecology, Global and Planetary Change Section, v. 82 , p. 5-37.

Shanley, J.B., Sundquist, E.T., and Denner, J.C., 1991, Water, energy, and biogeochemical budgets at Sleepers River, Danville, Vermont-A research plan: Eastern Snow Conference, 48th, Guelph, Ontario, June 7-8, 1991 [Proceedings], p. 81-90.

Sundquist, E.T., 1990, Long-term aspects of future atmospheric $\mathrm{CO}_{2}$ and sea-level changes, in Revelle, R., ed., Sea Level Change: Washington, National Research Council, p. 193-207. 


\section{SURFACE-WATER CHEMISTRY}

1990, Pliocene atmospheric $\mathrm{CO}_{2}$-some preliminary observations, in Gosnell, L.B., and Poore, R.Z., eds., Pliocene Climates-

Scenario for Global Warming: U.S. Geological Survey Open-File Report 90-64, p. 37-38.

1990, Influence of deep-sea benthic processes on atmospheric $\mathrm{CO}_{2}$ : Philosophical Transactions of the Royal Society, A, v. 331, p. 155 -165 .

1991, Steady- and nonsteady-state carbonatesilicate controls on atmospheric $\mathrm{CO}_{2}$ : Quaternary Science Reviews, v. 10, p. 283-296.

Sundquist, E.T., 1992, Terrestrial implications and uncertainties in the atmospheric carbon dioxide budget, in Kelmelis, J.A., and Snow, M., eds., Proceedings of the U.S. Geological Survey Global Change Research Forum, March 18-20, 1991, Herndon, Virginia: U.S. Geological Survey Circular 1086, Denver, U.S. Geological Survey, p. 33-36.

Sundquist, E.T., 1993, The global carbon dioxide budget: Science, v. 259, p. 934-941. 


\section{SURFACE-WATER CHEMISTRY}

TITLE: Geochemical Cycling of Trace Elements and Nutrients in Natural Water Systems (NR 81-109)

PERSONNEL: Owen P. Bricker, Project Chief Laura Bricker, Clerical Assistant

Philip M. Shackelford, Hydrological Technician

Anne K. O'Brien, Hydrologist

Margaret M. Kennedy, Chemist

ADDRESS: $\quad$ U.S. Geological Survey

432 National Center

12201 Sunrise Valley Drive

Reston, VA 22092

TELEPHONE: (703) 648-5824

PROBLEM: Natural water systems provide a wide range of conditions within which to examine the geochemical behavior and cycling of trace elements and nutrients relative to hydrochemically important mineral reactions. Processes of mineral dissolution, alteration, and genesis exert strong controls on the concentrations of chemical species in natural water systems and thus on water quality. Chemical composition of atmospheric precipitation input to terrestrial watersheds affects mineral reaction rates and may regulate reaction pathways and products. Knowledge of the geochemical behavior and cycles of major elements, trace elements, and nutrients is essential in order to understand and predict the consequences of deliberate or accidental anthropogenic additions of these substances to the environment.

OBJECTIVE: Define the role of mineral-water interactions in determining the chemical composition of natural waters with emphasis on major elements, trace elements, and nutrients. Quantitatively describe the geochemical behavior of these species in fresh-water, estuarine, and marine environments. Assess the impacts of anthropogenic contributions on natural cycles in these systems and evaluate the hydrogeochemistry of major elements, trace elements, and nutrients as it relates to water resource utilization.

APPROACH: Geochemical mass balance studies of the flux of major elements, trace elements, and nutrients in natural water systems are developed by detailed sampling and chemical analysis of input waters and outflow waters. The critical reactions that control changes in water chemistry are identified and quantified through examination of the solids that the waters contact and react with and through laboratory studies of rock soil-water interactions. 


\section{SURFACE-WATER CHEMISTRY}

PROGRESS: Research on atmospheric deposition chemistry and biogeochemical process in forested watersheds is continuing at sites in Maryland and Virginia. In Fiscal Year 1994, investigations of sulfur isotopes were initiated at several sites. Stable isotopes are being measured to provide information on atmospheric versus watershed sources of sulfur and to examine processes of retention and transmission of sulfate through the catchment systems. A study of ${ }^{35} \mathrm{~S}$ was initiated to begin to explore residence times in watershed systems. Continuing investigations of ${ }^{18} \mathrm{O}$ and Deuterium indicate that groundwater recharge in forested eastern watersheds occurs primarily during the period when vegetation is dormant. These studies show that, even in small upland watersheds with very thin soils, the groundwater reservoir is homogenized over very short periods of time. Geochemical modeling of waterrock interactions using NETPATH illustrates the importance of geologic substrate in controlling the inorganic chemistry of surface water and groundwater. Conversely, sulfate and nitrate primarily originate from atmospheric deposition. Investigations of trace element fluxes from atmospheric deposition through a small forested watershed in the Catoctin Mountains of Maryland began in Fiscal Year 1994 and will continue through Fiscal Year 1995. Geochemical mass-balance budgets for nitrate in five forested eastern watersheds are being evaluated. The magnitude of nitrate fluxes from forested systems into receiving waters such as the Chesapeake Bay are being assessed.

\section{REPORTS PUBLISHED 1989-1994:}

Acker, J.G., and Bricker, O.P., 1992, The influence of $\mathrm{pH}$ on biotite dissolution and alteration kinetics at low temperature: Geochimica et Cosmochim Acta, v. 56, p. 3073-3092.

Baron, J., and Mast, M.A., 1991, Regional characterization and setting, in Baron, J., ed., Biogeochemistry of a subalpine ecosystem-Loch Vale Watershed: New York., Springer-Verlag Ecological Studies Series, No. 90, p. 12-27.

Baron, J., Walthall, P.M., Mast, M.A., and Arthur, M., 1991, Soils, in Baron, J., ed., Biogeochemistry of a subalpine ecosystem-Loch Vale Watershed: New York, Springer-Verlag Ecological Studies Series, chap. 7 , p. 108-141.
Bricker, O.P., and Jones, B.F., in press, Main factors affecting the composition of natural waters, in Steines, E., and Salbu, B., eds., Trace Metals in the Environment: CRC Press.

Bricker, O.P., Paces, T., Johnson, C.E., Sverdrup, H., 1992, Weathering and erosion aspects of small catchment research, in Moldan B., and Cerny J., eds., Biogeochemistry of Small Catchment-A tool for environmental research: New York, John Wiley and Sons, p. 87-108.

Bricker, O.P., and Rice, K.C., 1989, Acid deposition to streams a geology-based method predicts their sensitivity: Environmental Science Technology, v. 23, p. 379-385. 


\section{SURFACE-WATER CHEMISTRY}

Bricker, O.P., and Rice, K.C., 1993, Acid rain: Annual Review of Earth and Planetary Sciences, v. 21, p. 151-174.

Denning. S.A., Baron, J., Mast, M.A., and Arthur, M., 1991, Hydrologic pathways and chemical composition of runoff during snowmelt at Loch Vale Watershed, Rocky Mountain National Park, Colorado, U.S.A.: Soil, Water, Air Pollution, p. 107-123.

Donoghue, J.F., Bricker, O.P., and Olsen, C.R., 1989, Particle-borne radionuclides as tracers for sediment in the Susquehanna River and Chesapeake Bay: Estuarine, Coastal and Shelf Science, v. 29, p. 341-360.

Eshleman, K.N., Pollard, J.S., O'Brien, A.K., 1993, Determination of contribution areas for saturaton overland flow from chemical hydrograph separation: Water Resources Research, v. 29, p. $3577-3587$.

Eshleman, K.N., Pollard, J.S., O'Brien, A.K., in press, Interactions between ground water and surface water in a Virginia Coastal Plain watershed 1., Hydrological flow path: Hydrological Processes, v. 00.

Johnson, C.E., Litaor, M.I., Billett, M.F., Bricker, O.P., 1992, Chemical weathering in small catchments-Climatic and anthropogenic influences, in Moldan B., and Cerny, J., eds., Biogeochemistry of small Catchments-A tool for environmental research: New York, John Wiley and Sons, p. 313-328.

Kendall, Carol, Mast, M.A., and Rice, K.C., 1992, Tracing watershed weathering reactions with ${ }^{13} \mathrm{C}$, in Kharaka, Y.K., and Maest, A.S., eds., Proceedings of the 7th International Symposium on Water-Rock Interaction, July 9-23, 1992, Park City, Utah: Rotterdam, The Netherlands, A.A. Balkema, p. 569-572.
Mast, M.A., Drever, J.I., and Baron, J., 1990, Chemical weathering in the Loch Vale Watershed Rocky Mountain National Park, Colorado: Water Resources Research, v. 26, no. 12, p. 2971-2978.

Mast, M.A., 1991, Geochemical characteristics of Loch Vale Watershed, in Baron, J., ed., Biogeochemistry of a subalpine ecosystem-Loch Vale Watershed: New York, Springer-Verlag Ecological Studies Series, p. 93-107.

O'Brien, A.K., Rice, K.D., Kennedy, M.M., Bricker, O.P., 1993, Comparison of episodic acidification of Mid-Atlantic Upland and Coastal Plain streams: Water Resources, $v$. 29 , p. 3029-3039.

O'Brien, A.K., Eshleman, K.N., and Pollard, J.S., in press, Interactions between ground water and surface water in a Virginia Coastal Plain watershed 2., Acid-base chemistry: Hydrological Processes, v. 00.

Puckett, L.J., 1990, Time- and pH-dependent leaching of ions from deciduous and coniferous foliage: Canadian Journal of Forest Research, v. 20 , no. 11 , p. 1779-1785.

1990, Estimates of ion sources in deciduous and coniferous throughfall: Atmospheric Environment, v. 24A, no. 3 , p. 545-555.

1991, Spatial variability and collector requirements for sampling throughfall volume and chemistry under a mixed-hardwood canopy: Canadian Journal of Forest Research, v. 21, p. 1581-1588.

Puckett, L.J., and Bricker O.P., 1992, Factors controlling the major ion chemistry of streams in the Blue Ridge and Ridge and Valley physiographic provinces of Virginia and Maryland: Hydrological Processes, v. 6, p. 79-98. 


\section{SURFACE-WATER CHEMISTRY}

Puckett, L.J., Woodside, M.D., Libby, B., and Schenning, M.R., 1993, Sinks for trace metals, nutrients, and sediments in wetlands of the Chickahominey River near Richmond, Va.: Wetlands, v. 13 , no. 12 , p. 105-114.

Rice, K.C., and Bricker O.P., 1991, Geologybased method of assessing sensitivity of streams to acidic deposition in Charles and Anne Arundel counties, Maryland: Chesapeake Bay Research and Monitoring Division, Tidewater Administration, Maryland Department of Water Resources, AD-90-06, p. 15.

Rice, K.C. and Bricker, O.P., 1992, Acid rain and its effect on streamwater quality on Catoctin Mountain, Maryland: U.S. Geological Survey Open-File Report 92-168. [Water Fact Sheet]

1992, Acid-rain induced changes in streamwater quality during storms on Catoctin Mountain, Maryland: U.S. Geological Survey OpenFile Report 92-649, Water Fact Sheet.

1993, Hydrologic, chemical, and isotopic characterization of two small watersheds on Catoctin Mountain, north-central Maryland, U.S.A.: Chemical Geology, v. 107, p. 319321.

Rice, K.C., Kennedy, M.M., Bricker, O.P., and Donnelly, C.A., 1993, Data on the quantity and chemical quality of precipitation, Catoctin Mountain, north-central Maryland, 1982-91: U.S. Geological Survey Open-File Report 93169.

Rice, K.C., Kennedy, M.M., Bricker, O.P., and Donnelly, C.A., 1993, Data on the quantity and chemical quality of precipitation, Catoctin Mountain, north-central Maryland, 1982-91: U.S. Geological Survey Open-File Report 93-169, 46 p. 


\section{SURFACE-WATER CHEMISTRY}

TITLE: Distribution and Speciation of Metals in Sedimentary Environments (NR 86-135)

PERSONNEL: Nancy S. Simon, Project Chief

Kristin O. Dennen, Geologist

Travis Cox, Physical Science Technician

ADDRESS: U.S. Geological Survey

432 National Center

12201 Sunrise Valley Drive

Reston, VA 22092

TELEPHONE: (703) 648-5863

PROBLEM: Total concentrations of metals in water and sediment samples are of limited use because they provide no direct information about biological impact. To be of the most use in environmental studies, descriptive information about the metal concentrations in samples must be determined. Descriptive information should include determination of the speciation or chemical form of the metal in samples and identification of the physical phase, (aqueous or solid), geochemical fraction (organic fraction or mineral fraction, which can include oxides, carbonates, sulfides), and particle size distribution of the metals in the samples. In addition to information about the biological impact of metals, the descriptive data specified above provides the information needed to model the transport and transformation of metals in the environment. More is known about the inorganic chemistry of metals than is known about the relationship between organic compounds and metals in the environment. The work by this project focuses on an understanding of the relationship between naturally-occurring organic matter and the metals in sedimentary systems. The role of metallo-organic compounds in the biogeochemical cycling of metals is of particular interest.

OBJECTIVE: Determine inorganic-organic reactions by which toxic metals are retained in, or mobilized from, the sediment, and the rates at which these processes occur. The primary emphasis of this work is an understanding of the relationship between naturally-occurring organic matter and the metals in sedimentary systems. Metal species need to be separated from complex matrices. Free metal ions need to be distinguished from complexed metal ions. Naturally-occurring metallo-organic complexes should be isolated to determine the molecular structure and functionality of these compounds. 


\section{SURFACE-WATER CHEMISTRY}

APPROACH: Determine (1) the distribution or partitioning of metals between the solution and solid phases, and (2) the species or chemical form of the metal in the phase(s) with which it is associated. Metal speciation includes determination of the free metal ion, the inorganically complexed metal and the organically complexed metal. Total metal concentrations are determined with atomic absorption spectroscopy. Concentrations of organically-bound metals are highest in solid sediment material, therefore, preliminary work emphasizes the separation of metallo-organic compounds from sediments. Supercritical fluid extraction (SFE) is the method used for separation. Liquid chromatography with electrochemical detection is used for fractionating and quantifying the extracted metallo-organic compounds. The redox chemistry, mobility, and bioavailability of the metals are assessed using adsorption-desorption studies, modified supercritical fluid extractions, and electrochemical techniques.

PROGRESS: Progress has been made at two study sites. (1) The project begun in 1992 at Couer d'Alene, Idaho, has been completed. Comparison of data from diffusion-controlled samplers and porewater from cores taken from these lacustrine sediments showed that the data are comparable but the diffusion-controlled samplers are are easier to sample and provide more well-defined profiles. The diffusive fluxes calculated from the interstitial water concentrations of metals indicated that the sediment is a source of metals to the overlying water. Analyses of total sediment solids indicated that this was a possibility, but interstitial water data were needed to substantiate the hypothesis. The interstitial water data collection and analyses have been completed and the results have been given to the Idaho District office. In addition to finding that the concentrations of metals in the interstitial waters of the sediments are elevated with respect to the water column, the data indicated that bicarbonate/carbonate are the major cations in the system. This latter finding is surprising considering that the problem in this area is acid mine drainage. A further study would be worth pursuing. Eutrophication of the lake is being proposed as the mechanism for release of metals from the sediment to the overlying water column. A model of the mechanism for the release of metals from these sediments must include an understanding of the carbonate chemistry of the lake sediments.

(2) Preliminary data from samples collected in two National Water Quality Assessment Program (NAWQA) study units that include a part of north Florida in the unit suggest that the problems of fate and transport of mercury in Florida are, in part, related to the interaction between mercury and algae and lichens (a symbiotic combination of algae and fungi). The concentrations of mercury in small fish and crustaceans collected in Florida range from 0.3 to $0.9 \mathrm{ppm}$. These concentrations are higher than expected because, although mercury is known to bioconcentrate, it is thought that this process happens gradually and high mercury concentrations are not expected early in the food chain. Concentrations of mercury in game 


\section{SURFACE-WATER CHEMISTRY}

fish that are equal to or greater than $1 \mathrm{ppm}$ result in posting of fish advisories. The method for quantifying methylmercury that is being used by this project with sediment and biological samples was developed by this project. It is an improvement over currently used techniques because it requires fewer steps and does not involve derivitization of the analyte.

Because metallo-organic bonds absorb infrared (IR) radiation in the far IR, an area of the spectrum that provides little interference from carbon-hydrogen bonds, it is theoretically possible to identify the spectra of metallo-organic compounds in complex environmental matrices. I had limited success in working with the Perkin Elmer Corporation on developing a technique for using this rapid, nondestructive technique for the analysis of metallo-organics in environmental samples.

In the past year cooperative work has been initiated with the Maryland, Arkansas, and Massachusetts district offices on watershed and metal transport studies.

\section{REPORTS PUBLISHED 1989-1994:}

Committee on Analytical Reagents, 1993, Reagent Chemicals, (8th ed.), American Chemical Society Specifications: Washington, D.C., American Chemical Society, 806 p.

1989 , Phase association of trace metals in sediments from the Calcasieu River, Louisiana. in Mallard, G.E., and Ragone, S.E., eds., U.S. Geological Survey Toxic Substances Hydrology Program-Proceedings of the technical meeting, Phoenix, Arizona, September 26-30, 1988: U.S. Geological Survey Water-Resources Investigations Report 88-4220, p. 301-308. estuarine sediment standard and sediment from the Calcasieu River Estuary, Louisiana: Chemical Geology, v. 100, p. 175-189.

Simon, N.S. and Morrison, J.F., 1991, The role of bed sediments and drift in the transport and fate of metallo-organic compounds in the Calcasieu River Estuary, Louisiana, in Mallard, G.E., and Aronson, D.A., eds., Proceedings of the technical meeting, March 11-15, 1991, Monterey, Calif.: U.S. Geological Survey Water-Resources Investigations Report 914034, p. 579-582.

1989, Nitrogen cycling between the sediment and the shallow-water column in the transition zone of the Potomac River and Estuary, II. The role of wind-driven resuspension and adsorption of ammonium: Estuarine, Coastal and Shelf Science, v. 28, p. 531-547.

Simon, N.S., Hatcher, S.A., and Demas, C., 1992, Comparison of methods for the recovery of chromium, managanese, and iron from an 


\section{SURFACE-WATER CHEMISTRY}

TITLE: Chemistry of Hydrosolic Metals and Related Constituents of Natural Water (WR 57-076)

PERSONNEL: John D. Hem, Project Chief

Jacqueline A. Hamilton, Secretary

Carol J. Lind, Chemist

Davison V. Vivit, Chemist

ADDRESS: U.S. Geological Survey

345 Middlefield Road, MS 427

Menlo Park, CA 94025

TELEPHONE: (415) 329-4531

PROBLEM: Hydrosolic metals are elements that form hydroxides with low aqueous solubilities. They may form colloidal suspensions (hydrosols). Some of these elements are toxic and they may interfere in various ways in practical utilization of water. Understanding the occurrence and behavior of these elements in water is complicated by effects of $\mathrm{pH}$, oxidation and reduction, formation of complex ions, coprecipitation with other elements, and intricate chemical kinetic relationships. Because natural aqueous geochemical systems generally are not at equilibrium, although some are at steady states, development of models and concepts appropriate for treatment of nonequilibrium systems has been a major objective in recent project studies.

OBJECTIVE: Define dilute-solution chemistry of elements of interest in the detail that is sufficient to apply findings to natural water systems; the final reports should be useful in predicting the behavior and fate of hydrosolic metals and associated substances, either in natural or polluted systems, as guides for designing optimal data collection programs and aids in the interpretation of water analyses and related hydrologic data.

APPROACH: Develop a predictive inorganic chemical model for behavior of the element of interest in dilute solution. Models are based on chemical thermodynamic and kinetic data from literature and appropriate laboratory experiments and may postulate either equilibrium closed-system or irreversible open-system conditions. Models are tested in chemical laboratory experiments and by applying them at appropriate field sites. Models are modified as necessary to allow for kinetic and biochemical factors. 


\section{SURFACE-WATER CHEMISTRY}

PROGRESS: A chapter written by J.D. Hem for the 1990-1991 National Water Summary, U.S. Geological Survey Water-Supply Paper 2400, released in December, examined the hydrogeochemistry of four drainage basins in the United States for which records of water quality cover the period 1905-1990. During that period the Saint Lawrence River at the outlet of Lake Ontario and the Mississippi River near New Orleans, La., showed an approximate doubling of mean sulfate concentrations, and for the St. Lawrence the increase in sulfate yield (tons per square mile of drainage) was approximately equal to annual contributions to the drainage basin from acid rain and dry fallout. The upward trend had leveled off by about 1980. A similar generalization holds for the Mississippi. No welldefined trend could be seen in data for the Columbia River, where a major part of the sulfate load at the U.S.-Canada boundary represents natural leaching of exposed sedimentary strata in the Canadian Rocky Mountains. Acid drainage from coal mining and industrial activities caused high sulfate and low pH at low stages in the Allegheny River above Pittsburgh, Pa. Since the late 1960's the reservoir system on the river and its tributaries has been used to increase discharges at low flow stages, and the quality of the water at low-flow at Pittsburgh has been substantially improved.

A revised version of this chapter has been submitted to Wiley-Interscience publishers for inclusion in a four-volume encyclopedia of Energy Technology and the Environment that is currently in preparation.

A paper by J.D. Hem and C.J. Lind was published in volume 58 of Geochimica et Cosmochimica Acta describing results of automated titrations of water samples from flow in the perennial reach of Pinal Creek, Arizona. The creek is contaminated by acidic drainage from copper mining activity at Miami, Arizona. Where it has perennial flow, the creek water has a $\mathrm{pH}$ near 6 and the metals originally present in the acidic drainage, except for manganese $(\mathrm{Mn})$, have been precipitated in the subsurface. Controlling the $\mathrm{pH}, \mathrm{CO}_{2}$ and $\mathrm{O}_{2}$ content of the water during laboratory titrations demonstrates the effect of these factors on forms and composition of manganese oxide and carbonate crusts that form in the creek bed.

Polymerization of dissolved aluminum oxyhydroxide ions can occur rapidly at or near semipermeable membranes, where a higher $\mathrm{pH}$ is maintained on one side of the membrane than on the other. Microcrystals of gibbsite could be deposited at such sites and physically interfere with the membrane function. For example, such microcrystals have been identified by electon microscopy in sections taken from bone-growth fronts. The possibility of this kind of inorganic interference mechanism in metabolic processes was pointed out in an invited oral presentation by J.D. Hem at the October 1993 National Meeting of the Geological Society of America in a session devoted to relationships among geochemistry and human health. 


\section{SURFACE-WATER CHEMISTRY}

A manuscript based on Dave Vivit's 1993 American Chemical Society spring meeting oral presentation was completed and reviewed. After Director's approval it was submitted for publication in a symposium volume containing papers presented at the American Chemical Society meeting on the general topic of applied nuclear magnetic resonance (NMR) spectroscopy. This paper points out that the ${ }^{27} \mathrm{Al} \mathrm{NMR}$ data we obtained from laboratory precipitation experiments at $\mathrm{pH} 4.90$ do not support the findings of other workers who have equated the "Al ${ }^{13 "}$ NMR results to those obtained from the ferron Alb determination. Although several samples of mine-drainage contaminated water from the Leadville, Colorado, area have been examined with ${ }^{27} \mathrm{Al}$ NMR the "Al ${ }^{13}$ " (or "keggin") structured complex has not been detected in natural water samples.

\section{REPORTS PUBLISHED: 1989-1994}

Davis, J.A., and Hem, J.D., 1989, The surface chemistry of aluminum oxides and hydroxides, in Sposito, Garrison, ed., The environmental chemistry of aluminum: Boca Raton, Florida, CRC Press Inc., p. 185-219.

Hem, J.D., 1989, Some nonequilibrium processes in water-rock interaction, in Miles, D.L., ed., Proceedings of the Sixth International Meeting on Water-Rock Interaction, Malvern, United Kingdom: Rotterdam, The Netherlands, A.A. Balkema, p. 297-300.

1993, Factors affecting stream water quality and water-quality trends in four drainage basins in the conterminous United States, 1905-1990, in Paulson, R.W., and Chase, E.B., eds., National Water Summary 1990-91: U.S. Geological Survey Water-Supply Paper 2400, p. 67-92.

1993 (Book Review), Impacts of Acid Deposition on Watersheds of the Quabbin Reservior, Yuretich, Richard, ed., Batchelder, Gail Virginia Irvine, Knapp, Elizabeth, McManamon, Ann and Yuretich, Richard contributing authors, Publication 166, Water Resources Research Center, University of
Massachusetts at Amherst: Geochimica et Cosmochimica Acta, v. 57, p. 5013.

Hem, J.D., Demayo, Adrian, and Smith, R.A., 1990, Hydrogeochemistry of rivers and lakes, in Wolman, M.G., and Riggs, H.C., eds., Surface Water Hydrology, The Geology of North America: Boulder, Colo., Geological Society of America, v. 0-1, chap. 9, p. 189231.

Hem, J.D., and Lind, C.J., 1991, Coprecipitation mechanisms and products in manganese oxidation in the presence of cadmium: Geochimica et Cosmochimica Acta, v. 55, p. 2435-2451.

1994, Chemistry of manganese precipitation in Pinal Creek, Arizona, U.S.A.-A laboratory study: Geochimica et Cosmochimica Acta, v. 58, p. 1601-1613.

Hem, J.D., Lind, C.J., and Roberson, C.E., 1989, Coprecipitation and redox reactions of manganese oxides with copper and nickel: Geochimica et Cosmochimica Acta, v. 53, p. 28112822.

Hem, J.D., and Roberson, C.E., 1990, Aluminum hydrolysis reactions and products in mildly 


\section{SURFACE-WATER CHEMISTRY}

acidic aqueous systems, in Melchior, D.C., and Bassett, R.L., eds., Chemical modeling of aqueous systems II: Washington, D.C., American Chemical Society, ACS Symposium Series No. 416, chap. 33, p. 429-446.

Lind, C.J., 1991, Copper-mining-related acid drainage, in Konsten, C.J.M., ed., Report of the international workshop on delayed environmental effects of chemical pollution with focus on the Nordic countries: Uppsala, Sweden, Foundation for Ecodevelopment "Stichting Mondiaal Alternatief, September 14-15, 1991, p. 42-43.

1991, Manganese minerals and associated fine particulates in the Pinal Creek stream bed, in Mallard, G.E., and Aronson, D.A., eds., U.S. Geological Survey Toxic Substances Hydrology Program-Proceedings of the technical meeting, Monterey, California, March 11-15, 1991: U.S. Geological Survey WRI report 91-4034, p. 486-491.

Lind, C.J. and Anderson, L.D., 1992, Trace metal scavenging by precipitating $\mathrm{Mn}$ and $\mathrm{Fe}$ oxides, in Kharaka, Y.K., and Maest, A.S., eds., Proceedings of the 7th International Symposium on Water-Rock Interaction, July 9-23, 1992, Park City, Utah: Rotterdam, The Netherlands, A.A. Balkema, v. 1, p. 397-402.

Lind, C.J. and Hem, J.D., 1993, Manganese minerals and associated fine particulates in the streambed of Pinal Creek, Arizona, U.S.A.A mining-related acid drainage problem: Applied Geochemistry, v. 8, no. 1, p. 67-80.

Nordstrom, D.K., and May, H.M., 1989, Aqueous equilibrium data for mononuclear aluminum species, in Sposito, Garrison, ed., The environmental chemistry of aluminum: Boca Raton, Fla., CRC Press Inc. p. 29-53.
Nordstrom, D.K., Plummer, L.N., Langmuir, Donald, Busenberg, Eurybiades, May, H.M., Jones, B.F., and Parkhurst, D.L., 1990, Revised chemical equilibrium data for major water-mineral reactions and their limitations, in Melchior, D.C., and Bassett, R.L., eds., Chemical modeling of aqueous systems II: Washington, D.C., American Chemical Society ACS Symposium Series No. 416, chap. 31, p. $398-413$. 


\section{SURFACE-WATER CHEMISTRY}

TITLE: $\quad$ Origin, Fate, and Transport of Organic Compounds in Surface and Ground Waters and Their Effect on Water Quality (WR 83-204)

PERSONNEL: Wilfred E. Pereira, Project Chief

Lucenia Thomas, Secretary

Frances D. Hostettler, Research Chemist

ADDRESS: U.S. Geological Survey

345 Middlefield Road, MS 496

Menlo Park, CA 94025

TELEPHONE: (415) 354-3336

PROBLEM: There is a general lack of knowledge of fundamental processes governing the fate and transport of anthropogenic organic compounds in surface and ground waters. Interactions of organic contaminants with natural organic coatings on sediments and porous media of aquifers are not well understood. Furthermore, abiotic and biological transformations of organic contaminants in surface and ground waters require extensive fundamental investigations if their effects on water quality are to be understood.

OBJECTIVE: (1) Determine physicochemical and biological processes, controlling the fate and transport of organic compounds in surface and ground waters. (2) Determine bioavailability of hydrophobic organic contaminants to stream biota. (3) Study transport of organic compounds from rivers through estuarine systems.

APPROACH: (1) Water, suspended sediments, biota (plant and benthic invertebrate tissues) and bed sediments, will be collected from the San Joaquin and Sacramento Rivers and Delta, and from San Francisco Bay. (2) Samples will be analyzed using electron-impact and chemical ionization ion-trap mass spectrometry. (3) Seasonal variations in organic contaminant loads, as affected by fresh-water influxes and salinity gradients, will be investigated. (4) Bioconcentration of selected hydrophobic organic contaminants will be studied.

PROGRESS: San Francisco Bay-Delta Study: A history of contamination of San Francisco Bay by organic contaminants is virtually unknown. Sediment cores collected from Richardson and San Pablo Bays were used to reconstruct chronologies of selected organic contaminants. Sediment chronologies were based on ${ }^{210} \mathrm{~Pb},{ }^{234} \mathrm{Th}$, and ${ }^{137} \mathrm{Cs}$ activity profiles. The sedimentary record in Richardson Bay indicated that anthropogenic inputs of polycyclic 


\section{SURFACE-WATER CHEMISTRY}

aromatic hydrocarbons (PAH) from pyrogenic and petrogenic sources are greater than preanthropogenic inputs (from burning of wood and coal, and from natural forest fires) by two orders of magnitude. The dominant origin of the modern contamination is from combustion processes. The sedimentary record in San Pablo Bay showed that a significant increase in total organic carbon and total PAH occurred in the early 1950's, perhaps as a result of a combination of increased urbanization, diversions of freshwater inflows, and increased municipal and industrial inputs to San Pablo Bay after World War II.

The sedimentary record of DDT and its degradation products DDD and DDE in Richardson Bay indicated that DDT first appeared in the sediment column about 1950, in agreement with its history of usage. A subsurface maximum DDT occurred at a depth corresponding to about the years 1955-1970, when DDT was used extensively. The concentration then declined following the ban of DDT in 1972. These chlorinated compounds are derived from both point and nonpoint sources. The sedimentary record of DDT, DDD, and DDE, in San Pablo Bay, indicated that the dates of initial deposition of these compounds also occurred about 1950, when DDT was first introduced into agriculture. In contrast to Richardson Bay, sediments in San Pablo Bay had higher concentrations of the degradation products DDD and DDE than DDT, suggesting that these compounds are derived mainly from agricultural inputs from the Sacramento and San Joaquin Rivers. Polycyclic aromatic hydrocarbons and DDT are unique indicators of anthropogenic activities in the Bay area.

\section{REPORTS PUBLISHED: 1989-1994}

Bishop, L.M., and Rostad, C.E., Pereira, W.E. Leiker, T.J., 1993, Data for selected organic contaminants in the Mississippi and Ohio Rivers near their confluence, June 1989 and May-June 1990: U.S. Geological Survey, Open-File Report No. 93-371.

Hostettler, F.D., and Rapp, J.B., Pereira, W.E., and Kvenvolden, K.A., 1994, A survey of Molecular marker compounds in sediments of San Francisco Bay, California, in Morganwalp, D.W., and Aronson, D.A., eds., U.S. Geological Survey Toxic Substances Hydrology Program-Proceedings of the technical meeting, Colorado Springs, Colo., September 20-24, 1993: U.S. Geological Survey WaterResources Investigations Report 94-4014.
Pereira, W.E., and Hostettler, F.D., 1993, Nonpoint source contamination of the Mississippi River and its tributaries by herbicides: Environmental Science Technology, v. 27, p. 1542-1552.

1993, Distribution of organochlorine compounds in sediments and livers of striped bass (Morone saxatilis) in San Francisco Bay-Delta Estuary, in Morganwalp, D.W., and Aronson, D.A., eds., U.S. Geological Survey Toxic Substances Hydrology Program-Proceedings of the technical meeting, Colorado Springs, Colo., September 20-24, 1993: U.S. Geological Survey Water-Resources Investigations Report 94-4014. 


\section{SURFACE-WATER CHEMISTRY}

Pereira, W.E., Hostettler, F.D., and Rapp, J.B., 1992, Bioaccumulation of hydrocarbons derived from terrestrial and anthropogenic sources in the Asian clam Potamocorbula amurensis in San Francisco Bay Estuary: Marine Pollution Bulletin, v. 24, p. 103-110.

Pereira, W.E., and Rostad, C.E., 1990, Occurrence, distributions and transport of herbicides and their degradation products in the lower Mississippi River and its tributaries: Journal of Environmental Science and Technology, v. 24, no. 9 , p. 1400-1406.

1992, Synthetic organic agrochemicals in the lower Mississippi River and its major tributaries-Distributions, tansport and fate International Journal of Contaminant Hydrology, v. 9, p. 175-188.

Pereira, W.E., Rostad, C.E., and Leiker, T.J., 1989, Preliminary assessment of the fate and transport of synthetic organic agrochemicals in the lower Mississippi River and its tributaries, in Mallard, G. E, and Ragone, S. E., eds., U.S. Geological Survey Toxic Substances Hydrology Program-Proceedings of the technical meeting, Phoenix, Ariz., September 26-30, 1988: U.S. Geological Survey WaterResources Investigations Report 88-4220., p. 453-464.

1990, Determination of trace levels of herbicides and their degradation products in surface and ground waters by gas chromatographic-ion trap mass spectrometry: Analytica Chimica Acta, v. 228, p. 69-75.

1990, Distribution of agrochemicals in the lower Mississippi River and its tributaries: Science of the Total Environment, v. 97/98, p. 41-53.

Rostad, C.E., Bishop, L.M., Ellis, G.S., Leiker, T.J., Monsterlect, S.G., and Pereira, W.E.,
1993, Organic contaminants on suspended sediments collected during five cruises of the Mississippi River and its principal tributaries, May 1988 to June 1990: U.S. Geological Survey Open-File Report 93-360.

Rostad, C.E. and Pereira, W.E., 1989, Analysis of chlorinated organic compounds in estuarine biota and sediments by chemical ionization tandem mass spectrometry: Biomedical and Environmental Mass Spectrometry, v. 18, p. 464-470.

1992, Distribution of selected anthropogenic organic compounds on suspended sediment in the Mississippi River, in Mallard, G.E., and Aronson, D.A., eds., U.S. Geological Survey Toxics Substances Hydrology Program-Proceedings of the technical meeting, Monterey, Calif., March 11-15, 1991: U.S. Geological Survey Water-Resources Investigations Report 91-4034, p. 347-348.

Rostad, C.E., Pereira, W.E., and Leiker, T.J., 1989, Determination of herbicides and their degradation products in surface water by gas chromatography/positive chemical ionization/tandem mass spectrometry: Biomedical and Environmental Mass Spectrometry, v. 18, p. 820-827.

Rostad, C.E., Pereira, W.E., 1992, Distribution of selected anthropogenic organic compounds on suspended sediment in the Mississippi River, in Mallard, G.E., and Aronson, D.A., eds., U.S. Geological Survey Toxics Substances Hydrology Program-Proceedings of the technical meeting, Monterey, Calif., March 1115, 1991: U.S. Geological Survey WaterResources Investigations Report 91-4034. 


\section{SURFACE-WATER HYDROLOGY}




\section{SURFACE-WATER HYDROLOGY}

TITLE: $\quad$ Precipitation-Runoff Modeling of Watershed Systems (CR 77-228)

PERSONNEL: George H. Leavesley, Project Chief

Sandra J. Piksa, Secretary

Lauren E. Hay, Hydrologist

Robert W. Lichty, Hydrologist

Larry D. Beaver, Hydrological Technician

Gregory J. McCabe, Physical Scientist

Andrew G. Fountain, Hydrologist

Steven L. Markstrom, Hydrologist

Linda G. Stannard, Hydrologist (Physics)

Charles G. Bierbaum, Hydrologist, Student,

(University of Colorado, Boulder, Colo.)

ADDRESS: U.S. Geological Survey

P.O. Box 25046, MS 412

Denver Federal Center

Denver, CO 80225

TELEPHONE: (303) 236-5027

PROBLEM: Modeling of watershed response to normal and extreme climatic conditions or to changes in the physical conditions of a watershed requires the simulation of a variety of complex hydrologic processes and process interactions. Some of these processes are well understood at a point or for a small area; others are poorly understood at all scales.

Increasing spatial and temporal variability in climate and watershed characteristics with an increase in watershed area adds significantly to the degree of difficulty in investigating and understanding these processes. Research is needed to better define these processes and to develop techniques to simulate these processes and their interactions at all watershed scales.

OBJECTIVE: Investigate watershed hydrologic processes and process interactions to (1) improve understanding of watershed system dynamics; (2) develop computer models to simulate and evaluate the effects of various combinations of precipitation, climate, and land use on streamflow, sediment yield, and other hydrologic components; and (3) develop procedures and techniques to estimate model parameters using measurable watershed and climatic characteristics.

APPROACH: Develop, test, and verify model components of individual hydrologic processes using data from watershed studies conducted by the U.S. Geological Survey (USGS), other Federal Agencies, and universities. Model components will be coupled in a modular-design watershed modeling system that supports both operational applications and further research work. For hydrologic processes that are poorly defined or for which there is 


\section{SURFACE-WATER HYDROLOGY}

insufficient data, field studies will be conducted to investigate these processes and develop new or improved simulation capabilities.

PROGRESS: Identified relations between atmospheric circulation and (1) temporal and spatial distributions of snowpack accumulations and runoff in the western United States, and (2) changes in the glacier mass balance of South Cascade Glacier. Variability in atmospheric circulation can explain 70 percent of the variability in the glacier mass balance of South Cascade glacier at a 99 percent confidence level and can explain as much as 80 percent of the variability in the glacier mass balance at a 95 percent confidence level.

Found that annual runoff in the East River basin is 3 to 7 times more sensitive to changes in precipitation than to changes in temperature. Increase in temperature primarily results in a shift in runoff from the summer to the spring season. Natural variability of runoff in the East River basin is so large that it can mask the effects of extreme climate changes for several decades.

Compared and evaluated the single flow direction (sfd) and multiple flow direction (mfd) techniques of computing the spatial and statistical distributions of the topographic index used in the computer model TOPMODEL $(\ln (\mathrm{a} / \tan b))$. The $\ln (\mathrm{a} / \operatorname{tanb})$ distribution computed with the sfd algorithm has a lower mean, and higher variance and skew than the distribution computed using the mfd algorithm. The differences between the two algorithms are consistent for (1) demonstrations of various grid-cell resolution, (2) demonstrations from diverse topographic and climatic settings, and (3) watersheds of different sizes. These differences only have a minor effect on the simulation of runoff by TOPMODEL.

Long-term records of temperature in the United States were examined to identify seasonal and annual changes. Abrupt changes in regional temperature occurred in the conterminous United States near 1930 and 1958. Summer temperatures exhibited the most widespread and frequent changes. Results suggest that significant changes in regional temperature occur abruptly as opposed to gradual uniform changes and appear to be related to changes in atmospheric circulation.

The Rhea-Colorado State University (RHEA-CSU) model was tested over a range of spatial scales and with different methods of interpolation and grid rotation. Model accuracy was assessed by comparing station precipitation with RHEA-CSU model simulated precipitation interpolated to station locations on a monthly and daily basis. Model accuracy also was determined by comparing measured and simulated runoff volumes produced from a watershed model using RHEA-CSU model precipitation and measured station precipitation data as input. 


\section{SURFACE-WATER HYDROLOGY}

Problems in assessing RHEA-CSU model accuracy were due to the model's scheme for interpolating to station locations, precipitation measurement errors, and methods of verification.

Output from the mesoscale Modular Modeling System (MM4) for the period January 1988 to May 1989 was used as input to the RHEA-CSU model and the resulting simulated precipitation was compared with that simulated for the same period using measured upper air data. Modular Modeling System data produced a significantly different spatial and temporal distribution of precipitation from that produced from the measured upper air data. In general the MM4 results provided less precipitation which, when used as input to a hydrologic model, produced a significant under estimate of basin runoff for the 1989 water year.

Collaborative work with IBM's research group resulted in development of a tool that links output from the Environmental Systems Research Institute's Geographic Information System (GIS) package-ARC/INFO with IBM's scientific visualization package-Data Explorer. This enables users to combine the analytical capabilities of a GIS system with the threedimensional and time series visualization capabilities of a scientific visualization system.

Initiated a study of the glaciers in Taylor Valley, Antarctica, as part of the National Science Foundation's Long Term Ecological Research program. Established a baseline set of measurement stakes on three glaciers to evaluate the magnitude of mass loss from the glacier and the meltwater component flowing to nearby lakes.

A 3-year intercomparison of wind shields for gages measuring solid precipitation was completed at Rabbit Ears Pass. Results indicated that a Russian double-ring shield, a Wyoming wind shield, and the Canadian Nipher shield produced equivalent gage catches. However, the Alter shield, the United States standard, produced a gage catch that was about 20 percent less than the other three and an unshielded gage caught about 50 percent less than these three.

Modularized the Agricultural Research Service's (ARS's) Root Zone Water Quality Model (RZWQM) and incorporated it into the Modular Modeling System (MMS). Initial testing produced comparable results to those from the PC version and beta testing was begun with ARS field data sets.

Version 1.0 of the MMS was completed and readied for distribution. System components completed included the model building tool Xmbuild, a module building tool Xmconvert, and 


\section{SURFACE-WATER HYDROLOGY}

a GIS interface tool set. A two-volume users manual was completed and was started through the colleague review process.

REPORTS PUBLISHED 1989-1994:

Ayers, M.A., Tasker, G.D., Wolock, D.M., McCabe, G.J., and Hay, L.E., 1990, Simulated effects of climatic change on runoff and drought in the Delaware River basin-Supplying water and saving the environment for 6 billion people, [Proceedings]: New York, American Society of Civil Engineers, p. 3137.

Ayers, M.A., Wolock, D.M., McCabe, G.J., and Hay, L.E., 1990, Simulated hydrologic effects of climatic change in the Delaware River basin-Aspects of groundwater in New Jersey: Geological Association of New Jersey, 7th, [Proceedings], p. 01-08.

Ayers, M.A., Wolock, D.M., McCabe, G.J. Jr., and Hay, L.E., 1990, Simulated hydrologic effects of climatic change in the Delaware River basin: U.S. Geological Survey Yearbook article, fiscal year 1989, p. 31-33.

Ayers, M.A., Wolock, D.M., McCabe, G.J., and Hay, L.E., 1990, Simulated hydrologic effects of climatic change in the Delaware River basin, in Proceedings of the Symposium on International and Transboundary Water Resources Issues: Bethesda, Md., American Water Resources Association, p. 587-594.

Ayers, M.A., Wolock, D.M., McCabe, G.J., Hay, L.E., and Tasker, G.D., 1993, Sensitivity of water resources in the Delaware River basin to climate variability and change: U.S. Geological Survey Open-File Report 92-52, 68 p.

Battaglin, W.A., Hay, L.E., Parker, R.S., and Leavesley, G.H., 1993, Application of a GIS for modeling the sensitivity of water resources to alterations in climate in the Gunnison River basin, Colorado, in Harlin, J.M., and Lanfear, K.J., eds., Proceedings of the Symposium on GIS and Water Resources, Mobile, Alabama, 1993: Bethesda, Md., American Water Resources Association Technical Publication, TPS-93-1, p. 203-210.

Battaglin W.A., Hay, L.E., Parker, R.S., and Leavesley, G.H., 1993, Application of a GIS for modeling the sensitivity of water resources to alterations in climate in the Gunnison River Basin, Colorado: Water Resources Bulletin v. 29 , n. 6 , p. 1021-1028.

Brazel, A.J., McCabe, G.J., Jr., and Verville, H.J., 1993, Incident solar radiation simulated by general circulation models for the southwestern United States: Climate Research, v. 2., p. 177-181.

Dettinger, M.D., Cayan, D.R., and McCabe, G.J., 1993, Decadal trends in runoff over the western United States and Links to persistent North Pacific sea-surface-temperature and atmospheric-circulation patterns: U.S. Department of Commerce, Annual Climate Diagnostics Workshop, 18th, Boulder, Colo., November $1-5$, p. 240-243.

Driedger, C.L. and Fountain, A.G., 1989, An analysis of recent glacial outburst floods at Mount Rainier, Washington State, U.S.A.: Annals of Glaciology, v. 13, p. 69-75.

Fountain, A.G., 1989, The storage of water in, and hydraulic characteristics of, the firn of South 


\section{SURFACE-WATER HYDROLOGY}

Cascade glacier, Washington State U.S.A.: Annals of Glaciology, v. 13, p. 51-55.

1991, Glacier mass-balance standards: EOS, v. 72 , no. 46, p. 511 and 514 .

1991, Review of The hydrology of ice caps in volcanic regions by Helgi Bjornson [book review]: EOS. v. 72 , no. 24, p. 261.

1991, Shape, length and flow conditions of conduits at South Cascade glacier, Washington State, U.S.A., in Prowse, T., and Ommanney, C., Proceedings of the Northern Hydrology Symposium, Saskatoon, Saskatchewan, July 1990: National Hydrology Research Institute, p. 89-104.

1992, Analysis of streamflow records from South Cascade glacier, Washington State, U.S.A., and implications for subglacial water flow: Journal of Glaciology, v. 38, no. 128, p. 51-64.

1992, Automatic system for measuring and recording fluorometry data from multiple sources: Selected Papers in Hydrological Sciences, U.S. Geological Survey Water-Supply Paper 2340, 39-47.

1993, Geometry and flow conditions of subglacial water at South Cascade glacier, Washington State, U.S.A.: Journal of Glaciology, v. 131, p. $143-156$.

Fountain, A.G., in press, Borehole water-level variations and implications for the subglacial hydraulics of South Cascade Glacier, Washington State, U.S.A.: Journal of Glaciology, v. 00 .

Fountain, A.G., in press, The effect of snow and firn hydrology on the physical and chemical characteristics of glacial runoff: Earth Surface Processes and Landforms, v. 00.

Hay, L.E., Battaglin, W.A., Branson, M.D., and Leavesley, G.H., 1993, Application of GIS in modeling orographic precipitation, Gunnison River basin, Colorado, U.S.A., in Application of Geographic Information Systems in Hydrology and Water Resources Management, Baden, Austria, April 19-22, 1993, Proceedings: Baden, Austria, HydroGIS 93, p. 491500.

Hay, L.E., Battaglin, W.A., Parker, R.S., and Leavesley, G.H., in press, Modeling the effects of climate change on water resources in the Gunnison River basin, Colorado-Environmental Modeling with GIS: Oxford University Press, chap. 16.

Hay, L.E., Battaglin, W.A., Parker, R.S., and Leavesley, G.H., in press, Modeling the effects of climate change on water resources in the Gunnison River basin, Colorado, using GIS technology, in Proceedings of First International Conference/Workshop on Integrating Geographic Information Systems and Environmental Modeling: Boulder, Colorado, September $15-19,1991$.

Hay, L.E., Branson, M.D., and Leavesley, G.H., 1992, Simulation of precipitation in the Gunnison River basin using an orographic-precipitation model, in Managing Water Resources During Global Change: Bethesda, Md., American Water Resources Association Annual Conference and Symposium, 28th, Reno, Nevada, November 1-5, 1992, p. 651-660.

Hay, L.E., and Campbell, J.P., 1990, Waterquality trends in New Jersey streams: U.S. Geological Survey Water-Resources Investigations Report 90-4046, 297 p. 


\section{SURFACE-WATER HYDROLOGY}

Hay, L.E., and Knapp, L., 1993, Visualization techniques for hydrologic modeling, in Burton, J.S., complier, Proceedings of the Federal interagency workshop on hydrologic modeling demands for the 90's, Fort Collins, Colo., June 1993: U.S. Geological Survey WaterResources Investigations Report 93-4018, sec. 3 , p. $1-8$.

Hay, L.E., and Knapp, L., 1994, Integrating a Geographic Information System, a Scientific Visualization System and Simulation Models: AWRA Annual Summer Symposium, Effects of Human-Induced Changes on Hydrologic Systems, Jackson Hole, Wyo., June 26-29, 1994.

Hay, L., Knapp, L., and Bromberg, J., 1993, Integrating Geographic Information Systems, Scientific Visualization Systems, Statistics, and an orographic precipitation model for a hydroclimatic study of the Gunnison River basin, southwestern Colorado: Second International Conference/Workshop on Integrating Geographic Information Systems and Environmental Modeling, September, 1993, Breckenridge, Colorado.

Hay, L.E., and Leavesley, G.H., 1994, A NestedModel Approach to Investigate the Effects of Climatic Change in Mountainous Regions: ASCE 21st Annual Conference, Water Resources Planning and Management Division, Denver, Colo., May 22-26, 1994.

Hay, L.E., McCabe, G.J., Wolock, D.M., and Ayers, M.A., 1991, Simulation of temperature and precipitation by weather-type analysis: Water Resources Research, v. 27, p. 493-501.

1992, Use of weather type analysis to disaggregate general circulation model predictions: Journal of Geophysical Research, Atmospheres, v. 97, p. 2781-2790.
Heim, R.R., and McCabe, G.J., 1991, Seasonal summaries of hydrologic conditions, water year 1988, in U.S. Geological Survey, National Water Summary 1988-89-Hydrologic Events and Floods and Droughts: U.S. Geological Survey Water-Supply Paper 2375, p. 26-33.

Heim, R.R., McCabe, G.J., and Brown, W.O., in press, Seasonal summaries of hydrologic conditions, water year 1991, in U.S. Geological Survey National Water Summary 1990-91Stream Water Quality: U.S. Geological Survey Water-Supply Paper 2400, p. 56-63.

Jarrett, R.D., 1989, Hydrology and paleohydrology used to improve the understanding of flood hydrometeorology in Colorado, in Albertson, M.L., and Kia, R.L., eds., Design of hydraulic structures 89-Proceedings of the Second International Symposium on the design of hydraulic structures, Brookfield, Vermont: A.A. Balkema Publishers, p. 9-16.

Knapp, L., McCabe, G.J., Hay, L.E., and Parker, R.S., 1993, A high resolution moisture index for use in the Gunnison River basin, Colorado: National Center for Geographic Information and Analysis, Breckenridge, Colo., September [Proceedings].

Latkovich, V.J., and Leavesley, G.H., 1993, Automated data acquisition and transmission, in Maidment, D.R., ed., Handbook of Hydrology: New York, McGraw-Hill, p. 25.1-25.21.

Leavesley, G.H., 1989, Problems of snowmeltrunoff modeling for a variety of physiographic and climatic conditions: Hydrological Sciences Journal v. 34 , no. 6 , p. 617-634.

Leavesley, G.H., Beasley, D.B., Pionke, H.B., and Leonard, R.A., 1990, Modeling of agricultural nonpoint-source surface runoff and sediment 


\section{SURFACE-WATER HYDROLOGY}

yield-A review from the modeler's perspective, in DeCoursey, D.G., ed., Proceedings of the International Symposium on Water Quality Modeling of Agricultural Non-Point Sources: U.S. Department of Agriculture, Agricultural Research Service, ARS-81, p. 171-194.

Leavesley, G.H., Branson, M.D., and Hay, L.E., 1992, Using coupled atmospheric and hydrologic models to investigate the effects of climate change in mountainous regions, in Managing water resources during global change: Bethesda, Md., American Water Resources Association Annual Conference and Symposium, 28th, Reno, Nevada, November 1-5, 1992, p. 691-700.

Leavesley, G.H., Lusby, G.C., and Lichty, R.W., 1989, Infiltration and erosion characteristics of selected tephra deposits from the 1980 eruption of Mount St. Helens, Washington: Hydrological Sciences Journal v. 34, no. 3, p. 339-353.

Leavesley, G.H., Restrepo, P., Stannard, L.G., and Dixon, M., 1992, The modular hydrologic modeling system-MHMS: Bethesda, Md., American Water Resources Association Annual Conference and Symposium, 18th, Managing water resources during global change, Reno, Nevada, November 1-5, 1992, p. 263 264.

Leavesley, G.H., Restrepo, P., Stannard, L.G., and Dixon, M., 1993, The modular hydrologic modeling system-MHMS, in Burton, J.S., compiler, Proceedings of the Federal Interagency Workshop on Hydrologic Modeling Demands for the 90's: U.S. Geological Survey Water-Resources Investigations Report 934618, sec. 4, p. 40-42.

Leavesley, G.H., and Stannard, L.G., 1989, A modular watershed-modeling and data-management system, in Proceedings United States/
Peoples Republic of China Flood Forecasting Symposium/Workshop, Portland, Oregon: National Weather Service, U.S. Department of Commerce, v. 1, p. 71-95.

1990, Application of remotely sensed data in a distributed-parameter watershed model: in Kite, G.W. and Wankiewicz, A., eds., Proceedings of Workshop on Applications of Remote Sensing in Hydrology, National Hydrologic Research Centre, Environment Canada, p. 47-64.

1990, A modular watershed-modeling system for use in mountainous regions: Schweizer Ingenieur und Architekt, no. 18, p. 380-383.

in press, The precipitation-runoff modeling system-PRMS, in Singh, V.P., ed. Computer models of watershed hydrology: Water Resources Publications, Fort Collins, Colorado, Chap. 9.

Legates, D.R., and McCabe, G.J., 1991, The reliability of general circulation model-simulated doubled $\mathrm{CO}_{2}$ precipitation scenarios, in Proceedings of the 10th Conference on Biometeorology and Aerobiology: American Meteorological Society, p. 200-203.

Legates, D.R., and McCabe, G.J., 1992, General circulation model estimates of regional precipitation, in Majumdar, S.K., Rosenfeld, L.M., Yarnal, B., Miller, W., and Kalkstein, L.S., eds., Global Climate Change-Implications, Challenges and Mitigation Measures: Lafayette, Pa., Pennsylvania Academy of Sciences, p. 302-314.

Lichty, R.W., and Karlinger, M.R., 1990, Climate factor for small-basin flood frequency: Water Resources Bulletin, v. 26, no. 4, p. 577-586. 


\section{SURFACE-WATER HYDROLOGY}

Lichty, R.W., and Karlinger, M.R., in press, Regional trends in statistical parameters-A climatic perspective for small-basin flood frequency: Water Resources Bulletin, v. 00.

McCabe, G.J., 1991, invited book review, Edgerton, L.T., The Rising Tide-Global Warming and World Sea Levels: Water Resources Bulletin, v. 27, p. 871.

1993, Relations between atmospheric circulation and snowpack in the Gunnison River basin, Colorado: Journal of Hydrology, $v$. 157, p. 157-175.

McCabe, G.J., Barker, J.L., and Chase, E.B., 1991, Review of water year 1988 hydrologic conditions and water-related events, in U.S. Geological Survey, National Water Summary 1988-1989-Hydrologic Events and Floods and Droughts: U.S. Geological Survey WaterSupply Paper 2375, p. 13-25.

1991, Review of water year 1989 hydrologic conditions and water-related events, in U.S. Geological Survey, National Water Summary 1988-1989-Hydrologic Events and Floods and Droughts: U.S. Geological Survey WaterSupply Paper 2375, p. 34-49.

McCabe, G.J., Brown, W.O., and Heim, R.R., 1993, Seasonal summaries of hydrologic conditions, water year 1990, in U.S. Geological Survey National Water Summary 1989-90 Stream Water Quality: U.S. Geological Survey Water-Supply Paper 2400, p. 32-39.

McCabe, G.J., Fretwell, J.D., and Chase, E.B., 1993, Review of water year 1990 hydrologic conditions and water-related events, in U.S. Geological Survey National Water Summary 1989-90-Stream Water Quality: U.S. Geological Survey Water-Supply Paper 2400, p. 14-31.
McCabe, G.J., Fretwell, J.D., and Chase, E.B., 1993, Review of water year 1991 hydrologic conditions and water-related events, in U.S. Geological Survey National Water Summary 1990-91-Stream Water Quality: U.S. Geological Survey Water-Supply Paper 2400, p. 40-55.

McCabe, G.J., and Heim, R.R., 1991, Seasonal summaries of hydrologic conditions, water year 1989, in U.S. Geological Survey, National Water Summary 1988-1989-Hydrologic Events and Floods and Droughts: U.S. Geological Survey Water-Supply Paper 2375, p. 50-57.

McCabe, G.J., and Hay, L.E., 1994, Hydrologic Effects of Hypothetical Climate Change in the East River Basin, Colorado: AWRA Annual Summer Symposium, Effects of HumanInduced Changes on Hydrologic Systems, Jackson Hole, Wyo., June 26-29, 1994.

McCabe, G.J., and Legates, D.R., 1992, General circulation model simulations of winter and summer sea-level pressures over North America: International Journal of Climatology, v. 12 , p. 815-827.

McCabe, G.J., Legates, D.R., and Dettinger, M.D., 1993, Relations between 700-millibar height anomalies and April 1 snowpack accumulations in the western United States, Proceedings, Eighteenth Annual Climate Diagnostics Workshop, U.S. Department of Commerce, Boulder, Colorado, November 1-5, p. 252-255.

McCabe, G.J., and Wolock, D.M.; 1991, Detectability of the effects of a hypothetical temperature increase on the Thornthwaite Moisture Index: Journal of Hydrology, v. 125, p. 2335. 


\section{SURFACE-WATER HYDROLOGY}

1992, Effects of climatic change and climatic variability on the Thornthwaite moisture index in the Delaware River basin: Climatic Change, v. 20, p. $143-153$.

1992, Development of scenarios for the simulation of the effects of climate change on water resources-Proceedings of the Workshop on the Effects of Global Climate Change on Hydrology and Water Resources at the Catchment Scale, Tsukuba, Japan, Feb. 3-6, 1992: Japan-U.S. Committee on Hydrology, Water Resources, and Global Climate Change, no. 1, p. 49-56.

1992, Sensitivity of irrigation demand in a humid-temperate region to hypothetical climatic change: Water Resources Bulletin, v. 28, no. 3 , p. 535-543.

McCabe, G.J., Wolock, D.M., Hay, L.E., and Ayers, M.A., 1990, Effects of climatic change on the Thornthwaite moisture index: WaterResources Bulletin, v. 26, no. 4, p. 633-643.

McCabe, G.J., Wolock, D.M., Tasker, G.D., and Ayers, M.A., 1991, Uncertainty in climate change and drought: Hydraulic Division of the American Society of Civil Engineers, [Proceedings], p. 1-6.

McCabe, G.J., Wolock, D.M., Tasker, G.D., Ayers, M.A., and Hay, L.E., 1993, Sensitivity of water resources in the Delaware River basin to climate change, in Kelmelis, J.A., and Snow, M., eds., U.S. Geological Survey, Global Change Research Forum, Proceedings: U.S. Geological Survey Circular 1086, p. 56-62.

Parker, R.S., Kuhn, G., Hay, L.E., and Elliot, J.G., 1992, Effects of potential climate change on the hydrology and the maintenance of channel morphology in the Gunnison River basin,
Colorado-Proceedings of the Workshop on the Effects of Global Climate Change on Hydrology and Water Resources at the Catchment Scale, Tsukuba, Japan, Feb. 3-6, 1992: Japan-U.S. Committee on Hydrology, Water Resources, and Global Climate Change, $p$. 399-410.

Peters, N.E., and Leavesley, G.H., in press, Hydrogeochemistry of snowmelt at Rabbit Ears Pass, Rocky Mountains, Colorado: Proceedings of the 1993 Eastern Snow Conference, Quebec City, Quebec, Canada, June 1993, p. 339-346.

Tangborn, W.V., Fountain, A.G., and Sikonia, W.D., 1990, Effect of altitude-area distribution on glacier mass balance-A comparison of North and South Klawatti Glaciers, Washington State, U.S.A.: Annals of Glaciology, v. 14 , p. 278-282.

Tasker, G.D., Ayers, M.A., Wolock, D.M., and McCabe, G.J., 1991, Sensitivity of drought risks in the Delaware River basin to climate change: Technology and Business Exposition and Symposium, Huntsville, Ala., Huntsville Association of Technical Societies [Proceedings], p. 153-159.

Wolock, D.M., Ayers, M.A., Hay, L.E., and McCabe, G.J., 1989, Prediction of the effects of climate change on watershed runoff in the Delaware River basin, Proceedings: New York, American Society of Civil Engineering, p. 673-678.

Wolock, D.M., McCabe, G.J., and Tasker, G.D., 1992, Sensitivity of a hydrologic model of the Delaware River basin to climate change, Proceedings: 1st National Conference on Climate Change and Water Resources Management, eds., T.M. Ballentine and E.Z. Stalchiv, Albu- 


\section{SURFACE-WATER HYDROLOGY}

querque, New Mexico, Nov. 5-7, 1991, II, p. 140-149.

Wolock, D.M., McCabe, G.J., Tasker, G.D., Ayers, M.A., and Hay, L.E., 1992, Sensitivity of a watershed model of the Delaware River basin to projected climatic changeProceedings of the Workshop on the Effects of Global Climate Change on Hydrology and Water Resources at the Catchment Scale, Tsukuba, Japan, Feb. 3-6, 1992: Japan-U.S. Committee on Hydrology, Water Resources, and Global Climate Change,p. 219-329.

Wolock, D.M., McCabe, G.J., Tasker, G.D., and Moss, M.E., 1993, Effects of climate change on water resources in the Delaware River basin: Water Resources Bulletin, v. 29, no. 3, p. $475-486$.

Yonetani, T. and McCabe, G.J., 1994, Abrupt changes in regional temperature in the conterminous United States, 1895-1989: Climate Research, v. 4, p. 13-23. 


\section{SURFACE-WATER HYDROLOGY}

TITLE: $\quad$ Statistical Analysis of Errors in Hydrologic Models (CR 83-279)

PERSONNEL: Brent M. Troutman, Project Chief

Jeanea Shown, Secretary
Michael R. Karlinger, Hydrologist

Aldo V. Vecchia, Statistician

D. Phillip Guertin, Hydrologist

Thomas M. Over, Student, (Colorado School of Mines)

ADDRESS: U.S. Geological Survey

P.O. Box 25046, MS 418

Denver Federal Center

Denver, CO 80225

\section{TELEPHONE: (303) 236-5038}

PROBLEM: Uncertainty in application of physically based surface-water hydrologic models is a function of adequacy of the conceptualization of the processes involved and of the quantity and quality of data available to use as input to the model. In any type of modeling exercise, even if the physical processes are well understood, spatial heterogeneities make application of the model on a basin-wide scale problematic, and it is almost always necessary to use some form of spatial averaging to obtain "effective" input variables. The over-all goal of our research is to investigate (1) model output errors as a function of model complexity and uncertainty in model input; (2) derivation of simplified yet physically based models that are appropriate to use with limited data; (3) ways of evaluating and coping with uncertainty caused by spatial variability of input variables.

OBJECTIVE: Develop unified approach to analyzing and partitioning errors in hydrologic modeling with particular attention to scale and spatial averaging problems; develop improvements to existing practices; and develop new approaches to managing error levels within the constraints of reduced budgets.

APPROACH: Use probabilistic and statistical techniques to estimate the individual contributions of various sources of error in hydrologic modeling.

PROGRESS: (1) Investigations of properties of the random topology channel network model, especially for large networks. Our strategy in looking at the effect of model input error has been to randomize various components of model input, including channel segment properties, such as length, and channel segment configuration. This has been done primarily via the random topology model used by geomorphologists since the 60 's. Hence, our investigations 


\section{SURFACE-WATER HYDROLOGY}

into model input error have led to a number of related studies on the properties of this and other random network models; (a) Continued investigations of properties of the width function; and (b) Studied distribution of subnetwork magnitudes for randomly selected points in a topologically random network.

(2) Investigations of spatial random network models. The random topology model does not give a unique spatial definition to networks being modeled. Hence, we have seen the need to look at random models that are well-defined spatially; we have used rectangular grids to do this: (a) Studied application of the one-parameter Gibbsian family of distributions (well-known for applications in thermodynamics and statistical mechanics) for modeling spatial behavior of channel networks; the parameter is a measure of drainage efficiency of the network: (i) Developed Markov chain procedure for simulating networks under the Gibbsian distribution; (ii) Developed parameter estimation procedures for networks defined using digital elevation data (for example, for "topographic trees"); (iii) Developed regionalization methods for predicting the Gibbsian parameter as a function of map scale; (iv) Looked at methods for using this model to predict network width function; (v) Applied methods developed using digital elevation data for Willow Creek, Montana; (b) Investigated extension of Gibbsian family of distributions to a two-parameter family: (i) Worked on inference problems for this family, including point and interval estimation using bootstrap procedures; (ii) Developed goodness-of-fit tests for evaluation of model; (iii) Applied methods to Willow Creek data again; (c) Investigated fractal and scaling properties of spatial models as measured by the behavior as the grid spacing grows smaller: (i) Refined fat fractal analysis of channel geometric properties; (ii) Investigated other geomorphological scaling laws, such as Hack's law.

(3) Worked with Bob Lichty on error analysis of regionalized flood magnitudes: (a) Investigated influence of climatic factors on regionalization error; (b) Mapped flood distribution moments based on ensemble averaging; (c) Collaborated with Marshall Moss on accuracy of spatial precipitation estimation for climate models.

(4) Work by Skip Vecchia: (a) Developed new methods for model identification analysis for periodic autoregressive moving average time-series models (these models are extremely useful for characterizing stochastic properties of seasonal time-series, such as monthly streamflows); (b) Developed a new efficient method of prediction for spatial regression models with correlated errors using maximum likelihood methods. The methods can be used for evaluating uncertainty in spatially distributed inputs to hydrologic models; (c) As part of the global change research initiative: (i) Developed a stochastic model for generation of jointstation monthly streamflows on the Upper Gunnison River Basin. The model will be used for 


\section{SURFACE-WATER HYDROLOGY}

studies on the sensitivity of the Gunnison River Basin to climatic change; (ii) Developed a statistical model for interpolating snowpack in western Colorado; and (iii) Worked with Andrew Fountain on improving methods for estimating glacier mass change; (d) With Gregg Wiche of North Dakota district office, completed statistical water mass balance model and lake level frequency analysis for Devils Lake.

(5) Investigations of random cascades (a) Performed research into correlation properties of spatial random cascade models; (b) Coadvised mathematics Ph.D. student from Colorado School of Mines who is writing a dissertation in this area.

\section{REPORTS PUBLISHED 1989-1994:}

Anderson, P.L., and Vecchia, A.V., 1993, Asymptotic results for periodic autoregressive-moving average processes: Journal of Time-Series Analysis, v. 14, p. 1-18.

Driver, N.E., and Troutman, B.M., 1989, Regression models for estimating urban storm runoff quality and quantity in the United States: Journal of Hydrology, v. 109, no. 109, p. 221236.

Jones, R.H., and Vecchia, A.V., 1993, Fitting continuous ARMA models to unequally spaced spatial data: Journal of the American Statistical Association, v. 88 , no. 423 , p. 947-954.

Karlinger, M.R., and Troutman, B.M., 1989, A random spatial network model based on elementary postulates: Water Resources Research, v. 25 , no. 5, p. 793-798. 1989, Predictors of the peak width for networks with exponential links: Stochastic Hydrology and Hydraulics, v. 3, p. 1-16. 1992 Fat fractal scaling of drainage networks from a random spatial network model: Water Resources Research, v. 28 , no. 7 , p. 19751981.
Lichty, R.W., and Karlinger, M.R., 1990, Climate factor for small-basin flood frequency: Water Resources Bulletin, v. 26, no. 4, p. 577-586.

Moody, J.A., and Troutman, B.M., 1992, Evaluation of the depth-integration method of measuring water discharge: Journal of Hydrology, v. 135 , p. 201-236.

Parker, R.S., and Troutman, B.M., 1989, Frequency distribution for suspended sediment loads: Water Resources Research, v. 25, no. 7, p. 1567-1574.

Troutman, B.M., and Karlinger, M.R., 1990, Reply to comment on Predictors of the peak width for networks with exponential links by Agnese, C., and D'Asaro, F.: Stochastic Hydrology and Hydraulics, v. 4, no. 1, p. 87-88. 1992, Gibbs' distribution on drainage networks: Water Resources Research, v. 28, no. 2, p. 563-577.

1993, A note on subtrees rooted along the primary path of a binary tree: Discrete Applied Mathematics, v. 42, p. 87-93. 


\section{SURFACE-WATER HYDROLOGY}

in press, Inference for a generalized Gibbsian distribution on channel networks: Water Resources Research, v. 00.

in press, Comment on Statistical inevitability of Horton's laws and the apparent randomness of stream channel networks by James W.

Kirchner: Geology, v. 00.

Troutman, B.M., Karlinger, M.R., and Guertin, D.P., 1989, Basin-scale relations via conditioning: Stochastic Hydrology and Hydraulics, v. 3, p. 111-133.

Vecchia, A.V., 1990, An innovations approach for interpolating a random surface based on sparse data in Proceedings of the 22nd Symposium on the Interface Between Computing Science and Statistics: New York, Springer-Verlag, p.

215-224.

1992 a, A new method of prediction for spatial regression models with correlated errors: Journal of the Royal Statistical Society, v. B-54, no. 3 , p. 813-830.

Vecchia, A.V., and Ballerini, R., 1991, Testing for periodic autocorrelations in seasonal time series data: Biometrika, v. 78 , no. 1, p. $53-$ 63.

Williams, G.P., and Troutman, B.M., 1990, Comparison of structural and least-squares lines for estimating geologic relationships: Mathematical Geology, v. 22, no. 8, p. 1027-1049. 


\section{SURFACE-WATER HYDROLOGY}

TITLE: $\quad$ Paleohydrology and Climate Change (CR 90-321)

PERSONNEL: Robert D. Jarrett, Project Chief

Jeanea Shown, Secretary

Thompson, Douglas, student (Colo. State Univ.)

Capesius, Joe, student, (Univ. of Denver)

Pruess, Jon, student, (Colorado State University)

Julie K. Sueker, student, (Univ. of Colo.)

ADDRESS: $\quad$ U.S. Geological Survey

P.O. Box 25046, MS 418

Denver Federal Center

Denver, CO 80225

\section{TELEPHONE: (303) 236-6447}

PROBLEM: To anticipate the effects of potential climate change (natural or anthropogenic) on hydrology and to assess hydrologic trends will require an understanding of past long-term hydrologic variability. There also is a critical need for data on extreme floods for engineering hydrology and flood-hazard mitigation. Probably the best information on hydrologic variability and extreme floods is provided by paleohydrologic and other proxy data analyzed with the help of hydrologic models. Methods for extending existing climatic and hydrologic records over long-time scales are needed. A relatively new approach, one that complements hydrologic modeling efforts, involves the application of paleohydrology to determine regional scale hydrologic variability over relatively long-time intervals (100 to 10,000 years). Existing techniques for paleohydrologic reconstruction have large errors; hence, there is a critical need to improve paleohydrologic techniques.

OBJECTIVE: The primary goals of this project are to (1) improve techniques to reconstruct the fluvial history of river basins, particularly for extreme floods; (2) improve the understanding of hydrologic and hydraulic processes to improve numerical models of rivers; and (3) improve the understanding of links between climate and hydrology. These goals are closely related because the development and use of paleohydrologic techniques require an understanding of geomorphic response to climate change and an improved understanding of hydrologic and hydraulic processes.

APPROACH: Interdisciplinary, process-oriented research is used to study past and present hydrologic and climatic conditions in mountainous and prairie environments, particularly the Rocky Mountains. The research includes (1) paleohydrologic research that consists of selecting several basins in different climatic regions to construct the fluvial history of each 


\section{SURFACE-WATER HYDROLOGY}

river basin. Using different methods (such as step-backwater, critical depth, and tractive force), estimate paleoflood discharges. Using a variety of geochronologic techniques (dendrochronology, carbon-14, thermoluminescense, and other absolute- and relative-age dating techniques), improve methods to make high-resolution time sequences of alluvial stratigraphy; (2) conduct instream, laboratory and numerical modeling studies to improve hydrologic and paleohydrologic methods of estimating velocity and discharge; and (3) analyze hydrologic, paleohydrologic, and climatic data to quantify long-term variability and to improve the understanding of the links between climate, fluvial processes, and hydrology. To better understand extreme floods, mitigate flood hazards, and decrease the uncertainty of paleoflood techniques, an interdisciplinary study of floods during or immediately after floods is being made.

PROGRESS: The report of the paleoflood hydrology of Arthurs Rock Gulch, Colorado Front Range, has received Director's approval, and one journal article on this study has been accepted for publication. The study investigates the fluvial history of the river basin, and the development and testing of methods used to conduct paleofluvial studies in mountain rivers. Additional hydrologic research in the Rocky Mountains includes a completed Masters thesis on sediment-transport processes for the North Saint Vrain Creek at the Rocky Mountain Hydrologic Research Center (RMHRC), Colorado; a completed Master's thesis on the effects of surface mining on fluvial geomorphology and channel recovery in the South Platte River Basin, Colorado; and a completed Master's thesis on the effects of debris flows on rapids formation in the Yampa River, Dinosaur National Monument, Colorado. Hydraulic data at the RMHRC is being analyzed to improve methods to estimate velocity, discharge, and paleodischarge in mountain rivers. Water-chemistry studies of headwater basins in the Colorado Rocky Mountains related to the NAWQA program are in progress by a Ph.D. student. Paleoflood studies in southwestern Colorado are in progress by a Master's student.

\section{REPORTS PUBLISHED 1989-1994}

Jarrett, R.D., 1990, Hydrologic and hydraulic research in mountain rivers: Water Resources Bulletin, v. 26, no. 3, p. 419-429.

1990, Paleohydrology techniques used to define the spatial occurrence of floods: Geomorphology, v. 3, no. 2, p. 181-195.

1990, Hydrologic and hydraulic research in mountain rivers, in Molnar, Ludovit, ed.,
Hydrology of Mountainous Areas, Stebske Pleso Workshop, Czechoslovakia, June, 1988, Proceedings: Brateslava, Czechoslovakia, International Association of Hydrologica Sciences Publication, no. 190, p. 107-117.

1991, Wading measurements of vertical velocity profiles: Geomorphology, v. 4, no. 3-4, p. 243-247. 


\section{SURFACE-WATER HYDROLOGY}

1991, Use of paleohydrologic investigations in developing a flood-warning system, Pikes Peak area, Colorado, in Gruntfest, Eve, ed., Multiobjective river corridor planning-Proceedings of the Urban Stream Corridor and Stormwater Management Workshop, March 14-16, 1989, Colorado Springs, Colo.: Madison, Wisconsin, The Association of State Floodplain Managers, p. 43-44.

1992, Hydraulics of Mountain RiversChannel flow resistance-centennial of Mannings' formula, in Yen, B.C., ed., International conference on channel flow and catchment runoff-Centennial of Mannings' and Kuichling's Rational Formula, Charlottsville, Va., Proceedings: Littleton, Colo., Water Resources Publications, p. 287-298.

1992, Paleohydrology and its value in analyzing floods and droughts, in Kite, G.W., and Harvey, K.D., eds., Using Hydrometric Data to Detect and Monitor Climatic Change, Saskatoon, Saskatchewan, Canada, April 8-9, 1992, Proceedings: Saskatoon, Saskatchewan, Canada, National Hydrology Research Institute Workshop no. 8, p. 89-106.

1993, Flood elevation limits in the Rocky Mountains, in Kuo, C.Y., ed., Engineering hydrology-Proceedings of the symposium sponsored by the Hydraulics Division of the American Society of Civil Engineers, July 25-30, 1993, San Francisco, Calif.: New York, American Society of Civil Engineers, p. 180-185.

1993, Paleohydrology and its value in analyzing floods and droughts: Electric Power Research Institute, TR-101242, v. 3, 15 p.

1994, Historic-flood evaluation and research needs in mountainous areas, in Cotroneo, G.V., and Rumer, R.R., eds., Hydraulic En- gineering '94 Volume 2-Proceedings of the symposium sponsored by the Hydraulics Division of the American Society of Civil Engineers, Buffalo, New York, August 1-5, 1994: New York, American Society of Civil Engineers, p. 875-879.

1993, Flood elevation limits in the Rocky Mountains, in Kuo, C.Y., ed., Engineering Hydrology-Proceedings of the symposium sponsored by the Hydraulics Division of the American Society of Civil Engineers, San Francisco, Calif., July 25-30, 1993: New York, American Society of Civil Engineers, p. 180-185.

Jarrett, R.D., and Costa, J.E., 1993, Hydrology and geomorphology of the 1982 Lawn Lake Dam failure, Colorado, in McCutchen, H.E., Hermann, Raymond, and Stevens, D.R., eds., Ecological effects of the Lawn Lake flood of 1982: Rocky Mountain National Park Scientific Monograph NPS/NRROMO/NRSM-93/21, U.S. Department of the Interior, National Park Service, p. 1-17.

Jarrett, R.D., and Waythomas, C.F., in press, Paleoflood hydrology and fluvial geomorphology of Arthurs Rock Gulch near Fort Collins, Larimer County, Colorado: U.S. Geological Survey Water-Resources Investigations Report 94-4032, $175 \mathrm{p}$.

Salas, J.D., Wohl, E.E., and Jarrett, R.D., 1994, Determination of flood characteristics using systematic, historical, and paleoflood data, in Rossi, Giuseppe, Harmancioglu, Nilgun, and Yevjevich, V., eds., Coping with Floods: Dordrecht, Kluwer Academic Publishers, p. 111-134.

Waythomas, C.F., and Jarrett, R.D., 1993, Differentiation of debris-flow and flash-flood deposits: Implications for paleoflood investigations, 


\section{SURFACE-WATER HYDROLOGY}

in Shen, H.W., Su, S.T., and Wen, Feng, eds., Hydraulic Engineering ' 93 Volume 2Proceedings of the symposium sponsored by the Hydraulics Division of the American Society of Civil Engineers, San Francisco, Calif., July 25-30, 1993: New York, American Society of Civil Engineers, p. 1900-1901.

in press, Flood geomorphology of Arthurs Rock Gulch, Colorado-Part I, paleoflood history: Geomorphology, v. 00.

Waythomas, C.F., Jarrett, R.D., and Osterkamp, W.O., 1992, Late Quaternary fluvial activity and climate variability in the Colorado Front Range foothills and piedmont: Current Research in the Pleistocene, v. 8, p. 122-124. 


\section{SURFACE-WATER HYDROLOGY}

TITLE Lake-Atmosphere Interactions (CR 94-341)

PERSONNEL: Steven W. Hostetler, Project Chief

Capesius, Joe, student, Univ. of Denver Thompson, Douglas, student, Colo. State Univ.

Sueker, Julie, student, Univ. of Colo. Pruess, Jon, student, Colo. State Univ.

\section{ADDRESS: $\quad$ U.S. Geological Survey \\ 3215 Marine Street \\ Boulder, CO 80303}

TELEPHONE: (503) 754-4370

PROBLEM: Modeling the thermal and dynamic interactions of lake systems with the atmosphere over time scales ranging from diurnal up to $10^{4}$ years is a fundamental and requisite component of lake-related research. It is necessary to continue to improve and modify these models and to make these models available for applied research that ranges from global climate modeling to site-specific investigations such as the lake-based WEBB studies and the lakes and reservoir program.

OBJECTIVE: The overall goal of the research will be to broaden our understanding of how lakes interact with the atmosphere on short (diurnal) to long $\left(10^{4}\right.$ year) time scales and to provide, through appropriate models of lake thermal structure and mixing, methods for investigating the effects of climate, climate change, and anthropogenic intervention on lake systems. The models also will be applied to investigate the effects of lakes on the atmosphere.

APPROACH: The overall approach of the project is: (1) to develop and apply physically based models of lake thermal structure and mixing, (2) to develop ancillary statistical and physically based hydrological, chemical, and biological models to broaden the application of thermal models, (3) to design and execute field studies to obtain data with which to build, verify, validate, and apply models, (4) to couple developed models with atmospheric models, (5) to apply the models to assess both the effect of climate change (and anthropogenic intervention) on lake systems and the effect of lake systems on the atmosphere, and (6) to make models developed by the project generally available for lake research.

PROGRESS: Completed high-resolution simulations of the climate and surface hydrology of the Great Basin 18,000 years ago, and the first paper from this activity has been published in Science. This work demonstrated for the first time the coupling of a hierarchy of climate and 


\section{SURFACE-WATER HYDROLOGY}

hydrologic models and the use of the coupled system to assess both the effects of large-scale climate change and the regional influences on those controls. In accomplishing this work, we have provided a conceptual and practicable framework for atmosphere-environmental modeling.

Collaborated with Larry Benson to develop a model of $\boldsymbol{\delta}^{18} \mathrm{O}$ and $\boldsymbol{\delta}^{2} \mathrm{H}$ in lakes. The model is the first physically based, predictive model of isotopic behavior in lakes, and has been widely recognized as a significant advance in this area of limnology and paleolimnology.

\section{REPORTS PUBLISHED 1989-1994:}

Bartlein, P.J., Webb, T., and Hostetler, S.W, 1989, Climatology, in Hunter, R.L., and Mann, C.J., eds., Techniques for determining prbabilities of events and processes affecting the performance of geologic repositories: Washington, D.C., U.S. Nuclear Regulatory Commission, p. 53-85.

Bartlein, P.J., Webb, T., III, and Hostetler, S.W., 1992, Climatology, in Hunter, R.L., and Mann, J. eds, Determining probabilities of geologic processes and events: Oxford University Press, Monographs in Mathematical Geology, p. 99-122.

Bates, G.T., Giorgi, F. and Hostetler, S.W., 1993, Toward the simulation of the effects of the Great Lakes on regional climate: Monthly Weather Review, v. 121 , no. 5, p. 13731387.

Benson L.V., Currey, D.M., Lao, Y., and Hostetler, S.W., 1991, Lake-size variations in the Lahontan and Bonneville basins between 13,000 and $9,000{ }^{14} \mathrm{C}$ yr B.P.: Paleogeography, Paleoclimatology, and Paleoecology, v. 95, p. 19-32.

Giorgi, F., Hostetler, S.W., and Shields-Brodeur, C., 1994, Analysis of the surface hydrology in a regional climate model: Quarter Journal of the Royal Meteorological Society, v. 120, p. 161-183.

Hostetler, S.W., 1991, Simulation of lake ice and its effect on the late-Pleistocene evaporation rate of Lake Lahontan: Climate Dynamics v. 6, p. 43-48.

1993, Modeling the late-Pleistocene paleohydrology of the Great Basin, in Proceedings of the U.S. Geological Survey Global Change Forum, Herndon, Va., March 18-20, 1991: U.S. Geological Survey Circular 1086, p. 90.

1994, Hydrologic and atmospheric models: The (continuing) problem of discordant scales:

Climate Change, v. 27, p. 345-350.

Hostetler, S.W., and Bartlein, P.J., 1990, Modeling climatically determined lake evaporation with application to simulating lake-level variations of Harney-Malheur Lake, Oregon: Water Resources Research, v. 26 , no. 10 , p. 26032612.

Hostetler, S.W., Bates, G.T., and Giorgi, F., 1993, Coupling of a lake model with a regional climate model: Journal of Geophysical Research, v. 98, no. D3, p. 5045-5058. 


\section{SURFACE-WATER HYDROLOGY}

1993, Coupling of a lake model with a highresolution climate model for climate-change on Hydrology and Water Resources at the Catchment Scale: Tsukuba, Japan, Japan-U.S. Committee on Hydrology, Water Resources and Global Climate Change, Public Works

Research Institute, p. 161-177.

1992, Analysis and modeling of long-term water temperature on the Steamboat Creek basin, Oregon: Implications for land use and fish habitat: Water Resources Bulletin, v. 27, no. 4 , p. 637-647.

Hostetler, S.W. and Benson, L.V., 1990, Paleoclimatic implications of the high stand of Lake Lahontan derived from models of evaporation and lake level: Climate Dynamics, v. 4, p. 207-217.

1993, Meteorological and water-temperature data for Pyramid Lake Nevada 1987-89: U.S. Geological Survey Open-File Report 92-W$309,15 \mathrm{p}$.

1994, Behavior of the stable isotopes of oxygen and hydrogen in the Truckee River-

Pyramid Lake surface-water system, Part 2: A predicitive model of $\delta^{18} \mathrm{O}$ and $\delta^{2} \mathrm{H}$ in Pyramid Lake: Limnology and Oceanography, v. 39(2), p. 56-364.

Hostetler, S.W. and Giorgi, F., 1992, Use of a regional atmospheric model to simulate lakeatmosphere feedbacks associated with Pleistocene Lakes Lahontan and Bonneville: Climate Dynamics, v. 7, p. 39-44.

1993, Use of high-resolution climate model data in landscape-scale hydrologic models-a demonstration: Water Resources Research, $v$. 29 , no. 6 , p. $1685-1695$.

in press, Effects of $2 \mathrm{XCO}_{2}$ climate on two large lake systems-Pyramid Lake, Nevada, and Yellowstone Lake, Wyoming: Global and Planetary Change, v. 00.

Hostetler, S.W., Giorgi, F., Bates, G.T., and Bartlein, P.J., 1994, Lake-atmosphere feedbacks in sustaining lakes Bonneville and Lahontan 18,000 years ago: Science, v. 263, p. 665-668.

Hostetler, S.W. and Varley, J., 1993, Preliminary results of simulating the thermal regime of Yellowstone Lake: Park Science, v. 13, no. 1, p. 16. 


\section{SURFACE-WATER HYDROLOGY}

TITLE: $\quad$ Mathematical Modeling Principles (CR 94-343 formerly WR 73-197)

PERSONNEL: James P. Bennett, Project Chief

Aleta R. Moores, Secretary (OA)

Jackie Walters, Clerk (OA)

ADDRESS: $\quad$ U.S. Geological Survey

P.O. Box 25046, MS 413

Denver Federal Center

Denver, CO 80225

TELEPHONE: (303) 236-4992

PROBLEM: The development of models of hydrologic systems requires the description of individual processes in mathematical terms and the solution of sets of complex equations in differential form. Research is needed on application of mathematical theory to the modeling of transport of sediments, including mudflows and hyperconcentrations such as occur after natural disasters such as volcanic eruptions or dam failures.

OBJECTIVE: Develop mathematical descriptions of flow and water-quality processes that can be linked together to form models of hydrologic systems. Develop mathematical techniques for efficient solution of equations on digital computer. Develop techniques for studying sensitivity of parameters.

APPROACH: The approach to the problem will be by theoretical study, model development, and model testing.

PROGRESS: Completed journal article on a general physics-based sand transport and resistance-to-flow algorithm for one-dimensional wide channels. Developed tensioned spline routines for general description of channel plan geometry and began adaptation of unit-width algorithm to situations with secondary circulation and laterally variable cross-section geometry. Developed and presented 1-week Water Resources Division seminar on mechanics of sediment transport. Consulted with U.S.Bureau of Reclamation on sedimentology of Elwha River dam removal. Began investigation of recorded extreme floods in Jumbo Wash, Arizona. 


\section{SURFACE-WATER HYDROLOGY}

REPORTS PUBLISHED 1989-1994:

Bennett, James P., 1993, Sediment transport simulations for two reaches of the Colorado River, Grand Canyon, Arizona: U.S. Geological Survey Water-Resources Investigations Report 93-4034, 42 p. 


\section{SURFACE-WATER HYDROLOGY}

TITLE: $\quad$ Numerical Simulation of Hydrodynamic Processes in Rivers, Estuaries, and Coastal Embayments (NR 69-019)

PERSONNEL: Robert A. Baltzer, Project Chief

Mary E. Abel, Secretary

Harry Jenter, Hydrologist

ADDRESS: U.S. Geological Survey

430 National Center

12201 Sunrise Valley Drive

Reston, VA 22092

TELEPHONE: (703) 648-5894

PROBLEM: Technical solutions to the problem of investigating and managing waste movement and disposal in regulated rivers, estuaries, and embayments require qualitative and quantitative assessments of the interactions among waste constituents undergoing dynamic transport. Mathematical, numerical, computer-simulation models offer one very powerful solution. Because water is both the vehicle by which the waste constituents are transported and the media in which the constituent interactions occur, the temporal and spatial variations of the flow appreciably govern the interactions qualitatively and quantitatively. Design of the desired simulation models depends in large measure on accurate mathematical-numerical representation of the hydrodynamics of the transient-flow process.

OBJECTIVE: (1) Explore thoroughly the hydrodynamics of one-, two-, and three-space dimensional transient flows (including the transport and interaction of constituents) in water ways and waterbodies; (2) develop mathematical-numerical techniques with which to simulate these processes; and (3) provide the hydrologist with a simulation system that includes rational mathematical-numerical models for evaluating the effect of past, present, and projected changes in prototype-waterbody systems.

APPROACH: Derive mathematical models based on sets of nonlinear, partial differential equations representing various transient flow conditions. Develop numerical techniques to simulate the various flow regimens represented by the models. Use field data gathered at specific field sites and (or) hypothetical data reflecting a projected change to provide the necessary boundary-condition information and driving function with which to particularize model solution. Use large-capacity, high-speed digital computers and videographic output equipment in making the simulations. 


\section{SURFACE-WATER HYDROLOGY}

PROGRESS: (1) Achieved a physically rational and numerically stable means for dynamically handling both cessation and initiation of flow/transport at very shallow depths in channels-also referred to as the "dry-channel" problem. The developed means employs a combination of three techniques, (a) sharply increased energy dissipation at very shallow depths, (b) diminishing significance of the convective terms with decreasing depth, and (c) an artificial, v-shaped "slit" in the channel bottom with which to maintain insignificant, but nevertheless, numerically continuous flow/transport throughout time.

(2) Continued work modifying the code of the three-dimensional flow/transport computer model, ECOMSi, including its particle-tracking capability, with the object being to improve its computational efficiency when executed on parallel (array) processors. Initial results, while not offering any profound improvements, did indicate particular locations within the code where other modifications or different numerical techniques may result in greater computational efficiency.

(3) Thoroughly edited, reworked and modified the draft of the report, "Tidal flux between submerged aquatic plant stands and the adjacent Potomac River near Washington, D.C.," (Rybicki, Jenter, Carter, Baltzer, and Tutora). Particular emphasis was given to properly identifying and discussing the hydrodynamic processes encountered.

Edited, rewrote portions of the draft, and incorporated additional material to create a revised draft of the paper "A computer system for processing time-dependent data used with simulation models," (Regan, Schaffranek, and Baltzer).

Continued to expand a glossary of technical concepts and terms encountered in flow/transport modeling in surface-water physics. The glossary currently contains over 290 main, crossreferenced technical entries.

(4) Initiated the incorporation of a basic water-quality simulation capability into the standard version of ECOMSi, the three-dimensional flow/transport model.

(5) Continued to develop and test the several pieces of FORTRAN code needed to incorporate a high-order, turbulent transport capability into the one-dimensional and two-dimensional flow/transport models, BRANCH and SWIFT2D, using taut-spline curves and taut-spline surfaces, respectively. 


\section{SURFACE-WATER HYDROLOGY}

\section{REPORTS PUBLISHED 1989-1994:}

Baltzer, R.A., Regan, R.S., and Schaffranek, R.W., 1989, Time dependent data systemOverview: U.S. Geological Survey Open-File Report 293, 5 p.

Blumberg, A.F., Signell, R.P. and Jenter, H.L., 1992, Modeling transport processes in the coastal ocean, Environmental Science in the Coastal Zone-Issues for Further Research: National Research Council, CGER Coastal Zones Retreat, Washington, D.C., [Proceedings] p. 20-43.

Blumberg, A.F., Signell, R.P. and Jenter, H.L., 1993, Modeling transport processes in the coastal ocean: Journal of Marine Environmental Engineering, Yverdon, Switzerland, Gordon and Breach Science Publishers, v. 1, p. 31-52.

Butman, B., Bothner, M. H., Hathway, J. C., Jenter, H. L., Knebel, H. J., Manheim, F. T., Signell, R. P., 1992, Contaminant transport and accumulation in Massachusetts Bay and Boston Harbor-A summary of U.S. Geological Survey studies, Woods Hole, Massachusetts: U.S. Geological Survey Open-File Report 92-202, $42 \mathrm{p}$.

Jenter, H.L. and Madsen, O.S., 1989, Bottom stress in wind-driven, depth-averaged coastal flows: Journal of Physical Oceanography, American Meteorological Society, Lancaster, Pa., v. 19, no. 7, p. 962-974.

Jenter, H.L., Rybicki, N.B., Baltzer, R.A., and Carter, V., 1991, Tidal mass exchange between a submersed aquatic vegetation bed and the main channel of the Potomac River: American Society of Civil Engineers, 1991 National Conference, Hydraulics Division, Nashville,
Tennessee, August 2-7, 1991 [Proceedings], p. 298-304.

Jenter, H.L., and Signell, R.P., 1992, NetCDF-A public-domaine software solution to data-access problems for numerical modelers: American Society of Civil Engineers, 2nd International Conference on Estuarine and Coastal Modeling, Tampa, Fla., November 13-15, 1991 [Proceedings], p. 72-82.

Jenter, H.L., Signell, R.P., and Blumberg, A.F., 1993, Modeling the Tides of Massachusetts and Cape Cod Bays: American Society of Civil Engineers National Conference on Hydraulic Engineering, San Francisco, Calif., July 25-30, 1993 [Proceedings], p. 23232332.

Lai, C., Schaffranek, R.W., and Baltzer, R.A., 1989, Frictional resistance treatment in unsteady open-channel flow simulation: International Conference on Channel Flow and Catchment Runoff, Centennial of Manning's Formula and Kuichling's Rational Formula, Charlottesville, Va., University of Virginia, May 22-26, 1989 [Proceedings], p. 688-698.

1992, Frictional resistance treatment in unsteady open-channel flow simulation, in Yen, B.C. ed., Channel Flow Resistance-Centennial of Manning's Formula: Littleton, Colo., Water Resources Publications, p. 409-420.

Lee, J.K., Schaffranek, R.W., and Baltzer, R.A., 1989, Convergence experiments with a hydrodynamic model of Port Royal Sound, South Carolina: American Society of Civil Engineers, Hydraulics Division, National Conference on Hydraulic Engineering, New Orleans, La., August 14-18, 1989 [Proceedings], p. 434-441. 


\section{SURFACE-WATER HYDROLOGY}

1989, Simulation of the effects of highway embankments on circulation and transport in Port Royal Sound, South Carolina: American Society of Civil Engineers, Sixth Symposium on Coastal and Ocean Management-Coastal Zone '89, Charleston, S.C., [Proceedings], v. 6, p. 4789-4808.

Lee, J.K., Schaffranek, R.W., and Baltzer, R.A., 1994, Simulating effects of highway embankments on estuarine circulation: American Society of Civil Engineers, New York, Journal of Waterway, Port, Coastal, and Ocean Engineering, v. 120 , no. 2 , paper no. 4971 , New York, p. 199-219.

Schaffranek, R.W., and Baltzer, R.A., 1989, Implementation of a hydrodynamic model for the Upper Potomac Estuary: American Society of Civil Engineers, Hydraulics Division, National Conference on Hydraulic Engineering, New Orleans, La., August 14-18, 1989 [Proceedings], p. 484-492.

1990, Horizontal density-gradient effects on simulation of flow and transport in the Potomac Estuary: New York, N.Y., American Society of Civil Engineers, 1990 National Conference, Hydraulics Division, Proceedings, v. II, p. 1251-1257.

Signell, R.P., Jenter, H.L. and Blumberg, A.F., 1994, Modeling the seasonal circulation in Massachusetts Bay: American Society of Civil Engineers, International Conference, Estuarine and Coastal Modeling, 3rd, Oak Brook, Ill., [Proceedings] p. 578-590. 


\section{SURFACE-WATER HYDROLOGY}

TITLE: $\quad$ Simulation Modeling of Hydrodynamic Systems (NR 80-104)

PERSONNEL: Raymond W. Schaffranek, Project Chief

ADDRESS: U.S. Geological Survey

430 National Center

12201 Sunrise Valley Drive

Reston, VA 22092

\section{TELEPHONE: (703) 648-5891}

PROBLEM: Managing water use in riverine and estuarine systems requires an understanding of the governing supply, circulation, mixing, and flushing processes. Qualitative and quantitative estimates of the hydrodynamic and transport properties of such water bodies can be computed by means of mathematical-numerical simulation models. To accurately simulate temporal and spatial variations of flow, which significantly define the transport processes, the simulation model must be capable of accounting for hydraulic and tide-induced fluctuations, water withdrawals, discharges, winds, nonuniform geometric configurations, and other human-induced or natural factors.

OBJECTIVE: (1) Investigate and develop various mathematical-numerical techniques with which to simulate the hydrodynamics of one-, two-, and three-space dimensional transient flows in various water bodies; (2) evaluate and (or) develop methods to describe the transport of solutes in water bodies on the basis of the comprehensive flow information derived from flow simulation models; and (3) develop and implement an operational system in support of flow/transport simulation models.

APPROACH: Use large-capacity, high-speed digital computers and various supporting peripheral equipment. Derive and develop mathematical models, constituting approximate numerical solutions to the governing nonlinear, partial differential equations to simulate the transient flow and transport processes. Use data, collected at specific locations or hypothetically imposed, to provide the required boundary-condition information with which to effect the numerical solution.

PROGRESS: Continued research into the numerical simulation of hydrodynamic and constituent transport processes in riverine and estuarine waterbody systems. Extended formulation and evaluated numerical methods to handle unsteady pressure-gradient effects in the interior domain of open-channel networks using the branch-network simulation model. 


\section{SURFACE-WATER HYDROLOGY}

Tested pressure-gradient formulation using branch-network model in conjunction with Hudson River chloride transport study. Examined various time-line interpolation techniques and approaches for simulating advective transport in Lagrangian framework. Experimented with varied numerical methods for dispersive transport simulation to provide full Lagrangian transport capability and conservation in interconnected-channel systems.

Investigated behavior of various types, mixed combinations, and alternate formulation methods for treatment of boundary conditions in open-channel flow models; model sensitivity and numerical model results are shown to be highly correlated to open-boundary treatment in free-surface unsteady flow simulation. Numerical analyses indicate that models formulated on different but equivalent forms of the governing unsteady-flow equation sets can behave consistently or inconsistently under similar types and combinations of boundary conditions. Completed extensive numerical analyses and model experiments and submitted paper on "Friction-Term Response to Boundary-Condition Type in Flow Models" to American Society of Civil Engineers (ASCE) Journal of Hydraulic Engineering.

Completed numerical experiments with two-dimensional hydrodynamic/transport model, formulated on the alternating-direction-implicit solution method, for analyzing changes in circulation patterns and transport properties due to highway crossings in wetland areas. Investigated improved methods for multiple open boundary-condition treatment in conjunction with nested model development. Reported results in paper with colleagues entitled "Simulating Effects of Highway Embankments on Estuarine Circulation," published in the ASCE Journal of Waterway, Port, Coastal, and Ocean Engineering. Changes in subembayment circulation patterns and flushing characteristics due to constricted highwaycauseway construction are evaluated and illustrated using numerical simulation results and analytical techniques demonstrated in the paper.

Consulted with several Water Resources Division District offices on surface-water modeling projects and varied hydrologic investigations. Included among these are projects involving investigation of saltwater intrusion in the Hudson River, water-quality conditions in the Foster Creek and Back River tributaries of Cooper River, and freshwater influence on saline conditions in Indian River Lagoon. Extended the branch-network model to allow for culverttype hydraulic structures to assist the South Carolina District Office in the Foster Creek/Cooper River project. Consulted and advised on preparation of cooperator report summarizing numerical findings in Cooper River modeling project. Developed twodimensional model of Hudson River transition zone and conducted initial model simulations and sensitivity analyses. Consulted and advised Albany Subdistrict Office on model findings and needed additional field activities and requirements. Advised Orlando Subdistrict Office 


\section{SURFACE-WATER HYDROLOGY}

on data requirements and field layout for Indian River Lagoon model implementation. Prepared abstracts and coauthored papers on Foster Creek/Cooper River and Hudson River project efforts for presentation at national meetings of professional societies.

Responded to inquiries from national and international governmental agencies, academic institutions, and private consulting companies on surface-water models, modeling problems, and hydrologic investigations. Provided source code and test data sets for models developed within the scope of research project in response to requests. Served as corresponding member of the Tidal Hydraulics technical committee of the ASCE Hydraulics Division and as control member of ASCE Task Committee on Salinity-Flow Relations for Selected Estuaries. Reviewed papers for colleagues on the development of new numerical methods for solution and simulation of free-surface flows.

\section{REPORTS PUBLISHED 1989-1994:}

Lai, C., Schaffranek, R.W., and Baltzer, R.A., 1989, Frictional resistance treatment in unsteady open-channel flow simulation: International Conference on Channel Flow and Catchment Runoff, Centennial of Manning's Formula and Kuichling's Rational Formula, Charlottesville, Va., University of Virginia, May 22-26, 1989 [Proceedings], p. 688-698.

1992, Frictional resistance treatment in unsteady open-channel flow simulation, in Yen, B.C., ed., Channel Flow ResistanceCentennial of Manning's Formula: Littleton, Colo., Water Resources Publications, p. 409420.

Lee, J.K., Schaffranek, R.W., and Baltzer, R.A., 1989, Convergence experiments with a hydrodynamic model of Port Royal Sound, South Carolina: American Society of Civil Engineers, Hydraulics Division, National Conference on Hydraulic Engineering, New Orleans, La., August 14-18, 1989 [Proceedings], p. 434-441.
1994, Simulating the effects of highway embankments on estuarine circulation: New York, N.Y., American Society of Civil Engineers, Journal of Waterway, Port, Coastal, and Ocean Engineering, v. 120, no. 2, p. 199-218.

Schaffranek, R.W., 1989, Proceedings of the advanced seminar on one-dimensional, openchannel flow and transport modeling: U.S. Geological Survey Water-Resources Investigations Report 89-4061, 99 p.

1992, Network applications of the USGS BRANCH model: American Society of Civil Engineers, Water Forum '92, Hydraulic Engineering Conference, New York, N.Y., [Proceedings], p. 1159-1164.

Schaffranek, R.W., and Baltzer, R.A., 1989, Implementation of a hydrodynamic model for the upper Potomac Estuary: American Society of Civil Engineers, Hydraulics Division, National Conference on Hydraulic Engineering, New Orleans, La., August 14-18, 1989 [Proceedings], p. 484-492. 


\section{SURFACE-WATER HYDROLOGY}

1990, Horizontal density-gradient effects on simulation of flow and transport in the Potomac Estuary: American Society of Civil Engineers, 1990 National Conference, Hydraulics Division, New York, N.Y., [Proceedings], v. II, p. 1251-1256.

Schaffranek, R.W., and Lai, C., in press, Treatment of nonhomogeneous terms in flow models: American Society of Civil Engineers, National Conference on Hydraulic Engineering, Buffalo, New York, August 1-5, 1994 [Proceedings] $6 \mathrm{p}$.

Weiss, L.A., Schaffranek, R.W., and deVries, M.P., in press, Flow and chloride transport in the tidal Hudson River, New York: American Society of Civil Engineers, National Conference on Hydraulic Engineering, Buffalo, New York, August 1-5, 1994 [Proceedings] 6 p. 


\section{SURFACE-WATER HYDROLOGY}

TITLE: $\quad$ Hydrologic Regression and Data-Network Design (NR 82-125)

PERSONNEL: Gary D. Tasker, Project Chief

Carol Padgett, Secretary

ADDRESS: U.S. Geological Survey

430 National Center

12201 Sunrise Valley Drive

Reston, VA 22092

TELEPHONE: (703) 648-5892

PROBLEM: Methods for objective evaluation of USGS hydrologic data-collection activities are needed so that activities can be modified, when necessary, and the efficiency of operations maximized.

OBJECTIVE: Produce objective methods for hydrologic network design and methods for information transfer.

APPROACH: Use cross-validation and computer simulation of hydrologic processes to evaluate the statistical and economic measures of the hydrologic data-collection programs.

PROGRESS: (a) With Joe Inman (Georgia District) applied (GLS) regression to a study of urban floods. This was a unique application of the GLS regression procedures because the spatial correlation structure of the data came about from using synthetic hydrology to generate the gage records.

(b) With Tim Raines (Texas District) a network design study was undertaken and completed for the urban stormwater quality data collection network for the Dallas-Fort Worth Metroplex. The study adapted the Network Analysis Using Generalized Least Squares method developed by this research project to find the most cost-effective monitoring program for the area.

(c) With Ray Slade (Texas District) a new computer-intensive method for estimating flood characteristics at ungaged sites was developed. Papers describing the method were presented and well received. 


\section{SURFACE-WATER HYDROLOGY}

(d) With Marshall Moss (National Research Program, retired) plans were made in cooperation with World Meteorological Organization (WMO) to complete the network design comparison study for WMO this summer in Koblenz, Germany.

\section{REPORTS PUBLISHED 1989-1994:}

Ayers, M., Tasker, G., Wolock, D., McCabe, G., and Hay, L., 1990, Simulated effects of climate change on runoff and drought in the Delaware River basin, in Singh and Helweg eds., Supplying and saving the environment for six billion people: American Society of Civil Engineers Conference, November 1990 [Proceedings], San Francisco, Calif., p. 31 -40 .

Ayers, M.A., Wolock, D.M., McCabe, G.J., Hay, L.E., and Tasker, G.D., 1993, Sensitivity of water resources in the Delaware River basin to climate variability and change: U.S. Geological Survey Open-file Report 92-52, 68 p.

Driver, N.E., and Tasker, G.D., 1990, Techniques for estimation of storm-runoff loads, volumes, and selected constituent concentrations in urban watersheds in the United States: U.S. Geological Survey Water-Supply Paper 2363, $44 \mathrm{p}$.

Gilroy, E.J., and Tasker, G.D., 1990, Multicollinearity and influential observations in hydrologic model selection, in Berk, K., and Malone, L., ed., Computing Science and Statistics: Symposium on the Interface, 21st, Orlando, Fla., April 1990, p. 350-354.

Ludwig, A.H., and Tasker, G.D., 1993, Regionalization of low-flow characteristics of Arkansas streams: U.S. Geological Survey Water-Resources Investigations Report 934013, 26 p.
McCabe, G.J., Wolock, D.M., Tasker,G.D., and Ayers, M.A., 1991, Uncertainty in climate change and drought, in Shane, R.M., ed., Hydraulic Engineering: 1991 National Conference, American Society of Civil Engineers, Nashville, Tenn., [Proceedings], p. 1-6.

McCabe, G.J., Wolock, D.M., Tasker, G.D., Ayers, M.A., and Hay, L.E., 1993, Sensitivity of water resources in the Delaware River basin to climate change, in Kelmelis, J.A., and Snow, M., (eds.), Proceedings of the U.S. Gelogical Survey Global Change Research Forum, Herndon, Va.: U.S. Geological Survey Circular 1086, p. 56-62.

Moss, M.E., and Tasker, G.D., 1990, Manual for comparing methods of designing hydrologicdata-collection networks: U.S. Geological Survey Open-File Report 90-389, 111 p.

1991, An intercomparison of hydrological network-design technologies: Hydrological Sciences Journal, v. 36,3,6, p. 201-213.

Smith, R.A., Alexander, R.B., Tasker, G.D., Price, C.V., Robinson, K.W., and White, D.A., in press, Statistical modeling of water quality in regional watersheds: Watershed ' 93 [Proceedings], Alexandria, Va.

Tasker, G.D., 1989, Regionalization of low flows using logistic and GLS regression, in Kavvas, M.L., ed., New Directions for Surface Water Modeling: International Association of Hydrological Sciences Publication Number 181, p. 323-331. 


\section{SURFACE-WATER HYDROLOGY}

1990, Some hydrological impacts of climate change for the Delaware River basin, in Khanbilvardi, R., and Gooch, T., eds., Optimizing the Resources for Water Management, New York: 17th Annual National Conference, American Society of Civil Engineers, Fort Worth, Texas, April 1990 [Proceedings], p. 541-544.

1991, Identifying stream gages to operate for regional information: Transportation Research Record, Bridge and Hydrology Research, No. 1319, Washington, D.C., National Research Council, p. 131-136.

1991, Evaluating drought risks for large highly regulated basins using monthly water-balance modeling, in Kirby, W.H., and Tan, W.Y., eds., Proceedings of the United States-China Bilateral Symposium on Droughts and SemiArid Region Hydrology: U.S. Geological Survey Open-file Report 91-244, p. 317-322.

1991, Estimating low-flow characteristics of streams at ungaged sites, in Kirby, W.H., and Tan, W.Y., eds., Proceedings of the United States-China Bilateral Symposium on Droughts and Semi-Arid Region Hydrology: U.S. Geological Survey Open-file Report 91-244, p. 215-219.

1993, Some hydrologic effects of climate change for the Apalachicola, Chattahoochee, and Flint River basins, in Hatcher, K.J. (ed.), Proceedings of the 1993 Georgia Water Resources Conference: Athens, Ga., Institute of Natural Resources, University of Georgia, p. 61-64.

1993, Effects of climate change on drought risks in the Appalachicola, Chattahoochee, and Flint River Basin, in Kuo, C.Y., ed., Proceedings of the Engineering Hydrology Symposium, July 25-30, 1993, New York, New
York: American Society of Engineers, p. 49-54.

Tasker, G.D., Ayers, M., Wolock, D., and McCabe, G., 1991, Sensitivity of drought risks in the Delaware River basin to climate change: Technical and Business Exhibition and Symposium, Huntsville, Alabama, Huntsville Association of Technical Societies, [Proceedings], p. 153-159.

Tasker, G.D., Gilroy, E.J., and Jennings, M.E., 1990, Estimation of urban stormwater loads at unmonitored sites by regression, in Jennings, M.E., ed., Urban Hydrology: American Water Resources Association Conference, Denver, Colo., [Proceedings], p. 127-137.

Tasker, G.D., and Slade, Jr., R.M., 1994, An interactive regional regression approach to estimating flood quantiles, in Gontane, D.G., and Tuvel, H.N., eds., Water policy and management-Solving the problems: Annual Conference, American Society of Civil Engineers, 21st, May 23-26, 1994, p. 782-785.

Tasker, G.D., and Stedinger, J.R., 1989, An operational GLS model for hydrologic regression: Journal of Hydrology, v. III, no. 1-4, p. 361375.

1992, Generalized least squares analyses for hydrologic regionalization, in Jennings, M., and Bhowmik, N.G., (eds.), Hydraulic Engineering, Saving a Threatened Resource-In Search of Solutions: Water Forum `92, Hydraulic Engineering Sessions, Baltimore, Md., August 2-6, 1992, p. 7-12.

Wolock, D.M., McCabe, G.J., Tasker, G.D., Ayers, M.A., and Hay, L.E., 1992, Sensitivity of Water Resources in the Delaware River Basin to Climate Change-Proceedings of the Workshop on the Effects of Global Climate 


\section{SURFACE-WATER HYDROLOGY}

Change on Hydrology and Water Resources at the Catchment Scale, Tsukuba, Japan, Feb.

3-6, 1992: Japan-U.S. Committee on Hydrology, Water Resources, and Global Climate

Change, p. 319-329.

Wolock, D.M., McCabe, G.J., Tasker, G.D., and Moss, M.E., 1993, Effects of climate change on water resources in the Delaware River

Basin: Water Resources Bulletin, v. 29, no. 3, p. 475-486. 


\section{SURFACE-WATER HYDROLOGY}

TITLE: $\quad$ Regional Hydrologic Processes (NR 84-133)

PERSONNEL: Jurate M. Landwehr, Project Chief

Glenna Dahl, Secretary

ADDRESS: U.S. Geological Survey

431 National Center

12201 Sunrise Valley Drive

Reston, VA 22092

TELEPHONE: (703) 648-5893

PROBLEM: The regional nature of hydrologic processes is generally defined in terms of shared meteorologic and basin (geologic and land cover) characteristics. Inferences have been attempted by regressing the measures of hydrologic interest against such characteristics. Such treatment has been insufficient to fully explain the variations or extremes in discharge patterns observed within a geographic area. Long-term influences, such as decadal to centennial climatic fluctuations, need to be considered, and the stochastic structure of the hydrologic process itself needs to be better defined.

OBJECTIVE: Develop hydrologic statistics within a regional context and identify the effect of persistence due to long-term climatic fluctuations.

APPROACH: Use the statistical theory of extremes and time-series analysis to analyze the distribution of flows as expressed through the spectrum of flow regimes. Consider several measures of persistence, treating this statistic as a random variable in itself, as well as giving it traditional treatment as a constant property of the underlying stochastic process. Examine empirical-flow information from both national and international data bases that will be and have been developed for this project. Use other surrogate hydrologic records, such as dendrochronologic records, ice core records, and so forth, as needed and available.

PROGRESS: The publication of the Devils Hole oxygen-18 record has engendered a great deal of interest in both the scientific and lay press, as it has provided a challenge to the most widely accepted theory for the occurrence of Pleistocene glacial epochs. A great deal of effort (time and study) has been required to answer these discussions carefully. Although much of this correspondence is not in the public literature (for example, responses to journal editors), three publications were placed in the open literature (USGS Open-File Report 93-357 and Scientific Correspondence in NATURE, v. 362 and v. 368). We were invited to 


\section{SURFACE-WATER HYDROLOGY}

participate in two-seminars at Pennsylvania State University, one to the global climate research community and one to the geology graduate program. A third paper on Devils Hole concerning the nature and import of the $\boldsymbol{8}^{13} \mathrm{C}$ isotope record was published in Science in January 1994. Work is proceeding on an intercomparison of several climatic records as well as the Devils Hole isotopic records.

The discharge records found in the Hydro-Climatic Data Netword (HCDN) are being investigated with respect to the inter-relationship and persistence of regional, seasonal-todecadal, climatic and hydrologic patterns. Since their release, the HCDN reports (USGS Open-File Report; CD-ROM and USGS FACT SHEET) continue to be widely requested. The Open File report has been reprinted (over 1,000 copies distributed) and has been approved for publication as a Water Supply Paper.

Project personnel also assisted in the analysis of the extent of growth of submersed macrophytes in the Potomac River. Due to the growing popularity of probability weighted moments (defined by project chief and collaborators in 1979) and their linear equivalent, L-moments, in regional streamflow analysis, the project chief has provided reviews of some recent work in this area.

\section{REPORTS PUBLISHED 1989-1994:}

Carter, V., Rybicki, N.B., Landwehr, J.M., and Turtora, M., in press, Role of weather and water quality in population dynamics of submersed macrophytes in the tidal Potomac River: Esturaries, v. 00.

Cayan, Daniel R., Gardner, James V., Landwehr, Jurate M., Namias, Jerome, and Peterson, David H., 1989, Introduction, in Peterson, David H., ed., Aspects of Climate Variability in the Pacific and the Western Americas: Washington, D.C., American Geophysical Union, Geophysical Monograph Series Number 55 , p. xi-xvi.

Coplen, T.B., Winograd, I.J., Landwehr, J.M., and Riggs, A.C., 1994, 500,000-year stable carbon isotope record from Devils Hole, Nev.: Science, v. 263, p. 361-365.
Landwehr, J.M., and Slack, J.R., 1990, HCDN (Hydro-Climatic Data Network)-A U.S. Geological Survey discharge data set for climatological impact analysis, in Preprints of Symposium on Global Change Systems, Special Sessions on Climate Variations and Hydrology, Anaheim, Calif., February 5-9, 1990: American Meteorological Society, Boston, Massachuesetts, p. 122.

1992, FACT SHEET: Hydro-Climatic Data Network (HCDN) -A U.S. Geological Survey streamflow data set for the United States for the study of climate fluctuations, 1874-1988: U.S. Geological Survey Open-File Report 92-632, 2 p.

Landwehr, J.M., Winograd, I.J., and Coplen, T.B., 1994, Scientific Correspondence-No 


\section{SURFACE-WATER HYDROLOGY}

verification for Milankovitch: Nature, v. 368, p. 594.

Ludwig, Kenneth R., Simmons, Kathleen R., Szabo, Barney J., Winograd, Isaac J., Landwehr, Jurate M., Riggs, Alan C., and Hoffman, Ray J., 1992, Mass-spectrometric ${ }^{230} \mathrm{Th}$ ${ }^{234} \mathrm{U}-{ }^{238} \mathrm{U}$ Dating the Devils Hole calcite vein: Science, v. 258, p. 284-287.

Ludwig, K.R., Simmons, K.R., Winograd, I.J., Szabo, B.J., Landwehr, J.M., and Riggs, A.C., 1993, Scientific Correspondence-Last interglacial in Devils Hole: Nature, v. 362, p. 596.

Peterson, David, ed., Aubrey, David, Cayan, Daniel R., Gardner, James V., Keeling, Charles D., Landwehr, Jurate M., Mulloch, David S., McGowan, John A., and Roden, Gunnar, associate eds., 1989, Aspects of Climate Variability in the Pacific and the Western Americas: Washington, D.C., American Geophysical Union, Geophysical Monograph Series Number $55,445 \mathrm{p}$.

Slack, J.R., and Landwehr, Jurate Maciunas, 1992, Hydro-Climatic Data Network (HCDN)-A U.S. Geological Survey streamflow data set for the United States for the study of climate variations 1987-1988: U.S. Geological Survey Open-File Report 92-129, 193 p. and computer diskette.

Slack, J.R., Lumb, Alan M., and Landwehr, Jurate Maciunas, 1993, Hydro-climatic data network (HCDN)-Streamflow data set, 1874-1988: U.S. Geological Survey Water-Resources Investigations Report 93-4076, CD-ROM.

Winograd, Isaac J., Coplen, Tyler B., Landwehr, Jurate M., Riggs, Alan C., Ludwig, Kenneth R., Szabo, Barney J., Kolesar, Peter T., and Revesz, Kinga M., 1992, Continuous 500,000 -year climate record from vein calcite in Devils Hole, Nev.: Science, v. 258, p. 255260.

Winograd, I.J., and Landwehr, J.M., 1993, A response to "Milankovitch theory viewed from Devils Hole" by Imbrie, J., Mix, A.C., and Martinson, D.G.: U.S. Geological Survey Open-File Report 93-357, 9 p. 


\section{SURFACE-WATER HYDROLOGY}

TITLE: $\quad$ Continental Hydrology and Global Climate (NR 88-144)

PERSONNEL: P.C.D. Milly, Project Chief

Krista A. Dunne, Physical Scientist

ADDRESS: $\quad$ U.S. Geological Survey

Geophysical Fluid Dynamics Laboratory/NOAA

Forrestal Campus, Route 1

P. O. Box 308

Princeton, NJ 08542

TELEPHONE: (609) 452-6507

PROBLEM: The hydrology of the continents helps determine the global climate. The hydrosphere and the atmosphere are tightly coupled due to the role of water in the radiation and heat budgets of the atmosphere. Future progress in studies of global hydrology and climate dynamics will require interdisciplinary analyses of the dynamics of this coupled system.

OBJECTIVE: (1) Develop improved models of the global climate system by improving the parameterization of hydrologic response of the land surface in those models. (2) Develop an improved understanding of the global hydrologic cycle and its interlationship with global climate.

APPROACH: Much of the research uses the numerical climate model of the Climate Dynamics Project at the Geophysical Fluid Dynamics Laboratory of the National Oceanic and Atmospheric Administration. It is the subject of model development, and one of the tools for studying coupled dynamics.

PROGRESS: (1) Previous project work on the sensitivity of climate to continental evaporation was published in Journal of Climate.

(2) A storage hypothesis concerning the control of partitioning of annual precipitation into runoff and evaporation was further developed and evaluated. Three papers on this area of work were completed and accepted for publication. 


\section{SURFACE-WATER HYDROLOGY}

(3) A critical evaluation of the concept of equilibrium evaporation was continued. It was shown that direct radiative heating of the convective boundary layer of the atmosphere could possibly explain apparent departures of evaporation from equilibrium.

(4) In collaboration with B. Scanlon (University of Texas, Austin), work on simulation and field measurement of soil temperature and water potential in a desert environment continued. Some of this work was published in Water Resources Research. Further analysis has clarified the relation among annual mean water-potential gradients, vapor fluxes, and nonlinearity of the thermal vapor diffusion process.

(5) This project has participated in the Project for Intercomparison of Land-surface Parameterization Schemes (PILPS), whose objective is to compare the performance of all major land-surface simulation modules that are used in conjunction with global and regional atmospheric models. Milly serves as a scientific advisor for this international project, and is a project participant.

(6) Climate-model simulations were used in a preliminary exploration of the possible effect of a biospheric feedback on continental water balances under an enhanced "greenhouse effect." Previous studies have suggested increased incidence of summer soil-water drought in middle latitudes under increased carbon dioxide concentrations in the atmosphere. We explained this as a result of increasing seasonality of water supply and demand, and showed that a small (15 percent) extension of the volume of soil penetrated by roots would be sufficient to offset the tendency toward drought that would be induced by equilibrium doubling of carbon dioxide.

\section{REPORTS PUBLISHED 1989-1994:}

Blain, C.A., and Milly, P.C.D., 1991, Development and application of a hillslope hydrologic model: Advances in Water Resources, v. 14, p. 168-174.

Kienitz, G., Milly, P.C.D., van Genuchten, M. Th., Rosbjerg, D., Shuttleworth, W.J., eds., 1991, Hydrological Interactions between Atmosphere, Soil and Vegetation: International Association of Hydrological Sciences, no. 204, $494 \mathrm{p}$.
Milly, P.C.D., 1991, A refinement of the combination equations for evaporation: Surveys in Geophysics, v. 12, p. 145-154.

1991, Some current themes in physical hydrology of the land-atmosphere interface, in Kienitz, G., Milly, P.C.D., van Genuchten, M.Th., Rosbjerg, D., Shuttleworth, W.J., eds., Hydrological Interactions between Atmosphere, Soil and Vegetation: International Association of Hydrological Sciences, no. 204, p. 3-10. 


\section{SURFACE-WATER HYDROLOGY}

1992, Potential evaporation and soil moisture in general circulation models: Journal of Climate, v. 5, p. 209-226.

1993, An analytic solution of the stochastic storage problem applicable to soil water: Water Resources Research, v. 11, no. 11, p. 3755-3758.

1993, Sensitivity of the global water cycle to the water holding capacity of soils, in Bolle, H.J., Feddes, R.A., Kalma, J.D., eds., Exchange processes at the land surface for a range of space and time scales: International Association of Hydrological Sciences, no. 212, p. 495-501 [Also published in Conference on Hydroclimatology, Anaheim, Calif., 1993, [Proceedings], p. 60-61].

Milly, P.C.D., in press, Climate, interseasonal storage of soil water, and the annual water balance: Advances in Water Resources, v. 17.

Milly, P. C. D., in press, Climate, soil-water storage, and the average annual water balance: Water Resources Research, v. 30.

Milly, P.C.D., and K.A. Dunne, 1994, Sensitivity of the global water cycle to the water-holding capacity of land: Journal of Climate, v. 7, p. 506-526.

Scanlon, B.R., and P.C.D. Milly, 1994, Water and heat fluxes in desert soils-2. numerical simulations: Water Resources Research, v. 30, p. 721-733. 


\section{SURFACE-WATER HYDROLOGY}

TITLE: $\quad$ Transport of Dissolved and Suspended Materials in Surface Waters (NR 90-147)

PERSONNEL: Jonathan Lee, Project Chief

Mary Abel, Secretary

Lara M. Lewis, student, (Univ. of Washington)

Amy C. Wheeless, student, (Virginia Polytechnic Institute)

ADDRESS: U.S. Geological Survey

430 National Center

12201 Sunrise Valley Drive

Reston, VA 22092

\section{TELEPHONE: (703) 648-4033}

PROBLEM: Although a major effort has been made to understand the hydrodynamics of surface waters, less effort has been devoted to the study of transport mechanisms and to the development and validation of computational models for simulating the transport of dissolved and suspended materials. Recent progress in hydrodynamics has created additional opportunities for advances in surface-water transport. It may be possible to develop and validate more physically correct descriptions of transport processes in terms of flow characteristics than have been previously available. Microscale processes must be expressed at the macroscale level by algorithms which can be validated in computational models using laboratory and field data.

OBJECTIVE: (1) The evaluation of existing methods and techniques; (2) the development, or validation, or both, by the use of laboratory and field data, of algorithms describing dissolved- and suspended-material transport processes; (3) the development, or validation, or both, of computational techniques for solving the partial-differential equations describing surface-water transport processes; (4) the development and validation of multidimensional, computational models for the transport of dissolved and suspended materials in surface waters; and (5) the development of techniques for the application of computational, surfacewater transport models to field problems.

APPROACH: Algorithms that quantify relationships between flow characteristics and transport processes will be selected from the literature or developed on the basis of concepts derived from the study of laboratory and field data. Computational schemes for the solution of the convective-dispersion equation in two and three dimensions will be analyzed for 


\section{SURFACE-WATER HYDROLOGY}

efficiency and accuracy. Advanced turbulence-closure schemes, necessary for the proper simulation of certain transport processes, will be studied in two- and three-dimensional models. Two- and three-dimensional flow and transport models will be developed for use in validating transport algorithms for both dissolved and suspended materials.

PROGRESS: A model was developed for the mass balance of radium in a lake in an effort to explain radium data collected in the Finger Lakes in New York by Tom Kraemer. The model accounts for inflows, outflows, precipitation, evapotranspiration, radioactive decay, settling of sediment particles to which radium is adsorbed, and, in the sediment column, advection, diffusion, decay, and compaction of the sediment.

With the help of summer student Gene Chun, tables and graphs of data collected at the Flood Plain Simulation Facility in 1986 and 1987 on flow through single and multiple contracted openings were prepared. These data are more complete than data collected in the 1970's at the Facility and will be useful in the validation of models used to study flow through contracted openings at highway crossings.

A proposal on determining vegetative resistance to flow in the Everglades. Part of the proposed Everglades Ecosystem Initiative, this work would provide the basis for understanding the movement of nutrients and contaminants through the Everglades. I proposed a project in three phases: (1) laboratory studies of flow through typical Everglades vegetation to develop appropriate mathematical expressions and coefficients for flow resistance; (2) the development of techniques for representing flow resistance in large-scale numerical hydraulic and hydrologic models of the Everglades; and (3) the validation of these methods using data collected by the Geological Survey and the South Florida Water Management District in numerical models of both small and large impoundments at the Everglades Nutrient Removal site.

A journal article, "Simulating effects of highway embankments on estuarine circulation," by Lee, Schaffranek, and Baltzer was published in March 1994 in the Journal of Waterway, Port, Coastal, and Ocean Engineering. This work demonstrated the use of the Surface-Water, Integrated, Flow and Transport Model, SWIFT2D, in quantifying the effect on flow and transport of highway embankments in Port Royal Sound, a South Carolina estuary. A nested submodel of the global model to show, among other things, that there was a major change in the flow pattern in Battery Creek, a branch of Port Royal Sound, during flood tide because of a jet-like effect at one of the embankment openings. 


\section{SURFACE-WATER HYDROLOGY}

The development of a hydrodynamic model based on the finite-element method to be used as a basis for transport modeling continued. A code was written for vertically averaged flow that represents velocity with nonconforming, linear shape functions. (The velocity nodes are located at the midsides of the sides of triangular elements.) These elements offer the advantage of diagonal mass matrices (the matrices multiplying the time derivative terms) in the momentum equations, which facilitates the use of a semi-implicit formulation. The code uses a linear, conforming representation of the water-surface elevation on a element, with the water-surface elevations nodes at the element vertices. The model gave good results in tests involving steady-state problems. The code is now being tested for unsteady flows.

\section{REPORTS PUBLISHED 1989-1994:}

Lee, J.K., Schaffranek, R.W., and Baltzer, R.A., 1994, Simulating effects of highway embankments on estuarine circulation: American Society of Civil Engineers, Journal of Waterway, Port, Coastal, and Ocean Engineering, v. 120 , no. 2 , p. 199-218. 


\section{SURFACE-WATER HYDROLOGY}

TITLE: Hydrodynamics and Mathematical Modeling of Circulation and Transport Phenomena in Tidal Estuaries (WR 76-140)

PERSONNEL: Ralph T. Cheng, Project Chief

Gwendolyn J. Lewis, Secretary

Jeffrey W. Gartner, Oceanographer

Jon R. Burau, Civil Engineer

Ellen T. McDonald, Hydrologist

Edward Gross, Hydrologist

Richard E. Smith, Hydrologist

ADDRESS: $\quad$ U.S. Geological Survey

345 Middlefield Road, MS 496

Menlo Park, CA 94025

TELEPHONE: (415) 354-3358

PROBLEM: The ecosystem of a tide-affected estuary consists of an extremely complicated balance of natural processes and human-induced activities. Some of the basic characteristics of such a system, for example, the San Francisco Bay estuarine system, are not well understood. A comprehensive description of the hydrodynamics and the related transport phenomena is still lacking. A better understanding of the effects among the interactive natural and human-induced processes on this system requires advances in basic science relating the physical, chemical, and biological estuarine processes. Circulation in a tidal estuary is generated in response to astronomical tides, inflow of freshwater, winds, and stratification due to salinity. The basin topography (bathymetry), air-water interaction, watersedimentation interface, mixing characteristics, frictional loss at the bottom, and the rotational effects of the earth, together with the above-mentioned driving forces, constitute an extremely complicated balance that conserves mass, momentum, energy, and conservative solutes in the system.

OBJECTIVE: (1) Understand processes and rates by which water, salt, and other solutes interact; (2) develop methods to enable quantification of the relative importance of river inflow, winds, tides and other dynamic forcings that act upon the system; and (3) develop and verify conceptual and numerical models of these interactions.

APPROACH: Include intensive field-data collection and mathematical-model development and implementation in project activities. Collect long-term current and stage data. Develop effective methods of solution to the equations that govern the basic hydrodynamic processes, that is, the conservation equations of mass, momentum, energy, and salt. Treat field datacollection and numerical-modeling research as complementary parts of a well-integrated 


\section{SURFACE-WATER HYDROLOGY}

program; use field data to calibrate and verify numerical models, and use numerical-model results to guide future data-collection activities. Use numerical models as research tools for investigations of short- and long-term transport phenomena after the models are calibrated and verified.

PROGRESS: This project collaborates with scientists in the Interagency Ecological Study Plan (IESP) for San Francisco Bay/Delta, and with other districts (Washington and South Carolina). Continuing progress has been made in both two- and three-dimensional estuarine hydrodynamic modeling research. The two-dimensional version of the Tital, Residual, and Intertidal Mudflat (TRIM) model is being used in California and South Carolina Districts. Using the TRIM model as a research tool, the hydrodynamic characteristics of San Diego Bay has been investigated. Preliminary results in modeling sediment transport processes in San Francisco Bay are very encouraging, they also pointed out that little time-series data relevant to sediment transport in San Francisco Bay are available. We have initiated a novel approach to velocity measurements in the boundary layer adjacent to sediment-water interface. These measurements are unique, and the measured velocity profiles will be used to define the variability of critical shear stress (a limiting shear stress, above this limit will cause sediment to erode).

Collaboration on three-dimensional estuarine modeling with Vincenzo Casulli (Italy) continues. By including baroclinic forcing, which is the major driving force for the generation of gravitational circulation, the numerical method is subject to a CourantFriederichs-Lewy (CFL) stability condition due to an internal wave. This means lower computational efficiency when the baroclinic forcing is included. This result may appear to be a negative finding, however, the identification if this difficulty is the first step toward solving this problem. We have compiled available three-dimensional hydrodynamic data, and a detailed calibration and validation of the three-dimensional model is in progress.

The Project Chief and Jeffrey W. Gartner continue to collaborate with staff of California District Office on numerical modeling and in field data collection and processing. A major field data collection effort was carried out in an attempt to define the mechanisms that balance the salt field in the northern reach of San Francisco Bay. The field study took place between March and May 1994 and used nearly the entire collection of the oceanographic instrument in this project and in California District Office. Jon Burau of the District Office and Jeffrey Gartner played the major roles in this study.

There were two unusual research activities that took place in the reporting period. By request from Washington District, we have developed a joint study between Washington District, this 


\section{SURFACE-WATER HYDROLOGY}

project (NRP), and Pacific Marine Geology (David Cacchione) to conduct physical oceanographic investigations in Sinclair Inlet, Washington.

Richard E. Smith and the Project Chief have identified the need to accurately define the bathymetry in the south end of South San Francisco Bay where the bathymetry is poorly defined for a large percentage of the area. San Jose Municipal Waste Water District discharges its waste water into this region. Thus an accurate representation of the bathymetry is of great importance to water quality of this region. Efforts to define the bathymetry for this region is supported by San Francisco Bay Regional Water Quality Control Board. The proposed effort is to complete the work before the end of Fiscal Year 1994

REPORTS PUBLISHED 1989-1994:

Burau, J.R., and Cheng, R.T., 1989, A vertically averaged spectral model for tidal circulation in estuaries, Part (I), Model formulation: U.S. Geological Survey Water-Resources Investigation Report, 88-4126.

1989, A general method for generating bathymetric data for hydrodynamic computer models-Computer program documentation and application to San Francisco Bay, California: U.S. Geological Survey Open-File Report, Report 89-28.

Casulli, V., Bertolazzi, E., and Cheng, R.T., 1993, TRIM_3D-A three-dimensional model for accurate simulation of shallow water flow: 1993 National Conference on Hydraulic Engineering, American Society of Civil Engineers, San Francisco, Calif., July 1993 [Proceedings], p. 1988-1993.

Casulli, V. and Cheng, R.T. 1992, Semi-implicit finite difference methods for three-dimensional shallow water flow: Internation Journal for Numerical Methods in Fluids, v. 15, p. 629648.

1990, Stability analysis of Eulerian-Lagrangian methods for the one-dimensional shallow- water equations: Applied Mathematical Modelling, v. 14, p. 122-131.

1994, Solutions of primitive equations for three-dimensional tidal circulation: Proceedings of the 3rd International Conference on Estuarine and Coastal Modeling, Chicago, Illinois, Sept. 1993: American Society of Civil Engineers, p. 396-406.

Casulli, Vincenzo, and Cheng, Ralph T., 1992, A semi-implicit finite-difference model for threedimensional tidal circulation, in Spaulding, M.L., Bedford, K., Blumberg, A.F., Cheng, R.T., and Swanson, C., eds., Estuarine and Coastal Modeling: International Conference on Estuarine and Coastal Modeling, 2nd, Tampa, Fla., November 13-15, 1991, p. 620-631.

Cheng, R.T., 1990, ed., Residual Currents and Long-term transport: Springer-Verlag, Coastal and Estuarine Studies, v. 38, 554 p.

Cheng, R.T., Burau, J.R., and Gartner, J.W., 1991, Interfacing data analysis and numerical modeling for tidal hydrodynamic phenomena, in Parker, B., Tidal hydrodynamics: John Wiley, p. 201-219. 


\section{SURFACE-WATER HYDROLOGY}

Cheng, R.T., and Casulli, V., 1992, Dispersion in tidally averaged transport equation, in Prandle, D., ed., Dynamics and exchanges in estuaries and the coastal zone: Coastal and Estuarine Studies, v. 40 , p. $409-428$.

Cheng, Ralph T., and Casulli, Vincenzo, 1992, Tidal, Residual, Intertidal Mudflat (TRIM) model using a semi-implicit Eulerian-Lagrangian Method: U.S. Geological Survey, OpenFile Report 92-62, 43 p.

Cheng, R.T., Casulli, V., and Gartner, J.W., 1993, Tidal, residual, intertidal mudflat (TRIM) model and its applications to San Francisco Bay, California: Estuarine, Coastal, and Shelf Science, v. 36, p. 235-280.

Cheng, R.T., Feng, S., and Xi, P., 1989, On intertidal transport equation, in Estuarine Circulation, Neilson, Kuo, and Brubaker, eds.: Humana Press, p. 133-156.

Cheng, R.T., Smith, P.E., and Casulli, V., 1993, Recent development in three-dimensional numerical estuarine models: National Conference on Hydraulic Engineering-Proceedings of the National Conference on Hydraulic Engineering, July 1993, San Francisco Calif.: American Society of Civil Engineers, p. 1982-1997.

Cheng, R.T., and Smith, P.E., 1990, A survey of three-dimensional numerical estuarine models, in Spaulding, M., ed. Estuarine and coastal modeling: ASCE Specialty Conference, $p$. 1-15.

Feng, S., Cheng, R.T., Xi, Sun, and Son, 1990, Lagrangian residual circulation and long-term transport processes in a weakly nonlinear baroclinic system, in Physics of Shallow Oceans, Wang Huatong and others, eds.: China Ocean Press, p. 1-20.
Ford, M., Wang, J., and Cheng, R.T., 1990, Predicting the vertical structure of tidal current and salinity in San Francisco Bay, California: Water Resources Research, v. 26, no. 5, p. 1027-1045.

Gartner, J.W., and Oltmann, R.N., 1990, Comparison of recording current meters in shallow waters of San Francisco Bay, California: U.S. Geological Survey Water-Resources Investigation Report 90-4018, 84 p.

Kamrath, Anke, Cheng, Ralph T., and Jovanovic, Marsha, 1991, Scientific visualization techniques applied to water quality and transport: ASCE, National Conference on Hydraulic Engineering, Nashville, Tenn., August 1991, p. $375-381$.

Smith, P.E., and Cheng, R.T., 1990, Recent progress on hydrodynamic modeling of San Francisco Bay, in Spaulding, M., ed., Estuarine and Coastal Modeling: American Society of Civil Engineers Specialty Conference, p. 502510.

Smith, P.E., Cheng, R.T., Burau, J.R., and Simpson, M.R., 1991, Gravitational circulation in a tidal strait: ASCE, National Conference on Hydraulic Engineering, Nashville, Tennessee, August 1991, [Proceedings], p. 429-434.

Spaulding, M.L, Bedford, K., Blumberg, A.F., Cheng, R.T., and Swanson, C., eds., 1992, Estuarine and Coastal Modeling-Proceedings of the Second International Conference on Estuarine and Coastal Modeling, Tampa, Fla., November 1991: New York, American Society of Civil Engineers, 786 p.

Wang, J., and Cheng, R.T., 1993, On low-pass digital filters in oceanography: Acta Oceanologics, v. 12, no. 2, p. 183-196. 


\section{SURFACE-WATER HYDROLOGY}

TITLE: $\quad$ Research Vessel Polaris Operations in San Francisco Bay and Adjacent Coastal Ocean (WR 77-156)

PERSONNEL: T. John Conomos, Project Chief

Mary S. Conger, Secretary

Byron J. Richards, Master R/V Polaris

William S. Conard, Chief Engineer R/V Polaris

ADDRESS: U.S. Geological Survey

345 Middlefield Road, MS 977

Menlo Park, CA 94025

TELEPHONE: (415) 329-4414

PROBLEM: A stable moving platform is needed to house at least 10 scientists throughout the year (for periods of weeks) so that large volumes of complex and continuous data can be carefully and rapidly collected and precisely measured and analyzed immediately after collection.

OBJECTIVE: Provide scientific platform (research vessel) for estuarine studies, platform functions, and measurement, collection, and subsequent analysis of geological, chemical, physical, and biological data throughout the year for extended time periods.

APPROACH: Provide support for research vessel, including operating support for dockage fees, boat maintenance, diesel fuel, and food for scientists and crew.

PROGRESS: Provided research vessel support for routine field sampling by personnel in several projects within the Branch of Regional Research (WR) and the California District. For example, the POLARIS has been used in the "San Francisco Bay River-Estuary Toxic Contaminant Study." 


\section{SURFACE-WATER HYDROLOGY}

TITLE: $\quad$ Analysis and Modeling of Conservative and Nonconservative Transport Processes (WR 83-183)

PERSONNEL: Roy A. Walters, Project Chief

Margaret E. Sullivan, Physical Scientist

ADDRESS: $\quad$ U.S. Geological Survey

1201 Pacific Ave., Suite 600, Tacoma, WA 98402

TELEPHONE: (206) 593-6505

PROBLEM: The biological and chemical characteristics of aquatic environments depend on a generally complicated balance of physical, chemical, and biological processes. Basic to describing these characteristics is an understanding of transport processes including both advection and mixing. For a given water body, these processes depend heavily on the mass, momentum, and energy transfers at boundaries and the internal response of the system. Many of these transfers and responses are poorly known and thus make fundamental understanding and predictions of important environmental systems impossible.

OBJECTIVE: Broad goals of this project are to quantitatively understand the physical processes responsible for the transport of conservative and nonconservative solutes of biological and chemical importance. Through the use of time series analysis and other methods, conceptual, statistical, and numerical models of these processes are being developed.

APPROACH: Use data analysis, including the application of digital filters, spectral analysis, empirical orthogonal function analysis, regression analysis, and time-series models, to examine daily to interannual time-scale physical transport phenomena. Use numerical models, including box and finite-element models, in one, two, and three dimensions to simulate these processes and provide a quantitative basis for assessment of the conceptual models.

PROGRESS: In the last year, the results for the Delaware Bay Climate Study have been fine-tuned and prepared for publication. A paper describing the existing hydrodynamics has been submitted to Journal of Geophysical Research. A draft paper presents an analysis of salt flux. An analysis of the changes in flow and salt flux associated with a rise in mean sea level is complete and manuscript prepartion has begun. Some significant results are the importance of the time-dependent variations of vertical eddy viscosity on frictional damping of the 


\section{SURFACE-WATER HYDROLOGY}

secondary tidal constituents, the importance of tidal straining in controlling stratification, and the importance of transverse variations in flow and salinity in determining the salt flux.

In cooperation with researchers at University of Texas, I have developed numerical methods for the solution of the three-dimensional shallow water equations that solve some significant and long-standing problems with the use of finite element methods. A paper on iterative methods was published in Advances in Water Resources, and a paper on p-methods is almost complete. These methods allow much higher resolution and help bridge the differences in spatial-scale between the various processes.

As a participant of the National Institute of Water and Atmospheric Research (NIWA), New Zealand, workshop relating to marine benthic ecology, we explored the causal relation between physical processes and population density of two species of bivalve. The results point out the mismatch in physical and biological spatial scales, and the fact that physical processes such as inundation period and incident wave energy govern the overall pattern in density.

I have taken a major role in developing new programs, one of which is the Columbia River thrust. Using models I have developed over the past 5 years, and concepts developed at the NIWA workshop and with Canadian and other colleagues, we have formulated a method to examine the passive and active transport of anadromous fish in the Columbia River mainstem. The declining fish populations in that area are currently a national and international issue.

REPORTS PUBLISHED 1989-1994:

Foreman, M.G.G, Baptista, A.M., and Walters, R.A., 1992, Tidal model studies of particle trajectories around a shallow coastal bank, Atmosphere-Ocean, v. 30, no. 1, p. 43-69.

Foreman, M.G.G., Henry, R.F., Walters, R.A., and Ballantyne, V.A., 1993, A finite element model for tides and resonance along the north coast of British Columbia: Journal of Geophysical Research, v. 98, no. C2, p. 2509-2531.

Foreman, M.G.G., Thomson, R.E, Lynch, D.R., and Walters, R.A., 1992, A finite element model for three-dimensional flows along the west coast of Vancouver Island, in Spaulding,
M.L., ed., Estuarine and Coastal Modeling, proceedings from Estuarine and Coastal Modeling, 2nd International Conference, Tampa, Fla., ASCE publication, p. 574-585.

Foreman, M.G.G., and Walters, R.A., 1990, A finite element tidal model for the southwest coast of Vancouver Island: Atmosphere-Ocean, v. 28, p. 261-287.

Foreman, M.G.G., Walters, R.A., Henry, R.F., Keller, P., and Dolling, A., in press, A tidal model for eastern Juan de Fuca Strait and the southern Strait of Georgia, Journal of Geophysical Research, v. 00. 


\section{SURFACE-WATER HYDROLOGY}

Henry, R.F., and Walters, R.A., 1991, User manual for PC TRIGRID: Sidney, B.C., Canada V8L 4B2, Institute of Ocean Sciences.

1993, A geometrically-based, automatic generator for irregular triangular networks: Communications in Numerical Methods in Engineering, v. 9, p. 555-566.

Walters, R.A., 1989, A tale of two estuaries: Columbia Bay, Alaska and San Francisco Bay, California, in Nielson, Kuo, and Brubaker, eds., Estuarine Circulation: Humana Press, p. 183-200.

1989, Small-amplitude, short-period variations in speed of a tidewater glacier in south-central Alaska: Annals of Glaciology, v. 12, p. 187191.

1992, A 3D, finite element model for coastal and estuarine circulation, Continental Shelf Research, v. 12 , no. 1 , p. 83-102.

1992, A Study of Salt Transport Processes in Delaware Bay, in Spaulding, M.L., ed., Estuarine and Coastal Modeling: Estuarine and Coastal Modeling 2nd International Conference, American Society of Civil Engineers, Tampa, Fla., November 13-15, 1991, [Proceedings], p. 240-251.

in press, A model study of tidal and residual circulation in Delaware Bay and River: Journal of Geophysical Research, v. 00.

Walters, R.A., and Foreman, M.G.G. 1992, A 3D finite element model for the baroclinic circulation on the Vancouver Island Shelf: Journal of Marine Systems, v. 3, p. 507-518.

Walters, R.A., and Meier, M.F., 1989, Variability of glacier mass balances in western North America, in Peterson, D.H., ed., Aspects of climate variability in the Pacific and the Western Americas: Geophysical Monograph 55, American Geophysical Union, p. 365-374.

Walters, R.A., and Werner, F.E., 1989, A comparison of two finite element models of tidal hydrodynamics using a North Sea data set: Advances in Water Resources, v. 12, p. 184193.

Walters, R.A., and Werner, F.E., 1991, Nonlinear generation of overtides, compound tides, and residuals, in Parker B.B., ed., Tidal hydrodynamics: New York, John Wiley and Sons, p. 297-320. 


\section{SURFACE-WATER HYDROLOGY}

TITLE: $\quad$ Coupled Transport and Geochemical Processes Determining the Fate of Chemicals in Surface Waters (WR 84-187)

PERSONNEL: Kenneth E. Bencala, Project Chief

Carolyn Harden, Secretary

Gary W. Zellweger, Hydrologist

Elizabeth W. Boyer, student, University of Virginia (NSF Grant)

ADDRESS: $\quad$ U.S. Geological Survey

345 Middlefield Road, MS 496

Menlo Park, CA 94025

TELEPHONE: (415) 354-3326

PROBLEM: Coupled transport and biogeochemical processes determine the fate of chemicals both naturally present in surface waters and those introduced through anthropogenic activities. In mountainous environments, coupled processes operate at scales which can be years and kilometers in watersheds or minutes and decimeters in the hyporheic zone. Although individual processes are often well understood in isolation, the ability to quantify chemical fate across the stream-watershed continuum requires development in design of field experiments and mechanistic formulations to integrate interpretation of multiple processes.

OBJECTIVE: Develop experimental field techniques and mechanistic formulations to quantitatively identify rates and extents of transport within the stream-watershed continuum. Focus on transport processes which most influence the fate of chemicals introduced from the surrounding watershed into pristine streams (for example, natural dissolved organic materials and nutrients, as well as, acid mine drainage).

APPROACH: Cooperate with hydrologists, geochemists, and ecologists to identify the processes of environmental fluid mechanics exerting significant influence on the fate of chemicals in mountainous watersheds. Study these processes (for example, transient storage of solutes in the hyporheic zone) specifically to estimate hydrologic parameters needed for quantitative determinations of solute transport. Dynamic field experimentation is the primary mode of study, augmented with detailed sampling studies and numerical simulations.

PROGRESS: Boyer and Hornberger (University of Virginia), have collaborated with Bencala and McKnight to carry-out extensive field sampling and application of the TOPMODEL watershed topography concepts to identify the significance of landscape spatial heterogeneities 


\section{SURFACE-WATER HYDROLOGY}

as a determinant of dissolved organic material transport in the Deer Creek and Snake River watersheds (Summit County, Colorado). The field sampling quantified both the highly variable dissolved organic material (DOM) concentration ranges and characteristic hydrologic response times of source areas. TOPMODEL is used to hydrologically constrain the temporal and spatial DOM mass-balance.

Runkel (Colorado District) has collaborated with Bencala and McKnight to use simple formulations of photoreduction and mass-constraints on available solid iron phases to simulate transport experiments in the naturally acidic Snake River (Summit County, Colorado).

Broshears and Kimball, Colorado and Utah Districts respectively, have worked with Runkel, Bencala, and McKnight to reduce the coupled transient storage/equilibrium reactive transport concepts to steady-state estimates of reach-scale iron removal time constants in the acid mine drainage St. Kevin Gulch (Leadville, Colorado-Upper Arkansas River Toxic Substances Hydrology Site).

Zellweger followed upon his developmental studies measuring low net flow losses (approximately 1 liter per second) from St. Kevin Gulch to assist Constantz in studies of temperature relations to such flow losses (Leadville, Colorado-Upper Arkansas River Toxic Substances Hydrology Site).

J. Harvey completed the publishing of his thesis work which illustrates in coastal wetlands the importance of bioporosity to exchange fluxes of conservative and reactive solutes to estuarine surface waters.

Bencala organized a multidisciplinary (with Duff, J.Harvey, Jackman, and Triska) review chapter to identify the future research need for complementary focus on numerical simulations with field observations in studies of the stream-catchment continuum.

\section{REPORTS PUBLISHED 1989-1994:}

Bencala, K.E., 1993, A perspective on streamcatchment connections: Journal of the North American Benthological Society, v. 12, p. 4447.

Bencala, K.E., Duff, J.H., Harvey, J.W., Jackman, A.P., and Triska, F.J., 1993, Modelling within the stream-catchment continuum, in
Jakeman, A.J., Beck, M.B., and McAleer, M.J., ed., Modelling Change in Environmental Systems: Wiley, p.163-187.

Bencala, K.E., Kimball, B.A., and McKnight, D.M., 1991, Use of variation in solute concentration to identify interactions of the substream zone with instream transport, in 


\section{SURFACE-WATER HYDROLOGY}

Mallard, G.E., and Aronson, D.A., eds., U.S. Geological Survey Toxics Substances Hydrology Program-Proceedings of the technical meeting, Monterey, Calif., March 11-15, 1991: U.S. Geological Survey Water-

Resources Investigations Report 91-4034, p. 377-379.

Bencala, K.E., McKnight, D.M., and Zellweger, G.W., 1990, Characterization of transport in an acidic and metal-rich mountain stream based on a lithium tracer injection and simulations of transient storage: Water Resources Research, v. 26, p. 989-1000.

Boyer, E.W., 1994, Hydrology and the variation of dissolved organic carbon in soil and stream waters of two headwater catchments-Summit County, Colorado: Charlottesville, Va., University of Virginia, Master of Science Thesis, Environmental Science, 102 p.

Boyer, E.W., Hornberger, G.W., and Bencala, K.E., 1993, Hydrological controls on the temporal variation of dissolved organic carbon in Deer Creek near Montezuma, Colorado, in McAleer, M., and Jakeman, A., ed., Proceedings of the 10th Biennial Conference of the Modeling and Simulation Society of Australia: December 6-10, 1993, The University of Western Australia, p. 501-506.

Broshears, R.E., Bencala, K.E., Kimball, B.A., and McKnight, D.M., 1993, Tracer-dilution experiments and solute-transport simulations for a mountain stream, Saint Kevin Gulch, Colorado: U.S. Geological Survey WaterResources Investigation Report 92-4081, 18 p.

Constantz, J., Thomas, C.L., and Zellweger, G.W., in press, Influence of daily streamtemperature variations on streamflow and groundwater recharge: Water Resources Research, v. 30.
Fuller, C.C., Davis, J.A., Zellweger, G.W., and Goddard, K.E., 1989, Coupled chemical, biological and physical processes in Whitewood Creek, South Dakota: evaluation of the controls of dissolved arsenic, in Mallard, G. E, and Ragone, S. E., eds., U.S. Geological Survey Toxic Substances Hydrology ProgramProceedings of the technical meeting, Phoenix, Ariz., September 26-30, 1988: U.S. Geological Survey Water-Resources Investigations Report 88-4220, p. 235-246.

Harvey, J.W., 1993, Measurement of variation in soil-solute tracer concentration across a range of effective pore sizes: Water Resources Research, v. 29, p. 1831-1837.

Harvey, J.W. and Bencala, K.E., 1993, The effect of streambed topography on surface-subsurface water exchange in mountain catchments: Water-Resources Research, v. 29(1), p. 8998.

Harvey, J.W., Bencala, K.E., and Zellweger, G.W., 1991, Preliminary investigation of the effect of hillslope hydrology on the mechanics of solute exchange between streams and subsurface gravel zones, in Mallard, G.E., and Aronson, D.A., eds., U.S. Geological Survey Toxics Substances Hydrology Program-Proceedings of the technical meeting, Monterey, Calif., March 11-15, 1991: U.S. Geological Survey Water-Resources Investigations Report 91-4034, p. 413-418.

Harvey, J.W., and Nuttle, W.K., in press, Fluxes of water and solute in a coastal wetland sediment 2-Effect of macropores on solute exchange with surface water: Journal of Hydrology, v. 00.

Hornberger, G.M., Bencala, K.E., and McKnight, D.M., 1994, Hydrological controls on dissolved organic carbon during snowmelt in the 


\section{SURFACE-WATER HYDROLOGY}

Snake River near Montezuma, Colorado: Biogeochemistry, v. 23, p. 1-20.

Jakeman, A.J., Hornberger, G.M., Littlewood, I.G., Whitehead, P.G., Harvey, J.W., and Bencala, K.E., 1992, A systematic approach to modeling the dynamic linkage of climate, physical catchment descriptors, and hydrologic response components: Mathematics and Computers in Simulation, v. 33, p.359-366.

Kimball, B.A., Bencala, K.E., and McKnight, D.M., 1989, Research on metals in acid mine drainage in the Leadville, Colorado, area, in Mallard, G. E, and Ragone, S. E., eds., U.S. Geological Survey Toxic Substances Hydrology Program-Proceedings of the technical meeting, Phoenix, Ariz., September 26-30, 1988: U.S. Geological Survey WaterResources Investigations Report 88-4220, p. 65-70.

Kimball, B.A., Broshears, R.E., Bencala, K.E., and McKnight, D.M., 1991, Comparison of rates of hydrologic and chemical processes in a stream affected by acid mine drainage, in Mallard, G.E., and Aronson, D.A., eds., U.S. Geological Survey Toxics Substances Hydrology Program-Proceedings of the technical meeting, Monterey, Calif., March 11-15, 1991: U.S. Geological Survey WaterResources Investigations Report 91-4034, p. 407-412.

Kimball, B.A., Broshears, R.E., McKnight, D.M., and Bencala, K.E., 1992, Effect of instream $\mathrm{pH}$ modification on aluminum in Kharaka, Y.K., and Maest, A.S., eds., Proceedings of the 7th International Symposium on WaterRock Interaction, July 9-23, 1992, Park City, Utah: Rotterdam, The Netherlands, A.A. Balkema, p. 393-396.
Kimball, B.A., Broshears, R.E., McKnight, D.M., and Bencala, K.E., 1994, Effects of instream $\mathrm{pH}$ modification on transport of sulfide-oxidation products, in Alpers, C.L., and Bowles, D., eds., The environmental geochemistry of sulfide oxidation: Washington, D.C., Americal Chemical Society Symposium Series, p. 224243.

McKnight, D.M., and Bencala, K.E., 1989, Reactive iron transport in an acidic stream in Summit County, Colorado-A hydrologic perspective: Geochimica et Cosmochimica Acta, v. 53, p. 2225-2234.

1990, The chemistry of iron, aluminum, and dissolved organic material in three acidic, metal-enriched, mountain streams, as controlled by watershed and in-stream processes: Water Resources Research, v. 26, p. 30873100 .

McKnight, D.M., Bencala, K.E., Harnish, R.A., and Runkel, R.L., 1994, Difficulties with intermediate scale experiments for studies of iron chemistry in acid mine drainage streams, in Morganwalp, D.W., and Aronson, D.A., eds., U.S. Geological Survey Toxic Substances Hydrology Program-Proceedings of the technical meeting, Colorado Springs, Colo., September 20-24, 1993: U.S. Geological Survey Water-Resources Investigations Report 94-4014.

McKnight, D.M., Bencala, K.E., Zellweger, G.W., Aiken, G.R., Feder, G.L., and Thorn, K.A., 1992, Sorption of dissolved organic carbon by hydrous aluminum and iron oxides occurring at the confluence of Deer Creek with the Snake River, Summit County, Colorado: Environmental Science and Technology, v. 28 , p. $1388-1396$. 


\section{SURFACE-WATER HYDROLOGY}

McKnight, D.M., Smith, R.L., Harnish, R.A., Miller, C.L., and Bencala, K.E., 1993, Seasonal relationships between planktonic microorganisms and dissolved organic material in alpine streams: Biogeochemistry, v. 21, p. 39-59.

McKnight, D.M., Wershaw, R.L., Bencala, K.E., Zellweger, G.W., and Feder, G.L., 1992, Humic substances and trace metals associated with $\mathrm{Fe}$ and $\mathrm{Al}$ oxides deposited in an acidic mountain stream: Science of the Total Environment, v. 117 , p.485-498.

Nuttle, W.K., and Harvey, J.W., in press, Fluxes of water and solute in a coastal wetland sediment 1-The contribution of regional groundwater discharge: Journal of Hydrology, v. 00.

Runkel, R.L., Bencala, K.E., and Broshears, R.E., 1994, An equilibrium-based simulation model for reactive solute transport in small streams, in Morganwalp, D.W., and Aronson, D.A., eds., U.S. Geological Survey Toxic Substances Hydrology Program-Proceedings of the technical meeting, Colorado Springs, Colo., September 20-24, 1993: U.S. Geological Survey Water-Resources Investigations Report 94-4014.

Stream Solute Workshop (Kuwabara, J.S., Triska, F.J., and Bencala, K.E, authors), 1990, Concepts and methods for assessing solute dynamics in stream ecosystems: Journal North American Benthological Society, v. 9, p. 95-119.

Triska, F.J., Kennedy, V.C., Avanzino, R.J., Zellweger, G.W., and Bencala, K.E., 1989, Retention and transport of nutrients in a thirdorder stream in northwestern Californiahyporheic processes: Ecology, v. 70, p. 18931905.

1989, Retention and transport of nutrients in a third-order stream-Channel processes: Ecology, v. 70 , p. $1877-1892$.
1990, In-situ retention-transport response to nitrate loading and storm discharge in a thirdorder stream: Journal North American Benthological Society, v. 9, p. 229-239.

Triska, F.T., Pringle, C.M., Zellweger, G.W., Duff, J.H., Avanzino, R.J., 1993, Dissolved inorganic nitrogen composition, transformation, retention, and transport in naturally phosphate-rich and phosphate-poor tropical streams: Canadian Journal of Fisheries and Aquatic Sciences, v. 50, p. 665-675.

Zellweger, G.W., 1994, Testing and comparison of four ionic tracers to measure stream flow loss by multiple tracer injection: Hydrological Processes, v. 8, p. 155-165.

1994, Tracer injections in small streams-Why and how we do them, in Morganwalp, D.W., and Aronson, D.A., eds., U.S. Geological Survey Toxic Substances Hydrology Program-Proceedings of the technical meeting, Colorado Springs, Colo., September 20-24, 1993: U.S. Geological Survey WaterResources Investigations Report 94-4014.

Zellweger, G.W., Avanzino, R.J., and Bencala, K.E., 1989, Comparison of tracer-dilution and current-meter discharge measurements in a small gravel-bed stream, Little Lost Man Creek, California: U.S. Geological Survey Water Resources Investigation Report 89$4150,20 \mathrm{p}$.

Zellweger, G.W., and Maura, W.S., 1991, Calculation of conservative-tracer and flume-discharge measurements on a small mountain stream, in Mallard, G.E., and Aronson, D.A., eds., U.S. Geological Survey Toxics Substances Hydrology Program-Proceedings of the technical meeting, Monterey, Calif., March 11-15, 1991: U.S. Geological Survey Water-Resources Investigations Report 914034, p. 434-438. 


\section{SURFACE-WATER HYDROLOGY}

TITLE: $\quad$ Fluvial Processes and River Mechanics (WR 83-194)

PERSONNEL: Cheng-lung Chen, Project Chief

Gwendolyn J. Lewis, Secretary

Chi-Hai Ling, Hydrologist

ADDRESS: $\quad$ U.S. Geological Survey

345 Middlefield Road, MS 496

Menlo Park, CA 94025

\section{TELEPHONE: (415) 354-3352}

PROBLEM: Many difficult problems in river mechanics may have stemmed from inadequate understanding of the multiplicity and interaction of fluvial processes. Some of the problems may have been solved, but in a very simplified, approximate way. Many efforts have been directed, but without apparent success, to fully account for the causes, occurrences, and mechanisms of catastrophic events, such as flash floods, debris flows, and channel changes resulting from torrential storms, sudden snow or glacier melt, dam break, volcanic eruptions, and earthquakes. Such failures may be partially attributed to the deficiency and incompleteness of existing empirical formulas (or models) representing the relationships between various processes and responses.

OBJECTIVE: Seek a full understanding of various fluvial processes on hillslopes and in river channels, which undergo changes in response to rapid disturbances, such as torrential storms, sudden snow or glacier melt, dam break, volcanic eruptions, and earthquakes. Improve or generalize existing empirical formulas that do not accurately describe the process-response relationships. Develop new relationships for various soils and highly-concentrated sedimentwater mixtures, such as those posed in the form of rheological or constitutive equations. Build mathematical models, using such relationships, for flash floods, debris flows, channel changes, and so forth. Ultimately apply these models to minimize the loss of life and property that may result from such catastrophic events.

APPROACH: Assess the validity and applicability of existing formulas for various fluvial processes, such as rainfall, infiltration, runoff, and sediment movement (erosion and deposition) on hillslopes and in river channels. Modify or generalize the existing formulas to the utmost extent that they will become more representative under a wider spectrum of field conditions. Formulate rheological or constitutive equations for various soils and highlyconcentrated sediment-water mixtures, and determine the values of rheological parameters and 


\section{SURFACE-WATER HYDROLOGY}

material constants using available field or laboratory data. Build mathematical models for flash floods, debris flows, channel changes, etc. and solve them on digital computers using optimum numerical schemes. Verify the models using actual events.

PROGRESS: Debris-flow research has progressed considerably in the theoretical phase. A series of journal papers have been prepared to document significant results obtained from the reassessment of the generalized viscoplastic fluid (GVF) model. The first paper examined the concept and rationale behind the semiempirical formulation of the GVF model in the light of the Reiner-Rivlin constitutive theory and the viscoplastic theory, thereby identifying the parameters that control the rheology of debris flow. The second paper assessed the validity of the GVF model in the light of the existing constitutive relations in the two asymptotic regimes, namely macro-viscous and grain-inertia regimes. The third paper examined the role that the radial distribution function plays in the rheological modeling of rapid debris flows based on kinetic theory. Using available data obtained from the rotating-cylinder experiments of neutrally buoyant solid spheres dispersing in an interstitial fluid, we were able to show that the dimensionless shear stress for debris flows in transition between the two asymptotic regimes varies mainly with the shear-rate number in addition to the grain concentration and some material constants, such as the coefficient of restitution. Other areas of research in progress include, but are not limited to, some important studies of high-gradient river hydraulics, such as the free-surface instability (or roll waves) in steep-channel flow (Chen) and the incipient motion for spherical sediment particles (Ling).

\section{REPORTS PUBLISHED 1989-1994:}

Chen, C.L., 1989, Power law of flow resistance in open channels-Manning's formula revisited: International Conference on Channel Flow and Catchment Runoff: University of Virginia, Charlottesville, Va., [Proceedings], p. 817848.

1991, Power law of flow resistance in open channels-Manning's formula revisited, in Yen, B.C., ed., Channel Flow ResistanceCentennial of Manning's Formula: Water Resources Publications, Littleton, Colo., p. 206-240.

1991, Unified theory on power laws for flow resistance: Journal of Hydraulic Engineering,
American Society of Civil Engineers, v. 117, no. 3, p. 371-389.

1992, Momentum and energy coefficients based on power-law velocity profile: Journal of Hydraulic Engineering, American Society of Civil Engineers, v. 118, no. 11, p. 15711584.

1992, Issues in debris flow research-Personal views: U.S. Geological Survey Water-Supply Paper Series, Selected Papers in the Hydrologic Sciences WSP 2340, p. 137-143.

1992, Discussion of "Derivation of infiltation equation using systems approach" by Singh, 


\section{SURFACE-WATER HYDROLOGY}

V.P., and Yu, F.X.: Journal of Irrigation and Drainage Engineering, Amerrican Society of Civil Engineers, v. 118, no. 6, p. 996-999.

1993, Unique laminar-flow stability limit based on shallow-water theory: Journal of Hydraulic Engineering, American Society of Civil Engineers, v. 119 , no. 7 , p. 816-829.

Chen, C.L., Ling, C.H., and Jan, C.D., 1991, Rheological model for ring-shear type debris flows: Federal Interagency Sedimentation Conference, Subcommittee on Sedimentation of the Interagency Advisory Committee on Water Data, 5th, Las Vegas, Nev., [Proceedings], v. 1, p. 5-1 to 5-8.

Jan, C.D., Shen, H.W., Ling, C.H., and Chen, C.L., 1992, A sphere moving down an inclined bumpy surface: Conference on Engineering Mechanics, American Society of Civil Engineers, 9th, College Station, Tex., [Proceedings], p. 768-771.

Ling, C.H., and Chen, C.L., 1989, Idealized debris flow in flume with bed driven by a conveyor belt: National Conference on Hydraulic Engineering, American Society of Civil Engineers, New Orleans, La., 1989 [Proceedings], p. 1144-1149.

Ling, C.H., Chen, C.L., and Jan, C.D., 1990, Rheological properties of simulated debris flows in the laboratory environment: International Symposium on the Hydraulics and $\mathrm{Hy}$ drology of Arid Lands, American Society of Civil Engineers, San Diego, Calif., [Proceedings], p. 218-224.

Ling, C.H., and Jan, C.D., 1992, Computer simulation of dry layered granular flow down an incline composed of grains: Conference on Engineering Mechanics, American Society of
Civil Engineers, 9th, College Station, Tex., [Proceedings], p. 760-763.

Ling, C.H., Jan, C.D., Chen, C.L., and Shen, H.W., 1992, Numerical simulation of a sphere moving down an incline with identical spheres placed equally apart: Conference on Engineering Mechanics, American Society of Civil Engineers, 9th, College Station, Tex., [Proceedings], p. 764-767. 



\section{APPENDIXES}




\begin{tabular}{|c|c|c|c|}
\hline PROJECT CHIEF & DISCIPLINE & $\begin{array}{l}\text { PROJECT } \\
\text { NUMBER }\end{array}$ & PROJECT TITLE \\
\hline Aiken, George R. & SW Chemistry & CR 93-331 & $\begin{array}{l}\text { Organic Carbon Migration in Aquatic } \\
\text { Environments } \ldots \ldots \ldots \ldots \ldots \ldots \ldots 345\end{array}$ \\
\hline Andrews, Edmund D. & $\begin{array}{l}\text { Geomorphology- } \\
\text { Sediment Transport }\end{array}$ & CR 82-273 & River Mechanics $\ldots \ldots \ldots \ldots$ \\
\hline Back, William & GW Chemistry & NR 57-034 & $\begin{array}{l}\text { Spatial Distribution of Chemical } \\
\text { Constituents in Ground Water . . . . . . } 143\end{array}$ \\
\hline Baedecker, Mary Jo & GW Chemistry & NR 83-129 & $\begin{array}{l}\text { Comparative Study of Organic } \\
\text { Degradation inSelected Hydrogeologic } \\
\text { Environments } \ldots \ldots \ldots \ldots \ldots \ldots\end{array}$ \\
\hline Baltzer, Robert A. & SW Hydrology & NR 69-019 & $\begin{array}{l}\text { Numerical Simulation of Hydrodynamic } \\
\text { Processes in Rivers, Estuaries, and } \\
\text { Coastal Embayments . . . . . . } 393\end{array}$ \\
\hline Bencala, Kenneth E. & SW Hydrology & WR 84-187 & $\begin{array}{l}\text { Coupled Transport and Geochemical } \\
\text { Processes Determining the Fate of } \\
\text { Chemicals in Surface Waters . . . . }\end{array}$ \\
\hline Bennett, James P. & SW Hydrology & CR 84-343 & Mathematical Modeling Principles .. \\
\hline Benson, Larry V. & GW Chemistry & CR 82-207 & Arid Regions Climate and Chemistry \\
\hline Betancourt, Julio L. & Ecology & WR 76-145 & $\begin{array}{l}\text { Biotic Response to Climatic Variability } \\
\text { and Human Impacts in Arid Lands } \ldots\end{array}$ \\
\hline Bredehoeft, John D. & GW Hydrology & WR 75-176 & Water Wells as Strain Meters . . . . . . . \\
\hline Bricker, Owen P. & SW Chemistry & NR $81-109$ & $\begin{array}{l}\text { Geochemical Cycling of Trace Elements } \\
\text { and Nutrients in Natural Water Systems . } 355\end{array}$ \\
\hline Brown, Charles E. & GW Hydrology & NR 84-130 & $\begin{array}{l}\text { Multivariate Statistical Techniques } \\
\text { for Assessing Regional Ground-Water } \\
\text { Quality and Quantity } \ldots \ldots \ldots 259\end{array}$ \\
\hline Callender, Edward & SW Chemistry & NR 76-065 & $\begin{array}{l}\text { Sedimentary Geochemical Processes } \\
\text { Affecting the Exchange of Nutrients and } \\
\text { Transition Metals Between Sediment } \\
\text { and Water in Riverine, Estuarine, and } \\
\text { Lacustrine Environments . . . . . . . } 348\end{array}$ \\
\hline Carter, Virginia P. & Ecology & NR 73-090 & $\begin{array}{l}\text { Remote Sensing and Ecological Research } \\
\text { in Wetlands } \ldots \ldots \ldots \ldots \ldots \ldots \ldots\end{array}$ \\
\hline
\end{tabular}




\begin{tabular}{|c|c|c|c|}
\hline PROJECT CHIEF & DISCIPLINE & $\begin{array}{l}\text { PROJECT } \\
\text { NUMBER }\end{array}$ & PROJECT TITLE \\
\hline Chen, Cheng-lung & SW Hydrology & WR 83-194 & Fluvial Processes and River Mechanics. \\
\hline Cheng, Ralph T. & SW Hydrology & WR 76-140 & $\begin{array}{l}\text { Hydrodynamics and Mathematical } \\
\text { Modeling of Circulation and Transport } \\
\text { Phenomena in Tidal Estuaries . . . . . }\end{array}$ \\
\hline Chiou, Cary T. & GW Chemistry & CR 83-283 & $\begin{array}{l}\text { Environmental Dynamics of Persistent } \\
\text { Organic Compounds } \ldots \ldots \ldots \ldots \ldots 126\end{array}$ \\
\hline Claassen, Hans C. & SW Chemistry & CR 75-189 & $\begin{array}{l}\text { Geochemical Kinetics Studies of Silicate } \\
\text { Rock Hydrologic Systems . . . . . . } 320\end{array}$ \\
\hline Cloern, James E. & Ecology & WR 79-164 & Plankton Dynamics in Tidal Estuaries . . . . \\
\hline Conomos, T. John & SW Hydrology & WR 77-156 & $\begin{array}{l}\text { Research Vessel Polaris Operations in } \\
\text { San Francisco Bay and Adjacent Coastal } \\
\text { Ocean } \ldots \ldots \ldots \ldots \ldots \ldots \ldots \ldots \ldots\end{array}$ \\
\hline
\end{tabular}

Constantz, James E. GW Hydrology

Cooley, Richard L. GW Hydrology

Coplen, Tyler B.

Davis, James A. III

Eberl, Dennis D.

Eganhouse, Robert P. GW Chemistry

Emmett, William W. GeomorphologySediment Transport

Essaid, Hedeff I.
GW Hydrology
WR 87-193 Temperature Effects in the Unsaturated

Zone ................ 300

CR 76-191 Mathematical Simulation of Subsurface-

Water Flow Using Uncertain and Incomplete

Data . . . . . . . . . . 231

NR 75-064 Physical Chemistry of Stable Isotope

Fractionation in Hydrologic Processes . . 159

WR 70-065 Partitioning of Solutes between Solid

and Aqueous Phases . . . . . . . . 186

CR 82-276 Geochemistry of Clay-Water Reactions . . 123

NR 91-151 Transport and Biogeochemical Fate of

Organic Substances in Aquatic

Environments . . . . . . . . . 181

CR 74-187 Hydraulics and Mechanics of Bedload-

Transport Processes . . . . . . . . . 96

WR 89-199 The Fate and Transport of Immiscible

Contaminants in the Subsurface . . . . . 305 


\begin{tabular}{|c|c|c|c|}
\hline PROJECT CHIEF & DISCIPLINE & $\begin{array}{l}\text { PROJECT } \\
\text { NUMBER }\end{array}$ & PROJECT TITLE \\
\hline Feder, Gerald L. & GW Chemistry & NR 79-132 & $\begin{array}{l}\text { Relationship Between Chemical Quality of } \\
\text { Natural Waters and Human Health } \\
\text { and Disease } \ldots \ldots \ldots \ldots \ldots \ldots \ldots\end{array}$ \\
\hline Godsy, Edward M. & Ecology & WR 71-068 & $\begin{array}{l}\text { Fate of Organic Chemicals in Subsurface } \\
\text { Environments } \ldots \ldots \ldots \ldots \ldots \ldots \ldots\end{array}$ \\
\hline Goerlitz, Donald F. & GW Chemistry & WR 84-189 & Chemistry of Aquatic Organic Matter . . . . \\
\hline Grove, David B. & GW Hydrology & CR 73-085 & $\begin{array}{l}\text { The Mathematical Simulation of the } \\
\text { Transport and Reaction of Chemical } \\
\text { Species in Ground Water . . . . . . }\end{array}$ \\
\hline Harvey, Ronald W. & Ecology & CR 91-327 & $\begin{array}{l}\text { Interaction of Bacteria with Environmental } \\
\text { Contaminants and Solid Surfaces in the } \\
\text { Aquatic Environment } \ldots \ldots \ldots \ldots \ldots\end{array}$ \\
\hline Hem, John D. & SW Chemistry & WR 57-076 & $\begin{array}{l}\text { Chemistry of Hydrosolic Metals and } \\
\text { Related Constituents of Natural Water . . } 362\end{array}$ \\
\hline Herkelrath, William N. & GW Hydrology & WR 82-179 & Nonisothermal Multiphase Flow . \\
\hline Hostetler, Steven W. & SW Hydrology & CR 94-341 & Lake-Atmosphere Interations \\
\hline Hsieh, Paul A. & GW Hydrology & WR 83-184 & Hydrology of Fractured Rocks ... \\
\hline Hupp, Cliff R. & Ecology & NR $90-145$ & Vegetation and Hydrogeomorphic Relations \\
\hline Ingebritsen, Steven E. & GW Hydrology & WR 74-121 & $\begin{array}{l}\text { Hydrologic Studies of Heat and Mass } \\
\text { Transport } \ldots \ldots \ldots \ldots \ldots \ldots \ldots \ldots\end{array}$ \\
\hline James, Ronald V. & GW Chemistry & WR 68-036 & $\begin{array}{l}\text { Factors Determining Solute Transfer } \\
\text { in the Unsaturated Zone } \ldots \ldots \ldots\end{array}$ \\
\hline Jarrett, Robert D. & SW Hydrology & CR 90-321 & Paleohydrology and Climate Change \\
\hline Jones, Blair F. & GW Chemistry & NR 69-020 & $\begin{array}{l}\text { Mineral-Water Interaction in Saline } \\
\text { Environments } \ldots \ldots \ldots \ldots \ldots \ldots \ldots\end{array}$ \\
\hline Kendall, Carol & GW Chemistry & WR 91-080 & $\begin{array}{l}\text { Stable Isotope Tracers of Biogeochemical } \\
\text { and Hydrologic Processes } \ldots \ldots \ldots \ldots\end{array}$ \\
\hline Kharaka, Yousif K. & GW Chemistry & WR 76-139 & $\begin{array}{l}\text { Geochemistry of Water in Fine Grained } \\
\text { Sediments } \ldots \ldots \ldots \ldots \ldots \ldots \ldots\end{array}$ \\
\hline
\end{tabular}




\begin{tabular}{|c|c|c|c|c|}
\hline PROJECT CHIEF & DISCIPLINE & $\begin{array}{l}\text { PROJECT } \\
\text { NUMBER }\end{array}$ & PROJECT TITLE & PAGE \\
\hline Kipp, Kenneth L. & GW Hydrology & CR 85-292 & $\begin{array}{l}\text { Ground-Water Solute-Transport } \\
\text { Simulation . . . . . . . . . }\end{array}$ & 242 \\
\hline Konikow, Leonard F. & GW Hydrology & NR $81-120$ & $\begin{array}{l}\text { Digital Modeling of Transport in the } \\
\text { Saturated Zone } \ldots \ldots \ldots \ldots \ldots\end{array}$ & 254 \\
\hline Kraemer, Thomas F. & GW Chemistry & NR $82-138$ & $\begin{array}{l}\text { Uranium-Thorium Series Radioisotopes in } \\
\text { Ground-Water and Surface-Water Systems . }\end{array}$ & 179 \\
\hline Kuwabara, James S. & Ecology & WR $86-190$ & $\begin{array}{l}\text { Solute Transport Involving Biological } \\
\text { Processes in Surface Waters . . . . . . }\end{array}$ & 84 \\
\hline LaBaugh, James W. & Ecology & CR 85-293 & $\begin{array}{l}\text { The Role of Chemical Fluxes in the } \\
\text { Biogeochemistry of Inland Surface } \\
\text { Waters, Including Lakes, Reservoirs, } \\
\text { and Wetlands } \ldots \ldots \ldots \ldots \ldots \ldots \ldots\end{array}$ & 13 \\
\hline Landa, Edward R. & GW Chemistry & NR 78-092 & $\begin{array}{l}\text { Hydrogeochemical Controls on the } \\
\text { Migration of Radionuclides from Uranium } \\
\text { Mill Tailings } \ldots \ldots \ldots \ldots \ldots \ldots \ldots\end{array}$ & 166 \\
\hline Landwehr, Jurate $\mathbf{M}$. & SW Hydrology & NR 84-133 & Regional Hydrologic Processes $\ldots . . .$. & 405 \\
\hline Leavesley, George H. & SW Hydrology & CR 77-228 & $\begin{array}{l}\text { Precipitation-Runoff Modeling of } \\
\text { Watershed System } \ldots \ldots \ldots \ldots \ldots \ldots\end{array}$ & 370 \\
\hline Lee, Jonathan & SW Hydrology & NR 90-147 & $\begin{array}{l}\text { Transport of Dissolved and Suspended } \\
\text { Materials in Surface Waters . . . . . }\end{array}$ & 411 \\
\hline Leenheer, Jerry A. & SW Chemistry & CR 84-285 & Comprehensive Organic Analysis of Water & 331 \\
\hline Leland, Harry V. & Ecology & CR 92-337 & $\begin{array}{l}\text { Effects of Toxic Substances on Aquatic } \\
\text { Communities } \ldots \ldots \ldots \ldots \ldots \ldots\end{array}$ & 34 \\
\hline Lovley, Derek R. & Ecology & NR $87-136$ & $\begin{array}{l}\text { Modeling of Microbially Catalyzed } \\
\text { Geochemical Reactions in Aquatic } \\
\text { Environments } \ldots \ldots \ldots \ldots \ldots \ldots \ldots\end{array}$ & 41 \\
\hline Luoma, Samuel N. & Ecology & WR 75-125 & $\begin{array}{l}\text { Availability of Trace Elements in } \\
\text { Sediments to Aquatic Organisms . }\end{array}$ & 58 \\
\hline Malcolm, Ronald L. & SW Chemistry & CR 68-046 & $\begin{array}{l}\text { Origin, Characterization, and } \\
\text { Quantification of Natural Organic } \\
\text { Solutes in Water } \ldots \ldots \ldots \ldots \ldots \ldots \ldots\end{array}$ & 310 \\
\hline
\end{tabular}




\begin{tabular}{ll} 
PROJECT CHIEF & DISCIPLINE \\
\hline Mariner, Robert H. & GW Chemistry \\
Marzolf, G. Richard & Ecology \\
McKnight, Diane M. & Ecology \\
Meade, Robert H. & $\begin{array}{l}\text { Geomorphology- } \\
\text { Sediment Transport }\end{array}$ \\
Meade, Robert H., Jr. & $\begin{array}{l}\text { Geomorphology- } \\
\text { Sediment Transport }\end{array}$ \\
Milly, P.C.D. & $\begin{array}{l}\text { SW Hydrology } \\
\text { Moench, Allen F. }\end{array}$ \\
\hline
\end{tabular}

Naff, Richard L.

Neuzil, Christopher E. GW Hydrology

Nichols, Frederic H. Ecology

Nimmo, John R.

Nordstrom, Darrell K. GW Chemistry

Oremland, Ronald S. Ecology

Osterkamp, Waite R. GeomorphologySediment Transport
PROJECT

NUMBER

PROJECT TITLE

PAGE

WR 79-165 Chemical and Isotope Studies of

Thermal Waters of the Western United

States . . . . . . . . . . . . . . 203

CR 91-325 Limnological Phenomena in Impounded

Rivers $\ldots \ldots \ldots \ldots \ldots \ldots \ldots 26$

CR 84-286 Interactions Between Organic Solutes

and Trace Metals in Natural Waters, and

Their Ecological Role . . . . . . . . 8

CR 75-102 Movement and Storage of Sediment in

River Systems . . . . . . . . . 92

CR 87-309 Sediment-Transported Pollutants in the

Mississippi River . . . . . . . . . . 103

NR 88-144 Continental Hydrology and Global Climate 408

WR 75-127 Analytical Modeling of Flow and

Transport in Aquifers and Geothermal

Reservoirs . . . . . . . . . . 282

CR 90-319 Application of Stochastic Processes in

Hydrogeology . . . . . . . . . . 246

NR 81-035 Hydrologic Behavior of Cretaceous Shales . 249

WR 86-192 Environmental Influences on Estuarine

Benthic Community Dynamics ... . . . 87

WR 89-198 Physical Characteristics that Determine

Flow in the Unsaturated Zone . . . . . 3.02

CR 92-326 Chemical Modeling and Thermodynamic Data

Evaluation of Major and Trace Elements

in Acid Mine Waters and Ground Waters . 133

WR 81-174 Microbial Biogeochemistry of Aquatic

Environments . . . . . . . . . 76

WR 79-311 Sediment Impacts from Disturbed and

Undisturbed Lands . . . . . . . . 116 


\begin{tabular}{|c|c|c|c|}
\hline PROJECT CHIEF & DISCIPLINE & $\begin{array}{l}\text { PROJECT } \\
\text { NUMBER }\end{array}$ & PROJECT TITLE \\
\hline Paillet, Frederick L. & GW Hydrology & CR 64-140 & $\begin{array}{l}\text { Borehole Geophysics as Applied to } \\
\text { Geohydrology } \ldots \ldots \ldots \ldots\end{array}$ \\
\hline Parkhurst, David L. & GW Chemistry & CR 89-318 & $\begin{array}{l}\text { Reaction-Transport Modeling in Ground- } \\
\text { Water systems } \ldots \ldots \ldots \ldots \ldots \ldots \ldots\end{array}$ \\
\hline Pereira, Wilfred E. & SW Chemistry & WR 83-204 & $\begin{array}{l}\text { Origin, Fate, and Transport of Organic } \\
\text { Compounds in Surface and Ground Waters } \\
\text { and Their Effect on Water Quality .... } 366\end{array}$ \\
\hline Peterson, David H. & Ecology & WR 68-046 & $\begin{array}{l}\text { Geochemistry of Riverine and Estuarine } \\
\text { Waters } \ldots \ldots \ldots \ldots \ldots \ldots \ldots \ldots\end{array}$ \\
\hline Plummer, L. Niel & GW Chemistry & NR $76-056$ & $\begin{array}{l}\text { Kinetics and Thermodynamics of Chemical } \\
\text { Evolution in Ground-Water Systems . . . } 150\end{array}$ \\
\hline Rathbun, Ronald E. & sW Chemistry & CR 77-301 & $\begin{array}{l}\text { Transport and Degradation of Organic } \\
\text { Substances in Streams } \ldots \ldots \ldots \ldots \ldots\end{array}$ \\
\hline Reddy, Michael M. & SW Chemistry & CR 83-284 & $\begin{array}{l}\text { Aqueous Crystal Growth and Dissolution } \\
\text { Kinetics of Earth Surface Minerals } \ldots \ldots 327\end{array}$ \\
\hline Reilly, Thomas E. & GW Hydrology & NR 91-152 & $\begin{array}{l}\text { Quantitative Analysis of Heterogeneous } \\
\text { Hydrogeologic Controls on Ground-Water } \\
\text { Flow and Transport } \ldots \ldots \ldots \ldots \ldots \ldots\end{array}$ \\
\hline Rubin, Jacob & GW Hydrology & WR $82-180$ & $\begin{array}{l}\text { Theories of Water Flow and of Solute } \\
\text { Transport in the Unsaturated Zone . . }\end{array}$ \\
\hline Sanford, Ward & GW Hydrology & NR $91-153$ & $\begin{array}{l}\text { Reaction-Transport Phenomena in } \\
\text { Hydrogeologic Settings . . . . . . . } 269\end{array}$ \\
\hline Schaffranek, Raymond W. & SW Hydrology & NR 80-104 & $\begin{array}{l}\text { Simulation Modeling of Hydrodynamic } \\
\text { Systems } \ldots \ldots \ldots \ldots \ldots \ldots \ldots \ldots \ldots\end{array}$ \\
\hline Shapiro, Allen M. & GW Hydrology & NR 84-134 & Transport Phenomena in Fractured Rock . . 261 \\
\hline Simon, Nancy S. & SW Chemistry & NR $86-135$ & $\begin{array}{l}\text { Distribution and Speciation of Metals } \\
\text { in Sedimentary Environments . . . . . }\end{array}$ \\
\hline Smith, J. Dungan & $\begin{array}{l}\text { Geomorphology- } \\
\text { Sediment Transport }\end{array}$ & CR 91-324 & $\begin{array}{l}\text { Applications of Fluid and Sediment } \\
\text { Mechanics to Basin and Regional Scale } \\
\text { Hydrologic and Geomorphic Problems }\end{array}$ \\
\hline
\end{tabular}




\begin{tabular}{|c|c|c|c|}
\hline PROJECT CHIEF & DISCIPLINE & $\begin{array}{l}\text { PROJECT } \\
\text { NUMBER }\end{array}$ & PROJECT TITLE \\
\hline Smith, Richard L. & Ecology & CR 86-295 & $\begin{array}{l}\text { Microbial Transformation of Dissolved } \\
\text { Organic Carbon in Aquatic Environments . }\end{array}$ \\
\hline Sorey, Michael L. & GW Hydrology & WR 73-102 & $\begin{array}{l}\text { Modeling and Monitoring Heat and Fluid } \\
\text { Flow in Geothermal Systems } \ldots \ldots \ldots\end{array}$ \\
\hline Sorey, Michael L. & GW Hydrology & WR 72-108 & $\begin{array}{l}\text { Technical Coordination and Support of } \\
\text { Water Resources Division Geothermal } \\
\text { Studies } \ldots \ldots \ldots \ldots \ldots \ldots \ldots \ldots \ldots\end{array}$ \\
\hline Stallard, Robert F. & SW Chemistry & CR 88-313 & $\begin{array}{l}\text { Sediment-Water Chemistry in Large } \\
\text { River Systems: Biogeochemical, } \\
\text { Geomorphic, and Human Controls . . }\end{array}$ \\
\hline Stonestrom, David A. & GW Hydrology & WR 63-024 & $\begin{array}{l}\text { Application of the Unsaturated Flow } \\
\text { Theory to the Phenomena of Infiltration }\end{array}$ \\
\hline Striegl, Robert G. & Ecology & CR 91-320 & $\begin{array}{l}\text { Characterization of Biotic and } \\
\text { Biogeochemical Interactions at } \\
\text { Environmental Interfaces . . . . . . . }\end{array}$ \\
\hline Sundquist, Eric T. & SW Chemistry & NR 79-099 & $\begin{array}{l}\text { Carbon Fluxes in Hydrologic and } \\
\text { Geologic Processes } \ldots \ldots \ldots \ldots\end{array}$ \\
\hline Tasker, Gary D. & SW Hydrology & NR $82-125$ & $\begin{array}{l}\text { Hydrologic Regression and Data-Network } \\
\text { Design } \ldots \ldots \ldots \ldots \ldots \ldots \ldots \ldots \ldots \ldots\end{array}$ \\
\hline Taylor, Howard E. & SW Chemistry & CR 83-282 & $\begin{array}{l}\text { Research in Analytical Environmental } \\
\text { Trace Element Chemistry and Its Impact } \\
\text { on Water Quality . . . . . . . . } 323\end{array}$ \\
\hline Thorstenson, Donald C. & GW Chemistry & CR 79-336 & Chemical Models of Natural Systems . . . 137 \\
\hline Triska, Frank J. & Ecology & WR 84-186 & $\begin{array}{l}\text { Biotic Interface with Fluvial Transport: } \\
\text { Processes Associated with Dissolved } \\
\text { Solutes in Transport . . . . . . . . }\end{array}$ \\
\hline Troutman, Brent M. & SW Hydrology & CR 83-279 & $\begin{array}{l}\text { Statistical Analysis of Errors in } \\
\text { Hydrologic Models } \ldots \ldots \ldots \ldots \ldots\end{array}$ \\
\hline Voss, Clifford I. & GW Hydrology & NR 78-089 & $\begin{array}{l}\text { Investigations of Single and Multiphase } \\
\text { Fluid Flow, Mass and Energy Transport, and } \\
\text { Fluid Phase Change in the Subsurface } \\
\text { Environment } \ldots \ldots \ldots \ldots \ldots \ldots \ldots \ldots\end{array}$ \\
\hline
\end{tabular}




\begin{tabular}{|c|c|c|c|c|}
\hline PROJECT CHIEF & DISCIPLINE & $\begin{array}{l}\text { PROJECT } \\
\text { NUMBER }\end{array}$ & PROJECT TITLE & AGE \\
\hline Wagner, Brian J. & GW Hydrology & WR $82-178$ & Ground-water Monitoring Network Design & 288 \\
\hline Walters, Roy A. & SW Hydrology & WR $83-183$ & $\begin{array}{l}\text { Analysis and Modeling of Conservative } \\
\text { and Nonconservative Transport Processes }\end{array}$ & 419 \\
\hline Webb, Robert H. & $\begin{array}{l}\text { Geomorphology- } \\
\text { Sediment Transport }\end{array}$ & WR $89-200$ & $\begin{array}{l}\text { Response of Fluvial Systems to Climatic } \\
\text { Variability } \ldots \ldots \ldots \ldots \ldots \ldots \ldots\end{array}$ & 112 \\
\hline Weeks, Edwin P. & GW Hydrology & CR 69-200 & $\begin{array}{l}\text { Field Applications of Unsaturated Zone } \\
\text { Flow Theory } \ldots \ldots \ldots \ldots \ldots \ldots\end{array}$ & 236 \\
\hline Wershaw, Robert L. & SW Chemistry & CR 68-132 & $\begin{array}{l}\text { Behavior of Natural Polyelectrolytes } \\
\text { in Water } \ldots \ldots \ldots \ldots \ldots \ldots \ldots\end{array}$ & 314 \\
\hline White, Arthur F. & GW Chemistry & WR 88-196 & $\begin{array}{l}\text { Geochemical Reactions Between Water } \\
\text { and Mineral Substrates } \ldots \ldots \ldots \ldots\end{array}$ & 210 \\
\hline Williams, Garnett P. & $\begin{array}{l}\text { Geomorphology- } \\
\text { Sediment Transport }\end{array}$ & CR 65-105 & $\begin{array}{l}\text { Effects of Water and Sediment Discharges } \\
\text { on Channel Morphology . . . . . . . }\end{array}$ & 94 \\
\hline Winograd, Isaac J. & GW Chemistry & NR 74-041 & $\begin{array}{l}\text { Interface of Paleoclimatology and } \\
\text { Aquifer Geochemistry } \ldots \ldots \ldots\end{array}$ & 147 \\
\hline Winter, Thomas C. & Ecology & CR 90-323 & $\begin{array}{l}\text { Interdisciplinary Research Initiative (IRI) } \\
\text { at the Shingobee Headwaters Research } \\
\text { Area, Minnesota } \ldots \ldots \ldots \ldots \ldots \ldots\end{array}$ & 23 \\
\hline Winter, Thomas C. & GW Hydrology & CR 74-090 & $\begin{array}{l}\text { The Role of Lakes in the Hydrologic } \\
\text { System, with Emphasis on Their Relation } \\
\text { to Ground Water . . . . . . . . . . . }\end{array}$ & 220 \\
\hline Wood, Warren W. & GW Chemistry & NR $81-122$ & $\begin{array}{l}\text { Dispersion of Toxic and Radioactive } \\
\text { Wastes in Ground-Water Systems . . . }\end{array}$ & 169 \\
\hline
\end{tabular}




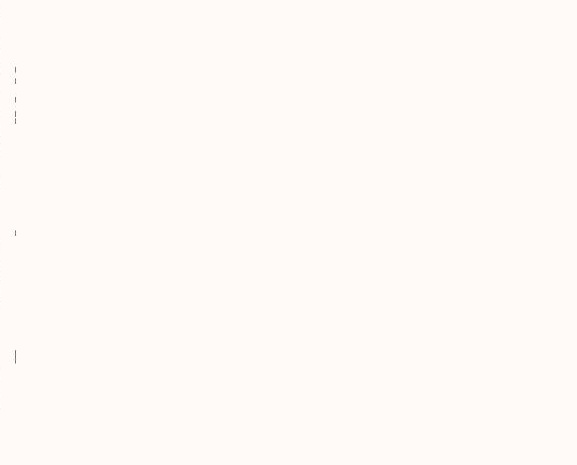


APPENDIX 2.-Topical Listing

\begin{tabular}{|c|c|c|c|}
\hline TOPIC & $\begin{array}{l}\text { PROJECT } \\
\text { CHIEF }\end{array}$ & $\begin{array}{l}\text { PROJECT } \\
\text { NUMBER }\end{array}$ & $\begin{array}{c}\text { PAGE } \\
\text { NUMBER }\end{array}$ \\
\hline \multirow[t]{4}{*}{ Acid rain: } & Bricker, Owen P. & NR109 & 355 \\
\hline & Malcolm, Ronald L. & CR046 & 310 \\
\hline & Reddy, Michael M. & CR284 & 327 \\
\hline & Taylor, Howard E. & CR282 & 323 \\
\hline \multirow[t]{6}{*}{ Acid Mine Drainage: } & Bencala, Kenneth E. & WR187 & 422 \\
\hline & Hem, John D. & WR076 & 362 \\
\hline & Kipp, Kenneth L. & CR292 & 242 \\
\hline & Luoma, Samuel N. & WR125 & 58 \\
\hline & McKnight, Diane M. & CR286 & 8 \\
\hline & Nordstrom, Darrell K. & CR326 & 133 \\
\hline \multirow[t]{11}{*}{ Aquatic Habitat: } & Andrews, Edmund D. & CR273 & 99 \\
\hline & Carter, Virginia P. & NR090 & 36 \\
\hline & Cloern, James E. & WR164 & 71 \\
\hline & Hupp, Cliff R. & NR145 & 46 \\
\hline & Leland, Harry V. & CR337 & 34 \\
\hline & Luoma, Samuel N. & WR125 & 58 \\
\hline & Marzolf, G. Richard & CR325 & 26 \\
\hline & McKnight, Diane M. & CR286 & 8 \\
\hline & Nichols, Frederic H. & WR192 & 87 \\
\hline & Triska, Frank J. & WR186 & 80 \\
\hline & Webb, Robert H. & WR200 & 112 \\
\hline \multirow[t]{12}{*}{ Carbon Cycle: } & Aiken, George R. & CR331 & 345 \\
\hline & Betancourt, Julio L. & WR145 & 63 \\
\hline & Bricker, Owen P. & NR109 & 355 \\
\hline & Carter, Virginia & NR090 & 36 \\
\hline & Cloern, James E. & WR164 & 71 \\
\hline & Coplen, Tyler B. & NR064 & 159 \\
\hline & Kendall, Carol & WR080 & 193 \\
\hline & Leenheer, Jerry A. & CR285 & 331 \\
\hline & Lovley, Derek R. & NR136 & 41 \\
\hline & McKnight, Diane $M$. & CR286 & 8 \\
\hline & Oremland, Ronald S. & WR174 & 76 \\
\hline & Reddy, Michael M. & CR284 & 327 \\
\hline
\end{tabular}




\begin{tabular}{|c|c|c|c|}
\hline TOFIC & $\begin{array}{l}\text { PROJECT } \\
\text { CHIEF }\end{array}$ & $\begin{array}{l}\text { PROJECT } \\
\text { NUMBER } \\
\end{array}$ & $\begin{array}{c}\text { PAGE } \\
\text { NUMBER }\end{array}$ \\
\hline & Smith, Richard L. & CR295 & 15 \\
\hline & Stallard, Robert F. & CR313 & 340 \\
\hline & Striegel, Robert G. & CR320 & 20 \\
\hline & Sundquist, Eric $\mathrm{T}$. & NR099 & 352 \\
\hline & Thorstenson, Donald C. & CR336 & 137 \\
\hline & Weeks, Edwin P. & CR200 & 236 \\
\hline \multirow[t]{14}{*}{ Estuaries: } & Baltzer, Robert A. & NR019 & 393 \\
\hline & Bricker, Owen P. & NR109 & 355 \\
\hline & Carter, Virginia P. & NR090 & 36 \\
\hline & Cheng, Ralph T. & WR140 & 414 \\
\hline & Cloern, James, E. & WR164 & 71 \\
\hline & Conomos, T. John & WR156 & 418 \\
\hline & Eganhouse, Robert P. & NR151 & 181 \\
\hline & Kuwabara, James S. & WR190 & 84 \\
\hline & Luoma, Samuel N. & WR125 & 58 \\
\hline & Nichols, Frederic $\mathrm{H}$. & WR192 & 87 \\
\hline & Pereira, Wilfred E. & WR204 & 366 \\
\hline & Peterson, David H. & WR046 & 50 \\
\hline & Schaffraneck, Raymond W. & NR104 & 397 \\
\hline & Walters, Roy A. & WR183 & 419 \\
\hline \multirow[t]{2}{*}{ Evapotranspiration: } & Weeks, Edwin P. & CR200 & 236 \\
\hline & Winter, Thomas C. & WR090 & 220 \\
\hline \multirow[t]{7}{*}{ Fractured Rock: } & Hsieh, Paul A. & WR184 & 296 \\
\hline & Nordstrom, Darrell K. & CR326 & 133 \\
\hline & Paillet, Frederick L. & CR140 & 224 \\
\hline & Shapiro, Allen M. & NR1:34 & 261 \\
\hline & Voss, Clifford I. & NR089 & 251 \\
\hline & Winter, Thomas C. & WR090 & 220 \\
\hline & Wood, Warren W. & NR122 & 169 \\
\hline \multirow[t]{3}{*}{ Geochemistry Isotopic tracers: } & $\begin{array}{l}\text { Coplen, Tyler B. } \\
\text { Kendall, Carol }\end{array}$ & $\begin{array}{l}\text { NR064 } \\
\text { WR080 }\end{array}$ & $\begin{array}{l}159 \\
193\end{array}$ \\
\hline & Kharaka, Yousif K. & WR139 & 199 \\
\hline & Kraemer, Thomas F. & NR138 & 179 \\
\hline
\end{tabular}




\begin{tabular}{|c|c|c|c|}
\hline TOPIC & $\begin{array}{l}\text { PROJECT } \\
\text { CHIEF }\end{array}$ & $\begin{array}{l}\text { PROJECT } \\
\text { NUMBER }\end{array}$ & $\begin{array}{l}\text { PAGE } \\
\text { NUMBER }\end{array}$ \\
\hline & Plummer, L. Niel & NR056 & 150 \\
\hline & White, Arthur F. & WR196 & 210 \\
\hline \multirow[t]{2}{*}{ Geophysics: } & Brown, Charles E. & NR130 & 259 \\
\hline & Paillet, Frederick L. & CR140 & 224 \\
\hline \multirow[t]{6}{*}{ Geothermal Resources: } & Sorey, Michael L. & WR102 & 274 \\
\hline & Sorey, Michael L. & WR108 & 277 \\
\hline & Mariner, Robert H. & WR165 & 203 \\
\hline & Ingebritsen, Steven E. & WR121 & 279 \\
\hline & Kharaka, Yousif K. & WR139 & 199 \\
\hline & Paillet, Frederick L. & CR140 & 224 \\
\hline \multirow[t]{22}{*}{$\begin{array}{l}\text { Ground-water Flow, Transport, } \\
\text { and Reactions: }\end{array}$} & $\begin{array}{l}\text { Baedecker, Mary Jo } \\
\text { Bredehoeft, John D. }\end{array}$ & $\begin{array}{l}\text { NR129 } \\
\text { WR176 }\end{array}$ & $\begin{array}{l}173 \\
284\end{array}$ \\
\hline & Coplen, Tyler B. & NR064 & 159 \\
\hline & Davis, James A., III & WR065 & 186 \\
\hline & Eganhouse, Robert P. & NR151 & 181 \\
\hline & Eberl, Dennis D. & CR276 & 123 \\
\hline & Essaid, Hedeff I. & WR199 & 305 \\
\hline & Herkelrath, William N. & WR179 & 290 \\
\hline & Ingebritsen, Steven E. & WR121 & 279 \\
\hline & Jones, Blair F. & NR020 & 139 \\
\hline & Kendall, Carol & WR080 & 193 \\
\hline & Kharaka, Yousif $K$. & WR139 & 199 \\
\hline & Kipp, Kenneth L. & CR292 & 242 \\
\hline & Konikow, Leonard F. & NR1 20 & 254 \\
\hline & Neuzil, Christopher E. & NR035 & 249 \\
\hline & Nordstrom, Darrell K. & CR326 & 133 \\
\hline & Parkhurst, David L. & CR318 & 130 \\
\hline & Plummer, L. Niel & NR056 & 150 \\
\hline & Reilly, Thomas E. & NR152 & 265 \\
\hline & Rubin, Jacob & WR180 & 293 \\
\hline & Sanford, Ward & NR153 & 269 \\
\hline & Thorstenson, Donald C. & NR093 & 137 \\
\hline & Voss, Clifford I. & NR089 & 251 \\
\hline
\end{tabular}




\begin{tabular}{|c|c|c|c|}
\hline TOPIC & $\begin{array}{l}\text { PROJECT } \\
\text { CHIEF }\end{array}$ & $\begin{array}{l}\text { PROJECT } \\
\text { NUMBER }\end{array}$ & $\begin{array}{l}\text { PAGE } \\
\text { NUMBER }\end{array}$ \\
\hline & Wagner, Brian J. & WR178 & 288 \\
\hline & Weeks, Edwin P. & CR2O0 & 236 \\
\hline & White, Arthur F. & WR196 & 210 \\
\hline & Wood, Warren W. & NR122 & 169 \\
\hline \multirow[t]{11}{*}{ Ground-water Hydraulics: } & $\begin{array}{l}\text { Bredehoeft, John D. } \\
\text { Brown, Charles E. }\end{array}$ & $\begin{array}{l}\text { WR176 } \\
\text { NR130 }\end{array}$ & $\begin{array}{l}284 \\
259\end{array}$ \\
\hline & Essaid, Hedeff I. & WR199 & 305 \\
\hline & Herkelrath, William N. & WR179 & 290 \\
\hline & Hsieh, Paul A. & WR184 & 296 \\
\hline & Konikow, Leonard F. & NR120 & 254 \\
\hline & Moench, Allen F. & WR127 & 282 \\
\hline & Neuzil, Christopher E. & NR035 & 249 \\
\hline & Paillet, Frederick L. & CR140 & 224 \\
\hline & Reilly, Thomas E. & NR1 52 & 265 \\
\hline & Shapiro, Allen M. & NR134 & 261 \\
\hline & Voss, Clifford I. & NR089 & 251 \\
\hline \multirow[t]{18}{*}{ Hydroclimatology: } & Benson, Larry V. & CR2O7 & 120 \\
\hline & Betancourt, Julio L. & WR145 & 63 \\
\hline & Coplen, Tyler B. & NR064 & 159 \\
\hline & Jarrett, Robert D. & CR321 & 384 \\
\hline & Kendall, Carol & WR080 & 193 \\
\hline & Landwehr, Jurate M. & NR133 & 405 \\
\hline & Leavesley, George H. & CR228 & 370 \\
\hline & Luoma, Samuel N. & WR125 & 58 \\
\hline & Milly, P.C.D. & NR144 & 408 \\
\hline & Peterson, David H. & WR046 & 50 \\
\hline & Striegl, Robert G. & CR320 & 20 \\
\hline & Walters, Roy A. & WR183 & 419 \\
\hline & Webb, Robert H. & WR200 & 112 \\
\hline & Weeks, Edwin P. & CR200 & 236 \\
\hline & White, Arthur F. & WR196 & 210 \\
\hline & Winograd, Isaac J. & NR041 & 147 \\
\hline & Winter, Thomas C. & CR090 & 220 \\
\hline & Wood, Warren W. & NR122 & 169 \\
\hline
\end{tabular}




\begin{tabular}{|c|c|c|c|}
\hline TOPIC & $\begin{array}{l}\text { PROJECT } \\
\text { CHIEF }\end{array}$ & $\begin{array}{l}\text { PROJECT } \\
\text { NUMBER }\end{array}$ & $\begin{array}{c}\text { PAGE } \\
\text { NUMBER }\end{array}$ \\
\hline \multirow[t]{20}{*}{ Hydrogeology: } & Back, William & NR034 & 143 \\
\hline & Bredehoeft, John D. & WR176 & 284 \\
\hline & Bricker, Owen P. & NR109 & 355 \\
\hline & Brown, Charles E. & NR130 & 259 \\
\hline & Cooley, Richard L. & CR191 & 231 \\
\hline & Coplen, Tyler B. & NR064 & 159 \\
\hline & Hsieh, Paul A. & WR184 & 296 \\
\hline & Ingebritsen, Steven E. & WR121 & 279 \\
\hline & Jones, Blair F. & NR020 & 139 \\
\hline & Konikow, Leonard F. & NR120 & 254 \\
\hline & Neuzil, Christopher E. & NR035 & 249 \\
\hline & Plummer, L. Niel & NR056 & 150 \\
\hline & Reilly, Thomas E. & NR152 & 265 \\
\hline & Shapiro, Allen M. & NR134 & 261 \\
\hline & Sorey, Michael L. & WR102 & 274 \\
\hline & Voss, Clifford I. & NR089 & 251 \\
\hline & Weeks, Edward P. & CR200 & 236 \\
\hline & Winograd, Isaac J. & NR041 & 147 \\
\hline & Winter, Thomas C. & CR090 & 220 \\
\hline & Wood, Warren W. & NR122 & 169 \\
\hline \multirow[t]{12}{*}{ Lakes: } & Winter, T.C. & CR323 & 23 \\
\hline & Benson, Larry V. & CR2O7 & 120 \\
\hline & Callender, Edward & NR065 & 348 \\
\hline & Cloern, James E. & WR164 & 71 \\
\hline & Kuwabara, James S. & WR190 & 84 \\
\hline & LaBaugh, James W. & CR293 & 13 \\
\hline & Oremland, Ronald S. & WR174 & 76 \\
\hline & Smith, Richard L. & CR295 & 15 \\
\hline & Striegl, Robert G. & CR320 & 20 \\
\hline & Taylor, Howard E. & CR282 & 323 \\
\hline & Winter, Thomas C. & CR090 & 220 \\
\hline & Wood, Warren W. & NR122 & 169 \\
\hline \multirow[t]{2}{*}{ Metals: } & Bricker, Owen P. & NR109 & 355 \\
\hline & Callender, Edward & NR065 & 348 \\
\hline
\end{tabular}




\begin{tabular}{|c|c|c|c|}
\hline TOPIC & $\begin{array}{c}\text { PROJECT } \\
\text { CHIEF }\end{array}$ & $\begin{array}{l}\text { PROJECT } \\
\text { NUMBER }\end{array}$ & $\begin{array}{c}\text { PAGE } \\
\text { NUMBER }\end{array}$ \\
\hline & Davis, James A., III & WR065 & 186 \\
\hline & Hem, John D. & WR076 & 362 \\
\hline & Hupp, Cliff R. & NR145 & 46 \\
\hline & Kuwabara, James S. & WR190 & 84 \\
\hline & Leland, Harry V. & CR337 & 34 \\
\hline & Lovley, Derek R. & NR136 & 41 \\
\hline & Luoma, Samuel N. & WR125 & 58 \\
\hline & McKnight, Diane M. & CR286 & 8 \\
\hline & Meade, Robert H., Jr. & CR309 & 103 \\
\hline & Nordstrom, Darrell K. & CR326 & 133 \\
\hline & Oremland, Ronald S. & WR174 & 76 \\
\hline & Simon, Nancy S. & NR135 & 359 \\
\hline & Stallard, Robert F. & CR313 & 340 \\
\hline & Taylor, Howard E. & CR282 & 323 \\
\hline & White, Arthur F. & WR196 & 210 \\
\hline \multicolumn{4}{|l|}{ Microbiology } \\
\hline \multirow[t]{2}{*}{ Aerobic: } & Oremland, Ronald S. & WR174 & 76 \\
\hline & Smith Richard L. & CR295 & 15 \\
\hline \multirow[t]{5}{*}{ Anaerobic: } & Godsy, Edward M. & WR068 & 55 \\
\hline & Harvey, Ronald W. & CR327 & 29 \\
\hline & Lovley, Derek R. & NR136 & 41 \\
\hline & Oremland, Ronald S. & WR174 & 76 \\
\hline & Smith, Richard L. & CR295 & 15 \\
\hline \multirow[t]{11}{*}{ Nutrients: } & Bricker, Owen P. & NR109 & 355 \\
\hline & Callender, Edward & NR065 & 348 \\
\hline & Feder, Gerald L. & NR132 & 177 \\
\hline & Kendall, Carol & WR080 & 193 \\
\hline & LaBaugh, James W. & CR293 & 13 \\
\hline & Leland, Harry V. & CR337 & 34 \\
\hline & Meade, Robert H., Jr. & CR309 & 103 \\
\hline & Peterson, David H. & WR046 & 50 \\
\hline & Smith, Richard L. & CR295 & 15 \\
\hline & Taylor, Howard E. & CR282 & 323 \\
\hline & Triska, Frank J. & WR186 & 80 \\
\hline
\end{tabular}




\begin{tabular}{|c|c|c|c|}
\hline TOPIC & $\begin{array}{l}\text { PROJECT } \\
\text { CHIEF }\end{array}$ & $\begin{array}{l}\text { PROJECT } \\
\text { NUMBER }\end{array}$ & $\begin{array}{r}\text { PAGE } \\
\text { NUMBE }\end{array}$ \\
\hline \multirow[t]{7}{*}{$\begin{array}{l}\text { Organic Compounds } \\
\text { (natural): }\end{array}$} & $\begin{array}{l}\text { Aiken, George R. } \\
\text { Chiou, Cary T. }\end{array}$ & $\begin{array}{l}\text { CR331 } \\
\text { CR283 }\end{array}$ & $\begin{array}{l}345 \\
126\end{array}$ \\
\hline & Eganhouse, Robert P. & NR151 & 181 \\
\hline & Leenheer, Jerry A. & CR285 & 331 \\
\hline & Malcolm, Ronald L. & CR046 & 310 \\
\hline & McKnight, Diane M. & CR286 & 8 \\
\hline & Meade, Robert H., Jr. & CR309 & 103 \\
\hline & Wershaw, Robert L. & CR132 & 314 \\
\hline \multirow[t]{13}{*}{$\begin{array}{l}\text { Organic Compounds } \\
\text { (man-made): }\end{array}$} & $\begin{array}{l}\text { Aiken, George R. } \\
\text { Baedecker, Mary Jo }\end{array}$ & $\begin{array}{l}\text { CR331 } \\
\text { NR129 }\end{array}$ & $\begin{array}{l}345 \\
173\end{array}$ \\
\hline & Chiou, Cary T. & CR283 & 126 \\
\hline & Eganhouse, Robert P. & NR151 & 181 \\
\hline & Essaid, Hedeff I. & WR199 & 305 \\
\hline & Feder, Gerald L. & NR132 & 177 \\
\hline & Godsy, Edward M. & WR068 & 55 \\
\hline & Goerlitz, Donald F. & WR189 & 207 \\
\hline & Herkelrath, William N. & WR179 & 290 \\
\hline & Leenheer, Jerry A. & CR285 & 331 \\
\hline & Meade, Robert H., Jr. & CR309 & 103 \\
\hline & Pereira, Wilfred E. & WR204 & 366 \\
\hline & Rathbun, Ronald E. & CR301 & 337 \\
\hline & Wershaw, Robert L. & CR132 & 314 \\
\hline \multirow[t]{5}{*}{ Radionuclides: } & Coplen, Tyler B. & NR064 & 159 \\
\hline & Davis, James A., III & WR065 & 186 \\
\hline & Kraemer, Thomas F. & NR138 & 179 \\
\hline & McKnight, Diane & CR286 & 8 \\
\hline & Nordstrom, Darrell K. & CR326 & 133 \\
\hline \multirow[t]{6}{*}{ Reservoirs: } & Andrews, Edmund D. & CR273 & 99 \\
\hline & Callender, Edward & NR065 & 348 \\
\hline & LaBaugh, James W. & CR293 & 13 \\
\hline & Leland, Harry V. & CR337 & 34 \\
\hline & Marzolf, G. Richard & CR325 & 26 \\
\hline & Taylor, Howard E. & CR282 & 323 \\
\hline
\end{tabular}




\begin{tabular}{cccc}
\hline TOPIC & $\begin{array}{c}\text { PROJECT } \\
\text { CHIEF }\end{array}$ & $\begin{array}{c}\text { PROJECT } \\
\text { NUMBER }\end{array}$ & $\begin{array}{c}\text { PAGE } \\
\text { NUMBER }\end{array}$ \\
\hline
\end{tabular}

Rivers and Streams:

Aiken, George R.

CR331

345

Andrews, Edmund D.

CR273

99

Bencala, Kenneth $E$.

422

Bennett, James $P$.

WR187

391

Bricker, Owen P.

CR343

355

Callender, Edward

NR109

348

Chen, Cheng-lung

NR065

427

Classen, Hans C.

WR194

320

Emmett, William W.

CR189

96

Hem, John D.

CR187

362

Jarrett, Robert D.

Kuwabara, James S.

WR076

384

Landwehr, Jurate $M$.

CR321

84

Leavesley, George H.

WR190

405

Lee, Jonathan

NR133

370

Leenheer, Jerry A.

CR228

411

Luoma, Samuel N.

NR147

331

Malcolm, Ronald L.

CR285

58

McKnight, Diane M.

WR125

310

Meade, Robert $\mathrm{H}$.

CR046

CR286

8

Milly, P.C.D.

CR102

92

Osterkamp, Waite R.

NR144

408

Pereira, Wilfred E.

WR311

116

Rathbun, Ronald E.

WR204

366

Reddy, Michael M

CR301

337

Schaffranek, Raymond W.

CR284

327

Simon, Nancy S.

NR104

397

Smith, J. Dungan

NR135

359

Stallard, Robert F.

CR324

108

Sundquist, Eric $\mathrm{T}$.

CR313

340

Tasker, Gary D.

NR099

352

Taylor, Howard E.

NR125

401

Triska, Frank J.

CR282

323

Troutman, Brent M.

WR186

80

CR279

380

Walters, Roy A.

WR183

419

Webb, Robert $\mathrm{H}$.

WR200

112 


\begin{tabular}{|c|c|c|c|}
\hline TOPIC & $\begin{array}{l}\text { PROJECT } \\
\text { CHIEF }\end{array}$ & $\begin{array}{l}\text { PROJECT } \\
\text { NUMBER }\end{array}$ & $\begin{array}{l}\text { PAGE } \\
\text { NUMBER }\end{array}$ \\
\hline & Wershaw, Robert L. & CR132 & 314 \\
\hline & Williams, Garnett P. & CR105 & 94 \\
\hline \multirow[t]{15}{*}{ Sediment Chemistry: } & $\begin{array}{l}\text { Aiken, George R. } \\
\text { Benson, Larry V. }\end{array}$ & $\begin{array}{l}\text { CR331 } \\
\text { CR207 }\end{array}$ & $\begin{array}{l}345 \\
120\end{array}$ \\
\hline & Bricker, Owen P. & NR109 & 355 \\
\hline & Callender, Edward & NR065 & 348 \\
\hline & Chiou, Cary T. & CR283 & 126 \\
\hline & Davis, James A., III & WR065 & 186 \\
\hline & Eganhouse, Robert P. & NR151 & 181 \\
\hline & James, Ronald V. & WR036 & 184 \\
\hline & Jones, Blair F. & NR020 & 139 \\
\hline & Leenheer, Jerry A. & CR285 & 331 \\
\hline & Luoma, Samuel N. & WR125 & 58 \\
\hline & Meade, Robert H., Jr. & CR309 & 103 \\
\hline & Pereira, Wilfred E. & WR204 & 366 \\
\hline & Stallard, Robert, F. & CR313 & 340 \\
\hline & Taylor, Howard E. & CR282 & 323 \\
\hline & White, Arthur F. & WR196 & 210 \\
\hline \multirow[t]{13}{*}{ Sediment Transport: } & Andrews, Edmund D. & CR273 & 99 \\
\hline & Bennett, James P. & WR197 & 391 \\
\hline & Chen, Cheng-lung & WR194 & 427 \\
\hline & Emmett, William W. & CR187 & 96 \\
\hline & Hupp, Cliff R. & NR145 & 46 \\
\hline & Jarrett, Robert D. & CR321 & 384 \\
\hline & Meade, Robert H. & CR102 & 92 \\
\hline & Meade, Robert H., Jr. & CR309 & 103 \\
\hline & Osterkamp, Waite R. & WR311 & 116 \\
\hline & Smith, J. Dungan & CR324 & 108 \\
\hline & Stallard, Robert F. & CR313 & 340 \\
\hline & Webb, Robert H. & WR200 & 112 \\
\hline & Williams, Garnett P. & CR105 & 94 \\
\hline \multirow[t]{3}{*}{ Snow, Ice, Glaciers: } & Claassen, Hans C. & CR189 & 320 \\
\hline & Coplen, Tyler B. & NR064 & 159 \\
\hline & Leavesley, George H. & CR228 & 370 \\
\hline
\end{tabular}




\begin{tabular}{|c|c|c|c|}
\hline TOPIC & $\begin{array}{l}\text { PROJECT } \\
\text { CHIEF }\end{array}$ & $\begin{array}{l}\text { PROJECT } \\
\text { NUMBER }\end{array}$ & $\begin{array}{l}\text { PAGE } \\
\text { NUMBER }\end{array}$ \\
\hline & Reddy, Michael M. & CR284 & 327 \\
\hline & Taylor, Howard E. & CR282 & 323 \\
\hline & Walters, Roy A. & WR183 & 419 \\
\hline \multirow[t]{7}{*}{ Statistical Hydrology: } & Brown, Charles E. & NR130 & 259 \\
\hline & Cooley, Richard L. & CR191 & 231 \\
\hline & Landwehr, Jurate M. & NR133 & 405 \\
\hline & Naff, Richard L. & CR319 & 246 \\
\hline & Tasker, Gary D. & NR125 & 401 \\
\hline & Troutman, Brent M. & CR279 & 380 \\
\hline & Wagner, Brian J. & WR178 & 288 \\
\hline \multirow[t]{8}{*}{ Surface Chemistry: } & Chiou, Cary T. & CR283 & 126 \\
\hline & Davis, James A., III & WR065 & 186 \\
\hline & Eberl, Dennis D. & CR276 & 123 \\
\hline & Jarrett, Robert D. & CR321 & 384 \\
\hline & Plummer, L. Niel & NR056 & 150 \\
\hline & Reddy, Michael M. & CR284 & 327 \\
\hline & Wershaw, Robert L. & CR132 & 314 \\
\hline & White, Arthur F. & WR196 & 210 \\
\hline \multirow[t]{8}{*}{ Surface-water Hydraulics: } & Baltzer, Robert A. & NR019 & 393 \\
\hline & Bennett, James $P$. & WR197 & 391 \\
\hline & Chen, Cheng-lung & WR194 & 427 \\
\hline & Cheng, Ralph T. & WR140 & 414 \\
\hline & Jarrett, Robert D. & CR321 & 384 \\
\hline & Lee, Jonathan & NR147 & 411 \\
\hline & Schaffranek, Raymond W. & NR104 & 397 \\
\hline & Walters, Roy A. & WR183 & 419 \\
\hline \multirow{7}{*}{$\begin{array}{l}\text { Surface-water Transport and } \\
\text { Reactions: }\end{array}$} & & & \\
\hline & Bencala, Kenneth E. & WR187 & 422 \\
\hline & Chen, Cheng-lung & WR194 & 427 \\
\hline & Cheng, Ralph T. & WR140 & 414 \\
\hline & Leavesley, George H. & CR228 & 370 \\
\hline & Nordstrom, Darrell K. & CR326 & 133 \\
\hline & Rathbun, Ronald E. & CR301 & 337 \\
\hline
\end{tabular}




\begin{tabular}{|c|c|c|c|}
\hline TOPIC & $\begin{array}{l}\text { PROJECT } \\
\text { CHIEF }\end{array}$ & $\begin{array}{l}\text { PROJECT } \\
\text { NUMBER }\end{array}$ & $\begin{array}{c}\text { PAGE } \\
\text { NUMBER }\end{array}$ \\
\hline & Triska, Frank J. & WR186 & 80 \\
\hline & Walters, Roy A. & WR183 & 419 \\
\hline \multirow[t]{14}{*}{ Unsaturated Zone: } & Chiou, Cary T. & CR283 & 126 \\
\hline & Constantz, James E. & WR193 & 300 \\
\hline & Essaid, Hedeff I. & WR199 & 305 \\
\hline & Herkelrath, William N. & WR179 & 290 \\
\hline & James, Ronald V. & WR036 & 184 \\
\hline & Kendall, Carol & WR080 & 193 \\
\hline & Milly, P.C.D. & NR144 & 408 \\
\hline & Nimmo, John R. & WR198 & 302 \\
\hline & Rubin, Jacob & WR180 & 293 \\
\hline & Striegl, Robert G. & CR320 & 20 \\
\hline & Stonestrom, David A. & WR024 & 271 \\
\hline & Thorstenson, Donald C. & CR336 & 137 \\
\hline & Voss, Clifford I. & NR089 & 251 \\
\hline & Weeks, Edwin P. & CR200 & 236 \\
\hline \multirow[t]{2}{*}{ Volcanic Hazards: } & Chen, Cheng-lung & WR194 & 427 \\
\hline & Sorey, Michael L. & WR102 & 274 \\
\hline \multirow[t]{5}{*}{ Wetlands: } & Carter, Virginia P. & NR090 & 36 \\
\hline & Hupp, Cliff R. & NR145 & 46 \\
\hline & LaBaugh, James W. & CR293 & 13 \\
\hline & Webb, Robert H. & WR200 & 112 \\
\hline & Winter, T.C. & CR323 & 23 \\
\hline
\end{tabular}

